\title{
Play Analysis and Digital Portfolio of Major Oil Reservoirs in the Permian Basin: Application and Transfer of Advanced Geological and Engineering Technologies for Incremental Production Opportunities
}

\author{
Final Report \\ Reporting Period Start Date: January 14, 2002 \\ Reporting Period End Date: May 13, 2004 \\ Shirley P. Dutton, Eugene M. Kim, Ronald F. Broadhead, \\ Caroline L. Breton, William D. Raatz, \\ Stephen C. Ruppel, and Charles Kerans \\ May 2004 \\ Work Performed under DE-FC26-02NT15131 \\ Prepared by \\ Bureau of Economic Geology \\ John A. and Katherine G. Jackson School of Geosciences \\ The University of Texas at Austin \\ University Station, P.O. Box X \\ Austin, TX 78713-8924 \\ and
}

New Mexico Bureau of Geology and Mineral Resources

New Mexico Institute of Mining and Technology

Socorro, NM 87801-4681 


\section{DISCLAIMER}

This report was prepared as an account of work sponsored by an agency of the United States Government. Neither the United States Government nor any agency thereof, nor any of their employees, makes any warranty, express or implied, or assumes any legal liability for responsibility for the accuracy, completeness, or usefulness of any information, apparatus, product, or process disclosed, or represents that its use would not infringe privately owned rights. Reference herein to any specific commercial product, process, or service by trade name, trademark, manufacturer, or otherwise does not necessarily constitute or imply its endorsement, recommendation, or favoring by the United States Government or any agency thereof. The views and opinions of authors expressed herein do not necessarily state or reflect those of the United States Government or any agency thereof. 


\begin{abstract}
The Permian Basin of west Texas and southeast New Mexico has produced $>30 \mathrm{Bbbl}\left(4.77 \times 10^{9} \mathrm{~m}^{3}\right)$ of oil through 2000 , most of it from 1,339 reservoirs having individual cumulative production $>1 \mathrm{MMbbl}\left(1.59 \times 10^{5} \mathrm{~m}^{3}\right)$. These significant-sized reservoirs are the focus of this report. Thirty-two Permian Basin oil plays were defined, and each of the 1,339 significant-sized reservoirs was assigned to a play. The reservoirs were mapped and compiled in a Geographic Information System (GIS) by play.

Associated reservoir information within linked data tables includes Railroad Commission of Texas reservoir number and district (Texas only), official field and reservoir name, year reservoir was discovered, depth to top of the reservoir, production in 2000, and cumulative production through 2000. Some tables also list subplays. Play boundaries were drawn for each play; the boundaries include areas where fields in that play occur but are $<1 \mathrm{MMbbl}\left(1.59 \times 10^{5} \mathrm{~m}^{3}\right)$ of cumulative production. This report contains a summary description of each play, including key reservoir characteristics and successful reservoirmanagement practices that have been used in the play. The $\mathrm{CD}$ accompanying the report contains a pdf version of the report, the GIS project, pdf maps of all plays, and digital data files.
\end{abstract}

Oil production from the reservoirs in the Permian Basin having cumulative production $>1 \mathrm{MMbbl}\left(1.59 \times 10^{5} \mathrm{~m}^{3}\right)$ was $301.4 \mathrm{MMbbl}\left(4.79 \times 10^{7} \mathrm{~m}^{3}\right)$ in 2000. Cumulative Permian Basin production through 2000 from these significant-sized reservoirs was $28.9 \mathrm{Bbbl}\left(4.59 \times 10^{9} \mathrm{~m}^{3}\right)$. The top four plays in cumulative production are the Northwest Shelf San Andres Platform Carbonate play (3.97 Bbbl $\left[6.31 \times 10^{8} \mathrm{~m}^{3}\right]$ ), the Leonard Restricted Platform Carbonate play $\left(3.30 \mathrm{Bbbl}\left[5.25 \times 10^{8} \mathrm{~m}^{3}\right)\right.$, the 
Pennsylvanian and Lower Permian Horseshoe Atoll Carbonate play (2.70 Bbbl

$\left.\left[4.29 \times 10^{8} \mathrm{~m}^{3}\right]\right)$, and the San Andres Platform Carbonate play $(2.15 \mathrm{Bbbl}$

$\left.\left[3.42 \times 10^{8} \mathrm{~m}^{3}\right]\right)$ 


\section{CONTENTS}

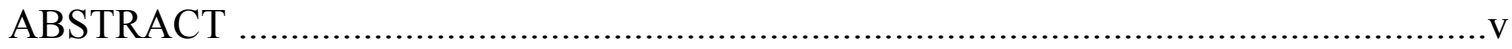

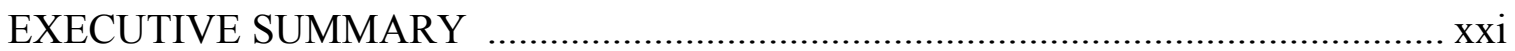

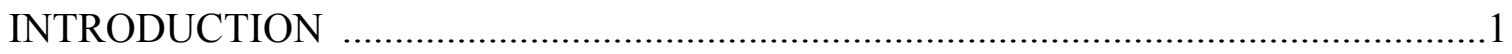

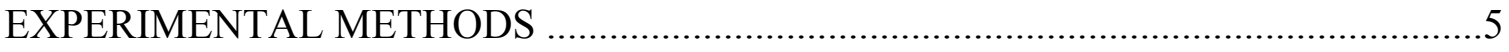

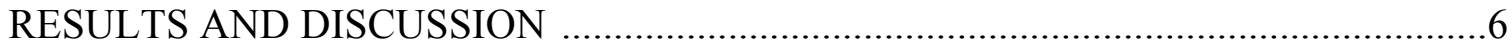

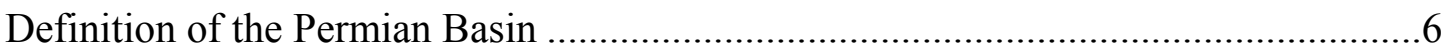

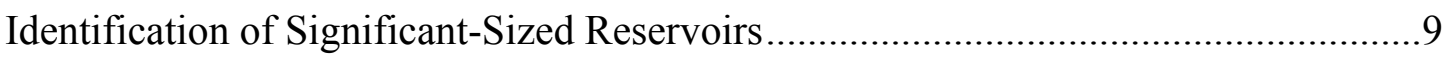

Texas

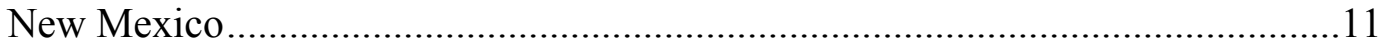

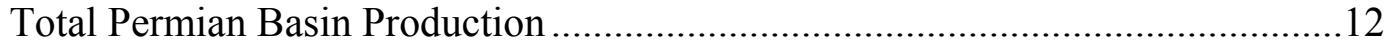

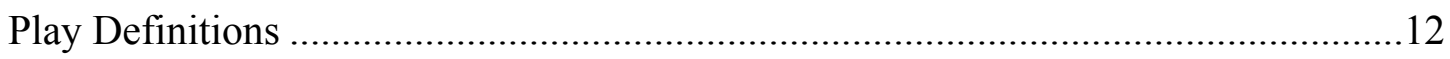

Play Designations of Reservoirs ..........................................................................13

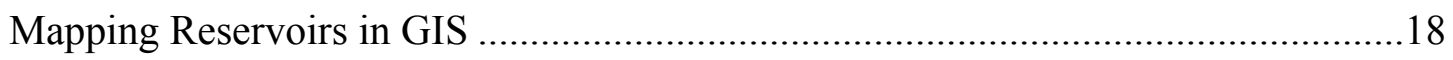

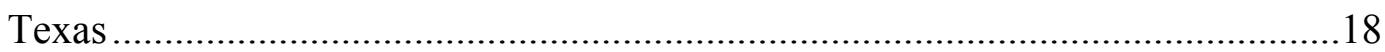

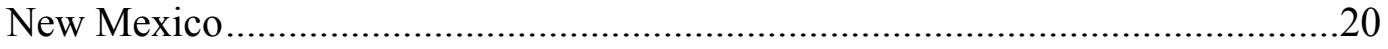

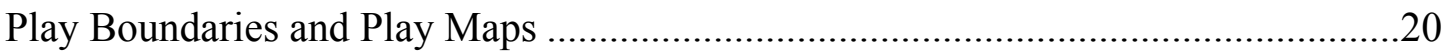

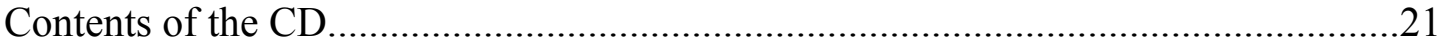

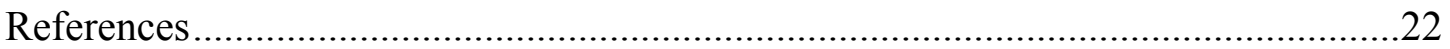

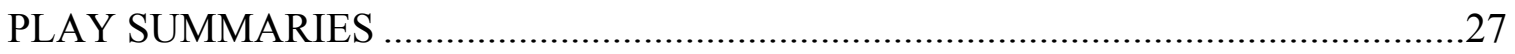

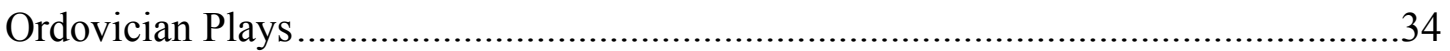

Ellenburger Selectively Dolomitized Ramp Carbonate.........................................36

Ellenburger Karst-Modified Restricted Ramp Carbonate.......................................46

Simpson Cratonic Sandstone ........................................................................56

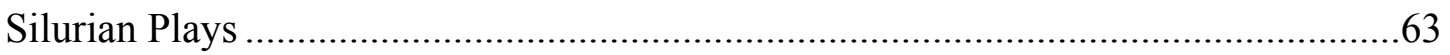

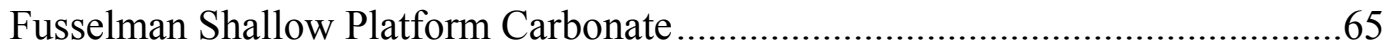

Wristen Buildups and Platform Carbonate ………….........................................75 


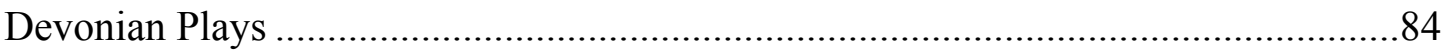

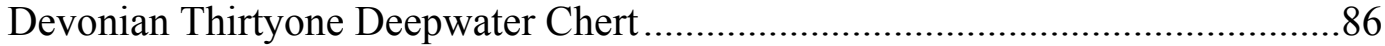

Devonian Thirtyone Ramp Carbonate ..............................................................95

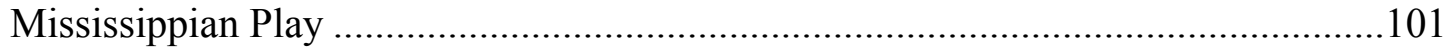

Mississippian Platform Carbonate ......................................................................101

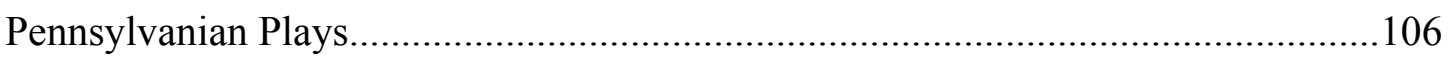

Northwest Shelf Strawn Patch Reef...................................................................109

Northwest Shelf Upper Pennsylvanian Carbonate.................................................113

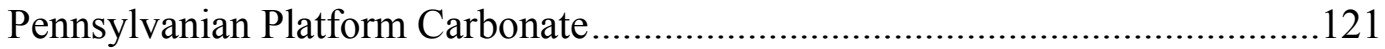

Pennsylvanian and Lower Permian Horseshoe Atoll Carbonate ...........................132

Upper Pennsylvanian and Lower Permian Slope and Basinal Sandstone ............144

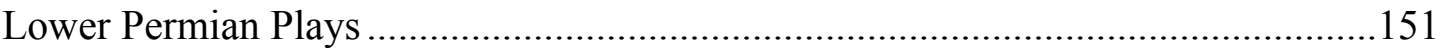

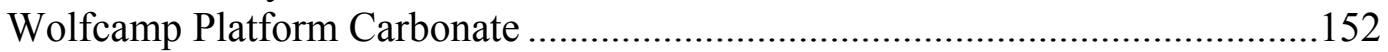

Wolfcamp/Leonard Slope and Basinal Carbonate ..................................................162

Abo Platform Carbonate …………................................................................172

Leonard Restricted Platform Carbonate...........................................................180

Bone Spring Basinal Sandstone and Carbonate..................................................200

Spraberry/Dean Submarine-Fan Sandstone .....................................................2205

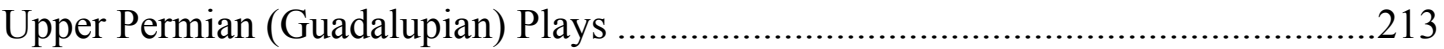

Northwest Shelf San Andres Platform Carbonate ............................................216

Eastern Shelf San Andres Platform Carbonate ………......................................226

San Andres Karst-Modified Platform Carbonate...............................................232

San Andres Platform Carbonate.......................................................................241

Upper San Andres and Grayburg Platform Mixed - Central Basin

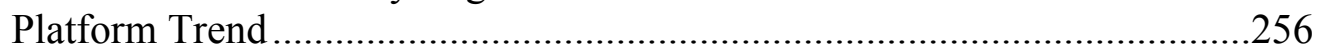

Upper San Andres and Grayburg Platform Mixed-Artesia Vacuum Trend......260

San Andres/Grayburg Lowstand Carbonate ……………...................................2.270

Grayburg Platform Mixed Clastic/Carbonate …………....................................22

Grayburg Platform Carbonate ...........................................................................228

Grayburg High-Energy Platform Carbonate-Ozona Arch ...............................296

Delaware Mountain Group Basinal Sandstone ....................................................303

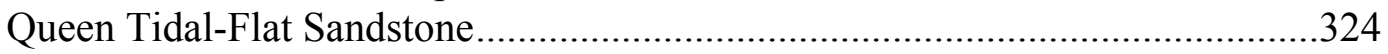

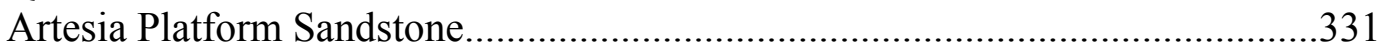

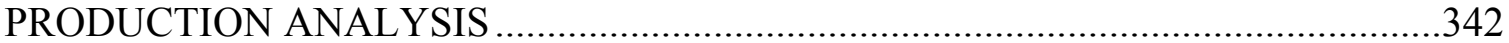

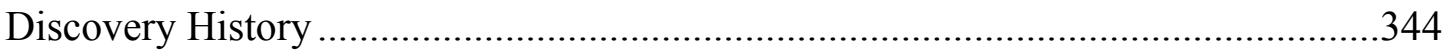

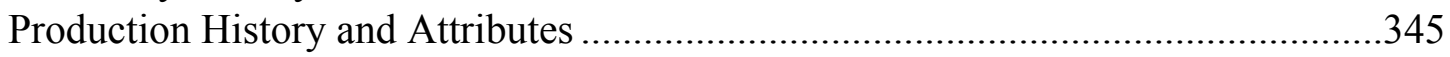

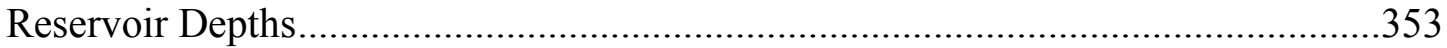

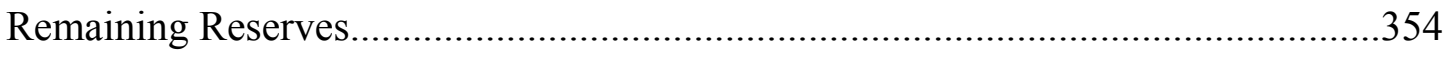

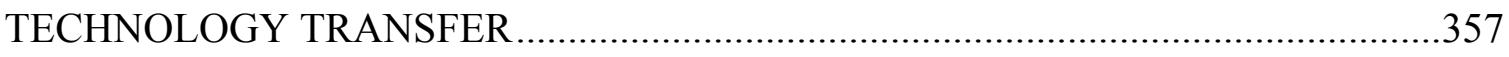




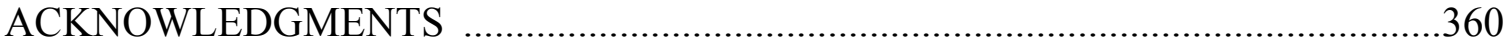

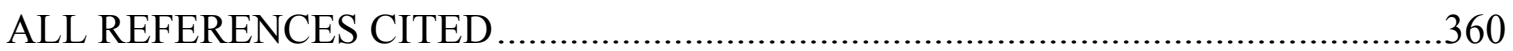

LIST OF ACRONYMS AND ABBREVIATIONS .................................................408

Figures

1. Counties in Texas and New Mexico in the Permian Basin geologic province.

2. Major subdivisions and boundaries of the Permian Basin in west Texas and southeast New Mexico

3. Stratigraphic nomenclature for the Cambrian through Pennsylvanian section and Permian section in the Permian Basin

4. Play map for the Ellenburger Selectively Dolomitized Ramp Carbonate play, showing location of reservoirs having $>1 \mathrm{MMbbl}$ cumulative production, the play boundary, and geologic features

5. Map of Barnhart field, Reagan County, Texas, showing structure at the top of the Ellenburger reservoir and interpreted correlation discontinuities caused by faults and karsted zones

6. Typical log of the Ellenburger reservoir in Barnhart field, Reagan County, Texas

7. West-east cross section of Barnhart field showing karsted and nonkarsted zones

8. Play map for the Ellenburger Karst-Modified Restricted Ramp Carbonate play, showing location of reservoirs having $>1$ MMbbl cumulative production, the play boundary, and geologic features

9. Karst facies and associated log signatures in the Gulf 000-1 TXL well, northeast Emma Ellenburger field, Andrews County, Texas

10. Log signatures and shut-in pressures in the Mobil 36-1 University well in Ellenburger Emma field, Andrews County, Texas 
11. Play map for the Simpson Cratonic Sandstone play, showing location of reservoirs having $>1 \mathrm{MMbbl}$ cumulative production, the play boundary, and geologic features

12. Log of Ordovician and Permian strata from a well in Martin McKee field, Andrews County, Texas, showing McKee producing interval

13. West-east cross section from Running W Waddell field, Crane County, Texas, showing updip erosion of Waddell sandstone

14. Play map for the Fusselman Shallow Platform Carbonate play, showing location of reservoirs having $>1 \mathrm{MMbbl}$ cumulative production, the play boundary, and geologic features

15. West-east cross section showing facies changes in the Fusselman Formation associated with a paleotopographic high near the eastern subcrop.

16. Wireline response of the Upper Ordovician-Devonian stratigraphic section in the Standard of Texas Simms No. 2 well, Midland County

17. Play map for the Wristen Buildups and Platform Carbonate play, showing location of reservoirs having $>1$ MMbbl cumulative production, the play boundary, and geologic features . .76

18. North-south cross sections illustrating the depositional history of the Silurian carbonate section in west Texas and New Mexico

19. Thickness map of the Wristen Group in west Texas and New Mexico

20. Stratigraphic section of the Fasken Formation (Wristen Group) in the Standard of Texas Fasken 5 No. 1 well

21. South-north dip cross section showing distribution of major Silurian and Devonian strata

22. Play map for the Devonian Thirtyone Deepwater Chert play, showing location of reservoirs having $>1 \mathrm{MMbbl}$ cumulative production, the play boundary, and geologic features

23. West-east cross section in Three Bar field, Andrews County, Texas

24. Typical stratigraphic succession and wireline-log signature of Thirtyone Formation in the Amoco 80 Three Bar Unit well, Three Bar field, Andrews County, Texas 
25. Play map for the Devonian Thirtyone Ramp Carbonate play, showing location of reservoirs having $>1 \mathrm{MMbbl}$ cumulative production, the play boundary, and geologic features

26. Stratigraphic section of the Thirtyone Formation in Headlee (Devonian) field, Ector County, Texas.

27. Play map for the Mississippian Platform Carbonate play, showing location of reservoirs having $>1 \mathrm{MMbbl}$ cumulative production, the play boundary, and geologic features

28. Map showing location of Chester limestone subcrop

29. South-north cross section A-A' of the upper Mississippian Meramec and Chester limestones.....

30. Play map for the Northwest Shelf Strawn Patch Reef play, showing location of reservoirs having $>1 \mathrm{MMbbl}$ cumulative production, the play boundary, and geologic features

31. Map of Strawn structure and porosity at the Lovington Northeast reservoir, showing structure of the Strawn limestone

32. Play map for the Northwest Shelf Upper Pennsylvanian Carbonate play, showing location of reservoirs having $>1$ MMbbl cumulative production, the play boundary, and geologic features

33. Stratigraphic column of Upper Pennsylvanian and Lower Permian strata, southeast New Mexico.

34. Depositional model for Upper Pennsylvanian algal-mound complex, South Dagger Draw reservoir

35. Structure-contour map on top of Upper Pennsylvanian dolostone reservoir and South Dagger Draw and North Dagger Draw reservoirs and time periods during which wells were drilled.....

36. Historical annual oil production and number of productive wells active in any given year, Baum Upper Pennsylvanian reservoir

37. Play map for the Pennsylvanian Platform Carbonate play, showing location of reservoirs having $>1 \mathrm{MMbbl}$ cumulative production, the play boundary, and geologic features

38. Idealized upward-shallowing cycle in Upper Pennsylvanian carbonates in the Southwest Andrews area 
39. Core description and gamma-ray log through the producing interval in the X-1 well, Andrews field, Southwest Andrews area, Andrews County....

40. Stratigraphic cross section showing distribution of porous limestone in the Canyon and Cisco intervals in Deep Rock and Parker fields, southwest Andrews County

41. Play map for the Pennsylvanian and Lower Permian Horseshoe Atoll Carbonate play, showing location of reservoirs having $>1 \mathrm{MMbbl}$ cumulative production, the play boundary, and geologic features

42. Isopach map of the Horseshoe Atoll carbonate

43. Typical log from the center of the Horseshoe Atoll in the SACROC unit showing high-frequency sequences

44. East-west cross section A-A' of the north part of SACROC unit.

45. Play map for the Upper Pennsylvanian and Lower Permian Slope and Basinal Sandstone play, showing location of reservoirs having $>1 \mathrm{MMbbl}$ cumulative production, the play boundary, and geologic features

46. Generalized west-east dip cross section, Virgilian and Wolfcampian Series, from the Eastern Shelf in North-Central Texas into the Midland Basin.

47. Southeast-northwest cross section of Lake Trammel, S., and Lake Trammel, W., fields, Nolan County, showing lowstand detached basin-floor submarine fans and lowstand slope-fan and prograding-delta complex

48. Play map for the Wolfcamp Platform Carbonate play, showing location of reservoirs having $>1 \mathrm{MMbbl}$ cumulative production, the play boundary, and geologic features

49. Typical vertical Wolfcamp facies succession in the Wolfcamp Platform Carbonate play .....

50. Southwest-northeast cross section of University Block 9 field, showing Wolfcamp stratigraphy, cycles, and facies as interpreted from core-calibrated image logs

51. Play map for the Wolfcamp/Leonard Slope and Basinal Carbonate play, showing location of reservoirs having $>1 \mathrm{MMbbl}$ cumulative production, the play boundary, and geologic features 
52. West-east cross section illustrating progradation of the Eastern Shelf margin and fields producing from Wolfcamp and Leonard periplatform carbonates in Glasscock and Sterling fields.....

53. Northwest-southeast stratigraphic cross section showing producing zones in Amacker Tippett Wolfcamp field, Upton County .... 166

54. Play map for the Abo Platform Carbonate play, showing location of reservoirs having $>1 \mathrm{MMbbl}$ cumulative production, the play boundary, and geologic features

55. Depositional model of the progradational Abo sequence and a seismic line from a multichannel, migrated, P-wave 3-D data volume in Kingdom Abo field

56. North-south structural cross section of the Empire Abo reservoir showing relationship of porous Abo reef to Abo backreef facies and basinal Bone Spring Formation

57. Play map for the Leonard Restricted Platform Carbonate play, showing location of reservoirs having $>1 \mathrm{MMbbl}$ cumulative production, the play boundary, and geologic features

58. Depositional model for middle Permian carbonate platform deposits in the Permian Basin

59. Typical log from Fullerton Clear Fork reservoir, from the Fullerton Clearfork Unit 5927 well

60. Sequence stratigraphic model of the Clear Fork reservoir succession at Fullerton field, Andrews County, Texas.

61. Structure contour map on top of Blinebry Member, Yeso Formation, Justis Blinebry reservoir

62. Structure contour map on top of the main Blinebry pay and isolith map of porosity $>7$ percent, Oil Center Blinebry reservoir .....

63. Block diagram of depositional environments in the Paddock Member of the Yeso Formation, Vacuum Glorieta reservoir.

64. Daily oil production from Vacuum Glorieta West unit showing estimated incremental production that will be derived from the drilling of horizontal wells 
65. Play map for the Bone Spring Basinal Sandstone and Carbonate play, showing location of reservoirs having $>1$ MMbbl cumulative production, the play boundary, and geologic features

66. South-north cross section of Mescalero Escarpe reservoir showing southward depositional dip and transition from shelf facies of Abo and Yeso Formations in the north to basinal carbonate and sandstone facies of the Bone Spring Formation in the south

67. Play map for the Spraberry/Dean Submarine-Fan Sandstone play, showing location of reservoirs having $>1$ MMbbl cumulative production, the play boundary, and geologic features

68. Type log of the Spraberry Formation in the central Spraberry Trend, showing several scales of division of the formation and principal vertical trends.

69. West-east Spraberry strike section in the distal parts of the Midland Basin

70. Play map for the Northwest Shelf San Andres Platform Carbonate play, showing location of reservoirs having $>1 \mathrm{MMbbl}$ cumulative production, the play boundary, and geologic features

71. Type log for Denver unit in Wasson San Andres field

72. North-south cross section showing the distribution of depositional facies and correlation markers across Denver unit, Wasson San Andres field.

73. Play map for the Eastern Shelf San Andres Platform Carbonate play, showing location of reservoirs having $>1$ MMbbl cumulative production, the play boundary, and geologic features

74. Typical gamma-ray-neutron log through the Permian section in Howard Glasscock field.

75. Play map for the San Andres Karst-Modified Platform Carbonate play, showing location of reservoirs having $>1 \mathrm{MMbbl}$ cumulative production, the play boundary, and geologic features

76. Sequence stratigraphy and facies tracts of Yates field illustrated on a west-east cross section

77. West-east cross section of Yates field showing depositional setting and $\log$ responses for major lithofacies and projected time-stratigraphic framework 
78. Typical gamma-ray/neutron log and characteristic lithologies and depositional environments for the upper San Andres and Grayburg Formations at Taylor-Link West field

79. Play map for the San Andres Platform Carbonate play, showing location of reservoirs having $>1$ MMbbl cumulative production, the play boundary, and geologic features

80. General Upper Permian stratigraphy and upper San Andres facies in the Emma field area, Andrews County.

81. Southwest-northeast stratigraphic cross section of Emma field showing lateral and vertical extent of various lithofacies.

82. Log/core correlations for the EPSAU No. 207 well in East Penwell San Andres unit (EPSAU), Penwell field, Ector County.

83. Paleoenvironmental reconstruction of Emma field area during late San Andres time

84. Southwest-northeast cross section showing distribution of skeletal grainstone and fusulinid packstone/wackestone reservoir facies across Emma field....

85. High-frequency cycles and rock-fabric facies in the Amerada Hess SSAU No. 2505 well, Seminole field, Gaines County....

86. Play map for the Upper San Andres and Grayburg Platform Mixed - Central Basin Platform Trend play, showing location of reservoirs having $>1$ MMbbl cumulative production, the play boundary, and geologic features

87. Play map for the Upper San Andres and Grayburg Platform Mixed-Artesia Vacuum Trend play, showing location of reservoirs having $>1 \mathrm{MMbbl}$ cumulative production, the play boundary, and geologic features .261

88. Annual oil production and number of injection wells in the Vacuum Grayburg San Andres reservoir from 1970 through 1993, showing the relationship between injection wells used for enhanced oil recovery and oil production

89. Annual combined oil and gas production for three wells in the Grayburg-Jackson reservoir, Upper San Andres and Grayburg Platform Mixed-Artesia Vacuum Trend play. 
90. Stratigraphic column for the H. E. West "A" No. 22 well in

Jackson-Grayburg field on the Northwest Shelf, Eddy County

91. Depositional model of the Grayburg Formation during a base-level rise.

92. Play map for the San Andres/Grayburg Lowstand Carbonate play, showing location of reservoirs having $>1$ MMbbl cumulative production, the play boundary, and geologic features

93. Type log for Mabee field showing vertical facies succession

94. Play map for the Grayburg Platform Mixed Clastic/Carbonate play, showing location of reservoirs having $>1$ MMbbl cumulative production, the play boundary, and geologic features

95. Type log for the Fuhrman-Mascho field from the Arrow West Furhman-Mascho Unit No. 124 well, showing vertical facies succession and cycle development. .278

96. North-south cross section of Fuhrman-Mascho field showing the cycle stratigraphy of the Grayburg and San Andres reservoir section based on cored wells

97. Play map for the Grayburg Platform Carbonate play, showing location of reservoirs having $>1 \mathrm{MMbbl}$ cumulative production, the play boundary, and geologic features

98. Northwest-southeast stratigraphic cross section of Penwell, Jordan, Waddell, Dune, and McElroy fields

99. West-east cross section showing Grayburg sequence framework in South Cowden field.

100. West-east cross section showing high-frequency cycles in Grayburg highstand deposits in South Cowden field

101. West-east cross section showing that permeability in South Cowden Grayburg is better developed to the east, in the downdip margins of the field where dolomite alteration and anhydrite dissolution have been most extensive. 288

102. Play map for the Grayburg High-Energy Platform Carbonate-Ozona Arch play, showing location of reservoirs having $>1$ MMbbl cumulative production, the play boundary, and geologic features 
103. Typical gamma-ray/resistivity log from Farmer field, Crockett County

104. West-east cross section showing upward-shoaling cycles in Farmer field, Crockett County

105. Play map for the Delaware Mountain Group Basinal Sandstone play, showing location of reservoirs having $>1$ MMbbl cumulative production, the play boundary, and geologic features

106. Depositional model proposed for the Bell Canyon sandstone, showing deposition in submarine channels with levees, overbank splays, and attached lobes

107. Typical log from East Ford field, which produces from the Ramsey sandstone in the upper Bell Canyon Formation....

108. Northwest-southeast strike cross section of the central part of the East Ford unit.

109. Net thickness of sandstone with porosity $\geq 15$ percent in the main pay zone at the Livingston Ridge and Lost Tank reservoirs

110. Average-production decline curve for wells productive from Livingston Ridge main pay, Livingston Ridge and Lost Tank reservoirs

111. Historical monthly production of oil, Phillips Petroleum Company No. 2 James A well, Cabin Lake reservoir

112. Annual production history of the Indian Draw Delaware reservoir, with production curves for primary and secondary (waterflood) recovery and estimated oil recovery by primary and secondary means

113. Plot of oil production, water:oil ratio, and gas:oil ratio in East Ford unit since 1990 and plot of gas and water injection since 1995

114. Play map for the Queen Tidal-Flat Sandstone play, showing location of reservoirs having $>1 \mathrm{MMbbl}$ cumulative production, the play boundary, and geologic features

115. Typical log of upper Permian Queen, Seven Rivers, and Yates Formations in the McFarland Queen reservoir, Andrews County, showing producing Queen sandstones $\mathrm{A}$ and $\mathrm{B}$

116. Typical log from Concho Bluff North Queen unit, Ector County, showing reservoir sandstones interbedded with halite and anhydrite. 
117. Play map for the Artesia Platform Sandstone play, showing location of reservoirs having $>1 \mathrm{MMbbl}$ cumulative production, the play boundary, and geologic features

118. Stratigraphic column of Guadalupian Artesia Group, Central Basin Platform and Northwest Shelf

119. Representative log of the Keystone Colby reservoir illustrating the five major Queen sandstone packages

120. West-east cross section of Keystone Colby reservoir 337

121. Typical log of Yates reservoir section in North Ward Estes field 338

122. Composition of 2002 U.S. oil production and proved oil reserves

123. Geographic distribution of 2002 Permian Basin oil production and proved oil reserves

124. Permian Basin cumulative oil production discovered by year.

125. Reservoir discovery-year histogram of the 1,339 major oil reservoirs in the Permian Basin that produced $>1$ MMbbl through 2000 346

126. Permian Basin oil production history from 1970 through 2000 for the 1,339 significant-sized oil reservoirs in the Permian Basin .346

127. Permian Basin cumulative production through 2000, by geologic age and Permian Basin production in 2000, by geologic age.

128. Production histories of significant-sized oil reservoirs in the Permian Basin by geologic age.

129. Permian Basin cumulative production through 2000 by lithology and Permian Basin production in 2000 by lithology

130. Production histories of significant-sized oil reservoirs in the Permian Basin by lithology.

131. Reservoir-depth histogram of significant-sized oil reservoirs in the Permian Basin 354

132. Permian Basin remaining reserves to 2015 by plays .355 


\section{Tables}

1. Production in 2000 and cumulative production through December 31, 2000, of oil plays in the Permian Basin, listed by reservoir age.

2. Cumulative production of oil plays in the Permian Basin, ranked by production ....15

3. Combined reservoirs by plays

4. Ellenburger Selectively Dolomitized Ramp Carbonate play..... .36

5. Ellenburger Karst-Modified Restricted Ramp Carbonate play.....

6. Simpson Cratonic Sandstone play .56

7. Fusselman Shallow Platform Carbonate play .67

8. Wristen Buildups and Platform Carbonate play .77

9. Devonian Thirtyone Deepwater Chert play .86

10. Devonian Thirtyone Ramp Carbonate play .95

11. Mississippian Platform Carbonate play 101

12. Pennsylvanian and Lower Permian Reef/Bank play 106

13. Upper Pennsylvanian Shelf Sandstone play 107

14. Northwest Shelf Strawn Patch Reef play 109

15. Northwest Shelf Upper Pennsylvanian Carbonate play.......

16. Pennsylvanian Platform Carbonate play..... 123

17. Pennsylvanian and Lower Permian Horseshoe Atoll Carbonate play 133

18. Upper Pennsylvanian and Lower Permian Slope and Basinal Sandstone play

19. Wolfcamp Platform Carbonate play

20. Wolfcamp/Leonard Slope and Basinal Carbonate play .... 162

21. Abo Platform Carbonate play 172

22. Leonard Restricted Platform Carbonate play. 181 
23. New Mexico subplays of the Leonard Restricted Platform Carbonate play.

24. Bone Spring Basinal Sandstone and Carbonate play........................................200

25. Spraberry/Dean Submarine-Fan Sandstone play .............................................206

26. Northwest Shelf San Andres Platform Carbonate play......................................216

27. Eastern Shelf San Andres Platform Carbonate play ..........................................226

28. San Andres Karst-Modified Platform Carbonate play .......................................232

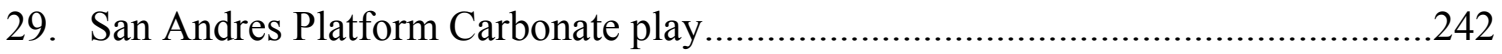

30. Upper San Andres and Grayburg Platform Mixed - Central Basin Platform Trend play...................................................256

31. Upper San Andres and Grayburg Platform Mixed-Artesia Vacuum Trend play.................................................................260

32. San Andres/Grayburg Lowstand Carbonate play ..........................................270

33. Grayburg Platform Mixed Clastic/Carbonate play ..........................................22

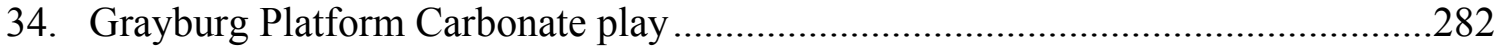

35. Grayburg High-Energy Platform Carbonate-Ozona Arch play..........................296

36. Delaware Mountain Group Basinal Sandstone play ............................................303

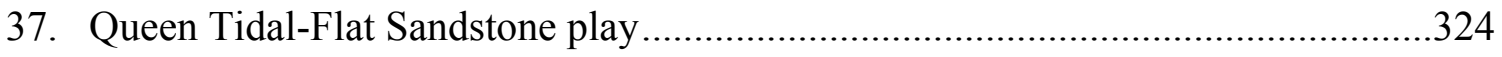

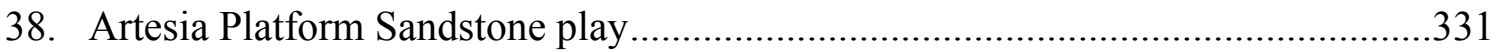

39. Largest oil reservoir in each Permian Basin play .............................................350

40. Permian Basin remaining reserves to 2015 by play ..........................................356 


\section{EXECUTIVE SUMMARY}

The target of this PUMP project was the Permian Basin of west Texas and southeast New Mexico, which is still one of the largest petroleum-producing basins in the United States. More than in any other region, increased use of preferred management practices in Permian Basin oil fields will have a substantial impact on domestic production because of the large remaining oil resource. The Bureau of Economic Geology (BEG) and the New Mexico Bureau of Geology and Mineral Resources (NMBGMR) teamed up to conduct this play analysis of the Permian Basin. The objectives of the project were to (1) develop an up-to-date portfolio of oil plays in the Permian Basin of west Texas and southeast New Mexico, (2) study key reservoirs from some of the largest or most active plays to incorporate information on improved practices in reservoir development in the portfolio, and (3) widely disseminate the play portfolio to the public.

The Permian Basin oil-play portfolio has been completed and is presented in this final project report. Thirty-two oil plays covering both the Texas and New Mexico parts of the Permian Basin were defined on the basis of reservoir stratigraphy, reservoir lithology, depositional environment, and structural and tectonic setting. The 1,339 significant-sized reservoirs in the Permian Basin, defined as reservoirs that had cumulative production $>1 \mathrm{MMbbl}\left(1.59 \times 10^{5} \mathrm{~m}^{3}\right)$ of oil through December 31,2000 , were each assigned to a play. A reservoir database was established that lists by play the Railroad Commission of Texas (RRC) reservoir number and district (Texas only), official field and reservoir name, year the reservoir was discovered, depth to the top of the reservoir, production during 2000, and cumulative production through 2000. In Texas, cumulative production is listed only under the final reservoir name into which one or more other reservoirs had been transferred.

All significant-sized oil reservoirs in the Permian Basin were mapped in a Geographic Information System (GIS). Different procedures were used for reservoirs in Texas and New Mexico because of different data available in each state. In both states, mapping of the reservoir outlines was done by play in ArcView ${ }^{\mathrm{TM}}$ GIS. The GIS play maps from Texas and New Mexico were merged to form digital data files, or shapefiles, of each play in the Permian Basin. Play boundaries were drawn for each play, which include areas where fields in that play occur but reservoirs are $<1 \mathrm{MMbbl}\left(1.59 \times 10^{5} \mathrm{~m}^{3}\right)$ of cumulative production. The final reservoir shapefile for each play contains the geographic location of the reservoirs in the play and all associated reservoir information within the linked dBASE data table. The final GIS product of this process is an ArcView project file containing the base map, the series of play-specific reservoir shapefiles, and the play-boundary shapefile.

Analysis of production data indicates that the Permian Basin remains a major oil-producing region. Oil production from the significant-sized reservoirs in the Permian Basin having cumulative production $>1 \mathrm{MMbbl}\left(1.59 \times 10^{5} \mathrm{~m}^{3}\right)$ was 301.4 MMbbl $\left(4.79 \times 10^{8} \mathrm{~m}^{3}\right)$ in 2000 . The top four oil-producing plays in 2000 were the Northwest Shelf San Andres Platform Carbonate play (50.7 MMbbl $\left.\left[\left(8.06 \times 10^{6} \mathrm{~m}^{3}\right)\right]\right)$, 
the Leonard Restricted Platform Carbonate play (49.9 MMbbl $\left.\left[\left(7.93 \times 10^{6} \mathrm{~m}^{3}\right)\right]\right)$, the Spraberry/Dean Submarine-Fan Sandstone play $\left(27.6 \mathrm{MMbbl}\left[\left(4.39 \times 10^{6} \mathrm{~m}^{3}\right)\right]\right)$, and the San Andres Platform Carbonate play (26.4 MMbbl $\left.\left[\left(4.20 \times 10^{6} \mathrm{~m}^{3}\right)\right]\right)$. Cumulative Permian Basin production through 2000 was $28.9 \mathrm{Bbbl}\left(4.79 \times 10^{9} \mathrm{~m}^{3}\right)$. The top four plays in cumulative production are the Northwest Shelf San Andres Platform Carbonate play (3.97 Bbbl $\left.\left[6.31 \times 10^{8} \mathrm{~m}^{3}\right]\right)$, the Leonard Restricted Platform Carbonate play (3.30 Bbbl $\left.\left[5.25 \times 10^{8} \mathrm{~m}^{3}\right]\right)$, the Pennsylvanian and Lower Permian Horseshoe Atoll Carbonate play $\left(2.70 \mathrm{Bbbl}\left[4.29 \times 10^{8} \mathrm{~m}^{3}\right]\right)$, and the San Andres Platform Carbonate play $\left(2.15 \mathrm{Bbbl}\left[3.42 \times 10^{8} \mathrm{~m}^{3}\right]\right)$.

Reservoir-characterization studies of key reservoirs from three of the largest or most active plays in the Permian Basin were conducted. Detailed studies were made of the following reservoirs: Kelly-Snyder (SACROC unit) in the Pennsylvanian and Lower Permian Horseshoe Atoll Carbonate play, Fullerton in the Leonardian Restricted Platform Carbonate play, and Barnhart (Ellenburger) in the Ellenburger Selectively Dolomitized Ramp Carbonate play. The geologic heterogeneity in these reservoirs was investigated to better understand production constraints that would apply to all reservoirs in that play. For each of these detailed reservoir studies, technologies for further, economically viable exploitation were investigated. Information on improved practices in reservoir development was incorporated into the portfolio.

The play portfolio presented in this report contains a summary description of each of the 32 oil plays, including key reservoir characteristics and preferred management practices. A map of each play locates all significant-sized reservoirs in the play. Pagesized maps are presented in hard copy in the report, and large play maps are included as pdf files on the $\mathrm{CD}$ that accompanies the report. The $\mathrm{CD}$ also contains a pdf version of the report, the GIS project, and a digital spreadsheet of the reservoir database. The GIS project links the play maps to a database listing cumulative production and other reservoir information. 


\section{INTRODUCTION}

This report summarizes the results of research conducted as part of the DOE Identification and Demonstration of Preferred Upstream Management Practices for the Oil Industry (PUMP II) program. The project, "Play Analysis and Digital Portfolio of Major Oil Reservoirs in the Permian Basin: Application and Transfer of Advanced Geological and Engineering Technologies for Incremental Production Opportunities," focused on the Permian Basin of west Texas and southeast New Mexico (figs. 1, 2), a major petroleum-producing basin in the United States. The Bureau of Economic Geology (BEG) and the New Mexico Bureau of Geology and Mineral Resources (NMBGMR) teamed up to conduct this play analysis of the Permian Basin. The objectives of the project were to (1) develop an up-to-date portfolio of oil plays in the Permian Basin of West Texas and southeast New Mexico, (2) study key reservoirs from some of the largest or most active plays to incorporate information on improved practices in reservoir development in the portfolio, and (3) widely disseminate the play portfolio to the public. The oil-play portfolio contains play maps that locate all significant-sized reservoirs in the play having a cumulative production of $>1 \mathrm{MMbbl}\left(1.59 \times 10^{5} \mathrm{~m}^{3}\right)$ through December 31, 2000 . Play maps are linked to a database listing cumulative production and other reservoir information. The portfolio also includes a summary description of each play, including key reservoir characteristics and preferred management practices, where possible.

The Permian Basin produced 17 percent of the total U.S. oil production in 2002, and it contains an estimated 22 percent of the proved oil reserves in the United States (Energy Information Administration, 2003). Moreover, this region has the biggest potential for additional

oil production in the country, containing 29 percent $\left[17.6 \mathrm{Bbbl}\left(2.80 \times 10^{9} \mathrm{~m}^{3}\right)\right]$ of estimated future oil reserve growth (Root and others, 1995). Original oil in place (OOIP) in the 


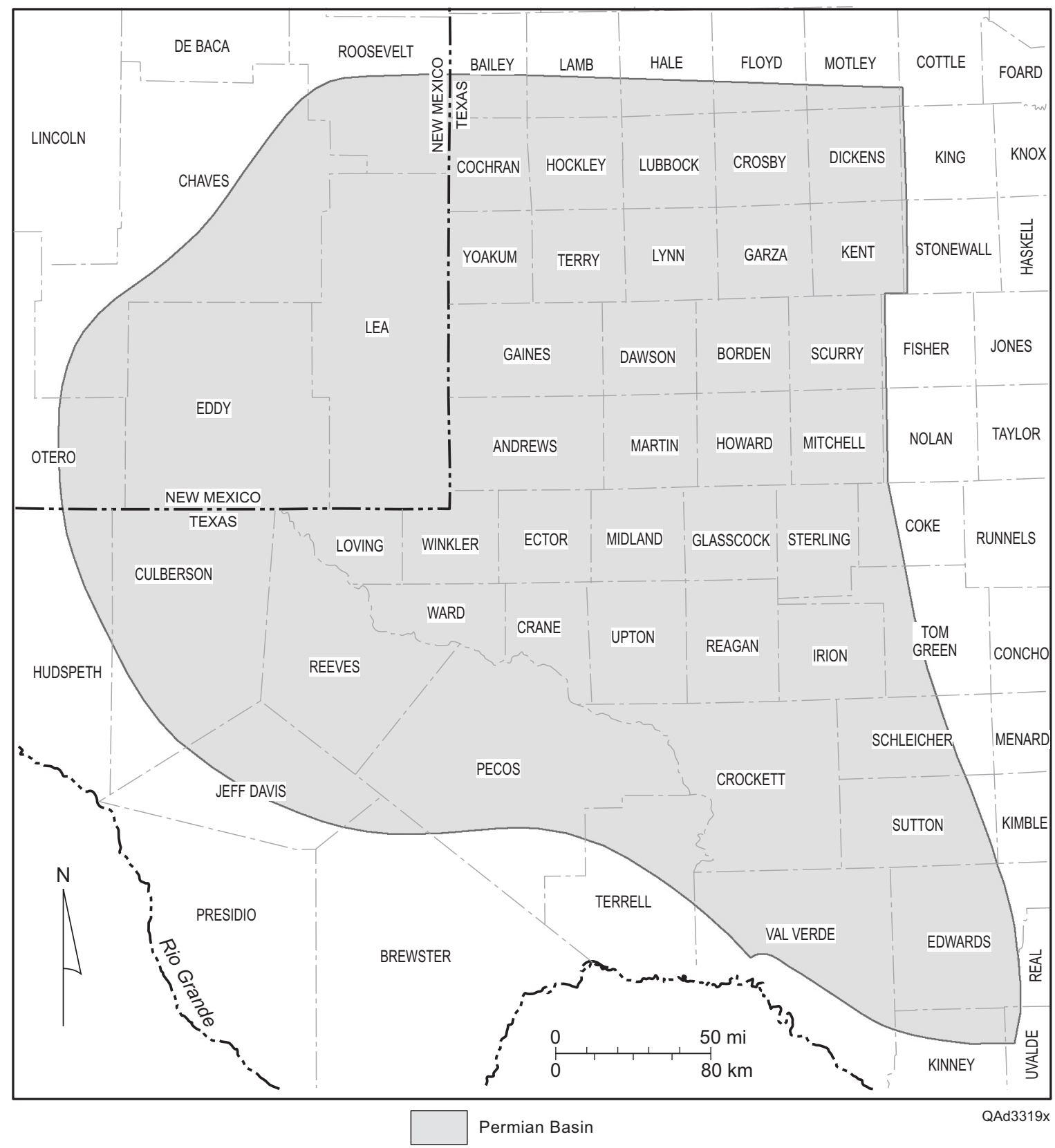

Figure 1. Counties in Texas and New Mexico in the Permian Basin geologic province. 


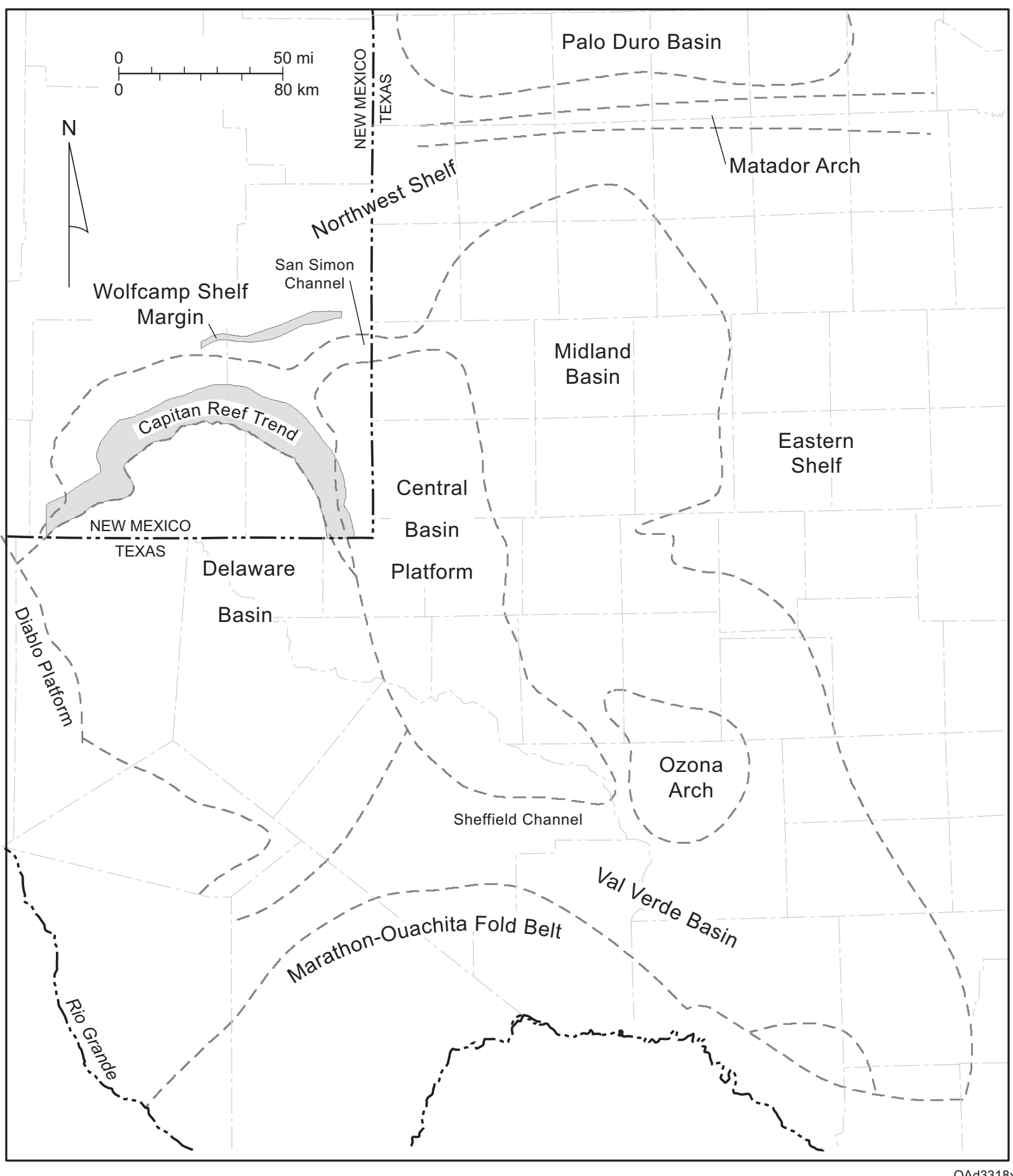

Figure 2. Major subdivisions and boundaries of the Permian Basin in west Texas and southeast New Mexico. Modified from Silver and Todd (1969), Hills (1984), Frenzel and others (1988), Kosters and others (1989), Ewing (1990), Tyler and others (1991), Kerans and Fitchen (1995). The Permian Basin is divided into the Northwest Shelf, Delaware Basin, Central Basin Platform, Midland Basin, Ozona Arch, Val Verde Basin, and Eastern Shelf. 
Permian Basin was $\sim 106 \mathrm{Bbbl}\left(1.69 \times 10^{10} \mathrm{~m}^{3}\right)$ of oil (Tyler and Banta, 1989). After reaching a peak production of $>665 \mathrm{MMbbl}\left(1.06 \times 10^{8} \mathrm{~m}^{3}\right)$ per year in the early 1970 's, Permian Basin oil production has continuously fallen. By 2000, production had fallen to 301.4 MMbbl $\left(4.79 \times 10^{7} \mathrm{~m}^{3}\right)$, or less than half its peak production. Despite the continuing fall in production, the Permian Basin still holds a significant volume of recoverable oil. Although $\sim 29 \mathrm{Bbbl}$ $\left(4.61 \times 10^{9} \mathrm{~m}^{3}\right)$ of oil has been produced to date, this production represents only $\sim 27$ percent of the OOIP. Of the huge remaining resource in the basin, as much as $30 \mathrm{Bbbl}\left(4.77 \times 10^{9} \mathrm{~m}^{3}\right)$ of mobile oil and $45 \mathrm{Bbbl}\left(7.15 \times 10^{9} \mathrm{~m}^{3}\right)$ of residual oil remains as a target for improved technology and recovery strategies (Tyler and Banta, 1989). More than in any other region, increased use of preferred management practices in Permian Basin oil fields will have a substantial impact on domestic production because of the large remaining oil resource.

The Permian Basin is a mature area in which much of its future production will result from improved recovery from existing fields. One way of increasing recovery in a reservoir is to apply methods that have been used successfully in similar reservoirs. In order to do so, however, it is necessary to understand how reservoirs group naturally into larger families, or plays. A play is an assemblage of geologically similar reservoirs exhibiting the same source, reservoir, and trap characteristics (White, 1980). Plays are delineated primarily according to the original depositional setting of the reservoirs or, less commonly, their relation to regional erosional surfaces or diagenetic facies (Galloway and others, 1983). Because of their relative geologic homogeneity, reservoirs in the same play have similar production characteristics. Characteristics of better known reservoirs may be extrapolated with relative confidence to other reservoirs within the same play. Reservoir development methods that have been demonstrated to work well in one reservoir should be applicable to other reservoirs in the play. 
This report updates and expands information in the pioneering volume Atlas of Major Texas Oil Reservoirs (Galloway and others, 1983), which was published by the Bureau of Economic Geology in 1983. Publication of the Texas oil atlas was a milestone in the application of geologic and engineering play analysis, but that volume is now out of date. The data in the atlas represent oil production only through December 31, 1981. Furthermore, the atlas included only reservoirs in the Texas part of the Permian Basin that had produced >10 MMbbl $\left(1.59 \times 10^{6} \mathrm{~m}^{3}\right)$ of oil. Finally, since publication of the oil atlas, there has been considerable additional geologic and engineering investigation of oil reservoirs in the Permian Basin. As a result of this work, many of the Permian Basin oil plays defined in the Atlas of Major Texas Oil Reservoirs needed to be revised and renamed. This new Permian Basin oil-play portfolio provides that revision and update.

\section{EXPERIMENTAL METHODS}

No experimental methods or equipment were used for this study. Information was obtained from published and publicly available sources and from commercially available databases. Reservoir locations in Texas were derived from producing-well location information in Landmark Graphic's Datastar ${ }^{\mathrm{TM}}$ and DrillingInfo.com, Inc. The ArcView ${ }^{\mathrm{TM}}$ GIS software package was used for mapping the reservoirs. 


\section{RESULTS AND DISCUSSION}

\section{Definition of the Permian Basin}

Oil production in the Permian Basin occurs from reservoirs in Paleozoic strata, from Ordovician through Permian age (fig. 3). For plays to be defined in the Permian Basin, it was necessary to determine the basin boundaries. The Permian Basin is subdivided into the Northwest Shelf, Delaware Basin, Central Basin Platform, Midland Basin, Ozona Arch, Val Verde Basin, and Eastern Shelf, (fig. 2). In the west, the basin is bounded by the Guadalupe, Sacramento, Sierra Blanca, and Capitan Mountains in New Mexico and the Diablo Plateau in Texas. To the north, the Permian Basin is bounded by the Sin Nombre Arch of DeBaca County and the Roosevelt Uplift of Roosevelt County in New Mexico. In Texas the Matador Arch forms the northern boundary and separates the Midland Basin from the Palo Duro Basin. The southern boundary is the Marathon-Ouachita Fold Belt.

The eastern boundary is more difficult to define. Reservoirs on the Eastern Shelf of the Midland Basin are traditionally considered to be in the Permian Basin geologic province (Galloway and others, 1983). The Eastern Shelf, however, grades eastward onto the Concho Platform and Bend Arch in the North-Central Texas geologic province, with no clearly defined eastern limit. For this study, the eastern boundary of the Permian Basin was selected to follow the approximate position of the shelf edge during early Wolfcampian (Cisco Saddle Creek Limestone) time (Brown and others, 1987, 1990). The counties that occur in the Permian Basin are shown in figure 1. This definition of the Permian Basin is similar to that of Hills (1984).

The current structural features of the Permian Basin (fig. 2) developed during Late Mississippian and Early Pennsylvanian time (Hills, 1984; Frenzel and others, 1988). Prior to this 
(a)

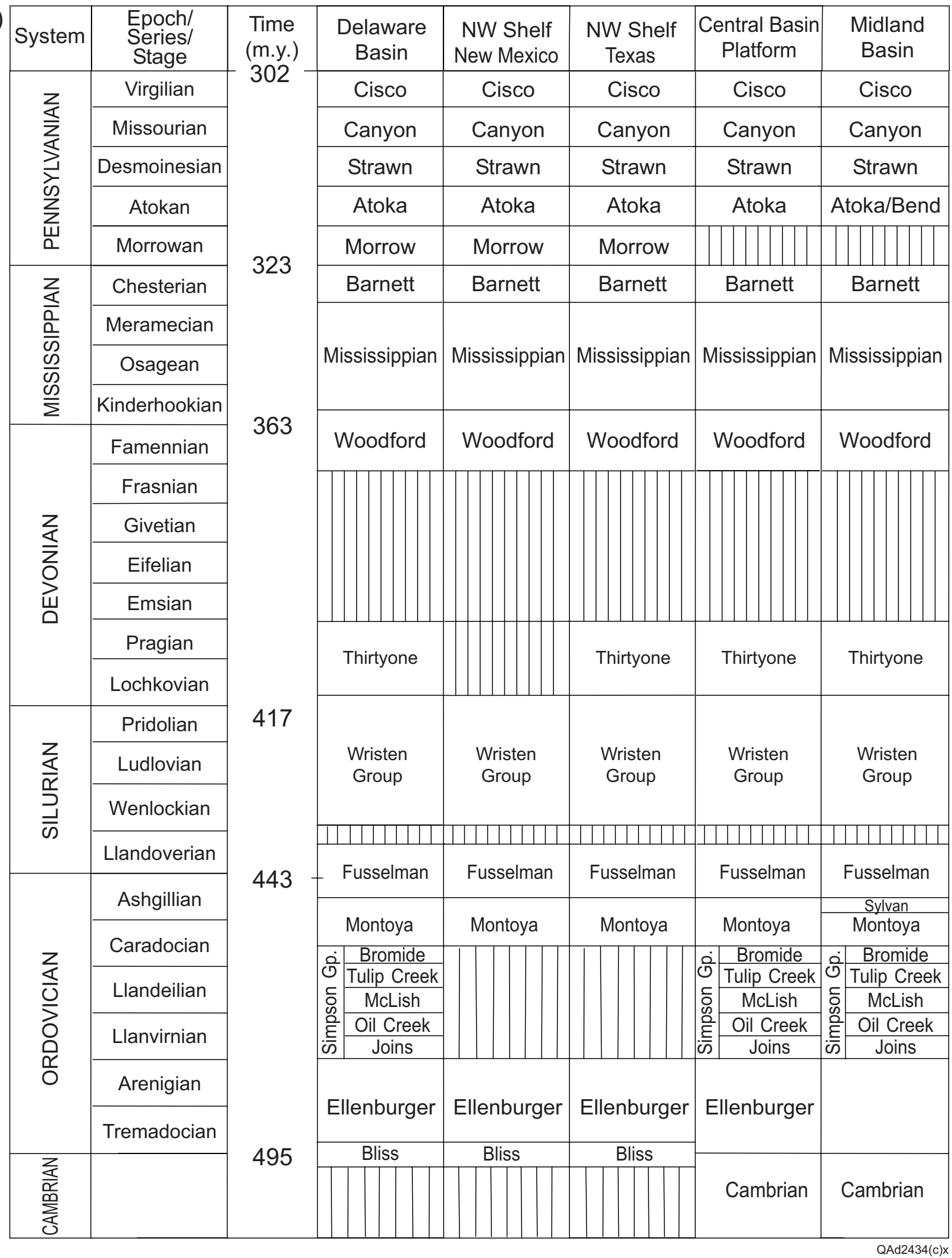

Figure 3a. Stratigraphic nomenclature for the Cambrian through Pennsylvanian section in the Permian Basin. 
(b)

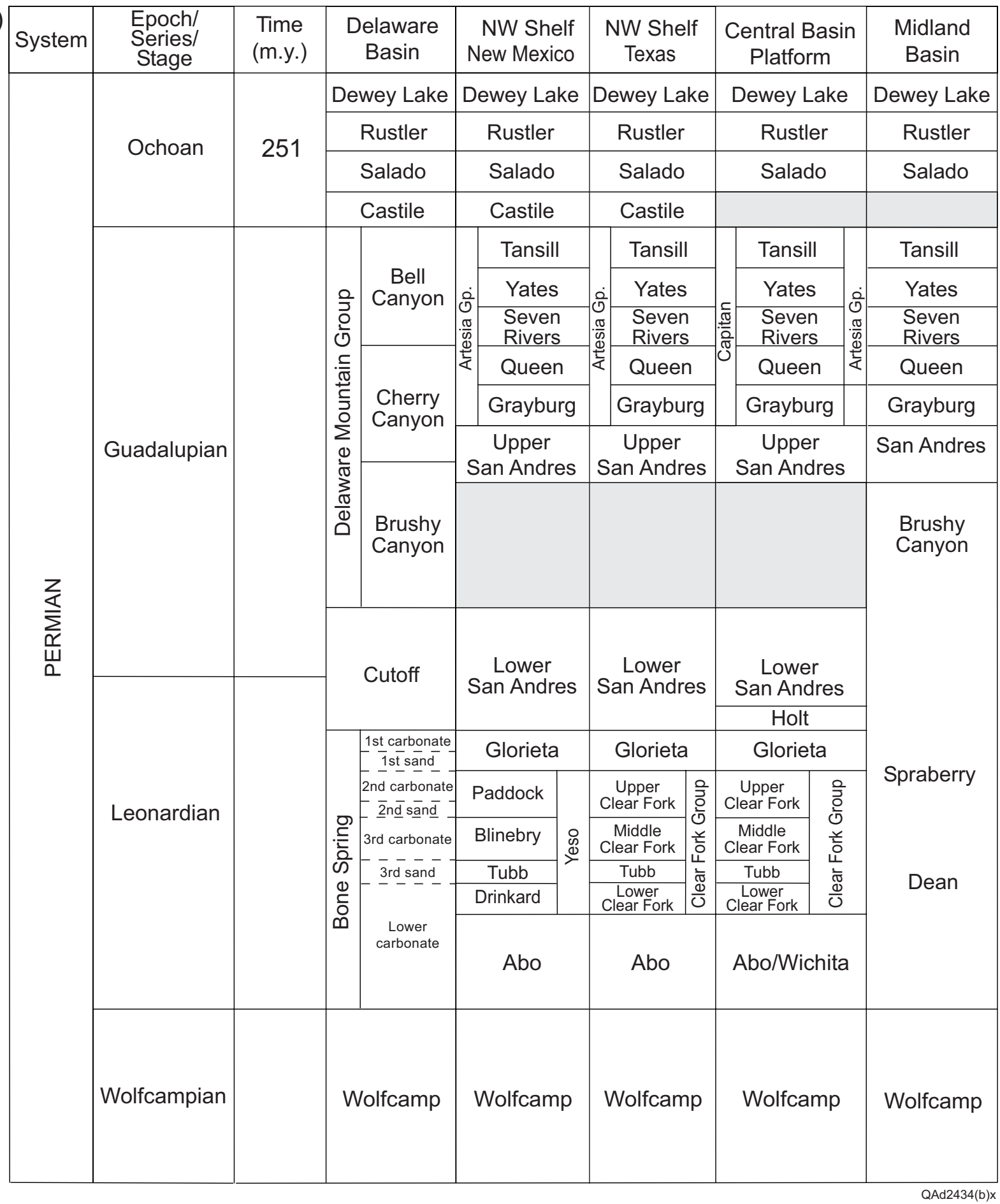

Figure $3 b$. Stratigraphic nomenclature for the Permian section in the Permian Basin. 
time, a shallow, downwarped area was centered in Pecos and Terrell Counties during Simpson time, which was named the Tobosa Basin (Galley, 1958).

Some plays extend from the Permian Basin east into North-Central Texas. So that truncating plays can be avoided, plays that occur mainly in the Permian Basin are presented in their entirety, even though some of the reservoirs in the play actually occur in counties in the North-Central Texas geologic province. Plays that occur mainly in North-Central Texas are not included in this project, even if a few of the reservoirs within the plays are in the Permian Basin. However, so that cumulative production for the Permian Basin can be totaled, reservoirs having production of $>1 \mathrm{MMbbl}\left(1.59 \times 10^{5} \mathrm{~m}^{3}\right)$ that are assigned to a North-Central Texas play but occur in Permian Basin counties are identified in tables in the database. These reservoirs are in the Pennsylvanian and Lower Permian Reef/Bank play and the Upper Pennsylvanian Shelf Sandstone play in North-Central Texas.

\section{Identification of Significant-Sized Reservoirs}

This play portfolio includes significant-sized reservoirs, which are defined herein as having cumulative production of $>1 \mathrm{MMbbl}\left(1.59 \times 10^{5} \mathrm{~m}^{3}\right)$ of oil through December 31, 2000 . Cumulative production data sources used to identify these reservoirs differed in Texas and New Mexico.

Texas

Production records of the Railroad Commission of Texas (RRC) were used to identify all reservoirs in the Texas part of the Permian Basin that had produced $>1 \mathrm{MMbbl}\left(1.59 \times 10^{5} \mathrm{~m}^{3}\right)$ of oil through 2000. Cumulative production data were obtained from the 2000 Oil and Gas 
Annual Report (Railroad Commission of Texas, 2001), along with official field and reservoir name, RRC District, year the reservoir was discovered, and depth to the top of the reservoir. The RRC unique reservoir number was obtained for each reservoir using the online database at http://driller.rrc.state.tx.us/Apps/WebObjects/acti. Condensate production was not included. A total of 1,040 reservoirs have produced $>1 \mathrm{MMbbl}\left(1.59 \times 10^{5} \mathrm{~m}^{3}\right)$ of oil in the Texas part of the Permian Basin.

Many reservoirs were initially designated as separate reservoirs by the RRC but subsequently transferred into another reservoir. In this report, cumulative production is listed only under the final reservoir name (as of 2000) into which one or more other reservoirs had been transferred. Reservoirs that had other reservoirs transferred into them are highlighted by gray shading in the play tables. Cumulative production values listed for these reservoirs represent total production, including production both before and after reservoirs were combined.

This method of reporting differs from that of the RRC in its annual reports. RRC reports list production from a reservoir from the time of discovery until its transfer into another reservoir. Once the reservoir is combined with another, production from the original reservoir continues to be listed year after year, never increasing because all new production is assigned to the new reservoir. We chose not to follow this method because some production that should be reported as part of total production from a reservoir would be lost if the reservoir had not produced $>1 \mathrm{MMbbl}\left(1.59 \times 10^{5} \mathrm{~m}^{3}\right)$ before it was transferred into another reservoir.

An example should help clarify this compilation method. Conger (Penn) reservoir in Glasscock County is listed in the 2000 Oil \& Gas Annual Report (Railroad Commission of Texas, 2001) as having produced 19,249,341 bbl $\left(3.06 \times 10^{6} \mathrm{~m}^{3}\right)$ of oil through 2000. In the play tables, however, Conger (Penn) is listed as having produced 20,406,213 bbl 
$\left(3.24 \times 10^{6} \mathrm{~m}^{3}\right)$. This difference occurs because three other reservoirs were transferred into Conger (Penn)—Big Salute (Canyon), Conger (Canyon), and Conger (Cisco). Big Salute produced $872,144 \mathrm{bbl}\left(1.39 \times 10^{5} \mathrm{~m}^{3}\right)$ of oil from the time it was discovered in 1974 until it was transferred into Conger (Penn) in 1978. Conger (Canyon) and Conger (Cisco) reservoirs produced 49,631 and 235,127 bbl $\left(7.89 \times 10^{3} \mathrm{~m}^{3}\right.$ and $\left.3.74 \times 10^{4} \mathrm{~m}^{3}\right)$, respectively, before they were transferred into the Conger (Penn) reservoir. Because the goal of this report is to show total production from significant-sized oil reservoirs, we have added production from these three reservoirs to the total shown for Conger (Penn). Otherwise, this production would not have been included because none of these three reservoirs produced $>1$ MMbbl $\left(1.59 \times 10^{5} \mathrm{~m}^{3}\right)$ before being transferred into Conger (Penn).

New Mexico

Cumulative production data for each reservoir in New Mexico through December 31, 1993, were obtained from the 1993 Annual Report of the New Mexico Oil and Gas Engineering Committee (New Mexico Oil and Gas Engineering Committee, 1993). Annual oil production data for each reservoir for years subsequent to 1993 were obtained from the 1994, 1995, 1996, 1997, 1998, 1999, and 2000 annual reports of the New Mexico Oil and Gas Engineering Committee. Cumulative production for each reservoir was calculated by taking the annual production from 1994 through 2000 and adding it to the cumulative production data obtained from the 1993 annual report. This approach was used because cumulative production data tabulated by reservoir in reports of the New Mexico Oil and Gas Engineering Committee through 1993 are valid. Cumulative production data in the post-1993 reports are not valid because they do not include historical production from several types of wells (Dutton and others, 2003), 
although the annual oil production data in these reports are valid. A total of 299 reservoirs in the New Mexico part of the Permian Basin had production $>1$ MMbbl $\left(1.59 \times 10^{5} \mathrm{~m}^{3}\right)$ through 2000 .

\section{Total Permian Basin Production}

The 1,339 significant-sized reservoirs in the Permian Basin produced a total of $28.9 \mathrm{Bbbl}$ $\left(4.59 \times 10^{9} \mathrm{~m}^{3}\right)$ of oil through $2000-24.4 \mathrm{Bbbl}\left(3.88 \times 10^{9} \mathrm{~m}^{3}\right)$ from 1,040 reservoirs in Texas and 4.5 Bbbl $\left(7.15 \times 10^{8} \mathrm{~m}^{3}\right)$ from 299 reservoirs in New Mexico. The production from these reservoirs accounts for 95 percent of total Permian Basin production of $30.4 \mathrm{Bbbl}$ $\left(4.83 \times 10^{9} \mathrm{~m}^{3}\right)$ through 2000 . Total production from all reservoirs in the Texas part of the Permian Basin (all reservoirs in RRC Districts 7C, 8, and 8A) was $25.6 \mathrm{Bbbl}\left(4.07 \times 10^{9} \mathrm{~m}^{3}\right)$ through 2000 (Railroad Commission of Texas, 2001). Total production from all reservoirs in the New Mexico part of the Permian Basin was $4.8 \mathrm{Bbbl}\left(7.63 \times 10^{8} \mathrm{~m}^{3}\right)$ through 2000 .

The value of $30.4 \mathrm{Bbbl}\left(4.83 \times 10^{9} \mathrm{~m}^{3}\right)$ cumulative oil production from the Permian Basin differs from that of the U.S. Geological Survey (USGS) 1995 assessment (U.S. Geological Survey, 1995, 1996). That study indicates that total Permian Basin oil production through 1990

was $34.9 \mathrm{Bbbl}\left(5.55 \times 10^{9} \mathrm{~m}^{3}\right)$. The reason for the difference is that the USGS study covered a larger area, extending farther east into North-Central Texas and farther northwest in New Mexico.

\section{Play Definitions}

A major goal of this project is to define oil plays in the Permian Basin. Plays can generally be considered as groups of reservoirs that have similar geologic parameters, such as a common stratigraphic unit, reservoir lithology, reservoir depositional environment, structural and tectonic setting, or trapping mechanism. Gas plays were not included in this project. 
Thirty-two oil plays covering both the Texas and New Mexico parts of the Permian Basin were defined (tables 1, 2). In most cases, the play names established in Texas can also be used in New Mexico because of identical stratigraphy, tectonic setting, and depositional environments. Twelve of the plays contain reservoirs in both Texas and New Mexico. Fifteen plays contain reservoirs in Texas only, and five plays contain reservoirs in New Mexico only. The plays have been extensively modified from those defined in the Atlas of Major Texas Oil Reservoirs (Galloway and others, 1983) on the basis of the past 20 years of research on Permian Basin reservoirs. The oil atlas and more recent play assessments of the Permian Basin by Kosters and others (1989), Tyler and others (1991), Holtz and Kerans (1992), Holtz and others (1992), Holtz (1993), Holtz and others (1993), New Mexico Bureau of Mines and Mineral Resources (1993), Ruppel and Holtz (1994), and Dutton and others (2000b) provided the foundation on which the play assessment was based.

\section{Play Designations of Reservoirs}

A total of 1,040 reservoirs in Texas and 299 reservoirs in New Mexico had produced $>1 \mathrm{MMbbl}\left(1.59 \times 10^{5} \mathrm{~m}^{3}\right)$ of oil through 2000 , and each of these reservoirs was assigned to a play. Reservoirs were assigned to plays on the basis of productive stratal unit (formation), depositional setting, tectonic and structural location within the Permian Basin, reservoir lithology, postdepositional karstification, and trapping mechanism of the reservoir. Reservoir assignments are listed, by play, in the tables that accompany the play summaries. A digital version of the play tables is on the $\mathrm{CD}$ that is included with this report. The plays have all been given a play code - a number from 101 to 132 - to facilitate sorting by plays in the digital data tables. 
Table 1. Production in 2000 and cumulative production through December 31, 2000, of oil plays in the Permian Basin, listed by reservoir age.

\begin{tabular}{|c|c|c|c|c|}
\hline PLAY & PLAY CODE & STATE & $\begin{array}{r}2000 \text { PROD } \\
\text { (MMbbl) }\end{array}$ & $\begin{array}{r}\text { CUMPROD } \\
\text { (MMbbl) }\end{array}$ \\
\hline \multicolumn{5}{|l|}{ Guadalupian } \\
\hline Artesia Platform Sandstone & 132 & $\mathrm{TX} \& \mathrm{NM}$ & $6,526,676$ & $1,855,409,025$ \\
\hline Delaware Mountain Group Basinal Sandstone & 130 & TX \& NM & $9,208,247$ & $351,912,395$ \\
\hline Grayburg High-Energy Platform Carbonate-Ozona Arch & 129 & $\mathrm{TX}$ & $1,968,685$ & $298,378,769$ \\
\hline Grayburg Platform Carbonate & 128 & TX & $10,104,204$ & $1,271,232,325$ \\
\hline Grayburg Platform Mixed Clastic/Carbonate & 127 & TX & $7,806,840$ & $669,727,337$ \\
\hline San Andres/Grayburg Lowstand Carbonate & 126 & TX & $9,357,241$ & $681,131,877$ \\
\hline Upper San Andres and Grayburg Platform Mixed_-Artesia Vacuum Trend & 125 & NM & $11,392,997$ & $796,416,386$ \\
\hline Upper San Andres and Grayburg Platform Mixed-Central Basin Platform Trend & 124 & NM & $5,790,360$ & $808,957,693$ \\
\hline San Andres Platform Carbonate & 123 & $\mathrm{TX}$ & $26,420,818$ & $2,151,296,650$ \\
\hline San Andres Karst-Modified Platform Carbonate & 122 & TX & $11,460,129$ & $1,567,103,814$ \\
\hline Eastern Shelf San Andres Platform Carbonate & 121 & TX & $6,613,837$ & $706,897,011$ \\
\hline \multirow[t]{2}{*}{ Northwest Shelf San Andres Platform Carbonate } & 120 & TX \& NM & $50,666,870$ & $3,969,256,500$ \\
\hline & & & $158,834,405$ & $15,307,319,948$ \\
\hline Spraberry/Dean Submarine-Fan Sandstone & 119 & TX & $27,576,283$ & $1,287,098,237$ \\
\hline Bone Spring Basinal Sandstone and Carbonate & 118 & NM & $2,455,154$ & $70,703,460$ \\
\hline Leonard Restricted Platform Carbonate & 117 & $\mathrm{TX} \& \mathrm{NM}$ & $49,928,957$ & $3,297,197,998$ \\
\hline \multirow{2}{*}{ Abo Platform Carbonate } & 116 & $\mathrm{TX} \& \mathrm{NM}$ & $6,105,583$ & $541,459,683$ \\
\hline & & & $86,065,977$ & $5,196,459,378$ \\
\hline \multicolumn{5}{|l|}{ Wolfcampian } \\
\hline Wolfcamp/Leonard Slope and Basinal Carbonate & 115 & $\mathrm{TX} \& \mathrm{NM}$ & $9,046,188$ & $194,975,500$ \\
\hline \multirow[t]{2}{*}{ Wolfcamp Platform Carbonate } & 114 & $\mathrm{TX} \& \mathrm{NM}$ & $4,012,646$ & $457,405,339$ \\
\hline & & & $13,058,834$ & $652,380,839$ \\
\hline \multicolumn{5}{|l|}{ Pennsylvanian } \\
\hline Upper Pennsylvanian and Lower Permian Slope and Basinal Sandstone* & 113 & TX & $1,802,373$ & $271,448,389$ \\
\hline Pennsylvanian and Lower Permian Horseshoe Atoll Carbonate & 112 & TX & $13,686,639$ & $2,699,242,936$ \\
\hline Pennsylvanian Platform Carbonate & 111 & TX & $2,076,281$ & $340,469,274$ \\
\hline Northwest Shelf Upper Pennsylvanian Carbonate & 110 & NM & $4,871,162$ & $353,848,173$ \\
\hline Northwest Shelf Strawn Patch Reef & 109 & NM & $1,064,882$ & $69,863,831$ \\
\hline Pennsylvanian and Lower Permian Reef/Bank** & 25 & $\mathrm{TX}$ & 315,183 & $92,104,283$ \\
\hline \multicolumn{5}{|l|}{ Mississippian } \\
\hline \multirow[t]{2}{*}{ Mississippian Platform Carbonate } & 108 & $\mathrm{TX}$ & 91,765 & $15,110,822$ \\
\hline & & & 91,765 & $15,110,822$ \\
\hline \multicolumn{5}{|l|}{ Devonian } \\
\hline Devonian Thirtyone Ramp Carbonate & 107 & TX & $1,747,319$ & $110,249,504$ \\
\hline \multirow[t]{2}{*}{ Devonian Thirtyone Deepwater Chert } & 106 & TX \& NM & $6,786,521$ & $785,929,988$ \\
\hline & & & $8,533,840$ & $896,179,492$ \\
\hline \multicolumn{5}{|l|}{ Silurian } \\
\hline Wristen Buildups and Platform Carbonate & 105 & TX \& NM & $4,773,912$ & $888,757,885$ \\
\hline \multirow{2}{*}{ Fusselman Shallow Platform Carbonate } & 104 & $\mathrm{TX} \& \mathrm{NM}$ & $2,046,889$ & $356,268,389$ \\
\hline & & & $6,820,801$ & $1,245,026,274$ \\
\hline \multicolumn{5}{|l|}{ Ordovician } \\
\hline Simpson Cratonic Sandstone & 103 & $\mathrm{TX} \& \mathrm{NM}$ & 420,651 & $103,228,356$ \\
\hline Ellenburger Karst-Modified Restricted Ramp Carbonate & 102 & $\mathrm{TX} \& \mathrm{NM}$ & $2,802,096$ & $1,487,309,287$ \\
\hline \multirow[t]{2}{*}{ Ellenburger Selectively Dolomitized Ramp Carbonate* \#\# } & 101 & $\mathrm{TX}$ & 537,120 & $163,734,910$ \\
\hline & & & $3,759,867$ & $1,754,272,553$ \\
\hline
\end{tabular}

*Includes all reservoirs in this play, including ones in North-Central Texas geologic province.

${ }^{* \star}$ Not included in play portfolio because most of play is in North-Central Texas geologic province. Production listed here represents only the 10 reservoirs in the Permian Basin part of the play.

\#Not included in play portfolio because most of play is in North-Central Texas geologic province. Production listed here represents only the 5 reservoirs in the Permian Basin part of the play.

\#\# Does not include $\sim 21 \mathrm{MMbbl}$ of production from Ellenburger reservoir at Big Lake field. All production from Big Lake field was assigned to the Grayburg by the RRC. 
Table 2. Cumulative production of oil plays in the Permian Basin, ranked by production.

Production is through December 31, 2000.

\section{Oil plays}

Cum. prod.

(MMbbl)

Northwest Shelf San Andres Platform Carbonate

$3,969.3$

Leonard Restricted Platform Carbonate

$3,297.2$

Pennsylvanian and Lower Permian Horseshoe Atoll Carbonate

$2,699.2$

San Andres Platform Carbonate

$2,151.3$

Artesia Platform Sandstone

$1,855.4$

San Andres Karst-Modified Platform Carbonate

$1,567.1$

Ellenburger Karst-Modified Restricted Ramp Carbonate

$1,487.3$

Spraberry/Dean Submarine-Fan Sandstone

$1,287.1$

Grayburg Platform Carbonate

$1,271.2$

Wristen Buildups and Platform Carbonate

888.8

Upper San Andres and Grayburg Platform Mixed-Central Basin Platform Trend

809.0

Upper San Andres and Grayburg Platform Mixed-Artesia Vacuum Trend

796.4

Devonian Thirtyone Deepwater Chert

785.9

Eastern Shelf San Andres Platform Carbonate

706.9

San Andres/Grayburg Lowstand Carbonate

681.1

Grayburg Platform Mixed Clastic/Carbonate

669.7

Abo Platform Carbonate

541.5

Wolfcamp Platform Carbonate

457.4

Fusselman Shallow Platform Carbonate

356.3

Northwest Shelf Upper Pennsylvanian Carbonate

353.8

Delaware Mountain Group Basinal Sandstone

351.9

Pennsylvanian Platform Carbonate

340.5

Grayburg High-Energy Platform Carbonate-Ozona Arch

298.4

Upper Pennsylvanian and Lower Permian Slope

271.4

Wolfcamp/Leonard Slope and Basinal Carbonate

195.0

Queen Tidal-Flat Sandstone

179.6

Ellenburger Selectively Dolomitized Ramp Carbonate ${ }^{* *}, \#$

163.7

Devonian Thirtyone Ramp Carbonate

110.2

Simpson Cratonic Sandstone

103.2

Pennsylvanian and Lower Permian Reef/Bank*

92.1

$\begin{array}{ll}\text { Bone Spring Basinal Sandstone and Carbonate } & 70.7\end{array}$

Northwest Shelf Strawn Patch Reef

69.7

Mississippian Platform Carbonate

15.1

Upper Pennsylvanian Shelf Sandstone ${ }^{\#}$

Total Permian Basin Production

$28,901.0$

\footnotetext{
** Includes all reservoirs in this play, including ones in North-Central Texas geologic province.

${ }^{*}$ Not included in play portfolio because most of play is in North-Central Texas geologic province. Production listed here represents only the 10 reservoirs in the Permian Basin part of the play.

\#Not included in play portfolio because most of play is in North-Central Texas geologic province. Production listed here represents only the five reservoirs in the Permian Basin part of the play.

${ }^{\#}$ Does not include approximately $21 \mathrm{MMbbl}$ of production from Ellenburger reservoir at Big Lake field. All production from Big Lake field is assigned to the Grayburg by the RRC.
} 
The names listed in the tables are the official field and reservoir names designated by the RRC or the Oil Conservation Division (OCD) of the New Mexico Energy, Minerals and Natural Resources Department. In some cases the official reservoir name that was assigned is now interpreted as not being accurate. For example, Moonlight (Mississippian) reservoir in Midland County, Texas, has been assigned to the Pennsylvanian Platform Carbonate play. Despite its official reservoir name, it is interpreted as producing from the Pennsylvanian Atoka interval (Candelaria, 1990).

Assignment of reservoirs to one of the 27 plays in Texas was based primarily on published information and information in hearing files of the RRC. Publications of the BEG, West Texas Geological Society, and Permian Basin Section SEPM, as well as discussions with BEG researchers, were used to make play assignments. The field summaries published by the Bureau of Economic Geology (1957) and the West Texas Geological Society (1982, 1987, 1990, 1994, 1996) and previous studies by Holtz and others (1993) and Dutton and others (2000b) were particularly helpful.

Oil and gas reservoirs (pools) in New Mexico are named according to rules promulgated by the OCD of the New Mexico Energy, Minerals and Natural Resources Department. For most New Mexico reservoirs, most or all production has been obtained from a single stratigraphic unit or formation. In these cases, assignment of a reservoir to a play is straightforward because most plays have a stratigraphic component to their definition. In some reservoirs, however, the OCD has permitted significant commingling of oil and gas production across formational boundaries. In these cases, the stratigraphic component of the pool name contains two or more formational names (for example, the Justis Blinebry Tubb Drinkard pool). In cases where both formational names have been assigned to the same play (for example, production from the Blinebry, Tubb, 
and Drinkard Members of the Yeso Formation is assigned in entirety to the Leonard Restricted Platform Carbonate play), assignment of a reservoir to a play is straightforward.

However, if the formations were assigned to different plays (for example, the Loco Hills Queen Grayburg San Andres pool), then production from the reservoir is divided between two plays. For these pools, records of numerous individual wells were examined to ascertain whether one constituent formation provided the overwhelming percentage of the production or whether all listed formations contributed major percentages of production. In most cases, it was found that one formation contributed the dominant amount of production, and the pool was assigned to the play associated with that formation. This assignment is apparent if only a few wells were completed in a second formation or if wells completed solely in one of the formations recovered only minor volumes of oil (stripper-type wells).

In a few cases, however, it became apparent that multiple formations are major contributors to production from a single pool. In such cases, these pools are cross-listed in multiple plays because it is not possible to assign fractional parts of commingled production to a single reservoir stratum. These cross-listed pools are generally very large, and it has been ascertained that each of the constituent formations has contributed $>1 \mathrm{MMbbl}\left(1.59 \times 10^{5} \mathrm{~m}^{3}\right)$ cumulative production.

Finally, a complication occurs in some lower Paleozoic reservoirs (mainly Devonian and Silurian) where the formational name is inaccurate with respect to modern stratigraphic interpretations. For example, reservoirs that produce from what is now recognized as the Silurian Wristen Group have been historically called Devonian, and this Devonian descriptor is used in the pool name. Because these name designations are official, they are left unchanged in the database. 
The task of assigning reservoirs to plays in New Mexico was also done on the basis of previous studies and published work. Information on reservoir lithology was obtained primarily from field summaries published by the Roswell Geological Society (Roswell Geological Society, 1956, 1960, 1967, 1977, 1988, 1995). Major sources of data are the well records, sample descriptions, and logs on file at the Subsurface Library of the NMBGMR. Descriptions of some reservoirs and plays have been published (LeMay, 1960, 1972; Malek-Aslani, 1985; Gawloski, 1987; Grant and Foster, 1989; New Mexico Bureau of Mines and Mineral Resources, 1993; Baldonado and Broadhead, 2002). Data on depositional environments of reservoirs were obtained from published studies.

\section{Mapping Reservoirs in GIS}

Each of the 1,339 oil reservoirs in the Permian Basin having cumulative production of $>1 \mathrm{MMbbl}\left(1.59 \times 10^{5} \mathrm{~m}^{3}\right)$ was mapped and compiled in a Geographic Information System (GIS) by play. Different procedures were used for reservoirs in Texas and New Mexico because of the different data available in each state. Final ArcView ${ }^{\mathrm{TM}}$ GIS files were produced that illustrate all reservoirs in each play, play boundaries, state and county lines, legal land grid, and boundaries of major geologic elements that relate to play trends and production.

Texas

Numerous data sources were utilized for mapping reservoirs in Texas. The initial dataset

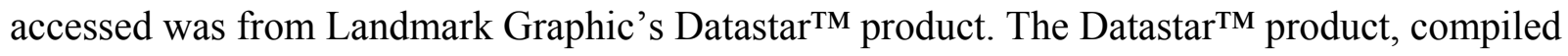
from data maintained by Whitestar Corporation, provides oil and gas well spots, land grids, and 
cultural information for the entire U.S. After initial mapping of reservoirs (Dutton and others, 2004), well-location data obtained from DrillingInfo.com, Inc., were used to verify locations by comparing mapped reservoirs. Other nondigital maps that were used for data verification include BEG oil and gas atlases (Galloway and others, 1983; Kosters and others, 1989), Geomap Company Permian Basin Executive reference map (Geomap Company, 1998), Structurmaps, Ltd., Permian Basin structure map (Structurmaps Ltd., 1970), and Midland Map Company Permian Basin regional base map (Midland Map Company, 1997). Well production was compared using Lasser Inc.'s Texas production database (Lasser Texas Production CD, 2003), as well as RRC production reports (Railroad Commission of Texas, 2001).

Actual mapping of reservoir outlines was done entirely in ArcView ${ }^{\mathrm{TM}}$ GIS using Texas abstract and county-line shapefiles as the base map (Dutton and others, 2004). In order to keep the distance from well locations to the reservoir boundary consistent for each reservoir mapped, selected wells were buffered by $0.5 \mathrm{mi}$. Reservoir outlines generated by this process are intended to show approximate location, size, and shape of each reservoir, but they are not precise boundaries. Reservoir shapes, therefore, should not be used to calculate subsurface reservoir area for accurate volumetric determinations.

The final reservoir shapefile for each play contains the geographic location of each reservoir and all associated information within the linked dBASE data table, including play name (PLAY), play code (PLAY_CODE), RRC unique reservoir number (RRC RESN), RRC district (RRC), field name (FLDNAME), reservoir name (RESNAME), state, county, discovery year (DISCYR), depth in feet to top of the reservoir (DEPTHTOP), 2000 production (2000 PROD) in barrels, and cumulative production (CUMPROD) in barrels through 2000. Some tables also list subplays. The final GIS product of this process is an ArcView project file containing base maps, 
the newly created series of play-specific reservoir shapefiles, and play-boundary shapefiles. The GIS project is included on the CD that accompanies this report. Data tables for each play are included in the play summaries and are available in digital form on the CD.

New Mexico

Those reservoirs with $>1 \mathrm{MMbbl}\left(1.59 \times 10^{5} \mathrm{~m}^{3}\right)$ production were placed into geologic plays and entered into ArcView ${ }^{\mathrm{TM}}$ GIS using pool (reservoir) shapefiles outlining field boundaries copied from the New Mexico pools project (Read and others, 2000). Oil pool boundaries indicated on these maps are the legal boundaries of the pools, as provided by the New Mexico Oil Conservation Division. The rectilinear boundaries of New Mexico reservoirs thus reflect the legal definition of the fields. Data tables for New Mexico reservoirs contain the same headers as for Texas, except for RRC unique reservoir number and district.

\section{Play Boundaries and Play Maps}

The GIS play maps from Texas and New Mexico were merged to form digital data files, or shapefiles, of each play in the Permian Basin. Play boundaries for each play were drawn to include areas where reservoirs in that play occur but are $<1 \mathrm{MMbbl}\left(1.59 \times 10^{5} \mathrm{~m}^{3}\right)$ of cumulative production. These areas should be considered as part of the play, even if no reservoirs from the play have yet produced $>1 \mathrm{MMbbl}\left(1.59 \times 10^{5} \mathrm{~m}^{3}\right)$.

Page-sized play maps, showing reservoirs in the play, play boundaries, and geologic features, are included in the play summaries in this report. These maps are useful in depicting the overall trend of the play and distribution of reservoirs. Reservoir names could not be shown on 
the page-sized maps because of space limitations. In the GIS project included on the CD accompanying this report, field names are available within the associated attribute table. In addition, pdf versions of the play maps are included on the $\mathrm{CD}$, and they have the fields named. Only field names are included, except in cases where reservoir names are also shown for clarity.

\section{Contents of the CD}

A CD is included with this report. It contains a pdf version of the report, pdf maps of all plays, the GIS project, and a digital spreadsheet of the reservoir database. In order for the GIS project to be used, ArcExplorer freeware from ESRI has been included on the CD. A user who has a copy of ArcView 3.1 or higher (a Desktop ESRI GIS software package) can use the full capability of the GIS project. For those not capable of running these GIS applications or those that want printed output, the play maps may also be viewed as pdf files (require Adobe

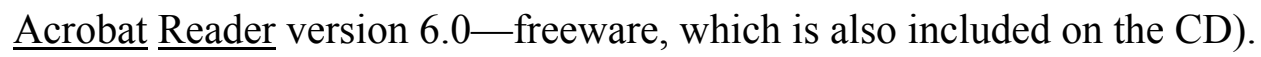

The GIS project consists of the ArcView ${ }^{\mathrm{TM}}$ project file (DOE_PUMPII.apr) and the DOE PUMP II GIS database, which is contained in the GIS2003 subfolder. Basemap data, contained in the basemap folder, include shapefiles such as state and county lines, legal land grid, and boundaries of major geologic elements. Each of the 32 play-boundary shapefiles, contained in the play_bnd folder, appears as a separate layer within the ArcView ${ }^{\mathrm{TM}}$ project, and each of these layers is linked to a play-production data table. The Texas and New Mexico reservoir data shapefiles are contained in two separate folders, named data_nm and data_tx. These shapefiles appear in the ArcView ${ }^{\mathrm{TM}}$ project as separate layers because of discrepancies within the data due to how the data were generated. There are 21 New Mexico reservoir data layers and 27 Texas 
reservoir data layers. Each reservoir data layer is color coded and linked to a corresponding data table.

The digital spreadsheet is an Excel ${ }^{\mathrm{TM}}$ file called Reservoir Database. It contains multiple sheets: (1) Master, (2) By plays, (3) By plays ann prod, (4) By plays cum prod, and (5) By age. The data in the sheets "Master" and "By plays" include all data associated with each reservoir, including play name (PLAY), play code (PLAY_CODE), RRC unique reservoir number (RRC_RESN), RRC district (RRC), field name (FLDNAME), reservoir name (RESNAME), state, county, discovery year (DISCYR), depth in feet to top of the reservoir (DEPTHTOP), 2000 production (2000 PROD) in barrels, and cumulative production (CUMPROD) in barrels through 2000. Some tables also list subplays (SUB_PLAY).

\section{References}

Baldonado, D., and Broadhead, R., 2002, Preliminary investigation of the regional stratigraphy of Siluro-Devonian carbonates, Tobosa Basin, New Mexico, in Hunt, T. J., and Lufholm, P. H., eds., The Permian Basin: preserving our past-securing our future: West Texas Geological Society, Publication 02-111, p. 55-69.

Brown, L. F., Jr., Solís Iriarte, R. F., and Johns, D. A., 1987, Regional stratigraphic cross sections, Upper Pennsylvanian and Lower Permian strata (Virgilian and Wolfcampian Series), North-Central Texas: The University of Texas at Austin, Bureau of Economic Geology cross sections, 27 p. and 27 plates.

1990, Regional depositional systems tracts, paleogeography, and sequence stratigraphy, Upper Pennsylvanian and Lower Permian strata, North- and West-Central Texas: The University of Texas at Austin, Bureau of Economic Geology Report of Investigations No. 197, 116 p.

Bureau of Economic Geology, 1957, Occurrence of oil and gas in West Texas, in Herald, F. A., ed., University of Texas, Austin, Bureau of Economic Geology, Publication No. 5716, 442 p.

Candelaria, M. P., 1990, Atoka detrital a subtle stratigraphic trap in the Midland Basin, in Flis, J. E., and Price, R. C., eds., Permian Basin oil and gas fields: innovative ideas 
in exploration and development: West Texas Geological Society, Publication No. 90-87, p. 104-106.

Dutton, S. P., Kim, E. M., Broadhead, R. F., Breton, C. L., Raatz, W. D., Ruppel, S. C., and Kerans, C., 2004, Play analysis and digital portfolio of major oil reservoirs in the Permian Basin: application and transfer of advanced geological and engineering technologies for incremental production opportunities: The University of Texas at Austin, Bureau of Economic Geology, annual report prepared for U.S. Department of Energy, Assistant Secretary for Fossil Energy, under contract no. DE-FC26-02NT15131, 104 p.

Dutton, S. P., Kim, E. M., Broadhead, R. F., Raatz, W., Breton, C., Ruppel, S. C., Kerans, C., and Holtz, M. H., 2003, Play analysis and digital portfolio of major oil reservoirs in the Permian Basin: application and transfer of advanced geological and engineering technologies for incremental production opportunities: The University of Texas at Austin, Bureau of Economic Geology, annual report prepared for U.S. Department of Energy, Assistant Secretary for Fossil Energy, under contract no. DE-FC26-02NT15131, 67 p.

Dutton, S. P., Zirczy, H. H., Tremblay, T. A., and Scott, A. R., 2000, Update of oil and gas reservoir data base, Permian and Fort Worth Basins, Texas: The University of Texas at Austin, Bureau of Economic Geology, final report prepared for the U.S. Geological Survey under order no. 99CRSA1102, 31 p.

Energy Information Administration, 2003, U.S. crude oil, natural gas, and natural gas liquids reserves: 2002 annual report, DOE/EIA-0216 (2002), 48 p.

Ewing, T. E., 1990, Tectonic map of Texas: The University of Texas at Austin, Bureau of Economic Geology, scale 1:750,000, 4 sheets.

Frenzel, H. N., Bloomer, R. R., Cline, R. B., Cys, J. M., Galley, J. E., Gibson, W. R., Hills, J. M., King, W. E., Seager, W. R., Kottlowski, F. E., Thompson, S., III, Luff, G. C., Pearson, B. T., and Van Siclen, D. C., 1988, The Permian Basin region, in Sloss, L. L., ed., Sedimentary cover-North American Craton; U.S.: Boulder, Colorado, Geological Society of America, The Geology of North America, v. D-2, p. 261-306.

Galley, J. D., 1958, Oil and gas geology in the Permian Basin in Texas and New Mexico, in Weeks, L. G., ed., Habitat of oil—a symposium: Tulsa, Oklahoma, American Association of Petroleum Geologists, p. 395-446.

Galloway, W. E., Ewing, T. E., Garrett, C. M., Jr., Tyler, N., and Bebout, D. G., 1983, Atlas of major Texas oil reservoirs: The University of Texas at Austin, Bureau of Economic Geology Special Publication, 139 p.

Gawloski, T. F., 1987, Nature, distribution, and petroleum potential of Bone Spring detrital sediments along the Northwest shelf of the Delaware Basin, in Cromwell, D., and Mazzullo, L., eds., The Leonardian facies in W. Texas and S.E. New Mexico and 
Guidebook to the Glass Mountains, West Texas: Permian Basin Section Society of Economic Paleontologists and Mineralogists, Publication 87-27, p. 84-105.

Geomap Company, 1998, Executive reference map, Permian Basin, Dallas, Texas, scale 1 inch $=32,000 \mathrm{ft}$.

Grant, P. R., Jr., and Foster, R. W., 1989, Future petroleum provinces in New Mexicodiscovering new reserves: New Mexico Bureau of Mines and Mineral Resources, $94 \mathrm{p}$.

Hills, J. M., 1984, Sedimentation, tectonism, and hydrocarbon generation in Delaware Basin, West Texas and southeastern New Mexico: American Association of Petroleum Geologists Bulletin, v. 68, p. 250-267.

Holtz, M. H., 1993, Estimating oil reserve variability by combining geologic and engineering parameters: Society of Petroleum Engineers Hydrocarbon Economics and Evaluation Symposium, Dallas, Texas, Paper No. 25827, p. 85-95.

Holtz, M. H., and Kerans, C., 1992, Characterization and categorization of West Texas Ellenburger reservoirs, in Candelaria, M. P., and Reed, C. L., eds., Paleokarst, karstrelated diagenesis, and reservoir development: examples from Ordovician-Devonian age strata of West Texas and the Mid-Continent: Permian Basin Section, Society of Economic Paleontologists and Mineralogists, Field Trip Guidebook, Publication No. $92-33$, p. $45-54$.

Holtz, M. H., Garrett, C. M., Jr., and Tremblay, T. A., 1993, Update of Atlas of Major Texas Oil Reservoirs Data Base and Atlas of Major Texas Gas Reservoirs Data Base: The University of Texas at Austin, Bureau of Economic Geology contract report prepared for the U.S. Geological Survey under Contract No. 1434-93-C-40079, 14 p. plus data tape.

Holtz, M. H., Ruppel, S. C., and Hocott, C. R., 1992, Integrated geologic and engineering determination of oil-reserve growth potential in carbonate reservoirs: Journal of Petroleum Technology, v. 44, no. 11, p. 1250-1257.

Holtz, M. H., Tyler, N., Garrett, C. M., Jr., White, W. G., and Banta, N. J., 1991, Atlas of major Texas oil reservoirs: data base: The University of Texas at Austin, Bureau of Economic Geology Special Publication, data disk.

Kerans, C., and Fitchen, W. M., 1995, Sequence hierarchy and facies architecture of a carbonateramp system: San Andres Formation of Algerita Escarpment and western Guadalupe Mountains, west Texas and New Mexico: The University of Texas at Austin, Bureau of Economic Geology Report of Investigations No. 235, 86 p.

Kosters, E. C., Bebout, D. G., Seni, S. J., Garrett, C. M., Jr., Brown, L. F., Jr., Hamlin, H. S., Dutton, S. P., Ruppel, S. C., Finley, R. J., and Tyler, Noel, 1989, Atlas of major Texas gas reservoirs: The University of Texas at Austin, Bureau of Economic Geology Special Publication, $161 \mathrm{p}$. 
Lasser Texas Production CD, 2003, Texas production database, Fort Worth, Texas, http://www.lasser.com/data/data.html.

LeMay, W. J., 1960, Abo reefing in southeastern New Mexico, in A symposium of oil and gas fields of southeastern New Mexico, 1960 supplement: Roswell Geological Society, p. xvii-xxi.

Malek-Aslani, M., 1985, Permian patch-reef reservoir, North Anderson Ranch field, southeastern New Mexico, in Roehl, P. O., and Choquette, P. W., eds., Carbonate petroleum reservoirs: Springer-Verlag, New York, p. 265-276.

Midland Map Company, 1997, Producing zone map, the Permian Basin, West Texas and Southeast New Mexico: Midland, Texas, 1 inch = 32,000 ft.

New Mexico Bureau of Mines and Mineral Resources, 1993, Atlas of major Rocky Mountain gas reservoirs: New Mexico Bureau of Mines and Mineral Resources, 206 p.

New Mexico Oil and Gas Engineering Committee, 1993, Annual report of the New Mexico Oil \& Gas Engineering Committee, v. 1A, southeast New Mexico: New Mexico Oil \& Gas Engineering Committee, Inc., Hobbs, New Mexico, 703 p.

Railroad Commission of Texas, 2001, 2000 Oil \& gas annual report, volume I: Austin, Texas, Railroad Commission of Texas Oil and Gas Division, 454 p.

Read, A., Broadhead, R., Lopez, A., Fleming, E., and Watrous, J., 2000, New Mexico oil and gas pool maps: New Mexico Bureau of Mines and Mineral Resources, NMBMMR Circular 209, version 1.0, 1 CD.

Root, D. H., Attanasi, E. D., Mast, R. F., and Gautier, D. L., 1995, Estimates of inferred reserves for the 1995 USGS national oil and gas resource assessment: U.S. Geological Survey Open-File Report 95-75L, 29 p.

Roswell Geological Society, 1956, A symposium of oil and gas fields of southeastern New Mexico: $376 \mathrm{p}$. $129 \mathrm{p}$.

1960, A symposium of oil and gas fields of southeastern New Mexico, supplement:

1967, A symposium of oil and gas fields of southeastern New Mexico, supplement: $185 \mathrm{p}$. 220 p.

1977, A symposium of oil and gas fields of southeastern New Mexico, supplement:

1988, A symposium of oil and gas fields of southeastern New Mexico, supplement: $336 \mathrm{p}$. 
$360 \mathrm{p}$.

1995, A symposium of oil and gas fields of southeastern New Mexico, supplement:

Ruppel, S. C., and Holtz, M. H., 1994, Depositional and diagenetic facies patterns and reservoir development in Silurian and Devonian rocks of the Permian Basin: The University of Texas at Austin, Bureau of Economic Geology Report of Investigations No. 216, 89 p.

Silver, B. A., and Todd, R. G., 1969, Permian cyclic strata, northern Midland and Delaware Basins, west Texas and southeastern New Mexico: American Association of Petroleum Geologists Bulletin, v. 53, p. 2223-2251.

Structurmaps, Ltd., 1970, The Permian Basin of west Texas and southeast New Mexico, Permian structure map showing oil \& gas production: Midland, Texas, 1 inch $=29,333 \mathrm{ft}$.

Tyler, N., and Banta, N. J., 1989, Oil and gas resources remaining in the Permian Basin: targets for additional hydrocarbon recovery: The University of Texas at Austin, Bureau of Economic Geology Geological Circular 89-4, 20 p.

Tyler, N., Bebout, D. G., Garrett, C. M., Jr., Guevara, E. H., Hocott, C. R., Holtz, M. H., Hovorka, S. D., Kerans, C., Lucia, F. J., Major, R. P., Ruppel, S. C., and Vander Stoep, G. W., 1991, Integrated characterization of Permian Basin reservoirs, University Lands, West Texas: targeting the remaining resource for advanced oil recovery: The University of Texas at Austin, Bureau of Economic Geology Report of Investigations No. 203, $136 \mathrm{p}$.

U.S. Geological Survey, 1995, National assessment of United States oil and gas resources: U.S. Geological Survey Circular 1118, 20 p.

1996, 1995 National assessment of United States oil and gas resources - results, methodology, and supporting data: U.S. Geological Survey Digital Data Series DDS-30, release 2, 1 CD-ROM.

West Texas Geological Society, 1982, Selected oil \& gas fields in West Texas, a reprint of symposium vol. I, II, and III: Midland, Texas, Publication No. 82-75, 691 p.

1987, Selected oil \& gas fields in West Texas vol. IV: Midland, Texas, Publication No. $87-83,130$ p.

1990, Selected oil \& gas fields in West Texas vol. V: Midland, Texas, Publication No. 90-86, 208 p.

1994, Selected oil \& gas fields in West Texas vol. VI: Midland, Texas, Publication No. 94-96, 325 p. 
1996, Selected oil \& gas fields in West Texas vol. VII: Midland, Texas, Publication No. 96-99, 284 p.

White, D. A., 1980, Assessing oil and gas plays in facies-cycle wedges: American Association of Petroleum Geologists Bulletin, v. 64, p. 1158-1178.

\section{PLAY SUMMARIES}

Each of the 32 oil plays in the Permian Basin was summarized using information from published literature and illustrated by selected appropriate diagrams. The play descriptions include key characteristics of the play, summarize and illustrate the reservoir heterogeneity that characterizes reservoirs in the play, and detail preferred management practices that have been used successfully in the play. Page-size play maps, showing reservoirs in the play, play boundaries, and geologic features, are included in each play summary. A table of all reservoirs in the play that had produced $>1 \mathrm{MMbbl}\left(1.59 \times 10^{5} \mathrm{~m}^{3}\right)$ through 2000 is also included.

Reservoirs that had other reservoirs transferred into them are highlighted by gray shading in the play tables. Cumulative production values listed for these combined reservoirs represent total production, including production both before and after the reservoirs were combined. A list of combined reservoirs, sorted by plays, is shown in table 3 .

Reservoir-characterization studies of key reservoirs from three of the largest or most active plays in the Permian Basin were conducted as part of this project. The reservoirs studied were Kelly-Snyder (SACROC unit) in the Pennsylvanian and Lower Permian Horseshoe Atoll Carbonate play, Fullerton in the Leonard Restricted Platform Carbonate play, and Barnhart (Ellenburger) in the Ellenburger Selectively Dolomitized Ramp Carbonate play. The geologic heterogeneity in these reservoirs was investigated so that production constraints that would apply 
to other reservoirs in that play could be better understood. For each of these detailed reservoir studies, technologies for further, economically viable exploitation were investigated. Information developed during these investigations was incorporated into the play summaries.

Many maps, cross sections, logs, and data tables are contained in the Atlas of Major Texas Oil Reservoirs (Galloway and others, 1983) and the Atlas of Major Texas Oil Reservoirs: Data Base (Holtz and others, 1991) but are not reproduced in this report. Although the play assignment of reservoirs in the original oil atlas differs from that of this report, the atlas remains a good source of information about the 194 largest reservoirs in the Permian Basin, those that had produced $>10 \mathrm{MMbbl}\left(1.59 \times 10^{6} \mathrm{~m}^{3}\right)$ through 1981 . The atlas includes data tables listing trap type, drive mechanism, thickness of oil column, porosity, permeability, water saturation, oil gravity, initial reservoir pressure and temperature, well spacing, residual oil saturation, original oil in place, ultimate recovery, and recovery efficiency. These data were compiled digitally by Holtz and others (1991). 
Table 3. Texas reservoirs in each play that have been combined with others; top name for each entry is final reservoir name, and indented name(s) listed below are reservoirs that have been combined into the top reservoir. Cumulative production in play tables is given for all combined fields and is listed only under the final reservoir name. For example, Barron Ranch (Ellen.) and Swenson-Garza (Ellen.) were combined into Swenson-Barron (Ellen.), and cumulative production from all three reservoirs is listed under SwensonBarron (Ellen.) in the play table.

Play 101 Ellenburger Selectively Dolomitized Ramp Carbonate

\section{Swenson-Barron (Ellen.) Barron Ranch (Ellen.) Swenson-Garza (Ellen.)}

Play 102 Ellenburger Karst-Modified Restricted Ramp Carbonate

Emma (Ellenburger) Triple-N (Ellenburger)

Magutex (Ellenburger) Andrews, Northeast (Ellen.)

Metz, East (Ellenburger) Metz (Ellenburger)

Nelson (Ellenburger)

Freund

Norman (Ellenburger, District 8) Norman (Ellen., District 8A)

Play 103 Simpson Cratonic Sandstone

Running W (Waddell)

Block B-21 (Waddell)

Block B-27 (Waddell)

Reed (Waddell, Middle)

Reed, N. (Waddell, MI.)

Play 104 Fusselman Shallow Platform Carbonate

Corrigan

Nystel

Inez Deep

Inez (Atoka)

Inez (Fusselman)

Midland Farms (Dev.)

Midland Farms Deep

Midland Farms (Fusselman)

Midland Farms, West (Dev.)
Play 105 Wristen Buildups and Platform Carbonate

Breedlove Breedlove, North (Dev.)

Hutex (Devonian) Prichard (Devonian)

Magutex (Devonian) Andrews, Northeast (Dev.)

Norman (Devonian) (District 8) Norman (Dev.) (District 8A)

Seagraves (Siluro-Devonian) Seagraves, W. (Devonian)

Play 106 Devonian Thirtyone Deepwater Chert

Block 31

Block 31, East (Devonian)

Crossett, S. (Detrital)

El Cinco (Detrital)

Crossett, S. (Devonian)

El Cinco (Devonian)

King Mountain (Devonian) King Mountain, S. (Dev.)

Play 107 Devonian Thirtyone Ramp Carbonate

Harper (Devonian) Harper, West (Devonian)

Play 111 Pennsylvanian Platform Carbonate

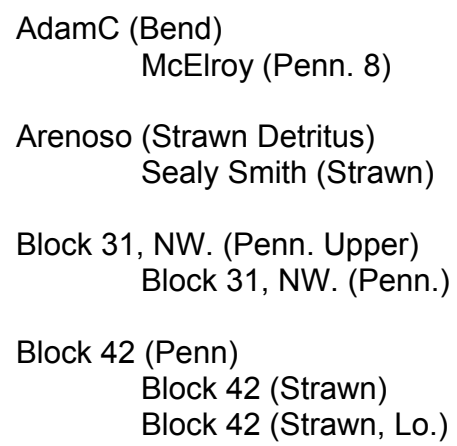


Dewey Lake, S. (Strawn) Arlis (Strawn)

Dora Roberts (Consolidated) Dora Roberts (Strawn) Dora Roberts (Penn.) Headlee (Wolfcamp)

Emma (Strawn) Triple-N (Penn., Lower)

Fasken (Penn.) Cowden, N. (Penn.)

H. S. A. (Pennsylvanian) Estes Block B-19 (Penn.)

Virey (Consolidated) Virey (Pennsylvanian) Virey (Strawn) Virey (Wolfcamp, Lower) Virey (Wolfcamp, Upper)

War-San (Consolidated) War-San (Pennsylvanian) War-San (Wolfcamp, Lower)

Play 112 Pennsylvanian and Lower Permian Horseshoe Atoll Carbonate

Fluvanna (Strawn) Fluvanna, N. (Strawn Reef)

Kelly-Snyder

Snyder, North

Kelly

Synder, N. (Strawn Zone B) Snyder, North (Strawn Zone C)

Play 113 Upper Pennsylvanian and Lower Permian Slope and Basinal Sandstone

Baker Ranch (Canyon) Cal, South (Canyon)

Bloodworth, NE (5750 Canyon) Bloodworth, NE. (5650 Bloodworth, NE. (5800 Canyon) Panther Gap, N. (Canyon 5660)

Conger (Penn) Big Salute (Canyon) Conger (Canyon) Conger (Cisco)

I. A. B., NE. (5150 Canyon) Sanco (Canyon)
Jameson (Strawn)

Fuller-Coke (Strawn)

Fuller-Coke, North (Strawn)

Fuller-Coke, South (Strawn)

Kelly-Snyder (Cisco Sand)

Brown (Cisco Sand)

George Parks (Cisco Sand)

Lake Trammel, W. (Canyon)

Lake Trammel (Canyon)

Pardue (Canyon)

Pardue

S-M-S (Canyon Sand)

Casey (Canyon Sand)

Play 114 Wolfcamp Platform Carbonate

Cowden, South (Canyon 8790) Cowden, South (Cisco 8640)

D. E. B. (Wolfcamp) Bottenfield (Wolfcamp) Toby-Jo (Wolfcamp)

D. E. B. (Wolfcamp, Zone B) Bottenfield (Wolfcamp, Zone B)

Nolley (Wolfcamp) Norman (Wolfcamp) Norman, S. (Wolfcamp) Norman, S. (Wolfcamp -B-)

Tippett, West (Hueco) Tippett (Hueco) Tippett (Wolfcamp) Tippett, W. (Detrital 5000)

Wemac (Wolfcamp) Bakke, North (Penn.) Wemac, N. (Wolfcamp Reef)

Play 115 Wolfcamp/Leonard Slope and Basinal Carbonate

Athey (Wolfcamp 10900) Athey, East (Wolfcamp 11,500)

Coyanosa (Wolfcamp) Athey (Wolfcamp 11,500)

Howard-Glasscock (Wolfcamp 7400) Howard Glasscock (Wolfcamp 7325)

Spraberry (Trend Area Cl. Fk.) Block 39, South (Clear Fork) Hirsch (Clear Fork) Spraberry (Trend Area Cl. Fk. S.) 
Play 116 Abo Platform Carbonate

Kingdom (Abo Reef) Kingdom, N. (Abo)

Slaughter (Abo)

Play 117 Leonard Restricted Platform Carbonate

Bayview (Glorieta)

Bayview (Glorieta, Upper)

Block A-28 (Wichita-Albany) Block A-28 (Drinkard, Lo.)

Brown \& Thorp (Clear Fork) Krasner (Clear Fork)

Crossett (3000 Clear Fork) Crossett (Tubb)

Crossett (3200)

Deep Rock (Glorieta 5950) Deep Rock (Glorieta)

Diamond -M- (Clear Fork)

Dorward Diamond -M- (San Andres)

Dorward (San Andres) Justiceburg (Glorieta)

Flanagan (Clearfork, Cons.) Flanagan (Clear Fork) Flanagan (Clear Fork, Upper) Westlund (Clear Fork, Upper)

Fullerton Fullerton (Clear Fork, Upper)

Garza (Glorieta, S. Deep) Garza (Glorieta, S., Z-1) Garza (Glorieta, S., Z-5)

Giebel (CFA) Giebel (Clearfork, Lower) Rudy (Witchita-Albany) [sic]

Goldsmith (5600)

TXL (Clear Fork, Upper)

H \& L (Glorieta) P-M-A (Glorieta) Post, NW. (Glorieta)

Hoople (Clear Fork) $\mathrm{Ha}-\mathrm{Ra}$ (Clear Fork) Ridge (Clear Fork) Ridge, South (Clear Fork)
Lee Harrison

Stennett

Leeper (Glorieta)

D-L-S (Clear Fork)

Lyles (Clear Fork)

Lyles (Clear Fork 3150)

Lyles (Clear Fork 3400)

Roberdeau (Clear Fork, 3400)

Roberdeau, N. (Clear Fork 3150)

Roberdeau, N. (Clear Fork 3400)

Roberdeau, N. (Glorieta)

Martin (Consolidated) Block 11 (Wichita, Lo.)

Martin (Clear Fork)

Martin (Clear Fork, Lo.)

Martin (Wichita)

Ownby

Waples Platter

Post (Glorieta) Justiceburg, NW. (Glorieta) O. S. Ranch (Glorieta)

Post

Prentice (6700)

Cobb (6700)

Prentice (Clear Fork, Lower) Clanahan (Clear Fork, Lower)

Prentice

Cobb

Roberdeau (Clear Fork, Upper) Roberdeau (Clear Fork, Middle) Crossett, West (Clear Fork, Mi.) Roberdeau (Clearfork, Lower)

Roberdeau, S. (Tubb) Roberdeau, S. (Clear Fork M.) Roberdeau, S. (Clear Fork 2800) Roberdeau, S. (Clear Fork 3400)

Robertson, N. (Clear Fork 7100) Robertson (Clear Fork, Lo.)

Sharon Ridge (Clear Fork) Sharon Ridge (2400)

Wasson 72 Wasson (Glorieta) Wasson, NE. (Wichita-Albany) Wasson 66 
Play 119 Spraberry/Dean Submarine-Fan Sandstone

Ackerly, North (Spraberry)

Christine (Spraberry)

Felken (Spraberry) Snowdon (Spraberry)

Jo-Mill (Spraberry) Arthur (Spraberry) Canon (Spraberry) Fowel (Spraberry, Lower)

Key (Spraberry, Upper) Key (Spraberry)

Lamesa, West (Spraberry) Huddle-Manning

Parks (Spraberry) Parks (Wolfcamp 9335) $\mathrm{R} \& \mathrm{~W}$ (Clear Fork)

Reo (Jo Mill, Lower) Borden (Spraberry)

Spraberry (Trend Area) (District 7C) Aldwell (Spraberry)

Calvin (Dean)

Calvin (Spraberry)

Centralia Draw (Dean)

Pembrook

Pembrook, North (Spraberry)

Stiles (Spraberry)

Sugg, North (Clean Fork)

Weiner-Floyd (Spraberry)

Spraberry (Trend Area) (District 8)

Billington (Spraberry)

Driver (Spraberry Sand)

Germania

Glass (Spraberry)

Midkiff (Spraberry Sand)

Playa (Spraberry)

Stanton (Spraberry)

Tex-Harvey (Floyd Sand)

Spraberry, W. (Deep, Spraberry) Spraberry, West (Deep) Spraberry, West (Deep, Spbry, Lo)

Sulphur Draw (Dean 8790)

Sulphur Draw (Spraberry)
Play 120 Northwest Shelf San Andres Platform Carbonate

Brahaney

Brahaney, West (San Andres)

Chambliss (San Andres)

Wasson

Russell (San Andres)

Play 121 Eastern Shelf San Andres Platform Carbonate

Garza (San Andres, Deep)

Garza (San Andres -B-)

Garza (San Andres -C-)

Garza (San Andres -D-)

Garza (San Andres -E-)

Guinn (San Andres)

Block L (San Andres, Middle)

Howard Glasscock

Albaugh (Yates Sd.)

McDowell (San Andres)

McDowell (San Andres, Lo.)

McDowell (San Andres Middle)

P.H.D.

P.H.D. (San Andres, Lo.)

Sharon Ridge (1700)

Coleman Ranch (San Andres)

Suniland

Suniland (Glorieta)

Suniland (San Andres)

Suniland (San Andres, Lower)

Play 123 San Andres Platform Carbonate

Goldsmith, N. (San Andres Con.)

Goldsmith, North

Parker (Grayburg, San Andres)

Parker

Parker, West (Grayburg)

Play 126 San Andres/Grayburg Lowstand Carbonate

Welch

Welch, South (San Andres) 
Play 127 Grayburg Platform Mixed

Clastic/Carbonate

\author{
Cowden, North \\ Block 9 (San Andres) \\ Fuhrman-Mascho \\ Deep Rock \\ Nix (Dolomite 4400)
}

Play 128 Grayburg Platform Carbonate

Double -H- (Grayburg) Edwards, North (San Andres)

Dune

Dune (San Andres)

McElroy

Church

Gulf-McElroy

McClintic

McElroy, East (San Andres)

Play 129 Grayburg High-Energy Platform

Carbonate-Ozona Arch

\section{Farmer \\ Amigo (San Andres) \\ Block 46, East (Grayburg)}

Play 130 Delaware Mountain Group Basinal Sandstone

Block 17, Southeast (Delaware) Block 18 (Delaware)

Geraldine (Ford)

Ford (Delaware Sand)

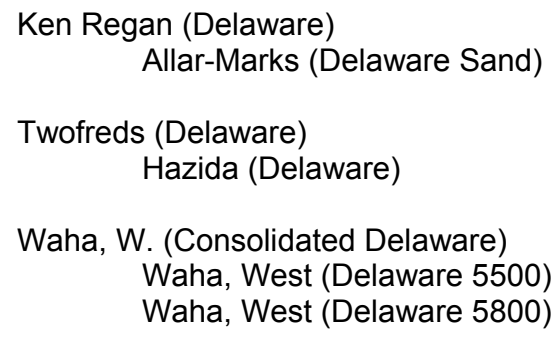

Play 131 Queen Tidal-Flat Sandstone

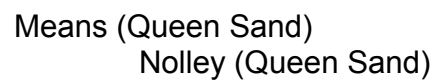

Play 132 Artesia Platform Sandstone

Fort Stockton (Yates Lower) Fort Stockton (Yates 3300)

Halley Emperor

Keystone (Colby) Keystone (Lime)

Monahans (Queen Sand) Monahans, W. (Queen 3075)

Scarborough

Eaves

Leck

Ward, South

Dobbs

Ward-Estes, North

Estes

H. S. A. (O'Brien Sand, Lower)

H. S. A., North (O'Brien, Upper) 


\section{Ordovician Plays}

Three oil plays in the Permian Basin produce from Ordovician reservoirs: Ellenburger Selectively Dolomitized Ramp Carbonate, Ellenburger Karst-Modified Restricted Ramp Carbonate, and Simpson Cratonic Sandstone (table 1). A third Ellenburger play, Ellenburger Tectonically Fractured Dolostone, lies along the eastern side of the Delaware Basin and in the Val Verde Basin (Holtz and Kerans, 1992). The reservoirs in this play produce gas, however, and are not included in this report. All Ellenburger reservoirs were grouped into one play called Ellenburger Fractured Dolomite in the Atlas of Major Texas Oil Reservoirs (Galloway and others, 1983). Simpson reservoirs were included in the Central Basin Platform Unconformity play in the oil atlas.

The Lower Ordovician Ellenburger Group (fig. 3) was deposited on a restricted carbonate ramp, resulting in a thick (up to $1,700 \mathrm{ft}[520 \mathrm{~m}]$ ), areally extensive sequence of mud-dominated carbonates with localized grainstones (Kerans and others, 1989). The basinward direction was to the southeast. Sea-level fall in the early Middle Ordovician resulted in exposure of the ramp and development of widespread karst terrain (Kerans, 1990). Transgression in the Middle Ordovician flooded the area, and the shales, carbonates, and sandstones of the Simpson Group (fig. 3) were deposited. A shallow, downwarped area centered in Pecos and Terrell Counties (fig. 1) during Simpson time was named the Tobosa Basin by Galley (1958). The Upper Ordovician in the Permian Basin is represented by limestones and dolostones of the Montoya Formation (fig. 3) (Wright, 1979; Frenzel and others, 1988). A few Montoya reservoirs have produced >1 MMbbl $\left(1.59 \times 10^{5} \mathrm{~m}^{3}\right)$ of oil, but they are included with the Silurian Fusselman Shallow Platform Carbonate play. 
References

Frenzel, H. N., Bloomer, R. R., Cline, R. B., Cys, J. M., Galley, J. E., Gibson, W. R., Hills, J. M., King, W. E., Seager, W. R., Kottlowski, F. E., Thompson, S., III, Luff, G. C., Pearson, B. T., and Van Siclen, D. C., 1988, The Permian Basin region, in Sloss, L. L., ed., Sedimentary cover-North American Craton; U.S.: Boulder, Colorado, Geological Society of America, The Geology of North America, v. D-2, p. 261-306.

Galley, J. D., 1958, Oil and gas geology in the Permian Basin in Texas and New Mexico, in Weeks, L. G., ed., Habitat of oil-a symposium: Tulsa, Oklahoma, American Association of Petroleum Geologists, p. 395-446.

Galloway, W. E., Ewing, T. E., Garrett, C. M., Jr., Tyler, N., and Bebout, D. G., 1983, Atlas of major Texas oil reservoirs: The University of Texas at Austin, Bureau of Economic Geology Special Publication, 139 p.

Holtz, M. H., and Kerans, C., 1992, Characterization and categorization of West Texas Ellenburger reservoirs, in Candelaria, M. P., and Reed, C. L., eds., Paleokarst, karstrelated diagenesis, and reservoir development: examples from Ordovician-Devonian age strata of West Texas and the Mid-Continent: Permian Basin Section, Society of Economic Paleontologists and Mineralogists, Field Trip Guidebook, Publication No. 92-33, p. 45-54.

Holtz, M. H., Tyler, N., Garrett, C. M., Jr., White, W. G., and Banta, N. J., 1991, Atlas of major Texas oil reservoirs: data base: The University of Texas at Austin, Bureau of Economic Geology Special Publication, data disk.

Kerans, C., 1990, Depositional systems and karst geology of the Ellenburger Group (Lower Ordovician), subsurface West Texas: The University of Texas at Austin, Bureau of Economic Geology Report of Investigations No. 193, 37 p.

Kerans, C., Holtz, M. H., and Tyler, N., 1989, Controlling styles of reservoir heterogeneity in Ellenburger Group carbonates, West Texas, in Cunningham, B. K., and Cromwell, D. W., eds., The lower Paleozoic of west Texas and southern New Mexico-modern exploration concepts: Permian Basin Section, Society of Economic Paleontologists and Mineralogists, Publication No. 89-31, p. 131-144.

Wright, W. F., 1979, Petroleum geology of the Permian Basin: West Texas Geological Society Publication No. 79-71, 98 p. 
Ellenburger Selectively Dolomitized Ramp Carbonate (Play 101)

The Ellenburger Selectively Dolomitized Ramp Carbonate play consists of 31 reservoirs in Texas that had produced $>1 \mathrm{MMbbl}\left(1.59 \times 10^{5} \mathrm{~m}^{3}\right)$ of oil through 2000 ; cumulative production from the play was $163.7 \mathrm{MMbbl}\left(2.60 \times 10^{7} \mathrm{~m}^{3}\right)$ (table 4$)$. The play is located along the south and east margins of the Midland Basin (fig. 4), in the area of the Ozona Arch and the Eastern Shelf (fig. 2). In most of the area, the Ellenburger is overlain by Permian, Pennsylvanian, or Mississippian strata (Holtz and Kerans, 1992). The Ellenburger has been partly truncated by pre-Pennsylvanian erosion (Britt, 1988). Traps are formed by simple anticlines, truncated flanks of anticlines, permeability barriers across anticlines, and locally fractured low-permeability dolostones along faults and steep flexures (Britt, 1988; Mazzullo, 1989).

Table 4. Ellenburger Selectively Dolomitized Ramp Carbonate play (play 101). Production shown for fields that have had others combined into them represents the totals; combined fields are highlighted.

\begin{tabular}{|c|c|c|c|c|c|c|c|c|c|}
\hline RRC RESN & RRC & FLDNAME & RESNAME & STATE & COUNTY & DISCYR & DEPTHTOP & 2000 PROD & CUMPROD \\
\hline 5783001 & $7 \mathrm{C}$ & BARNHART & & TX & REAGAN & 1941 & 9008 & 20,274 & $16,446,688$ \\
\hline \multirow[t]{2}{*}{6621250} & $7 \mathrm{~B}$ & BECKHAM & ELLENBURGER & TX & NOLAN & 1967 & 6183 & 6,815 & $1,351,572$ \\
\hline & $7 \mathrm{C}$ & BIG LAKE & ELLENBURGER & $T X$ & REAGAN & 1928 & 8890 & & * \\
\hline 8629500 & $7 \mathrm{~B}$ & BLACKWELL, NORTH & ELLENBURGER & TX & NOLAN & 1953 & 6540 & 16,029 & $2,083,547$ \\
\hline 25377568 & $7 \mathrm{~B}$ & DORA, NORTH & ELLENBURGER & TX & NOLAN & 1953 & 5914 & 21 & $4,299,502$ \\
\hline 26606333 & $8 \mathrm{~A}$ & DUNIGAN & ELLENBURGER & $T X$ & BORDEN & 1958 & 8737 & 1,859 & $1,136,041$ \\
\hline 28393333 & $7 \mathrm{C}$ & ELKHORN & ELLENBURGER & TX & CROCKETT & 1951 & 7185 & 11,036 & $12,109,347$ \\
\hline 30414500 & $7 \mathrm{~B}$ & FAVER, NORTH & ELLENBURGER & TX & NOLAN & 1953 & 6006 & 0 & $1,340,294$ \\
\hline 31690250 & $8 \mathrm{~A}$ & FLUVANNA & ELLENBURGER & TX & BORDEN & 1952 & 8358 & 5,108 & $3,079,237$ \\
\hline 31697166 & $8 \mathrm{~A}$ & FLUVANNA, SW. & ELLEN. & $T X$ & BORDEN & 1968 & 8306 & 3,395 & $1,559,708$ \\
\hline 32449400 & $7 \mathrm{C}$ & FRADEAN & ELLENBURGER & $\mathrm{TX}$ & UPTON & 1959 & 10186 & 0 & $2,154,464$ \\
\hline 32653800 & $7 \mathrm{~B}$ & FRANKIRK & ELLENBURGER & TX & STONEWALL & 1958 & 5928 & 11,298 & $5,488,629$ \\
\hline 38866333 & $8 \mathrm{~A}$ & HAPPY & ELLENBURGER & $T X$ & GARZA & 1958 & 8281 & 90,740 & $3,075,019$ \\
\hline 40295400 & $7 \mathrm{C}$ & HELUMA & ELLENBURGER & TX & UPTON & 1956 & 10590 & 2,957 & $4,097,691$ \\
\hline 42341500 & $7 \mathrm{C}$ & HOLT RANCH & ELLENBURGER & TX & CROCKETT & 1965 & 7897 & 5,772 & $2,380,554$ \\
\hline 44717500 & $7 \mathrm{C}$ & IRION 163 & ELLEN & $T X$ & IRION & 1977 & 8916 & 7,885 & $2,605,958$ \\
\hline 45582200 & 8 & JAMESON N. & ELLEN & TX & MITCHELL & 1978 & 7157 & 3,680 & $1,602,269$ \\
\hline 49413400 & $7 \mathrm{C}$ & KING MOUNTAIN & ELLENBURGER & TX & UPTON & 1955 & 11775 & 235 & $6,890,744$ \\
\hline 61204001 & $7 \mathrm{C}$ & MIDWAY LANE & & $\mathrm{TX}$ & CROCKETT & 1947 & 7596 & 2,984 & $4,555,520$ \\
\hline 63756333 & $7 \mathrm{~B}$ & MULLEN RANCH & ELLENBURGER & $\mathrm{TX}$ & STONEWALL & 1955 & 6440 & 7,624 & $1,093,028$ \\
\hline 67388500 & $7 \mathrm{~B}$ & ONYX & ELLENBURGER & TX & STONEWALL & 1957 & 6489 & 0 & $1,697,041$ \\
\hline 69098332 & $7 \mathrm{~B}$ & PARDUE & ELLENBURGER & $T X$ & FISHER & 1949 & 5962 & 28,247 & $6,011,033$ \\
\hline 72214500 & $8 \mathrm{~A}$ & POLAR, NORTH & ELLENBURGER & TX & KENT & 1950 & 7780 & 0 & $1,439,914$ \\
\hline 72225500 & $8 \mathrm{~A}$ & POLLAN & ELLENBURGER & TX & GARZA & 1978 & 7733 & 0 & $2,931,773$ \\
\hline 82864664 & 8 & SHEFFIELD & ELLENBURGER & $\mathrm{TX}$ & PECOS & 1952 & 9272 & 0 & $2,366,006$ \\
\hline 87019200 & $7 \mathrm{~B}$ & SUGGS & ELLENBURGER & $\mathrm{TX}$ & NOLAN & 1982 & 6482 & 81,452 & $9,683,164$ \\
\hline 87640500 & $8 \mathrm{~A}$ & SWENSON-BARRON & ELLEN. & TX & GARZA & 1977 & 8000 & 0 & $13,153,109$ \\
\hline 88611142 & $8 \mathrm{~A}$ & TEAS & ELLENBURGER & TX & GARZA & 1958 & 8396 & 4,761 & $1,100,062$ \\
\hline 90315666 & $7 \mathrm{C}$ & TODD, DEEP & ELLENBURGER & $T X$ & CROCKETT & 1940 & 6232 & 209,230 & $44,300,279$ \\
\hline 92290333 & $8 \mathrm{~A}$ & U-LAZY -S- & ELLENBURGER & TX & BORDEN & 1957 & 8633 & 0 & $2,338,392$ \\
\hline 98297500 & $7 \mathrm{~B}$ & WITHERS & ELLENBURGER & $\mathrm{TX}$ & NOLAN & 1979 & 6520 & 15,718 & $1,364,325$ \\
\hline & & Totals & & & & & & 537,120 & $163,734,910$ \\
\hline
\end{tabular}

*Estimated production of Big Lake field from Ellenburger reservoir is 21 million bbl.

All production from Big Lake field is assigned to the Grayburg by the RRC (see Play 129 Grayburg High-Energy Platform Carbonate--Ozona Arch play). 


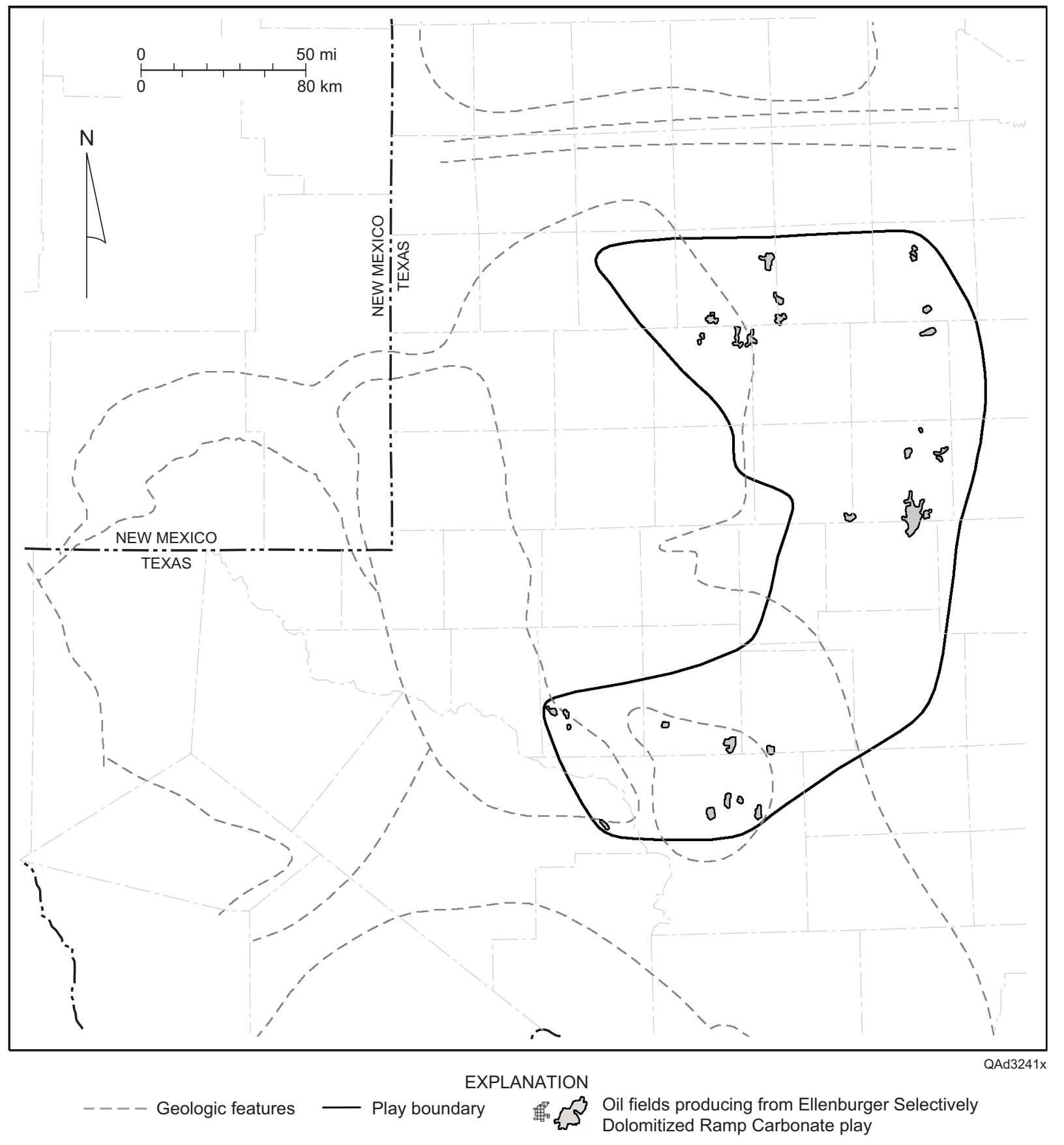

Figure 4. Play map for the Ellenburger Selectively Dolomitized Ramp Carbonate play, showing location of reservoirs having $>1 \mathrm{MMbbl}$ cumulative production, the play boundary, and geologic features. See figure 1 for county names and figure 2 for identification of geologic features.

The carbonates of this play were deposited in a mid- to outer-ramp setting (Holtz and Kerans, 1992); their present composition is mainly dolostone, with lesser amounts of limestone 
(Holtz and Kerans, 1992; Hunt, 2000). Reservoirs are composed of one or more upwardshallowing sequences that contain subtidal, peloid-ooid packstone-grainstone at the base, overlain by burrowed wackestones and peritidal, cryptalgal laminated mudstones (Holtz and Kerans, 1992). Early tidal-flat dolomitization by seepage reflux and late-burial dolomitization were more localized in the rocks in this play than in the Ellenburger Karst-Modified Restricted Ramp Carbonate play, where dolomitization was pervasive (Holtz and Kerans, 1992).

Ellenburger rocks in this play experienced several episodes of exposure, karstification, and fracturing. Porosity development appears to be controlled by a combination of primary depositional facies distribution, localized karsting, fracturing, and selective dolomitization (Tyler and others, 1991; Combs and others, 2003). The processes and products of karst-related diagenesis in these Ordovician reservoirs were detailed by Loucks $(1999,2003)$. Much of the reservoir porosity is made up of secondary intercrystalline pores that resulted from selective, late-stage burial dolomitization of grainstones (Kerans, 1990; Kupecz and Land, 1991; Holtz and Kerans, 1992). Fractures probably provided pathways for migrating dolomitizing fluids and still contribute to reservoir porosity and permeability. Two sets of fractures, oriented NE-SW and NW-SE, have been identified, but the NW-SE set is dominant in most horizons (Gomez and others, 2001).

Net-pay thickness ranges from 4 to $223 \mathrm{ft}$ (1 to $68 \mathrm{~m}$ ) and averages $43 \mathrm{ft}$ (13 m) (Holtz and Kerans, 1992). Porosity, mostly intercrystalline and interparticle, ranges from 1 to 20 percent and averages 6.4 percent. Permeability values range from 0.2 to $48 \mathrm{md}\left(0.2\right.$ to $\left.48 \times 10^{-3} \mu \mathrm{m}^{2}\right)$ and are log-normally distributed around a geometric mean value of $12 \mathrm{md}\left(12 \times 10^{-3} \mu \mathrm{m}^{2}\right)$.

Known production from the major reservoirs in this play is $163.7 \mathrm{MMbbl}\left(2.60 \times 10^{7} \mathrm{~m}^{3}\right)$ (table 4), but this figure does not include production from the Big Lake (Ellenburger) reservoir. 
The Ellenburger reservoir at Big Lake field was discovered in 1928, but production from the Ellenburger was combined with production from the Grayburg interval in the annual reports of the Railroad Commission of Texas. Anderson and others (1954) reported that the Ellenburger reservoir had produced 18.8 MMbbl $\left(2.99 \times 10^{6} \mathrm{~m}^{3}\right)$ of oil through October 1, 1953, and projected that ultimate recovery would be $20.9 \mathrm{MMbbl}\left(3.32 \times 10^{6} \mathrm{~m}^{3}\right)$ of oil. Galloway and others (1983) reported $21 \mathrm{MMbbl}\left(3.34 \times 10^{6} \mathrm{~m}^{3}\right)$ had been produced in Big Lake (Ellenburger) through 1981, and Tyler and others (1991) showed 21.2 MMbbl $\left(3.37 \times 10^{6} \mathrm{~m}^{3}\right)$ of cumulative production through 1987 . Because it is not possible to accurately calculate Ellenburger production at Big Lake, we have followed the precedent set by the RRC and assigned all production from Big Lake to the Grayburg (see play 129, Grayburg High Energy Platform Carbonate-Ozona Arch). It should be kept in mind that $\sim 21 \mathrm{MMbbl}\left(3.34 \times 10^{6} \mathrm{~m}^{3}\right)$ of that production actually came from the Ellenburger.

A new technique for recovering additional oil—high-pressure air injection (HPAI)— is being tested in Barnhart field in Reagan County. Barnhart field is a structural trap having four-way closure and a top seal formed by Wolfcamp shale (figs. 5, 6) (Hunt, 2000). The pore network in the reservoir is influenced by local development of collapsed paleocave facies (Combs and others, 2003). Distribution of paleocave facies can be defined by log response calibrated with core (fig. 7). The Barnhart reservoir is interpreted as having at least two easttrending regions of paleocave facies that may complicate fluid flow in the field (Combs and others, 2003).

HPAI, a tertiary oil-recovery technology, creates downhole combustion of oxygen and oil, producing flue gas (nitrogen and carbon dioxide) that serves to repressurize and flood the reservoir. The HPAI process pumps air into the reservoir under high temperature and pressure. 


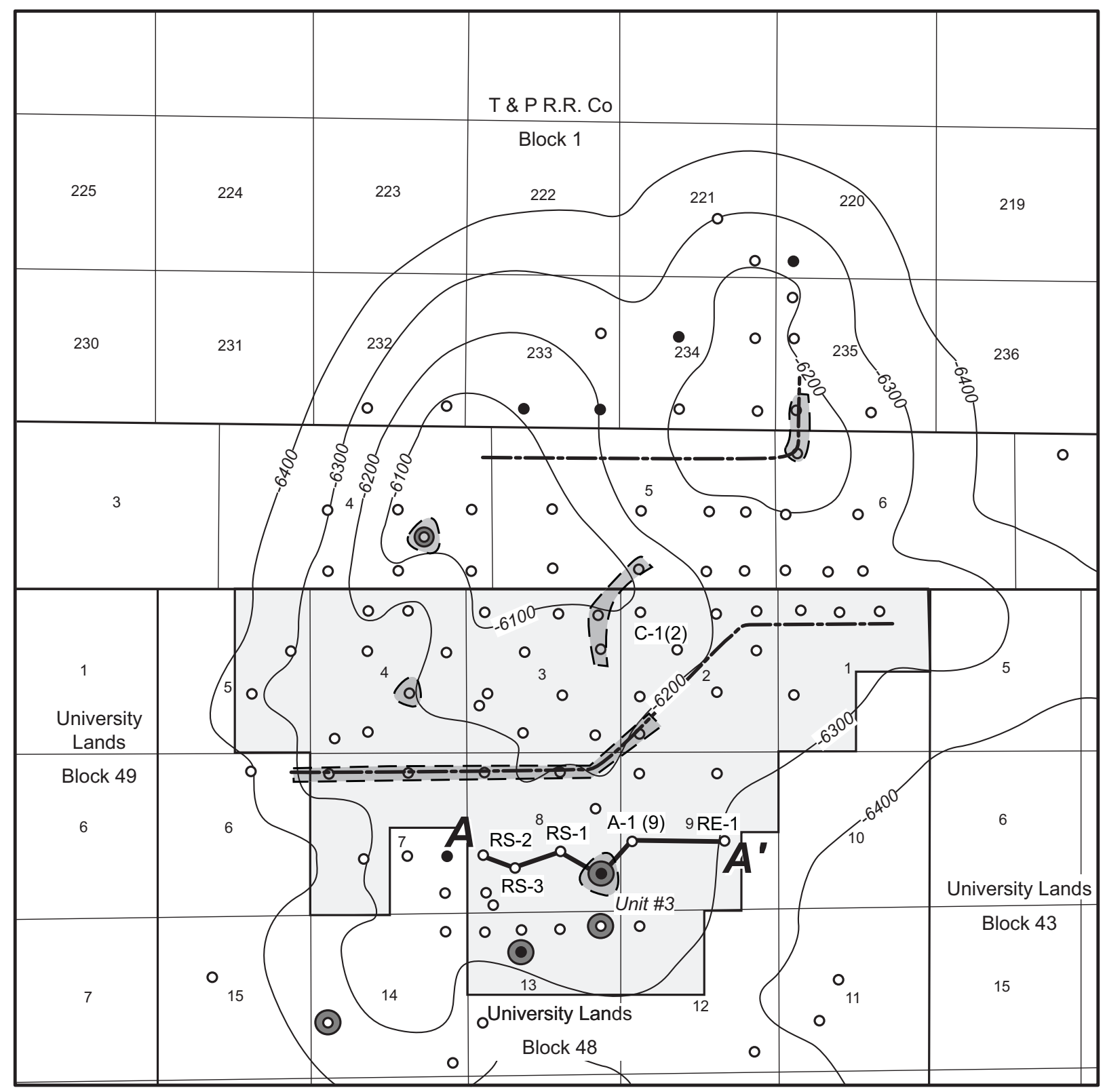

QAd3206x

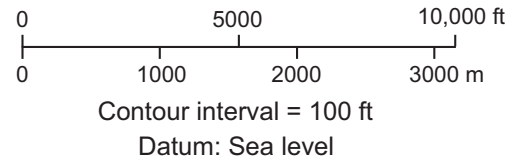

Goldrus unit boundary

( ) Core (not necessarily whole core; may be chips.)

- Well

- Producing well

(_) Correlation discontinuity zones; wellcorrelation confidence with surrounding wells is low

--- Proposed fault; correlation boundary

Figure 5. Map of Barnhart field, Reagan County, Texas, showing structure at the top of the Ellenburger reservoir and interpreted correlation discontinuities caused by faults and karsted zones. From Combs and others (2003); after Cotton (1966). Cross section A-A' shown in figure 7. 


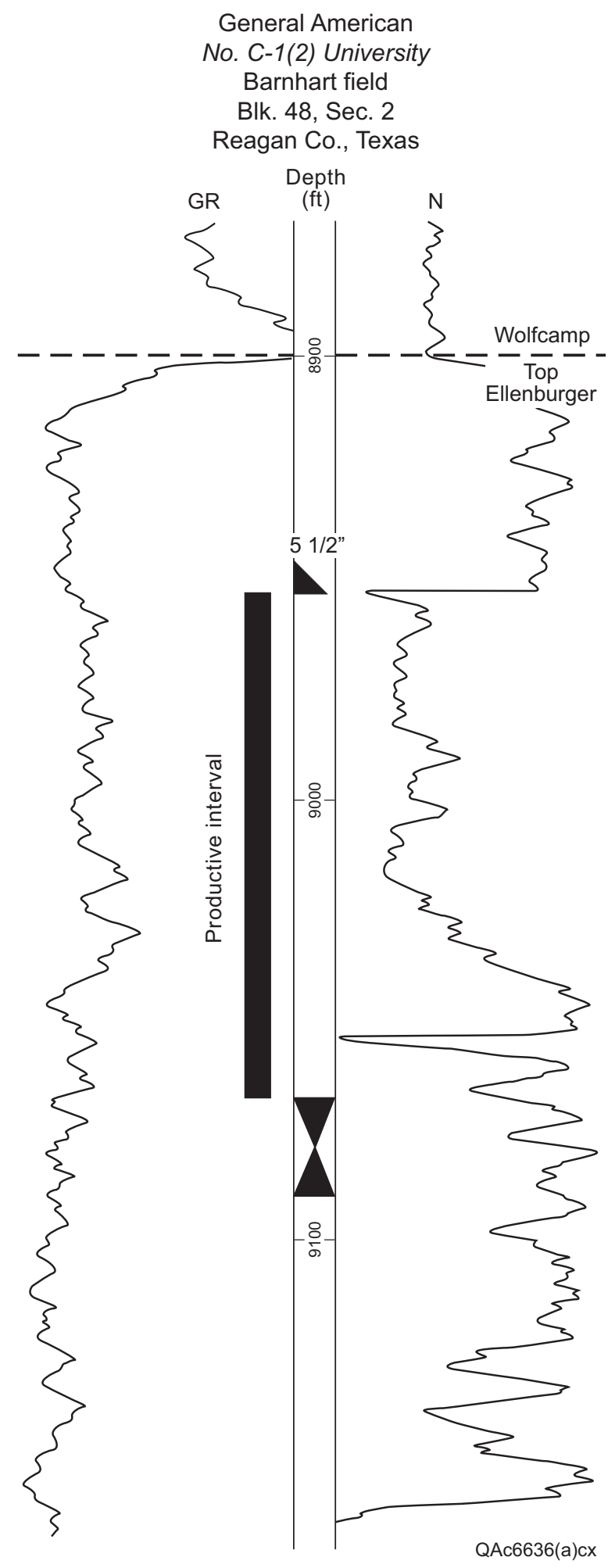

Figure 6. Typical log of the Ellenburger reservoir in Barnhart field, Reagan County, Texas. After Cotton (1966). 


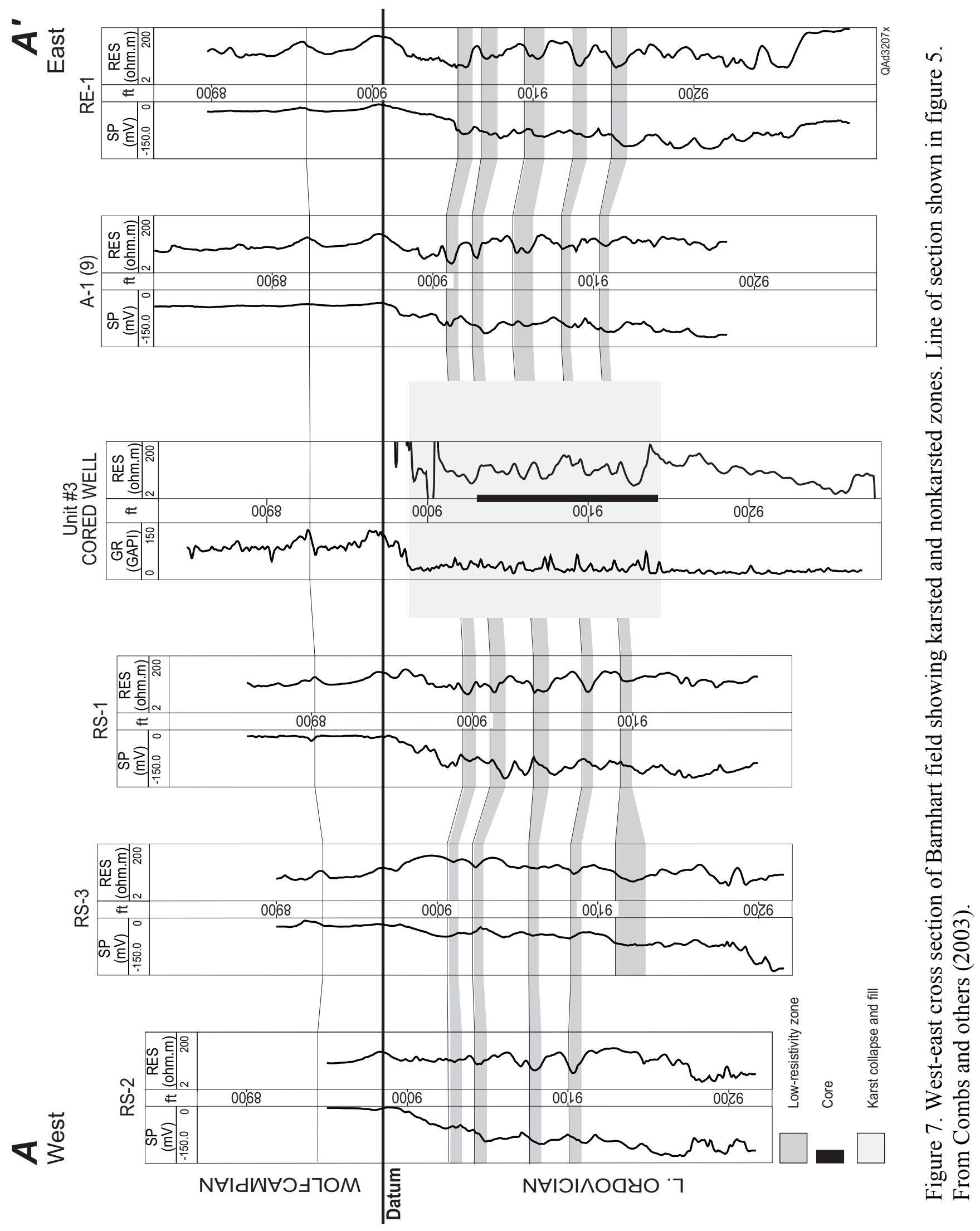


The oxygen causes combustion of 4 to 5 percent of the residual oil in the depleted reservoir (J. Olsen, personal communication, 2003). Oil recovery is improved because the process

(1) lowers the viscosity of the oil, (2) creates thermally generated microfractures in the reservoir, and (3) increases reservoir pressure.

The process has been used mainly in low-permeability reservoirs. The HPAI process has been successful in reservoirs of the Red River Formation (Ordovician dolostones and limestones) in the Williston Basin of South Dakota, North Dakota, and Montana (Kumar and others, 1995; Fassihi and others, 1996; Watts and others, 1997; Glandt and others, 1998), but it is being tried for the first time in the Permian Basin in Barnhart field (S. Ruppel, personal communication, 2003). A pilot was conducted that increased production to three to five times the rates observed before HPAI, and now a larger demonstration is planned. Barnhart field produced only 16.5 MMbbl $\left(2.62 \times 10^{6} \mathrm{~m}^{3}\right)$ of an estimated 116 MMbbl $\left(1.84 \times 10^{7} \mathrm{~m}^{3}\right)$ of OOIP during primary production (S. Ruppel, personal communication, 2003). The goal of combining HPAI with an array of vertical and horizontal injection and producer wells is to restore energy to this pressure-depleted reservoir and thus recover large additional volumes of the remaining resource.

\section{References}

Anderson, K. F., Elliott, W. C., Jr., and Moore, J. L., 1954, Petroleum-engineering study of the Ellenburger reservoir, Big Lake field, Reagan County, Tex.: U.S. Bureau of Mines Report of Investigations No. 5048, 28 p.

Britt, T. L., 1988, Joy of searching for eroded Ellenburger traps (abs.): American Association of Petroleum Geologists Bulletin, v. 72, p. 99.

Combs, D. M., Loucks, R. G., and Ruppel, S. C., 2003, Lower Ordovician Ellenburger Group collapsed Paleocave facies and associated pore network in the Barnhart field, Texas, in Hunt, T. J., and Lufholm, P. H., eds., The Permian Basin: back to basics: West Texas Geological Society Publication No. 03-112, p. 397-418. 
Cotton, C. B., 1966, Barnhart, in Oil and gas fields in west Texas symposium: West Texas Geological Society, Publication No. 66-52, p. 38-41.

Fassihi, M. R., Yannimaras, D. V., Westfall, E. E., and Gilham, T. H., 1996, Economics of light oil injection projects, in Tenth Symposium on Improved Oil Recovery, Tulsa, Oklahoma: Society of Petroleum Engineers, SPE/DOE 35393, p. 501-509.

Galloway, W. E., Ewing, T. E., Garrett, C. M., Jr., Tyler, N., and Bebout, D. G., 1983, Atlas of major Texas oil reservoirs: The University of Texas at Austin, Bureau of Economic Geology Special Publication, 139 p.

Glandt, C. A., Pieterson, R., Dombrowski, A., and Balzarini, M. A., 1998, Coral Creek field study: a comprehensive assessment of the potential of high-pressure air injection in a mature waterflood project, in SPE Midcontinent Operations Symposium, Oklahoma City, Oklahoma: Society of Petroleum Engineers, SPE 52198, 11 p.

Gomez, L. A., Gale, J. F. W., Ruppel, S. C., and Laubach, S. E., 2001, Fracture characterization using rotary-drilled sidewall cores: an example from the Ellenburger Formation, West Texas, in Viveiros, J. J., and Ingram, S. M., eds., The Permian Basin: microns to satellites, looking for oil and gas at all scales: West Texas Geological Society Publication No. 01-110, p. 81-89.

Holtz, M. H., and Kerans, C., 1992, Characterization and categorization of West Texas Ellenburger reservoirs, in Candelaria, M. P., and Reed, C. L., eds., Paleokarst, karstrelated diagenesis, and reservoir development: examples from Ordovician-Devonian age strata of West Texas and the Mid-Continent: Permian Basin Section, Society of Economic Paleontologists and Mineralogists, Field Trip Guidebook, Publication No. 92-33, p. 45-54.

Hunt, T., 2000, Review of Barnhart field: Ellenburger Group, Ozona Uplift, Reagan County, Texas, in DeMis, W. D., Nelis, M. K., and Trentham, R. C., eds., The Permian Basin: proving ground for tomorrow's technologies: West Texas Geological Society Publication No. 00-109, p. 107-111.

Kerans, C., 1990, Depositional systems and karst geology of the Ellenburger Group (Lower Ordovician), subsurface West Texas: The University of Texas at Austin, Bureau of Economic Geology Report of Investigations No. 193, 37 p.

Kumar, V. K., Fassihi, M. R., and Yannimaras, D. V., 1995, Case history and appraisal of the Medicine Pole Hills Unit air-injection project, in SPE Reservoir Engineering, August 1995: Society of Petroleum Engineers, p. 198-202.

Kupecz, J. A., and Land, L. S., 1991, Late-stage dolomitization of the Lower Ordovician Ellenburger Group, West Texas: Journal of Sedimentary Petrology, v. 61, p. 551-574. 
Loucks, R. G., 1999, Paleocave carbonate reservoirs: origins, burial-depth modifications, spatial complexity, and reservoir implications: American Association of Petroleum Geologists Bulletin, v. 83, p. 1795-1834.

2003, Understanding the development of breccias and fractures in Ordovician carbonate reservoirs, in Hunt, T. J., and Lufholm, P. H., eds., The Permian Basin: back

to basics: West Texas Geological Society Publication No. 03-112, p. 231-252.

Mazzullo, S. J., 1989, Formational and zonal subdivisions of the Ellenburger Group (Lower Ordovician), southern Midland Basin, Texas, in Cunningham, B. K. and Cromwell, D. W., eds., The lower Paleozoic of West Texas and southern New Mexico-modern exploration concepts: Permian Basin Section, Society of Economic Paleontologists and Mineralogists Publication No. 89-31, p. 113-121.

Tyler, N., Bebout, D. G., Garrett, C. M., Jr., Guevara, E. H., Hocott, C. R., Holtz, M. H., Hovorka, S. D., Kerans, C., Lucia, F. J., Major, R. P., Ruppel, S. C., and Vander Stoep, G. W., 1991, Integrated characterization of Permian Basin reservoirs, University Lands, West Texas: targeting the remaining resource for advanced oil recovery: The University of Texas at Austin, Bureau of Economic Geology Report of Investigations No. 203, $136 \mathrm{p}$.

Watts, B. C., Hall, T. F., and Petri, D. J., 1997, The Horse Creek air injection project: an overview, in SPE Rocky Mountain Regional Meeting, Casper, Wyoming: Society of Petroleum Engineers, SPE 38359, p. 143-154. 
Ellenburger Karst-Modified Restricted Ramp Carbonate (Play 102)

The Ellenburger Karst-Modified Restricted Ramp Carbonate play consists of 86 reservoirs in Texas and New Mexico that had produced $>1 \mathrm{MMbbl}\left(1.59 \times 10^{5} \mathrm{~m}^{3}\right)$ of oil through 2000; cumulative production from the play was $1,487.3 \mathrm{MMbbl}\left(2.36 \times 10^{8} \mathrm{~m}^{3}\right)$ (table 5). This play is located mainly on the Central Basin Platform (fig. 8) and is restricted to the area where the Ellenburger is overlain by the Simpson Group (Holtz and Kerans, 1992). Traps are mostly faulted anticlines, but simple anticlines are interpreted to be traps for some fields (Galloway and others, 1983).

Geologic interpretation of reservoirs in the Lower Ordovician Ellenburger Group in west Texas and southeast New Mexico has been presented in numerous papers, including Kerans (1988, 1989, 1990), Clemons (1989), Kerans and Lucia (1989), Mazzullo (1989), Loucks and Handford (1992), Goldhammer and others (1993), Lucia (1995), Hammes and others (1996), and Loucks (1999). Petrophysical information is summarized in Kerans and others (1989) and Holtz and Kerans (1992).

The reservoir rocks of the Ellenburger Group in west Texas and southeast New Mexico are dolostones that were deposited on a restricted carbonate ramp and substantially modified by erosion and karstification (Kerans, 1990). The Ellenburger exhibits a range of mostly lowenergy, mud-rich facies representing supratidal to shallow-marine environments. Production from several of the Andrews County Ellenburger reservoirs comes from an ooid-peloid grainstone facies assemblage (Kerans, 1990; Tyler and others, 1991). Mud-dominated Ellenburger lithologies generally have $<2$ percent matrix porosity; rare grainstone facies contain intergranular porosity as high as 10 percent locally. 
Table 5. Ellenburger Karst-Modified Restricted Ramp Carbonate play (play 102). Production shown for fields that have had others combined into them represents the totals; combined fields are highlighted.

\begin{tabular}{|c|c|c|c|c|c|c|c|c|c|}
\hline RRC RESN & RRC & FLDNAME & RESNAME & STATE & COUNTY & DISCYR & DEPTHTOP & 2000 PROD & CUMPROD \\
\hline 587498 & $7 \mathrm{C}$ & ADAMC & ELLENBURGER & $T X$ & UPTON & 1953 & 11575 & 19,257 & $1,162,037$ \\
\hline 2207380 & $7 \mathrm{C}$ & AMACKER-TIPPETT & ELLENBURGER & TX & UPTON & 1953 & 11890 & 9,398 & $17,917,650$ \\
\hline 2596200 & 8 & ANDECTOR & ELLENBURGER & $\mathrm{TX}$ & ECTOR & 1946 & 8545 & 276,880 & $177,718,593$ \\
\hline 2727500 & 8 & ANDREWS, NORTH & ELLENBURGER & TX & ANDREWS & 1959 & 12349 & 0 & $28,873,225$ \\
\hline 3278001 & 8 & APCO-WARNER & & TX & PECOS & 1939 & 4600 & 12,911 & $12,564,506$ \\
\hline 5166444 & 8 & BAKKE & ELLENBURGER & $\mathrm{TX}$ & ANDREWS & 1956 & 12400 & 0 & $23,722,974$ \\
\hline 5859333 & 8 & BARROW & ELLENBURGER & $\mathrm{TX}$ & ECTOR & 1955 & 13578 & 4,170 & $1,436,411$ \\
\hline 6671332 & 8 & BEDFORD & ELLENBURGER & TX & ANDREWS & 1950 & 11018 & 16,151 & $7,884,926$ \\
\hline 9202332 & 8 & BLOCK 9 & ELLENBURGER & $\mathrm{TX}$ & ANDREWS & 1958 & 12508 & 3,980 & $3,542,455$ \\
\hline 9250400 & 8 & BLOCK 12 & ELLENBURGER & $\mathrm{TX}$ & ANDREWS & 1952 & 10884 & 24,613 & $4,705,759$ \\
\hline 9251333 & 8 & BLOCK 12, EAST & ELLENBURGER & TX & ANDREWS & 1953 & 10117 & 0 & $9,262,118$ \\
\hline 9358540 & 8 & BLOCK 31 & ELLENBURGER & $\mathrm{TX}$ & CRANE & 1945 & 10291 & 28,860 & $6,266,474$ \\
\hline 8958200 & 8 & BLOCK A-34 & ELLENBURGER & $\mathrm{TX}$ & ANDREWS & 1954 & 13250 & 7,233 & $4,378,343$ \\
\hline 8990666 & 8 & BLOCK A-49 & ELLENBURGER & TX & ANDREWS & 1962 & 11200 & 8,041 & $1,623,307$ \\
\hline 18254600 & 8 & CIRCLE BAR & ELLEN & $\mathrm{TX}$ & ECTOR & 1962 & 12758 & 17,161 & $3,816,623$ \\
\hline 21292875 & 8 & COWDEN, SOUTH & 13800 & $\mathrm{TX}$ & ECTOR & 1966 & 13900 & 12,831 & $2,744,404$ \\
\hline 21292625 & 8 & COWDEN, SOUTH & ELLENBURGER & $T X$ & ECTOR & 1954 & 12883 & 0 & $5,459,419$ \\
\hline 21577270 & 8 & CRAWAR & ELLENBURGER & $\mathrm{TX}$ & CRANE & 1954 & 8236 & 0 & $1,111,683$ \\
\hline 23380300 & $7 \mathrm{C}$ & DAVIS & ELLENBURGER & $\mathrm{TX}$ & UPTON & 1950 & 13050 & 0 & $1,370,746$ \\
\hline 23907284 & 8 & DEEP ROCK & ELLENBURGER & $\mathrm{TX}$ & ANDREWS & 1954 & 12252 & 23,030 & $14,245,387$ \\
\hline 25188600 & 8 & DOLLARHIDE & ELLENBURGER & $\mathrm{TX}$ & ANDREWS & 1947 & 10137 & 57,387 & $26,460,708$ \\
\hline 25189400 & 8 & DOLLARHIDE, EAST & ELLENBURGER & $\mathrm{TX}$ & ANDREWS & 1959 & 12610 & 61,894 & $6,432,601$ \\
\hline 25395332 & 8 & DORA ROBERTS & ELLENBURGER & $T X$ & MIDLAND & 1954 & 12835 & 46,740 & $50,731,918$ \\
\hline 28843222 & 8 & EMBAR & ELLENBURGER & TX & ANDREWS & 1942 & 7977 & 8,143 & $22,646,307$ \\
\hline 28899249 & 8 & EMMA & ELLENBURGER & TX & ANDREWS & 1953 & 13307 & 26,198 & $54,500,181$ \\
\hline 30394375 & 8 & FASKEN & ELLENBURGER & $\mathrm{TX}$ & ANDREWS & 1953 & 12604 & 22,691 & $3,641,104$ \\
\hline 31768333 & 8 & FLYING -W- & ELLEN & TX & WINKLER & 1970 & 11768 & 0 & $1,003,126$ \\
\hline 33230400 & 8 & FULLERTON & ELLENBURGER & $\mathrm{TX}$ & ANDREWS & 1945 & 9945 & 0 & $2,067,603$ \\
\hline 33231250 & 8 & FULLERTON, EAST & ELLEN. & $\mathrm{TX}$ & ANDREWS & 1967 & 11428 & 3,077 & $1,236,825$ \\
\hline 33232510 & 8 & FULLERTON, NORTH & ELLENBURGER & TX & ANDREWS & 1991 & 9872 & 2,179 & $1,054,548$ \\
\hline 33235250 & 8 & FULLERTON, SOUTH & ELLENBURGER & $\mathrm{TX}$ & ANDREWS & 1948 & 10600 & 112,479 & $13,774,543$ \\
\hline 35197380 & 8 & GLASCO & ELLENBURGER & $\mathrm{TX}$ & ANDREWS & 1985 & 13806 & 36,343 & $2,830,825$ \\
\hline 35652248 & 8 & GOLDSMITH & ELLENBURGER & TX & ECTOR & 1947 & 9495 & 10,560 & $2,136,727$ \\
\hline 35654332 & 8 & GOLDSMITH, N. & ELLENBURGER & $T X$ & ECTOR & 1954 & 8896 & 15,938 & $5,595,412$ \\
\hline 35659375 & 8 & GOLDSMITH, W. & ELLENBURGER & $\mathrm{TX}$ & ECTOR & 1954 & 9428 & 22,927 & $4,018,423$ \\
\hline 39176498 & 8 & HARPER & ELLENBURGER & $T X$ & ECTOR & 1962 & 12436 & 101,351 & $23,900,923$ \\
\hline 39182666 & 8 & HARPER, SE. & ELLEN. & $\mathrm{TX}$ & ECTOR & 1965 & 12505 & 17,884 & $1,829,238$ \\
\hline 39969600 & 8 & HEADLEE & ELLENBURGER & $\mathrm{TX}$ & ECTOR & 1953 & 13106 & 0 & $38,326,414$ \\
\hline 44521498 & 8 & INEZ & ELLENBURGER & $\mathrm{TX}$ & ANDREWS & 1961 & 12505 & 0 & $16,436,191$ \\
\hline 47267228 & 8 & JORDAN & ELLENBURGER & $T X$ & ECTOR & 1947 & 8914 & 47,880 & $31,726,443$ \\
\hline 49038071 & 8 & KERMIT & ELLENBURGER & $\mathrm{TX}$ & WINKLER & 1943 & 10744 & 34,730 & $5,521,825$ \\
\hline 49129330 & 8 & KEYSTONE & ELLENBURGER & $T X$ & WINKLER & 1943 & 9524 & 266,296 & $146,847,044$ \\
\hline 49411500 & 8 & KING LAKE & ELLENBURGER & $\mathrm{TX}$ & ECTOR & 1988 & 11082 & 36,121 & $2,059,844$ \\
\hline 52624300 & 8 & LEA & ELLENBURGER & $\mathrm{TX}$ & CRANE & 1953 & 8165 & 19,653 & $20,496,500$ \\
\hline 53009500 & 8 & LEHN-APCO, SOUTH & ELLEN & $\mathrm{TX}$ & PECOS & 1977 & 4740 & 789 & $1,210,952$ \\
\hline 55256284 & 8 & LOWE & ELLENBURGER & TX & ANDREWS & 1957 & 13314 & 17,643 & $11,896,530$ \\
\hline 56822250 & 8 & MAGUTEX & ELLENBURGER & $\mathrm{TX}$ & ANDREWS & 1952 & 13840 & 41,194 & $17,610,065$ \\
\hline 57774332 & 8 & MARTIN & ELLENBURGER & $\mathrm{TX}$ & ANDREWS & 1946 & 8400 & 7,899 & $36,536,319$ \\
\hline 59339500 & 8 & MCELROY, NORTH & ELLENBURGER & $\mathrm{TX}$ & CRANE & 1973 & 12024 & 11,415 & $3,430,675$ \\
\hline 59419166 & 8 & MCFARLAND & ELLENBURGER & $\mathrm{TX}$ & ANDREWS & 1961 & 13898 & 21,201 & $5,636,171$ \\
\hline 60874500 & 8 & METZ, EAST & ELLENBURGER & TX & ECTOR & 1961 & 9046 & 5,571 & $2,984,224$ \\
\hline 61118332 & 8 & MIDLAND FARMS & ELLENBURGER & $T X$ & ANDREWS & 1952 & 12672 & 88,495 & $50,853,026$ \\
\hline 61121666 & 8 & MIDLAND FARMS, NE. & ELLENBURGER & TX & ANDREWS & 1953 & 12540 & 8 & $7,643,557$ \\
\hline 62415332 & 8 & MONAHANS & ELLENBURGER & $\mathrm{TX}$ & WARD & 1942 & 10550 & 0 & $5,318,009$ \\
\hline 62417360 & 8 & MONAHANS, N. & ELLENBURGER & $T X$ & WINKLER & 1955 & 11990 & 128,738 & $8,663,172$ \\
\hline 62703200 & 8 & MOONLIGHT & ELLENBURGER & $\mathrm{TX}$ & MIDLAND & 1983 & 13325 & 0 & $1,014,717$ \\
\hline 64890500 & 8 & NELSON & ELLENBURGER & TX & ANDREWS & 1946 & 10384 & 1,336 & $5,070,077$ \\
\hline 65766444 & 8 & NOLLEY & ELLEN. & TX & ANDREWS & 1968 & 13939 & 0 & $2,678,693$ \\
\hline 65967600 & 8 & NORMAN & ELLENBURGER & $\mathrm{TX}$ & GAINES & 1970 & 13865 & 120,891 & $2,195,849$ \\
\hline 70279250 & $7 \mathrm{C}$ & PEGASUS & ELLENBURGER & TX & UPTON & 1949 & 12530 & 122,277 & $96,008,159$ \\
\hline 70537330 & 8 & PENWELL & ELLENBURGER & $T X$ & ECTOR & 1946 & 8888 & 15,718 & $14,203,574$ \\
\hline 73103666 & 8 & PRICHARD & ELLENBURGER & $\mathrm{TX}$ & ANDREWS & 1953 & 13475 & 14,572 & $1,061,819$ \\
\hline 74793333 & 8 & RATLIFF & ELLENBURGER & $\mathrm{TX}$ & ECTOR & 1954 & 13559 & 21,980 & $3,368,635$ \\
\hline 80474500 & 8 & SAND HILLS, EAST & ELLENBURGER & $\mathrm{TX}$ & CRANE & 1968 & 5703 & 54,158 & $2,253,367$ \\
\hline 80475500 & 8 & SAND HILLS, N. & ELLENBURGER & TX & CRANE & 1957 & 6030 & 24,284 & $1,177,511$ \\
\hline 82570300 & 8 & SHAFTER LAKE & ELLENBURGER & $T X$ & ANDREWS & 1948 & 11685 & 8,945 & $6,629,516$ \\
\hline 87599284 & 8 & SWEETIE PECK & ELLENBURGER & $\mathrm{TX}$ & MIDLAND & 1950 & 13128 & 34,388 & $10,038,376$ \\
\hline 88071290 & 8 & $\mathrm{TXL}$ & ELLENBURGER & $T X$ & ECTOR & 1949 & 9600 & 70,397 & $129,551,707$ \\
\hline
\end{tabular}


Table 5, continued. Ellenburger Karst-Modified Restricted Ramp Carbonate play (play 102).

$\begin{array}{rrl}\text { RRC RESN } & \text { RRC } & \text { FLDNAME } \\ & & \\ 92548500 & 8 & \text { UNIVERSITY BLOCK 13 } \\ 92618250 & 8 & \text { UNIVERSITY WADDELL } \\ 93485300 & 8 & \text { VENTEAM } \\ 93958250 & 8 & \text { VIREY } \\ 95108375 & 8 & \text { WAR-SAN } \\ 96291333 & 8 & \text { WEMAC } \\ 96756400 & 8 & \text { WHEELER } \\ 97834500 & 7 \text { C } & \text { WILSHIRE } \\ 94439400 & 8 & \text { W. T. FORD } \\ 99275375 & 8 & \text { YARBROUGH \& ALLEN } \\ 99409500 & 8 & \text { YORK } \\ & & \text { BRUNSON } \\ & & \text { DOLLARHIDE } \\ & & \text { FOWLER } \\ & & \text { JUSTIS } \\ & \text { STATELINE } \\ & \text { TEAGUE } \\ & \text { TEAGUE NORTH } \\ & & \text { Totals }\end{array}$

RESNAME
ELLEN.
ELLENBURGER
ELLENBURGER
ELLENBURGER
ELLENBURGER
ELLENBURGER
ELLENBURGER
ELLENBURGER
ELLENBURGER
ELLENBURGER
ELLENBURGER
ELLENBURGER
ELLENBURGER
ELLENBURGER
ELLENBURGER
ELLENBURGER
ELLENBURGER
ELLENBURGER

$\begin{array}{ll}\text { STATE COUNTY } \\ \text { TX } & \text { ANDREWS } \\ \text { TX } & \text { CRANE } \\ \text { TX } & \text { ECTOR } \\ \text { TX } & \text { MIDLAND } \\ \text { TX } & \text { MIDLAND } \\ \text { TX } & \text { ANDREWS } \\ \text { TX } & \text { WINKLER } \\ \text { TX } & \text { UPTON } \\ \text { TX } & \text { ECTOR } \\ \text { TX } & \text { ECTOR } \\ \text { TX } & \text { ECTOR } \\ \text { NM } & \text { LEA } \\ \text { NM } & \text { LEA } \\ \text { NM } & \text { LEA } \\ \text { NM } & \text { LEA } \\ \text { NM } & \text { LEA } \\ \text { NM } & \text { LEA } \\ \text { NM } & \text { LEA }\end{array}$

DISCYR

1960
1947
1995
1954
1954
1954
1942
1951
1991
1947
1955
1945
1951
1949
1957
1965
1950
1988 10800
10620 10800
10620 13250 13276 13070
13306 13306
10697 10697
11944 12260 10490 12395 12395
8059 8059
10135 9505 8115 12100 12100
9700 10200 13070

2000 PROD

$56,641 \quad 14,978,243$ $9,039,824$ $\begin{array}{rr}9,039,824 \\ 71,711 & 30,996,282\end{array}$ 46,946 $46,946 \quad 14,916,750$ $1,627 \quad 5,847,947$ $\begin{array}{rr}5,997 & 17,952,199 \\ 0 & 41,080,326\end{array}$ $41,080,326$
$1,072,228$ $40,502,338$ $2,636,804$ $2,636,804$
$27,654,212$ $27,654,212$
$3,512,341$ $17,012,002$ $7,663,268$ $4,191,567$ $2,485,768$
$1,772,980$ $2,802,096 \quad 1,487,309,287$

Intercrystalline and intergranular porosity does not contribute significantly to production in most Ellenburger reservoirs. The main control on porosity distribution in Ellenburger reservoirs in this play is extensive erosion and karstification that occurred during the early Middle Ordovician (post-Sauk) lowstand (Kerans, 1988; Lucia, 1995). Dominant pore types in most Ellenburger reservoirs are secondary, fracture/touching vugs associated with karst development (Kerans, 1989; Tyler and others, 1991).

Reservoir heterogeneity is mainly the result of extensive dissolution, cave formation, and subsequent infilling (Kerans, 1988). Ellenburger platform carbonates were subaerially exposed when sea level fell at the end of Ellenburger Group sedimentation, and a regionally extensive, water-table karst system developed. The cave systems collapsed and were infilled during sealevel rise associated with deposition of the overlying Middle Ordovician Simpson Group. The resulting karst-facies stratigraphy includes, from top to bottom, cave-roof (50 to $150 \mathrm{ft}$ [15 to $45 \mathrm{~m}$ ] thick), cave-fill (50 to $150 \mathrm{ft}$ [15 to $45 \mathrm{~m}$ ] thick), and lower-collapse-zone (20 to $400 \mathrm{ft}$ [6 to $122 \mathrm{~m}$ ] thick) facies (figs. 9, 10). The cave-roof facies is composed of intact dolostone and 


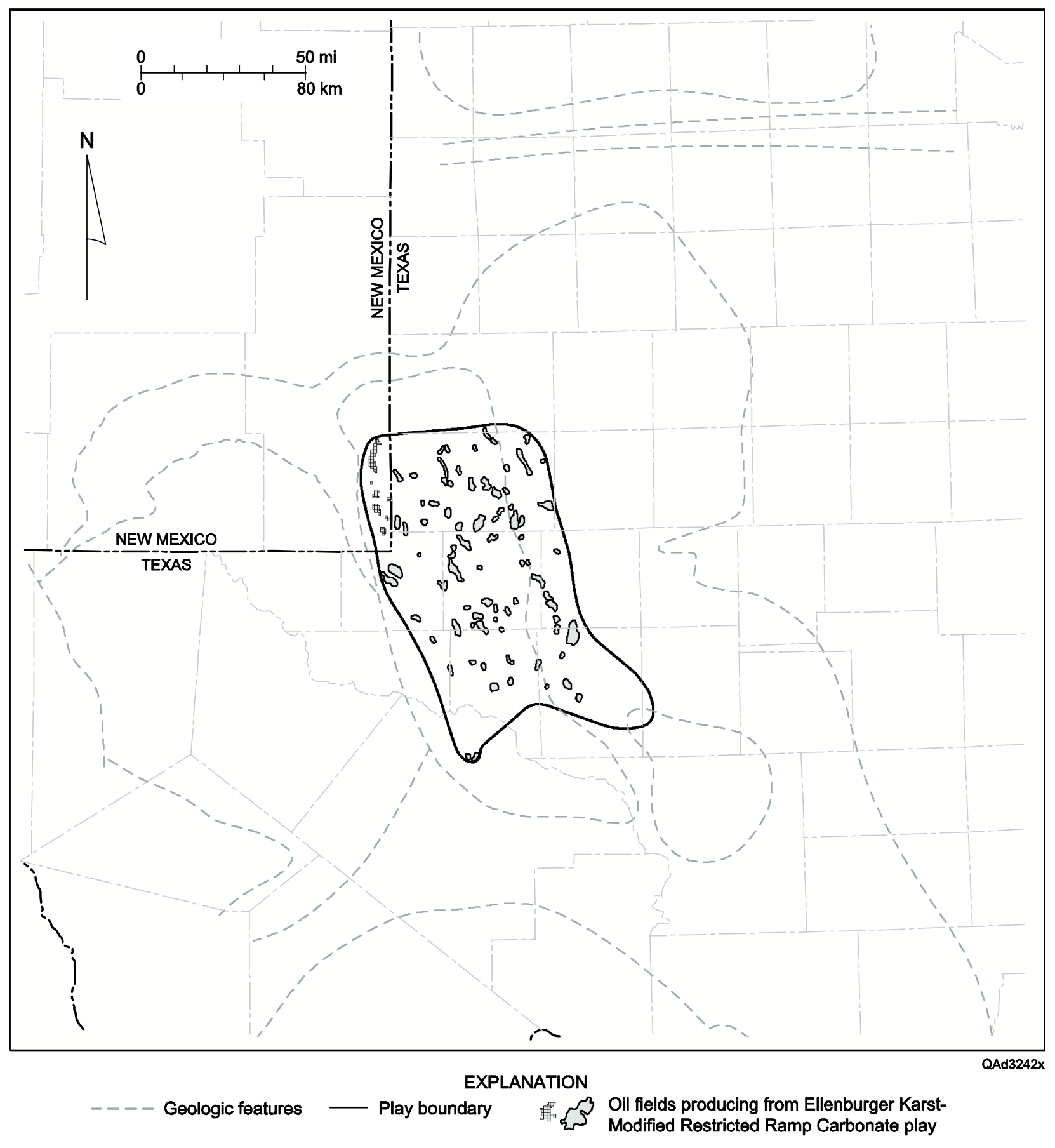

Figure 8. Play map for the Ellenburger Karst-Modified Restricted Ramp Carbonate play, showing location of reservoirs having $>1$ MMbbl cumulative production, the play boundary, and geologic features. See figure 1 for county names and figure 2 for identification of geologic features. 


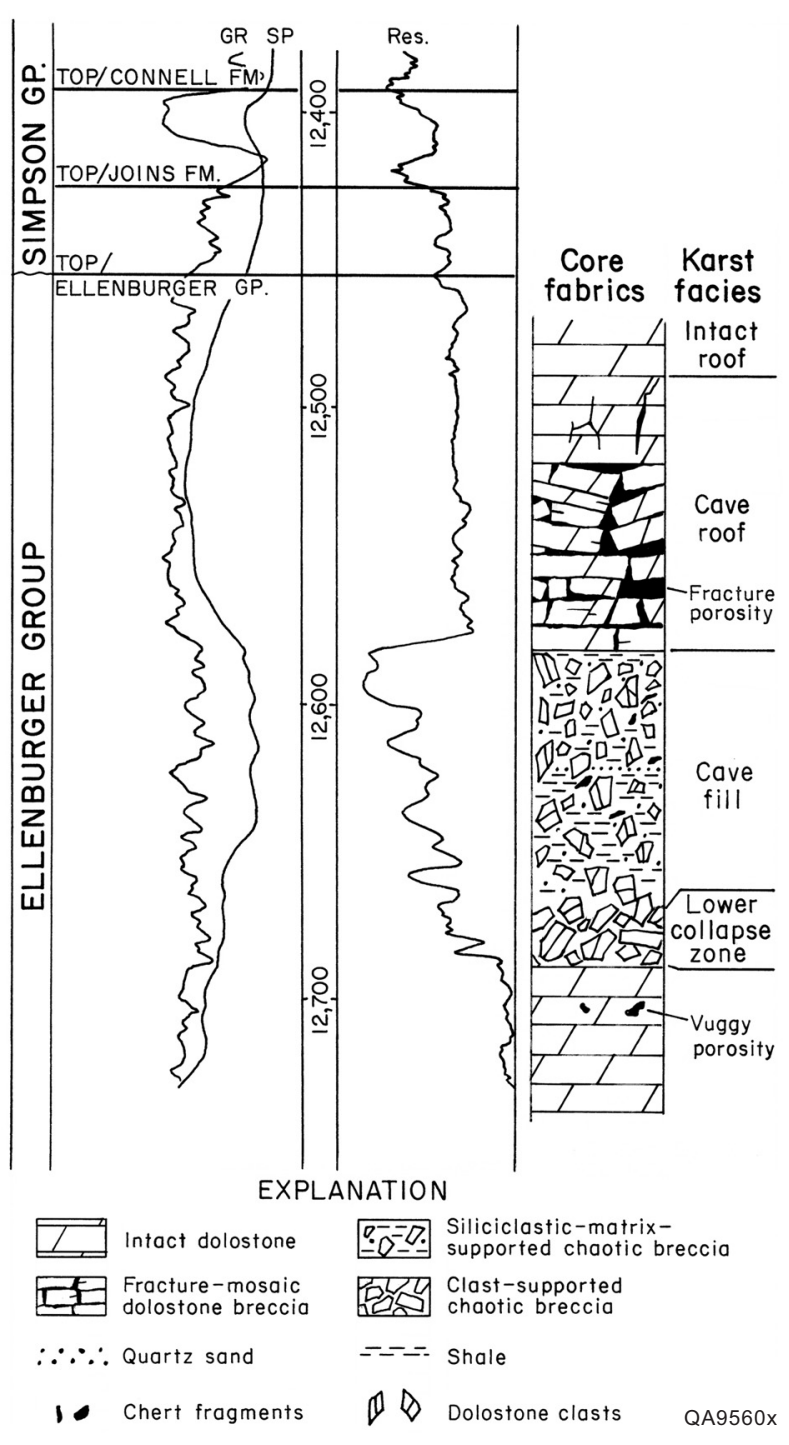

Figure 9. Karst facies and associated log signatures in the Gulf 000-1 TXL well, northeast Emma Ellenburger field, Andrews County, Texas. From Kerans (1988), reprinted by permission of the AAPG, whose permission is required for further use. CC Copyright 1988. The American Association of Petroleum Geologists. All rights reserved.

dolostone fracture and mosaic breccia. The cave-fill deposits are siliciclastic-matrix-supported chaotic breccia, and the cave-floor facies is a carbonate-clast-supported chaotic breccia (Kerans, 1988). Tectonic fractures probably enhance the permeability created by karst-related fractures and touching-vug pores (Kosters and others, 1989; Kerans, 1990; Loucks, 1999).

Pressure-test data in Emma field, Andrews County, indicate that cave-roof and lowercollapse zones are permeable intervals separated by low-permeability cave-fill facies (Kerans, 


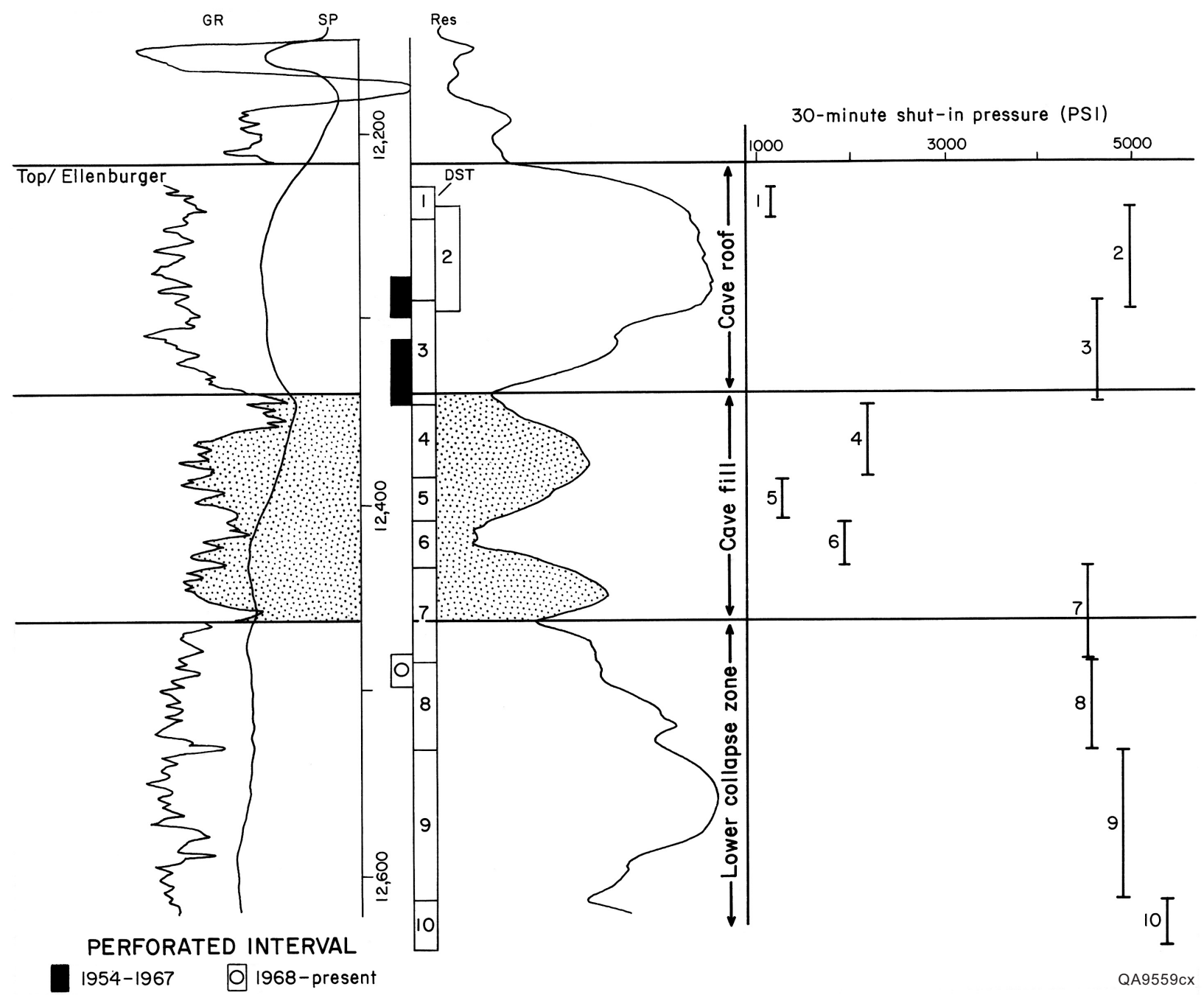

Figure 10. Log signatures and shut-in pressures in the Mobil 36-1 University well in Ellenburger Emma field, Andrews County, Texas. Results of shut-in pressure tests show that the cave-fill facies is a low-permeability zone separating cave-roof and lower-collapse-zone reservoir units. Recompletion in the lower-collapse zone in 1968 resulted in production of an additional $200,000 \mathrm{bbl}$ of oil that would not have been produced by the initial completion in the caveroof facies. From Kerans (1988), reprinted by permission of the AAPG, whose permission is required for further use. CCopyright 1988. The American Association of Petroleum Geologists. All rights reserved.

1988). The cave-fill facies thus acts as an internal flow barrier separating cave-roof and lowercollapse reservoir zones. This flow barrier is located between 100 and $200 \mathrm{ft}$ (30 and $60 \mathrm{~m})$ below the erosional top of the Ellenburger Group, probably reflecting the presence of a paleowater table. Adjacent low-permeability host rocks may also contribute to the vertical 
permeability barrier formed by cave-fill deposits (Loucks, 1999). Wells that were completed only in the top 50 to $100 \mathrm{ft}$ ( 15 to $30 \mathrm{~m}$ ) of the Ellenburger to avoid problems associated with water coning may leave lower permeable units undrained (Kerans, 1988, 1989, 1990).

The Ellenburger Formation in New Mexico is a restricted inner-platform cyclic dolomite having extensive subaerial diagenesis associated with changes in relative sea level (Clemons, 1989; Kerans and Lucia, 1989; Goldhammer and others, 1993). Although dolomitized, the Langley Ellenburger reservoir in Lea County contains identifiable intertidal to supratidal facies successions that include alternations of laminated mudstone/wackestone, peloid/ooid grainstone, peloid-algal mat boundstone, and intraclast and pebble breccia (Verseput, 1989). (Langley is not listed in table 5 because it had only produced $779,000 \mathrm{bbl}\left(1.24 \times 10^{5} \mathrm{~m}^{3}\right)$ through 2000$)$.

Ellenburger porosity types include intercrystalline matrix, vugs, major karst dissolution, and fractures (Mazzullo, 1989), the most significant type being dissolution and collapse breccia karst (see Loucks, 1999). In addition, isolated high-porosity zones are preserved in some deeper water muddy-carbonate facies that underwent late burial dolomitization, resulting in coarsegrained textures (Kerans and Lucia, 1989). In the Langley reservoir, maximum intergranular porosity in the peloid-algal mat boundstone and peloid/ooid grainstone facies is 5 percent and permeability is $0.5 \mathrm{md}\left(0.5 \times 10^{-3} \mu \mathrm{m}^{2}\right)$ (Verseput, 1989). Non-fabric-selective fractures and solution-collapse breccia also occur and enhance both porosity (up to 8 percent) and permeability (up to $50 \mathrm{md}\left[50 \times 10^{-3} \mu \mathrm{m}^{2}\right]$ ). In the Stateline reservoir in Lea County, the Ellenburger is composed completely of fabric-destructive dolomite (Amthor and Friedman, 1989). Largely lowpermeability upper Ellenburger strata are underlain by lower units interpreted as cave-roof facies that contain abundant stylolites, fractures, molds, vugs, and dissolution cavities that increase porosity to as high as 15 percent (Amthor and Friedman, 1989). 
Net-pay thickness in the Ellenburger Karst-Modified Restricted Ramp Carbonate play ranges between 20 and $410 \mathrm{ft}(6$ and $125 \mathrm{~m})$ and averages $180 \mathrm{ft}(55 \mathrm{~m})$ (Holtz and Kerans, 1992). Porosity ranges from 1 to 8 percent and averages 3.2 percent; production is controlled by the fracture and touching-vug pore systems, not by the low matrix porosity. Permeability is highly variable, ranging from 2 to $750 \mathrm{md}\left(2\right.$ to $\left.750 \times 10^{-3} \mu \mathrm{m}^{2}\right)$, and the geometric mean is $32 \mathrm{md}\left(32 \times 10^{-3} \mu \mathrm{m}^{2}\right)$ (Holtz and Kerans, 1992).

\section{References}

Amthor, J. E., and Friedman, G. M., 1989, Petrophysical character of Ellenburger karst facies: Stateline (Ellenburger) field, Lea County, southeastern New Mexico, in Cunningham, B. K., and Cromwell, D. W., eds., The lower Paleozoic of West Texas and southern New Mexico-modern exploration concepts: Permian Basin Section Society of Economic Paleontologists and Mineralogists, Publication No. 89-31, p. 133-144.

Clemons, R. E., 1989, The Ellenburger-El Paso connection: Lower Ordovician shelf carbonates, in Cunningham, B. K., and Cromwell, D. W., eds., The lower Paleozoic of West Texas and southern New Mexico - modern exploration concepts: Permian Basin Section Society of Economic Paleontologists and Mineralogists, Publication No. 89-31, p. 85104.

Galloway, W. E., Ewing, T. E., Garrett, C. M., Jr., Tyler, N., and Bebout, D. G., 1983, Atlas of major Texas oil reservoirs: The University of Texas at Austin, Bureau of Economic Geology Special Publication, 139 p.

Goldhammer, R. K., Lehmann, P. J., and Dunn, P. A., 1993, The origin of high-frequency platform carbonate cycles and third-order sequences (Lower Ordovician El Paso Group, west Texas): constraints from outcrop data and stratigraphic modeling: Journal of Sedimentary Petrology, v. 63, p. 318-359.

Hammes, U., Lucia, F. J., and Kerans, C., 1996, Reservoir heterogeneity in karst-related reservoirs: Lower Ordovician Ellenburger Group, west Texas, in Stoudt, E. L., ed., Precambrian-Devonian geology of the Franklin Mountains, west Texas-analogs for exploration and production in Ordovician and Silurian karsted reservoirs in the Permian Basin: West Texas Geological Society Publication 96-100, p. 99-115.

Holtz, M. H., and Kerans, C., 1992, Characterization and categorization of West Texas Ellenburger reservoirs, in Candelaria, M. P., and Reed, C. L., eds., Paleokarst, karstrelated diagenesis, and reservoir development: examples from Ordovician-Devonian age 
strata of West Texas and the Mid-Continent: Permian Basin Section, Society of Economic Paleontologists and Mineralogists, Field Trip Guidebook, Publication No. 92-33, p. 45-54.

Kerans, C., 1988, Karst-controlled reservoir heterogeneity in Ellenburger Group carbonates of West Texas: American Association of Petroleum Geologists Bulletin, v. 72, p. 11601183.

1989, Karst-controlled reservoir heterogeneity and an example from the Ellenburger (Lower Ordovician) of West Texas: The University of Texas at Austin, Bureau of Economic Geology Report of Investigations No. 186, 40 p.

1990, Depositional systems and karst geology of the Ellenburger Group (Lower Ordovician), subsurface West Texas: The University of Texas at Austin, Bureau of Economic Geology Report of Investigations No. 193, 37 p.

Kerans, C., Holtz, M. H., and Tyler, N., 1989, Controlling styles of reservoir heterogeneity in Ellenburger Group carbonates, West Texas, in Cunningham, B. K., and Cromwell, D. W., eds., The Lower Paleozoic of West Texas and Southern New Mexico-Modern Exploration Concepts: Permian Basin Section, Society of Economic Paleontologists and Mineralogists, Publication No. 89-31, p. 131-144.

Kerans, C., and Lucia, F. J., 1989, Recognition of second, third, and fourth/fifth order scales of cyclicity in the El Paso Group and their relation to genesis and architecture of Ellenburger reservoirs, in Cunningham, B. K., and Cromwell, D. W., eds., The lower Paleozoic of West Texas and southern New Mexico-modern exploration concepts: Permian Basin Section, Society of Economic Paleontologists and Mineralogists, Publication No. 89-31, p. 105-110.

Kosters, E. C., Bebout, D. G., Seni, S. J., Garrett, C. M., Jr., Brown, L. F., Jr., Hamlin, H. S., Dutton, S. P., Ruppel, S. C., Finley, R. J., and Tyler, Noel, 1989, Atlas of major Texas gas reservoirs: The University of Texas at Austin, Bureau of Economic Geology Special Publication, $161 \mathrm{p}$.

Loucks, R. G., 1999, Paleocave carbonate reservoirs: origins, burial-depth modifications, spatial complexity, and reservoir implications: American Association of Petroleum Geologists Bulletin, v. 83, p. 1795-1834.

Loucks, R. G., and Handford, C. R., 1992, Origin and recognition of fractures, breccias, and sediment fills in paleocave-reservoir networks, in Candelaria, M. P., and Reed, C. L., eds., Paleokarst, karst related diagenesis and reservoir development: examples from Ordovician-Devonian age strata of west Texas and the mid-continent: Permian Basin Section, Society of Economic Paleontologists and Mineralogists, Publication 92-33, p. $31-44$. 
Lucia, F. J., 1995, Lower Paleozoic cavern development, collapse, and dolomitization, Franklin Mountains, El Paso, Texas, in Budd, D. A., Saller, A. H., and Harris, P. M., eds., Unconformities and porosity in carbonate strata: American Association of Petroleum Geologists, American Association of Petroleum Geologists Memoir 63, p. 279-300.

Mazullo, S. J., 1989, Formational and zonal subdivisions of the Ellenburger Group (Lower Ordovician), southern Midland basin, Texas, in Cunningham, B. K., and Cromwell, D. W., eds., The lower Paleozoic of West Texas and southern New Mexicomodern exploration concepts: Permian Basin Section, Society of Economic Paleontologists and Mineralogists, Publication No. 89-31, p. 113-122.

Tyler, N., Bebout, D. G., Garrett, C. M., Jr., Guevara, E. H., Hocott, C. R., Holtz, M. H., Hovorka, S. D., Kerans, C., Lucia, F. J., Major, R. P., Ruppel, S. C., and Vander Stoep, G. W., 1991, Integrated characterization of Permian Basin reservoirs, University Lands, West Texas: targeting the remaining resource for advanced oil recovery: The University of Texas at Austin, Bureau of Economic Geology Report of Investigations No. 203, $136 \mathrm{p}$.

Verseput, T. D., 1989, Depositional setting of the Ellenburger-Langley field, Lea County, New Mexico, in Cunningham, B. K., and Cromwell, D. W., eds., The lower Paleozoic of West Texas and southern New Mexico - modern exploration concepts: Permian Basin Section, Society of Economic Paleontologists and Mineralogists, Publication No. 89-31, p. 145158. 
Simpson Cratonic Sandstone (Play 103)

The Simpson Cratonic Sandstone play consists of 19 reservoirs that had produced $>1 \mathrm{MMbbl}\left(1.59 \times 10^{5} \mathrm{~m}^{3}\right)$ of oil through 2000 ; cumulative production from the play was 103.2 MMbbl $\left(1.64 \times 10^{7} \mathrm{~m}^{3}\right)$ (table 6). Reservoirs of the Simpson Cratonic Sandstone play are distributed along the Central Basin Platform (fig. 11), where they are associated with local structures. The Middle Ordovician Simpson Group was deposited in the Tobosa Basin, a shallow, downwarped area centered in Pecos and Terrell Counties during Simpson time (Galley, 1958).

Reservoirs in the play are found within three regionally extensive sandstones of the Simpson Group — the Connell, Waddell, and McKee (Wright, 1979). The Connell sandstone occurs at the base of the Oil Creek Formation, the Waddell sandstone at the base of the McLish Formation, and the McKee sandstone at the base of the Tulip Creek Formation (fig. 12) (Gibson, 1965). These three formations are composed mostly of green shales; the productive sandstones

Table 6. Simpson Cratonic Sandstone play (play 103). Production shown for fields that have had others combined into them represents the totals; combined fields are highlighted.

\begin{tabular}{|c|c|c|c|c|c|c|c|c|c|}
\hline RRC RESN & RRC & FLDNAME & RESNAME & STATE & COUNTY & DISCYR & DEPTHTOP & 2000 PROD & CUMPROD \\
\hline 292001 & 8 & ABELL & & $\mathrm{TX}$ & PECOS & 1940 & 5400 & 2,308 & $8,106,194$ \\
\hline 293625 & 8 & ABELL, EAST & MCKEE & TX & PECOS & 1956 & 5415 & 6,553 & $2,322,612$ \\
\hline 293875 & 8 & ABELL, EAST & WADDELL, W. SEG. & $T X$ & PECOS & 1957 & 6090 & 7,800 & $2,014,539$ \\
\hline 296500 & 8 & ABELL, NORTHWEST & MCKEE SAND & $\mathrm{TX}$ & PECOS & 1949 & 5432 & 0 & $1,435,103$ \\
\hline 2596400 & 8 & ANDECTOR & MCKEE & TX & ECTOR & 1948 & 7635 & 7,650 & $3,374,471$ \\
\hline 2596800 & 8 & ANDECTOR & WADDELL & $T X$ & ECTOR & 1948 & 7835 & 9,882 & $2,029,953$ \\
\hline 9358270 & 8 & BLOCK 31 & CONNELL & $\mathrm{TX}$ & CRANE & 1948 & 10170 & 0 & $1,083,545$ \\
\hline 21577810 & 8 & CRAWAR & WADDELL & TX & WARD & 1955 & 7645 & 1,737 & $1,587,021$ \\
\hline 47267076 & 8 & JORDAN & CONNELL SAND & $\mathrm{TX}$ & ECTOR & 1948 & 8830 & 0 & $4,445,230$ \\
\hline 52624200 & 8 & LEA & CONNELL & TX & CRANE & 1953 & 8178 & 8,501 & $3,431,877$ \\
\hline 57774498 & 8 & MARTIN & MCKEE & TX & ANDREWS & 1945 & 8300 & 32,417 & $6,816,298$ \\
\hline 78936800 & 8 & RUNNING W & WADDELL & TX & CRANE & 1954 & 6148 & 67,370 & $25,266,119$ \\
\hline 80473372 & 8 & SAND HILLS & ORDOVICIAN & $\mathrm{TX}$ & CRANE & 1936 & 6300 & 14,256 & $13,143,342$ \\
\hline 88073500 & 8 & TX L, NORTH & WADDELL & $\mathrm{TX}$ & ECTOR & 1961 & 9386 & 4,291 & $2,716,712$ \\
\hline 91630001 & 8 & TUCKER & & $\mathrm{TX}$ & CRANE & 1946 & 5770 & 124 & $2,241,122$ \\
\hline \multirow[t]{5}{*}{99275750} & 8 & YARBROUGH \& ALLEN & WADDELL & TX & ECTOR & 1950 & 10110 & 2,850 & $1,235,313$ \\
\hline & & HARE & SIMPSON & NM & LEA & 1947 & 7550 & 38,743 & $17,193,665$ \\
\hline & & JUSTIS & MCKEE & NM & LEA & 1957 & 7700 & 0 & $1,312,000$ \\
\hline & & TEAGUE & SIMPSON & NM & LEA & 1948 & 9340 & 216,169 & $3,473,240$ \\
\hline & & Totals & & & & & & 420,651 & $103,228,356$ \\
\hline
\end{tabular}




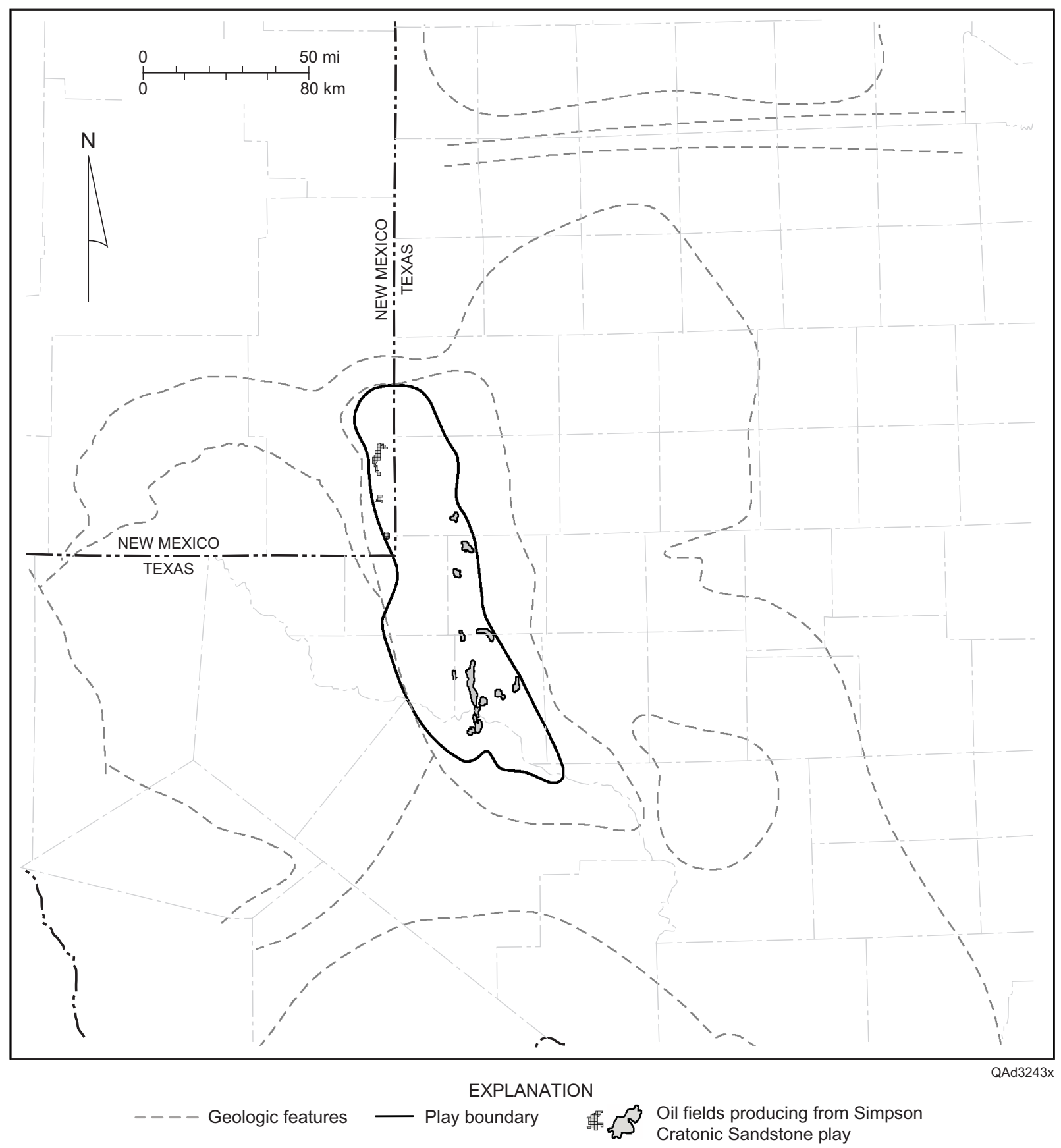

Figure 11. Play map for the Simpson Cratonic Sandstone play, showing location of reservoirs having $>1$ MMbbl cumulative production, the play boundary, and geologic features. See figure 1 for county names and figure 2 for identification of geologic features. 


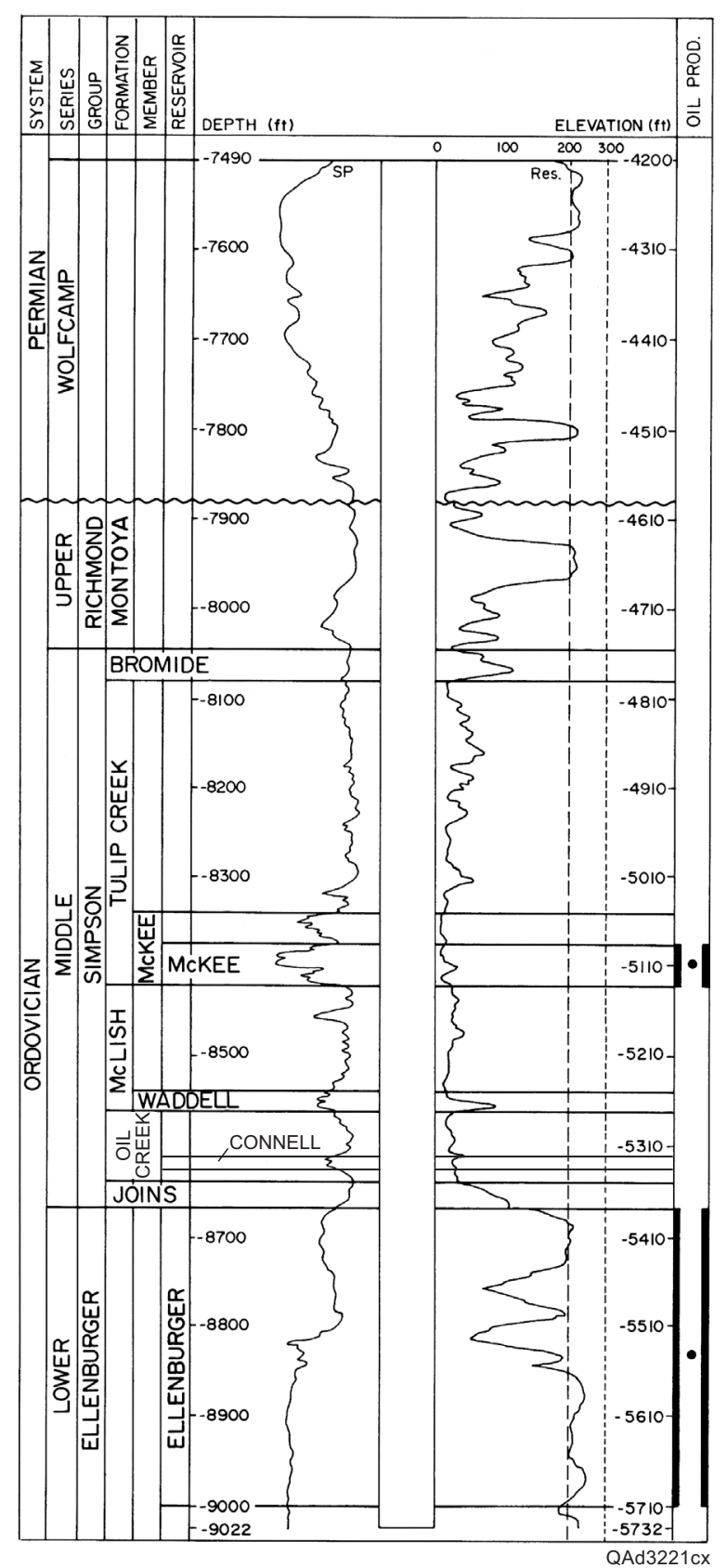

Figure 12. Log of Ordovician and Permian strata from a well in Martin McKee field, Andrews County, Texas, showing McKee producing interval. From Galloway and others (1983); after Herald (1957).

are $\sim 20$ to $50 \mathrm{ft}$ ( $\sim 6$ to $15 \mathrm{~m}$ ) thick (Galley, 1958). The Joins and Bromide Formations (fig. 12) are largely nonproductive. The sediment source was interpreted to be the Transcontinental Arch to the northwest. There is no evidence that the Central Basin Platform was a positive feature during deposition of the Simpson sandstones (Frenzel and others, 1988). 
The Simpson Group was deposited when sea level rose in the Middle Ordovician and marine transgression ended the period of exposure and karstification of the underlying Ellenburger (Kerans, 1988). Rocks of the Simpson Group are composed of interbedded shale, limestone, and sandstone; sandstones make up $\sim 5$ percent of the total thickness of the Simpson Group. Little has been published about the origin of Simpson sandstones. Connell sandstones in outcrop in Culberson County, Texas, consist of fine- to coarse-grained sandstone composed of frosted, rounded quartz grains (Suhm and Ethington, 1975). Cements include variable amounts of quartz overgrowths and dolomite cement (Suhm and Ethington, 1975). The Connell sandstone is interpreted as having been deposited in high-energy shoreface and nearshore environments, to more distal and lower energy marine environments (Suhm and Ethington, 1975). Simpson sandstones of the southern Midcontinent were interpreted by Candelaria and others (1994) as strandline sandstones deposited during sea-level lowstands. The sands were transported into the basin by fluvial and eolian processes (Candelaria and others, 1994). As sea level rose, a series of widespread, back-stepping, shoreface complexes represented the transgressive systems tract.

Oil is trapped in the producing sandstones of the Simpson Group along folded and faulted structures of the Central Basin Platform, with Simpson shales providing the seal. High-angle faults on the flanks of the anticlines may form part of the trapping mechanism, as at the Teague McKee reservoir (Sharp, 1956). Other reservoirs produce where the Simpson sandstones are truncated by erosion along the flanks of anticlines underneath a major regional unconformity (fig. 13). The seal is provided by overlying post-Simpson rocks, mainly Pennsylvanian and Permian shales and carbonates (Symposium Committee, 1956; Gibson, 1965; Wright, 1979; Galloway and others, 1983). The unconformity was formed during major late Paleozoic uplift that formed the Central Basin Platform and the smaller structures associated with Simpson traps. 


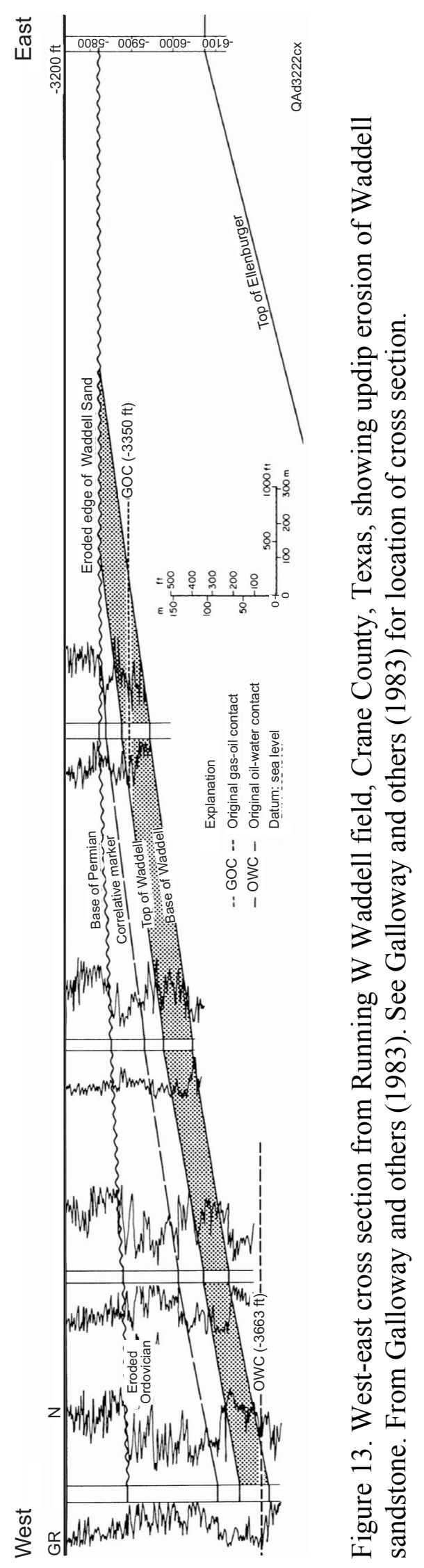


The Running W (Waddell) reservoir in Crane County produces where erosional pinch-out of the Waddell sandstone is overlain by Permian rocks (Galloway and others, 1983). Crawar Waddell field produces from a north-south-trending anticline that is bound on the east by a northwestsoutheast-trending reverse fault (Wojcik, 1990). Candelaria and others (1994) suggested that stratigraphic traps may occur in retrogradational Simpson shoreface sandstones that are laterally discontinuous and vertically segregated.

Porosity ranges from 11 percent in Crawar Waddell field to 16 percent at Martin McKee. Permeability averages $45 \mathrm{md}\left(45 \times 10^{-3} \mu \mathrm{m}^{2}\right)$ in Crawar Waddell (Wojcik, 1990) and $164 \mathrm{md}$ $\left(164 \times 10^{-3} \mu \mathrm{m}^{2}\right)$ in Running W Waddell field (Galloway and others, 1983).

\section{References}

Candelaria, M. P., Handford, C. R., and Reed, C. L., 1994, Sequence model for the Simpson Group of the southern mid-continent: a tool for stratigraphic trap prediction, in Gibbs, J. F., ed., Synergy equals energy - teams, tools, and techniques: West Texas Geological Society Publication 94-94, p. 177.

Frenzel, H. N., Bloomer, R. R., Cline, R. B., Cys, J. M., Galley, J. E., Gibson, W. R., Hills, J. M., King, W. E., Seager, W. R., Kottlowski, F. E., Thompson, S., III, Luff, G. C., Pearson, B. T., and Van Siclen, D. C., 1988, The Permian Basin region, in Sloss, L. L., ed., Sedimentary cover-North American Craton; U.S.: Boulder, Colorado, Geological Society of America, The Geology of North America, v. D-2, p. 261-306.

Galley, J. D., 1958, Oil and gas geology in the Permian Basin in Texas and New Mexico, in Weeks, L. G., ed., Habitat of oil-a symposium: Tulsa, Oklahoma, American Association of Petroleum Geologists, p. 395-446.

Galloway, W. E., Ewing, T. E., Garrett, C. M., Jr., Tyler, N., and Bebout, D. G., 1983, Atlas of major Texas oil reservoirs: The University of Texas at Austin, Bureau of Economic Geology Special Publication, 139 p.

Gibson, G. R., 1965, Oil and gas in southwestern region — geologic framework, in Young, A., and Galley, J. E., eds., Fluids in the subsurface environment: American Association of Petroleum Geologists Memoir 4, p. 66-100. 
Herald, F. A., ed., 1957, Occurrence of oil and gas in west Texas: University of Texas, Austin, Bureau of Economic Geology Publication No. 5716, 442 p.

Kerans, C., 1988, Karst-controlled reservoir heterogeneity in Ellenburger Group carbonates of West Texas: American Association of Petroleum Geologists Bulletin, v. 72, p. 11601183.

Sharp, J. L., 1956, Teague (McKee), in Oil and gas fields of southeastern New Mexico: Roswell Geological Society, p. 334-335.

Suhm, R. W., and Ethington, R. L., 1975, Stratigraphy and conodonts of Simpson Group (Middle Ordovician), Beach and Baylor Mountains, West Texas: American Association of Petroleum Geologists Bulletin, v. 59, p. 1126-1135.

Symposium Committee, 1956, Hare (Simpson), in Oil and gas fields of southeastern New Mexico: Roswell Geological Society, p. 197.

Wojcik, R., 1990, Crawar (Waddell), in Grace, R. M., ed., Oil \& Gas Fields in West Texas Symposium, v. 5: West Texas Geological Society, Publication No. 90-86, p. 71-72.

Wright, W. F., 1979, Petroleum geology of the Permian Basin: West Texas Geological Society Publication No. 79-71, 98 p. 


\section{Silurian Plays}

Carbonate and chert rocks of Silurian and Devonian age (fig. 3) constitute a thick succession (as much as 2,000 $\mathrm{ft}[610 \mathrm{~m}]$ ) of platform and deeper water slope and basin deposits that underlies most of the Permian Basin (Ruppel and Holtz, 1994). Most previous studies have grouped large parts of this succession as the Siluro-Devonian because of uncertainty over the stratigraphic and temporal interrelationships of these deposits. In the Atlas of Major Texas Oil Reservoirs (Galloway and others, 1983) Siluro-Devonian reservoirs were grouped into three plays: Siluro-Devonian Ramp Carbonate, Siluro-Devonian Ramp Carbonate (South Central Basin Platform), and Siluro-Devonian Ramp Carbonate (North Central Basin Platform). Regional stratigraphic analysis of these deposits by Ruppel and Holtz (1994) and more recent biostratigraphic studies by Barrick and others (1993) and Barrick (1995) have more clearly defined the stratigraphy of these rocks. In this report the "Siluro-Devonian" has been subdivided into four plays - two that are dominantly Silurian and two Devonian.

Reservoirs productive from Silurian rocks can be subdivided into two distinct lithologic successions: the Fusselman Formation (which actually ranges from Upper Ordovician to Middle Silurian) and the Wristen Group (Middle to Upper Silurian) (fig. 3). The two Silurian plays are the Fusselman Shallow Platform Carbonate and the Wristen Buildups and Platform Carbonate.

The few Upper Ordovician Montoya reservoirs that have produced $>1 \mathrm{MMbbl}\left(1.59 \times 10^{5} \mathrm{~m}^{3}\right)$ of oil are included in the Fusselman play. Devonian reservoirs are grouped in the Devonian Thirtyone Deepwater Chert and Devonian Thirtyone Ramp Carbonate plays. 


\section{References}

Barrick, J. E., 1995, Biostratigraphy of uppermost Ordovician through Devonian depositional sequences in the Permian basin, west Texas and Southeastern New Mexico, in Pausé, P. H., and Candelaria, M. P., eds., Carbonate facies and sequence stratigraphy: practical applications of carbonate models: Permian Basin Section, Society of Economic Paleontologists and Mineralogists, Publication 95-36, p. 207-216.

Barrick, J. E., Finney, S. C., and Haywa-Branch, J. N., 1993, Revision of ages of the Fusselman, Wristen, and Thirtyone formations (Late Ordovician-Early Devonian) in the subsurface of West Texas based on conodonts and graptolites: Texas Journal of Science, v. 45, p. 231-247.

Galloway, W. E., Ewing, T. E., Garrett, C. M., Jr., Tyler, N., and Bebout, D. G., 1983, Atlas of major Texas oil reservoirs: The University of Texas at Austin, Bureau of Economic Geology Special Publication, 139 p.

Ruppel, S. C., and Holtz, M. H., 1994, Depositional and diagenetic facies patterns and reservoir development in Silurian and Devonian rocks of the Permian Basin: The University of Texas at Austin, Bureau of Economic Geology Report of Investigations No. 216, 89 p. 
Fusselman Shallow Platform Carbonate (Play 104)

The Fusselman Shallow Platform Carbonate play lies over a large area of west Texas and southeast New Mexico (fig. 14). This reservoir group consists of 63 reservoirs that had produced $>1 \mathrm{MMbbl}\left(1.59 \times 10^{5} \mathrm{~m}^{3}\right)$ of oil through 2000 ; cumulative production from the play was 356.3 MMbbl $\left(5.66 \times 10^{7} \mathrm{~m}^{3}\right)$ (table 7). A large number of smaller reservoirs that have not produced $>1 \mathrm{MMbbl}\left(1.59 \times 10^{5} \mathrm{~m}^{3}\right)$ are also productive from the Fusselman. Ruppel and Holtz (1994) documented a total of 233 productive reservoirs in the Fusselman in 1989, only 47 of which had produced $>1 \mathrm{MMbbl}\left(1.59 \times 10^{5} \mathrm{~m}^{3}\right)$ at that time. A few reservoirs that produce from the Upper Ordovician Montoya Formation are also included in the play.

The Fusselman in the subsurface is Late Ordovician to Early Silurian in age (fig. 3) (Barrick and others, 1993). Fusselman rocks are widespread, extending across much of west Texas and southeast New Mexico (Ruppel and Holtz, 1994). Throughout almost all of this area, the Fusselman is composed of limestones and dolostones that were deposited on an open-marine, shallow-water carbonate platform that extended over much of the Midcontinent region. The Fusselman is primarily dolostone and cherty dolostone in the north half of its distribution, whereas limestone is more common in the south (Ruppel and Holtz, 1994). In New Mexico the formation is largely of shallow-water origin, dolomitized, and commonly brecciated. Differentiation of the Fusselman from the bounding Montoya Formation and Wristen Group is difficult in New Mexico owing to the similar dolostone content of each.

Fusselman reservoirs include stratigraphic pinch-out traps, simple anticlinal traps, and fault-bounded anticlinal traps (Tyler and others, 1991). The Woodford Shale (fig. 3) acts as a source rock (Comer, 1991) and, where it directly overlies the Fusselman, as a seal. Fusselman 


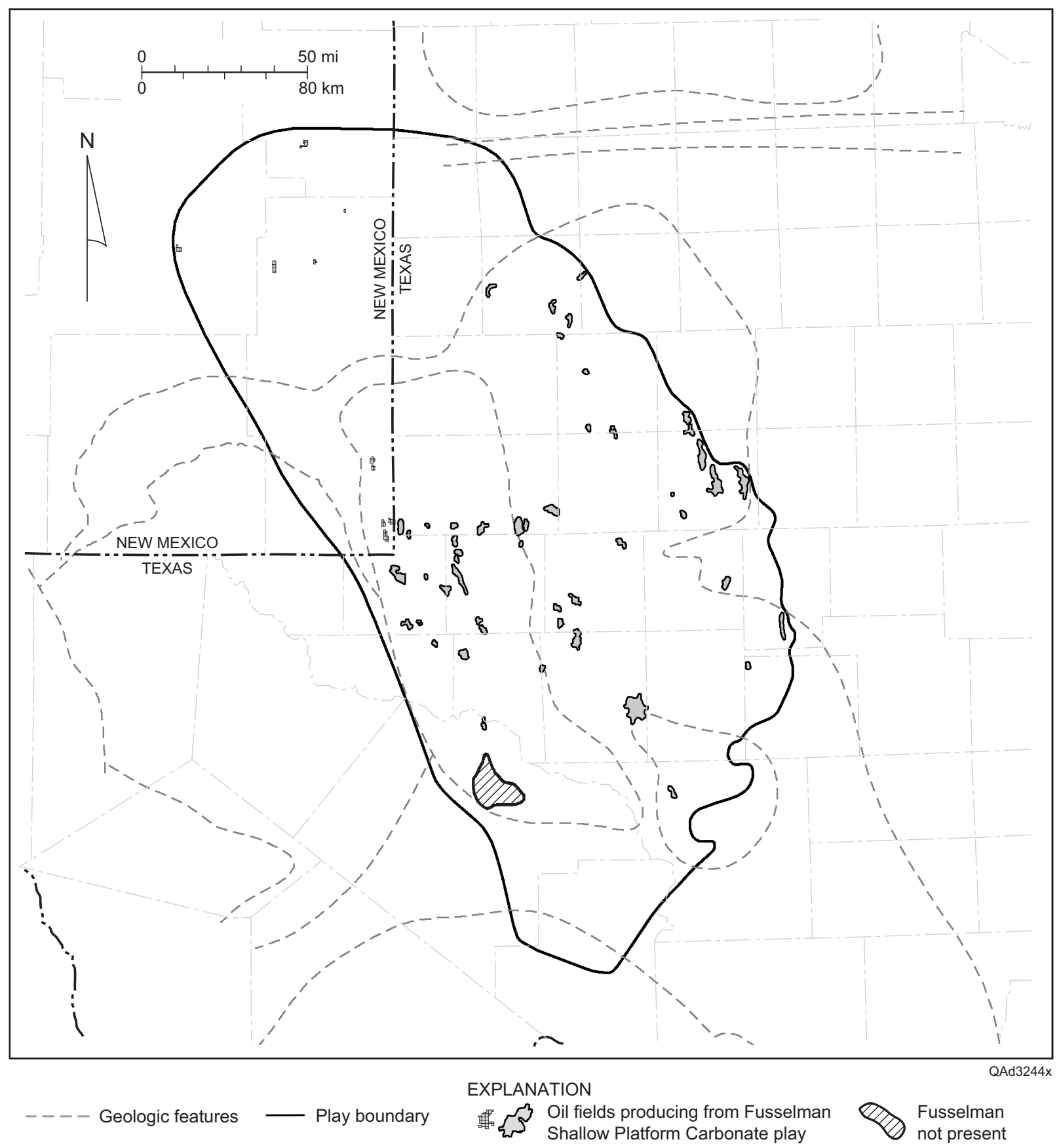

Figure 14. Play map for the Fusselman Shallow Platform Carbonate play, showing location of reservoirs having $>1 \mathrm{MMbbl}$ cumulative production, the play boundary, and geologic features. See figure 1 for county names and figure 2 for identification of geologic features.

rocks are productive in two major settings in Texas: (1) along the northwest-southeast-trending Fusselman subcrop margin from Terry to Sterling Counties, Texas, and (2) on major structures in 
Table 7. Fusselman Shallow Platform Carbonate play (play 104). Production shown for fields that have had others combined into them represents the totals; combined fields are highlighted.

\begin{tabular}{|c|c|c|c|c|c|c|c|c|c|}
\hline RRC RESN & RRC & FLDNAME & RESNAME & STATE & COUNTY & DISCYR & DEPTHTOP & 2000 PROD & CUMPROD \\
\hline 292667 & 8 & ABELL & SILURIAN-MONTOYA & $\mathrm{TX}$ & PECOS & 1948 & 4936 & 0 & $12,619,167$ \\
\hline 292725 & 8 & ABELL & SILURIAN - MONTOYA, N. W. & $\mathrm{TX}$ & CRANE & 1962 & 5110 & 6,772 & $1,432,119$ \\
\hline 3644852 & 8 & ARMER & 6350 & $\mathrm{TX}$ & CRANE & 1955 & 6340 & 15,822 & $4,779,874$ \\
\hline 250750 & 8 & A. W. & FUSSELMAN & $\mathrm{TX}$ & WINKLER & 1964 & 9717 & 0 & $1,348,292$ \\
\hline 6671498 & 8 & BEDFORD & FUSSELMAN & $\mathrm{TX}$ & ANDREWS & 1951 & 9702 & 4,906 & $1,854,661$ \\
\hline 7109500 & $7 \mathrm{C}$ & BENEDUM & FUSSELMAN & $\mathrm{TX}$ & UPTON & 1966 & 11110 & 50,999 & $2,931,937$ \\
\hline 8044400 & 8 & BIG SPRING & FUSSELMAN & $\mathrm{TX}$ & HOWARD & 1955 & 9589 & 34,539 & $7,238,047$ \\
\hline 9230426 & 8 & BLOCK 11 & FUSSELMAN & $\mathrm{TX}$ & ANDREWS & 1961 & 7956 & 1,836 & $1,069,231$ \\
\hline 12469666 & $8 \mathrm{~A}$ & BROWNFIELD, S. & FUSSELMAN & $\mathrm{TX}$ & TERRY & 1968 & 12020 & 81,018 & $5,524,831$ \\
\hline 18535500 & $8 \mathrm{~A}$ & CLARA GOOD & FUSSELMAN & $\mathrm{TX}$ & BORDEN & 1956 & 9740 & 9,383 & $1,158,807$ \\
\hline 19113750 & 8 & COAHOMA, N. & FUSSEL & $\mathrm{TX}$ & HOWARD & 1969 & 8791 & 16,167 & $2,778,608$ \\
\hline 20787001 & $8 \mathrm{~A}$ & CORRIGAN & & $\mathrm{TX}$ & TERRY & 1950 & 11475 & 14,547 & $4,235,262$ \\
\hline 20788500 & $8 \mathrm{~A}$ & CORRIGAN, EAST & FUSSELMAN & $\mathrm{TX}$ & TERRY & 1952 & 11615 & 102,547 & $4,669,363$ \\
\hline 25188800 & 8 & DOLLARHIDE & SILURIAN & $\mathrm{TX}$ & ANDREWS & 1947 & 8345 & 157,860 & $40,980,095$ \\
\hline 25189600 & 8 & DOLLARHIDE, EAST & SILURIAN & $\mathrm{TX}$ & ANDREWS & 1949 & 11000 & 0 & $1,337,356$ \\
\hline 26706333 & $8 \mathrm{~A}$ & DUPREE & FUSSELMAN & $\mathrm{TX}$ & DAWSON & 1960 & 11670 & 11,175 & $1,608,926$ \\
\hline 28899332 & 8 & EMMA & FUSSELMAN & $T X$ & ANDREWS & 1954 & 11288 & 0 & $1,933,151$ \\
\hline 29292400 & $7 \mathrm{C}$ & ESCONDIDO & FUSSELMAN & $\mathrm{TX}$ & CROCKETT & 1963 & 8560 & 2,398 & $1,060,327$ \\
\hline 30398500 & 8 & FASKEN, S. & FUSSELMAN & $\mathrm{TX}$ & ECTOR & 1957 & 12270 & 8,983 & $1,655,361$ \\
\hline 33989001 & 8 & GARDEN CITY & & $\mathrm{TX}$ & GLASSCOCK & 1946 & 9740 & 727 & $1,128,766$ \\
\hline 35652434 & 8 & GOLDSMITH & FUSSELMAN & $\mathrm{TX}$ & ECTOR & 1954 & 7763 & 1,595 & $4,696,451$ \\
\hline 35654830 & 8 & GOLDSMITH, N. & SILURIAN & $\mathrm{TX}$ & ECTOR & 1948 & 8255 & 3,464 & $1,524,694$ \\
\hline 35659500 & 8 & GOLDSMITH, W. & FUSSELMAN & $\mathrm{TX}$ & ECTOR & 1955 & 8294 & 1,621 & $2,672,229$ \\
\hline 35744666 & $8 \mathrm{~A}$ & GOOD, SE. & FUSSELMAN & $\mathrm{TX}$ & BORDEN & 1958 & 9692 & 50,928 & $10,453,193$ \\
\hline 38255464 & 8 & HALLEY & MONTOYA & $\mathrm{TX}$ & WINKLER & 1956 & 10350 & 0 & $2,969,405$ \\
\hline 44521350 & 8 & INEZ & DEEP & $T X$ & ANDREWS & 1989 & 11500 & 34,595 & $4,349,034$ \\
\hline 47267304 & 8 & JORDAN & FUSSELMAN & $\mathrm{TX}$ & ECTOR & 1951 & 7420 & 1,481 & $1,704,012$ \\
\hline 49129660 & 8 & KEYSTONE & SILURIAN & $\mathrm{TX}$ & WINKLER & 1955 & 8500 & 131,446 & $30,949,283$ \\
\hline 54590300 & $7 \mathrm{C}$ & LONE JOE DEEP & FUSSELMAN & $\mathrm{TX}$ & IRION & 1987 & 9046 & 123,223 & $8,076,439$ \\
\hline 55256710 & 8 & LOWE & SILURIAN & $\mathrm{TX}$ & ANDREWS & 1953 & 12818 & 27,168 & $14,948,341$ \\
\hline 55822500 & 8 & LUTHER, SE. & SILURIAN-DEVONIAN & $\mathrm{TX}$ & HOWARD & 1953 & 9855 & 440,822 & $28,797,594$ \\
\hline 59339700 & 8 & MCELROY, NORTH & SILURIAN & $\mathrm{TX}$ & CRANE & 1973 & 11049 & 30,508 & $1,015,002$ \\
\hline 61130001 & 8 & MIDLAND FARMS DEEP & & TX & ANDREWS & 1986 & 11924 & 140,003 & $13,227,411$ \\
\hline 61143400 & 8 & MID-MAR, EAST & FUSSELMAN & $\mathrm{TX}$ & MIDLAND & 1982 & 11711 & 8,750 & $2,750,895$ \\
\hline 62415415 & 8 & MONAHANS & FUSSELMAN & $\mathrm{TX}$ & WARD & 1954 & 8336 & 0 & $1,262,546$ \\
\hline 62417450 & 8 & MONAHANS, NORTH & FUSSELMAN & TX & WINKLER & 1957 & 10026 & 46,718 & $1,944,511$ \\
\hline 62417630 & 8 & MONAHANS, NORTH & MONTOYA & $\mathrm{TX}$ & WINKLER & 1956 & 10080 & 4,616 & $1,036,863$ \\
\hline 62711300 & 8 & MOORE & DEEP FSLM & $\mathrm{TX}$ & HOWARD & 1982 & 10032 & 33,495 & $5,073,129$ \\
\hline 63289500 & $8 \mathrm{~A}$ & MOUND LAKE & FUSSELMAN & $\mathrm{TX}$ & TERRY & 1962 & 11320 & 0 & $2,532,705$ \\
\hline 69233400 & 8 & PARKS & FUSSELMAN-MONTOYA & $\mathrm{TX}$ & MIDLAND & 1983 & 12405 & 21,273 & $1,143,084$ \\
\hline 69563250 & $8 \mathrm{~A}$ & PATRICIA & FUSSELMAN & TX & DAWSON & 1959 & 12020 & 23,626 & $3,983,286$ \\
\hline 70279375 & $7 \mathrm{C}$ & PEGASUS & FUSSELMAN & $\mathrm{TX}$ & MIDLAND & 1958 & 12100 & 29,675 & $3,378,847$ \\
\hline 70537396 & 8 & PENWELL & FUSSELMAN & $\mathrm{TX}$ & ECTOR & 1953 & 7490 & 0 & $1,848,684$ \\
\hline 88977426 & $8 \mathrm{~A}$ & TEX-HAMON & FUSSELMAN & $\mathrm{TX}$ & DAWSON & 1962 & 11574 & 26,123 & $16,869,275$ \\
\hline 88977710 & $8 \mathrm{~A}$ & TEX-HAMON & MONTOYA & $\mathrm{TX}$ & DAWSON & 1962 & 11675 & 0 & $4,833,739$ \\
\hline 90365300 & $8 \mathrm{~A}$ & TOKIO & FUSSELMAN & $\mathrm{TX}$ & TERRY & 1979 & 12871 & 11,722 & $1,415,477$ \\
\hline 88071638 & 8 & $T X L$ & SILURIAN & $\mathrm{TX}$ & ECTOR & 1946 & 8465 & 13,427 & $9,307,489$ \\
\hline 93958375 & 8 & VIREY & FUSSELMAN & $\mathrm{TX}$ & MIDLAND & 1955 & 12234 & 8,041 & $1,425,380$ \\
\hline 94187200 & 8 & W.A.M., SOUTH & FUSSELMAN & $\mathrm{TX}$ & STERLING & 1965 & 8677 & 7,778 & $2,470,860$ \\
\hline 95108500 & 8 & WAR-SAN & FUSSELMAN & $\mathrm{TX}$ & MIDLAND & 1954 & 12514 & 916 & $2,095,899$ \\
\hline 96756600 & 8 & WHEELER & SILURIAN & $\mathrm{TX}$ & WINKLER & 1945 & 9300 & 4,486 & $2,711,661$ \\
\hline \multirow[t]{13}{*}{99733500} & 8 & ZEBULON & & $\mathrm{TX}$ & HOWARD & 1988 & 10324 & 54,676 & $1,448,904$ \\
\hline & & BOUGH & DEVONIAN & NM & LEA & 1965 & 11920 & 7356 & $3,798,039$ \\
\hline & & BRUNSON & FUSSELMAN & NM & LEA & 1980 & 7200 & 0 & $1,162,659$ \\
\hline & & CAPROCK EAST & DEVONIAN & NM & LEA & 1951 & 10450 & 56435 & $23,613,469$ \\
\hline & & CHISUM & DEVONIAN & NM & CHAVES & 1950 & 6490 & 33089 & $1,222,275$ \\
\hline & & DOLLARHIDE & FUSSELMAN & NM & LEA & 1952 & 8710 & 9930 & $6,620,935$ \\
\hline & & FOUR LAKES & DEVONIAN & NM & LEA & 1956 & 12809 & 0 & $1,865,501$ \\
\hline & & JUSTIS & FUSSELMAN & NM & LEA & 1958 & 5900 & 37687 & $10,987,716$ \\
\hline & & JUSTIS & MONTOYA & NM & LEA & 1958 & 6886 & 6872 & $4,772,033$ \\
\hline & & JUSTIS NORTH & FUSSELMAN & NM & LEA & 1961 & 7050 & 14529 & $3,356,310$ \\
\hline & & MCCORMACK & SILURIAN & NM & LEA & 1947 & 7145 & 10268 & $1,222,210$ \\
\hline & & PETERSON SOUTH & FUSSELMAN & NM & ROOSEVELT & 1978 & 7800 & 68868 & $3,386,739$ \\
\hline & & Totals & & & & & & $2,046,889$ & $356,268,389$ \\
\hline
\end{tabular}

the south part of the area (Ruppel and Holtz, 1994). Stratigraphic traps, which are most common

along the eastern subcrop margin, are the result both of facies changes over local topographic

highs and local truncation of the Fusselman beneath the overlying Wristen Group (fig. 15) 


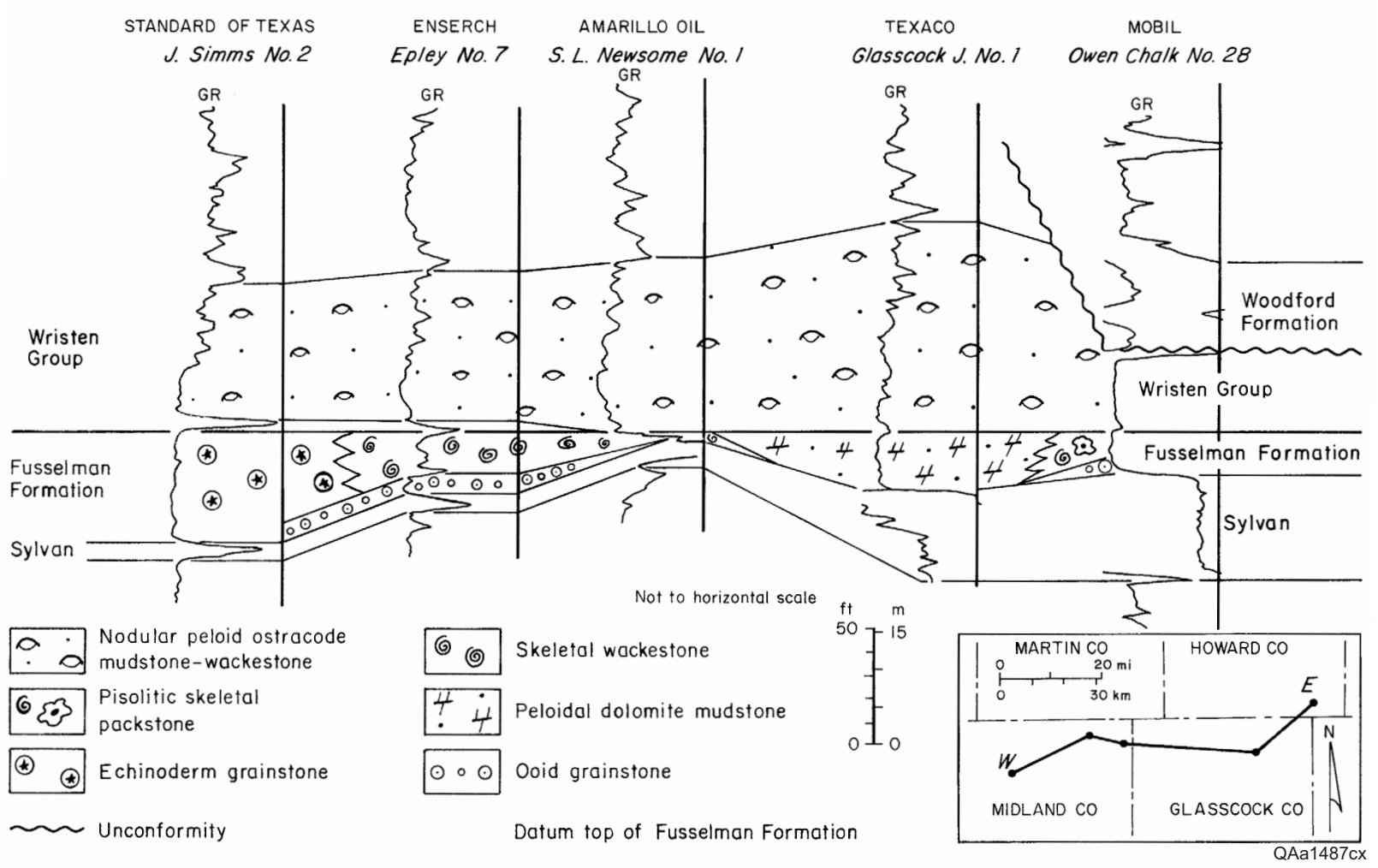

Figure 15. West-east cross section showing facies changes in the Fusselman Formation associated with a paleotopographic high near the eastern subcrop. From Ruppel and Holtz (1994); after Garfield and Longman (1989).

(Ruppel and Holtz, 1994; Mazzullo, 1997). Structural traps predominate in the rest of the play area. New Mexico production occurs in three provinces: on the Northwest Shelf where the Woodford Shale lies directly on the Fusselman (three reservoirs), to the southeast where Wristen Group rests on the Fusselman (one reservoir), and within fault-bounded structural highs on the Central Basin Platform (seven reservoirs). On the Northwest Shelf the Fusselman is beveled by the pre-Woodford unconformity along a northeast-southwest trend in Roosevelt and Chaves Counties. Thicknesses ranging from $>600 \mathrm{ft}(180 \mathrm{~m})$ in southeast Lea County to zero east of 
Roswell, with a meandering zero line from approximately T12S R25E to T4S R28E. The formation is also eroded locally across highs on the Central Basin Platform.

Fusselman reservoir facies were described by Garfield and Longman (1989), Geesaman and Scott (1989), Canter and others (1992), and Ruppel and Holtz (1994). The base of the Fusselman is composed of ooid grainstone and packstone (Ruppel and Holtz, 1994) (figs. 15, 16) that are probably of Late Ordovician age (Barrick, 1995). Porosity in these rocks is principally intergranular, and therefore permeability is commonly relatively high. Overlying these rocks are thin deposits of carbonate mudstone and skeletal wackestone of early Silurian age (Barrick, 1995). The upper part of the Fusselman is composed of pelmatozoan grainstone and packstone; some local carbonate buildups occur in this part of the section (fig. 16). Interparticle pore space in these rocks is commonly filled with cements, but vuggy and intercrystalline porosity developed by leaching is locally significant. Porosity development was enhanced by diagenesis associated with high-frequency sea-level fall and exposure during and after Fusselman deposition (Ruppel and Holtz, 1994). At the top of the Fusselman is wispy-laminated to nodular-bedded wackestone.

Paleokarst has been identified in Fusselman reservoirs in the Permian Basin (Mazzullo and others, 1989; Mazzullo and Mazzullo, 1992; Mazzullo, 1997; Ball, 2002), and collapse breccias and dissolution-enhanced fractures contribute to reservoir porosity. Outcrops in the Franklin Mountains contain three unconformity-bounded sequences, with the uppermost surface heavily karsted (LeMone, 1996), whereas four major sea-level falls are documented in Oklahoma and the subsurface of West Texas (Johnson, 1987; Ruppel and Holtz, 1994). Fractures in Fusselman core from Dollarhide field are concentrated in karsted intervals (Ball, 2002). Tectonic fractures were identified in parts of the Dollarhide reservoir with image logs, but tectonic 


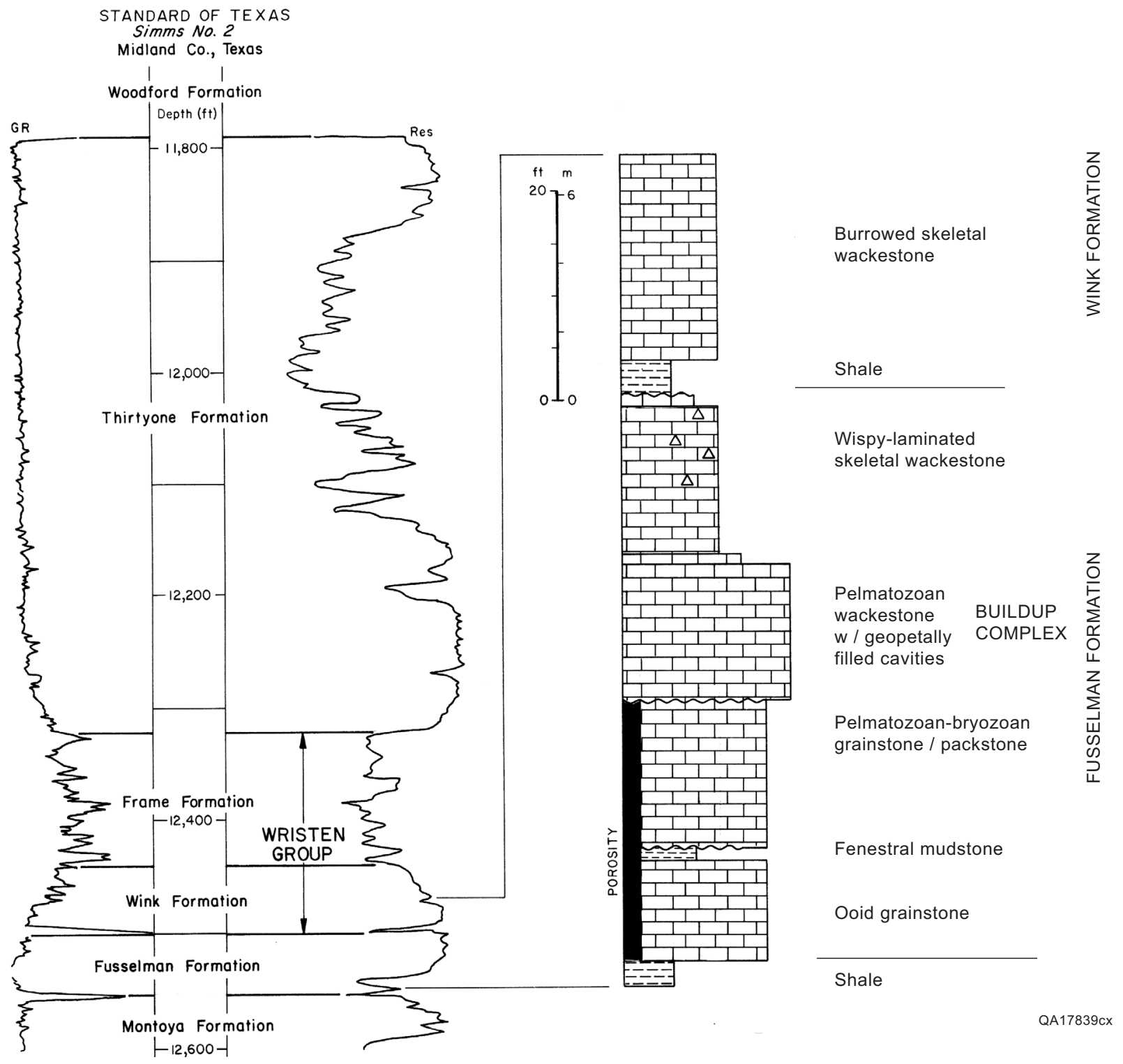

Figure 16. Wireline response of the Upper Ordovician-Devonian stratigraphic section in the Standard of Texas Simms No. 2 well, Midland County. The Fusselman facies succession is typical of much of the play area. From Ruppel and Holtz (1994).

fractures are not dominant (Ball, 2002, 2003). Trapping at Dollarhide field is both structural and stratigraphic. Porous intervals pinch out laterally and vertically into rock that is nonporous and unfractured or that has cement-filled fractures (Ball, 2002, 2003). Core and borehole-imaging logs have been helpful in identifying internal complexity within the Dollarhide reservoir. 
Some of the reservoirs included in this play produce from the Montoya Formation, a thin succession of Upper Ordovician shallow-water limestones and dolostones that underlies the Fusselman. Montoya deposition began during the Late Ordovician on an extensive shallow-water platform. Fusselman Formation carbonates reflect the continued growth and development of this shallow-water platform from the Late Ordovician into the Early Silurian (Ruppel and Holtz, 1994). Early Montoya shallow, subtidal carbonates were deposited in normal marine conditions, whereas later Montoya deposition occurred in a peritidal setting (Ball, 2002; Behnken, 2003). Sea-level fluctuations resulted in early dolomitization and several karsting events (Ball, 2002). Distinction of the Montoya from the Fusselman where the Sylvan Shale is not present is difficult. The Sylvan Shale is a gray-green shale that occurs in parts of the Midland Basin between the Montoya and Fusselman (fig. 3); it was interpreted as being of Late Ordovician age by Ruppel and Holtz (1994). Because the Montoya and the Fusselman are similar lithologically, they are combined into one play for this report.

Porosity in Fusselman reservoirs averages 8 percent and ranges from 1 to 18 percent. Mean permeability is $12 \mathrm{md}\left(12 \times 10^{-3} \mu^{2}\right)$ and ranges from 0.6 to $85 \mathrm{md}\left(0.6\right.$ to $\left.85 \times 10^{-3} \mu \mathrm{m}^{2}\right)$ (Ruppel and Holtz, 1994). Core porosity in open-marine deposits of the lower Montoya is higher (average 6.2 percent) than in upper Montoya peritidal deposits (average 2.5 percent) (Behnken, 2003).

Production from mature Dollarhide field has been increased by the program of recompletions and infill drilling at 20-acre spacing (Ball, 2003). Field production had fallen to $400 \mathrm{bbl} /$ day $\left(63.6 \mathrm{~m}^{3} / \mathrm{d}\right)$, but targeting of bypassed pay zones identified on behind-pipe hydrocarbon logs has increased production to $1,200 \mathrm{bbl} /$ day $\left(191 \mathrm{~m}^{3} / \mathrm{d}\right)$ (Ball, 2003). Completions in the Montoya dolomite intervals have been improved by using casing 
perforations instead of open-hole completions, selectively perforating the Montoya interval, and treating the interval with a larger volume of acid or gelled acid (Ball, 2003). Water production has decreased from 21,000 to $19,000 \mathrm{bbl} /$ day $\left(3.34 \times 10^{3}\right.$ to $\left.3.02 \times 10^{3} \mathrm{~m}^{3} / \mathrm{d}\right)$ by squeezing wet and depleted zones.

\section{References}

Ball, B. C., 2002, A Fusselman and Montoya core from the Dollarhide field, Andrews County, Texas, in Hunt, T. J., and Lufholm, P. H., eds., Permian Basin: preserving our pastsecuring our future: West Texas Geological Society Publication No. 02-111, p. 207-208.

2003, Identifying bypassed pay in the Fusselman and Montoya reservoirs of the Dollarhide field, Andrews County, Texas, in Hunt, T. J., and Lufholm, P. H., eds., The Permian Basin: back to basics: West Texas Geological Society Publication No. 03-112, p. $1-12$.

Barrick, J. E., 1995, Biostratigraphy of uppermost Ordovician through Devonian depositional sequences in the Permian basin, west Texas and Southeastern New Mexico, in Pausé, P. H., and Candelaria, M. P., eds., Carbonate facies and sequence stratigraphy: practical applications of carbonate models: Permian Basin Section, Society of Economic Paleontologists and Mineralogists, Publication 95-36, p. 207-216.

Barrick, J. E., Finney, S. C., and Haywa-Branch, J. N., 1993, Revision of ages of the Fusselman, Wristen, and Thirtyone formations (Late Ordovician-Early Devonian) in the subsurface of West Texas based on conodonts and graptolites: Texas Journal of Science, v. 45, p. 231-247.

Behnken, F. H., 2003, Montoya conventional core description, depositional lithofacies, diagenesis and thin section petrography from the Pure Resources, Inc., Dollarhide Unit 25-2-S, Andrews County, Texas, in Hunt, T. J., and Lufholm, P. H., eds., The Permian Basin: back to basics: West Texas Geological Society Publication No. 03-112, p. 13-35.

Canter, K. L., Wheeler, D. M., and Geesaman, R. C., 1992, Sequence stratigraphy and depositional facies of the Siluro-Devonian interval of the northern Permian Basin, in Candelaria, M. P., and Reed, C. L., eds., Paleokarst, karst-related diagenesis, and reservoir development: examples from Ordovician-Devonian age strata of West Texas and the Mid-Continent: Permian Basin Section, Society of Economic Paleontologists and Mineralogists, Field Trip Guidebook, Publication No. 92-33, p. 93-109. 
Comer, J. B., 1991, Stratigraphic analysis of the Upper Devonian Woodford Formation, Permian Basin, West Texas and southeastern New Mexico: The University of Texas at Austin, Bureau of Economic Geology Report of Investigations No. 201, 63 p.

Garfield, T. R., and Longman, 1989, Depositional variations on the Fusselman formation, Central Midland Basin, West Texas, in Cunningham, B. K. and Cromwell, D. W., eds., The lower Paleozoic of West Texas and southern New Mexico-modern exploration concepts: Permian Basin Section, Society of Economic Paleontologists and Mineralogists, Publication No. 89-31, p. 187-202.

Geesaman, R. C., and Scott, A. J., 1989, Stratigraphy, lithofacies and depositional models of the Fusselman /Formation, Central Midland Basin, in Cunningham, B. K., and Cromwell, D. W., eds., The lower Paleozoic of West Texas and southern New Mexico - modern exploration concepts: Permian Basin Section, Society of Economic Paleontologists and Mineralogists, Publication No. 89-31, p. 175-186.

Johnson, M. E., 1987, Extent and bathymetry of North American platform seas in the Early Silurian: Paleoceanography, v. 2, no. 2, p. 185-211.

LeMone, D. V., 1996, The Tobosa basin-related stratigraphy of the Franklin Mountains, Texas and New Mexico, in Stoudt, E. L., ed., Precambrian-Devonian geology of the Franklin Mountains, West Texas - analogs for exploration and production in Ordovician and Silurian karsted reservoirs in the Permian Basin: West Texas Geological Society, Guidebook No. 96-100, p. 47-70.

Mazzullo, S. J., 1997, Stratigraphic exploration plays in Ordovician to Lower Permian strata in the Midland Basin and on the Eastern Shelf, in DeMis, W. D., ed., Permian Basin oil and gas fields: turning ideas into production: West Texas Geological Society Publication No. 97-102, p. 1-37.

Mazzullo, S. J., and Mazzullo, L. J., 1992, Paleokarst and karst-associated hydrocarbon reservoirs in the Fusselman Formation, West Texas, Permian Basin, in Candelaria, M. P., and Reed, C. L., eds., Paleokarst, karst related diagenesis and reservoir development: examples from Ordovician-Devonian age strata of west Texas and the mid-continent: Permian Basin Section, Society of Economic Paleontologists and Mineralogists, Publication 92-33, p. 110-120.

Mazzullo, L. J., Mazzullo, S. J., and Durham, T. E., 1989, Geologic controls on reservoir development in Silurian and Devonian carbonates northern Midland Basin, Texas, in Cunningham, B. K., and Cromwell, D. W., eds., The lower Paleozoic of West Texas and southern New Mexico - modern exploration concepts: Permian Basin Section, Society of Economic Paleontologists and Mineralogists, Publication No. 89-31, p. 209-218.

Ruppel, S. C., and Holtz, M. H., 1994, Depositional and diagenetic facies patterns and reservoir development in Silurian and Devonian rocks of the Permian Basin: The University of Texas at Austin, Bureau of Economic Geology Report of Investigations No. 216, 89 p. 
Tyler, N., Bebout, D. G., Garrett, C. M., Jr., Guevara, E. H., Hocott, C. R., Holtz, M. H., Hovorka, S. D., Kerans, C., Lucia, F. J., Major, R. P., Ruppel, S. C., and Vander Stoep, G. W., 1991, Integrated characterization of Permian Basin reservoirs, University Lands, West Texas: targeting the remaining resource for advanced oil recovery: The University of Texas at Austin, Bureau of Economic Geology Report of Investigations No. 203, $136 \mathrm{p}$. 
Wristen Buildups and Platform Carbonate (Play 105)

The Wristen Buildups and Platform Carbonate play consists of 85 reservoirs in Texas and New Mexico (fig. 17) that had produced $>1$ MMbbl $\left(1.59 \times 10^{5} \mathrm{~m}^{3}\right)$ of oil through 2000 ; cumulative production from the play was $888.8 \mathrm{MMbbl}\left(1.41 \times 10^{8} \mathrm{~m}^{3}\right)($ table 8$)$. Rocks of the Silurian Wristen Group were deposited across most of the Permian Basin in a platform-to-basin setting that developed during the Middle Silurian (fig. 18) (Ruppel and Holtz, 1994). The Wristen platform margin trended east-west across southern Andrews and northern Midland Counties, and it marks the southern limit of the play (fig. 19).

The Wristen Group was divided into the Wink, Frame, and Fasken Formations by Ruppel and Holtz (1994) (fig. 18). Facies of the Wristen Group were described by Canter and others (1992) and Ruppel and Holtz (1994). South of central Andrews County, the Wristen is generally $<500 \mathrm{ft}$ (150 m) thick (Ruppel and Holtz, 1994), and it is composed of slope and basin mudstones and wackestones of the Wink and Frame Formations. To the north, the Wristen is composed of a diverse assemblage of shallow-water platform carbonates that constitute the Fasken Formation. The Fasken reaches thicknesses of $>1,200 \mathrm{ft}(>365 \mathrm{~m})$ in Texas (Ruppel and Holtz, 1994). The transition from the platform facies of Fasken in the north to the deeper water facies of the Wink and Frame in the south defines the general position of the Wristen platform margin (fig. 19). Wristen production is derived nearly entirely from the shallow-water Fasken facies in the north.

Production from reservoirs assigned in this report to the Silurian Wristen Group has in the past been assigned to a variety of Silurian and Devonian units. Many Wristen reservoirs, for example, are officially named "Silurian," Devonian," or "Siluro-Devonian." Recent biostratigraphy (Barrick and others, 1993; Barrick, 1995) and regional stratigraphic analysis 


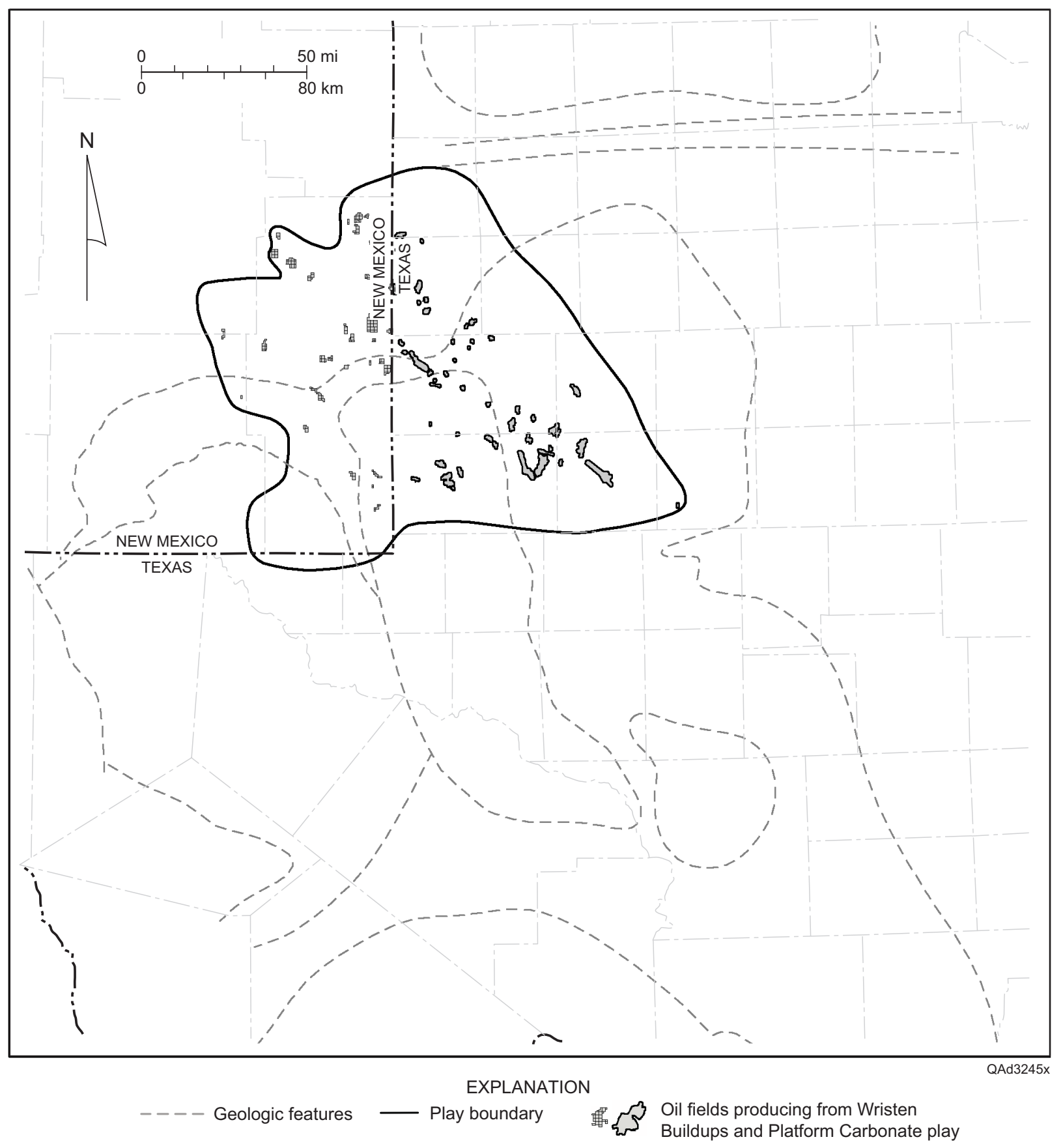

Figure 17. Play map for the Wristen Buildups and Platform Carbonate play, showing location of reservoirs having $>1 \mathrm{MMbbl}$ cumulative production, the play boundary, and geologic features. See figure 1 for county names and figure 2 for identification of geologic features.

(Ruppel and Holtz, 1994) indicates that Devonian strata do not extend north of the extreme south part of Lea County. The vast majority of dolomitic carbonates present in southeast New Mexico 
Table 8. Wristen Buildups and Platform Carbonate play (play 105). Production shown for fields that have had others combined into them represents the totals; combined fields are highlighted.

\begin{tabular}{|c|c|c|c|c|c|c|c|c|c|}
\hline RRC RESN & RRC & FLDNAME & RESNAME & STATE & COUNTY & DISCYR & DEPTHTOP & 2000 PROD & CUMPROD \\
\hline 1964333 & $8 \mathrm{~A}$ & ALSABROOK & DEVONIAN & TX & GAINES & 1953 & 11135 & 0 & $3,815,802$ \\
\hline 2404333 & $8 \mathrm{~A}$ & AMROW & DEVONIAN & $\mathrm{TX}$ & GAINES & 1954 & 12628 & 81,826 & $15,980,351$ \\
\hline 9172250 & 8 & BLOCK 6 & DEVONIAN & $\mathrm{TX}$ & ANDREWS & 1952 & 12530 & 28,758 & $4,478,026$ \\
\hline 9175500 & 8 & BLOCK $6, \mathrm{NE}$ & SILURIAN & $T X$ & ANDREWS & 1974 & 12471 & 79,329 & $3,623,929$ \\
\hline 9188250 & 8 & BLOCK 7 & DEVONIAN & $\mathrm{TX}$ & MARTIN & 1950 & 12280 & 56,478 & $5,209,687$ \\
\hline 8930333 & $8 \mathrm{~A}$ & BLOCK A-7 & DEVONIAN & $\mathrm{TX}$ & GAINES & 1959 & 11100 & 34,318 & $1,699,349$ \\
\hline 8990333 & 8 & BLOCK A-49 & DEVONIAN & $\mathrm{TX}$ & ANDREWS & 1965 & 8637 & 32,136 & $2,088,379$ \\
\hline 9060333 & $8 \mathrm{~A}$ & BLOCK D & DEVONIAN & TX & YOAKUM & 1957 & 11923 & 71,104 & $1,931,322$ \\
\hline 11308200 & $8 \mathrm{~A}$ & BRAHANEY & DEVONIAN & $\mathrm{TX}$ & YOAKUM & 1979 & 11372 & 28,021 & $8,824,267$ \\
\hline 11313300 & $8 \mathrm{~A}$ & BRAHANEY, NORTHWEST & DEVONIAN & $\mathrm{TX}$ & YOAKUM & 1982 & 11893 & 125,499 & $14,748,050$ \\
\hline 11314200 & $8 \mathrm{~A}$ & BRAHANEY, W. & DEV & $\mathrm{TX}$ & YOAKUM & 1981 & 11645 & 29,944 & $1,447,939$ \\
\hline 11334300 & $8 \mathrm{~A}$ & BRALLEY & SILURIAN & $\mathrm{TX}$ & YOAKUM & 1991 & 13108 & 167,650 & $1,927,011$ \\
\hline 11751001 & 8 & BREEDLOVE & & TX & MARTIN & 1951 & 12078 & 147,679 & $31,736,195$ \\
\hline 12160600 & $8 \mathrm{~A}$ & BRONCO & SILURO-DEVONIAN & $\mathrm{TX}$ & YOAKUM & 1952 & 11692 & 107,639 & $14,292,254$ \\
\hline 12978600 & 8 & BUCKWHEAT & SILURO-DEVONIAN & $\mathrm{TX}$ & HOWARD & 1989 & 10182 & 50,716 & $1,488,718$ \\
\hline 16860333 & $8 \mathrm{~A}$ & CHAMPMON & DEV. & $\mathrm{TX}$ & GAINES & 1959 & 12735 & 31,725 & $1,334,656$ \\
\hline 25243500 & $8 \mathrm{~A}$ & DOMINION & SILURIAN & $\mathrm{TX}$ & TERRY & 1979 & 13342 & 14,927 & $1,005,286$ \\
\hline 28873500 & $8 \mathrm{~A}$ & EMERALD & SILURIAN & $\mathrm{TX}$ & YOAKUM & 1988 & 12372 & 152,558 & $1,550,264$ \\
\hline 30776500 & $8 \mathrm{~A}$ & FIELDS & DEVONIAN & $\mathrm{TX}$ & YOAKUM & 1954 & 12030 & 6,799 & $4,042,266$ \\
\hline 31222600 & $8 \mathrm{~A}$ & FLANAGAN & DEVONIAN & $\mathrm{TX}$ & GAINES & 1949 & 10345 & 29,621 & $2,600,285$ \\
\hline 33230900 & 8 & FULLERTON & 8500 & $\mathrm{TX}$ & ANDREWS & 1944 & 8658 & 181,239 & $51,119,358$ \\
\hline 33230300 & 8 & FULLERTON & DEVONIAN & $\mathrm{TX}$ & ANDREWS & 1987 & 8276 & 101,222 & $2,734,646$ \\
\hline 35197333 & 8 & GLASCO & DEVONIAN & $T X$ & ANDREWS & 1953 & 12543 & 116,288 & $21,207,037$ \\
\hline 38832333 & $8 \mathrm{~A}$ & HAP & DEVONIAN & $\mathrm{TX}$ & GAINES & 1955 & 12356 & 69,274 & $1,588,017$ \\
\hline 43878800 & 8 & HUTEX & DEVONIAN & TX & ANDREWS & 1953 & 12509 & 263,951 & $48,354,343$ \\
\hline 46132001 & $8 \mathrm{~A}$ & JENKINS & & TX & GAINES & 1948 & 9100 & 9,959 & $1,441,170$ \\
\hline 47187001 & $8 \mathrm{~A}$ & JONES RANCH & & $\mathrm{TX}$ & GAINES & 1945 & 11200 & 12,589 & $7,849,382$ \\
\hline 51812500 & $8 \mathrm{~A}$ & LANDON & DEVONIAN & $\mathrm{TX}$ & COCHRAN & 1949 & 10913 & 3,013 & $1,676,236$ \\
\hline 56822125 & 8 & MAGUTEX & DEVONIAN & TX & ANDREWS & 1953 & 12504 & 229,455 & $48,627,371$ \\
\hline 58027500 & $8 \mathrm{~A}$ & MARY TWO & DEVONIAN & $\mathrm{TX}$ & YOAKUM & 1981 & 13220 & 24,484 & $1,388,687$ \\
\hline 65766333 & 8 & NOLLEY & DEVONIAN & $\mathrm{TX}$ & ANDREWS & 1967 & 12311 & 17,416 & $4,321,428$ \\
\hline 65967400 & 8 & NORMAN & DEVONIAN & $\mathrm{TX}$ & GAINES & 1961 & 12214 & 66,696 & $7,734,263$ \\
\hline 66373250 & $8 \mathrm{~A}$ & ODC & DEVONIAN & $\mathrm{TX}$ & GAINES & 1956 & 11993 & 11,656 & $2,812,852$ \\
\hline 74041100 & 8 & RK & DEVONIAN & $\mathrm{TX}$ & MARTIN & 1975 & 11815 & 525,717 & $21,538,949$ \\
\hline 79004250 & $8 \mathrm{~A}$ & RUSSELL, NORTH & DEVONIAN & $\mathrm{TX}$ & GAINES & 1948 & 11125 & 125,995 & $79,739,814$ \\
\hline 81913500 & $8 \mathrm{~A}$ & SEAGRAVES & SILURO - DEVONIAN & TX & GAINES & 1955 & 13028 & 0 & $4,944,608$ \\
\hline 81917666 & $8 \mathrm{~A}$ & SEAGRAVES, S. & SILURO - DEVONIAN & $\mathrm{TX}$ & GAINES & 1955 & 12997 & 15,519 & $1,783,158$ \\
\hline 82225040 & $8 \mathrm{~A}$ & SEMINOLE & DEVONIAN & $\mathrm{TX}$ & GAINES & 1977 & 11500 & 110,836 & $5,811,135$ \\
\hline 82229750 & $8 \mathrm{~A}$ & SEMINOLE, NW. & DEVONIAN FB 2 & $\mathrm{TX}$ & GAINES & 1964 & 11456 & 10,604 & $1,508,906$ \\
\hline 82233200 & $8 \mathrm{~A}$ & SEMINOLE, W. & DEVONIAN & $\mathrm{TX}$ & GAINES & 1956 & 11136 & 7,588 & $1,271,248$ \\
\hline 82233400 & $8 \mathrm{~A}$ & SEMINOLE, W. & DEVONIAN FB 2 & $\mathrm{TX}$ & GAINES & 1957 & 10554 & 0 & $1,783,937$ \\
\hline 82570200 & 8 & SHAFTER LAKE & DEVONIAN & TX & ANDREWS & 1947 & 9425 & 192,314 & $27,459,338$ \\
\hline 89038500 & $8 \mathrm{~A}$ & TEX-SIN & DEVONIAN & $\mathrm{TX}$ & GAINES & 1962 & 12285 & 84,781 & $7,998,812$ \\
\hline 91406500 & $8 \mathrm{~A}$ & TRIPP & DEVONIAN & $\mathrm{TX}$ & GAINES & 1964 & 12577 & 19,646 & $1,657,515$ \\
\hline 92548250 & 8 & UNIVERSITY BLOCK 13 & DEVONIAN & $\mathrm{TX}$ & ANDREWS & 1960 & 8826 & 6,576 & $1,478,228$ \\
\hline 94748666 & $8 \mathrm{~A}$ & WALKER & DEVONIAN & $\mathrm{TX}$ & COCHRAN & 1967 & 11818 & 0 & $1,692,316$ \\
\hline 96202500 & $8 \mathrm{~A}$ & WELLS & DEVONIAN & $\mathrm{TX}$ & DAWSON & 1955 & 12083 & 102,137 & $8,760,790$ \\
\hline 96408166 & $8 \mathrm{~A}$ & WESCOTT & DEV. & TX & GAINES & 1964 & 12360 & 38,035 & $3,933,775$ \\
\hline 96487500 & $8 \mathrm{~A}$ & WEST & DEVONIAN & $\mathrm{TX}$ & YOAKUM & 1957 & 11058 & 75,184 & $23,898,463$ \\
\hline
\end{tabular}

above the Fusselman Formation and below the Woodford Shale therefore belong to the Silurianage Wristen Group (fig. 3).

In New Mexico it is locally difficult to differentiate the Wristen (Fasken Formation) from the underlying Fusselman. Where distinguishable, the Wristen (Fasken Formation) thickens in a westerly direction across west Texas and into New Mexico (fig. 19). It reaches thicknesses of 1,400 ft (425 m) in the area of western Andrews County and southeastern Lea County (fig. 19). 
Table 8, continued. Wristen Buildups and Platform Carbonate play (play 105).

$\begin{array}{ll}\text { RRC RESN RRC } & \text { FLDNAME } \\ & \text { ANDERSON RANCH } \\ & \text { BAGLEY } \\ & \text { BRONCO } \\ & \text { BRONCO WEST } \\ & \text { CAUDILL } \\ & \text { CROSSROADS } \\ & \text { CROSSROADS EAST } \\ & \text { CROSSROADS SOUTH } \\ & \text { CROSSROADS WEST } \\ & \text { DEAN } \\ & \text { DENTON } \\ & \text { DENTON SOUTH } \\ & \text { ECHOLS } \\ & \text { ECHOLS NORTH } \\ & \text { FOWLER } \\ & \text { GARRETT WEST } \\ & \text { GLADIOLA } \\ & \text { GLADIOLA SOUTHWEST } \\ & \text { KING } \\ & \text { KNOWLES } \\ & \text { KNOWLES SOUTH } \\ & \text { LANGLEY } \\ & \text { LEA } \\ \text { LITTLE LUCKY LAKE } & \text { LOVINGTON } \\ \text { MCCORMACK SOUTH } \\ \text { MEDICINE ROCK } \\ \text { MESCALERO } \\ \text { MOORE } \\ \text { RANGER LAKE WEST } \\ \text { SHOE BAR } \\ \text { SHOE BAR EAST } \\ \text { SHUGART } \\ \text { TEAGUE NORTHWEST } \\ \text { VACUUM MID } \\ \text { VACUUM SOUTH } \\ \text { Totals } \\ \\ \end{array}$

RESNAME
DEVONIAN
SILURO-DEVONIAN
SILURO-DEVONIAN
DEVONIAN
DEVONIAN
SILURO-DEVONIAN
DEVONIAN
DEVONIAN
DEVONIAN
DEVONIAN
DEVONIAN
DEVONIAN
DEVONIAN
DEVONIAN
DEVONIAN
DEVONIAN
DEVONIAN
DEVONIAN
DEVONIAN
DEVONIAN
DEVONIAN
DEVONIAN
DEVONIAN
DEVONIAN
DEVONIAN
SILURIAN
DEVONIAN
DEVONIAN
DEVONIAN
DEVONIAN
DEVONIAN
DEVONIAN
SILURO-DEVONIAN
DEVONIAN
DEVONIAN
DEVONIAN

\begin{tabular}{|c|c|c|c|c|c|}
\hline STATE & COUNTY & DISCYR & DEPTHTOP & 2000 PROD & CUMPROD \\
\hline NM & LEA & 1953 & 13374 & 6,311 & $8,732,227$ \\
\hline NM & LEA & 1949 & 10950 & 115,910 & $28,461,902$ \\
\hline NM & LEA & 1955 & 11700 & 47,298 & $16,048,762$ \\
\hline NM & LEA & 1965 & 12170 & 6,347 & $1,420,225$ \\
\hline NM & LEA & 1954 & 13585 & 24,661 & $5,711,745$ \\
\hline NM & LEA & 1948 & 12115 & 59,787 & $43,440,653$ \\
\hline NM & LEA & 1956 & 12173 & 48,240 & $2,540,103$ \\
\hline NM & LEA & 1954 & 12250 & 33,601 & $3,272,563$ \\
\hline NM & LEA & 1959 & 12000 & 672 & $2,063,579$ \\
\hline NM & LEA & 1955 & 13600 & 172 & $3,034,645$ \\
\hline NM & LEA & 1949 & 11360 & 268,927 & $101,227,563$ \\
\hline NM & LEA & 1955 & 13110 & 4,627 & $3,748,807$ \\
\hline NM & LEA & 1951 & 11500 & 0 & $4,622,000$ \\
\hline NM & LEA & 1952 & 12057 & 18,995 & $1,416,811$ \\
\hline NM & LEA & 1955 & 7587 & 7,257 & $1,326,698$ \\
\hline NM & LEA & 1970 & 12850 & 13,930 & $3,115,656$ \\
\hline NM & LEA & 1950 & 11859 & 42,531 & $52,841,901$ \\
\hline NM & LEA & 1960 & 12304 & 9,052 & $4,435,681$ \\
\hline NM & LEA & 1956 & 12439 & 13,350 & $6,238,669$ \\
\hline NM & LEA & 1949 & 12570 & 21,013 & $4,941,623$ \\
\hline NM & LEA & 1954 & 12140 & 95,498 & $9,712,376$ \\
\hline NM & LEA & 1979 & 12150 & 2,850 & $1,370,899$ \\
\hline NM & LEA & 1960 & 3774 & 22,604 & $7,800,254$ \\
\hline NM & CHAVES & 1958 & 11050 & 6,774 & $1,826,075$ \\
\hline NM & LEA & 1969 & 11570 & 14,997 & $1,735,773$ \\
\hline NM & LEA & 1967 & 7100 & 58,516 & $1,015,681$ \\
\hline NM & LEA & 1961 & 12630 & 0 & $1,638,000$ \\
\hline NM & LEA & 1952 & 9850 & 19,533 & $5,832,949$ \\
\hline NM & LEA & 1952 & 10100 & 11,513 & $22,218,658$ \\
\hline NM & LEA & 1967 & 12850 & 8,424 & $1,185,371$ \\
\hline NM & LEA & 1953 & 12480 & 0 & $1,082,000$ \\
\hline NM & LEA & 1968 & 13013 & 10,132 & $1,944,953$ \\
\hline NM & EDDY & 1957 & 12362 & 4,805 & $1,114,333$ \\
\hline NM & LEA & 1992 & 7450 & 48,909 & $1,001,274$ \\
\hline NM & LEA & 1963 & 11644 & 5,183 & $1,766,983$ \\
\hline \multirow[t]{2}{*}{ NM } & LEA & 1958 & 11546 & 22,592 & $8,930,675$ \\
\hline & & & & $4,773,912$ & $888,757,885$ \\
\hline
\end{tabular}

Fasken Formation reservoirs are developed in two settings: (1) platform-margin buildup successions along the platform margin in central Andrews County and (2) shallow-water facies in the interior of the platform (Ruppel and Holtz, 1994). Reservoirs in both settings are mainly localized over structural traps. Platform-margin deposits are composed of skeletal wackestones to grainstones to boundstones (fig. 20), whereas inner-platform deposits are composed of mudstones to pellet and skeletal wackestones to grainstones (Ruppel and Holtz, 1994). Porosity in the buildup-related reservoirs is developed as primary intergranular porosity in flanking and capping grainstones and as leached vuggy porosity in boundstones and wackestones. Porosity in Fasken shallow-water carbonate reservoirs is associated with the formation of vugs, molds, and 
Late Silurian (Ludlovian)

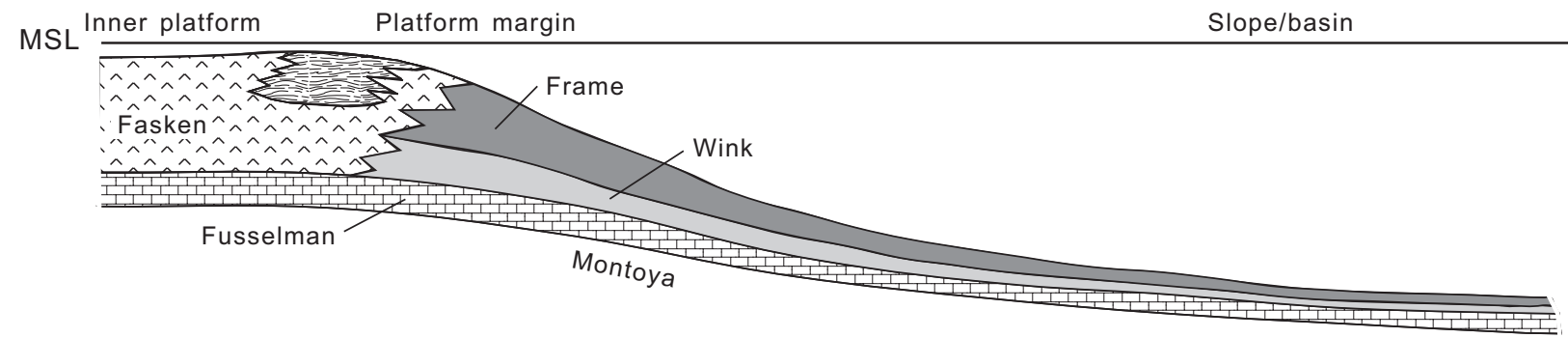

Middle Silurian (Wenlockian)

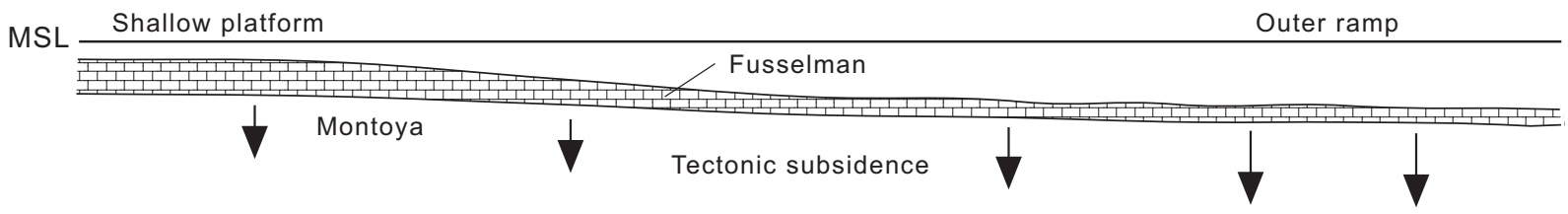

Late Ordovician - Early Silurian

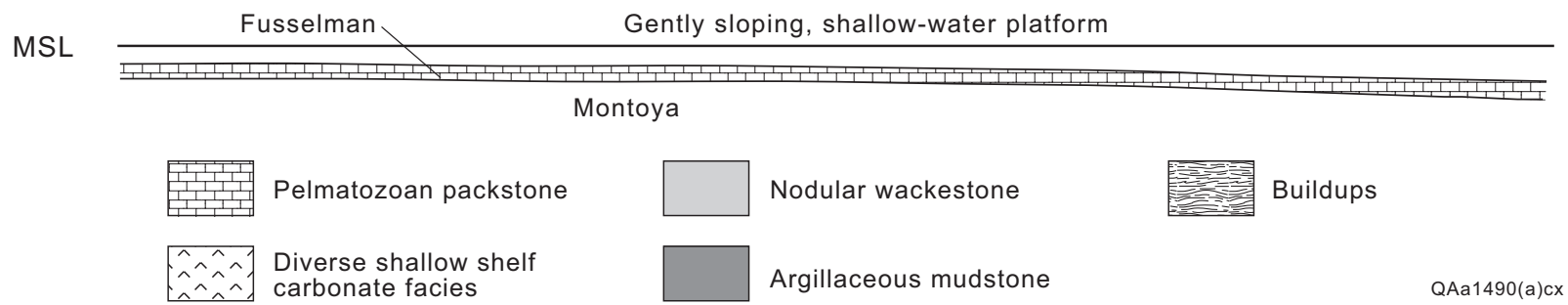

Figure 18. North-south cross sections illustrating the depositional history of the Silurian carbonate section in west Texas and New Mexico. From Ruppel and Holtz (1994). The Wristen Group is divided into the deepwater carbonates of the Wink and Frame Formations and the shallow-water platform carbonates of the Fasken Formation (Ruppel and Holtz, 1994). The Wristen platform margin trended east-west across southern Andrews and northern Midland Counties.

intercrystalline pores by dolomitization and leaching of skeletal fragments (Ruppel and Holtz, 1994).

Leaching and dolomitization apparently resulted from multiple exposure events associated with sea-level fall during and after Fasken deposition (Canter and others, 1992; Ruppel and Holtz, 1994). Karst features have been interpreted from cores in Fasken reservoirs at Emerald field in Yoakum County (Entzminger and Loucks, 1989), Buckwheat field in Howard 


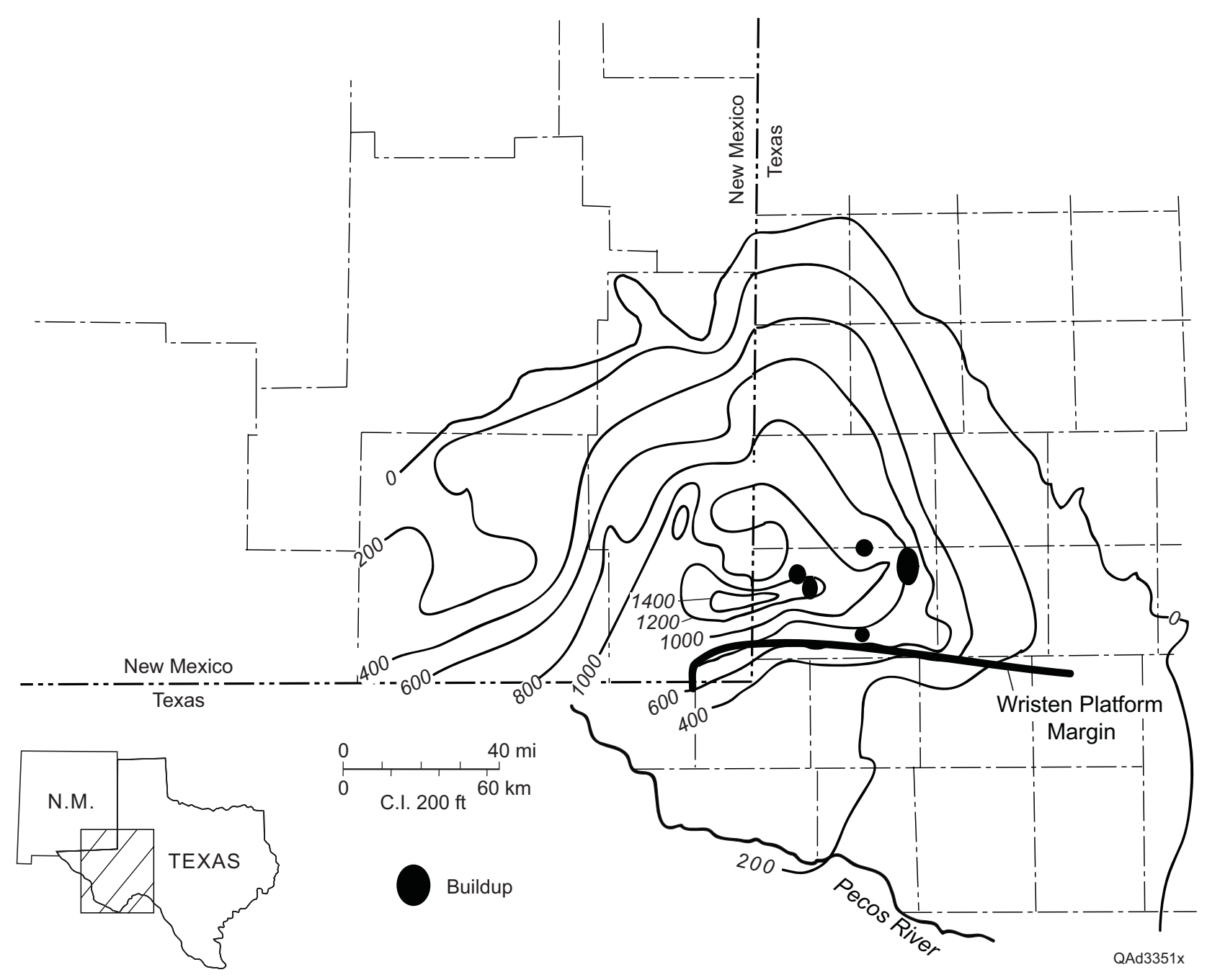

Figure 19. Thickness map of the Wristen Group in west Texas and New Mexico. The New Mexico part of the Wristen was added to the Wristen isopach map of Texas (Ruppel and Holtz, 1994) on the basis of biostratigraphy (Barrick and others, 1993; Barrick, 1995) and regional stratigraphy (Ruppel and Holtz, 1994; Baldonado and Broadhead, 2002, and unpublished).

County (Troschinetz, 1989), and Fullerton field in Andrews County. (Buckwheat field produces from both Fusselman and Wristen reservoirs and is assigned to the Fusselman play.) Karsting is probably associated with regional uplift and erosion of the North American craton during the Middle Devonian (Entzminger and Loucks, 1989; Ruppel and Holtz, 1994). 


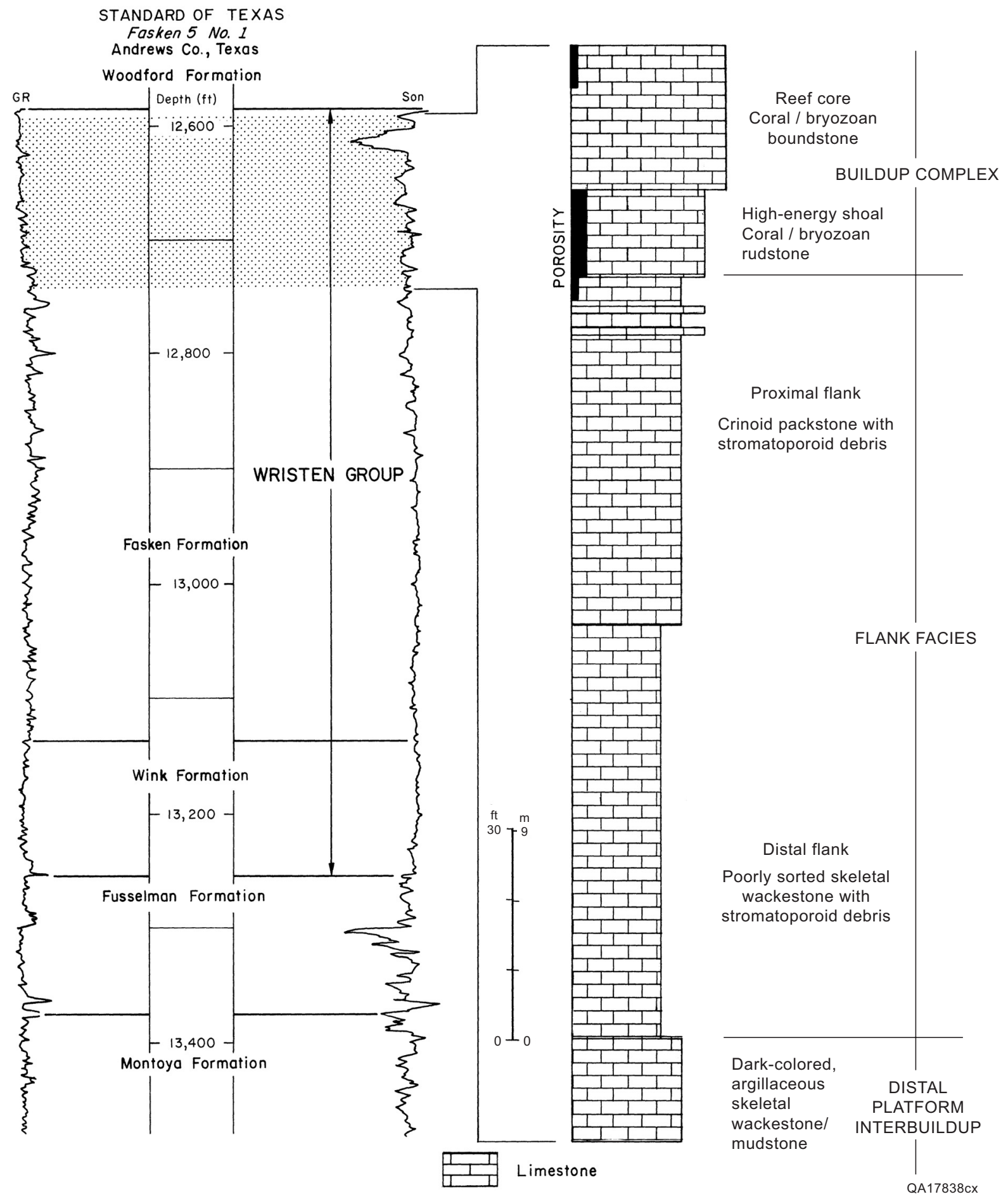

Figure 20. Stratigraphic section of the Fasken Formation (Wristen Group) in the Standard of Texas Fasken 5 No. 1 well. The Fasken section is an aggradational, upward-shallowing, platform-margin succession that is capped by a carbonate buildup. From Ruppel and Holtz (1994). 
The overlying Woodford Shale acts as both source (Comer, 1991) and seal. Traps are dominantly structural. Reservoir net pay in the play ranges from 6 to $300 \mathrm{ft}$ (2 to $90 \mathrm{~m}$ ) and averages $57 \mathrm{ft}(17 \mathrm{~m})$. Porosity ranges from 3 to 14 percent and averages 7 percent (Ruppel and Holtz, 1994). Permeability ranges from 3 to $400 \mathrm{md}\left(3\right.$ to $\left.400 \times 10^{-3} \mu \mathrm{m}^{2}\right)$ and averages $45 \mathrm{md}$ $\left(45 \times 10^{-3} \mu \mathrm{m}^{2}\right)$. In general, production from individual reservoirs in this play peaks within a few years after discovery and then undergoes a sharp decline. Unlike many younger carbonate reservoirs in the Permian Basin, Wristen reservoirs typically have active water drives (Galloway and others, 1983).

\section{References}

Baldonado, D., and Broadhead, R., 2002, Preliminary investigation of the regional stratigraphy of Siluro-Devonian carbonates, Tobosa Basin, New Mexico, in Hunt, T. J., and Lufholm, P. H., eds., The Permian Basin: preserving our past—securing our future: West Texas Geological Society, Publication 02-111, p. 55-69.

Barrick, J. E., 1995, Biostratigraphy of uppermost Ordovician through Devonian depositional sequences in the Permian basin, west Texas and Southeastern New Mexico, in Pausé, P. H., and Candelaria, M. P., eds., Carbonate facies and sequence stratigraphy: practical applications of carbonate models: Permian Basin Section, Society of Economic Paleontologists and Mineralogists, Publication 95-36, p. 207-216.

Barrick, J. E., Finney, S. C., and Haywa-Branch, J. N., 1993, Revision of ages of the Fusselman, Wristen, and Thirtyone formations (Late Ordovician-Early Devonian) in the subsurface of West Texas based on conodonts and graptolites: Texas Journal of Science, v. 45, p. 231-247.

Canter, K. L., Wheeler, D. M., and Geesaman, R. C., 1992, Sequence stratigraphy and depositional facies of the Siluro-Devonian interval of the northern Permian Basin, in Candelaria, M. P., and Reed, C. L., eds., Paleokarst, karst-related diagenesis, and reservoir development: examples from Ordovician-Devonian age strata of West Texas and the Mid-Continent: Permian Basin Section, Society of Economic Paleontologists and Mineralogists, Field Trip Guidebook, Publication No. 92-33, p. 93-109.

Comer, J. B., 1991, Stratigraphic analysis of the Upper Devonian Woodford Formation, Permian Basin, West Texas and southeastern New Mexico: The University of Texas at Austin, Bureau of Economic Geology Report of Investigations No. 201, 63 p. 
Entzminger, D. J., and Loucks, R. G., 1992, Paleocave reservoirs in the Wristen Formation at Emerald Field, Gaines and Yoakum Counties, Texas, in Candelaria, M. P., and Reed, C. L., eds., Paleokarst, karst-related diagenesis, and reservoir development: examples from Ordovician-Devonian age strata of West Texas and the Mid-Continent: Permian Basin Section- Society of Economic Paleontologists and Mineralogists, Field Trip Guidebook, Publication No. 92-33, p. 126-130.

Galloway, W. E., Ewing, T. E., Garrett, C. M., Jr., Tyler, N., and Bebout, D. G., 1983, Atlas of major Texas oil reservoirs: The University of Texas at Austin, Bureau of Economic Geology Special Publication, 139 p.

Ruppel, S. C., and Holtz, M. H., 1994, Depositional and diagenetic facies patterns and reservoir development in Silurian and Devonian rocks of the Permian Basin: The University of Texas at Austin, Bureau of Economic Geology Report of Investigations No. 216, 89 p.

Troschinetz, J., 1989, An example of karsted Silurian reservoir: Buckwheat field, Howard County, Texas, in Candelaria, M. P., and Reed, C. L., eds., Paleokarst, karst-related diagenesis, and reservoir development: examples from Ordovician-Devonian age strata of West Texas and the Mid-Continent: Permian Basin Section, Society of Economic Paleontologists and Mineralogists, Field Trip Guidebook, Publication No. 92-33, p. $131-133$. 


\section{Devonian Plays}

The Lower Devonian Thirtyone Formation (fig. 3) overlies the Silurian Wristen Group apparently conformably throughout the southern Midland Basin and southern Central Basin Platform. With the exception of local outliers, the Thirtyone is interpreted as having been entirely removed north of this area by Middle Devonian erosion (McGlasson, 1967; Canter and others, 1992; Ruppel and Holtz, 1994; Barrick, 1995). The Thirtyone Formation contains two end-member reservoir facies, (1) skeletal packstones and grainstones and (2) spiculitic chert (fig. 21). Carbonate packstones and grainstones were deposited as in-place accumulations on the Early Devonian shallow-water platform and as resedimented carbonate sands on the outer ramp to slope. Cherts accumulated in deeper water beyond the extent of carbonate deposition. Each of these facies, whose distribution is reciprocal, constitutes a distinct reservoir trend (Ruppel and Holtz, 1994). Thirtyone Formation carbonates are more abundant in the upper part of the formation and to the north, whereas Thirtyone cherts are most abundant in the lower part of the formation and in the south part of the subcrop (fig. 21).

\section{References}

Barrick, J. E., 1995, Biostratigraphy of uppermost Ordovician through Devonian depositional sequences in the Permian basin, west Texas and Southeastern New Mexico, in Pausé, P. H., and Candelaria, M. P., eds., Carbonate facies and sequence stratigraphy: practical applications of carbonate models: Permian Basin Section, Society of Economic Paleontologists and Mineralogists, Publication 95-36, p. 207-216.

Canter, K. L., Wheeler, D. M., and Geesaman, R. C., 1992, Sequence stratigraphy and depositional facies of the Siluro-Devonian interval of the northern Permian Basin, in Candelaria, M. P., and Reed, C. L., eds., Paleokarst, karst-related diagenesis, and reservoir development: examples from Ordovician-Devonian age strata of West Texas and the Mid-Continent: Permian Basin Section, Society of Economic Paleontologists and Mineralogists, Field Trip Guidebook, Publication No. 92-33, p. 93-109. 
McGlasson, E. H., 1967, The Siluro-Devonian of West Texas and southeast New Mexico, in Oswald, D. H., ed., International Symposium on the Devonian System, v. II: Calgary, Alberta, Alberta Society of Petroleum Geologists, p. 937-948.

Ruppel, S. C., and Holtz, M. H., 1994, Depositional and diagenetic facies patterns and reservoir development in Silurian and Devonian rocks of the Permian Basin: The University of Texas at Austin, Bureau of Economic Geology Report of Investigations No. 216, 89 p.

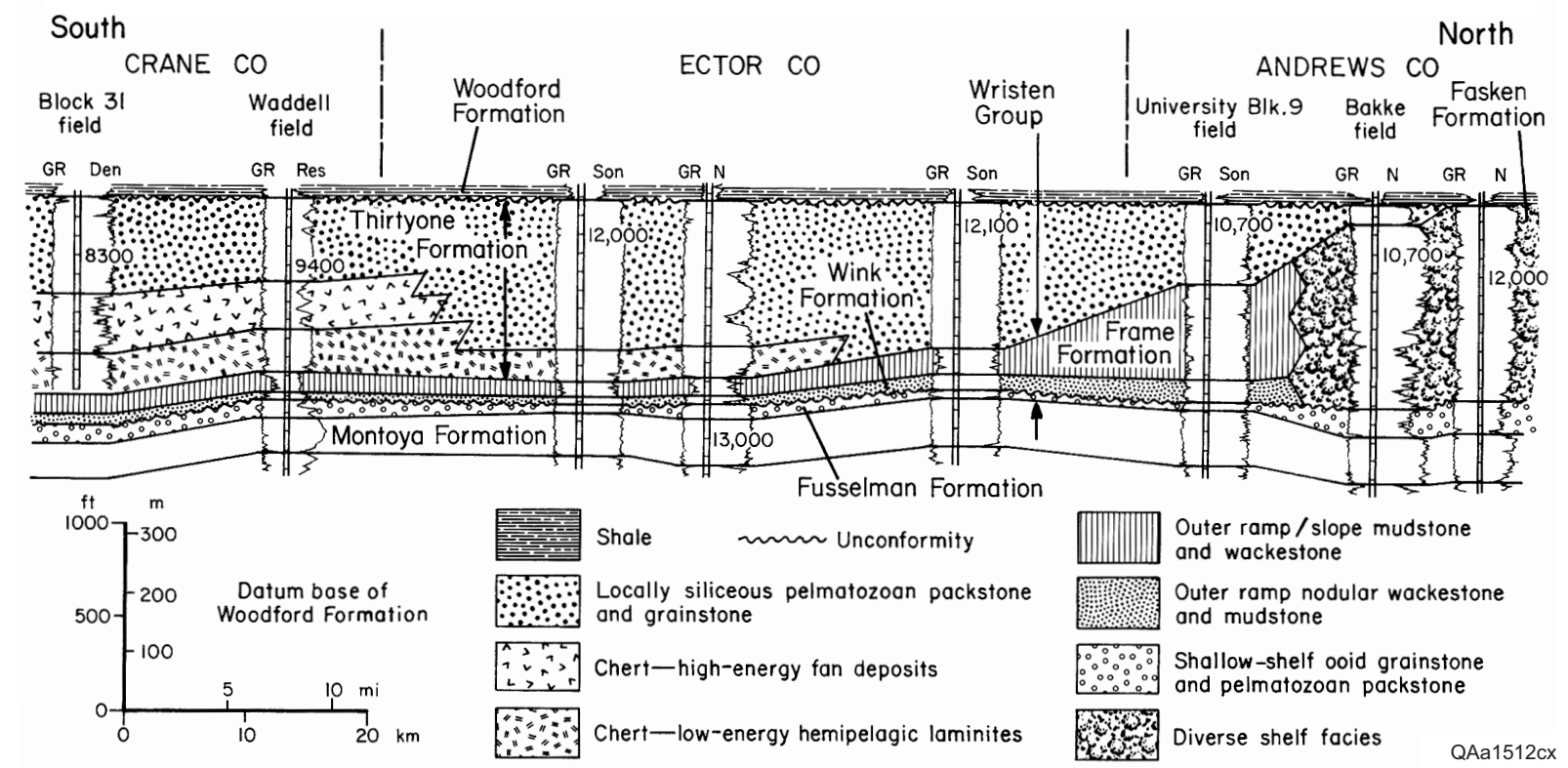

Figure 21. South-north dip cross section showing distribution of major Silurian and Devonian strata. From Ruppel and Holtz (1994). Cross section depicts the wedge-on-wedge relationship between the Wristen Group strata and overlying Thirtyone Formation strata. See Ruppel and Holtz (1994) for location of cross section. 
Devonian Thirtyone Deepwater Chert (Play 106)

The Devonian Thirtyone Deepwater Chert play consists of 44 reservoirs that had produced $>1 \mathrm{MMbbl}\left(1.59 \times 10^{5} \mathrm{~m}^{3}\right)$ of oil through 2000 ; cumulative production from the play was 785.9 MMbbl $\left(1.25 \times 10^{8} \mathrm{~m}^{3}\right)($ table 9$)$. All but one of the reservoirs in the play is in Texas, along the south part of the Central Basin Platform and adjacent areas (fig. 22). Thirtyone Deepwater Chert reservoirs are concentrated along the Thirtyone basin axis, where chert is

Table 9. Devonian Thirtyone Deepwater Chert play (play 106). Production shown for fields that have had others combined into them represents the totals; combined fields are highlighted.

\begin{tabular}{|c|c|c|c|c|c|c|c|c|c|}
\hline RRC RESN & RRC & FLDNAME & RESNAME & STATE & COUNTY & DISCYR & DEPTHTOP & 2000 PROD & CUMPROD \\
\hline 292203 & 8 & ABELL & DEVONIAN & TX & CRANE & 1953 & 5245 & 112,298 & $11,901,722$ \\
\hline 587332 & $7 \mathrm{C}$ & ADAMC & DEVONIAN & $T X$ & UPTON & 1953 & 10490 & 28,430 & $5,208,779$ \\
\hline 4184333 & 8 & ATAPCO & DEVONIAN & $\mathrm{TX}$ & CRANE & 1959 & 5520 & 63,160 & $1,398,972$ \\
\hline 5524664 & 8 & BAR-MAR & DEV. & TX & CRANE & 1965 & 5258 & 205,886 & $5,143,157$ \\
\hline 6671166 & 8 & BEDFORD & DEVONIAN & $T X$ & ANDREWS & 1945 & 8777 & 271,459 & $19,358,362$ \\
\hline 9230142 & 8 & BLOCK 11 & DEVONIAN & $T X$ & ANDREWS & 1951 & 8230 & 71,365 & $11,110,212$ \\
\hline 9236333 & 8 & BLOCK 11, SW. & DEVONIAN & TX & ANDREWS & 1952 & 8160 & 8,153 & $5,113,708$ \\
\hline 9358450 & 8 & BLOCK 31 & DEVONIAN & TX & CRANE & 1945 & 8812 & 576,450 & $223,850,169$ \\
\hline 20607001 & 8 & CORDONA LAKE & & TX & CRANE & 1949 & 5470 & 450,129 & $32,578,669$ \\
\hline 20615500 & 8 & CORDONA LAKE, WEST & DEV. & TX & CRANE & 1965 & 5561 & 9,327 & $1,490,496$ \\
\hline 21577180 & 8 & CRAWAR & DEVONIAN, NORTH & TX & CRANE & 1958 & 6450 & 82,659 & $6,308,067$ \\
\hline 21907111 & 8 & CROSSETT & DEVONIAN & $T X$ & CRANE & 1944 & 5440 & 404,815 & $25,568,056$ \\
\hline 21912333 & 8 & CROSSETT, S. & DETRITAL & TX & CROCKETT & 1965 & 4924 & 916,976 & $16,972,491$ \\
\hline 21912666 & 8 & CROSSETT, S. & DEVONIAN & TX & CROCKETT & 1956 & 5324 & 0 & $17,145,768$ \\
\hline 23543666 & 8 & DAWSON & DEVONIAN & $T X$ & CRANE & 1955 & 5168 & 0 & $2,165,509$ \\
\hline 25188400 & 8 & DOLLARHIDE & DEVONIAN & $T X$ & ANDREWS & 1955 & 8051 & $1,551,384$ & $97,596,076$ \\
\hline 25189200 & 8 & DOLLARHIDE, EAST & DEVONIAN & $\mathrm{TX}$ & ANDREWS & 1949 & 10186 & 249,835 & $9,284,134$ \\
\hline 31768001 & 8 & FLYING -W- & & $T X$ & WINKLER & 1949 & 9660 & 16,890 & $1,944,700$ \\
\hline 32555666 & $7 \mathrm{C}$ & FRANCO & DEVONIAN & $\mathrm{TX}$ & UPTON & 1964 & 10633 & 13,929 & $1,765,137$ \\
\hline 35652186 & 8 & GOLDSMITH & DEVONIAN & TX & ECTOR & 1948 & 7875 & 123,246 & $15,171,587$ \\
\hline 35654166 & 8 & GOLDSMITH, N. & DEVONIAN & $T X$ & ECTOR & 1946 & 7900 & 23,752 & $9,021,147$ \\
\hline 38255174 & 8 & HALLEY & DEVONIAN & $T X$ & WINKLER & 1956 & 9884 & 0 & $3,425,981$ \\
\hline 40296500 & $7 \mathrm{C}$ & HELUMA, EAST & DEVONIAN & TX & UPTON & 1973 & 8740 & 39,768 & $4,563,131$ \\
\hline 40300500 & $7 \mathrm{C}$ & HELUMA, SE & DEVONIAN & $T X$ & UPTON & 1979 & 9024 & 28,200 & $1,613,983$ \\
\hline 49042250 & 8 & KERMIT, SOUTH & DEVONIAN-OIL & $T X$ & WINKLER & 1957 & 8220 & 140 & $9,656,276$ \\
\hline 49129198 & 8 & KEYSTONE & DEVONIAN & TX & WINKLER & 1946 & 8040 & 6,597 & $15,403,476$ \\
\hline 49413200 & $7 \mathrm{C}$ & KING MOUNTAIN & DEVONIAN & TX & UPTON & 1956 & 10459 & 21,950 & $1,870,050$ \\
\hline 59560300 & $7 \mathrm{C}$ & MCKAY CREEK & CABALLOS & $\mathrm{TX}$ & TERRELL & 1979 & 6238 & 12,161 & $1,173,298$ \\
\hline 62417270 & 8 & MONAHANS, NORTH & DEVONIAN & TX & WINKLER & 1955 & 9447 & 1,963 & $6,347,324$ \\
\hline 68222080 & 8 & P\&P & DEVONIAN & TX & CRANE & 1995 & 5508 & 188,795 & $1,375,704$ \\
\hline 70129348 & 8 & PECOS VALLEY & DEVONIAN 5400 & $T X$ & PECOS & 1953 & 5771 & 168,096 & $8,388,267$ \\
\hline 70129812 & 8 & PECOS VALLEY & PERMIAN, LOWER & TX & PECOS & 1956 & 5140 & 39,022 & $3,236,057$ \\
\hline 70279125 & $7 \mathrm{C}$ & PEGASUS & DEVONIAN & $\mathrm{TX}$ & UPTON & 1952 & 12353 & 29,575 & $1,442,855$ \\
\hline 89408205 & 8 & THISTLE & CABALLOS NOVACULITE & TX & PECOS & 1984 & 2679 & 9,821 & $1,291,062$ \\
\hline 89690250 & 8 & THREE BAR & DEVONIAN & $T X$ & ANDREWS & 1945 & 8385 & 126,428 & $41,023,054$ \\
\hline 91450333 & 8 & TROPORO & DEVONIAN & $T X$ & CRANE & 1957 & 5404 & 61,872 & $5,576,672$ \\
\hline 91455500 & 8 & TROPORO, N & DEVONIAN & $T X$ & CRANE & 1979 & 5555 & 20,556 & $1,261,495$ \\
\hline 91803200 & 8 & TUNIS CREEK & DEVONIAN & $\mathrm{TX}$ & PECOS & 1982 & 6835 & 103,474 & $3,607,730$ \\
\hline 88071174 & 8 & TXL & DEVONIAN & TX & ECTOR & 1944 & 8050 & 58,311 & $58,747,516$ \\
\hline 88071232 & 8 & $T X L$ & DEVONIAN-MAIN PAY & $T X$ & ECTOR & 1970 & 8075 & 29,758 & $2,465,157$ \\
\hline 92618125 & 8 & UNIVERSITY WADDELL & DEVONIAN & $T X$ & CRANE & 1949 & 9040 & 529,063 & $70,267,302$ \\
\hline 96756200 & 8 & WHEELER & DEVONIAN & $\mathrm{TX}$ & WINKLER & 1945 & 8590 & 15,734 & $10,348,368$ \\
\hline \multirow[t]{3}{*}{99275250} & 8 & YARBROUGH \& ALLEN & DEVONIAN & TX & ECTOR & 1954 & 8505 & 45,369 & $3,569,192$ \\
\hline & & DOLLARHIDE & DEVONIAN & NM & LEA & 1952 & 8167 & 69725 & $9,179,120$ \\
\hline & & Totals & & & & & & $6,786,521$ & $785,929,988$ \\
\hline
\end{tabular}




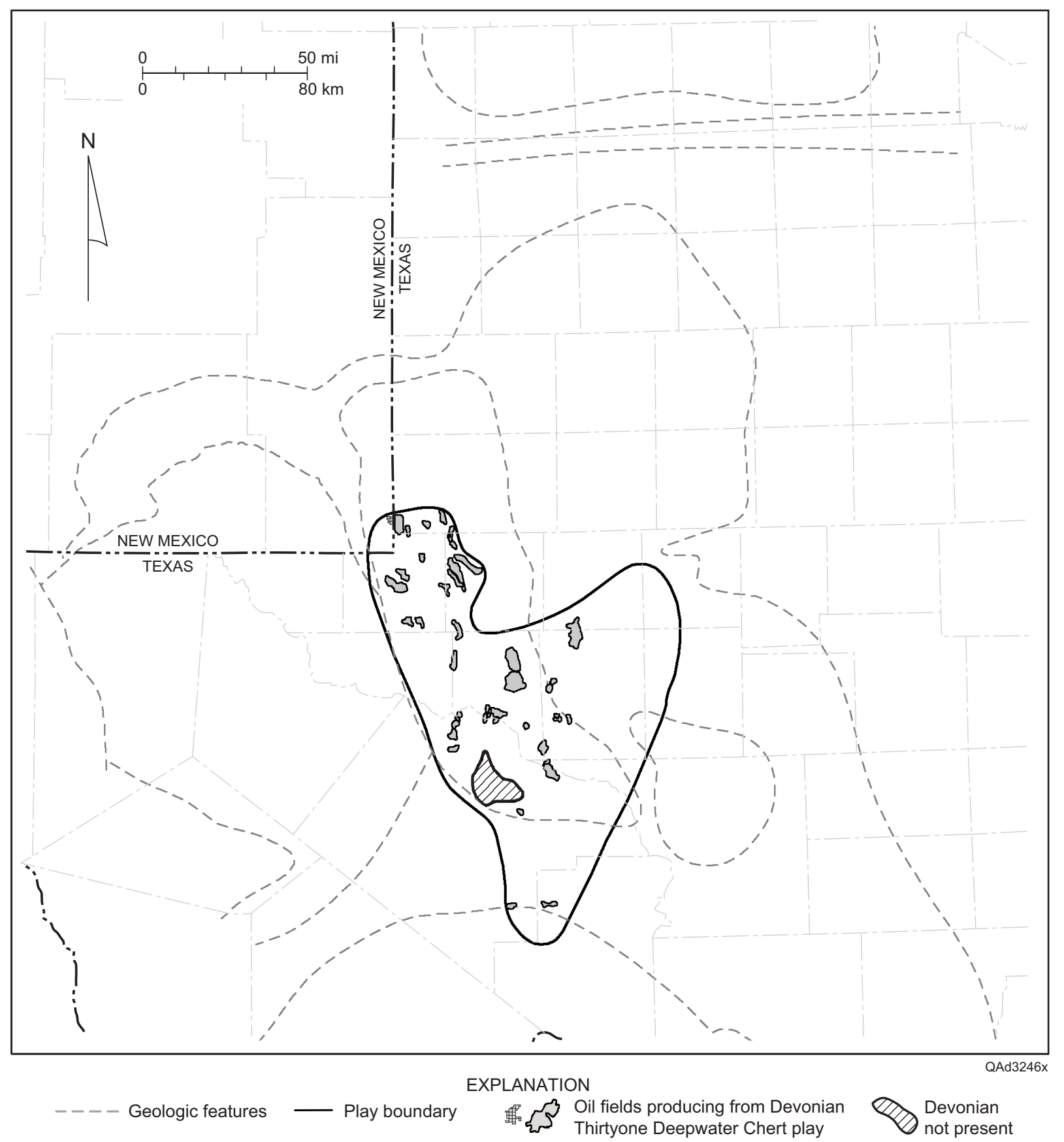

Figure 22. Play map for the Devonian Thirtyone Deepwater Chert play, showing location of reservoirs having $>1 \mathrm{MMbbl}$ cumulative production, the play boundary, and geologic features. See figure 1 for county names and figure 2 for identification of geologic features. 
thickest (Ruppel and Holtz, 1994). The Devonian is missing on the Fort Stockton high in northern Pecos County (Ewing, 1990), so the play is not present in this area (fig. 22). Traps are anticlinal structures, or they were formed by erosional truncation (Tyler and others, 1991). The largest fields are associated with structural uplifts bounded by basement reverse faults that formed during the Pennsylvanian (Montgomery, 1998).

Thick-bedded laminated chert, commonly called "tripolitic chert," is the most important reservoir facies in the Thirtyone Formation (Ruppel and Holtz, 1994). The chert is highly porous and contains varying amounts of carbonate. Burrowed chert facies have more variable porosity but are productive in some reservoirs (Saller and others, 2001). Thirtyone Formation chert strata accumulated in deepwater slope and basin settings by submarine gravity flow and hemipelagic sedimentation (Ruppel and Holtz, 1994).

Geologic interpretation of the Devonian Thirtyone Chert in West Texas was summarized in Saller and others (1991), Ruppel and Holtz (1994), Ruppel and Hovorka (1995a, b), Ruppel and Barnaby (2001), and Saller and others (2001). Reservoirs in the north part of the play (for example, Dollarhide and Three Bar in Andrews County) are developed in a continuous, porous, spiculitic chert interval at the base of the Thirtyone Formation (Ruppel and Barnaby, 2001) (figs. 23, 24). Chert in this setting was deposited on a gently sloping outer platform during regional transgression. Heterogeneity in these reservoirs is caused mainly by faulting, fracturing, and dissolution of carbonate along unconformities (Ruppel and Barnaby, 2001). Reservoirs in the south part of the play (for example, University Waddell and Block 31 in Crane County) produce from basin-center, submarine-fan cherts that exhibit more complex geometries and considerably more lateral and vertical heterogeneity than is observed to the north (Barnaby and others, 1998). Reservoirs are composed of thin, vertically stacked, 


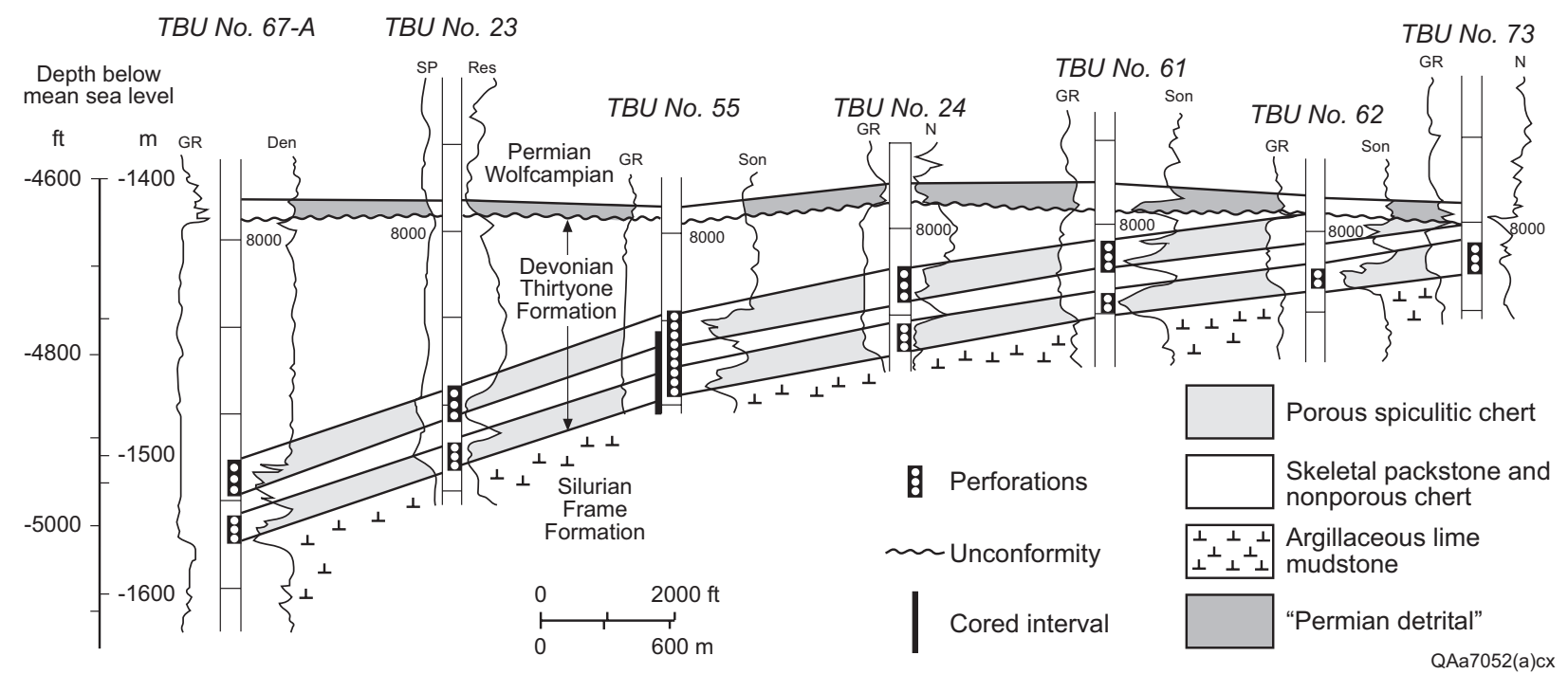

Figure 23. West-east cross section in Three Bar field, Andrews County, Texas. Cross section is perpendicular to the structural axis of the field and shows updip truncation of the reservoir pay zone beneath the sub-Permian unconformity. From Ruppel and Hovorka (1995); see that publication for location of cross section.

and laterally discontinuous cherts deposited as debris flows and turbidites (Ruppel and Barnaby, 2001).

Most of the porosity in the Thirtyone chert is moldic and intercrystalline (Tyler and others, 1991). Moldic pores formed by leaching of sponge spicules and carbonate allochems. Intercrystalline pores developed within the chert matrix. Micropores, which are $<5 \mu \mathrm{m}$ in diameter, make up at least 50 percent of the total porosity (Saller and others, 1991; Ruppel and Barnaby, 2001). Porosity and permeability generally decrease with increased carbonate content. Fractures in the brittle chert matrix are locally important in some reservoirs, such as Three Bar (Ruppel and Holtz, 1994).

In the area of this play, erosion during the Pennsylvanian removed Mississippian and earlier Pennsylvanian strata (Kosters and others, 1989); in most fields, Devonian reservoir 

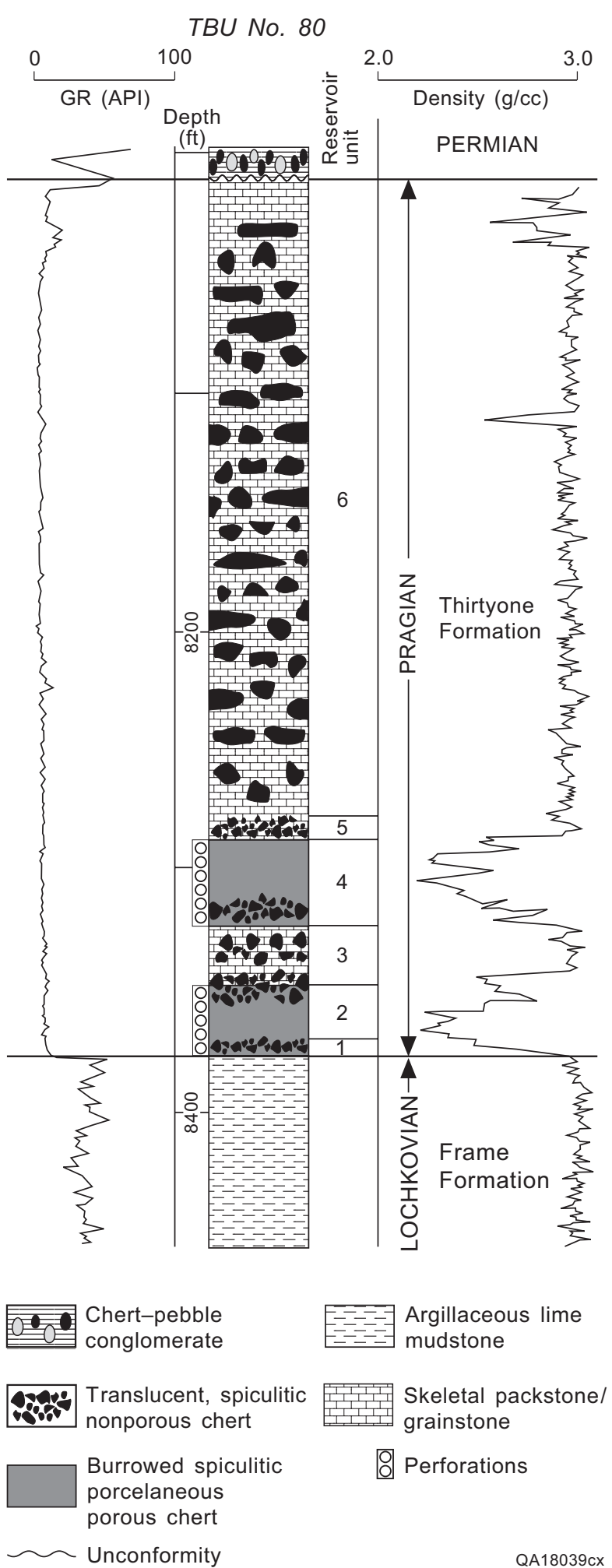

Skeletal packstone/
grainstone
O Perforations
QA18039cx

Figure 24. Typical stratigraphic succession and wireline-log signature of Thirtyone Formation in the Amoco 80 Three Bar Unit well, Three Bar field, Andrews County, Texas. From Ruppel and Hovorka (1995). 
intervals are directly overlain by Permian strata. In some areas a zone of eroded and reworked chert conglomerate rests above the Devonian Thirtyone chert (fig. 23). This "Permian Detrital" zone is productive in Crossett, S. (Detrital), field (Richards, 1982). Although the reservoir zone is not in situ Devonian Thirtyone Chert, the Crossett, S. (Detrital), reservoir has been included in the Devonian Thirtyone Chert play.

Ruppel and Holtz (1994) estimated that approximately $700 \mathrm{MMbbl}\left(1.11 \times 10^{8} \mathrm{~m}^{3}\right)$ of mobile oil remains in reservoirs of this play. Reservoirs in the Thirtyone Chert play have been the subject of a variety of enhanced-recovery techniques. North Cross Unit of Crossett Devonian field and South Cross Unit of Crossett South Devonian fields have undergone $\mathrm{CO}_{2}$ floods (L. S. Melzer, personal communication, 2003). Dollarhide (Devonian), which had an estimated $146 \mathrm{MMbbl}\left(2.32 \times 10^{7} \mathrm{~m}^{3}\right)$ of original oil in place (OOIP), has undergone secondary waterflooding and tertiary infill drilling and $\mathrm{CO}_{2}$ injection (Saller and others, 1991, 2001). Different areas of the field have responded differently to various phases of recovery, but the overall field recovery was 13 percent of OOIP by primary recovery, 30 percent by the waterflood, 3.5 percent by infill drilling, and 11 percent by the $\mathrm{CO}_{2}$ flood (Saller and others, 2001). Compartmentalization caused by faulting and facies changes had a minor effect during primary recovery but a more major influence on secondary and tertiary recovery (Saller and others, 2001). Infill drilling was most effective in areas having thicker zones of the heterogeneous burrowed chert facies and near the edges of reservoir compartments (Saller and others, 2001). Response to the $\mathrm{CO}_{2}$ flood was better in areas having thicker zones of the homogeneous laminated, microporous chert facies (Saller and others, 2001).

Recovery at Three Bar (Devonian) field was 27 percent of OOIP during primary and secondary recovery. The lower recovery compared with that of Dollarhide is probably caused 
by greater reservoir heterogeneity and structural complexity at Three Bar (Ruppel and Hovorka, 1995a, b; Montgomery, 1998).

Block 31 (Devonian) is the largest reservoir in the play, having produced $>223 \mathrm{MMbbl}$ $\left(3.55 \times 10^{7} \mathrm{~m}^{3}\right)$ through 2000 . Ultimate recovery from this reservoir is estimated to be as high as 60 percent (Galloway and others, 1983). Good recovery probably results from the presence of thick intervals of the porous, thick-bedded, laminated chert facies (Ruppel and Holtz, 1994); early pressure maintenance; and infill drilling. The first miscible gas-injection, enhanced-oilrecovery project was initiated in the Block 31 Devonian reservoir in 1952 (Galloway and others, 1983; Ebanks, 1988). The high-pressure, lean-gas injection and infill-drilling programs carried out in this reservoir both increased recoverable reserves (Galloway and others, 1983).

Porosity in the Thirtyone chert reservoirs, which is highly variable because of variations in chert:carbonate ratio, ranges from 2 to 30 percent and averages 15 percent (Ruppel and Holtz, 1994). Matrix permeability is also variable but averages about $23 \mathrm{md}\left(23 \times 10^{-3} \mu \mathrm{m}^{2}\right)$. Fracture permeability is critical in many of the reservoirs. Reservoir net pay in the play ranges from 15 to $170 \mathrm{ft}(5$ to $50 \mathrm{~m})$ and averages $61 \mathrm{ft}(19 \mathrm{~m})$.

\section{References}

Barnaby, R. J., Grubb, J. G., Barros-Griffiths, I., and Lake, L. W., 1998, Reservoir heterogeneity of turbidite channel/levee and submarine fan facies in a Lower Devonian chert and siliceous carbonate reservoir: University Waddell field, west Texas, in DeMis, W. D. and Nelis, M. K., eds., The search continues into the 21 st century: West Texas Geological Society Publication No. 98-105, p. 93.

Ebanks, W. J., Jr., 1988, Geologic description of Middle Devonian chert reservoir, Block 31 field, Crane County, Texas (abs.): American Association of Petroleum Geologists Bulletin, v. 72, p. 181. 
Ewing, T. E., 1990, Tectonic map of Texas: The University of Texas at Austin, Bureau of Economic Geology, scale 1:750,000, 4 sheets.

Galloway, W. E., Ewing, T. E., Garrett, C. M., Jr., Tyler, N., and Bebout, D. G., 1983, Atlas of major Texas oil reservoirs: The University of Texas at Austin, Bureau of Economic Geology Special Publication, 139 p.

Kosters, E. C., Bebout, D. G., Seni, S. J., Garrett, C. M., Jr., Brown, L. F., Jr., Hamlin, H. S., Dutton, S. P., Ruppel, S. C., Finley, R. J., and Tyler, Noel, 1989, Atlas of major Texas gas reservoirs: The University of Texas at Austin, Bureau of Economic Geology Special Publication, $161 \mathrm{p}$.

Montgomery, S. L., 1998, Thirtyone Formation, Permian Basin, Texas: structural and lithologic heterogeneity in a Lower Devonian chert reservoir: American Association of Petroleum Geologists Bulletin, v. 82, p. 1-24.

Richards, J. W., 1982, Crossett, South-El Cinco: selected oil \& gas fields in West Texas: West Texas Geological Society Publication No. 82-75, p. 205-211.

Ruppel, S. C., and Barnaby, R. J., 2001, Contrasting styles of reservoir development in proximal and distal chert facies: Devonian Thirtyone Formation, Texas: American Association of Petroleum Geologists Bulletin, v. 84, p. 7-34.

Ruppel, S. C., and Holtz, M. H., 1994, Depositional and diagenetic facies patterns and reservoir development in Silurian and Devonian rocks of the Permian Basin: The University of Texas at Austin, Bureau of Economic Geology Report of Investigations No. 216, 89 p.

Ruppel, S. C., and Hovorka, S. D., 1995a, Chert reservoir development in the Devonian Thirtyone Formation: Three Bar Field, west Texas: The University of Texas at Austin, Bureau of Economic Geology Report of Investigations No. 230, 50 p.

1995b, Controls on reservoir development in Devonian chert: Permian Basin, Texas: American Association of Petroleum Geologists Bulletin, v. 79, p. 1757-1785.

Saller, A. H., Ball, B., Robertson, S., McPherson, B., Wene, C., Nims, R. and Gogas, J., 2001, Reservoir characteristics of Devonian cherts and their control on oil recovery: Dollarhide Field, west Texas: American Association of Petroleum Geologists Bulletin, v. 85, p. $35-50$.

Saller, A. H., Van Horn, D., Miller, J. A., and Guy, B. T., 1991, Reservoir geology of Devonian carbonates and chert-implications for tertiary recovery, Dollarhide Field, Andrews County, Texas: American Association of Petroleum Geologists Bulletin, v. 75, p. 86-107.

Tyler, N., Bebout, D. G., Garrett, C. M., Jr., Guevara, E. H., Hocott, C. R., Holtz, M. H., Hovorka, S. D., Kerans, C., Lucia, F. J., Major, R. P., Ruppel, S. C., and Vander Stoep, G. W., 1991, Integrated characterization of Permian Basin reservoirs, University Lands, 
West Texas: targeting the remaining resource for advanced oil recovery: The University of Texas at Austin, Bureau of Economic Geology Report of Investigations No. 203, $136 \mathrm{p}$. 
Devonian Thirtyone Ramp Carbonate (Play 107)

The Devonian Thirtyone Ramp Carbonate is the smaller of the two plays that produce from the Thirtyone Formation (Ruppel and Holtz, 1994). The Thirtyone Ramp Carbonate play consists of 17 reservoirs that have produced $>1 \mathrm{MMbbl}\left(1.59 \times 10^{5} \mathrm{~m}^{3}\right)$ of oil through 2000 ; cumulative production from the play is $110.2 \mathrm{MMbbl}\left(1.75 \times 10^{7} \mathrm{~m}^{3}\right)$ (table 10). Reservoirs in the play occur in the north part of the Thirtyone Formation area, in Andrews, Ector, and Midland Counties (fig. 25). Traps are simple and faulted anticlines (Galloway and others, 1983).

Carbonates of the Thirtyone Formation were deposited on a shallow-water carbonate platform that prograded basinward (south) during sea-level highstand (Ruppel and Holtz, 1994). The reservoirs in this play are made up of skeletal packstones and grainstones composed primarily of pelmatozoan debris (fig. 26). At the north end of the trend, the packstones were deposited in sand shoals and bars in a shallow-water setting. Farther south, the packstones appear to have been deposited by downslope gravity-flow processes in an outer-ramp to slope setting

Table 10. Devonian Thirtyone Ramp Carbonate play (play 107). Production shown for fields that have had others combined into them represents the totals; combined fields are highlighted.

\begin{tabular}{|c|c|c|c|c|c|c|c|c|c|}
\hline RRC RESN & RRC & FLDNAME & RESNAME & STATE & E COUNTY & DISCYR & DEPTHTOP & 2000 PROD & CUMPROD \\
\hline 2727250 & 8 & ANDREWS, N. & DEVONIAN & $\mathrm{TX}$ & ANDREWS & 1960 & 10424 & 84,434 & $7,844,331$ \\
\hline 2730284 & 8 & ANDREWS, SOUTH & DEVONIAN & $\mathrm{TX}$ & ANDREWS & 1953 & 11075 & 5,759 & $10,316,428$ \\
\hline 4605222 & 8 & AZALEA & DEVONIAN & TX & MIDLAND & 1957 & 11520 & 35,158 & $1,714,524$ \\
\hline 5166333 & 8 & BAKKE & DEVONIAN & $\mathrm{TX}$ & ANDREWS & 1956 & 10500 & 59,408 & $17,106,630$ \\
\hline 9202166 & 8 & BLOCK 9 & DEVONIAN & $\mathrm{TX}$ & ANDREWS & 1960 & 12540 & 3,612 & $1,540,950$ \\
\hline 12763333 & 8 & BRYANT -G- & DEVONIAN & $\mathrm{TX}$ & MIDLAND & 1979 & 12002 & 563,813 & $1,643,736$ \\
\hline 23907142 & 8 & DEEP ROCK & DEVONIAN & $\mathrm{TX}$ & ANDREWS & 1963 & 10063 & 18,460 & $1,713,689$ \\
\hline 25395166 & 8 & DORA ROBERTS & DEVONIAN & $T X$ & MIDLAND & 1955 & 12010 & 16,055 & $2,528,808$ \\
\hline 28843111 & 8 & EMBAR & DEVONIAN & TX & ANDREWS & 1954 & 9346 & 10,846 & $1,335,402$ \\
\hline 28899166 & 8 & EMMA & DEVONIAN & $\mathrm{TX}$ & ANDREWS & 1954 & 10192 & 6,778 & $5,753,019$ \\
\hline 33176284 & 8 & FUHRMAN-MASCHO & DEVONIAN & TX & ANDREWS & 1956 & 10000 & 12,649 & $1,835,504$ \\
\hline 35652310 & 8 & GOLDSMITH & FIGURE 5 DEVONIAN & $T X$ & ECTOR & 1956 & 7760 & 0 & $1,358,571$ \\
\hline 39176332 & 8 & HARPER & DEVONIAN & $\mathrm{TX}$ & ECTOR & 1962 & 10005 & 87,721 & $10,515,508$ \\
\hline 39969400 & 8 & HEADLEE & DEVONIAN & $T X$ & ECTOR & 1953 & 11756 & 0 & $14,167,925$ \\
\hline 39971500 & 8 & HEADLEE, N. & DEVONIAN & $T X$ & ECTOR & 1956 & 12210 & 49,323 & $6,195,590$ \\
\hline 91350100 & 8 & TRIPLE-N & DEVONIAN & $\mathrm{TX}$ & ANDREWS & 1957 & 10600 & 3,706 & $1,072,723$ \\
\hline 92534250 & 8 & UNIVERSITY BLOCK 9 & DEVONIAN & $T X$ & ANDREWS & 1954 & 10450 & 789,597 & $23,606,166$ \\
\hline \multicolumn{4}{|c|}{ Totals } & & & & & $1,747,319$ & $110,249,504$ \\
\hline
\end{tabular}




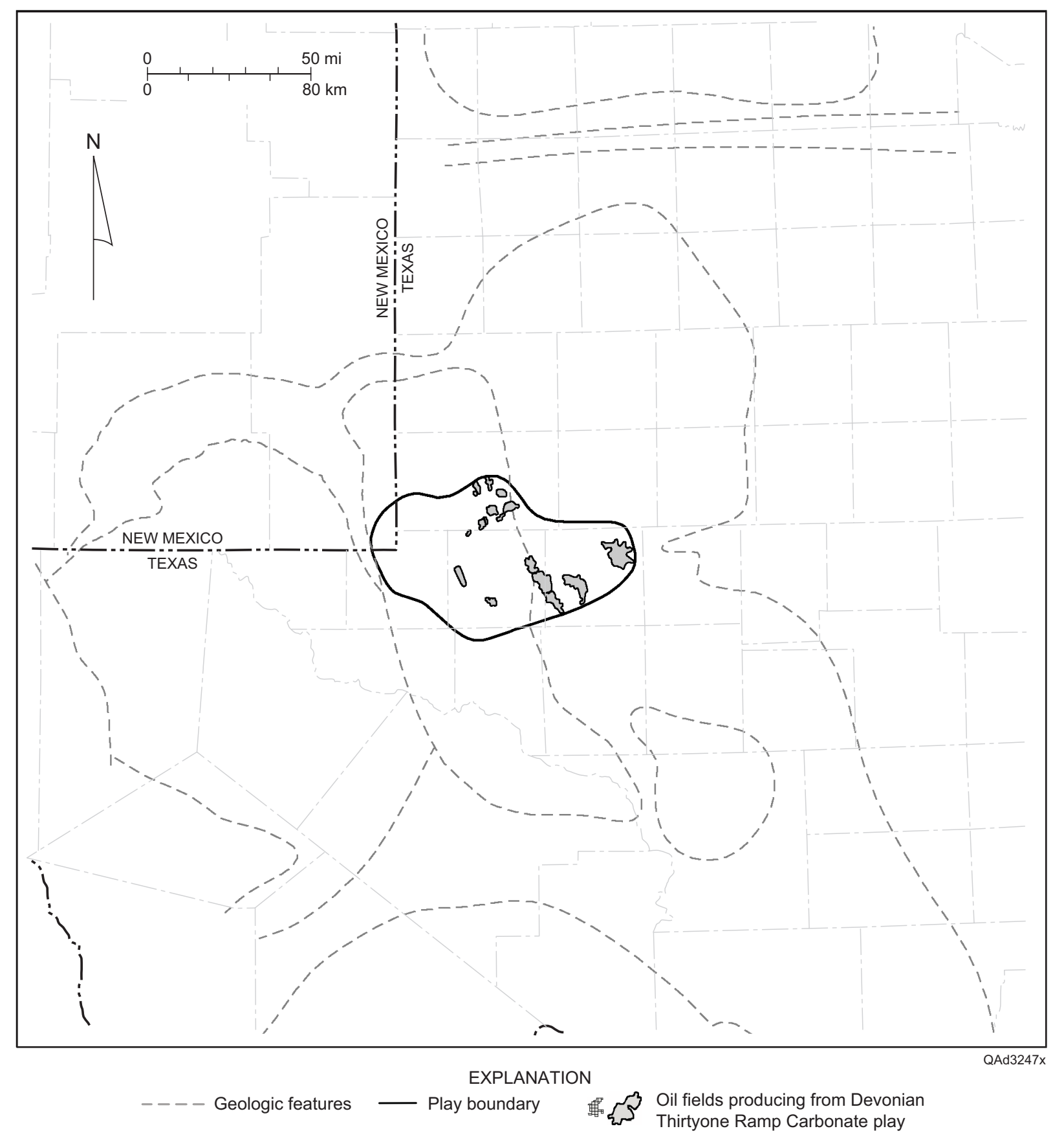

Figure 25. Play map for the Devonian Thirtyone Ramp Carbonate play, showing location of reservoirs having $>1 \mathrm{MMbbl}$ cumulative production, the play boundary, and geologic features. See figure 1 for county names and figure 2 for identification of geologic features. 


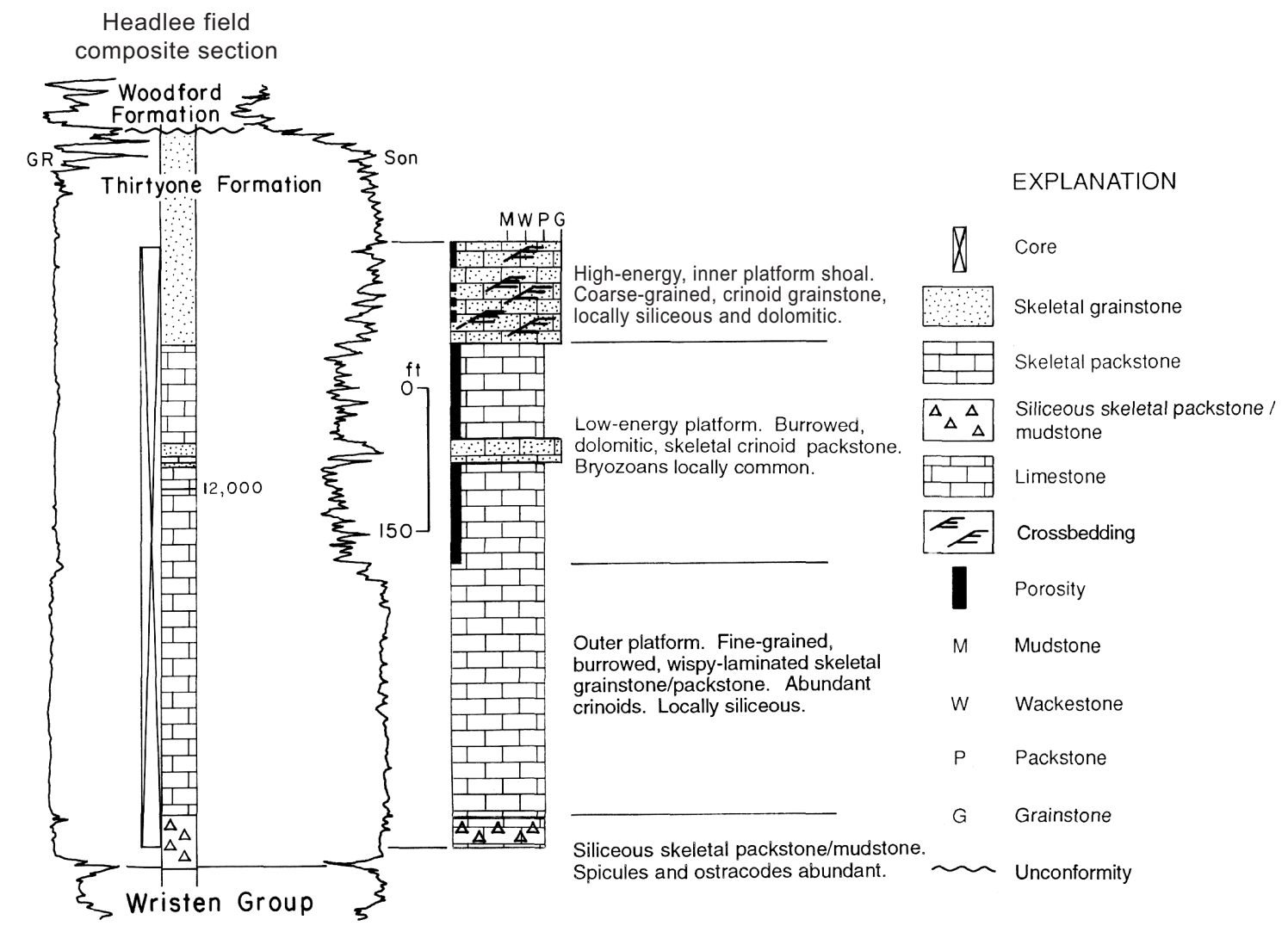

QA18040cx

Figure 26. Stratigraphic section of the Thirtyone Formation in Headlee (Devonian) field, Ector County, Texas. From Ruppel and Holtz (1994). The Thirtyone Formation in this field is almost entirely carbonate, composed of an upward-shallowing succession.

(Tyler and others, 1991; Ruppel and Holtz, 1994). The Thirtyone carbonates are mostly limestone, but there are local areas of dolostone. The Thirtyone Formation in the Bryant -G(Devonian) reservoir in Midland County, Texas, includes silicified skeletal packstones and grainstones (Wind, 1998).

Porosity developed generally as a result of leaching of carbonate mud in skeletal packstones, producing intergranular pore space (Ruppel and Holtz, 1994). Intercrystalline porosity is associated with dolomitization in some fields, such as Bakke, University Block 9, and South Andrews, and with development of karst horizons in Three Bar field (Ruppel and Holtz, 
1994; Weiner and Heyer, 1999). In University Block 9 field, the best porosity was preserved in shelf packstones and wackestones because mud inhibited precipitation of pore-filling cement (Weiner and Heyer, 1999, 2000). Average porosity is 6 percent, but in some reservoirs more extensive leaching associated with dolomitization has produced intercrystalline pores and small vugs associated with higher porosity values.

Horizontal drilling increased production from the Thirtyone carbonate reservoir in University Block 9 field in Andrews County by $>2,000 \mathrm{bbl} / \mathrm{day}\left(31.8 \mathrm{~m}^{3} / \mathrm{d}\right.$ ) (Weiner and Heyer, 2000). Image logs, cores, and 3-D seismic data were used to identify reservoir compartments formed by faults. These data indicated that structure of the field is more complicated than was initially interpreted. In 1967 the field was mapped as an unfaulted dome (Galloway and others, 1983). More recently, modern 3-D seismic data were interpreted as indicating an arcuate, fielddefining fault having reverse and strike-slip components and several antithetic normal and reverse faults (Weiner and Heyer, 1999). Horizontal reentries ranging from 1,000 to 1,700 ft (305 to $518 \mathrm{~m}$ ) long were drilled to reach untapped compartments in the field. Some of the lateral reentries drilled out of old, depleted wells were recompleted in new compartments and produced $>150 \mathrm{bbl} /$ day $\left(23.8 \mathrm{~m}^{3} / \mathrm{d}\right)$.

Horizontal drilling — both reentry laterals and multilateral, newly drilled wells—also increased production of both gas and oil from the Bryant -G- (Devonian) reservoir (Burkett, 2002; Rowan and others, 2002). Laterals in the Bryant $-\mathrm{G}-$ (Devonian) ranged from 1,270 to $5,440 \mathrm{ft}$ (387 to $1,658 \mathrm{~m}$ ) long. The open-hole laterals were stimulated with acid conveyed by tubing (Rowan and others, 2002).

North Cross unit in Crossett Devonian field and South Cross unit in Crossett South Devonian field are undergoing $\mathrm{CO}_{2}$ floods (L. S. Melzer, personal communication, 2003). The 
$\mathrm{CO}_{2}$ flood at North Cross unit was initiated as a secondary flood in 1972; production response was observed after 1 year, and fieldwide oil-production response occurred after 2 years (Kinder Morgan, 2004). Through 1994, the $\mathrm{CO}_{2}$ flood had recovered 24 percent of OOIP, and residual oil saturation was reduced to 3 percent in the area swept by $\mathrm{CO}_{2}$.

Reservoir net pay in the play ranges from 14 to $310 \mathrm{ft}$ (4 to $94 \mathrm{~m}$ ) and averages $80 \mathrm{ft}$ (24 m). Porosity ranges from 3.5 to 9.5 and averages 6.4 percent; permeability ranges from 0.4 to $30 \mathrm{md}\left(30 \times 10^{-3} \mu \mathrm{m}^{2}\right)$ and averages $1.5 \mathrm{md}\left(1.5 \times 10^{-3} \mu \mathrm{m}^{2}\right)$ (Ruppel and Holtz, 1994).

\section{References}

Burkett, M. A., 2002, Application of horizontal drilling in low-permeability reservoirs, in Transactions, Southwest Section, American Association of Petroleum Geologists, Ruidoso, New Mexico, p. 139-146.

Galloway, W. E., Ewing, T. E., Garrett, C. M., Jr., Tyler, N., and Bebout, D. G., 1983, Atlas of major Texas oil reservoirs: The University of Texas at Austin, Bureau of Economic Geology Special Publication, $139 \mathrm{p}$.

Kinder Morgan, 2004, North Cross Devonian unit: http://www.kindermorgan.com/business/co2/success_north_cross.cfm.

Rowan, D. E., Miller, K., and Cowley, E., 2002, Horizontal lateral revitalization of a low permeable carbonate reservoir at the Bryant -G- Field, Midland County, Texas: Transactions, Southwest Section, American Association of Petroleum Geologists, Ruidoso, New Mexico, p. 96.

Ruppel, S. C., and Holtz, M. H., 1994, Depositional and diagenetic facies patterns and reservoir development in Silurian and Devonian rocks of the Permian Basin: The University of Texas at Austin, Bureau of Economic Geology Report of Investigations No. 216, 89 p.

Tyler, N., Bebout, D. G., Garrett, C. M., Jr., Guevara, E. H., Hocott, C. R., Holtz, M. H., Hovorka, S. D., Kerans, C., Lucia, F. J., Major, R. P., Ruppel, S. C., and Vander Stoep, G. W., 1991, Integrated characterization of Permian Basin reservoirs, University Lands, West Texas: targeting the remaining resource for advanced oil recovery: The University of Texas at Austin, Bureau of Economic Geology Report of Investigations No. 203, $136 \mathrm{p}$. 
Weiner, S., and Heyer, J., 1999, Geological model of a highly compartmentalized reservoir: the Devonian Thirtyone Formation, University Block 9 Field, in Grace, D. T., and Hinterlong, G. D., eds., The Permian Basin: providing energy for America: West Texas Geological Society Publication No. 99-106, p. 1-8.

2000, Horizontal well applications in a highly compartmentalized reservoir: the Devonian Thirtyone Formation, University Block 9 Field, Andrews County, Texas, in Reid, S. T., ed., Geo-2000: into the future: Transactions, Southwest Section, American Association of Petroleum Geologists, Publication SWS 2000-107, p. 255.

Wind, F. H., 1998, Early silica mobilization and certification in the Thirtyone Formation, Bryant G Devonian Unit, Midland Co., TX, in DeMis, W. D. and Nelis, M. K., eds., The search continues into the 21st century: West Texas Geological Society Publication No. 98-105, p. $67-72$. 


\section{Mississippian Play}

Mississippian Platform Carbonate (Play 108)

The Mississippian Platform Carbonate play is the smallest oil-producing play in the Permian Basin, having cumulative production of only $15.1 \mathrm{MMbbl}\left(2.40 \times 10^{6} \mathrm{~m}^{3}\right)$ from five reservoirs (table 11). Because no Mississippian reservoirs had produced >10 MMbbl $\left(1.59 \times 10^{6} \mathrm{~m}^{3}\right)$, this play was not included in the Atlas of Major Texas Oil Reservoirs (Galloway and others, 1983). The play is shown as extending across much of the Permian Basin (fig. 27) because smaller Mississippian reservoirs $\left(<1 \mathrm{MMbbl}\left[<1.59 \times 10^{5} \mathrm{~m}^{3}\right]\right)$ cumulative production) are located throughout the area. The play does not include areas where the Mississippian was removed by erosion (fig. 27) (Ruppel, 1983; Frenzel and others, 1988; Ruppel, 1989). Production in the play is controlled by both structural and stratigraphic traps (Wright, 1979).

Little information is available about this play. Frenzel and others (1988) noted that Osage and Meramec carbonate strata in west Texas generally consist of finely crystalline, nonporous limestones. Hamilton and Asquith (2000) described the stratigraphy and facies of upper Mississippian (Meramec and Chester) deposits in New Mexico and adjacent West Texas. Upper Mississippian platform carbonates are the shelf equivalents of the Barnett Shale, which

Table 11. Mississippian Platform Carbonate play (play 108).

\begin{tabular}{lrll} 
RRC RESN & RRC & FLDNAME & RESNAME \\
& & & \\
11308333 & $8 A$ & BRAHANEY & MISSISSIPPIAN \\
24377300 & 8 A & DEROEN & MISSISSIPPIAN \\
31690001 & 8 A & FLUVANNA & \\
34961250 & 8 A & GIN & MISS. \\
51742333 & 8 A & LAMESA, WEST & MISS. \\
& \multicolumn{3}{c}{ Totals }
\end{tabular}

$\begin{array}{rrrrrr}\text { STATE COUNTY } & \text { DISCYR } & \text { DEPTHTOP } & \mathbf{2 0 0 0} \text { PROD } & \text { CUMPROD } \\ \text { TX } & \text { YOAKUM } & 1960 & 10880 & 11,119 & 4,268,423 \\ \text { TX } & \text { DAWSON } & 1981 & 10182 & 58,502 & 2,002,217 \\ \text { TX } & \text { BORDEN } & 1951 & 8173 & 10,857 & 5,788,200 \\ \text { TX DAWSON } & 1965 & 11403 & 5,984 & 1,148,179 \\ \text { TX } & \text { DAWSON } & 1959 & 11280 & 5,303 & 1,903,803 \\ & & & & & \\ & & & & & \\ & & & & & \end{array}$




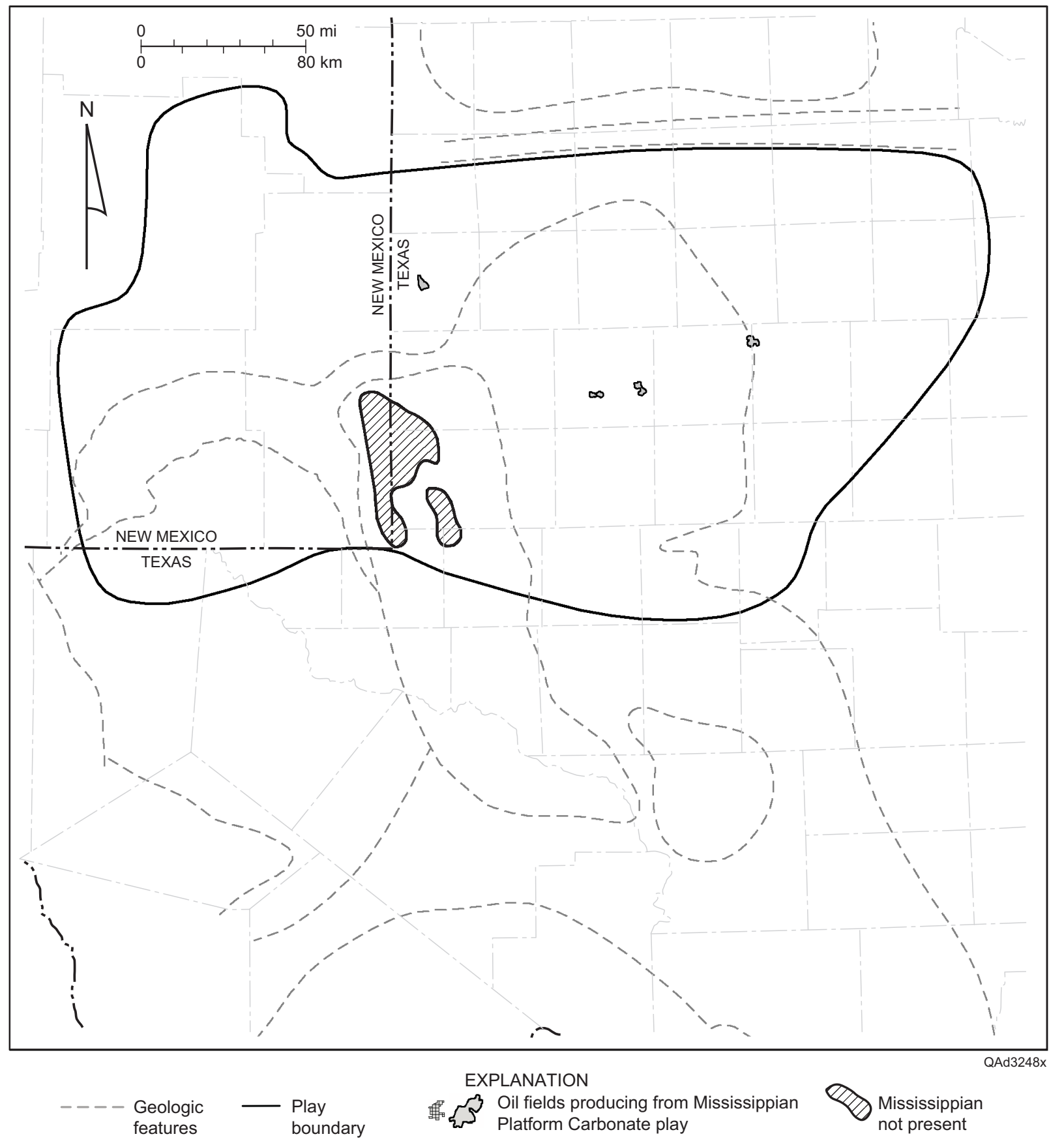

Figure 27. Play map for the Mississippian Platform Carbonate play, showing location of reservoirs having $>1 \mathrm{MMbbl}$ cumulative production, the play boundary, and geologic features. See figure 1 for county names and figure 2 for identification of geologic features.

was deposited in the deeper basin to the south and east (figs. 28, 29). Hamilton and Asquith (2000) studied the depositional and diagenetic history of Austin Upper Mississippian field, a gas 


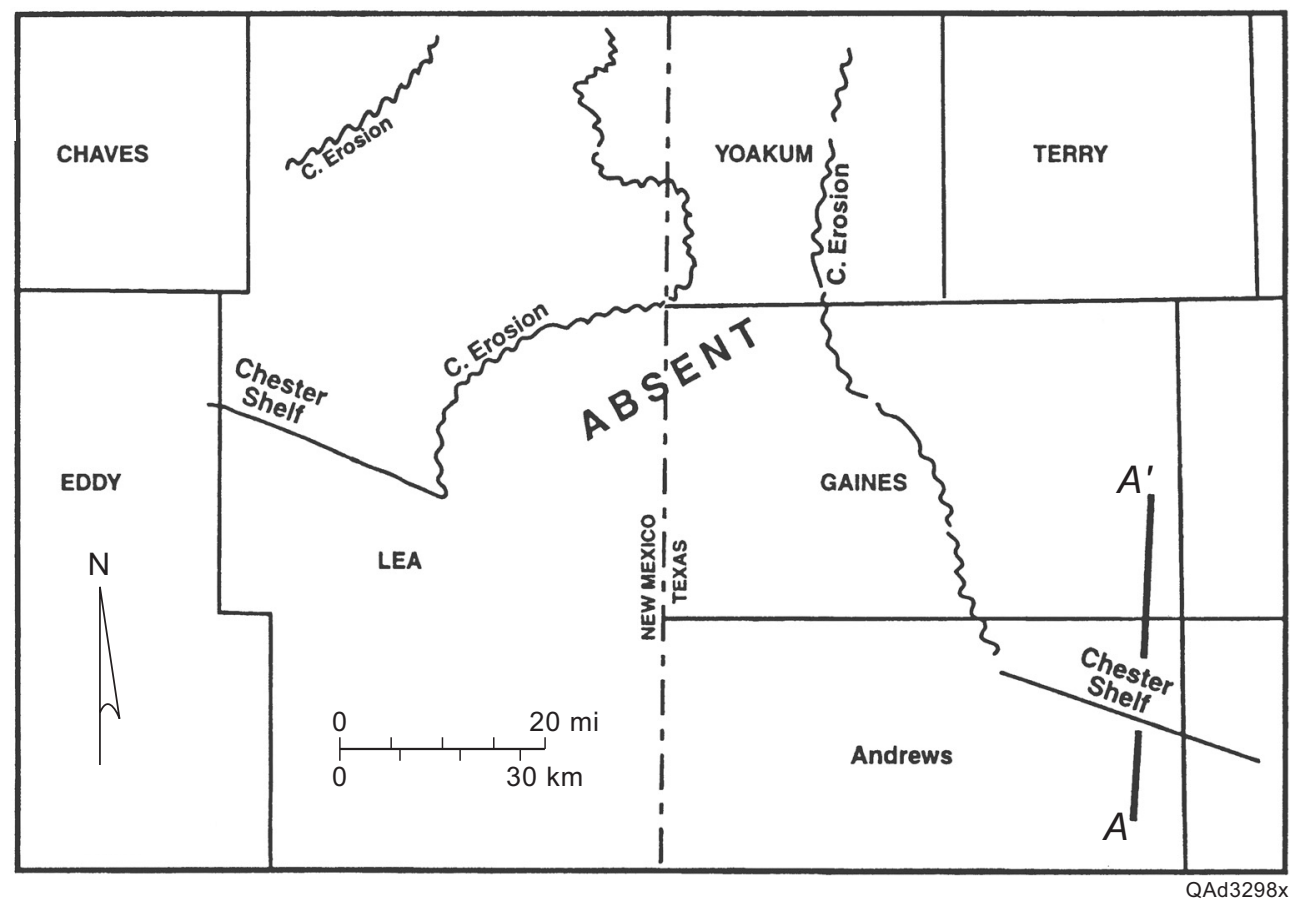

Figure 28. Map showing location of Chester limestone subcrop. From Hamilton and Asquith (2000). Upper Mississippian carbonates were deposited on the Chester platform while the Barnett Shale was deposited in the basin to the south. Cross section A-A' shown in figure 29.

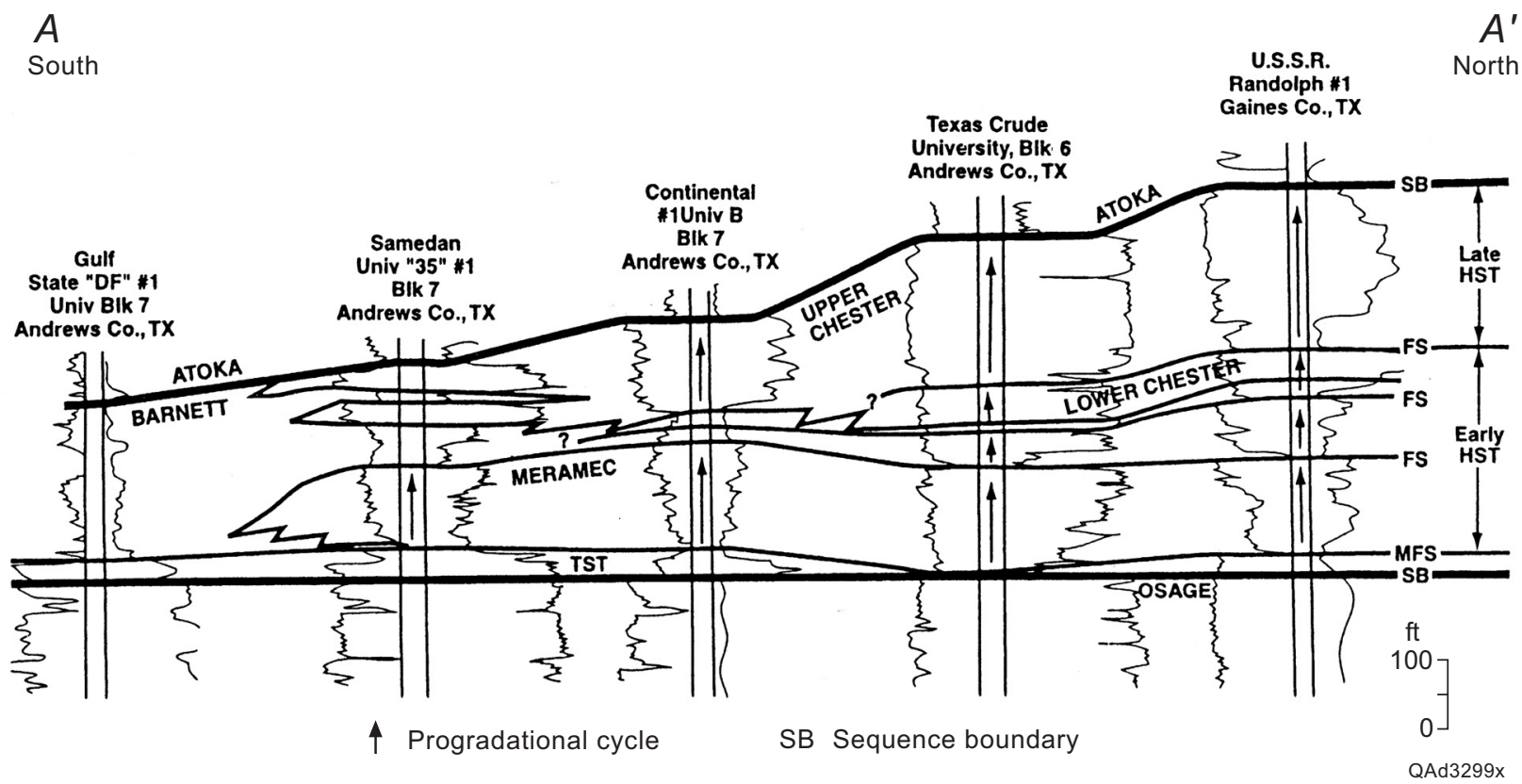

Figure 29. South-north cross section A-A' of the upper Mississippian Meramec and Chester limestones. From Hamilton and Asquith (2000). Line of section shown in figure 28. 
reservoir in Lea County. Production from Austin field is from ooid grainstones in the top $100 \mathrm{ft}$ $(30 \mathrm{~m})$ of the upper Chester. Mississippian fields in eastern Gaines and western Dawson Counties are also interpreted as occurring in Chester ooid grainstones that developed landward of the platform margin (Hamilton and Asquith, 2000). The ooid grainstones form elongate lenticular trends perpendicular to the platform margin. Intergranular pores are preserved where precipitation of equant calcite cement was not complete.

Production from Mississippian limestone in Reeves and Pecos Counties is mainly from the upper Mississippian. Log analysis of a porous interval near the base of the Mississippian (Kinderhook?) suggests that it may represent an additional pay zone (Asquith and others, 1998).

West Lamesa field in Dawson County, Texas, produces from limestone and chert, whereas Brahaney field, Yoakum County, Texas, produces from dolomite and dolomitic limestone (Wright, 1979). Fluvanna field, Borden County, produces from weathered Mississippian chert at the top of the Mississippian section (Grimes, 1982). Mississippian reservoirs include fracture, vuggy, intercrystalline, and cavernous pores (Wright, 1979).

A wide range of porosity and permeability has been reported for Mississippian reservoirs. Porosity averages 7 percent in Gin field. Mississippian reservoir rocks in Brahaney field average 12 percent porosity and $5 \mathrm{md}\left(5 \times 10^{-3} \mu \mathrm{m}^{2}\right)$ permeability (Files of the Railroad Commission of Texas). Porosity in Fluvanna field averages 21 percent; permeability ranges from 4 to $181 \mathrm{md}$ (4 to $181 \times 10^{-3} \mu \mathrm{m}^{2}$ ) and averages $40 \mathrm{md}\left(40 \times 10^{-3} \mu \mathrm{m}^{2}\right)$ (Files of the Railroad Commission of Texas). 


\section{References}

Asquith, G. B., Hardage, B. A., Lancaster, D. E., and Pendleton, V. M., 1998, Petrophysics of the Mississippian limestones in the Waha/West Waha area Reeves and Pecos counties, Texas, in DeMis, W. D., and Nelis, M. K., eds., The search continues into the $21 \mathrm{st}$ century: West Texas Geological Society Publication No. 98-105, p. 173-180.

Frenzel, H. N., Bloomer, R. R., Cline, R. B., Cys, J. M., Galley, J. E., Gibson, W. R., Hills, J. M., King, W. E., Seager, W. R., Kottlowski, F. E., Thompson, S., III, Luff, G. C., Pearson, B. T., and Van Siclen, D. C., 1988, The Permian Basin region, in Sloss, L. L., ed., Sedimentary cover-North American Craton; U.S.: Boulder, Colorado, Geological Society of America, The Geology of North America, v. D-2, p. 261-306.

Galloway, W. E., Ewing, T. E., Garrett, C. M., Jr., Tyler, N., and Bebout, D. G., 1983, Atlas of major Texas oil reservoirs: The University of Texas at Austin, Bureau of Economic Geology Special Publication, 139 p.

Grimes, D. N., 1982, Fluvanna field: selected oil \& gas fields in West Texas: West Texas Geological Society Publication No. 82-75, p. 232-236.

Hamilton, D. C., and Asquith, G. B., 2000, Depositional, diagenetic, and production histories of Chester ooid grainstones in the Austin (Upper Mississippian) field: Lea County, New Mexico, in DeMis, W. D., Nelis, M. K., and Trentham, R. C., eds., The Permian Basin: proving ground for tomorrow's technologies: West Texas Geological Society Publication No. 00-109, p. 95-106.

Ruppel, S. C., 1983, Facies and depositional setting of Mississippian rocks in the Palo DuroHardeman Basin area, in Shaw, R. L., and Pollan, B. J., Permian Basin cores-a workshop: Permian Basin Section, Society of Economic Paleontologists and Mineralogists Core Workshop No. 2, Midland, Texas, May 17-18, p. 47-67.

1989, Summary of Mississippian stratigraphy in north and north-central Texas, in Mear, C. E., McNulty, C. L., and McNulty, M. E., eds., A symposium on the petroleum geology of Mississippian carbonates in north-central Texas: Fort Worth Geological Society and Texas Christian University, p. 49-55.

Wright, W. F., 1979, Petroleum geology of the Permian Basin: West Texas Geological Society Publication No. 79-71, 98 p. 


\section{Pennsylvanian Plays}

The Pennsylvanian oil plays that occur completely, or partly, within the Permian Basin are: (1) Northwest Shelf Strawn Patch Reef, (2) Northwest Shelf Upper Pennsylvanian Carbonate, (3) Pennsylvanian Platform Carbonate, (4) Pennsylvanian and Lower Permian Horseshoe Atoll Carbonate, (5) Upper Pennsylvanian and Lower Permian Slope and Basinal Sandstone, (6) Pennsylvanian and Lower Permian Reef/Bank, and (7) Upper Pennsylvanian Shelf Sandstone. All Pennsylvanian oil plays that occur in Texas are delineated in the oil atlas (Galloway and others, 1983). Two of the original Texas play names have been modified slightly, and all play boundaries have been expanded; otherwise the play definitions have not been changed.

Oil in the Pennsylvanian and Lower Permian Reef/Bank play is produced from dispersed limestone buildups characterized by prominent depositional topography (Galloway and others, 1983). The Pennsylvanian and Lower Permian Reef/Bank play is not included in this portfolio of Permian Basin plays because most of the reservoirs in the play are located in the North-Central Texas geologic province. Ten fields in the play, however, are in the Permian Basin, in Kent, Crockett, Mitchell, and Irion Counties (table 12). The largest fields in the Permian Basin part of

Table 12. Pennsylvanian and Lower Permian Reef/Bank play. ${ }^{1}$

$\begin{array}{rrll}\text { RRC RESN } & \text { RRC } & \text { FLDNAME } & \text { RESNAME } \\ 10556500 & \text { 8A } & \text { BOOMERANG } & \text { PENNSYLVANIAN REEF } \\ 10560500 & \text { 8A } & \text { BOOMERANG, S. } & \text { STRAWN LIME } \\ 18436333 & \text { 8A } & \text { CLAIREMONT } & \text { PENN., LOWER } \\ 18437333 & 8 \text { A } & \text { CLAIREMONT, EAST } & \text { STRAWN } \\ 45582666 & 8 & \text { JAMESON, NORTH } & \text { STRAWN } \\ 74505500 & 7 C & \text { RANCH } & \text { STRAWN } \\ 83873750 & 7 C & \text { SIXTY SEVEN } & \text { STRAWN REEF } \\ 90315001 & \text { 7C } & \text { TODD, DEEP } & \\ 90315333 & \text { 7C } & \text { TODD, DEEP } & \text { CRINOIDAL } \\ 98803500 & \text { 7C } & \text { WORLD, WEST } & \text { STRAWN } \\ & & \end{array}$

$\begin{array}{llrrrr}\text { STATE COUNTY } & \text { DISCYR } & \text { DEPTHTOP } & \text { 2000 PROD } & \text { CUMPROD } \\ \text { TX } & \text { KENT } & 1955 & 6582 & 11,653 & 3,293,149 \\ \text { TX } & \text { KENT } & 1964 & 6623 & 15,741 & 5,589,563 \\ \text { TX } & \text { KENT } & 1950 & 6742 & 32,794 & 15,880,427 \\ \text { TX } & \text { KENT } & 1960 & 6494 & 12,607 & 1,456,046 \\ \text { TX } & \text { MITCHELL } & 1953 & 5866 & 32,005 & 9,622,521 \\ \text { TX } & \text { CROCKETT } & 1953 & 8156 & 6,680 & 3,744,987 \\ \text { TX } & \text { IRION } & 1956 & 6898 & 23,313 & 2,867,254 \\ \text { TX } & \text { CROCKETT } & 1940 & 5691 & 0 & 3,679,628 \\ \text { TX } & \text { CROCKETT } & 1940 & 5778 & 169,638 & 37,338,101 \\ \text { TX } & \text { CROCKETT } & 1954 & 8190 & 10,752 & 8,632,607 \\ & & & & & \\ & & & & \mathbf{3 1 5 , 1 8 3} & \mathbf{9 2 , 1 0 4 , 2 8 3}\end{array}$

${ }^{1}$ This play is not included in the play portfolio because most of the play is in the North-Central Texas geologic province. Production listed here represents only the 10 reservoirs in the Permian Basin, as defined in figure 1. 
the play are Todd, Deep (Crinoidal), which produced $37.3 \mathrm{MMbbl}\left(5.93 \times 10^{6} \mathrm{~m}^{3}\right)$ of oil through 2000, and Clairemont (Penn., Lower), which produced 15.9 MMbbl $\left(2.53 \times 10^{6} \mathrm{~m}^{3}\right)$. Total cumulative production from the 10 fields in the Permian Basin part of the play is $92.1 \mathrm{MMbbl}$ $\left(1.46 \times 10^{7} \mathrm{~m}^{3}\right)($ table 12$)$.

Similarly, the Upper Pennsylvanian Shelf Sandstone play is located mainly in NorthCentral Texas and thus is not described in this report. Five reservoirs in this play occur in the Permian Basin (table 13). These five reservoirs had cumulative production of 7.3 MMbbl $\left(1.16 \times 10^{6} \mathrm{~m}^{3}\right)$ through $2000($ table 13$)$.

Present structural features of the Permian Basin, including the Central Basin Platform and Midland and Delaware Basins (fig. 2), began forming in Early Pennsylvanian time (Frenzel and others, 1988). The thickness and distribution of Pennsylvanian rocks in the Permian Basin are quite variable owing to nondeposition and erosion over positive areas such as the Central Basin Platform. Pennsylvanian faulting formed many of the oil-producing anticlines in the area.

Pennsylvanian rocks in the Permian Basin are commonly cyclic because they formed during a time of high-amplitude, high-frequency eustatic sea-level fluctuations caused by glaciation and deglaciation in the Southern Hemisphere (Heckel, 1986).

Table 13. Upper Pennsylvanian Shelf Sandstone play ${ }^{1}$.

\begin{tabular}{|c|c|c|c|c|c|c|c|c|c|}
\hline RRC RESN & RRC & FLDNAME & RESNAME & STATE & COUNTY & DISCYR & DEPTHTOP & 2000 PROD & CUMPROD \\
\hline 2711001 & $8 \mathrm{~A}$ & ANDREW NOODLE CREEK & & $\mathrm{TX}$ & KENT & 1969 & 4010 & 0 & $1,063,283$ \\
\hline 21959500 & $8 \mathrm{~A}$ & CROTON CREEK, E. & TANNEHILL & TX & DICKENS & 1969 & 4574 & 0 & $1,285,205$ \\
\hline 64626380 & $8 \mathrm{~A}$ & NAVIGATOR & TANNEHILL B & TX & DICKENS & 1996 & 4418 & 323,280 & $1,273,061$ \\
\hline 78525500 & $8 \mathrm{~A}$ & ROUGH DRAW, N. & NOODLE CREEK & TX & KENT & 1963 & 4140 & 4,050 & $1,620,751$ \\
\hline \multirow[t]{2}{*}{91784700} & $8 \mathrm{~A}$ & TUMBLEWEED, NW. & TANNEHILL & $\begin{array}{l}\text { TX } \\
\text { TX }\end{array}$ & DICKENS & 1986 & 4108 & 99,226 & $2,021,8$ \\
\hline & & Totals & & & & & & 426,556 & $7,264,1$ \\
\hline
\end{tabular}


References

Frenzel, H. N., Bloomer, R. R., Cline, R. B., Cys, J. M., Galley, J. E., Gibson, W. R., Hills, J. M., King, W. E., Seager, W. R., Kottlowski, F. E., Thompson, S., III, Luff, G. C., Pearson, B. T., and Van Siclen, D. C., 1988, The Permian Basin region, in Sloss, L. L., ed., Sedimentary cover-North American Craton; U.S.: Boulder, Colorado, Geological Society of America, The Geology of North America, v. D-2, p. 261-306.

Galloway, W. E., Ewing, T. E., Garrett, C. M., Jr., Tyler, N., and Bebout, D. G., 1983, Atlas of major Texas oil reservoirs: The University of Texas at Austin, Bureau of Economic Geology Special Publication, 139 p.

Heckel, P. H., 1986, Sea-level curve for Pennsylvanian eustatic marine transgressive-regressive depositional cycles along the Midcontinent outcrop belt, North America: Geology, v. 14, p. 330-334. 
Northwest Shelf Strawn Patch Reef (Play 109)

Reservoirs of the Northwest Shelf Strawn Patch Reef play lie in New Mexico on the Northwest Shelf of the Permian Basin and are also present within the Delaware Basin (fig. 30). Most reservoirs lie within a triangular trend formed roughly by the cities of Lovington, Carlsbad, and Artesia. Oil-productive reservoirs are found mainly in the eastern two-thirds of this triangular trend; gas reservoirs are found in the west part of the trend, as well as outside the main trends. The play boundary terminates on the west in the transition zone between oil and gas production, and the gas fields of the west part of the play are not shown in figure 30. There are 104 known, discovered Strawn reservoirs in the play, 13 of which have produced $>1$ MMbbl $\left(1.59 \times 10^{5} \mathrm{~m}^{3}\right)$ of oil (fig. 30 , table 14$)$. Cumulative production from these 13 reservoirs was 69.9 MMbbl $\left(1.11 \times 10^{7} \mathrm{~m}^{3}\right)$ as of 2000 . Annual production from these 13 reservoirs was 1.06 MMbbl $\left(1.69 \times 10^{5} \mathrm{~m}^{3}\right)$ during 2000 . Production from this play has seen an overall decrease during the 1990's as production from existing reservoirs has matured.

Reservoirs are patch reefs of Strawn (Desmoinesian: Middle Pennsylvanian) age. The patch reefs grew on a south-dipping carbonate ramp that was present before the western Permian Basin segmented into the Northwest Shelf and the Delaware Basin. Reservoirs are principally

Table 14. Northwest Shelf Strawn Patch Reef play (play 109).

\begin{tabular}{|c|c|c|c|c|c|c|c|c|}
\hline \multirow[t]{15}{*}{ RRC RESN RRC } & FLDNAME & RESNAME & STATE & COUNTY & DISCYR & DEPTHTOP & 2000 PROD & CUMPROD \\
\hline & BIG EDDY & STRAWN & NM & EDDY & 1966 & 11333 & 0 & $1,402,000$ \\
\hline & BURTON FLAT EAST & STRAWN & NM & EDDY & 1976 & 10600 & 67,662 & $2,990,681$ \\
\hline & CASEY & STRAWN & NM & LEA & 1975 & 11326 & 17,989 & $3,414,520$ \\
\hline & CASS & PENNSYLVANIAN & NM & LEA & 1944 & 7700 & 0 & $2,885,000$ \\
\hline & GOLDEN LANE & STRAWN & NM & EDDY & 1969 & 11098 & 18,432 & $1,448,602$ \\
\hline & HUMBLE CITY & STRAWN & NM & EDDY & 1972 & 11429 & 24,093 & $1,303,341$ \\
\hline & HUMBLE CITY SOUTH & STRAWN & NM & LEA & 1982 & 11520 & 20,520 & $3,444,361$ \\
\hline & LOVINGTON NORTHEAST & PENNSYLVANIAN & NM & LEA & 1952 & 11256 & 0 & $16,921,580$ \\
\hline & LOVINGTON WEST & STRAWN & NM & LEA & 1985 & 11594 & 479,493 & $5,162,551$ \\
\hline & LUSK & STRAWN & NM & LEA \& EDDY & 1960 & 11168 & 38,447 & $20,682,947$ \\
\hline & REEVES & PENNSYLVANIAN & NM & LEA & 1956 & 10950 & 14,066 & $1,286,874$ \\
\hline & SHIPP & STRAWN & NM & LEA & 1985 & 11138 & 43,428 & $7,624,050$ \\
\hline & SHOE BAR NORTH & STRAWN & NM & LEA & 1973 & 11275 & 340,752 & $1,297,324$ \\
\hline & Totals & & & & & & $1,064,882$ & $69,863,831$ \\
\hline
\end{tabular}




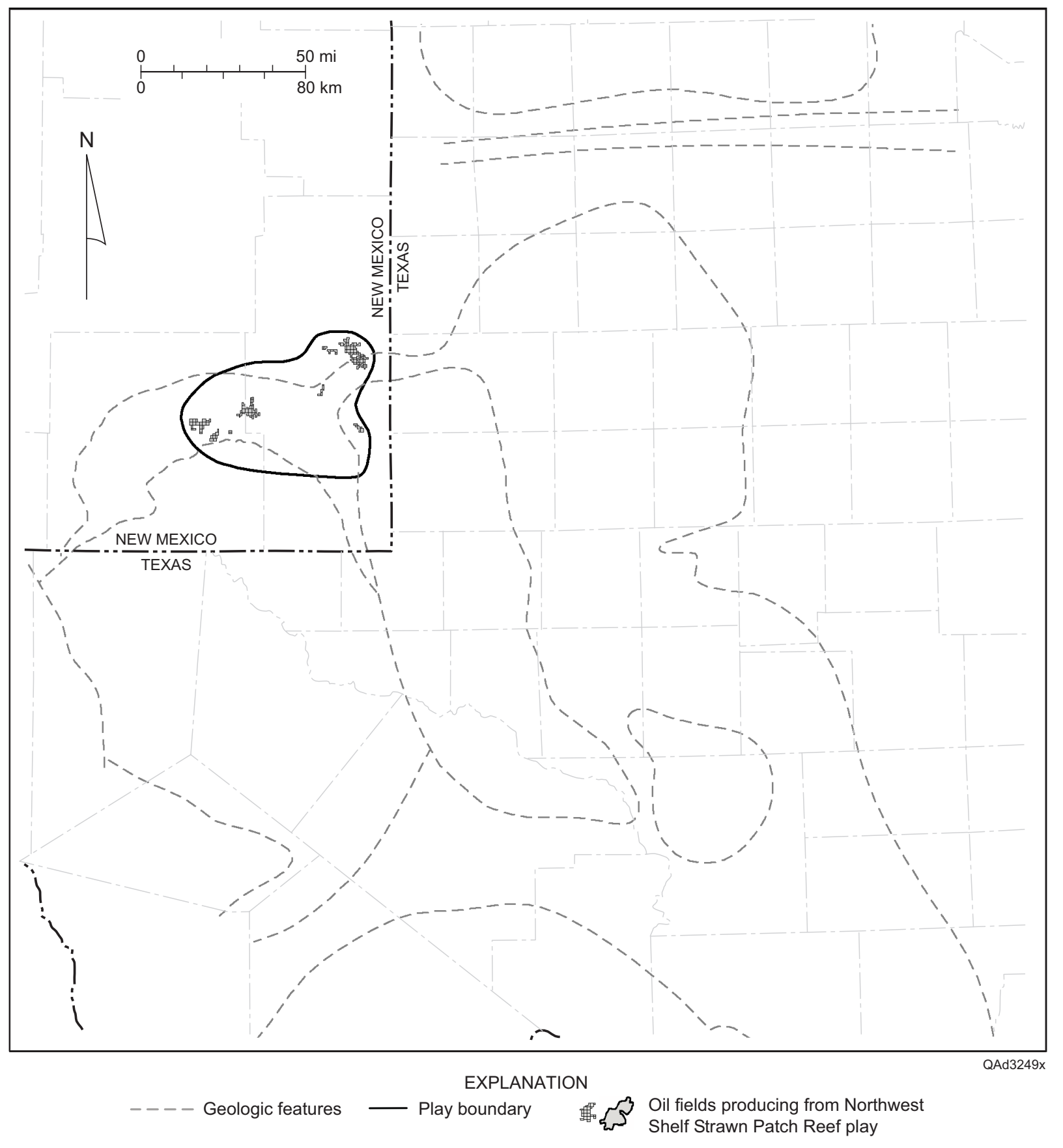

Figure 30. Play map for the Northwest Shelf Strawn Patch Reef play, showing location of reservoirs having $>1 \mathrm{MMbbl}$ cumulative production, the play boundary, and geologic features. See figure 1 for county names and figure 2 for identification of geologic features. 
bioherms composed of phylloid algal, coralgal, and foraminiferal lime wackestones and packstones (Harris, 1990). Bioherm growth was localized on preexisting structures that had bathymetric expression (Thornton and Gaston, 1967; Harris, 1990). Seals are interbedded marine mudstones. The larger Strawn reservoirs are internally complex and exhibit intricate porosity variations (fig. 31).

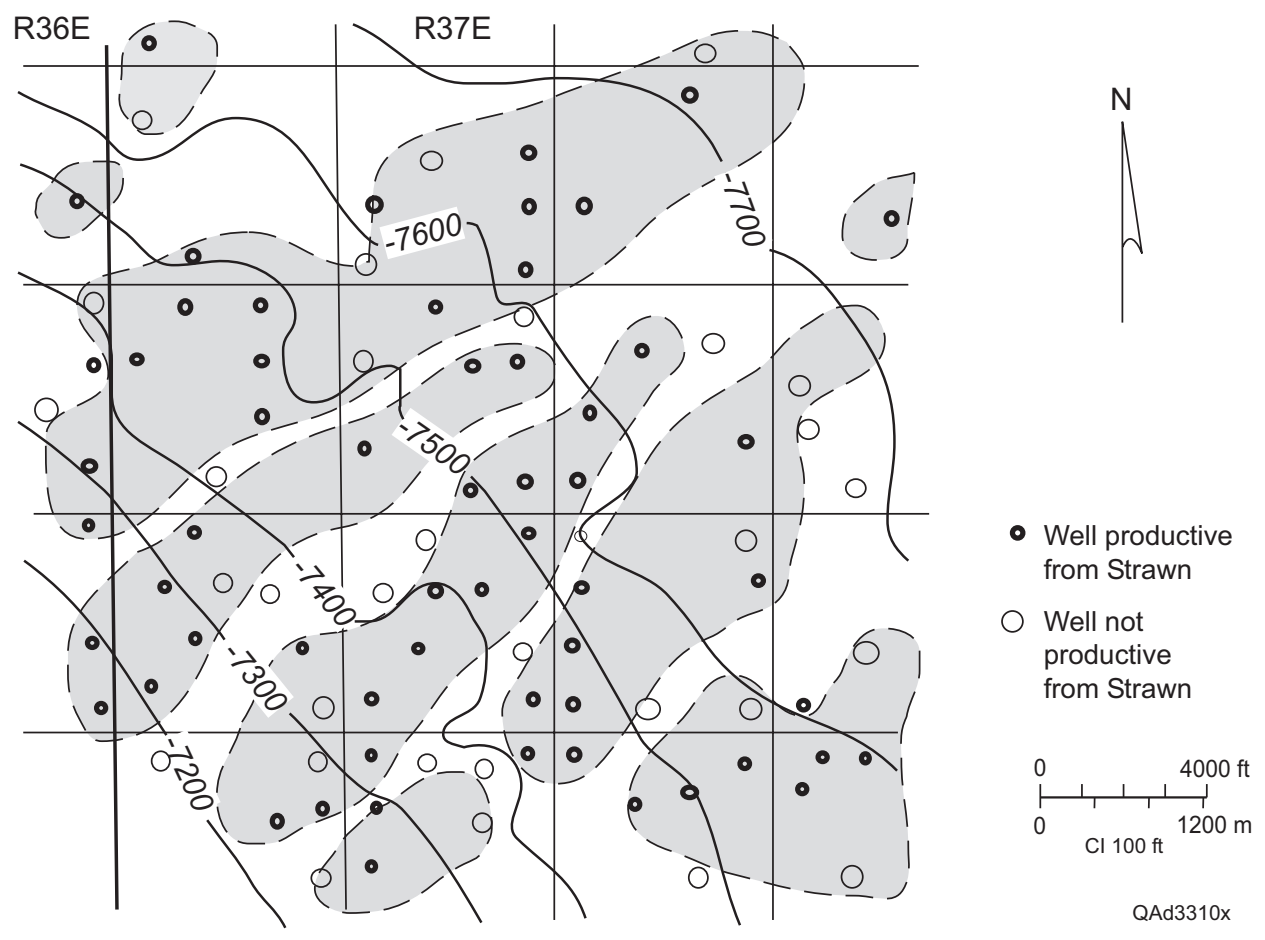

Figure 31. Map of Strawn structure and porosity at the Lovington Northeast reservoir. Shown is structure of the Strawn limestone. Contour interval is $50 \mathrm{ft}$. Shaded areas are where the Strawn has porosity $\geq 4$ percent. Modified by Speer (1993) from Caughey (1988). 


\section{References}

Caughey, C. A., 1988, Lovington Penn. Northeast (oil), in A symposium of oil and gas fields of southeastern New Mexico, supplement: Roswell Geological Society, p. 231-232.

Harris, D. C., 1990, Ramp buildups in the lower Strawn limestone (Penn.): controls on stratigraphic reservoir variability, in Flis, J. E., and Price, R. C., eds., Permian Basin oil and gas fields: innovative ideas in exploration and development: West Texas Geological Society, Publication 90-87, p. 91-101.

Speer, S. W., 1993a, Granite Wash (Permian), in Atlas of major Rocky Mountain gas reservoirs: New Mexico Bureau of Mines and Mineral Resources, p. 162.

1993b, Strawn, in Atlas of major Rocky Mountain gas reservoirs: New Mexico Bureau of Mines and Mineral Resources, p. 157.

Thornton, D. E., and Gaston, H. H., Jr., 1967, Lusk Strawn field, in A symposium of oil and gas fields of southeastern New Mexico, supplement: Roswell Geological Society, p. 15-20. 
Northwest Shelf Upper Pennsylvanian Carbonate (Play 110)

Reservoirs of the Northwest Shelf Upper Pennsylvanian Carbonate play lie on the Northwest Shelf of the Permian Basin, in New Mexico (fig. 32). The trend of reservoirs extends from the shelf edge near Carlsbad in Eddy County onto the shelf interior in Roosevelt and Chaves Counties. There are 197 known, discovered reservoirs in this play, 34 of which have produced $>1$ million bbl oil $\left(1.59 \times 10^{5} \mathrm{~m}^{3}\right)($ table 15$)$. Cumulative production from these 34 reservoirs was $353.8 \mathrm{MMbbl}\left(5.62 \times 10^{7} \mathrm{~m}^{3}\right)$ through 2000 . During the 1990 's, annual production from this play peaked at 11.2 MMbbl $\left(1.78 \times 10^{6} \mathrm{~m}^{3}\right)$ during 1996 and has since

Table 15. Northwest Shelf Upper Pennsylvanian Carbonate play (play 110).

$\begin{array}{ll}\text { RRC RESN RRC } & \text { FLDNAME } \\ & \text { ALLISON } \\ & \text { ANDERSON RANCH NORTH } \\ & \text { BAGLEY } \\ & \text { BAGLEY NORTH } \\ & \text { BAR-U } \\ & \text { BAUM } \\ & \text { BOUGH } \\ & \text { CERCA } \\ & \text { CROSSROADS } \\ & \text { DAGGER DRAW NORTH } \\ & \text { DAGGER DRAW SOUTH } \\ & \text { DEAN } \\ & \text { FLYING M SOUTH } \\ & \text { HIGH PLAINS } \\ & \text { HIGHTOWER EAST } \\ & \text { INBE } \\ & \text { INDIAN BASIN } \\ & \text { JENKINS } \\ & \text { LAZY J } \\ & \text { LEAMEX } \\ & \text { MILNESAND } \\ & \text { NONOMBRE } \\ & \text { PRAIRIE SOUTH } \\ \text { RANGER LAKE } \\ \text { SAUNDERS } \\ \text { SAUNDERS EAST } \\ \text { SHOE BAR } \\ \text { TOBAC } \\ \text { TRAVIS } \\ \text { TRES PAPALOTES } \\ \text { TRES PAPALOTES WEST } \\ \text { TULK } \\ \text { VACUUM } \\ \text { VADA } \\ \text { TOtals } \\ \end{array}$

RESNAME

PENNSYLVANIAN

CISCO CANYON

PENNSYLVANIAN

PERMO PENN

PENNSYLVANIAN

UPPER PENNSYLVANIAN

PERMO PENN

UPPER PENNSYLVANIAN

PENNSYLVANIAN

UPPER PENN

UPPER PENN

PERMO PENN

BOUGH

PERMO PENN

UPPER PENNSYLVANIAN

PERMO PENN

UPPER PENNSYLVANIAN

CISCO

PENNSYLVANIAN

PENNSYLVANIAN

PENNSYLVANIAN

UPPER PENNSYLVANIAN

CISCO

PENNSYLVANIAN

PERMO-UPPER PENN

PERMO PENN

PENNSYLVANIAN

PENNSYLVANIAN

UPPER PENNSYLVANIAN

PENNSYLVANIAN

PENNSYLVANIAN

PENNSYLVANIAN

UPPER PENNSYLVANIAN

PENNSYLVANIAN
STATE COUNTY

NM LEA

NM LEA

NM LEA

NM LEA

NM LEA

NM LEA

NM LEA

NM LEA

NM LEA

NM EDDY

NM EDDY

NM LEA

NM LEA

NM LEA

NM LEA

NM LEA

NM EDDY

NM LEA

NM LEA

NM LEA

NM ROOSEVELT

NM LEA

NM ROOSEVELT

NM LEA

NM LEA

NM LEA

NM LEA

NM CHAVES

NM EDDY

NM LEA

NM LEA

NM LEA

NM LEA

NM ROOSEVELT \&
DISCYR DEPTHTOP 2000 PROD

1954

1984

1949

1957

1955

1955
1949

1949
1968

1949

1974

1971

1955

1965

1985

1959

1962

1963

1963

1952

1956
1956

1965

1960

1956

1980
1962
1954

1954

1964

1977

1970

1972

1965

1964

1967

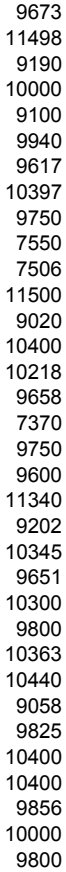

11498
9190

10000

9940

9617

10397
9750

7550

7506

11500
9020

9020
10400

10218

7370

9750

9600
11340

9202

10345

9651

10300
9800

10363

10440

9825

10400
10400

10400

10000

9800

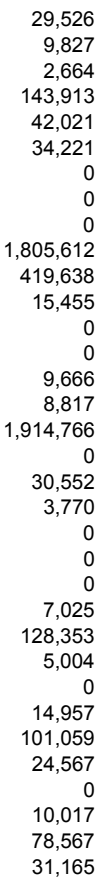

$4,871,162$
CUMPROD

$23,833,082$ $1,321,870$ $4,339,919$ $52,951,956$

$1,364,117$

$15,224,467$

$6,329,000$

$1,975,473$

$2,170,000$

$48,909,673$

$16,214,241$

$6,165,150$

$1,211,000$

$1,056,081$

$1,054,219$

$16,439,579$

$13,274,441$

$2,099,000$

$7,630,855$

$1,367,438$

$1,001,000$

$1,077,000$

$2,906,000$

$5,084,059$

$38,920,906$

$2,716,804$

$1,056,568$

$9,227,853$

$1,986,681$

$1,942,584$

$1,237,313$

$1,809,541$

$6,613,696$

$53,336,607$

$353,848,173$ 


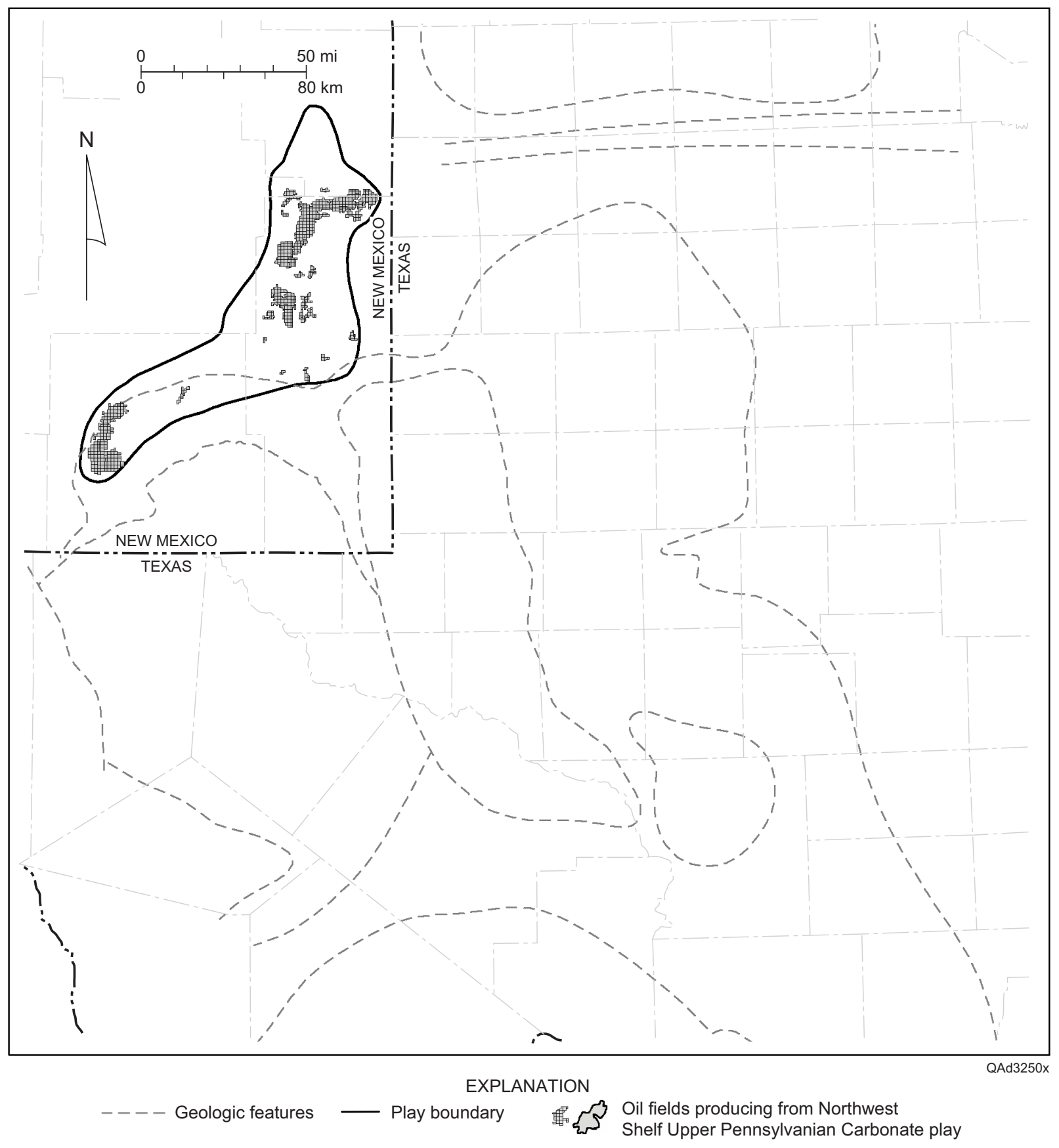

Figure 32. Play map for the Northwest Shelf Upper Pennsylvanian Carbonate play, showing location of reservoirs having $>1 \mathrm{MMbbl}$ cumulative production, the play boundary, and geologic features. See figure 1 for county names and figure 2 for identification of geologic features.

declined by 56 percent to $4.9 \mathrm{MMbbl}\left(7.79 \times 10^{5} \mathrm{~m}^{3}\right)$ per year, largely as a result of production decline in the Dagger Draw North and Dagger Draw South reservoirs. Production increase 
during the early 1990's was a result of new oil brought online with redevelopment of the Dagger Draw reservoir.

Reservoirs are carbonates of Canyon (Upper Pennsylvanian: Missourian) age, the Cisco and Bough D zones of Virgilian (Upper Pennsylvanian) age, and the Bough B and C zones of earliest Wolfcampian (Permian) age (fig. 33). The exact age of Bough A, B, and C zones is problematic. They have been traditionally considered by the industry and regulatory entities as Virgilian in age, but fusulinid biostratigraphy indicates that they are of earliest Wolfcampian age (Cys and Mazzullo, 1985; Cys, 1986). More recent work based on correlation with conodonts has suggested that the Bough intervals may perhaps be of latest Virgilian age after all

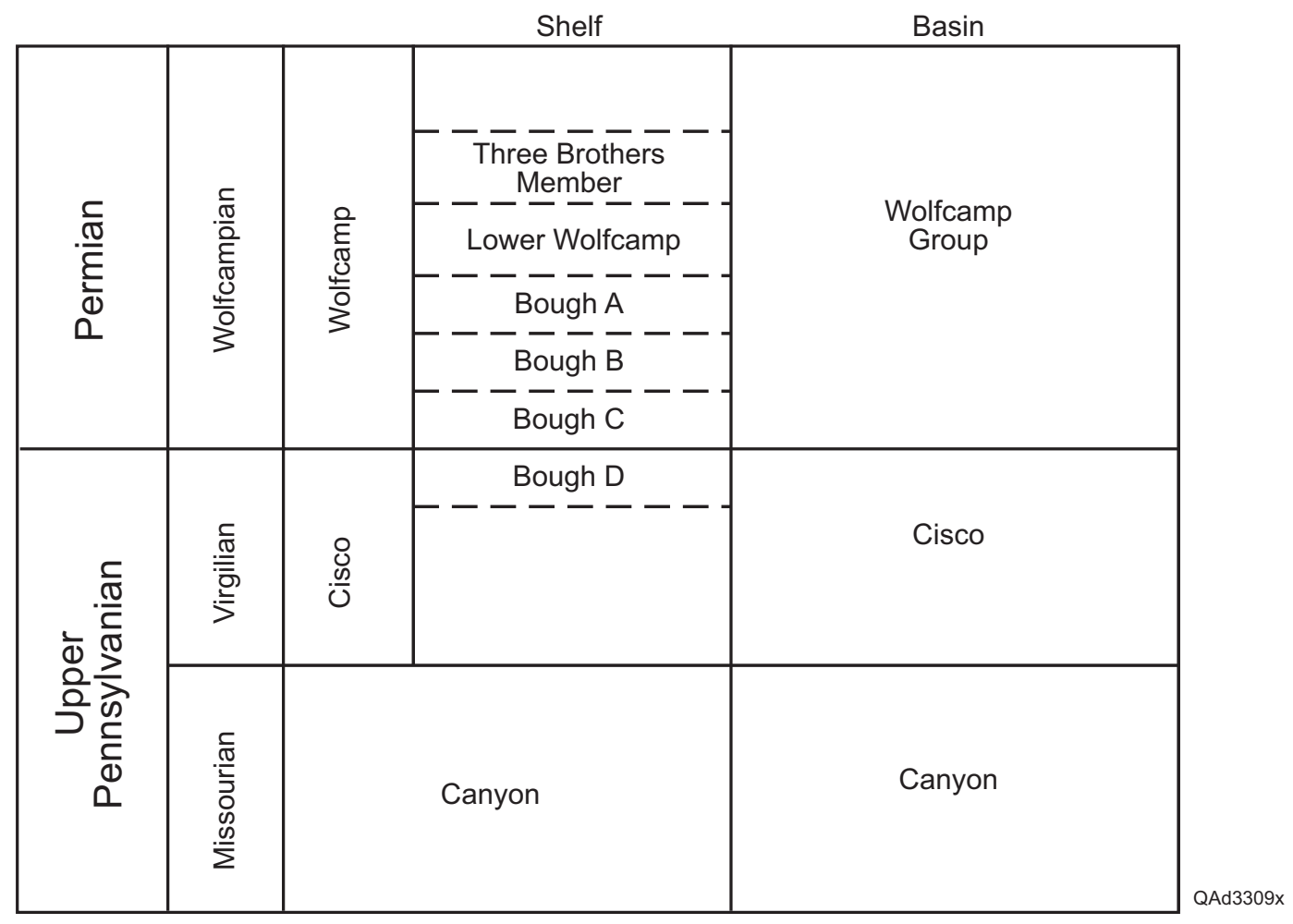

Figure 33. Stratigraphic column of Upper Pennsylvanian and Lower Permian strata, southeast New Mexico. 
(see Wahlman, 2001). Whatever their correct age assignment, Bough B and C zones form major reservoirs in the trend on the Northwest Shelf from Saunders northward to Allison, although the underlying Bough D zone of definite Late Pennsylvanian age also contributes significant production in many of the reservoirs along this trend. The stratigraphic relationship of reservoirs in the Northwest Shelf part of this play to the reservoirs in the Wolfcamp Platform Carbonate play (play 114) is not well established, but available data indicate that the reservoirs assigned to the Wolfcamp Platform Carbonate play are younger than those assigned to this play. Wolfcamp Platform Carbonate play reservoirs produce mainly from Bough A and younger zones.

Traps in the Northwest Shelf Upper Pennsylvanian Carbonate play are primarily stratigraphic and are formed by phylloid algal mounds and associated grainstones and packstones (Cys, 1986; Speer, 1993; Cox and others, 1998; Mazzullo, 1998). Reservoirs on the Northwest Shelf are limestones. Wide, well-bedded phylloid algal banks grew across shallow-water bathymetric highs on shelf areas (Wahlman, 2001). The boundaries of many of the reservoirs on the Northwest Shelf are regulatory, and much of the oil has accumulated in essentially continuous stratigraphic traps that cross regulatory reservoir boundaries. Reservoirs at or near the shelf edge (for example, Dagger Draw, Dagger Draw South) are Missourian to Virgilian in age, older than on the Northwest Shelf, and they have generally been dolomitized. On the shelf edge, traps are formed primarily by massive phylloid algal mounds that grew along bathymetric breaks (Wahlman, 2001). Productive porosity is mostly intercrystalline, intergranular, and vugular; the porosity system is dominated by vugular porosity. Depth to production varies from $7,400 \mathrm{ft}$ to $11,500 \mathrm{ft}(2,250$ to $3,505 \mathrm{~m})$.

At Dagger Draw North and Dagger Draw South, production is obtained from a dolomitized fairway of shelf-edge algal mounds and intermound grainstones and packstones 


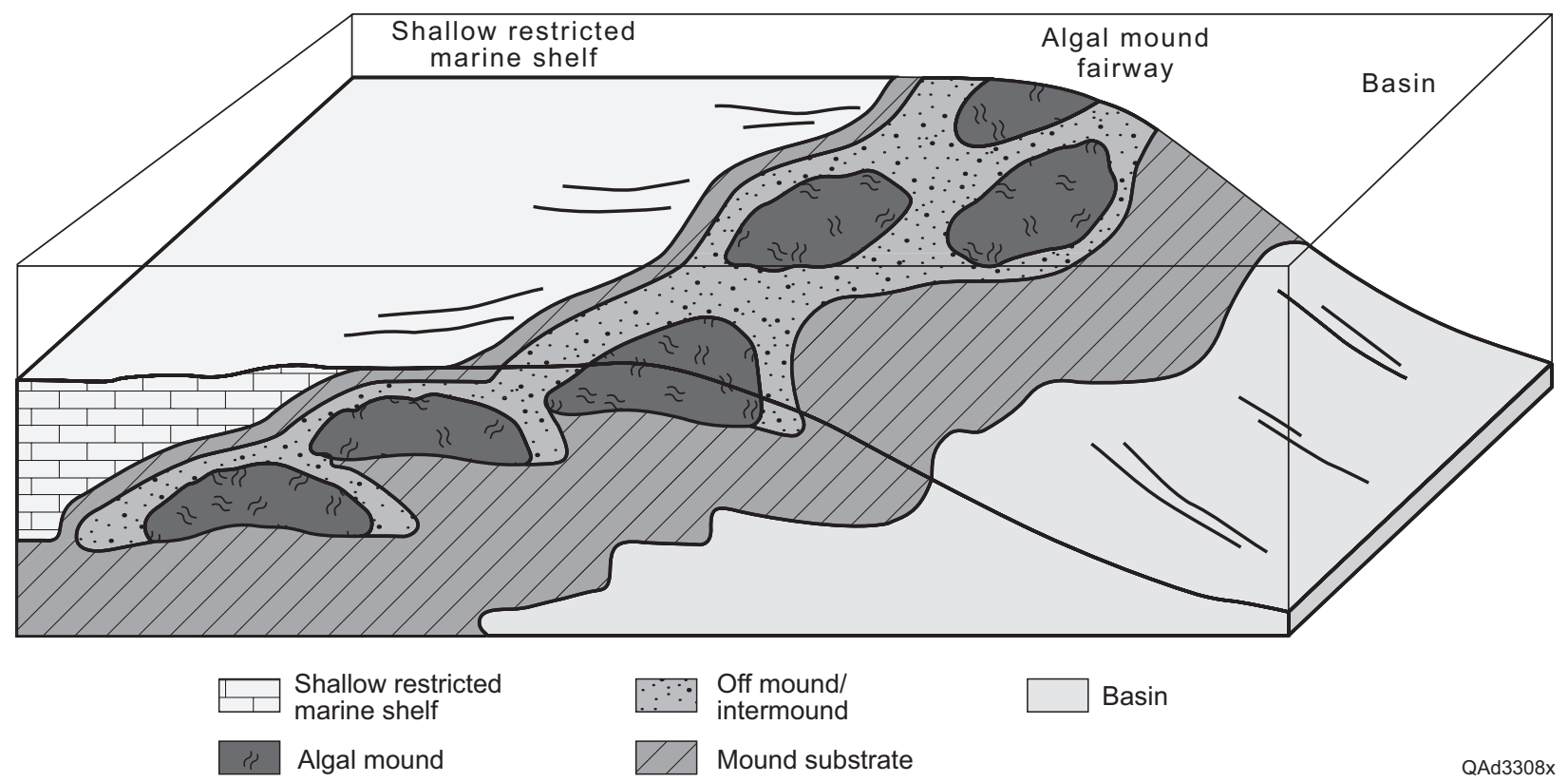

Figure 34. Depositional model for Upper Pennsylvanian algal-mound complex, South Dagger Draw reservoir. After Cox and others (1998).

(Cox and others, 1998; fig. 34). Impermeable, thinly bedded limestones lie shelfward and act as a seal on the shelf side of the algal mound trend. Impermeable basinal black shales, which may also act as source rocks for the algal mound complex, lie basinward.

Upper Pennsylvanian carbonate reservoirs on the Northwest Shelf have typically been discovered by drilling small, seismically defined anticlines. Initial development has generally been concentrated on the crests of the anticlines and, in most of the larger fields, generally has not extended into off-structure areas (Broadhead, 1999; fig. 35). However, in many cases, the anticlinal structures have little, if anything, to do with oil entrapment. Subsequent drilling in many reservoirs proceeded in discrete phases into off-structure areas, each with a corresponding 


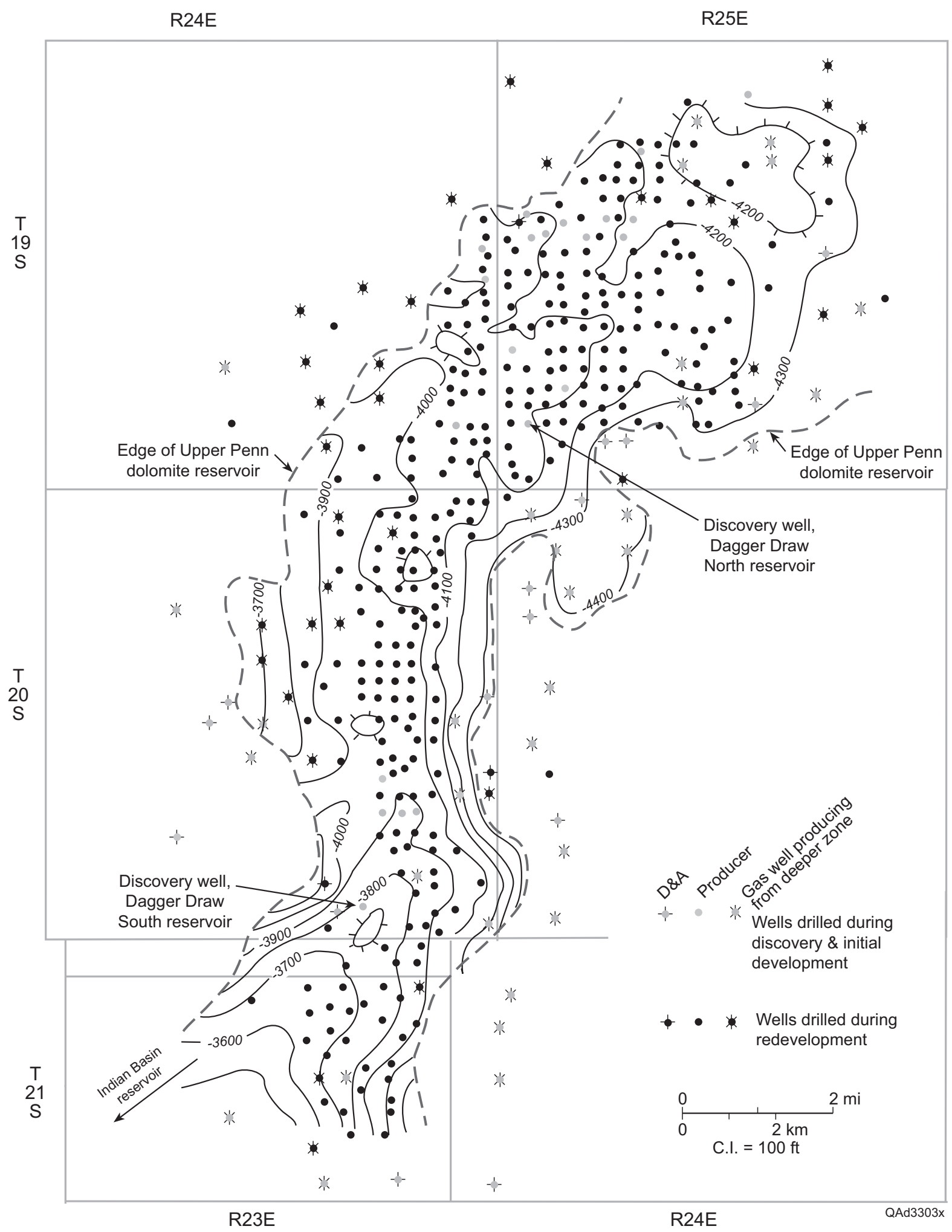

Figure 35. Structure-contour map on top of Upper Pennsylvanian dolostone reservoir and South Dagger Draw and North Dagger Draw reservoirs and time periods during which wells were drilled. After Broadhead (1999). Contours from Reddy (1995). 


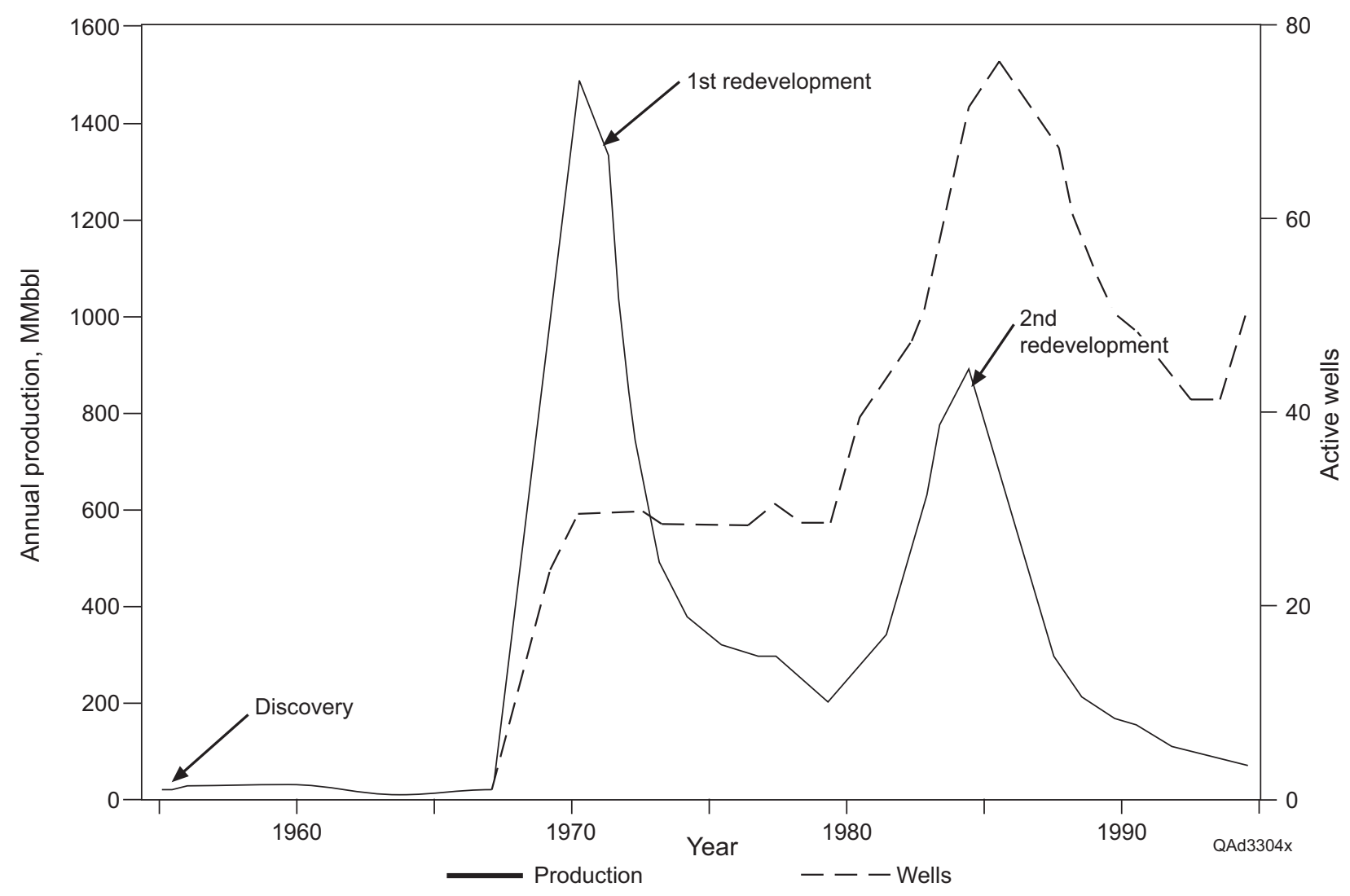

Figure 36. Historical annual oil production and number of productive wells active in any given year, Baum Upper Pennsylvanian reservoir. After Broadhead (1999).

increase in production (fig. 36). The stratigraphic nature of entrapment was often not recognized until large portions of the reservoir were drilled out many years after initial discovery.

Recognition of the stratigraphic nature of these reservoirs early in development is necessary if the reservoir is to be developed efficiently and completely in the years immediately following discovery. 


\section{References}

Broadhead, R. F., 1999, Underdeveloped oil fields-Upper Pennsylvanian and lower Wolfcampian carbonate reservoirs of southeast New Mexico: Carbonates and Evaporites, v. 14 , no. 1 , p. 84-105.

Cox, D. M., Brinton, L., and Tinker, S. W., 1998, Depositional facies and porosity development of an Upper Pennsylvanian algal mound reservoir, South Dagger Draw, Eddy County, New Mexico, in Winfree, K., ed., Cored reservoir examples from Upper Pennsylvanian and Lower Permian carbonate margins, slopes and basinal sandstones: West Texas Geological Society, Publication 98-103, variously paginated.

Cys, J. M., 1986, Lower Permian grainstone reservoirs, southern Tatum Basin, southeastern New Mexico, in Ahlen, J. L., and Hanson, M. E., eds., Southwest Section of American Association of Petroleum Geologists Transactions and guidebook of 1986 convention, Ruidoso, New Mexico: New Mexico Bureau of Mines and Mineral Resources, p. 115-120.

Cys, J. M., and Mazzullo, S. J., 1985, Depositional and diagenetic history of a Lower Permian (Wolfcamp) phylloid-algal reservoir, Hueco Formation, Morton field, southeastern New Mexico, in Roehl, P. O., and Choquette, P. W., eds., Carbonate petroleum reservoirs: New York, Springer-Verlag, p. 277-288.

Mazzullo, S. J., 1998, Depositional model and exploration strategies for the Cisco-Canyon (Upper Pennsylvanian) on the Northwest shelf, southeastern New Mexico, in DeMis, W. D., and Nelis, M. K., eds., The search continues into the 21 st century: West Texas Geological Society, Publication 98-105, p. 31-40.

Reddy, G., 1995, Dagger Draw South, in A symposium of oil and gas fields of southeastern New Mexico, 1995 supplement: Roswell Geological Society, p. 76-77.

Speer, S.W., 1993, Upper Pennsylvanian, in Atlas of major Rocky Mountain gas reservoirs: New Mexico Bureau of Mines and Mineral Resources, p. 154-156.

Wahlman, G. P., 2001, Pennsylvanian-Lower Permian mounds and reefs in the Permian Basin (west Texas-New Mexico): composition, evolution, distribution, and reservoir characteristics, in Viveiros, J. J., and Ingram, S. M., eds., The Permian Basin: microns to satellites, looking for oil and gas at all scales: West Texas Geological Society Publication No. 01-110, p. 57-64. 
Pennsylvanian Platform Carbonate (Play 111)

The Pennsylvanian Platform Carbonate play has been expanded both geographically and geologically from the Pennsylvanian Platform Carbonate play that was described in the Atlas of Major Texas Oil Reservoirs (Galloway and others, 1983). As originally defined by Galloway and others (1983), the play consisted of reservoirs that produce from Middle and Upper Pennsylvanian (Strawn, Canyon, and Cisco) carbonates located on the east edge of the Central Basin Platform. The play has been expanded in this report to include Atoka through Cisco reservoirs on the Texas part of the Northwest Shelf and Central Basin Platform and in the Midland Basin (fig. 37). The expanded play has produced $340.5 \mathrm{MMbbl}\left(5.41 \times 10^{7} \mathrm{~m}^{3}\right)$ from 74 reservoirs (table 16).

The Central Basin Platform was an active, high-relief uplift during much of the Pennsylvanian (Frenzel and others, 1988). Lower Pennsylvanian Atoka deposits are interpreted to have been deposited before uplift of the Central Basin Platform (Tai and Dorobek, 1999). Upper Strawn strata may be the earliest synorogenic deposits, deposited on a carbonate ramp that prograded eastward (Tai and Dorobek, 1999). The most intensive uplift of the Central Basin Platform postdated the Strawn and continued from Middle Pennsylvanian to Early Permian time (Tai and Dorobek, 1999). Atokan and Desmoinesian carbonates in the Midland Basin were deposited on low-relief ramps at a time of relatively low regional subsidence, whereas Missourian and Virgilian deposits were deposited on higher-relief carbonate platforms at a time of higher rates of regional subsidence (Hanson and others, 1991; Mazzulo, 1997). Highfrequency glacioeustatic sea-level fluctuations during the Pennsylvanian resulted in highly cyclic depositional sequences (Wahlman, 2001). 


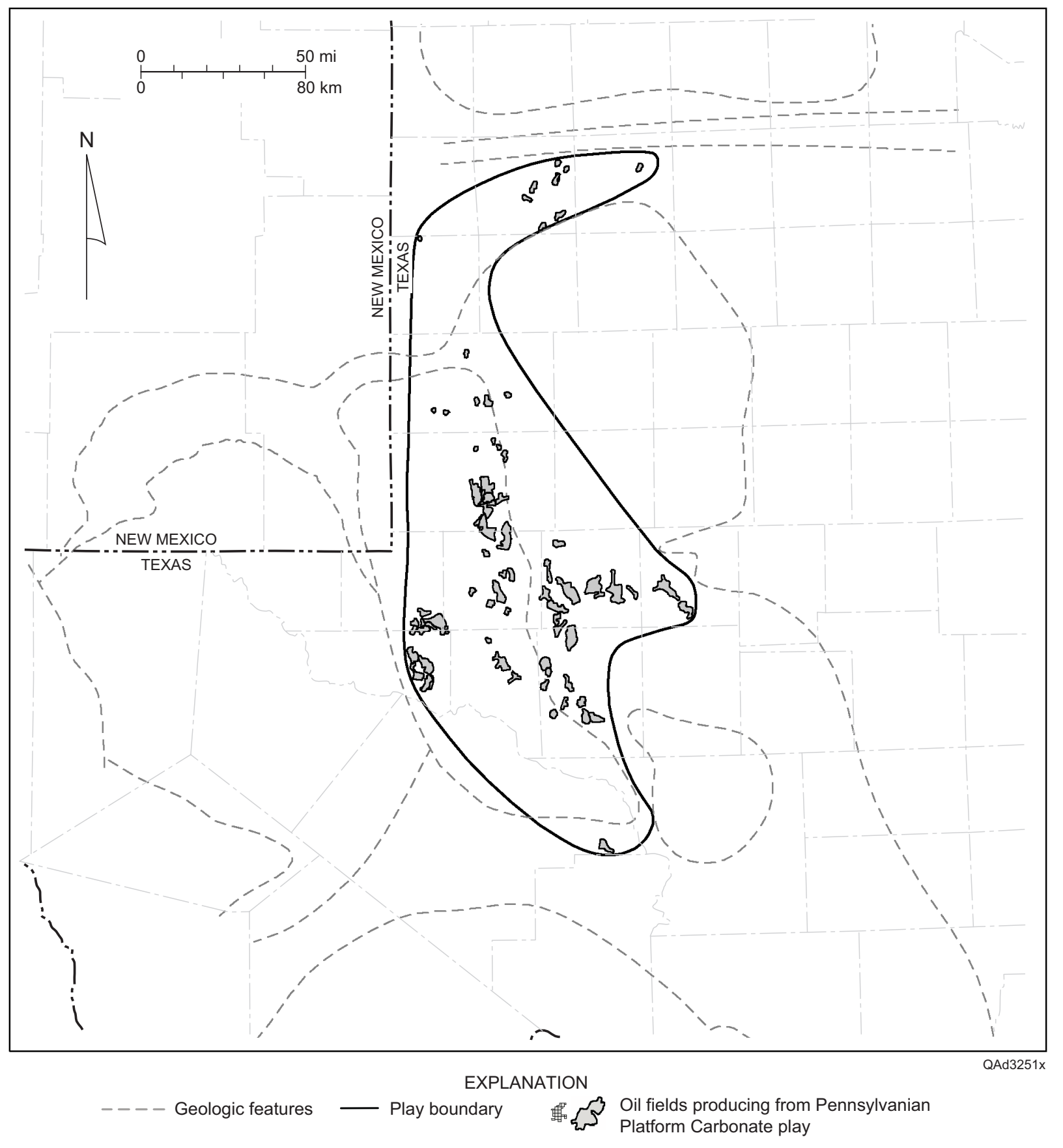

Figure 37. Play map for the Pennsylvanian Platform Carbonate play, showing location of reservoirs having $>1 \mathrm{MMbbl}$ cumulative production, the play boundary, and geologic features. See figure 1 for county names and figure 2 for identification of geologic features. 
Table 16. Pennsylvanian Platform Carbonate play (play 111). Production shown for fields that have had others combined into them represents the totals; combined fields are highlighted.

\begin{tabular}{|c|c|c|c|c|c|c|c|c|c|}
\hline RRC RESN & RRC & FLDNAME & RESNAME & STATE & COUNTY & DISCYR & DEPTHTOP & 2000 PROD & CUMPROD \\
\hline 587166 & $7 \mathrm{C}$ & ADAMC & BEND & TX & UPTON & 1958 & 9236 & 806 & $1,289,736$ \\
\hline 2207608 & $7 \mathrm{C}$ & AMACKER-TIPPETT & STRAWN & TX & UPTON & 1954 & 9870 & 3,822 & $1,842,947$ \\
\hline 2212111 & $7 \mathrm{C}$ & AMACKER-TIPPETT, S. & BEND & TX & UPTON & 1961 & 9848 & 11,984 & $6,908,189$ \\
\hline 2213250 & $7 \mathrm{C}$ & AMACKER-TIPPETT, SE & BEND 10600 & TX & UPTON & 1966 & 10637 & 19,801 & $4,159,301$ \\
\hline 2725500 & 8 & ANDREWS & PENNSYLVANIAN & TX & ANDREWS & 1954 & 9220 & 0 & $15,502,674$ \\
\hline 2727750 & 8 & ANDREWS, NORTH & STRAWN & TX & ANDREWS & 1959 & 9589 & 0 & $3,673,474$ \\
\hline 3177500 & $8 \mathrm{~A}$ & ANTON, SOUTH & STRAWN & TX & HOCKLEY & 1957 & 9952 & 3,914 & $1,178,657$ \\
\hline 3520500 & 8 & ARENOSO & STRAWN DETRITUS & $T X$ & WINKLER & 1965 & 8587 & 100,645 & $22,978,851$ \\
\hline 4605080 & 8 & AZALEA & ATOKA & TX & MIDLAND & 1973 & 10898 & 25,979 & $2,996,387$ \\
\hline 5166555 & 8 & BAKKE & PENN. & TX & ANDREWS & 1956 & 8956 & 12,190 & $12,336,328$ \\
\hline 9359250 & 8 & BLOCK 31, EAST & ATOKA & TX & CRANE & 1965 & 8122 & 1,748 & $1,225,223$ \\
\hline 9362500 & 8 & BLOCK 31, NW. & PENN UPPER & TX & CRANE & 1969 & 7907 & 22,107 & $4,489,708$ \\
\hline 9450200 & 7C & BLOCK 42 & PENN & TX & UPTON & 1956 & 9450 & 19,971 & $2,559,545$ \\
\hline 8958800 & 8 & BLOCK A-34 & STRAWN & TX & ANDREWS & 1954 & 9916 & 0 & $1,100,472$ \\
\hline 11240500 & 8 & BRADFORD RANCH & ATOKA & TX & MIDLAND & 1979 & 11221 & 4,779 & $5,717,992$ \\
\hline 21287250 & 8 & COWDEN & CISCO & TX & ECTOR & 1955 & 8846 & 91,618 & $6,348,910$ \\
\hline 21289180 & 8 & COWDEN, NORTH & CANYON & TX & ECTOR & 1973 & 9094 & 37,950 & $1,428,470$ \\
\hline 21292750 & 8 & COWDEN, SOUTH & PENNSYLVANIAN & $T X$ & ECTOR & 1955 & 8360 & 4,554 & $1,095,207$ \\
\hline 23131250 & 8 & DARMER & CANYON & TX & WINKLER & 1964 & 8500 & 42,577 & $2,323,635$ \\
\hline 23138500 & 8 & DARMER, NE. & PENN. & TX & WINKLER & 1978 & 8256 & 13,649 & $1,055,362$ \\
\hline 23907710 & 8 & DEEP ROCK & PENN. & TX & ANDREWS & 1961 & 9037 & 76,028 & $7,857,006$ \\
\hline 24396100 & 8 & DESPERADO & ATOKA & TX & MIDLAND & 1984 & 10845 & 56,793 & $3,642,912$ \\
\hline 24489380 & 8 & DEWEY LAKE, S. & STRAWN & TX & GLASSCOCK & 1983 & 10055 & 18,543 & $1,115,433$ \\
\hline 25395100 & 8 & DORA ROBERTS & CONSOLIDATED & TX & MIDLAND & 1995 & 10341 & 34,294 & $2,371,206$ \\
\hline 25585500 & $8 \mathrm{~A}$ & DOSS & CANYON & TX & GAINES & 1949 & 8850 & 0 & $1,712,794$ \\
\hline 28899747 & 8 & EMMA & STRAWN & TX & ANDREWS & 1958 & 9123 & 2,822 & $3,239,757$ \\
\hline 29507500 & 8 & ESTES BLOCK 34 & PENN. & TX & WARD & 1957 & 8150 & 29,578 & $4,999,188$ \\
\hline 30394500 & 8 & FASKEN & PENN. & TX & ECTOR & 1956 & 10158 & 32,773 & $5,955,633$ \\
\hline 35653777 & 8 & GOLDSMITH, E. & PENNSYLVANIAN & TX & ECTOR & 1953 & 8621 & 4,224 & $1,655,075$ \\
\hline 38227333 & 8 & HALLANAN & STRAWN & TX & MIDLAND & 1952 & 10570 & 3,824 & $4,202,854$ \\
\hline 39176830 & 8 & HARPER & STRAWN & TX & ECTOR & 1962 & 9028 & 35,940 & $1,014,517$ \\
\hline 40295600 & 7C & HELUMA & PENN. & TX & UPTON & 1956 & 8030 & 10,867 & $1,930,528$ \\
\hline 37821710 & 8 & H. S. A. & PENNSYLVANIAN & TX & WARD & 1960 & 8088 & 1,413 & $3,516,869$ \\
\hline 43083250 & $8 \mathrm{~A}$ & HUAT & CANYON & TX & GAINES & 1961 & 10470 & 51,032 & $6,037,105$ \\
\hline 44238500 & $8 \mathrm{~A}$ & IDALOU & STRAWN & TX & LUBBOCK & 1970 & 9264 & 10,230 & $2,063,298$ \\
\hline 46134250 & $8 \mathrm{~A}$ & JENKINS, NORTH & CANYON & TX & GAINES & 1952 & 8590 & 0 & $1,079,745$ \\
\hline 47007600 & 8 & JOHNSON & PENN & TX & ECTOR & 1973 & 9261 & 0 & $1,132,603$ \\
\hline 47267456 & 8 & JORDAN & PENNSYLVANIAN & TX & CRANE & 1953 & 7830 & 0 & $2,104,294$ \\
\hline 49415545 & $7 \mathrm{C}$ & KING MOUNTAIN, N. & CIScO & TX & UPTON & 1975 & 8764 & 7,937 & $2,014,219$ \\
\hline 51812750 & $8 \mathrm{~A}$ & LANDON & STRAWN & TX & COCHRAN & 1947 & 10340 & 2,714 & $1,210,407$ \\
\hline 52567500 & 8 & LAZY R & STRAWN DETRITUS & TX & ECTOR & 1963 & 8307 & 2,689 & $1,211,321$ \\
\hline 53411710 & $8 \mathrm{~A}$ & LEVELLAND & STRAWN & TX & HOCKLEY & 1957 & 10120 & 0 & $1,044,056$ \\
\hline 53414500 & $8 \mathrm{~A}$ & LEVELLAND, NE. & STRAWN & TX & HOCKLEY & 1964 & 10084 & 15,627 & $3,448,189$ \\
\hline 59419498 & 8 & MCFARLAND & PENNSYLVANIAN & TX & ANDREWS & 1956 & 10423 & 15,707 & $5,053,412$ \\
\hline 60138500 & 8 & MEANS, EAST & STRAWN & TX & ANDREWS & 1954 & 10616 & 14,460 & $4,041,930$ \\
\hline 61473500 & 8 & MILLER BLOCK B-29 & PENN. & TX & WARD & 1959 & 8104 & 3,428 & $2,737,993$ \\
\hline 62416666 & 8 & MONAHANS, E. & PENN., LO. & TX & WINKLER & 1964 & 8873 & 6,913 & $1,325,184$ \\
\hline 62418666 & 8 & MONAHANS, NE. & PENN DETRITAL, UP & TX & WINKLER & 1968 & 8128 & 14,434 & $3,878,539$ \\
\hline 62703400 & 8 & MOONLIGHT & MISSISSIPPIAN & TX & MIDLAND & 1984 & 11599 & 18,387 & $1,162,891$ \\
\hline 65766111 & 8 & NOLLEY & CANYON & TX & ANDREWS & 1967 & 10384 & 19,572 & $2,131,200$ \\
\hline 69193568 & 8 & PARKER & PENNSYLVANIAN & TX & ANDREWS & 1954 & 9087 & 13,914 & $8,334,854$ \\
\hline 69200500 & 8 & PARKER, WEST & PENN. & TX & ANDREWS & 1967 & 9046 & 5,109 & $1,151,180$ \\
\hline 69233498 & 8 & PARKS & PENNSYLVANIAN & TX & MIDLAND & 1950 & 10440 & 63,991 & $15,249,943$ \\
\hline 70279500 & $7 \mathrm{C}$ & PEGASUS & PENNSYLVANIAN & TX & UPTON & 1951 & 10470 & 123,311 & $17,127,951$ \\
\hline 74590075 & $8 \mathrm{~A}$ & RAND-PAULSON & CANYON & TX & HOCKLEY & 1995 & 9638 & 39,819 & $1,123,263$ \\
\hline 78167001 & $8 \mathrm{~A}$ & ROPES & & TX & HOCKLEY & 1950 & 9290 & 16,910 & $25,593,426$ \\
\hline 78175333 & $8 \mathrm{~A}$ & ROPES, WEST & CISCO SAND & TX & HOCKLEY & 1953 & 9875 & 5,449 & $7,217,081$ \\
\hline 79659700 & 8 & SAINT LAWRENCE & STRAWN & TX & GLASSCOCK & 1983 & 9890 & 11,994 & $1,469,268$ \\
\hline 81913750 & $8 \mathrm{~A}$ & SEAGRAVES & STRAWN & TX & GAINES & 1956 & 11243 & 7,155 & $1,049,161$ \\
\hline 82231540 & $8 \mathrm{~A}$ & SEMINOLE, SE. & STRAWN & TX & GAINES & 1973 & 10792 & 10,447 & $2,249,644$ \\
\hline 84347333 & $8 \mathrm{~A}$ & SMYER, N. & CANYON & TX & HOCKLEY & 1956 & 9630 & 0 & $5,195,857$ \\
\hline 84347666 & $8 \mathrm{~A}$ & SMYER, N. & STRAWN & TX & HOCKLEY & 1956 & 9968 & 0 & $6,354,886$ \\
\hline 87599568 & 8 & SWEETIE PECK & PENNSYLVANIAN & TX & MIDLAND & 1960 & 10342 & 5,911 & $2,158,236$ \\
\hline 89134750 & $7 \mathrm{C}$ & TEXEL & PENNSYLVANIAN & TX & UPTON & 1954 & 9143 & 5,441 & $1,621,367$ \\
\hline 91350600 & 8 & TRIPLE-N & PENN., UPPER & $T X$ & ANDREWS & 1958 & 8912 & 47,044 & $16,084,222$ \\
\hline 88071522 & 8 & $\mathrm{TXL}$ & PENNSYLVANIAN & TX & ECTOR & 1956 & 8450 & 0 & $1,045,392$ \\
\hline 92534500 & 8 & UNIVERSITY BLOCK 9 & PENN. & TX & ANDREWS & 1954 & 8956 & 292,047 & $15,782,648$ \\
\hline 93958100 & 8 & VIREY & CONSOLIDATED & TX & MIDLAND & 1995 & 10844 & 57,783 & $3,429,592$ \\
\hline 94640500 & 8 & WAGON WHEEL & PENN & TX & WARD & 1979 & 8812 & 367,335 & $9,445,581$ \\
\hline 95138406 & 8 & WARD, SOUTH & PENN. DETRI., UP. & $T X$ & WARD & 1963 & 7700 & 5,000 & $1,631,943$ \\
\hline 95108090 & 8 & WAR-SAN & CONSOLIDATED & TX & MIDLAND & 1995 & 10794 & 34,375 & $3,223,679$ \\
\hline 96408664 & $8 \mathrm{~A}$ & WESCOTT & STRAWN & TX & GAINES & 1954 & 11008 & 44,214 & $5,564,505$ \\
\hline 97834750 & $7 \mathrm{C}$ & WILSHIRE & PENNSYLVANIAN & TX & UPTON & 1952 & 9810 & 4,304 & $1,374,833$ \\
\hline 99583600 & 8 & YUCCA BUTTE, W & STRAWN & TX & PECOS & 1975 & 8304 & 6,405 & $1,889,536$ \\
\hline & & Totals & & & & & & $2,076,281$ & $340,469,274$ \\
\hline
\end{tabular}


Atokan reservoirs in the Midland Basin in Andrews and Midland Counties are composed of thin (15 to $20 \mathrm{ft}$ [5 to $6 \mathrm{~m}$ ]), silty to bioclastic-rich zones in the "Atoka" shale (Candelaria, 1990). During sea-level lowstands, carbonate detritus was carried from carbonate banks into relatively deeper water and deposited in extensive, sheetlike units up to $40 \mathrm{mi}(64 \mathrm{~km})$ long by $10 \mathrm{mi}(16 \mathrm{~km})$ wide (Candelaria, 1990). The Atoka reservoirs have porosity ranging from 6 to 8 percent; permeability is commonly less than $0.1 \mathrm{md}\left(0.1 \times 10^{-3} \mu \mathrm{m}^{2}\right)$. Natural fractures are interpreted to enhance storage capacity, continuity, and fluid transmissibility in these lowporosity, low-permeability reservoirs (Candelaria, 1990). Wells are typically stimulated by fracturing with diesel or lease crude oil to minimize formation damage by water and injecting 50,000 to 100,000 pounds of sand proppant. Simple acidizing treatments can damage Atoka reservoirs (Candelaria, 1990).

Some workers correlate the "Atoka" shale in this area to the Lower Pennsylvanian (Morrowan or Atokan), whereas others correlate it to the Upper Mississippian (Chester) Barnett Shale (Candelaria, 1990). The Atoka reservoirs have been included with the Pennsylvanian Platform Carbonate play in this report. Moonlight (Mississippian) reservoir has also been assigned to the Pennsylvanian Platform Carbonate play because, despite its name, it is interpreted as producing from a zone of bioclastic wackestones within the "Atoka" shale (Candelaria, 1990), similar to the Atoka reservoirs in fields such as Desperado and Azalea.

Strawn reservoirs on the Central Basin Platform and in the Midland Basin produce from shallow-marine, fossiliferous limestone; the traps are anticlines and faulted anticlines (Kosters and others, 1989). The reservoir in Seminole SE and other Strawn fields in Gaines County consist of Chaetetes (coral or sponge) biolithite and associated ooid and skeletal grainstones (Mazzullo, 1982). Strawn limestones also form reservoirs on the Northwest Shelf, in Hockley, 
Lubbock, and Cochran Counties (fig. 37). Strawn carbonates in the Wilshire Pennsylvanian reservoir, Upton County, were deposited on a shallow carbonate ramp that prograded eastward away from the incipient Central Basin Platform (Tai and Dorobek, 1999). Upper Strawn strata are missing at Wilshire field, probably because of post-Strawn uplift and erosion on the faultbounded anticline that forms the trap (Tai and Dorobek, 1999). Several Strawn reservoirs in Ward, Winkler, and Ector Counties on the Central Basin Platform produce from detrital limestone, dolomite, chert, and sandstone, known as "Strawn Detritus." These detrital facies are attributed to erosion of older carbonates and cherts on exposed Pennsylvanian structures (Kosters and others, 1989; Van Der Loop, 1991; Tai and Dorobek, 1999). The largest of these fields is the Arenoso Strawn Detritus reservoir, which produces mainly from chert conglomerates and sandstones deposited in alluvial-fan, braided-stream, and shoreface environments (Van Der Loop, 1991).

On the east side of the Midland Basin, the Strawn produces in reservoirs such as the St. Lawrence from high-frequency, upward-shallowing cycles. Cycles are composed of lowenergy, mud-rich facies at the base, overlain by high-energy, grain-rich facies that form the reservoirs (Sivils and Stoudt, 2001; Sivils, 2002). Core-measured porosity (maximum 10 percent) agrees well with log porosity. Correlation of cycles is possible because of the close tie between log signature of cycles and cycles observed in core (Sivils, 2002).

Many of the larger reservoirs in this play, such as the Andrews, Triple-N, and University Block 9, produce from Upper Pennsylvanian carbonates on the east side of the Central Basin Platform and in Hockley County (fig. 37). Detailed descriptions of a typical Upper Pennsylvanian platform-carbonate reservoir on the Central Basin Platform were published by Saller and others (1994, 1999a, b) and Dickson and Saller (1995). The Strawn through Cisco 
section represents one long-term regression on the east side of the Central Basin Platform, and a major unconformity occurs at the top of the Pennsylvanian (Saller and others, 1999b). These studies illustrate that the reservoirs are developed in highly cyclic successions of shallow-water carbonate-platform facies. The deposits thin to the west, indicating that the Central Basin Platform was a depositional high during the Late Pennsylvanian and Early Permian (Saller and others, 1999b). Stratigraphic heterogeneity is created by cyclic alternations of porous and nonporous limestone facies and shales (figs. 38, 39). Additional heterogeneity is contributed by karst-related diagenesis at and below cycle tops during sea-level-fall events (Dickson and Saller, 1995). Porosity in these rocks is developed primarily in phylloid algal boundstones, thick

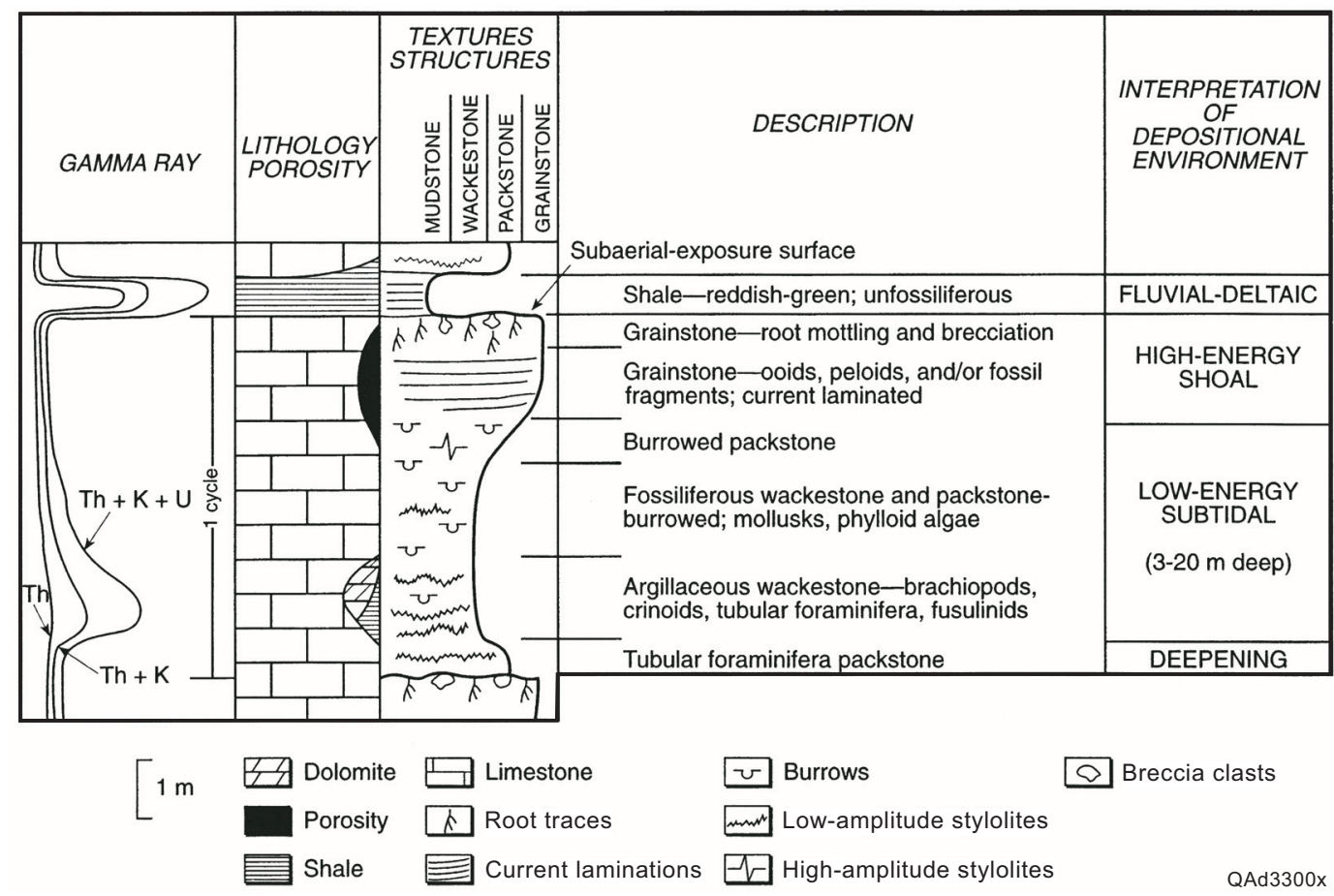

Figure 38. Idealized upward-shallowing cycle in Upper Pennsylvanian carbonates in the Southwest Andrews area. From Saller and others (1999b). 


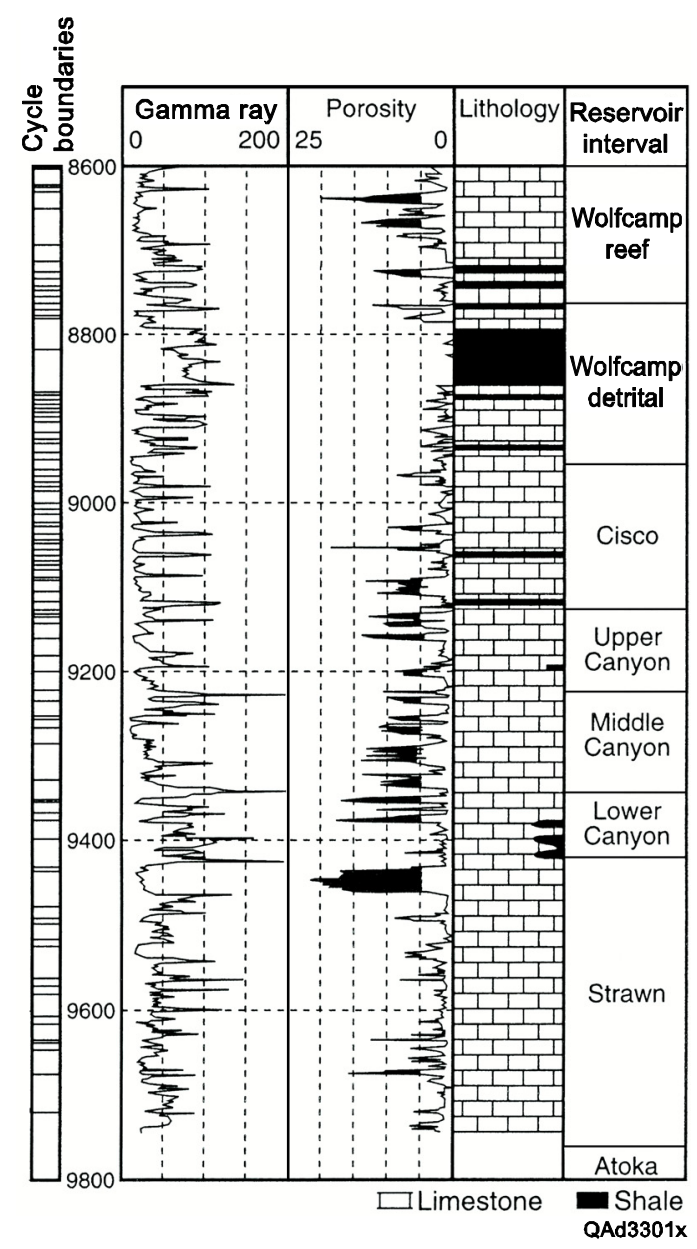

Figure 39. Core description and gamma-ray log through the producing interval in the X-1 well, Andrews field, Southwest Andrews area, Andrews County. After Saller and others (1999a), reprinted by permission of the AAPG, whose permission is required for further use. CCopyright 1999. The American Association of Petroleum Geologists. All rights reserved. See Saller and others (1999a) for well location.

grainstones, and a few wackestone/packstones (Saller and others, 1999a). Phylloid algae were the dominant mound builders in shelf and shelf-margin areas during the Middle and Late Pennsylvanian (Wahlman, 2001). Phylloid-algal buildups developed during the late, highstand parts of Pennsylvanian depositional sequences and were commonly exposed to meteoric diagenesis when sea level fell (Wahlman, 2002).

Reservoir-grade porosity ( $>4$ percent) occurs in 5 to 25 percent of the gross reservoir interval (fig. 40) (Saller and others, 1999a). Porosity is best developed in the upper part of cycles $>6 \mathrm{ft}(2 \mathrm{~m})$ thick that were subjected to subaerial erosion for brief to moderate lengths of time 


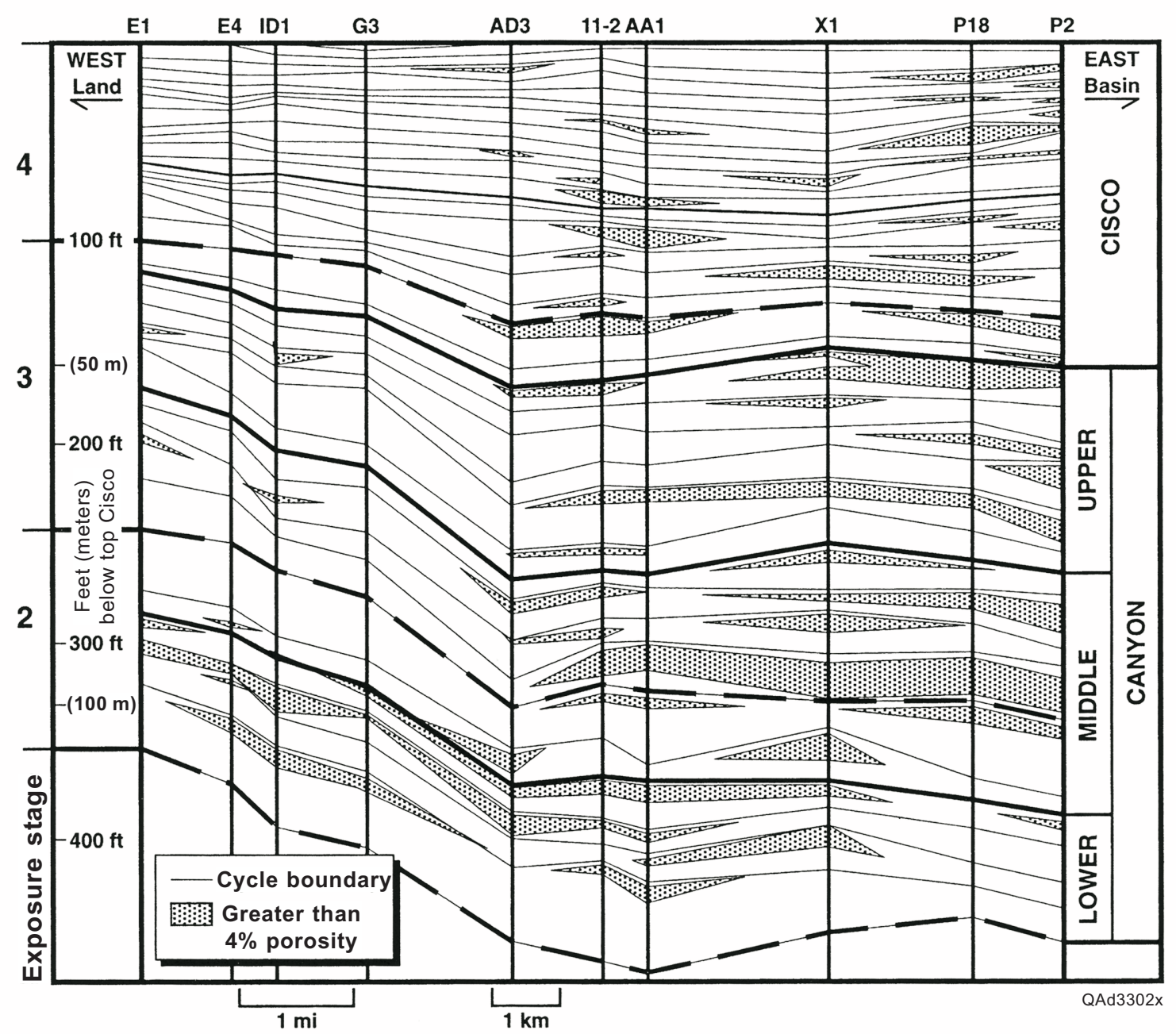

Figure 40. Stratigraphic cross section showing distribution of porous limestone in the Canyon and Cisco intervals in Deep Rock and Parker fields, southwest Andrews County. After Saller and others (1999a), reprinted by permission of the AAPG, whose permission is required for further use. CCopyright 1999. The American Association of Petroleum Geologists. All rights reserved. See Saller and others (1999a) for location of cross section.

(Saller and others, 1999b). Reservoir porosity is largely determined by the amount of burial compaction and cementation and not by the amount of porosity created during subaerial exposure (Dickson and Saller, 1995). Porosity in Ropes field, which produces from a CanyonCisco limestone buildup, averages 8.5 percent; permeability averages $66 \mathrm{md}\left(66 \times 10^{-3} \mu \mathrm{m}^{2}\right)$ and ranges from 0.1 to $1,100 \mathrm{md}\left(0.1\right.$ to $\left.1,100 \times 10^{-3} \mu^{2}\right)$ (Godfrey, 1982; Collier and others, 1998). 
Simple anticlinal closures form traps for most of these reservoirs. The traps are interpreted to be postdepositional, but productive areas within the structural traps are limited because of the irregular distribution of porous facies (Galloway and others, 1983). Ropes field produces from a stratigraphic trap (Godfrey, 1966; Collier and others, 1998).

\section{References}

Candelaria, M. P., 1990, Atoka detrital a subtle stratigraphic trap in the Midland Basin, in Flis, J. E., and Price, R. C., eds., Permian Basin oil and gas fields: innovative ideas in exploration and development: West Texas Geological Society, Publication No. 90-87, p. 104-106.

Collier, H., Shaw, R., and McCracken, M., 1998, Integrating sample, seismic, petrophysical, and engineering data to revitalize an old field; Ropes Canyon Reef Unit, Hockley County, Texas, in DeMis, W. D. and Nelis, M. K., eds., The search continues into the 21 st century: West Texas Geological Society Publication No. 98-105, p. 105-106.

Dickson, J. A. D., and Saller, A. H., 1995, Identification of subaerial exposure surfaces am porosity preservation in Pennsylvanian and lower Permian shelf limestones, eastern Central Basin Platform Texas, in Budd, D. A., Saller, A. H., and Harris, P. M., eds., Unconformities in carbonate shelf strata - their recognition and the significance of associated porosity: American Association of Petroleum Geologists Memoir 57, p. 239 257.

Frenzel, H. N., Bloomer, R. R., Cline, R. B., Cys, J. M., Galley, J. E., Gibson, W. R., Hills, J. M., King, W. E., Seager, W. R., Kottlowski, F. E., Thompson, S., III, Luff, G. C., Pearson, B. T., and Van Siclen, D. C., 1988, The Permian Basin region, in Sloss, L. L., ed., Sedimentary cover-North American Craton; U.S.: Boulder, Colorado, Geological Society of America, The Geology of North America, v. D-2, p. 261-306.

Galloway, W. E., Ewing, T. E., Garrett, C. M., Jr., Tyler, N., and Bebout, D. G., 1983, Atlas of major Texas oil reservoirs: The University of Texas at Austin, Bureau of Economic Geology Special Publication, 139 p.

Godfrey, C. B., 1982, Ropes \& South Ropes Penn.: selected oil \& gas fields in West Texas: West Texas Geological Society Publication No. 82-75, p. 565-567.

Hanson, B. M., Powers, B. K., Garrett, C. M., Jr., McGookey, D. E., McGlasson, E. H., Horak, R. L., Mazzullo, S. J., Reid, A. M., Calhoun, G. G., Clendening, J., and Claxton, B., 1991, The Permian Basin, in Gluskoter, H. J., Rice, D. D., and Taylor, R. B., eds., The 
Geology of North America, v. P-2, Economic Geology, U.S.: Geological Society of America, p. 339-356.

Kosters, E. C., Bebout, D. G., Seni, S. J., Garrett, C. M., Jr., Brown, L. F., Jr., Hamlin, H. S., Dutton, S. P., Ruppel, S. C., Finley, R. J., and Tyler, Noel, 1989, Atlas of major Texas gas reservoirs: The University of Texas at Austin, Bureau of Economic Geology Special Publication, $161 \mathrm{p}$.

Mazzullo, S. J., 1982, Types and controls on Permo-Pennsylvanian carbonate stratigraphic traps of shallow-marine origin in Permian Basin: exploration models: Oil and Gas Journal, v. 80, p. $127-141$.

1997, Stratigraphic exploration plays in Ordovician to Lower Permian strata in the Midland Basin and on the Eastern Shelf, in DeMis, W. D., ed., Permian Basin oil and gas fields: turning ideas into production: West Texas Geological Society Publication No. 97-102, p. 1-37.

Saller, A. H., Dickson, J. A. D., and Boyd, S. A., 1994, Cycle stratigraphy and porosity in Pennsylvanian and lower Permian shelf limestones, eastern Central Basin Platform, Texas: American Association of Petroleum Geologists Bulletin, v. 78, p. 1820-1842.

Saller, A. H., Dickson, J. A. D., and Matsuda, F., 1999a, Evolution and distribution of porosity associated with subaerial exposure in upper Paleozoic platform limestones, West Texas: American Association of Petroleum Geologists Bulletin, v. 83, p. 1835-1854.

Saller, A. H., Dickson, J. A. D., Rasbury, E. T., and Ebato, T., 1999b, Effects of long-term accommodation changes on short term cycles: Upper Paleozoic platform limestones, West Texas, in Advances in carbonate sequence stratigraphy: application to reservoirs, outcrops, and models: Society of Economic Paleontologists and Mineralogists Special Publication No. 63, p. 227-246.

Sivils, D. J., 2002, Reservoir characterization of the Strawn (Desmoinesian) from St. Lawrence Field, Glasscock County, Texas, in Transactions, Southwest Section, American Association of Petroleum Geologists, Ruidoso, New Mexico, p. 193-197.

Sivils, D. J., and Stoudt, E. L., 2001, Reservoir characterization of the Strawn (Desmoinesian) from St. Lawrence field, Glasscock County, Texas, in Viveiros, J. J., and Ingram, S. M., eds., The Permian Basin: microns to satellites, looking for oil and gas at all scales: West Texas Geological Society Publication No. 01-110, p. 53.

Tai, P., and Dorobek, S. L., 1999, Preliminary study on the Late Paleozoic tectonic and stratigraphic history at Wilshire field, central Upton County, southwestern Midland Basin, west Texas, in Grace, D. T., and Hinterlong, G. D., eds., The Permian Basin: providing energy for America: West Texas Geological Society Publication No. 99-106, p. 19-29. 
Van Der Loop, M., 1991, Depositional environments in the Arenoso field, Winkler County, Texas, in Candelaria, M., ed., Permian Basin plays - tomorrow's technology today: West Texas Geological Society Publication No. 91-89, p. 73-91.

Wahlman, G. P., 2001, Pennsylvanian-Lower Permian mounds and reefs in the Permian Basin (west Texas-New Mexico): composition, evolution, distribution, and reservoir characteristics, in Viveiros, J. J., and Ingram, S. M., eds., The Permian Basin: microns to satellites, looking for oil and gas at all scales: West Texas Geological Society Publication No. 01-110, p. 57-64.

2002, Pennsylvanian and Lower Permian shelf-margin mounds and reefs in the Permian Basin region (West Texas-New Mexico): composition, evolution, distribution, and reservoir characteristics, in Transactions, Southwest Section, American Association of Petroleum Geologists, Ruidoso, New Mexico, p. 169. 
Pennsylvanian and Lower Permian Horseshoe Atoll Carbonate (Play 112)

This large play, the Pennsylvanian and Lower Permian Horseshoe Atoll Carbonate, has produced 2,699.2 $\mathrm{MMbbl}\left(4.29 \times 10^{8} \mathrm{~m}^{3}\right)$ from 70 reservoirs within the Horseshoe Atoll, a nonreefal, isolated, carbonate platform system in the northern Midland Basin (table 17, figs. 41, 42). Production is from stacked Strawn through Wolfcamp limestones and dolomitic limestones that aggraded from the floor of the basin in a northward-opening arc (Galloway and others, 1983). Deposition of the Horseshoe Atoll began on a broad Strawn carbonate platform that lay basinward of the clastic deposition in North-Central Texas (Vest, 1970). Isolated reservoirs produce from Strawn carbonates in Garza and Borden Counties, where carbonate mounds developed on local structural highs in the underlying Ellenburger (F. J. Lucia, personal communication, 2000). During lowstands, these mounds were subaerially exposed, and meteoric diagenesis developed moldic porosity.

Through time, isolated carbonate knolls and pinnacles evolved from the laterally continuous carbonate platform. Subsidence of the Midland Basin led to repeated backstepping of the platform from Strawn through Canyon and Cisco time, and considerable relief developed on the vertically accreting pinnacles (Vest, 1970; Galloway and others, 1983; Kerans, 2001b). Early-middle Canyon, high-frequency eustatic shifts produced systematic upward-coarsening, tight-to-porous cycles that cause strongly layered reservoir heterogeneity (fig. 43). In the later Canyon and Cisco, high-frequency cycles show higher amplitude eustatic shifts and cycle-scale karstification (Kerans, 2001b). The lithofacies that compose the Horseshoe Atoll include spongealgal-bryozoan and phylloid-algal-mound wackestones and boundstones, crestal tidal-flat and peritidal wackestones, shoal and shoreface grainstones, shelf crinoidal wackestones, and debrisflow lithoclast packstones and wackestones (Galloway and others, 1983; Schatzinger, 1988). 
Table 17. Pennsylvanian and Lower Permian Horseshoe Atoll Carbonate play (play 112). Production shown for fields that have had others combined into them represents the totals; combined fields are highlighted.

\begin{tabular}{|c|c|c|c|c|c|c|c|c|c|}
\hline RRC RESN & RRC & FLDNAME & RESNAME & STATE & COUNTY & DISCYR & DEPTHTOP & 2000 PROD & CUMPROD \\
\hline 450250 & $8 \mathrm{~A}$ & ACKERLY, NORTH & CANYON REEF & $\mathrm{TX}$ & DAWSON & 1958 & 9154 & 11,621 & $1,198,872$ \\
\hline 450375 & $8 \mathrm{~A}$ & ACKERLY, NORTH & $\mathrm{CISCO}$ & TX & DAWSON & 1972 & 8766 & 0 & $1,106,255$ \\
\hline 570500 & $8 \mathrm{~A}$ & ADAIR & WOLFCAMP & TX & TERRY & 1950 & 8505 & 41,192 & $52,422,109$ \\
\hline 573500 & $8 \mathrm{~A}$ & ADAIR, NORTHEAST & WOLFCAMP & $\mathrm{TX}$ & TERRY & 1954 & 8846 & 11,361 & $1,326,016$ \\
\hline 3250510 & $8 \mathrm{~A}$ & APCLARK & STRAWN & TX & BORDEN & 1996 & 8534 & 159,265 & $1,231,864$ \\
\hline 4690300 & 8 & B.C. & CANYON & TX & HOWARD & 1985 & 9041 & 15,035 & $1,226,734$ \\
\hline 12476400 & $8 \mathrm{~A}$ & BROWNFIELD, S. & STRAWN & $\mathrm{TX}$ & TERRY & 1981 & 10613 & 20,545 & $1,349,752$ \\
\hline 12469333 & $8 \mathrm{~A}$ & BROWNFIELD, SOUTH & CANYON & $T X$ & TERRY & 1950 & 9330 & 5,381 & $5,252,940$ \\
\hline 14627666 & $8 \mathrm{~A}$ & CAIN & STRAWN & TX & GARZA & 1959 & 7652 & 10,735 & $1,047,176$ \\
\hline 14215250 & 8 & c. C. GUNN & CANYON REEF & $\mathrm{TX}$ & HOWARD & 1987 & 7564 & 30,109 & $1,006,890$ \\
\hline 19346142 & $8 \mathrm{~A}$ & COGDELL & AREA & TX & KENT & 1949 & 6796 & 600,930 & $264,228,838$ \\
\hline 19347250 & $8 \mathrm{~A}$ & COGDELL, EAST & CANYON & TX & SCURRY & 1958 & 6813 & 25,162 & $5,745,654$ \\
\hline 19351333 & $8 \mathrm{~A}$ & COGDELL, SE. & CANYON 6800 & $\mathrm{TX}$ & SCURRY & 1970 & 6832 & 3,718 & $1,935,449$ \\
\hline 24562142 & $8 \mathrm{~A}$ & DIAMOND -M- & CANYON LIME AREA & TX & SCURRY & 1948 & 6569 & $1,076,585$ & $248,878,432$ \\
\hline 25728500 & $8 \mathrm{~A}$ & DOUBLE J & CANYON REEF & TX & BORDEN & 1969 & 6641 & 82,743 & $4,335,241$ \\
\hline 25957600 & $8 \mathrm{~A}$ & DOVER & STRAWN & TX & GARZA & 1985 & 8123 & 54,320 & $1,268,004$ \\
\hline 28829500 & $8 \mathrm{~A}$ & ELZON, W. & STRAWN 6950 & $T X$ & KENT & 1967 & 6972 & 20 & $1,674,677$ \\
\hline 31690750 & $8 \mathrm{~A}$ & FLUVANNA & STRAWN & TX & BORDEN & 1954 & 7769 & 32,125 & $13,893,241$ \\
\hline 31697847 & $8 \mathrm{~A}$ & FLUVANNA, SW. & STRAWN, UPPER & TX & BORDEN & 1973 & 7902 & 8,245 & $3,048,201$ \\
\hline 33191250 & $8 \mathrm{~A}$ & FULLER, EAST & CANYON & $\mathrm{TX}$ & SCURRY & 1961 & 6846 & 20,059 & $2,016,286$ \\
\hline 34849500 & $8 \mathrm{~A}$ & GILL & PENN. REEF 6900 & TX & SCURRY & 1970 & 6937 & 86,966 & $1,155,277$ \\
\hline 35738001 & $8 \mathrm{~A}$ & GOOD & & TX & BORDEN & 1949 & 7905 & 97,619 & $49,768,450$ \\
\hline 35741500 & $8 \mathrm{~A}$ & GOOD, NORTHEAST & CANYON REEF & TX & BORDEN & 1953 & 8066 & 62,258 & $3,509,246$ \\
\hline 35744333 & $8 \mathrm{~A}$ & GOOD, SE. & CANYON REEF & TX & BORDEN & 1959 & 8123 & 0 & $1,095,717$ \\
\hline 38866666 & $8 \mathrm{~A}$ & HAPPY & STRAWN & TX & GARZA & 1958 & 7951 & 1,367 & $1,839,792$ \\
\hline 40716333 & $8 \mathrm{~A}$ & HERMLEIGH & STRAWN & $\mathrm{TX}$ & SCURRY & 1953 & 6530 & 27,627 & $1,051,427$ \\
\hline 41816333 & $8 \mathrm{~A}$ & HOBO & PENNSYLVANIAN & TX & BORDEN & 1951 & 7100 & 33,656 & $12,964,339$ \\
\hline 48583001 & $8 \mathrm{~A}$ & KELLY-SNYDER & & $T X$ & SCURRY & 1948 & 6795 & $3,183,905$ & $1,264,215,085$ \\
\hline 49678500 & $8 \mathrm{~A}$ & KIRKPATRICK & PENN. & TX & GARZA & 1961 & 7902 & 1,367 & $1,534,724$ \\
\hline 55578500 & $8 \mathrm{~A}$ & LUCY, NORTH & PENN & TX & BORDEN & 1973 & 7830 & 13,944 & $2,259,712$ \\
\hline 55818333 & 8 & LUTHER, NORTH & CANYON REEF & TX & HOWARD & 1952 & 7950 & 15 & $1,789,764$ \\
\hline 55975500 & $8 \mathrm{~A}$ & LYN KAY & 6150 & $\mathrm{TX}$ & KENT & 1975 & 6164 & 27,520 & $1,157,730$ \\
\hline 61046250 & 8 & MIDDLETON & CANYON REEF & $\mathrm{TX}$ & HOWARD & 1986 & 8536 & 51,998 & $1,285,697$ \\
\hline 63799500 & $8 \mathrm{~A}$ & MUNGERVILLE & PENNSYLVANIAN & $\mathrm{TX}$ & DAWSON & 1951 & 8570 & 82,273 & $9,030,669$ \\
\hline 64217500 & $8 \mathrm{~A}$ & MYRTLE, NW. & STRAWN & $\mathrm{TX}$ & BORDEN & 1967 & 8030 & 125 & $1,013,491$ \\
\hline 64221666 & $8 \mathrm{~A}$ & MYRTLE, W. & STRAWN & $T X$ & BORDEN & 1956 & 8072 & 3,498 & $2,662,450$ \\
\hline 66669500 & 8 & OCEANIC & PENNSYLVANIAN & $\mathrm{TX}$ & HOWARD & 1953 & 8140 & 136,138 & $24,059,565$ \\
\hline 66672500 & 8 & OCEANIC, N.E. & PENNSYLVANIAN & $\mathrm{TX}$ & BORDEN & 1968 & 8135 & 7,463 & $1,495,837$ \\
\hline 70661300 & 8 & PERRIWINKLE & CANYON & $\mathrm{TX}$ & MARTIN & 1985 & 9420 & 72,795 & $1,062,980$ \\
\hline 72213500 & $8 \mathrm{~A}$ & POLAR, EAST & PENNSYLVANIAN & TX & KENT & 1950 & 6855 & 0 & $1,993,424$ \\
\hline 72560500 & $8 \mathrm{~A}$ & POST, WEST & STRAWN & $T X$ & GARZA & 1979 & 8482 & 0 & $1,099,724$ \\
\hline 75780001 & $8 \mathrm{~A}$ & REINECKE & & $T X$ & BORDEN & 1950 & 6791 & 562,858 & $85,247,005$ \\
\hline 75781500 & $8 \mathrm{~A}$ & REINECKE, E. & CANYON & TX & BORDEN & 1966 & 6794 & 2,329 & $1,281,886$ \\
\hline 79131666 & 8 & RUWE-COB & PENN REEF & TX & HOWARD & 1967 & 7424 & 12,681 & $1,207,162$ \\
\hline 79887001 & $8 \mathrm{~A}$ & SALT CREEK & & $\mathrm{TX}$ & KENT & 1950 & 6200 & $5,792,610$ & $356,369,037$ \\
\hline 79891500 & $8 \mathrm{~A}$ & SALT CREEK, SOUTH & PENN., LOWER & $\mathrm{TX}$ & KENT & 1952 & 6622 & 0 & $1,403,717$ \\
\hline 81021250 & 8 & SARA-MAG & CANYON REEF & $\mathrm{TX}$ & HOWARD & 1954 & 7580 & 250,936 & $3,937,283$ \\
\hline 81987400 & $8 \mathrm{~A}$ & SEAN ANDREW & PENN. & TX & DAWSON & 1994 & 8329 & 51,699 & $1,296,502$ \\
\hline 84470750 & $8 \mathrm{~A}$ & SNYDER, N & STRAWN ZONE B & $\mathrm{TX}$ & SCURRY & 1950 & 7300 & 9,371 & $7,936,335$ \\
\hline 85292750 & $8 \mathrm{~A}$ & SPRABERRY, WEST & PENN. & TX & DAWSON & 1953 & 8060 & 4,988 & $2,293,014$ \\
\hline 85743666 & $8 \mathrm{~A}$ & STATEX & CISCO REEF & $\mathrm{TX}$ & TERRY & 1952 & 10032 & 12,433 & $2,870,697$ \\
\hline 87646500 & $8 \mathrm{~A}$ & SWENSON-GARZA & STRAWN & $\mathrm{TX}$ & GARZA & 1971 & 7356 & 0 & $1,390,411$ \\
\hline 88611568 & $8 \mathrm{~A}$ & TEAS & PENN. 8100 & TX & GARZA & 1958 & 8069 & 20,205 & $3,892,415$ \\
\hline 88760100 & $8 \mathrm{~A}$ & TEN GALLON & CANYON LIME & TX & SCURRY & 1992 & 6760 & 57,981 & $1,173,235$ \\
\hline 88977142 & $8 \mathrm{~A}$ & TEX-HAMON & CANYON & $T X$ & DAWSON & 1962 & 10060 & 9,715 & $1,399,045$ \\
\hline 90268333 & $8 \mathrm{~A}$ & TOBE & STRAWN & TX & GARZA & 1951 & 7451 & 22,077 & $1,733,188$ \\
\hline 90697500 & $8 \mathrm{~A}$ & TONTO, NE. & CISCO 5030 & $\mathrm{TX}$ & SCURRY & 1966 & 5046 & 6,147 & $1,700,852$ \\
\hline 91318500 & $8 \mathrm{~A}$ & TRIPLE D & PENN. REEF & $T X$ & DAWSON & 1958 & 8497 & 1,913 & $1,088,474$ \\
\hline 91115500 & $8 \mathrm{~A}$ & TRI-RUE & REEF & TX & SCURRY & 1956 & 6862 & 100,444 & $6,516,418$ \\
\hline 91670700 & $8 \mathrm{~A}$ & TUFBOW & STRAWN & $\mathrm{TX}$ & GARZA & 1979 & 7599 & 21,027 & $1,300,773$ \\
\hline 92290666 & $8 \mathrm{~A}$ & U-LAZY -S- & PENNSYLVANIAN & $T X$ & BORDEN & 1958 & 8084 & 4,390 & $3,015,323$ \\
\hline 93308001 & 8 & VEALMOOR & & TX & HOWARD & 1948 & 7934 & 106,125 & $39,565,153$ \\
\hline 93310001 & 8 & VEALMOOR, EAST & & $\mathrm{TX}$ & HOWARD & 1950 & 7414 & 154,771 & $62,692,195$ \\
\hline 93854500 & 8 & VINCENT, $N$. & PENNSYLVANIAN REEF & TX & HOWARD & 1957 & 7444 & 28,497 & $2,558,261$ \\
\hline 93857500 & 8 & VINCENT, S. & STRAWN & $T X$ & HOWARD & 1964 & 7839 & 17,244 & $1,195,546$ \\
\hline 93860500 & 8 & VINCENT, WEST & PENN. & $\mathrm{TX}$ & HOWARD & 1957 & 7454 & 23,579 & $1,116,613$ \\
\hline 94114001 & $8 \mathrm{~A}$ & VON ROEDER & & $\mathrm{TX}$ & BORDEN & 1959 & 6835 & 63,015 & $19,299,794$ \\
\hline 94114666 & $8 \mathrm{~A}$ & VON ROEDER & WOLFCAMP & TX & BORDEN & 1964 & 6063 & 9,091 & $1,020,734$ \\
\hline 94116001 & $8 \mathrm{~A}$ & VON ROEDER, NORTH & & TX & BORDEN & 1954 & 6835 & 12,654 & $10,322,342$ \\
\hline 96180001 & $8 \mathrm{~A}$ & WELLMAN & & $\mathrm{TX}$ & TERRY & 1950 & 9712 & 228,174 & $74,181,795$ \\
\hline \multicolumn{4}{|c|}{ Totals } & & & & & $13,686,639$ & $2,699,242,936$ \\
\hline
\end{tabular}




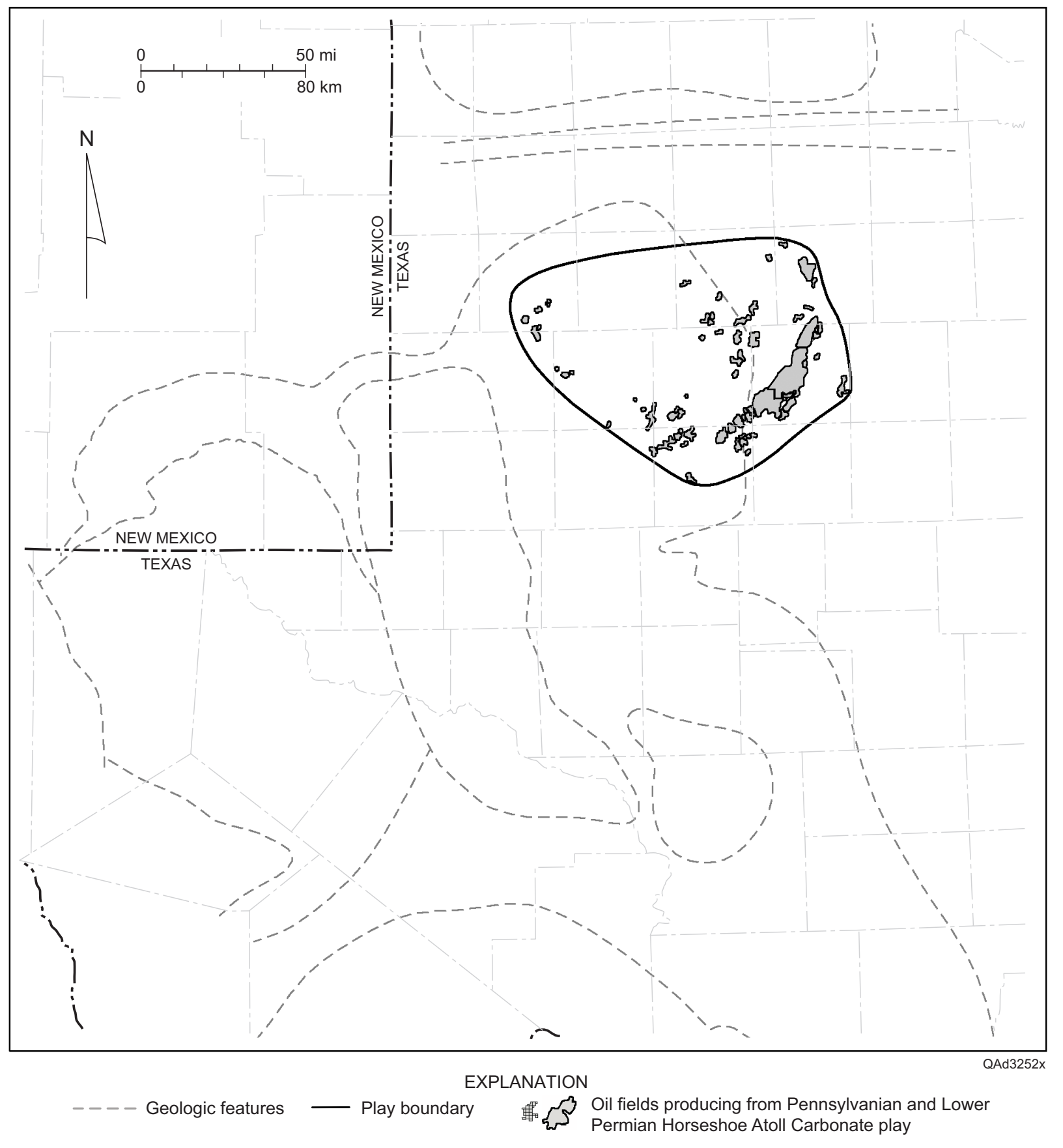

Figure 41. Play map for the Pennsylvanian and Lower Permian Horseshoe Atoll Carbonate play, showing location of reservoirs having $>1 \mathrm{MMbbl}$ cumulative production, the play boundary, and geologic features. See figure 1 for county names and figure 2 for identification of geologic features. 


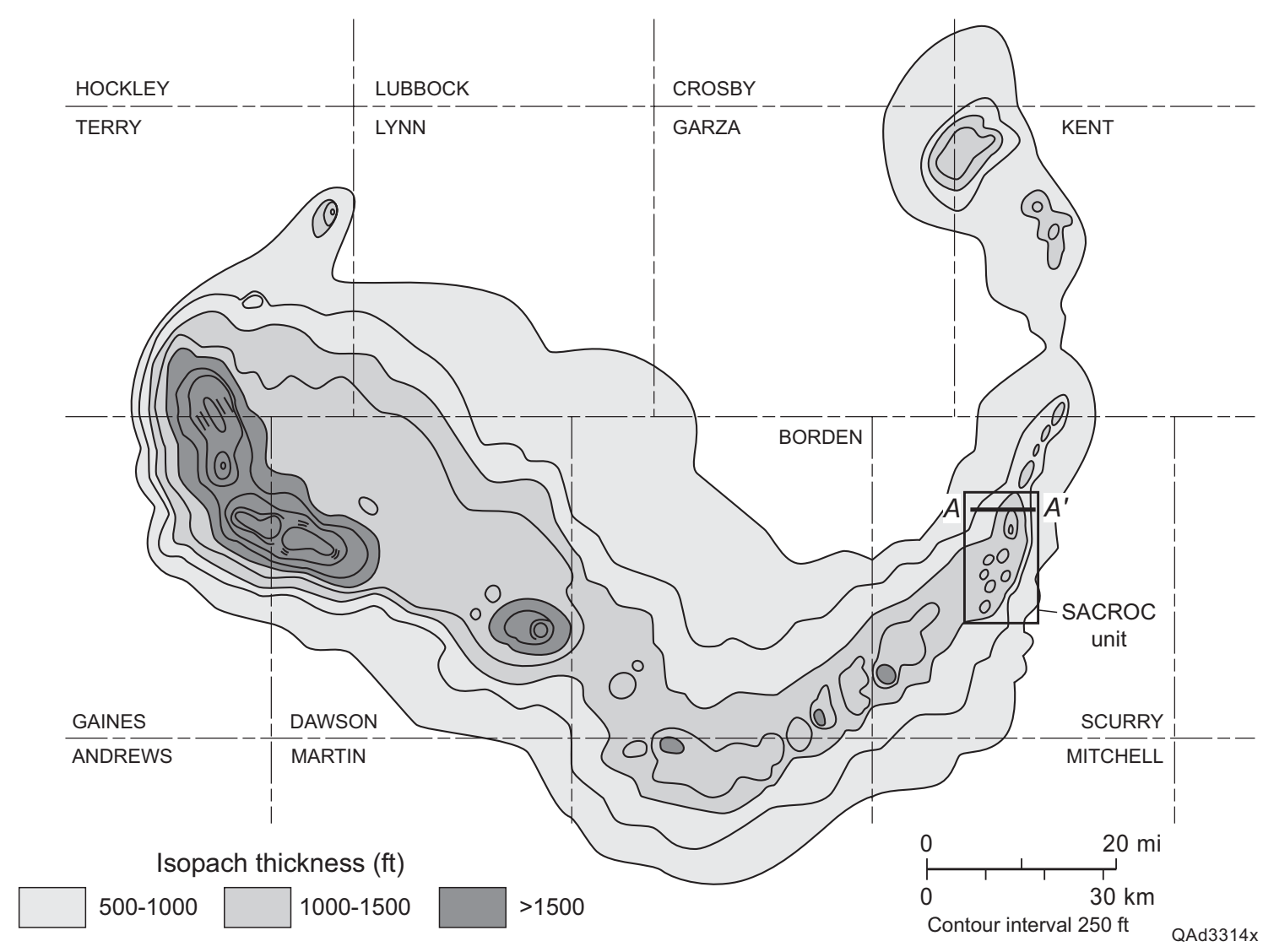

Figure 42. Isopach map of the Horseshoe Atoll carbonate. Modified from Galloway and others (1983); after Vest (1970). The thickest carbonate buildup is along the western margin, which is structurally lower, and where active atoll accretion continued into Early Permian time (Galloway and others, 1983). Cross section A-A' shown in figure 44.

Prevailing winds and ocean currents influenced the distribution of carbonate facies (Walker and others, 1991; 1995). Percentages of grainstones are highest in the northeast, windward part of the platform, whereas mud-dominated facies predominate to the southwest (Schatzinger, 1988; Walker and others, 1991; 1995).

Because the Horseshoe Atoll was deposited under icehouse conditions during a time of peak glaciation, there were high-frequency oscillations of sea level by 65 to $460 \mathrm{ft}$ (20 to $140 \mathrm{~m}$ ) (Reid and Reid, 1999; C. Kerans, personal communication, 2002). Fresh water percolated through the carbonate platform during sea-level lowstands, resulting in the development of 


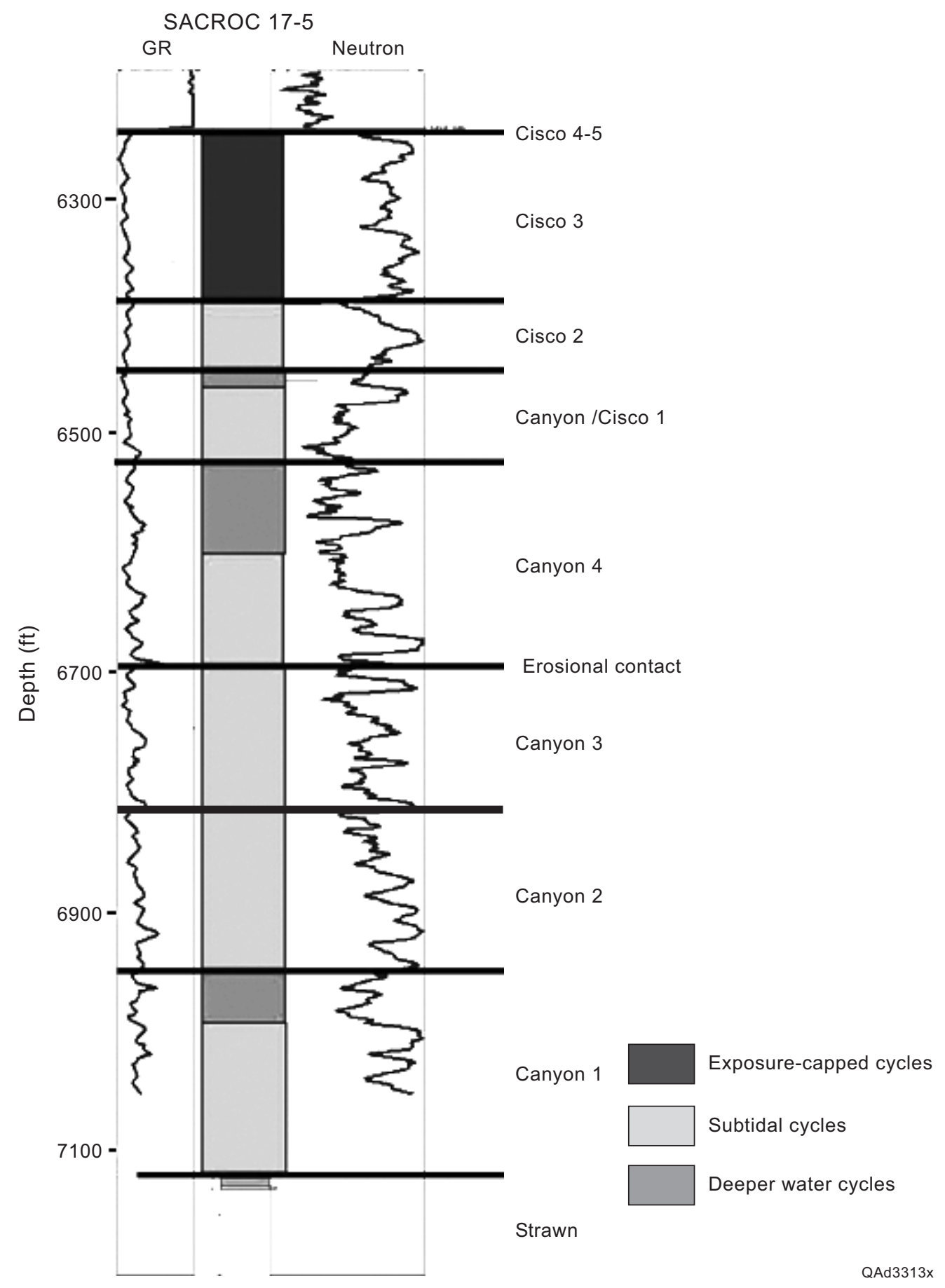

Figure 43. Typical log from the center of the Horseshoe Atoll in the SACROC unit showing high-frequency sequences.

caves, karst, and fractures, as well as fabric-selective moldic porosity (Reid and Reid, 1991;

Mazzullo, 1997; C. Kerans, personal communication, 2002). Prolonged exposure in the middle 
Cisco terminated platform growth locally (Kerans, 2001b). Exposure and erosion at sequence boundaries produced a series of truncation surfaces, with local development of lowstand/ transgressive wedges on the flanks of the platform. The Horseshoe Atoll was buried beneath prograding slope and basin clastic sediments from the east; Wolfcamp shales provide top and lateral seals.

A few of the reservoirs in this play were deposited south of the Horseshoe Atoll during sea-level lowstands, including BC Canyon in Howard County, Perriwinkle Canyon in Martin County, and Tex-Hamon Canyon in Dawson County (Reid and others, 1990; Mozynski and Reid, 1992; Mazzullo, 1997, 2000). Reservoirs occur in both in situ carbonate buildups and reworked limestone-clast breccias derived from the exposed carbonate platform. These shallowwater carbonates were deposited during lowstands in areas that were relative deepwater-slope environments during sea-level highstands (Mazzullo, 1997). Because the lowstand carbonate reservoirs are included, the play boundary extends farther south than is commonly shown for the outline of the Horseshoe Atoll.

Detailed reservoir studies have been conducted of the SACROC unit (Kerans, 2001a, b; Raines and others, 2001). The SACROC (Scurry Area Canyon Reef Operators Committee) unit, which incorporates nearly all of Kelly-Snyder field and part of Diamond -M- field, is the largest producing unit of the Horseshoe Atoll play. (Horseshoe Atoll production is listed in table 17 under Railroad Commission of Texas reservoir names and not by units. Thus, production from the SACROC unit is listed under the Kelly-Snyder reservoir, and production from the Sharon Ridge unit is listed under the Diamond -M- (Canyon Lime Area) reservoir.) Since discovery in the 1940's, primary, secondary, and tertiary recovery activities in the SACROC unit have been extensive, including the first $\mathrm{CO}_{2}$ flood in west Texas. 
The north part of the SACROC unit is depositionally and diagenetically complex (Raines and others, 2001). In this area, the 700-ft-thick (310-m) reservoir column consists of Canyon and Cisco carbonates that change from layered, open-shelf subtidal cycles having minimal diagenetic overprint (lower and mid-Canyon) to high-energy, shoal-related cycles having frequent exposure surfaces (upper Canyon-lower Cisco) and increased evidence of cycle and sequence-scale erosion (fig. 44) (Kerans, 2001a, b). Early Cisco deposition was characterized by dramatic changes in depositional style, including growth of pinnacle reefs and formation of complex, fractured, muddy, crinoid-dominated facies that resemble Waulsortian deeper-water buildups (Wilson, 1975). Porosity in the SACROC unit ranges from 4.0 to 20.0 percent and averages 9.8 percent; permeability ranges from $1 \mathrm{md}$ to $1,760 \mathrm{md}\left(1\right.$ to $\left.1,760 \times 10^{-3} \mu^{2}\right)$ and averages $19 \mathrm{md}\left(19 \times 10^{-3} \mu \mathrm{m}^{2}\right)$ (Wingate, 1996).

Seismic data were used extensively in constructing the stratigraphic framework of the SACROC unit and allowed significant advances in our understanding of the stratigraphic architecture that were not possible with logs alone. The result of this modeling is a 3-D volume that is drastically different from that previously generated. Huge volumes of the platform previously modeled as laterally continuous layers can be shown to consist of erosionally generated slope wedges associated with major icehouse eustatic sea-level falls (fig. 44). Complex promontories and reentrants similar to the present-day Bahama platform mark the edges of the field, and large windward-leeward asymmetries control reservoir-quality distribution. Muddy zones are extensive across the entire reservoir and have a large impact on flow (C. Kerans, personal communication, 2002). This modern model of the north part of the SACROC unit should greatly aid ongoing efforts for enhanced recovery using water-alternating-with-gas (WAG) processes and related practices. An estimated $700 \mathrm{MMbbl}\left(1.11 \times 10^{8} \mathrm{~m}^{3}\right)$ of 


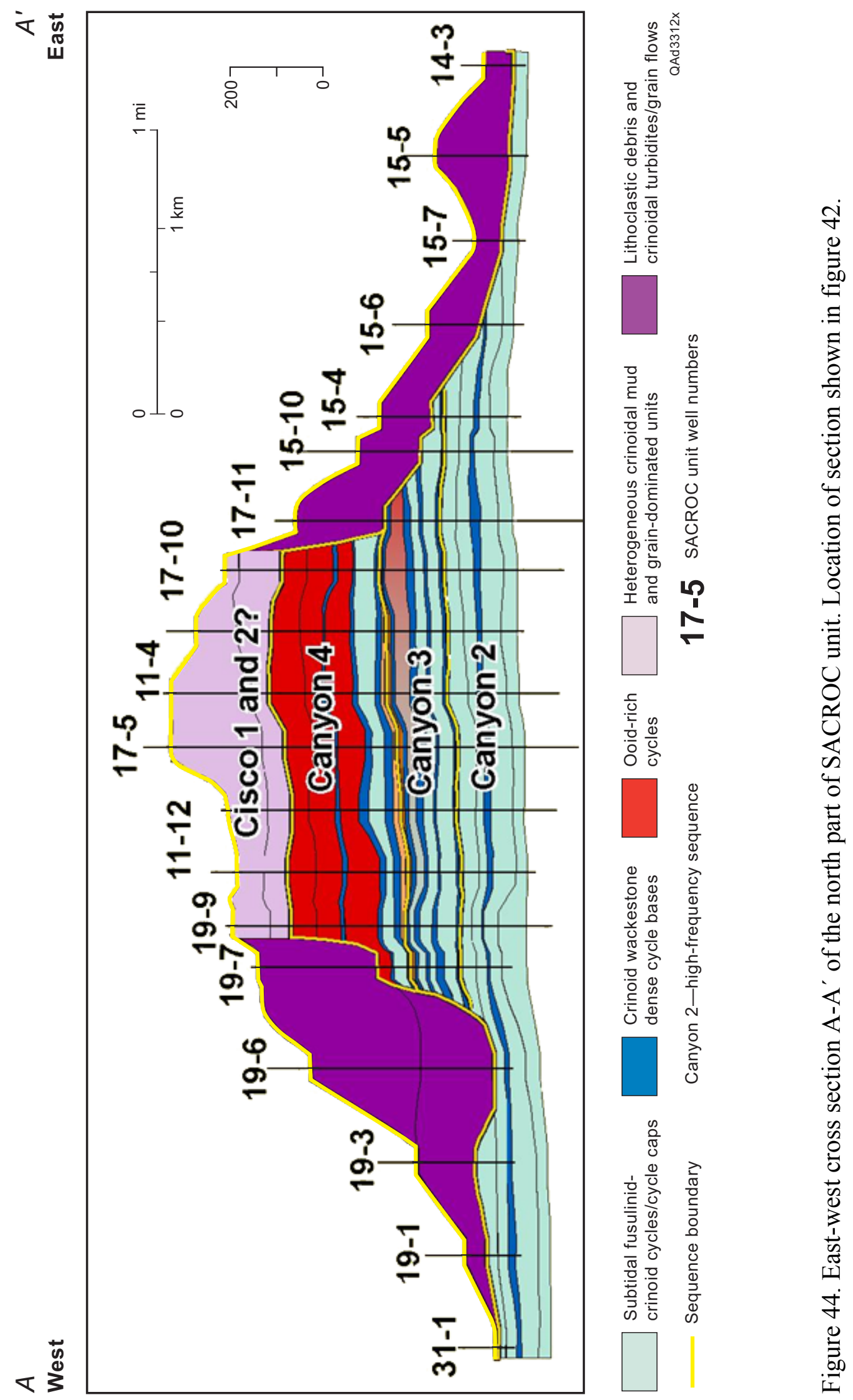


unrecovered mobile oil remains in the Pennsylvanian and Lower Permian Horseshoe Atoll Carbonate play (Tyler and Banta, 1989).

The SACROC unit has undergone $\mathrm{CO}_{2}$ flooding since 1972 , but recent modifications to the $\mathrm{CO}_{2}$-flood design in the central part of the unit have increased production by $\sim 6,000 \mathrm{bbl} / \mathrm{d}$ $\left(9.54 \times 10^{2} \mathrm{~m}^{3}\right)$ (Raines and others, 2001). Unit production in 2002 was at an 8-year high of $11,000 \mathrm{bbl} / \mathrm{d}\left(1.75 \times 10^{3} \mathrm{~m}^{3}\right)$ (Raines, 2002). The changes to the flood include (Raines and others, 2001)

(1) Targeting oil that is residual to the earlier waterflood, instead of attempting to recover oil unswept by the earlier waterflood.

(2) Ensuring that the pressure inside areas to be flooded is above minimum miscibility pressure before $\mathrm{CO}_{2}$ injection begins. If water is injected to raise the pressure in the area, it is injected below the parting pressure so that the formation is not fractured.

(3) Using smaller, injection-centered 5-spot patterns of about 40 acres.

(4) Containing the $\mathrm{CO}_{2}$ project area by a row of water-curtain wells beyond the producers to reduce $\mathrm{CO}_{2}$ migration outside the pattern. Mass-balance analysis indicated that approximately 50 percent of injected $\mathrm{CO}_{2}$ was being lost out of intended patterns.

(5) Increasing the volume of $\mathrm{CO}_{2}$ injected to $\sim 70$ percent of the hydrocarbon pore volume in the pattern area.

(6) Using a multiphase Water Alternating with Gas (WAG) injection scheme instead of one or two continuous $\mathrm{CO}_{2}$ slugs. WAG injection slows down the $\mathrm{CO}_{2}$ flood front to delay breakthrough and reduces costs. 
(7) Acquiring 4-D (time-lapse) cross-well seismic data to track $\mathrm{CO}_{2}$ in the reservoir by comparing seismic velocity profiles between wells after less-dense $\mathrm{CO}_{2}$ has replaced oil and water (Raines, 2003).

The revised $\mathrm{CO}_{2}$ flood has arrested production decline in the SACROC unit. In 2001 the central area that is undergoing the $\mathrm{CO}_{2}$ flood contributed $\sim 75$ percent of total unit production (Raines and others, 2001). Many of the lessons learned at the SACROC unit should be applicable both to $\mathrm{CO}_{2}$ floods in other reservoirs in this play and carbonate reservoirs in other plays in the Permian Basin. $\mathrm{CO}_{2}$ floods are also being conducted in other fields producing from the Horseshoe Atoll, including Salt Creek, Cogdell, Diamond -M-, the Sharon Ridge unit of Diamond -M- field (Kinder Morgan, personal communication, 2002), and Cogdell field (S. Pennell, personal communication, 2002). Phase $1 \mathrm{CO}_{2}$ flood at the north end of Cogdell field started in late 2001 and has increased production from an average of 369 bopd in 2001 to 2500 bopd in November 2002. Salt Creek field has undergone secondary waterflooding and tertiary $\mathrm{CO}_{2}$ flooding that have achieved a recovery of more than 50 percent of OOIP; ultimate recovery may be as high as 60 percent of OOIP (Genetti and others, 2002).

\section{References}

Galloway, W. E., Ewing, T. E., Garrett, C. M., Jr., Tyler, N., and Bebout, D. G., 1983, Atlas of major Texas oil reservoirs: The University of Texas at Austin, Bureau of Economic Geology Special Publication, $139 \mathrm{p}$.

Genetti, D. B., Whitaker, C. A., Smith, D. P., and Price, L. M., 2003, Applying improved recovery processes and effective reservoir management to maximize oil recovery at Salt Creek: Society of Petroleum Engineers, SPE $13^{\text {th }}$ Middle East Oil Show \& Conference, Bahrain, April, SPE 81458, 11 p. 
Kerans, C., 2001a, Reservoir architecture at SACROC and the Canyon-Cisco transition, in Viveiros, J. J., and Ingram, S. M., eds., The Permian Basin: microns to satellites, looking for oil and gas at all scales: West Texas Geological Society Publication No. 01-110, p. 49.

2001b, Stratigraphic and diagenetic controls on reservoir architecture of a nonreefal icehouse isolated platform-Sacroc Unit, Horseshoe Atoll, Texas (abs.): American Association of Petroleum Geologists Bulletin, v. 85, p. 386-387.

Mazzullo, S. J., 1997, Stratigraphic exploration plays in Ordovician to Lower Permian strata in the Midland Basin and on the Eastern Shelf, in DeMis, W. D., ed., Permian Basin oil and gas fields: turning ideas into production: West Texas Geological Society Publication No. 97-102, p. 1-37.

2000, Models of porosity evolution in Pennsylvanian lowstand carbonates (now in slope-to-basinal settings) and in Lower Permian, highstand-resedimented basinal carbonates, in Reid, S. T., ed., Geo-2000: into the future: Transactions, Southwest Section American Association of Petroleum Geologists, Publication SWS 2000-107, p. $130-138$.

Mozynski, D. C., and Reid, A. M., 1992, Perriwinkle-Perriwinkle North fields, Martin County, Texas: a Cisco-Canyon lowstand reef complex, in Cromwell, D. W., Moussa, M. T., and Mazzullo, L. J., eds., Transactions, Southwest Section, American Association of Petroleum Geologists, SWS 92-90, p. 61-78.

Raines, M. A., Dobitz, J. K., and Wehner, S. C., 2001, A review of the Pennsylvanian SACROC unit, in Viveiros, J. J., and Ingram, S. M., eds., The Permian Basin: microns to satellites, looking for oil and gas at all scales: West Texas Geological Society Publication No. 01-110, p. 67-74.

Raines, M. A., 2002, Interpretations on a Pennsylvanian reef, in Transactions, American Association of Petroleum Geologists Southwest Section Convention: Roswell Geological Society, p. 210.

2003, Reef heterogeneity as seen by wireline and cross-well seismic in the Pennsylvanian SACROC Unit, Scurry County, Texas, in Hunt, T. J., and Lufholm, P. H., eds., The Permian Basin: back to basics: West Texas Geological Society Publication No. 03-112, p. 325.

Reid, A. M., Mozynski, D. C., and Robinson, W. C., 1990, B.C. Canyon field: a low sea level stand, early Canyon carbonate buildup, in Flis, J. E., and Price, R. C., eds., Permian Basin oil and gas fields: innovative ideas in exploration and development: West Texas Geological Society, Publication No. 90-87, p. 119-129. 
Reid, A. M., and Reid, S. A. T., 1991, The Cogdell Field study, Kent and Scurry Counties, Texas: a post-mortem, in Candelaria, M., ed., Permian Basin plays, tomorrow's technology today: West Texas Geological Society, Publication No. 91-89, p. 39-66.

1999, Glacio-eustatic sea level fluctuations and the formation of Pennsylvanian age carbonate reservoirs in the Permian Basin of West Texas, in Grace, D. T., and Hinterlong, G. D., eds., The Permian Basin: providing energy for America: West Texas Geological Society Publication No. 99-106, p. 71-79.

Schatzinger, R. A., 1988, Changes in facies and depositional environments along and across the trend of the Horseshoe Atoll, Scurry and Kent Counties, Texas, in Cunningham, B. K., ed., Permian and Pennsylvanian stratigraphy, Midland Basin, West Texas: studies to aid in hydrocarbon exploration: Permian Basin Section, Society of Economic Paleontologists and Mineralogists, Publication No. 88-28, p. 79-107.

Tyler, N., and Banta, N. J., 1989, Oil and gas resources remaining in the Permian Basin: targets for additional hydrocarbon recovery: The University of Texas at Austin, Bureau of Economic Geology Geological Circular 89-4, 20 p.

Vest, E. L., 1970, Oil fields of Pennsylvanian-Permian Horseshoe Atoll, West Texas, in Halbouty, M. T., ed., Geology of giant petroleum fields: American Association of Petroleum Geologists Memoir 14, p. 185-203.

Walker, D. A., Golonka, J., Reid, A., and Reid, S., 1995, The effects of paleolatitude and paleogeography on carbonate sedimentation in the Late Paleozoic, in Huc, A.-Y., ed., Paleogeography, paleoclimate, and source rocks: American Association of Petroleum Geologists Studies in Geology No. 40, p. 133-155.

Walker, D. A., Golonka, J., Reid, A., and Tomlinson-Reid, S., 1991, The effects of late Paleozoic paleolatitude and paleogeography on carbonate sedimentation in the Midland basin, Texas, in Candelaria, M., ed., Permian Basin plays - tomorrow's technology today: West Texas Geological Society Publication No. 91-89, p. 141-162.

Wilson, J. L., 1975, Carbonate facies in geologic history: New York, Springer-Verlag, 471 p.

Wingate, T. P., 1996, Kelly-Snyder field (SACROC unit): oil \& gas fields in West Texas, v. VII: West Texas Geological Society Publication Number 96-99, p.71-76. 
Upper Pennsylvanian and Lower Permian Slope and Basinal Sandstone (Play 113)

The Upper Pennsylvanian and Lower Permian Slope and Basinal Sandstone play, called Upper Pennsylvanian Slope Sandstone in the oil atlas (Galloway and others, 1983), has produced 271.4 MMbbl $\left(4.31 \times 10^{7} \mathrm{~m}^{3}\right)$ from 59 reservoirs in the Midland Basin and along the Eastern Shelf (table 18, fig. 45). Much of the play is in the North-Central Texas geologic province, but because a significant part of the play is located in the Permian Basin, the entire play is included in this portfolio. Of the 59 reservoirs in the play (fig. 45), 28 are in the Permian Basin and 31 are in North-Central Texas. The reservoirs in the Permian Basin had cumulative production of 108.3 MMbbl $\left(1.72 \times 10^{7} \mathrm{~m}^{3}\right)$, compared with 163.1 MMbbl $\left(2.59 \times 10^{7} \mathrm{~m}^{3}\right)$ from the NorthCentral Texas reservoirs.

As the Eastern Shelf prograded into the Midland Basin during Cisco and Wolfcamp deposition, a sequence of submarine fans accumulated at the base of offlapping slope wedges (fig. 46) (Galloway and Brown, 1972; Galloway and others, 1983; Brown and others, 1987, 1990). Reservoir sand bodies were deposited in lower parts of the slope wedges along a broad north-south-trending belt. As a result of miscorrelation of slope and basin reservoirs with older shelf units, the "Canyon" sandstone reservoirs of this play are commonly correlative with Cisco or Wolfcamp strata on the Eastern Shelf (Galloway and others, 1983; Neuberger, 1987).

The sandstones of this play were interpreted by Brown and others $(1987,1990)$ and Whitsitt (1992b) to have been deposited during periods of sea-level lowstand. Rapid fall of relative sea level eroded submarine canyons and produced Type 1 unconformities; basin-floor fans were deposited on the unconformities. During maximum fall of relative sea level and earliest relative rise, lowstand slope fans and deltaic/slope wedge systems prograded into the Midland Basin (fig. 47) (Brown and others, 1990). The reservoirs are developed within large, 
Table 18. Upper Pennsylvanian and Lower Permian Slope and Basinal Sandstone play (play 113). Production shown for fields that have had others combined into them represents the totals; combined fields are highlighted.

\begin{tabular}{|c|c|c|c|c|c|c|c|c|c|}
\hline RRC RESN & RRC & FLDNAME & RESNAME & STATE & COUNTY & DISCYR & DEPTHTOP & 2000 PROD & CUMPROD \\
\hline 2718400 & $7 \mathrm{C}$ & ANDREW A. & CANYON & $\mathrm{TX}$ & IRION & 1979 & 7390 & 58,724 & $3,321,404$ \\
\hline 3602550 & $7 \mathrm{C}$ & ARLEDGE & PENN SAND & $\mathrm{TX}$ & COKE & 1974 & 5270 & 7,065 & $1,191,965$ \\
\hline 4170666 & $7 \mathrm{~B}$ & ASPERMONT LAKE & CANYON SAND & TX & STONEWALL & 1951 & 4862 & 9,193 & $2,236,772$ \\
\hline 5143300 & $7 \mathrm{C}$ & BAKER RANCH & CANYON & TX & IRION & 1978 & 7019 & 24,266 & $2,298,589$ \\
\hline 9630400 & $7 \mathrm{C}$ & BLOODWORTH, NE. & 5750 CANYON & $\mathrm{TX}$ & NOLAN & 1967 & 8,124 & 8,124 & $3,710,179$ \\
\hline 12175852 & $7 \mathrm{C}$ & BRONTE & 4800 SAND & $\mathrm{TX}$ & COKE & 1952 & 4838 & 0 & $6,075,918$ \\
\hline 12244075 & $7 \mathrm{C}$ & BROOKS & CANYON K & TX & IRION & 1973 & 6494 & 19,495 & $1,072,548$ \\
\hline 17991500 & $7 \mathrm{C}$ & CHRISTI & CANYON 6800 & $\mathrm{TX}$ & IRION & 1971 & 6824 & 5,798 & $1,192,011$ \\
\hline 18799498 & $7 \mathrm{~B}$ & CLAYTONVILLE & CANYON SD. 5200 & $\mathrm{TX}$ & FISHER & 1955 & 5197 & 3,458 & $2,094,750$ \\
\hline 19346284 & $8 \mathrm{~A}$ & COGDELL & FULLER SAND & TX & KENT & 1950 & 4985 & 0 & $1,234,509$ \\
\hline 20097700 & 8 & CONGER & PENN & $\mathrm{TX}$ & GLASSCOCK & 1978 & 7739 & 222,782 & $20,406,213$ \\
\hline 20101500 & $7 \mathrm{C}$ & CONGER, SW & PENN & TX & REAGAN & 1979 & 8134 & 19,879 & $2,675,544$ \\
\hline 25930284 & $7 \mathrm{C}$ & DOVE CREEK & CANYON -C- & TX & TOM GREEN & 1965 & 6497 & 11,268 & $1,205,124$ \\
\hline 25930426 & $7 \mathrm{C}$ & DOVE CREEK & CANYON -D- & $\mathrm{TX}$ & IRION & 1965 & 6540 & 30,509 & $3,140,304$ \\
\hline 31628250 & $7 \mathrm{~B}$ & FLOWERS & CANYON SAND & $\mathrm{TX}$ & STONEWALL & 1951 & 4024 & 99,721 & $31,076,719$ \\
\hline 31634500 & 7B & FLOWERS, W. & CANYON SAND & TX & STONEWALL & 1952 & 4270 & 9,629 & $5,653,948$ \\
\hline 32653400 & $7 \mathrm{~B}$ & FRANKIRK & CANYON SAND & $T X$ & STONEWALL & 1952 & 4587 & 18,389 & $1,526,680$ \\
\hline 32654332 & $7 \mathrm{~B}$ & FRANKIRK, EAST & CANYON SD & $\mathrm{TX}$ & STONEWALL & 1960 & 4406 & 6,874 & $1,940,490$ \\
\hline 33190001 & $8 \mathrm{~A}$ & FULLER & & TX & SCURRY & 1951 & 5147 & 18,667 & $7,431,645$ \\
\hline 33191500 & $8 \mathrm{~A}$ & FULLER, EAST & FULLER -B- & $T X$ & SCURRY & 1961 & 4935 & 15,763 & $1,251,629$ \\
\hline 33196332 & $8 \mathrm{~A}$ & FULLER, SE. & FULLER & $\mathrm{TX}$ & SCURRY & 1957 & 5032 & 6,292 & $1,233,168$ \\
\hline 33196498 & $8 \mathrm{~A}$ & FULLER, SE. & FULLER -C- & TX & SCURRY & 1961 & 5029 & 23,956 & $1,356,946$ \\
\hline 37328333 & $7 \mathrm{~B}$ & GUEST & CANYON SAND & $T X$ & STONEWALL & 1951 & 4557 & 47,833 & $10,548,187$ \\
\hline 44042125 & $7 \mathrm{C}$ & I. A. B. & HARRIS SAND & $\mathrm{TX}$ & COKE & 1970 & 5275 & 1,894 & $1,097,186$ \\
\hline 44042750 & $7 \mathrm{C}$ & I. A. B. & PENN 5070 & $T X$ & COKE & 1957 & 5063 & 323 & $1,023,437$ \\
\hline 44045600 & $7 \mathrm{C}$ & I. A. B., NE. & PENN. 5150 & TX & COKE & 1961 & 5192 & 12,038 & $2,950,613$ \\
\hline 45580666 & $7 \mathrm{C}$ & JAMESON & STRAWN & $\mathrm{TX}$ & COKE & 1952 & 5800 & 113,419 & $42,408,749$ \\
\hline 45991666 & $8 \mathrm{~A}$ & JAYTON, WEST & STRAWN SAND & $\mathrm{TX}$ & KENT & 1963 & 6466 & 8,681 & $1,938,821$ \\
\hline 47542250 & 7B & JUDY GAIL & CANYON SAND & TX & FISHER & 1953 & 4546 & 66,486 & $2,726,433$ \\
\hline 48422500 & $7 \mathrm{~B}$ & KEELER-WIMBERLY & CANYON SD. & $\mathrm{TX}$ & FISHER & 1952 & 4528 & 9,894 & $1,116,777$ \\
\hline 48583498 & $8 \mathrm{~A}$ & KELLY-SNYDER & CISCO SAND & $\mathrm{TX}$ & SCURRY & 1952 & 6180 & 12,056 & $15,359,584$ \\
\hline 51592500 & 7B & LAKE TRAMMEL, S. & CANYON & TX & NOLAN & 1951 & 5130 & 48,488 & $3,686,833$ \\
\hline 51595333 & $7 \mathrm{~B}$ & LAKE TRAMMEL, W. & CANYON & $\mathrm{TX}$ & NOLAN & 1953 & 5217 & 67,116 & $12,832,787$ \\
\hline 56382200 & $8 \mathrm{~A}$ & MABEN & $\mathrm{CISCO}$ & $\mathrm{TX}$ & KENT & 1989 & 5664 & 112,246 & $1,481,691$ \\
\hline 60496500 & 7B & MENGEL, E. & CANYON SAND & TX & STONEWALL & 1961 & 4276 & 107,241 & $2,081,076$ \\
\hline 60989200 & $8 \mathrm{~A}$ & MICHELLE KAY & $\mathrm{CISCO}$ & $T X$ & KENT & 1983 & 5835 & 86,782 & $2,252,054$ \\
\hline 65821666 & $7 \mathrm{~B}$ & NOODLE, N. & CISCO, LOWER & $T X$ & JONES & 1953 & 3669 & 9,738 & $2,102,487$ \\
\hline 65823400 & $7 \mathrm{~B}$ & NOODLE, NW. & CANYON SD. 4000 & TX & JONES & 1955 & 3950 & 3,208 & $1,071,443$ \\
\hline 67999333 & $7 \mathrm{C}$ & OZONA, NW. & CANYON & $\mathrm{TX}$ & CROCKETT & 1963 & 6675 & 17,508 & $1,913,927$ \\
\hline 69098166 & 7B & PARDUE & CANYON & TX & FISHER & 1949 & 4415 & 10,899 & $3,231,747$ \\
\hline 71779001 & $7 \mathrm{~B}$ & PITZER & & TX & JONES & 1946 & 4655 & 22,741 & $3,484,394$ \\
\hline 73243500 & $7 \mathrm{C}$ & PROBANDT & CANYON & $\mathrm{TX}$ & TOM GREEN & 1975 & 7169 & 8,505 & $1,468,833$ \\
\hline 74863200 & $7 \mathrm{~B}$ & RAVEN CREEK & CANYON SAND & $\mathrm{TX}$ & FISHER & 1954 & 4228 & 2,079 & $1,602,581$ \\
\hline 76360500 & $7 \mathrm{~B}$ & RICE BROS. & CANYON & $T X$ & FISHER & 1975 & 4486 & 11,095 & $1,511,631$ \\
\hline 77622500 & $7 \mathrm{C}$ & ROCK PEN & CANYON & $\mathrm{TX}$ & IRION & 1976 & 7145 & 35,014 & $3,205,731$ \\
\hline 78567125 & $7 \mathrm{~B}$ & ROUND TOP & CANYON & $\mathrm{TX}$ & FISHER & 1953 & 4568 & 6,197 & $2,862,869$ \\
\hline 78819500 & $7 \mathrm{~B}$ & ROYSTON & CANYON & TX & FISHER & 1953 & 4460 & 3,751 & $1,358,151$ \\
\hline 83873250 & $7 \mathrm{C}$ & SIXTY SEVEN & CANYON & TX & IRION & 1966 & 6684 & 3,002 & $1,081,381$ \\
\hline 79303666 & $8 \mathrm{~A}$ & S-M-S & CANYON SAND & TX & KENT & 1954 & 6100 & 17,465 & $11,405,716$ \\
\hline 87015881 & $7 \mathrm{C}$ & SUGG RANCH & CANYON & TX & STERLING & 1987 & 7860 & 166,487 & $7,615,629$ \\
\hline 87018550 & 8 & SUGG RANCH & CANYON DIST 08 & $T X$ & STERLING & 1987 & 7860 & 89,130 & $6,483,258$ \\
\hline 87613500 & $7 \mathrm{~B}$ & SWEETWATER & CANYON SAND & $\mathrm{TX}$ & FISHER & 1955 & 5230 & 3,757 & $4,807,189$ \\
\hline 87920500 & $7 \mathrm{C}$ & T. D. & 6575 & $\mathrm{TX}$ & TOM GREEN & 1982 & 6592 & 17,388 & $1,001,559$ \\
\hline 90383250 & 7B & TOLAR & CANYON & TX & FISHER & 1953 & 4502 & 5,203 & $1,524,888$ \\
\hline 90674375 & $7 \mathrm{~B}$ & TOMPKINS & CANYON SD. 4900 & $T X$ & STONEWALL & 1956 & 4824 & 0 & $1,452,542$ \\
\hline 90674875 & $7 \mathrm{~B}$ & TOMPKINS & STRAWN SAND & $T X$ & STONEWALL & 1955 & 5347 & 0 & $2,154,676$ \\
\hline 90694125 & $8 \mathrm{~A}$ & TONTO & CANYON SAND & $T X$ & SCURRY & 1955 & 6690 & 16,982 & $3,093,714$ \\
\hline 93410710 & $7 \mathrm{C}$ & VELREX & HENDERSON UPPER & $\mathrm{TX}$ & SCHLEICHER & 1964 & 6406 & 14,060 & $1,008,498$ \\
\hline 99658500 & $7 \mathrm{C}$ & ZAN-ZAN & MID. CANYON & TX & IRION & 1988 & 6014 & 23,815 & $1,174,262$ \\
\hline \multicolumn{4}{|c|}{ Totals } & & & & & $1,802,373$ & $271,448,389$ \\
\hline
\end{tabular}

elongate, fan-shaped lobes of sandstone that thin up depositional and structural dip and lap out against the slope and shelf margin.

In Flowers (Canyon Sand) field, production is from turbidite sandstones deposited in submarine-fan channel, lobe, and overbank/levee environments (Neuberger, 1987). Sandstones 


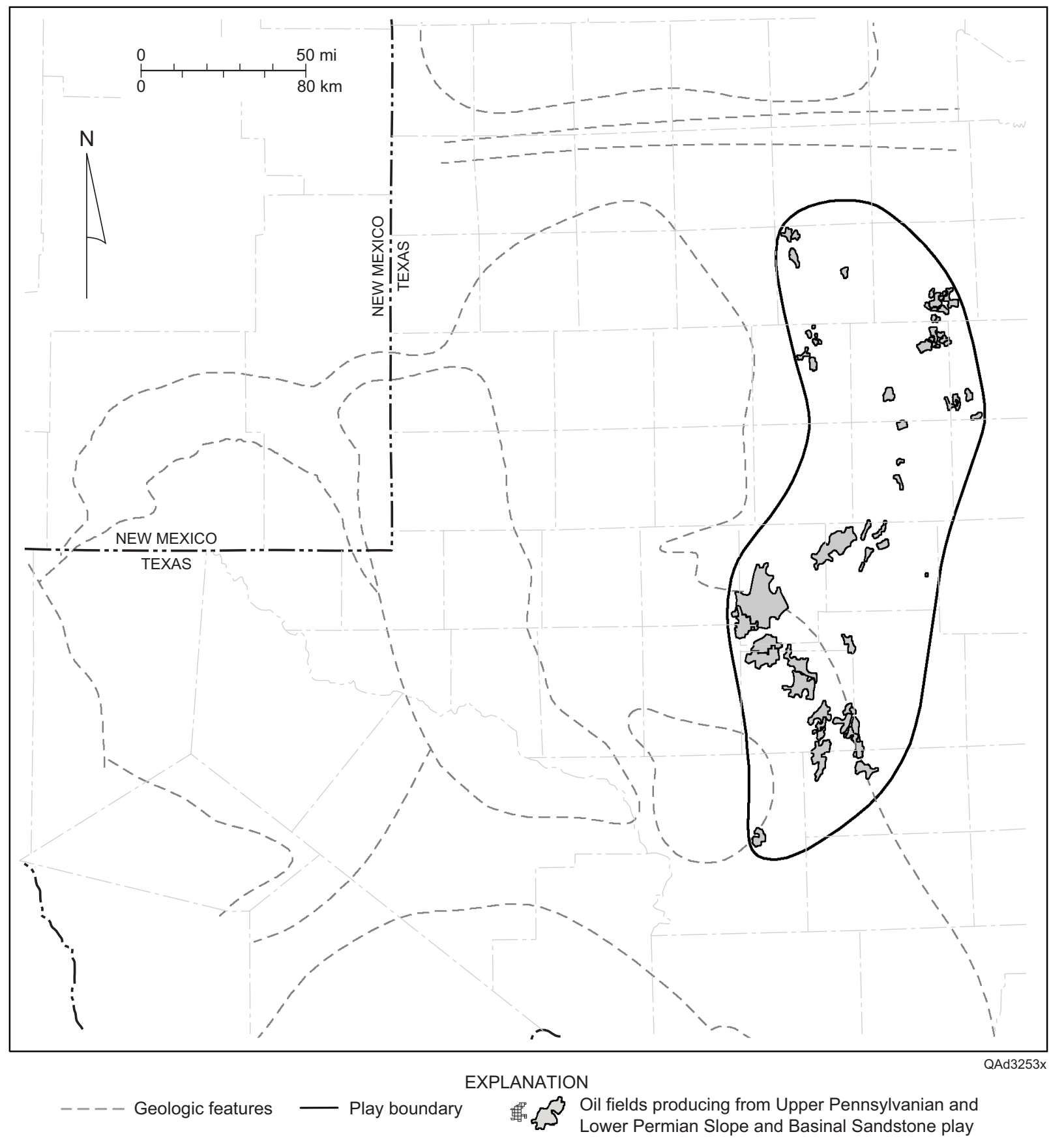

Figure 45. Play map for the Upper Pennsylvanian and Lower Permian Slope and Basinal Sandstone play, showing location of reservoirs having $>1$ MMbbl cumulative production, the play boundary, and geologic features. See figure 1 for county names and figure 2 for identification of geologic features. 


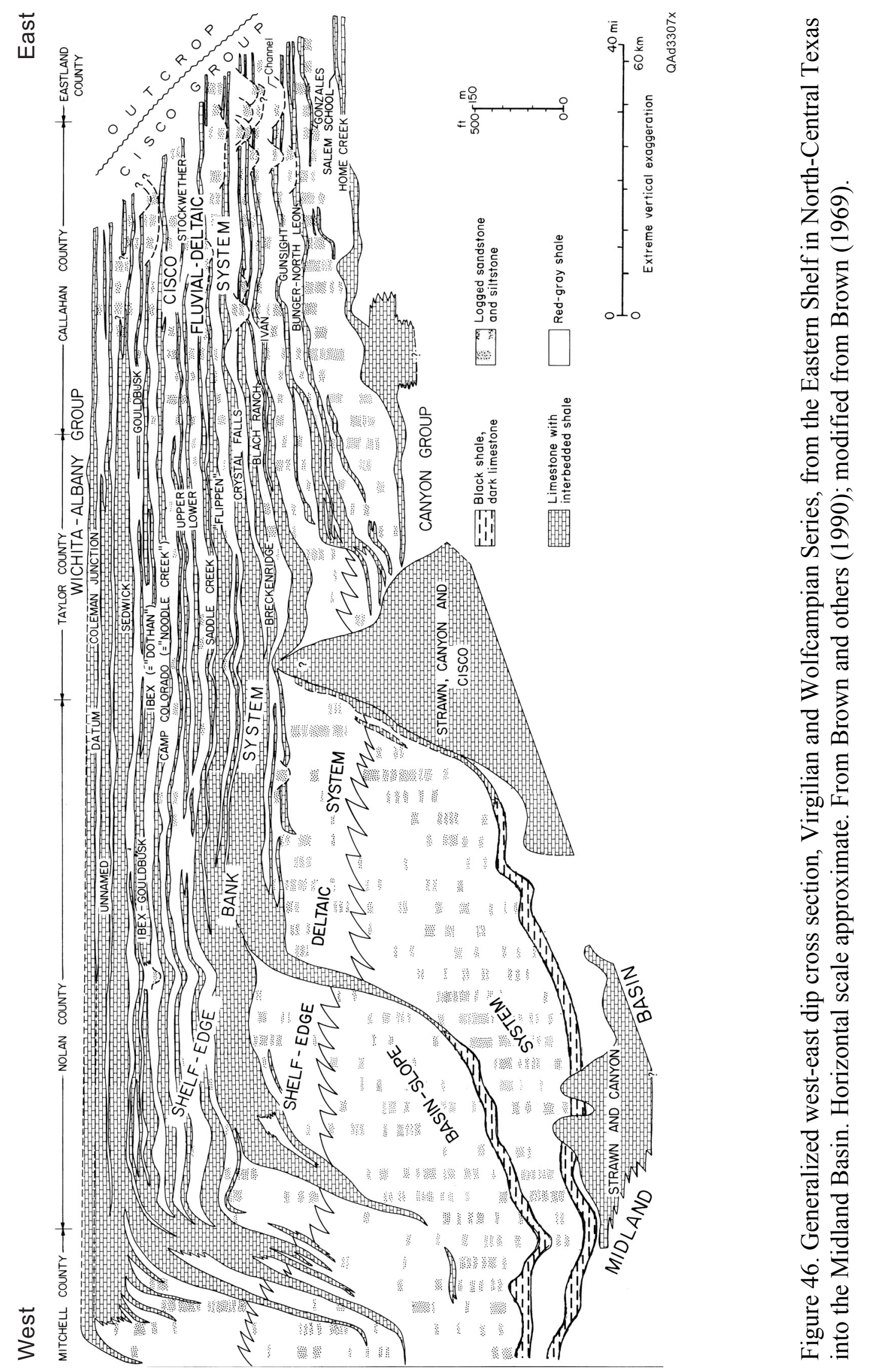




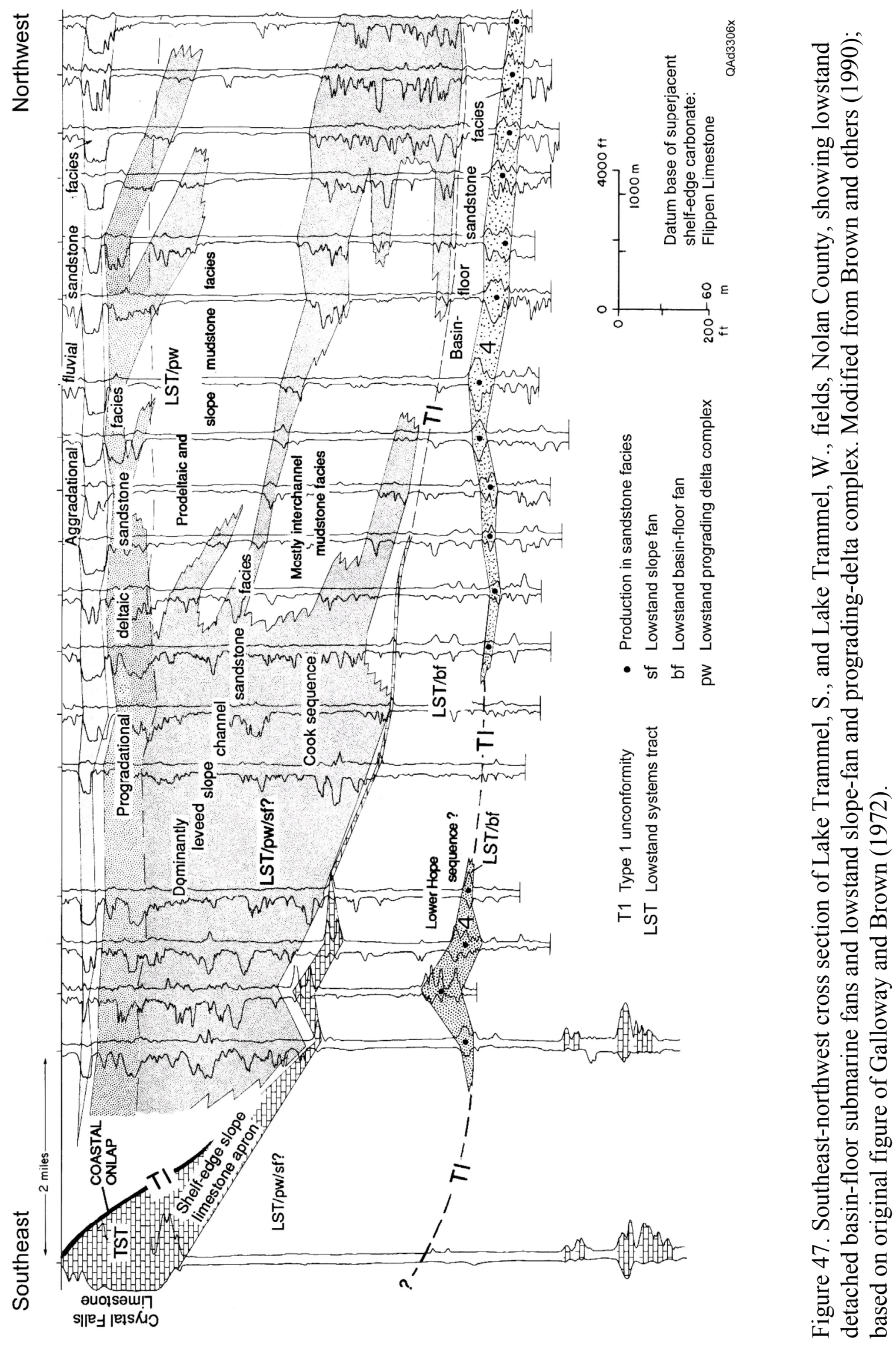


are fine- to very fine grained, thin- to thick-bedded turbidites (Neuberger, 1987). The reservoir zone is a complex of vertically separated, laterally discontinuous, lobate to elongate sandstones (Galloway and others, 1983). The reservoir at Zan Zan (Middle Canyon) field in Irion County is composed of thin- to medium-bedded, fine-grained sandstone (Whitsitt, 1992a).

The southern boundary of the play (fig. 45) represents the transition to predominantly gas production instead of oil. Slope and basinal sandstones continue south into Schleicher, Sutton, Crockett, Val Verde, and Edwards Counties, where they produce gas in the Upper Pennsylvanian and Lower Permian Slope and Basinal Sandstone gas play (Kosters and others, 1989).

Reservoir sandstones in the play have average porosity ranging from 12 to 19 percent and average permeability ranging from 2 to $117 \mathrm{md}\left(2\right.$ to $\left.117 \times 10^{-3} \mu \mathrm{m}^{2}\right)$ (Galloway and others, 1983). Log-calculated water saturation in productive intervals of Zan Zan (Middle Canyon) field is commonly $>50$ percent, but these values may be in error because siderite cement in the sandstones may increase resistivity or because of the presence of abundant water in micropores (Whitsitt, 1992a). Core data should be used to supplement well logs to accurately evaluate reservoir properties of these low-resistivity sandstones (Whitsitt, 1992a). 


\section{References}

Brown, L. F., Jr., 1969, North Texas (eastern shelf) Pennsylvanian delta systems, in Fisher, W. L., Brown, L. F., Jr., Scott, A. J., and McGowen, J. H., eds., Delta systems in the exploration for oil and gas: The University of Texas at Austin, Bureau of Economic Geology Special Publication, p. 40-53.

Brown, L. F., Jr., Solís Iriarte, R. F., and Johns, D. A., 1987, Regional stratigraphic cross sections, Upper Pennsylvanian and Lower Permian strata (Virgilian and Wolfcampian Series), North-Central Texas: The University of Texas at Austin, Bureau of Economic Geology cross sections, 27 p. and 27 plates.

1990, Regional depositional systems tracts, paleogeography, and sequence stratigraphy, Upper Pennsylvanian and Lower Permian strata, North- and West-Central Texas: The University of Texas at Austin, Bureau of Economic Geology Report of Investigations No. 197, $116 \mathrm{p}$.

Galloway, W. E., and Brown, L. F., Jr., 1972, Depositional systems and shelf-slope relationships in Upper Pennsylvanian rocks, North-Central Texas: The University of Texas at Austin, Bureau of Economic Geology Report of Investigations No. 75, 62 p.

Galloway, W. E., Ewing, T. E., Garrett, C. M., Jr., Tyler, N., and Bebout, D. G., 1983, Atlas of major Texas oil reservoirs: The University of Texas at Austin, Bureau of Economic Geology Special Publication, 139 p.

Kosters, E. C., Bebout, D. G., Seni, S. J., Garrett, C. M., Jr., Brown, L. F., Jr., Hamlin, H. S., Dutton, S. P., Ruppel, S. C., Finley, R. J., and Tyler, Noel, 1989, Atlas of major Texas gas reservoirs: The University of Texas at Austin, Bureau of Economic Geology Special Publication, $161 \mathrm{p}$.

Neuberger, D. J., 1987, Swastika (Upper Pennsylvanian) shelf-margin deltas and delta-fed turbidites, Flowers "Canyon Sand Field" area, Stonewall County, Texas: The University of Texas at Austin, M.S. thesis, $171 \mathrm{p}$.

Whitsitt, P., 1992a, Petrography and log analysis of the Zan Zan middle "Canyon" sandstone, eastern Irion County, Texas, in Cromwell, D. W., Moussa, M. T., and Mazzullo, L. J., eds., Transactions, Southwest Section American Association of Petroleum Geologists, SWS 92-90, p. 101-106.

1992b, Sequence stratigraphy of the upper and middle "Canyon" oil and gas fields in eastern Irion County, Texas, and the potential for future exploration, in Cromwell, D. W., Moussa, M. T., and Mazzullo, L. J., eds., Transactions, Southwest Section American Association of Petroleum Geologists, SWS 92-90, p. 107-111. 


\section{Lower Permian Plays}

Five plays in the Permian Basin produce from Lower Permian (Wolfcampian and Leonardian) reservoirs: (1) Wolfcamp Platform Carbonate, (2) Wolfcamp/Leonard Slope and Basinal Carbonate, (3) Leonard Restricted Platform Carbonate, (4) Abo Platform Carbonate, and (5) Spraberry/Dean Submarine-Fan Sandstone. Only three of these plays (1, 3, and 5) were described in the oil atlas (Galloway and others, 1983). The Wolfcamp/Leonard Deepwater Carbonate play was defined by Kosters and others (1989) as a gas play and by Tyler and others (1991) as an oil play. The Abo Platform Carbonate play was defined by Holtz and others (1993).

The Leonard Restricted Platform Carbonate play was called the Clear Fork Platform Carbonate play in the oil atlas.

\section{References}

Galloway, W. E., Ewing, T. E., Garrett, C. M., Jr., Tyler, N., and Bebout, D. G., 1983, Atlas of major Texas oil reservoirs: The University of Texas at Austin, Bureau of Economic Geology Special Publication, 139 p.

Holtz, M. H., Garrett, C. M., Jr., and Tremblay, T. A., 1993, Update of Atlas of Major Texas Oil Reservoirs Data Base and Atlas of Major Texas Gas Reservoirs Data Base: The University of Texas at Austin, Bureau of Economic Geology contract report prepared for the U.S. Geological Survey under Contract No. 1434-93-C-40079, 14 p. plus data tape.

Kosters, E. C., Bebout, D. G., Seni, S. J., Garrett, C. M., Jr., Brown, L. F., Jr., Hamlin, H. S., Dutton, S. P., Ruppel, S. C., Finley, R. J., and Tyler, Noel, 1989, Atlas of major Texas gas reservoirs: The University of Texas at Austin, Bureau of Economic Geology Special Publication, $161 \mathrm{p}$.

Tyler, N., Bebout, D. G., Garrett, C. M., Jr., Guevara, E. H., Hocott, C. R., Holtz, M. H., Hovorka, S. D., Kerans, C., Lucia, F. J., Major, R. P., Ruppel, S. C., and Vander Stoep, G. W., 1991, Integrated characterization of Permian Basin reservoirs, University Lands, West Texas: targeting the remaining resource for advanced oil recovery: The University of Texas at Austin, Bureau of Economic Geology Report of Investigations No. 203, $136 \mathrm{p}$. 
Wolfcamp Platform Carbonate (Play 114)

The Wolfcamp Platform Carbonate play, which lies on the Central Basin Platform and

Northwest Shelf in Texas and New Mexico (fig. 48), has produced 460.5 MMbbl $\left(7.32 \times 10^{7} \mathrm{~m}^{3}\right)$

through 2000 from 54 reservoirs (table 19). The play is split into two parts by the San Simon

Channel (figs. 2, 48). Many of the reservoirs in the play are located along the east margin of the

Central Basin Platform; the west part of the Central Basin Platform remained exposed

Table 19. Wolfcamp Platform Carbonate play (play 114). Production shown for fields that have had others combined into them represents the totals; combined fields are highlighted.

\begin{tabular}{|c|c|c|c|c|c|c|c|c|c|}
\hline RRC RESN & RRC & FLDNAME & RESNAME & STATE & COUNTY & DISCYR & DEPTHTOP & 2000 PROD & CUMPROD \\
\hline 1964666 & $8 \mathrm{~A}$ & ALSABROOK & WOLFCAMP & $\mathrm{TX}$ & GAINES & 1953 & 9125 & 0 & $1,053,164$ \\
\hline 2725750 & 8 & ANDREWS & WOLFCAMP & $\mathrm{TX}$ & ANDREWS & 1953 & 8596 & 0 & $22,785,915$ \\
\hline 2725760 & 8 & ANDREWS & WOLFCAMP-PENN. & TX & ANDREWS & 1995 & 9380 & 666,442 & $3,692,443$ \\
\hline 2730852 & 8 & ANDREWS, SOUTH & WOLFCAMP & TX & ANDREWS & 1953 & 9183 & 63,186 & $15,169,599$ \\
\hline 5166888 & 8 & BAKKE & WOLFCAMP & $\mathrm{TX}$ & ANDREWS & 1956 & 8492 & 178,729 & $25,048,339$ \\
\hline 21292125 & 8 & COWDEN, SOUTH & CANYON 8790 & TX & ECTOR & 1966 & 9202 & 534,499 & $43,011,248$ \\
\hline 21292250 & 8 & COWDEN, SOUTH & CANYON 8900 & $\mathrm{TX}$ & ECTOR & 1968 & 8993 & 57,366 & $13,270,487$ \\
\hline 22576333 & $8 \mathrm{~A}$ & D. E. B. & WOLFCAMP & TX & GAINES & 1960 & 9200 & 495,459 & $22,699,269$ \\
\hline 22576666 & $8 \mathrm{~A}$ & D. E. B. & WOLFCAMP, ZONE B & TX & GAINES & 1960 & 9400 & 15,297 & $1,468,007$ \\
\hline 26538830 & 8 & DUNE & WOLFCAMP & TX & CRANE & 1957 & 7710 & 11,083 & $7,564,044$ \\
\hline 27779500 & 8 & EDWARDS -04-, S. & 7900 & $\mathrm{TX}$ & CRANE & 1967 & 7925 & 0 & $2,312,280$ \\
\hline 27746500 & 8 & EDWARDS, WEST & CANYON & TX & ECTOR & 1970 & 8962 & 65,268 & $23,979,851$ \\
\hline 30394750 & 8 & FASKEN & WOLFCAMP & TX & ANDREWS & 1952 & 8571 & 60,615 & $7,451,167$ \\
\hline 30394875 & 8 & FASKEN & WOLFCAMP, NORTH & $\mathrm{TX}$ & ANDREWS & 1956 & 8290 & 6,240 & $1,343,663$ \\
\hline 30398875 & 8 & FASKEN, SOUTH & WOLFCAMP & $T X$ & ECTOR & 1960 & 8475 & 27,596 & $1,298,246$ \\
\hline 31768666 & 8 & FLYING -W- & WOLFCAMP & TX & WINKLER & 1955 & 8190 & 21,904 & $1,525,905$ \\
\hline 33235750 & 8 & FULLERTON, SOUTH & WOLFCAMP & $\mathrm{TX}$ & ANDREWS & 1955 & 8245 & 23,569 & $4,217,011$ \\
\hline 45726550 & $8 \mathrm{~A}$ & JANICE & WOLFCAMP & $T X$ & YOAKUM & 1981 & 8937 & 33,269 & $1,577,530$ \\
\hline 59419830 & 8 & MCFARLAND & WOLFCAMP & TX & ANDREWS & 1955 & 9134 & 72,720 & $8,558,308$ \\
\hline 60142750 & 8 & MEANS, SOUTH & WOLFCAMP & TX & ANDREWS & 1956 & 9378 & 85,212 & $7,257,075$ \\
\hline 61118830 & 8 & MIDLAND FARMS & WOLFCAMP & $T X$ & ANDREWS & 1954 & 9539 & 77,430 & $15,397,011$ \\
\hline 65766888 & 8 & NOLLEY & WOLFCAMP & TX & ANDREWS & 1951 & 9227 & 213,962 & $30,459,183$ \\
\hline 69193710 & 8 & PARKER & WOLFCAMP & TX & ANDREWS & 1953 & 8554 & 338,613 & $5,501,626$ \\
\hline 80473868 & 8 & SAND HILLS & WOLFCAMP & $\mathrm{TX}$ & CRANE & 1958 & 5684 & 27,310 & $2,537,187$ \\
\hline 82225568 & $8 \mathrm{~A}$ & SEMINOLE & WOLFCAMP LIME & TX & GAINES & 1963 & 9259 & 14,592 & $1,455,586$ \\
\hline 82225710 & $8 \mathrm{~A}$ & SEMINOLE & WOLFCAMP REEF & $\mathrm{TX}$ & GAINES & 1962 & 9162 & 27,292 & $1,452,509$ \\
\hline 82570600 & 8 & SHAFTER LAKE & WOLFCAMP & $\mathrm{TX}$ & ANDREWS & 1951 & 8405 & 2,330 & $12,195,348$ \\
\hline 84819850 & $7 \mathrm{C}$ & SOUTHWEST MESA & WOLFCAMP & $T X$ & CROCKETT & 1988 & 6268 & 24,833 & $1,463,139$ \\
\hline 88969800 & $8 \mathrm{~A}$ & TEX-FLOR & WOLFCAMP & TX & GAINES & 1977 & 9152 & 11,066 & $1,810,349$ \\
\hline 90196666 & $7 \mathrm{C}$ & TIPPETT, W. & WOLFCAMP LO. & $\mathrm{TX}$ & CROCKETT & 1967 & 5564 & 0 & $1,365,836$ \\
\hline 90196333 & 7C & TIPPETT, WEST & HUECO & TX & CROCKETT & 1968 & 5012 & 5,579 & $1,469,047$ \\
\hline 88071928 & 8 & $T \times L$ & WOLFCAMP, NORTH & TX & ECTOR & 1959 & 7535 & 9,903 & $4,584,422$ \\
\hline 92534750 & 8 & UNIVERSITY BLOCK 9 & WOLFCAMP & TX & ANDREWS & 1953 & 8430 & 183,250 & $28,350,317$ \\
\hline 95397800 & $8 \mathrm{~A}$ & WASSON & WOLFCAMP & $T X$ & GAINES & 1956 & 8448 & 18,923 & $6,060,592$ \\
\hline 96291666 & 8 & WEMAC & WOLFCAMP & TX & ANDREWS & 1953 & 8708 & 4,009 & $4,239,021$ \\
\hline 96296500 & 8 & WEMAC, SOUTH & WOLFCAMP & TX & ANDREWS & 1962 & 8786 & 2,577 & $1,701,980$ \\
\hline \multirow[t]{18}{*}{96756800} & 8 & WHEELER & WOLFCAMP & $\mathrm{TX}$ & ECTOR & 1959 & 7604 & 60,959 & $5,753,930$ \\
\hline & & ANDERSON RANCH & WOLFCAMP & NM & LEA & 1953 & 9760 & 19,061 & $4,235,028$ \\
\hline & & ANDERSON RANCH N & HWOLFCAMP & NM & LEA & 1960 & 9823 & 30,797 & $6,652,176$ \\
\hline & & BRONCO & WOLFCAMP & NM & LEA & 1953 & 9600 & 994 & $2,086,478$ \\
\hline & & CAUDILL & PERMO PENN & NM & LEA & 1956 & 10285 & 6,593 & $1,979,249$ \\
\hline & & DENTON & WOLFCAMP & NM & LEA & 1950 & 9240 & 242,272 & $41,755,373$ \\
\hline & & GLADIOLA & WOLFCAMP & NM & LEA & 1950 & 9578 & 14,524 & $4,144,627$ \\
\hline & & HENSHAW & WOLFCAMP & NM & EDDY & 1960 & 8822 & 11,483 & $3,401,748$ \\
\hline & & KEMNITZ & LOWER WOLFCAMP & NM & LEA & 1956 & 10742 & 18,731 & $16,608,371$ \\
\hline & & KEMNITZ WEST & WOLFCAMP & NM & LEA & 1963 & 10678 & 2,748 & $1,029,531$ \\
\hline & & KING & WOLFCAMP & NM & LEA & 1951 & 9300 & 21,755 & $1,369,908$ \\
\hline & & LANE & WOLFCAMP & NM & LEA & 1955 & 9700 & 0 & $1,028,000$ \\
\hline & & MORTON & WOLFCAMP & NM & LEA & 1964 & 10310 & 8,430 & $2,605,976$ \\
\hline & & MORTON EAST & WOLFCAMP & NM & LEA & 1970 & 10506 & 21,786 & $1,781,208$ \\
\hline & & TODD & WOLFCAMP & NM & ROOSEVELT & 1971 & 7580 & 31,769 & $1,115,408$ \\
\hline & & TOWNSEND & PERMO-UPPER PENN & NM & LEA & 1952 & 10400 & 124,759 & $24,101,823$ \\
\hline & & TULK & WOLFCAMP & NM & LEA & 1951 & 9700 & 15,862 & $2,429,801$ \\
\hline & & Totals & & & & & & $4,012,646$ & $457,405,339$ \\
\hline
\end{tabular}




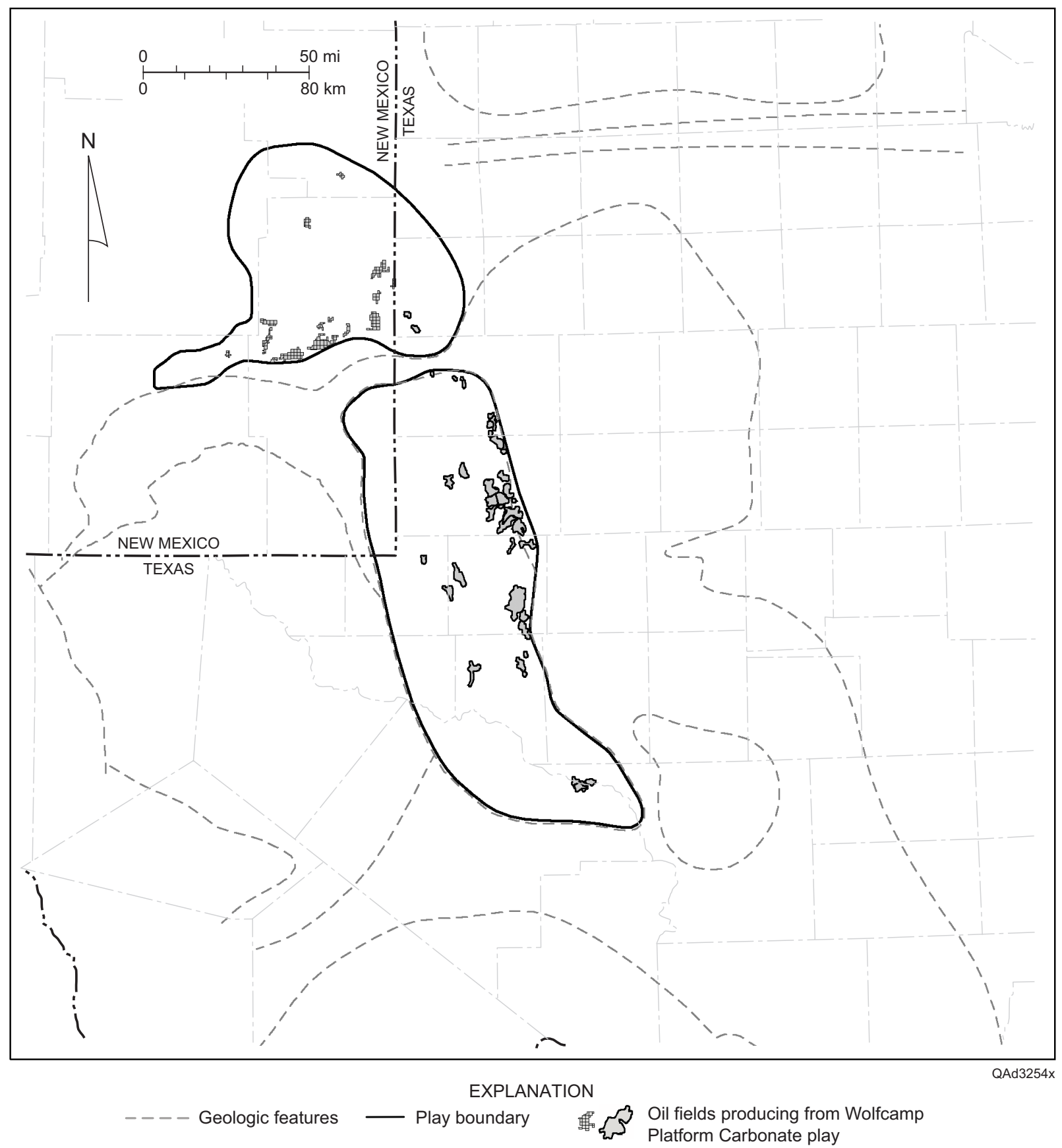

Figure 48. Play map for the Wolfcamp Platform Carbonate play, showing location of reservoirs having $>1 \mathrm{MMbbl}$ cumulative production, the play boundary, and geologic features. See figure 1 for county names and figure 2 for identification of geologic features.

throughout the Wolfcamp (Wright, 1979). Wolfcamp Platform Carbonate reservoirs in New Mexico were deposited on the shelf and shelf margin of the northern Delaware Basin. Although 
similar in age and depositional setting to reservoirs in the Northwest Shelf Upper Pennsylvanian Carbonate play (play 110), the reservoir strata in the Wolfcamp Platform Carbonate play in New Mexico are generally thought to be slightly younger and are traditionally grouped into a separate play. Carbonate-debris beds, which were derived from Wolfcamp platform-margin buildups, are found in downslope basinal deposits in the Midland and Delaware Basins and compose the Wolfcamp/Leonard Slope and Basinal Carbonate play (play 115).

Fusulinid biostratigraphy indicates that reservoirs in the Wolfcamp Platform Carbonate play occur mostly in Lower and Middle Wolfcamp strata (Candelaria and others, 1992; Saller and others, 1999b). Two of the largest reservoirs in the play, Edwards West and South Cowden (table 19), are interpreted as producing from the Wolfcamp on the basis of biostratigraphy, despite having been reported and named as producing from Canyon reservoirs (Candelaria and others, 1992).

Large-scale stratigraphic relations and facies of the Wolfcamp were documented along the east margin of the Central Basin Platform (Candelaria and others, 1992) and the northern Midland Basin (Mazzullo and Reid, 1989). Recent studies of typical Wolfcamp fields on the Central Basin Platform show that, like many reservoirs in the Pennsylvanian Platform Carbonate Play, these reservoirs are composed of highly cyclic shallow-water carbonate facies that are variably overprinted by diagenesis that took place at and below cycle tops during sea-level-fall events (Candelaria and others, 1992; Saller and others, 1994, 1999a, b; Dickson and Saller, 1995; Ruppel, 2001). Although reservoirs developed in Wolfcamp platform carbonates are commonly referred to as reefs because of their geometries, recent studies have illustrated that many of the reservoirs are composed of cyclic deposits of interbedded skeletal and ooid-bearing grainstones and organic-rich wackestones and packstones (fig. 49) (Mazzullo, 1982; Saller and others, 1994; 


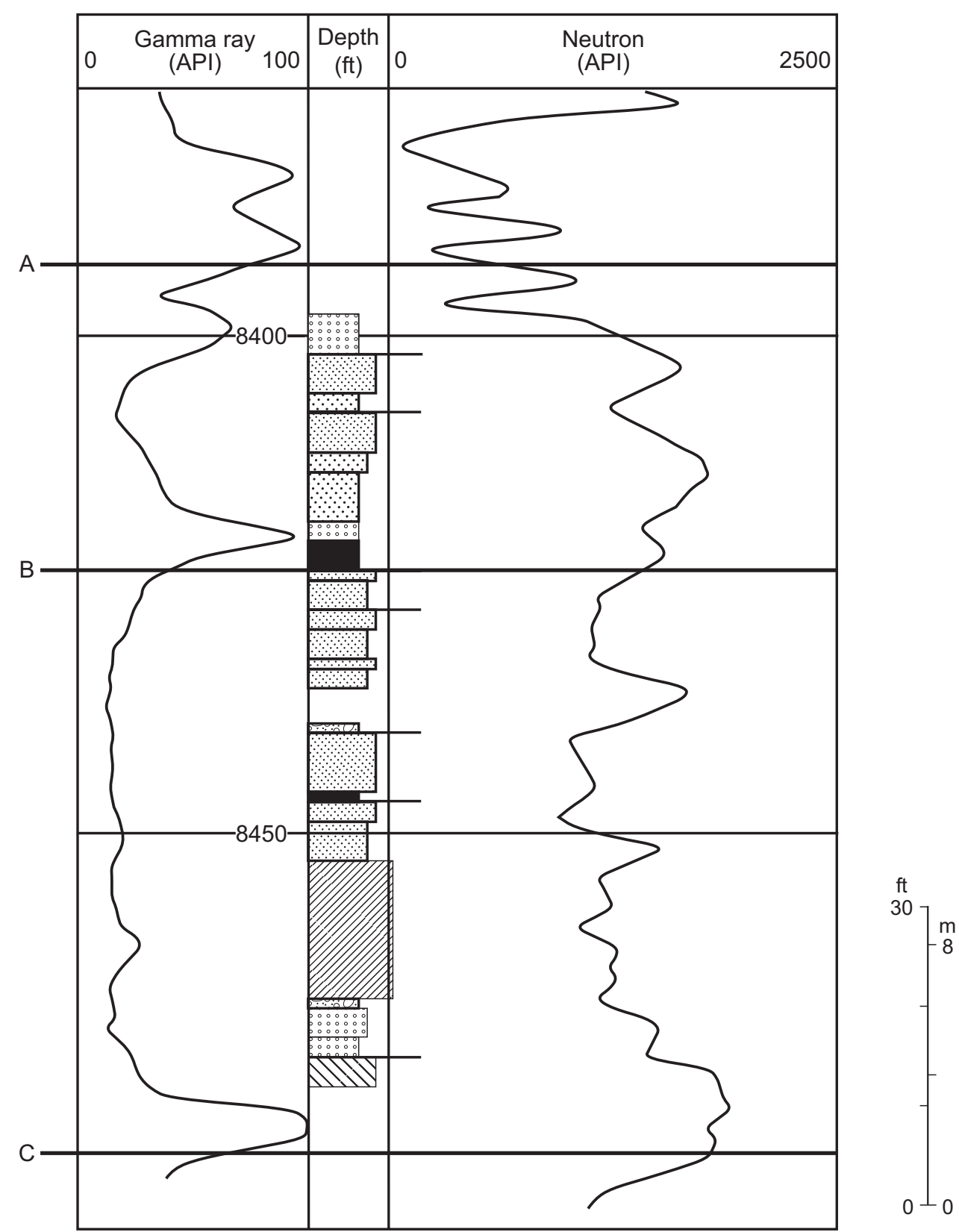

Well-sorted, grain-dominated skeletal facies

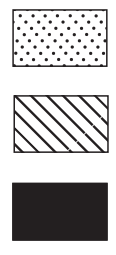

Oncolitic, algal wackestone

Nodular, mixed skeletal wackestone-packstone

Fusulinid wackestonepackstone

Peloidal grain-rich

packstone

Peloidal mudstone-

wackestone

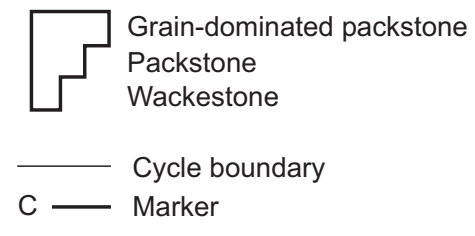

Mud-rich to grain-rich

algal buildup

QAd3328cx

Figure 49. Typical vertical Wolfcamp facies succession in the Wolfcamp Platform Carbonate play. From Ruppel (2001). Core and log are from University Block 9 field, Andrews County, from the Shell 9A No. 1 well (Cross Timbers 11 SA No. 1 well). See Ruppel (2001) for location of well. 
Ruppel, 2001). Shelf-margin organic buildups in the Wolfcamp are micrite dominated and composed of phylloid algae, foraminifera, and Tubiphytes (Mazzullo and Reid, 1989; Wahlman, 2001). These buildups generally do not have reservoir-quality porosity, but porosity is well developed in flanking and capping bioclastic packstone-grainstone facies (Wahlman, 2001).

Correlation of the Wolfcamp succession and identification of facies, cycles, and karst intervals are difficult using wireline logs alone (Ruppel, 2001). Image logs calibrated to core can be used to resolve major depositional facies, cycle boundaries, and karst diagenesis (fig. 50) and develop an accurate reservoir model.

Traps are structural and stratigraphic (Galloway and others, 1983; Candelaria and others, 1992). Structural closure forms the trap in many fields, including Andrews, Bakke, Midland Farms, and University Block 9. Updip facies change and porosity pinch-out create the stratigraphic traps at the Dune and Nolley Wolfcamp reservoirs, and dolomitization of platformmargin facies at Seminole Wolfcamp Reef reservoir forms a diagenetic stratigraphic trap (Tyler and others, 1991; Candelaria and others, 1992). Expected ultimate recovery per well in the play ranges from $60,000 \mathrm{bbl}\left(9.54 \times 10^{3} \mathrm{~m}^{3}\right)$ to $>500,000 \mathrm{bbl}\left(7.95 \times 10^{4} \mathrm{~m}^{3}\right)$ (Candelaria and others, 1992). In the grainstone facies that is the main reservoir facies, porosity can be as high as 12 to 15 percent, and permeability can be 40 to $60 \mathrm{md}\left(40-60 \times 10^{-3} \mu \mathrm{m}^{2}\right)$ (Candelaria and others, 1992). However, in many fields in this play the reservoir facies average 5 to 8 percent porosity and $<1 \mathrm{md}\left(<1 \times 10^{-3} \mu^{2}\right)$ matrix permeability (Ruppel, 2001; Stoudt and others, 2001). Permeability in Edwards West field is due mainly to fractures associated with karst because matrix permeability is $<1 \mathrm{md}\left(<1 \times 10^{-3} \mu \mathrm{m}^{2}\right)$ (Stoudt and others, 2001).

Reservoirs in New Mexico are located on or shelfward (northward) of the east-westtrending Wolfcampian shelf margin (fig. 2; see Malek-Aslani, 1970). Although some reservoirs 


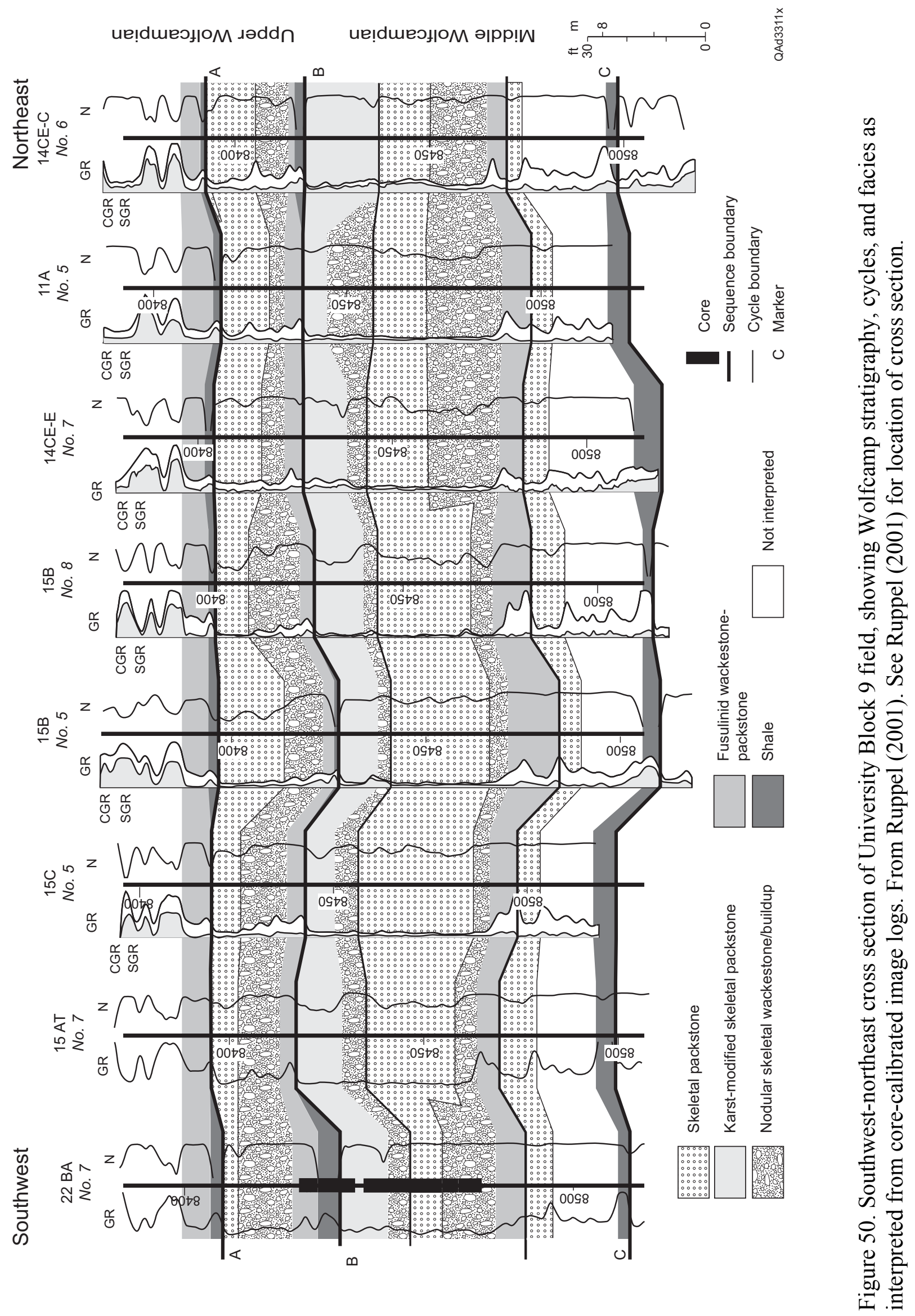


are found well north of the shelf margin, most are clustered on or near the shelf margin.

Production is derived largely from lower Wolfcamp units. Shelf-margin reservoirs are interpreted to lie within a barrier-reef complex, with lithologies consisting of reefal (hydrozoan boundstones), backreef (skeletal grainstones), and forereef (talus slope) facies (Malek-Aslani, 1970). The northern shelf area reservoirs are composed of shallow-marine limestone facies, with most accumulations found in phylloid-algal bioherms developed on preexisting paleobathymetric highs or as grainstones capping and flanking the bioherms (Cys and Mazzullo, 1985; MalekAslani, 1985; Cys, 1986).

Traps on the shelf in New Mexico are largely stratigraphic, with porosity pinch-outs formed from porous biohermal and grainstone facies that grade laterally into low-porosity nonbiohermal facies. On the shelf margin, traps are combinations of structural ridges and stratigraphic pinch-outs (porous reefal facies laterally juxtaposed with lower porosity nonreef strata). The structural ridges trend generally north-south and are thought to be bounded by lowrelief faults. Because of the relationship of Wolfcamp reservoirs to positive structural elements that have a tectonic origin, it is common to find Wolfcamp reservoirs stacked atop structurally controlled reservoirs in older, deeper strata.

Two Wolfcamp reservoirs in New Mexico, Vacuum and Corbin, have been assigned to the Wolfcamp/Leonard Slope and Basinal Carbonate play (115) on the basis of their location south of the Wolfcamp shelf margin as mapped by Malek-Aslani (1970, 1985; figs. 48, 51; tables 19, 20). The mapped shelf margin is based on lower Wolfcamp facies. Vacuum is productive from both the upper and lower parts of the Wolfcamp, and Corbin South is productive from the upper and middle parts of the Wolfcamp. The lower and middle Wolfcamp in this area comprise interbedded dark shales and limestones and are basinal facies. The upper Wolfcamp, however, 
comprises dominantly light-colored carbonates. At the Vacuum reservoir, the upper Wolfcamp has a mound-shaped appearance, and crosswell seismic tomography indicates that the productive interval has internal clinoformal bedding (Martin and others, 2002). On the basis of overall shape and internal bedding surfaces, Martin and others (2002) suggested that the upper Wolfcamp reservoir may be an isolated algal mound deposited on the Wolfcamp shelf. If this is the case, then the upper parts of the Vacuum and Corbin South reservoirs are in the Wolfcamp Platform Carbonate play (114) and the shelf edge prograded southward at least 10 to 12 miles during Wolfcamp time from the Kemnitz reservoir (fig. 48) to a position south of the Vacuum reservoir (fig. 51). If the upper part of the Vacuum reservoir is a shelf deposit, then general location and lithologic composition suggest that the upper part of the Corbin South reservoir was also deposited on the Wolfcamp shelf and not in the basin. Alternatively, the southward-prograding clinoforms seen via crosswell seismic tomography in the Vacuum reservoir may indicate southward-prograding slope deposits.

\section{References}

Candelaria, M. P. Sarg, J. F., and Wilde, G. L., 1992, Wolfcamp sequence stratigraphy of the eastern Central Basin Platform, in Mruk, D. H., and Curran, C., eds., Permian Basin exploration and production strategies: application of sequence stratigraphic and reservoir characterization concepts: West Texas Geological Society Publication 92-91, p. 27-44.

Cys, J. M., 1986, Lower Permian grainstone reservoirs, southern Tatum Basin, southeastern New Mexico, in Ahlen, J. L., and Hanson, M. E., eds., Southwest Section, American Association of Petroleum Geologists Transactions and guidebook of 1986 convention, Ruidoso, New Mexico: New Mexico Bureau of Mines and Mineral Resources, p. $115-120$.

Cys, J. M., and Mazzullo, S. J., 1985, Depositional and diagenetic history of a Lower Permian (Wolfcamp) phylloid-algal reservoir, Hueco Formation, Morton field, southeastern New Mexico, in Roehl, P. O., and Choquette, P. W., eds., Carbonate petroleum reservoirs: New York, Springer-Verlag, p. 277-288. 
Dickson, J. A. D., and Saller, A. H., 1995, Identification of subaerial exposure surfaces and porosity preservation in Pennsylvanian and lower Permian shelf limestones, eastern Central Basin Platform Texas, in Budd, D. A., Saller, A. H., and Harris, P. M., eds., Unconformities in carbonate shelf strata-their recognition and the significance of associated porosity: American Association of Petroleum Geologists Memoir 57, p. 239-257.

Galloway, W. E., Ewing, T. E., Garrett, C. M., Jr., Tyler, N., and Bebout, D. G., 1983, Atlas of major Texas oil reservoirs: The University of Texas at Austin, Bureau of Economic Geology Special Publication, 139 p.

Malek-Aslani, M., 1970, Lower Wolfcampian reef in Kemnitz field, Lea County, New Mexico: American Association of Petroleum Geologists, Bulletin, v. 54, p. 2317-2335.

1985, Permian patch-reef reservoir, North Anderson Ranch field, southeastern New Mexico, in Roehl, P. O., and Choquette, P. W., eds., Carbonate petroleum reservoirs: New York, Springer-Verlag, p. 265-276.

Martin, R. L., Welch, C. L., Hinterlong, G. D., Meyer, J., and Evans, R., 2002, Using crosswell seismic tomography to provide better resolution in the Wolfcamp Formation in Lea County, New Mexico, in Hunt, T. J., and Lufholm, P. H., eds., The Permian Basin: preserving our past—-securing our future: West Texas Geological Society, Publication 02-111, p. 25-34.

Mazzullo, S. J., 1982, Types and controls on Permo-Pennsylvanian carbonate stratigraphic traps of shallow-marine origin in Permian Basin: exploration models: Oil and Gas Journal, v. 80 , p. $127-141$.

Mazzullo, S. J., and Reid, A. M., 1989, Lower Permian platform and basin depositional systems, northern Midland Basin, Texas, in Crevello, P. D., Wilson, J. L., Sarg, J. F., and Read, J. F., eds., Controls on carbonate platform and basin development: Society of Economic Paleontologists and Mineralogists Special Publication 44, p. 305-320.

Ruppel, S. C., 2001, Stratal architecture and facies development in a middle Wolfcampian platform carbonate reservoir: University Block 9 Field Andrews County, Texas, in Stoudt, E. L., and Sivils, D. J., eds., Wolfcampian of West Texas (Permian Basin, Sierra Diablo and Hueco Mountains) - shelfal and periplatform carbonate reservoirs and outcrop analogs: Permian Basin Section SEPM Core Workshop and Field Trip Guidebook, Publication No. 2001-41, p. 3-1-3-18.

Saller, A. H., Dickson, J. A. D., and Boyd, S. A., 1994, Cycle stratigraphy and porosity in Pennsylvanian and lower Permian shelf limestones, eastern Central Basin Platform, Texas: American Association of Petroleum Geologists Bulletin, v. 78, p. 1820-1842. 
Saller, A. H., Dickson, J. A. D., and Matsuda, F., 1999a, Evolution and distribution of porosity associated with subaerial exposure in upper Paleozoic platform limestones, West Texas: American Association of Petroleum Geologists Bulletin, v. 83, p. 1835-1854.

Saller, A. H., Dickson, J. A. D., Rasbury, E. T., and Ebato, T.,1999b, Effects of long-term accommodation changes on short term cycles: Upper Paleozoic platform limestones, West Texas, in Advances in carbonate sequence stratigraphy: application to reservoirs, outcrops, and models: SEPM Special Publication No. 63, p. 227-246.

Stoudt, E. L., Prezbindowski, D. R., and Sivils, D. J., 2001, Phillips Edwards West field, Ector County, Texas - controls on reservoir distribution in Wolfcamp shelfal carbonates, in Viveiros, J. J., and Ingram, S. M., eds., The Permian Basin: microns to satellites, looking for oil and gas at all scales: West Texas Geological Society Publication No. 01-110, p. 55.

Tyler, N., Bebout, D. G., Garrett, C. M., Jr., Guevara, E. H., Hocott, C. R., Holtz, M. H., Hovorka, S. D., Kerans, C., Lucia, F. J., Major, R. P., Ruppel, S. C., and Vander Stoep, G. W., 1991, Integrated characterization of Permian Basin reservoirs, University Lands, West Texas: targeting the remaining resource for advanced oil recovery: The University of Texas at Austin, Bureau of Economic Geology Report of Investigations No. 203, $136 \mathrm{p}$.

Wahlman, G. P., 2001, Pennsylvanian-Lower Permian mounds and reefs in the Permian Basin (west Texas-New Mexico): composition, evolution, distribution, and reservoir characteristics, in Viveiros, J. J., and Ingram, S. M., eds., The Permian Basin: microns to satellites, looking for oil and gas at all scales: West Texas Geological Society Publication No. 01-110, p. 57-64.

Wright, W. F., 1979, Petroleum geology of the Permian Basin: West Texas Geological Society Publication No. 79-71, 98 p. 
Wolfcamp/Leonard Slope and Basinal Carbonate (Play 115)

The Wolfcamp/Leonard Slope and Basinal Carbonate play, which is located in the

Midland and Delaware Basins adjacent to the Central Basin Platform and Eastern Shelf (fig. 51), has produced 191.9 MMbbl $\left(3.05 \times 10^{7} \mathrm{~m}^{3}\right)$ from 41 reservoirs (table 20). None of the reservoirs in the play had produced $>10 \mathrm{MMbbl}\left(1.59 \times 10^{6} \mathrm{~m}^{3}\right)$ of oil by 1982 , so the play is not included in the Atlas of Major Texas Oil Reservoirs (Galloway and others, 1983). Although the reservoirs in Glasscock County have been named Wolfcamp (table 20), regional fusulinid biostratigraphy shows that they are actually Lower Leonardian (Mazzullo, 1997) (fig. 52).

Table 20. Wolfcamp/Leonard Slope and Basinal Carbonate play (play 115). Production shown for fields that have had others combined into them represents the totals; combined fields are highlighted.

\begin{tabular}{|c|c|c|c|c|c|c|c|c|c|}
\hline RRC RESN & RRC & FLDNAME & RESNAME & STATE & COUNTY & DISCYR & DEPTHTOP & 2000 PROD & CUMPROD \\
\hline 2207912 & $7 \mathrm{C}$ & AMACKER-TIPPETT & WOLFCAMP & TX & UPTON & 1954 & 9090 & 161,453 & $5,567,355$ \\
\hline 2220900 & $7 \mathrm{C}$ & AMACKER-TIPPET, SW & 9100 & $T X$ & UPTON & 1980 & 9344 & 583,285 & $5,264,842$ \\
\hline 2220700 & $7 \mathrm{C}$ & AMACKER-TIPPETT, SW & WOLFCAMP & $\mathrm{TX}$ & UPTON & 1977 & 9218 & $2,593,888$ & $16,046,136$ \\
\hline 2220710 & $7 \mathrm{C}$ & AMACKER-TIPPETT, SW. & WOLFCAMP A & TX & UPTON & 1988 & 9069 & 201,693 & $4,442,155$ \\
\hline 4228664 & 8 & ATHEY & WOLFCAMP 10900 & TX & PECOS & 1967 & 11263 & 60,515 & $2,411,926$ \\
\hline 5229500 & $8 \mathrm{~A}$ & BALE, EAST & WOLFCAMP & TX & GAINES & 1972 & 10005 & 2,665 & $1,636,763$ \\
\hline 8735500 & 8 & BLALOCK LAKE, E. & WOLFCAMP & TX & GLASSCOCK & 1971 & 7914 & 188,510 & $5,978,078$ \\
\hline 8739500 & 8 & BLALOCK LAKE, S. & WOLFCAMP & $T X$ & GLASSCOCK & 1974 & 8246 & 389,662 & $10,256,922$ \\
\hline 8740500 & 8 & BLALOCK LAKE, SE & WOLFCAMP & $\mathrm{TX}$ & GLASSCOCK & 1981 & 8245 & 229,826 & $9,974,801$ \\
\hline 19235700 & 8 & COBRA & WOLFCAMP & TX & GLASSCOCK & 1984 & 7947 & $1,080,278$ & $10,587,410$ \\
\hline 20844500 & 7C & CORVETTE & WOLFCAMP & $T X$ & UPTON & 1991 & 9388 & 110,532 & $4,826,776$ \\
\hline 21382875 & 8 & COYANOSA & WOLFCAMP & $\mathrm{TX}$ & PECOS & 1970 & 11614 & 2,768 & $6,299,774$ \\
\hline 21597250 & 8 & CREDO & WOLFCAMP & TX & STERLING & 1962 & 7334 & 12,169 & $3,951,915$ \\
\hline 21597500 & 8 & CREDO & WOLFCAMP, LOWER -B- & $T X$ & STERLING & 1962 & 7430 & 735 & $2,497,526$ \\
\hline 24488650 & 8 & DEWEY LAKE & WOLFCAMP & $\mathrm{TX}$ & GLASSCOCK & 1982 & 8449 & 6,970 & $1,395,910$ \\
\hline 24562710 & $8 \mathrm{~A}$ & DIAMOND -M- & WOLFCAMP & TX & SCURRY & 1952 & 5310 & 0 & $2,596,809$ \\
\hline 34001750 & 8 & GARDEN CITY, W. & WOLFCAMP 7880 & TX & GLASSCOCK & 1966 & 7920 & 286,123 & $3,479,124$ \\
\hline 35708670 & 8 & GOMEZ & WOLFCAMP UPPER & $\mathrm{TX}$ & PECOS & 1977 & 10620 & 3,144 & $1,227,066$ \\
\hline 38866600 & $8 \mathrm{~A}$ & HAPPY & SPRABERRY LIME & $\mathrm{TX}$ & GARZA & 1989 & 4970 & 976,132 & $7,336,714$ \\
\hline 42971664 & 8 & HOWARD-GLASSCOCK & WOLFCAMP 7400 & TX & HOWARD & 1970 & 7441 & 76,590 & $6,178,414$ \\
\hline 43926600 & 8 & HUTTO, SOUTH & WOLFCAMP & $\mathrm{TX}$ & HOWARD & 1964 & 7421 & 36,345 & $3,330,447$ \\
\hline 48338500 & $8 \mathrm{~A}$ & KAY & WOLFCAMP REEF & $\mathrm{TX}$ & GAINES & 1959 & 10349 & 0 & $1,976,465$ \\
\hline 57324650 & 8 & MARALO & WOLFCAMP & TX & PECOS & 1984 & 11055 & 11,421 & $1,200,187$ \\
\hline 72810500 & 8 & POWELL & 8300 & $\mathrm{TX}$ & GLASSCOCK & 1982 & 8552 & 12,202 & $2,181,282$ \\
\hline 78279300 & 8 & ROSE CREEK, N & WOLFCAMP & $\mathrm{TX}$ & STERLING & 1982 & 5084 & 70,894 & $1,582,370$ \\
\hline 85279400 & $7 \mathrm{C}$ & SPRABERRY & TREND AREA CL. FK. & $\mathrm{TX}$ & REAGAN & 1955 & 6194 & 79,498 & $11,327,959$ \\
\hline 85280400 & 8 & SPRABERRY & TREND AREA CL. FK. & TX & MIDLAND & 1955 & 7000 & 21,289 & $3,375,768$ \\
\hline 85447300 & $7 \mathrm{C}$ & SRH & CLEAR FORK & $\mathrm{TX}$ & REAGAN & 1995 & 4837 & 129,667 & $1,266,029$ \\
\hline 90369666 & $8 \mathrm{~A}$ & TOKIO, SOUTH & WOLFCAMP & TX & TERRY & 1953 & 9860 & 15,016 & $3,114,383$ \\
\hline 91336498 & 8 & TRIPLE M & WOLFCAMP UPPER & $\mathrm{TX}$ & STERLING & 1963 & 6746 & 6,623 & $3,109,333$ \\
\hline 91424475 & $7 \mathrm{C}$ & TRIUMPH & WOLFCAMP & $\mathrm{TX}$ & UPTON & 1992 & 8530 & 183,282 & $3,362,056$ \\
\hline 95129600 & 8 & WAR-WINK, S. & WOLFCAMP & $\mathrm{TX}$ & WARD & 1976 & 12758 & 270,499 & $12,741,227$ \\
\hline \multirow[t]{11}{*}{95130900} & 8 & WAR-WINK, W. & WOLFCAMP & TX & WARD & 1976 & 11545 & 604,798 & $2,865,482$ \\
\hline & & BAISH & WOLFCAMP & NM & LEA & 1962 & 9800 & 28,315 & $1,068,654$ \\
\hline & & BURTON FLAT NORTH & WOLFCAMP & NM & EDDY & 1975 & 9160 & 0 & $3,226,531$ \\
\hline & & CORBIN SOUTH & WOLFCAMP & NM & LEA & 1967 & 11000 & 127,055 & $6,609,050$ \\
\hline & & JOHNSON RANCH & WOLFCAMP & NM & LEA & 1985 & 13500 & 291,937 & $1,380,757$ \\
\hline & & SCHARB & WOLFCAMP & NM & LEA & 1980 & 10519 & 16,981 & $1,199,917$ \\
\hline & & SHOE BAR NORTH & WOLFCAMP & NM & LEA & 1973 & 10456 & 15,877 & $1,706,095$ \\
\hline & & VACUUM & WOLFCAMP & NM & LEA & 1963 & 9950 & 78,821 & $6,660,250$ \\
\hline & & VACUUM NORTH & LOWER WOLFCAMP & NM & LEA & 1967 & 10690 & 1,093 & $1,952,599$ \\
\hline & & WANTZ & GRANITE WASH & NM & LEA & 1963 & 7270 & 77,637 & $7,782,243$ \\
\hline & & Cotals & & & & & & $9,046,188$ & $194,975,500$ \\
\hline
\end{tabular}




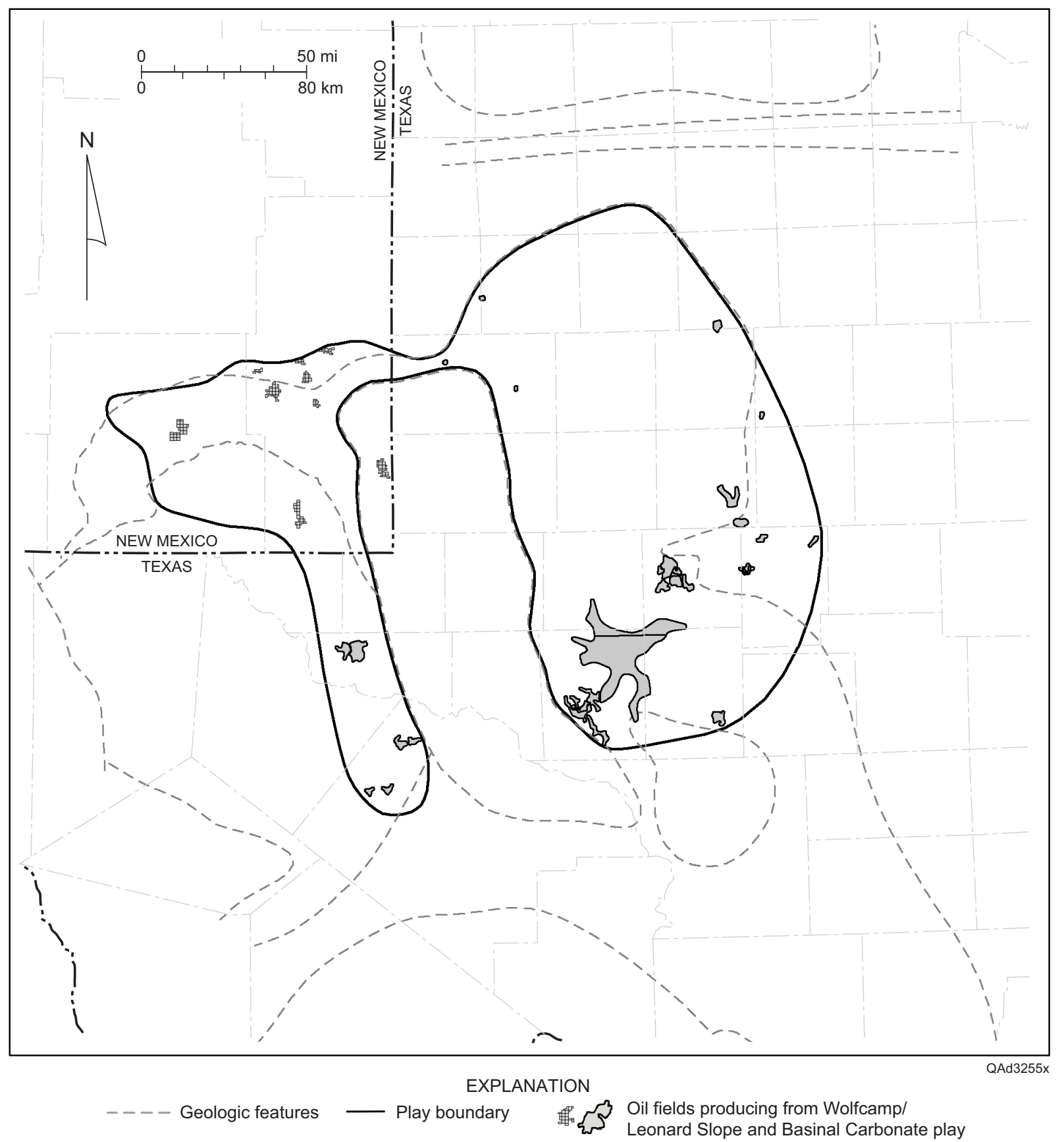

Figure 51. Play map for the Wolfcamp/Leonard Slope and Basinal Carbonate play, showing location of reservoirs having $>1 \mathrm{MMbbl}$ cumulative production, the play boundary, and geologic features. See figure 1 for county names and figure 2 for identification of geologic features. 


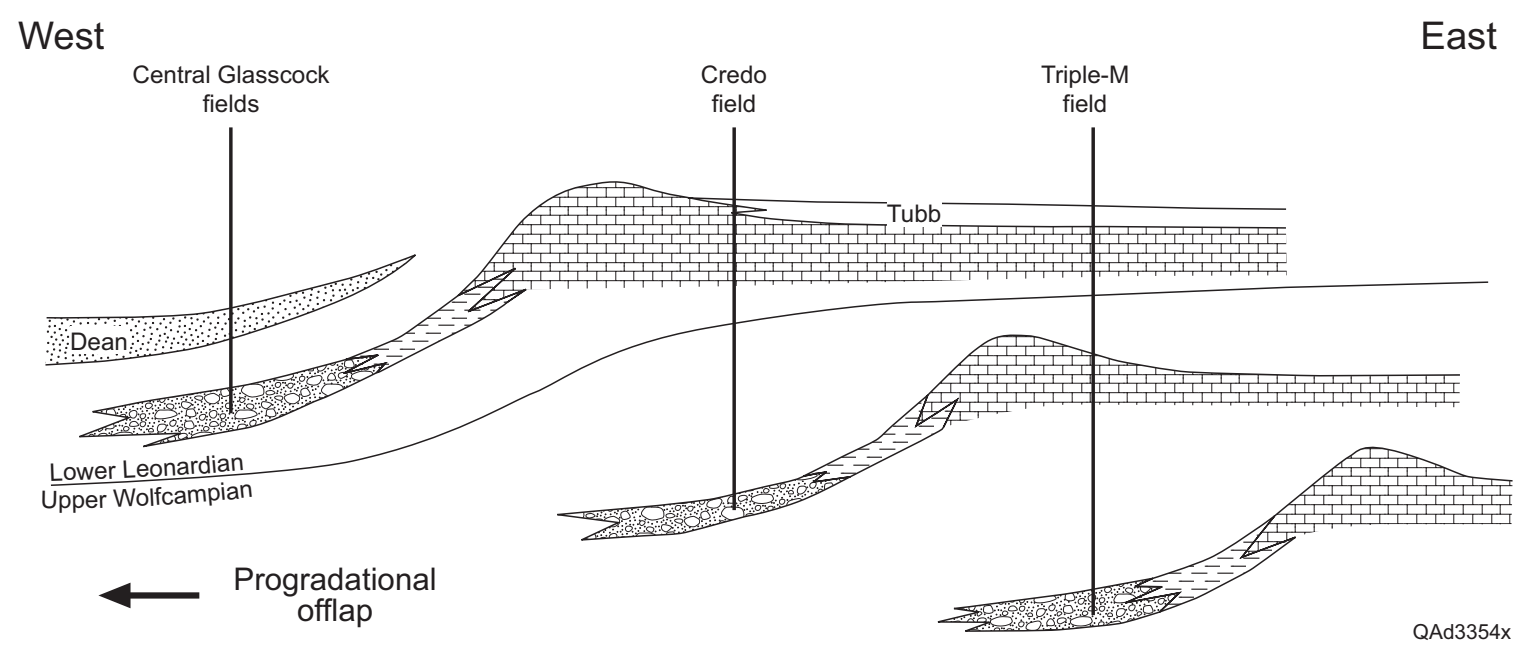

Figure 52. West-east cross section illustrating progradation of the Eastern Shelf margin and fields producing from Wolfcamp and Leonard periplatform carbonates in Glasscock and Sterling fields. From Mazzullo (1997).

Wolfcamp and Lower Leonard deposits in the Midland and Delaware Basins are composed primarily of dark shales and interbedded detrital carbonate (Wilson, 1975; Hobson and others, 1985a, b; Mazzullo and others, 1987; Mazzullo and Reid, 1989). Carbonate interbeds consists of a variety of resedimented deposits, including breccias, sand, and muds deposited by debris flows, turbidity currents, grain flow, and bottom currents on the lower slope and basin floor (Hobson and others, 1985a, b; Loucks and others, 1985; Mazzullo and Reid, 1987; Montgomery, 1996; Mazzullo, 1997). These rocks contain clasts of shallow-water facies identical to those observed in platform and platform-margin sequences, including skeletal grainstones and wackestones and ooid grainstones, indicating that they were derived by downslope transport from the platform margin. Large detached blocks of dolostone are also common, particularly in proximal parts of the debris flows (Mazzullo and Reid, 1987). Traps are largely stratigraphic, with reservoirs encased in dark-gray to black, kerogen-rich basinal shales, which act as both the seal and the source rock. 
Mazzullo $(1997,2000)$ interpreted Wolfcamp and Leonard resedimented carbonates as having been deposited during periods of sea-level highstand. Other workers have interpreted the basinal carbonate debris as having been shed into the basins during both highstands and lowstands (Becher and von der Hoya, 1990; Pacht and others, 1995; Simo and others, 2000). Pacht and others (1995) concluded that although much of the basinal carbonate debris was deposited during highstand time, porous debris flows were best developed in lowstand systems tracts along the northwest margin of the Midland Basin.

The allochthonous carbonates of this play are distributed in distinct lobes that trend normal to the shelf edge. Considerable vertical and lateral heterogeneity within these sequences has been created by the irregular stacking of discrete depositional units (Hobson and others, 1985a, b; Becher and von der Hoya, 1990). Cores of Wolfcamp and Leonard deepwater carbonates are illustrated and described in Kaufman and others, 2001; Merriam, 2001; Sivils, 2001; Sivils and Stoudt, 2001). Amacker Tippett Wolfcamp field produces mainly from fusulinid algal grainstones and large slide blocks (fig. 53) (Van Der Loop, 1990). Pay zones have porosity of $\geq 3$ percent and gamma-ray values of $\leq 25$ API units. The reservoir facies at Powell Wolfcamp field are packstones and grainstones located in channels that incise into brecciated carbonate debris flows and shales. Porosity, which ranges from 6 to 22 percent, is composed of interparticle, moldic, and fracture pores (Montgomery, 1996). Reservoir permeability ranges from 100 to $500 \mathrm{md}\left(100\right.$ to $500 \times 10^{-3} \mu \mathrm{m}^{2}$ ).

Three-dimensional seismic surveys have successfully imaged productive channels in northwestern Glasscock County by identifying zones of thicker Wolfcamp isochrons and lower amplitudes. Use of 3-D seismic surveys has increased rates of drilling success in the Powell Ranch area to $>70$ percent (Dufford and Holland, 1993; Montgomery, 1996). 


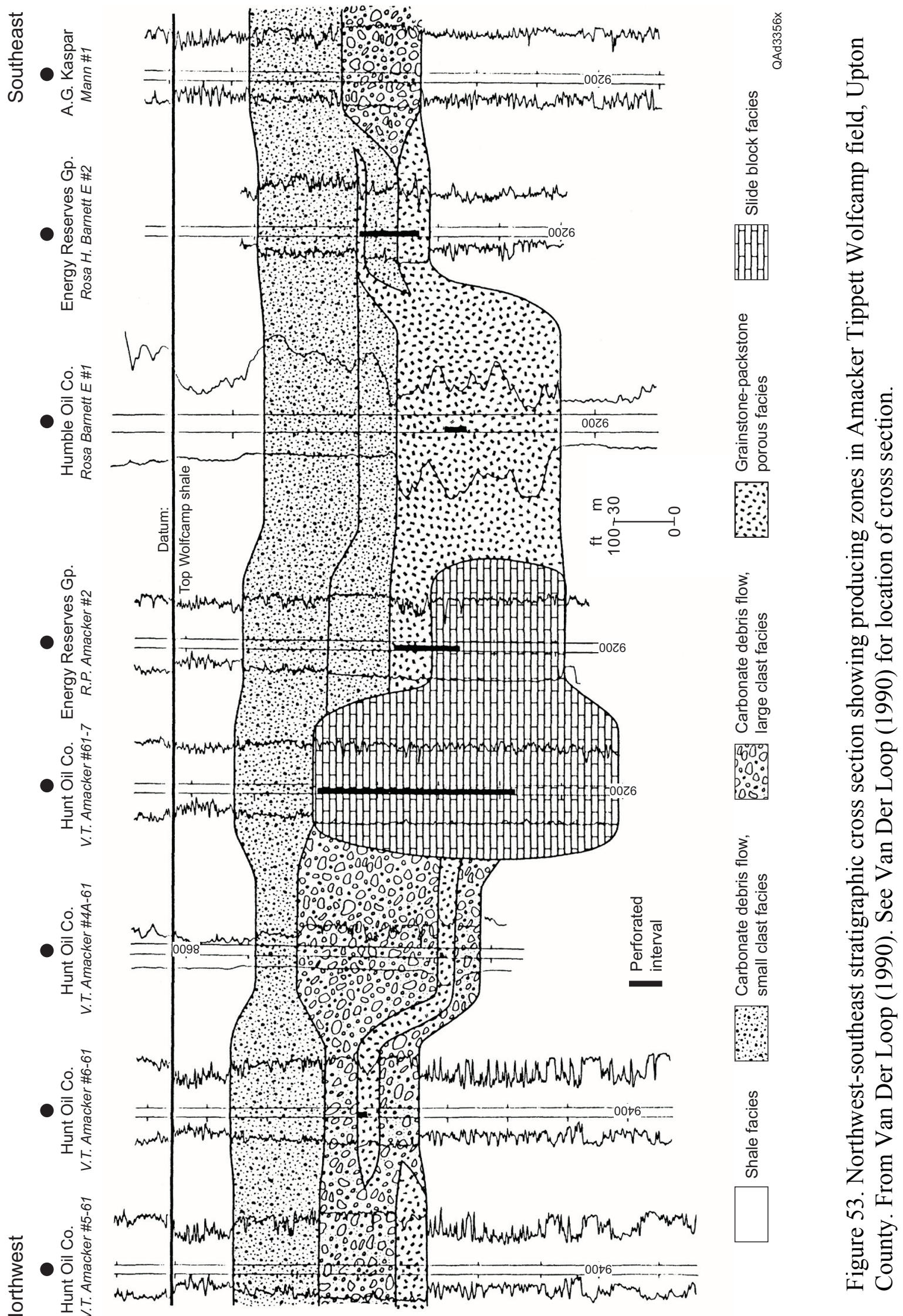


New Mexico reservoirs in this play are located basinward of the Wolfcamp shelf margin (fig. 2). The Wolfcamp shelf margin appears to be roughly coincident with the overlying, younger Abo shelf margin but in some places may be seaward of it or landward of it by as much as 1 mile. Production is derived largely from limestones in the lower Wolfcamp, although limestones in the middle to upper Wolfcamp are productive in some reservoirs. Most productive strata appear to be carbonate debris flows derived from the shelf margin (see Loucks and others, 1985) or possibly the slope.

Two lower Wolfcampian reservoirs in New Mexico (Vacuum North, Shoe Bar North) were placed in this play because they lie immediately south of the shelf edge as mapped by Malek-Aslani (1970). The lithology and depositional setting of these reservoirs are not well known, so it is conceivable that they are actually platform-margin reservoirs deposited during temporally limited progradation of the shelf margin. However, their position in terms of known paleobathymetry indicates that they should be included in the Wolfcamp/Leonard Slope and Basinal Carbonate play rather than in the Wolfcamp Platform Carbonate play. Farther south, the Scharb reservoir is formed by allochthonous debris flow carbonates deposited on the Wolfcamp paleoslope (Mazzullo and Arrant, 1988). Burton Flat North is productive from basinal carbonates in a shale-rich part of the Wolfcamp. The Wolfcamp at Johnson Ranch is a basinal facies composed of interbedded brown limestone and brown shale. Two Wolfcamp reservoirs in New Mexico, Vacuum and Corbin, have been assigned to the Wolfcamp/Leonard Slope and Basinal Carbonate play (115) on the basis of their location south of the Wolfcamp shelf margin as mapped by Malek-Aslani (1970, 1985; figs. 48, 51; tables 19, 20). The mapped shelf margin is based on lower Wolfcamp facies. Vacuum is productive from both the upper and lower parts of the Wolfcamp, and Corbin South is productive from the upper and middle parts of the 
Wolfcamp. The lower and middle Wolfcamp in this area comprise interbedded dark shales and limestones and are basinal facies. The upper Wolfcamp, however, is composed dominantly of light-colored carbonates. At the Vacuum reservoir, the upper Wolfcamp has a mound-shaped appearance, and crosswell seismic tomography indicates that the productive interval has internal clinoformal bedding (Martin and others, 2002). On the basis of overall shape and internal bedding surfaces, Martin and others (2002) suggested that the upper Wolfcamp reservoir may be an isolated algal mound deposited on the Wolfcamp shelf. If this is the case, then the upper parts of the Vacuum and Corbin South reservoirs are in the Wolfcamp Platform Carbonate play (114) and the shelf edge prograded southward at least 10 to 12 miles during Wolfcamp time from the Kemnitz reservoir (fig. 48) to a position south of the Vacuum reservoir (fig. 51). If the upper part of the Vacuum reservoir is a shelf deposit, then general location and lithologic composition suggest that the upper part of the Corbin South reservoir was also deposited on the Wolfcamp shelf and not in the basin. Alternatively, the southward-prograding clinoforms seen via crosswell seismic tomography in the Vacuum reservoir may indicate southward-prograding slope deposits.

One New Mexico reservoir included in the play, Wantz Granite Wash, is productive from granite-wash clastics. Reservoirs in the Granite Wash subplay are productive from laterally discontinuous Wolfcampian-age conglomerates and "granite wash" arkosic sandstones deposited on the flanks of structural highs of Early Permian age and in paleotopographic lows on top of structural highs of Early Permian age (Bowsher and Abendshein, 1988; Speer, 1993). The sandstones are encased in shales that seal the sandstone and conglomerate reservoirs.

Examination of drill cuttings and logs indicates that a part of the reservoir resides in fractured Precambrian granite that underlies the granite wash (A.L. Bowsher, cited in Speer, 1993). Low-displacement, high-angle faults, acting in concert with the lenticular geometry of reservoir 
sands and conglomerates, compartmentalize reservoirs. Compartmentalization has perhaps

prevented optimal development, with standard vertical wells drilled on 40-acre spacing.

\section{References}

Becher, J. W., and von der Hoya, H. A., 1990, Wolfcampian and Early Leonardian fore-reef debris fans: Midland Basin, west Texas, in Flis, J. E., and Price, R. C., eds., Permian Basin oil and gas fields: innovative ideas in exploration and development: West Texas Geological Society, Publication No. 90-87, p. 153-155.

Bowsher, A. L., and Abendshein, M., 1988, Wantz Granite Wash (oil), in A symposium of oil and gas fields of southeastern New Mexico, supplement: Roswell Geological Society, p. $328-329$.

Dufford, S., and Holland, T., 1993, Wolfcamp detrital: a 3D case history Glasscock County, Texas, in Gibbs, J., and Cromwell, D., eds., New dimensions in the Permian Basin: West Texas Geological Society Publication 93-93, p. 75.

Galloway, W. E., Ewing, T. E., Garrett, C. M., Jr., Tyler, N., and Bebout, D. G., 1983, Atlas of major Texas oil reservoirs: The University of Texas at Austin, Bureau of Economic Geology Special Publication, 139 p.

Hobson, J. P., Caldwell, C. D., and Toomey, D. F., 1985a, Early Permian deep-water allochthonous limestone facies and reservoir, west Texas: American Association of Petroleum Geologists Bulletin, v. 69, p. 2130-2147.

1985b, Sedimentary facies and biota of early Permian deep-water allochthonous limestone, southwest Reagan County, Texas, in Crevello, P. D., and Harris, P. M., eds., Deep-water carbonates - a core workshop: Society of Economic Paleontologists and Mineralogists Core Workshop No. 6, p. 93-139.

Kaufman, J., Fiske, D., and Caputo, J., 2001, Contrasting depositional models for Wolfcamp periplatform carbonate reservoirs, Reagan and Upton Counties, Midland Basin, Texas, in Stoudt, E. L., and Sivils, D. J., eds., Wolfcampian of West Texas (Permian Basin, Sierra Diablo and Hueco Mountains) - shelfal and periplatform carbonate reservoirs and outcrop analogs: Permian Basin Section SEPM Core Workshop and Field Trip Guidebook, Publication No. 2001-41, p. 1-1-1-2.

Loucks, R. G., Brown, A. A., Achauer, C. W., and Budd, D. A., 1985, Carbonate gravity flow sedimentation on low angle slopes off the Wolfcampian northwest shelf of the Delaware Basin, in Crevello, P. D., and Harris, P. M., eds., Deep-water carbonates - a core workshop: Society of Economic Paleontologists and Mineralogists Core Workshop No. 6, p. 56-92. 
Malek-Aslani, M., 1970, Lower Wolfcampian reef in Kemnitz field, Lea County, New Mexico: American Association of Petroleum Geologists Bulletin, v. 54, p. 2317-2335.

1985, Permian patch-reef reservoir, North Anderson Ranch field, southeastern New Mexico, in Roehl, P. O., and Choquette, P. W., eds., Carbonate petroleum reservoirs: New York, Springer-Verlag, p. 265-276.

Martin, R. L., Welch, C. L., Hinterlong, G. D., Meyer, J., and Evans, R., 2002, Using crosswell seismic tomography to provide better resolution in the Wolfcamp Formation in Lea County, New Mexico, in Hunt, T. J., and Lufholm, P. H., eds., The Permian Basin: preserving our past - securing our future: West Texas Geological Society, Publication $02-111$, p. 25-34.

Mazzullo, S. J., 1997, Stratigraphic exploration plays in Ordovician to Lower Permian strata in the Midland Basin and on the Eastern Shelf, in DeMis, W. D., ed., Permian Basin oil and gas fields: turning ideas into production: West Texas Geological Society Publication No. 97-102, p. 1-37.

2000, Models of porosity evolution in Pennsylvanian lowstand carbonates (now in slope-to-basinal settings) and in Lower Permian, highstand-resedimented basinal carbonates, in Reid, S. T., ed., Geo-2000: into the future: American Association of Petroleum Geologists, Southwest Section, Transactions, Publication SWS 2000-107, p. $130-138$.

Mazzullo, L. J., and Arrant, B. G., 1988, Scharb Wolfcamp (oil), in A symposium of oil and gas fields of southeastern New Mexico, supplement: Roswell Geological Society, p. 289290.

Mazzullo, S. J., and Reid, A. M., 1987, Basinal Lower Permian facies, Permian Basin: part IIdepositional setting and reservoir facies of Wolfcampian-lower Leonardian basinal carbonates: West Texas Geological Society Bulletin, v. 26, no. 8, p. 5-10.

1989, Lower Permian platform and basin depositional systems, northern Midland Basin, Texas, in Crevello, P. D., Wilson, J. L., Sarg, J. F., and Read, J. F., eds., Controls on carbonate platform and basin development: Society of Economic Paleontologists and Mineralogists Special Publication 44, p. 305-320.

Mazzullo, S. J., Reid, A. M., and Mazzullo, L. J., 1987, Basinal Lower Permian facies, Permian Basin: part 1-stratigraphy of the Wolfcampian-Leonardian boundary: West Texas Geological Society Bulletin, v. 26, no. 7, p. 5-9.

Merriam, C. H., 2001, Depositional history of Lower Permian (Wolfcampian-Leonardian) carbonate buildups, Midland Basin, Upton County, Texas, Texas, in Stoudt, E. L., and Sivils, D. J., eds., Wolfcampian of West Texas (Permian Basin, Sierra Diablo and Hueco Mountains) — shelfal and periplatform carbonate reservoirs and outcrop analogs: 
Permian Basin Section SEPM Core Workshop and Field Trip Guidebook, Publication No. 2001-41, p. 2-1-2-22.

Montgomery, S. L., 1996, Permian "Wolfcamp" limestone reservoirs: Powell Ranch field, eastern Midland Basin: American Association of Petroleum Geologists Bulletin, v. 80, p. 1349-1365.

Pacht, J. A., Brooks, L., Messa, F., 1995, Stratigraphic analysis of 3D and 2D seismic data to delineate porous carbonate debris flows in Permian strata along the northwestern and eastern margins of the Midland Basin, in Martin, R. L., ed., In search of new Permian Basin oil and gas fields: using today's technologies and tomorrow's ideas for exploration, development, and 3D seismic in a mature basin: West Texas Geological Society Publication No. 95-98, p. 83-86.

Simo, J. A., Wahlman, G. P., Beall, J. L., and Stoklosa, M. L., 2000, Lower Permian (Wolfcampian) in the Hueco Mountains; stratigraphic and age relations, in DeMis, W. D., Nelis, M. K., and Trentham, R. C., eds., The Permian Basin: proving ground for tomorrow's technologies: West Texas Geological Society, Publication No. 00-109, p. $63-64$.

Sivils, D. J., 2001, Examples of Wolfcampian debris flow deposits from the Eastern Shelf of the Midland Basin, Glasscock County, Texas, in Stoudt, E. L., and Sivils, D. J., eds., Wolfcampian of West Texas (Permian Basin, Sierra Diablo and Hueco Mountains) shelfal and periplatform carbonate reservoirs and outcrop analogs: Permian Basin Section SEPM Core Workshop and Field Trip Guidebook, Publication No. 2001-41, p. 4-1-4-9.

Sivils, D. J., and Stoudt, E. L., 2001, Basinal Wolfcampian carbonate debris flow, Midland Basin, Texas, in Stoudt, E. L., and Sivils, D. J., eds., Wolfcampian of West Texas (Permian Basin, Sierra Diablo and Hueco Mountains) — shelfal and periplatform carbonate reservoirs and outcrop analogs: Permian Basin Section SEPM Core Workshop and Field Trip Guidebook, Publication No. 2001-41, p. 5-1-5-3.

Speer, S. W., 1993, Granite Wash (Permian), in Atlas of major Rocky Mountain gas reservoirs: New Mexico Bureau of Mines and Mineral Resources, p. 162.

Van Der Loop, M., 1990, Amacker Tippett Wolfcamp field, Upton County, Texas, in Flis, J. E., and Price, R. C., eds., Permian Basin oil and gas fields: innovative ideas in exploration and development: West Texas Geological Society, Publication No. 90-87, p. 133-151.

Wilson, J. L., 1975, Carbonate facies in geologic history: New York, Springer-Verlag, 471 p. 
Abo Platform Carbonate (Play 116)

The Abo Platform Carbonate play includes 23 reservoirs in Texas and New Mexico that have produced $>1 \mathrm{MMbbl}\left(1.59 \times 10^{5} \mathrm{~m}^{3}\right)$ through 2000 (table 21). Total production from these reservoirs is $541.5 \mathrm{MMbbl}\left(8.61 \times 10^{7} \mathrm{~m}^{3}\right)$. Reservoirs in the play are developed along the south margin of the Northwest Shelf and along the west margin of the Central Basin Platform (fig. 54). Deposition of the Abo at the beginning of the Leonard marks the transition from paleogeographically complex Upper Pennsylvanian-Wolfcampian isolated buildups to more organized shelf margin platforms (Kerans, 2000). Outcrop study of the Abo interval in Apache Canyon of the Sierra Diablo Mountains, west Texas, indicates that it is composed of six high-frequency sequences: three aggradational sequences making up the transgressive sequence set and three prograding clinoforms making up the highstand sequence set (Kerans, 2000; Kerans and others, 2000).

Table 21. Abo Platform Carbonate play (play 116). Production shown for fields that have had others combined into them represents the totals; combined fields are highlighted.

\begin{tabular}{|c|c|c|c|c|c|c|c|c|c|}
\hline RRC RESN & RRC & FLDNAME & RESNAME & STATE & COUNTY & DISCYR & DEPTHTOP & 2000 PROD & CUMPROD \\
\hline 8234002 & $8 \mathrm{~A}$ & BILLY & $\mathrm{ABO}$ & $\mathrm{TX}$ & LAMB & 1995 & 6674 & 119,876 & $1,168,302$ \\
\hline 12376666 & $8 \mathrm{~A}$ & BROWN & WICHITA - ALBANY & TX & GAINES & 1960 & 8004 & 20,255 & $4,550,006$ \\
\hline 49460500 & $8 \mathrm{~A}$ & KINGDOM & ABO REEF & TX & TERRY & 1970 & 8120 & $1,262,687$ & $57,666,707$ \\
\hline 53411070 & $8 \mathrm{~A}$ & LEVELLAND & $\mathrm{ABO}$ & $\mathrm{TX}$ & HOCKLEY & 1976 & 7566 & 21,576 & $1,521,730$ \\
\hline 53411852 & $8 \mathrm{~A}$ & LEVELLAND & WICHITA-ALBANY & $T X$ & HOCKLEY & 1965 & 7488 & 19,083 & $1,039,496$ \\
\hline 87157200 & $8 \mathrm{~A}$ & SUNDOWN & $\mathrm{ABO}$ & TX & HOCKLEY & 1978 & 7926 & 29,741 & $1,056,569$ \\
\hline 91621001 & $8 \mathrm{~A}$ & TSTAR & $\mathrm{ABO}$ & $T X$ & HOCKLEY & 1996 & 8039 & 837,713 & $3,223,835$ \\
\hline 95397600 & $8 \mathrm{~A}$ & WASSON & WICHITA ALBANY & $T X$ & GAINES & 1960 & 11038 & 99,477 & $11,639,560$ \\
\hline \multirow[t]{16}{*}{95402333} & $8 \mathrm{~A}$ & WASSON, S. & WICHITA - ALBANY & TX & GAINES & 1962 & 7711 & 19,268 & $4,652,147$ \\
\hline & & BRUNSON SOUTH & ABO DRINKARD & NM & LEA & 1988 & 6750 & 102,791 & $10,117,489$ \\
\hline & & BUCKEYE & $\mathrm{ABO}$ & NM & LEA & 1965 & 8950 & 19,140 & $2,529,960$ \\
\hline & & CORBIN & $\mathrm{ABO}$ & NM & LEA & 1959 & 8410 & 72,551 & $15,684,050$ \\
\hline & & DOUBLE A & LOWER ABO & NM & LEA & 1964 & 9300 & 12,498 & $1,076,771$ \\
\hline & & DOUBLE A SOUTH & $\mathrm{ABO}$ & NM & LEA & 1964 & 8900 & 24,923 & $1,970,186$ \\
\hline & & EMPIRE & $\mathrm{ABO}$ & NM & EDDY & 1957 & 6014 & 45,511 & $225,140,765$ \\
\hline & & JACKSON & $\mathrm{ABO}$ & NM & EDDY & 1961 & 6910 & 1,646 & $1,053,208$ \\
\hline & & LOVINGTON & $\mathrm{ABO}$ & NM & LEA & 1951 & 8340 & 80,989 & $33,983,198$ \\
\hline & & MALJAMAR & $\mathrm{ABO}$ & NM & LEA & 1959 & 8977 & 3,834 & $1,029,476$ \\
\hline & & MONUMENT & $\mathrm{ABO}$ & NM & LEA & 1948 & 7180 & $1,291,446$ & $7,139,437$ \\
\hline & & MONUMENT NORTH & $\mathrm{ABO}$ & NM & LEA & 1977 & 7300 & 220,836 & $1,204,844$ \\
\hline & & VACUUM & ABO REEF & NM & LEA & 1960 & 8650 & 366,857 & $91,163,873$ \\
\hline & & VACUUM NORTH & $\mathrm{ABO}$ & NM & LEA & 1963 & 8500 & $1,298,837$ & $52,981,986$ \\
\hline & & WANTZ & $\mathrm{ABO}$ & NM & LEA & 1950 & 6560 & 134,048 & $9,866,088$ \\
\hline & & Totals & & & & & & $6,105,583$ & $541,459,683$ \\
\hline
\end{tabular}




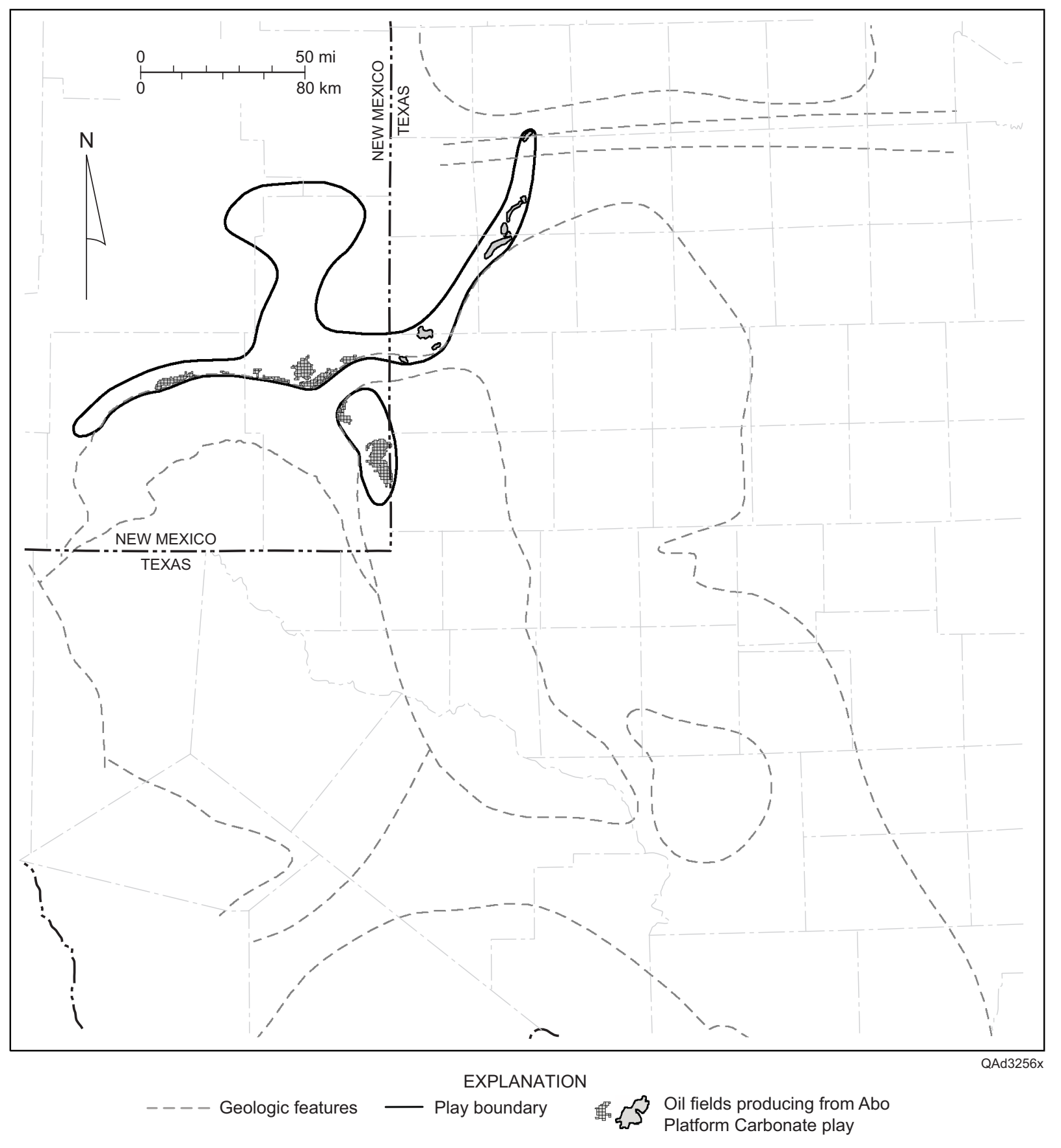

Figure 54. Play map for the Abo Platform Carbonate play, showing location of reservoirs having $>1 \mathrm{MMbbl}$ cumulative production, the play boundary, and geologic features. See figure 1 for county names and figure 2 for identification of geologic features.

The Abo is productive from shelf and shelf-margin facies on the Northwest Shelf and Central

Basin Platform (fig. 54). Although commonly referred to as the Abo Reef Trend, Abo reservoirs 
do not represent organic reef facies (Mazzullo, 1982). Outcrop studies (Kerans and others, 2000) demonstrate that platform-margin Abo successions are dominated by grain-rich packstones and grainstones that have undergone significant karst-related diagenesis. Analysis of the Abo succession at Kingdom Abo field in Terry and Hockley Counties, Texas, has confirmed the importance of grain-rich skeletal carbonates and karst-related diagenesis in the subsurface (Kerans, 2000; Kerans and others, 2000). The facies model for Kingdom Abo field is of a strongly progradational highstand ramp having three main facies tracts: inner shelf, shelf crest/shelf margin, and slope (fig. 55a). The field produces from upper-slope fusulinid packstones and grainstones and shelf-crest peloidal grainstones of the highstand sequence set (Kerans, 2000; Kerans and others, 2000). True reefal boundstone is only sparsely developed. The narrow shelf-parallel sweet spot of Abo production is interpreted to be a combination of maximum grainstone thickness and paleokarst overprint (Kerans, 2000; Kerans and others, 2000).

The dominant frequency of 3-D seismic data at reservoir depths is commonly too low to define Abo clinoform stratigraphy (Zeng and Kerans, 2003). High-frequency seismic data ( $>70 \mathrm{~Hz}$ ) follow thinner, time-bounded, clinoform depositional elements (time-stratigraphic units) in the Abo, but low-frequency seismic data tend to image thicker, low-angle lithofacies units (time-transgressive units) (fig. 55b) (Zeng and Kerans, 2003).

At Kingdom (Abo) and Kingdom, North (Abo), fields, the average porosity is 6.5 percent and average permeability is $9 \mathrm{md}\left(9 \times 10^{-3} \mu \mathrm{m}^{2}\right)$; pay cutoffs are 4 percent porosity and $1 \mathrm{md}$ $\left(1 \times 10^{-3} \mu \mathrm{m}^{2}\right)$ permeability (Party and others, 1998).

The Abo Platform Carbonate play extends into New Mexico along the southern edge of the Northwest Shelf and on the northwest margin of the Central Basin Platform (fig. 54). In 
(a)

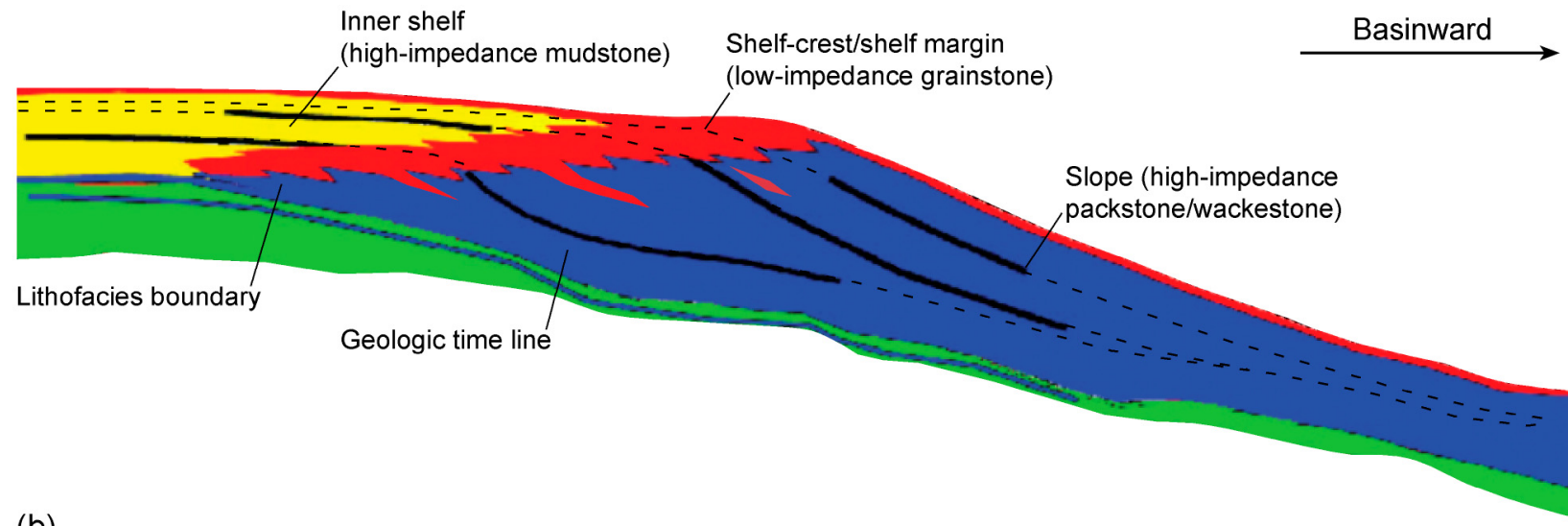

(b)

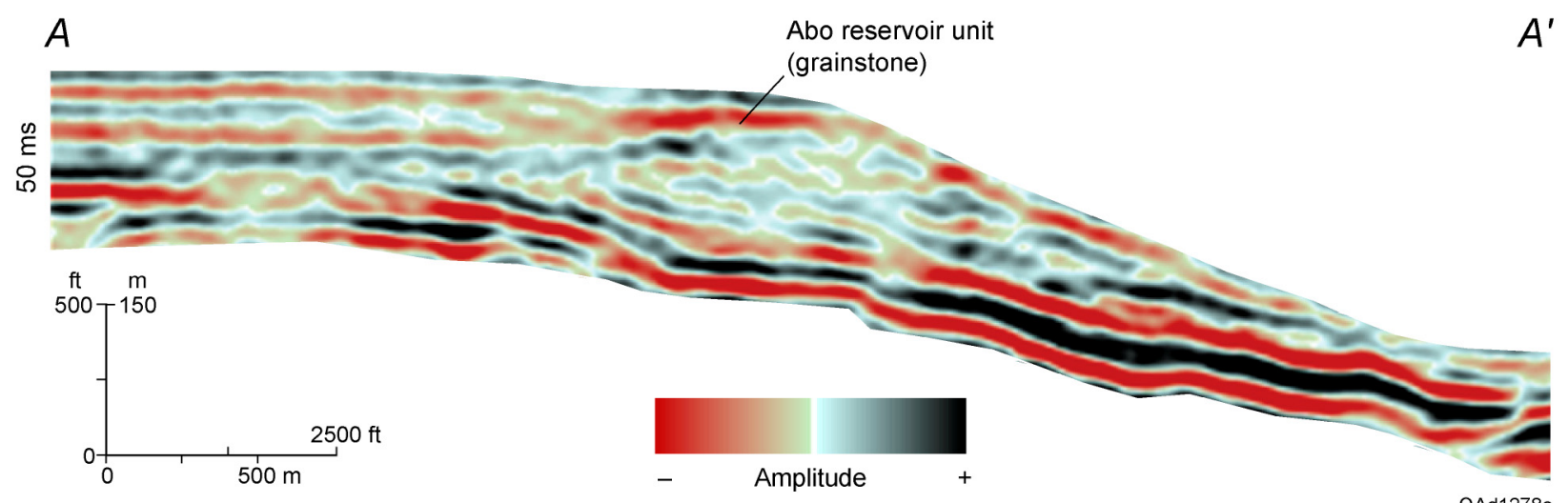

Figure 55. (a) Depositional model of the progradational Abo sequence. Time-stratigraphic units comprise clinoform deposits that consist of inner shelf, shelf-crest/shelf-margin, and slope facies. Three time-transgressive lithostratigraphic units (inner shelf mudstone, shelf-crest/shelfmargin grainstone, and slope wackestone) develop when the system progrades basinward. Lithostratigraphic units dip landward and cross geologic time lines. (b) A seismic line from a multichannel, migrated, P-wave 3-D data volume in Kingdom Abo field shows a slightly landward dipping seismic reflection event that corresponds to the time-transgressive, shelfcrest/shelf-margin grainstone lithofacies. See Zeng and Kerans (2000) for location of seismic section. After Zeng and Kerans (2000), reprinted by permission of the AAPG, whose permission is required for further use. CCopyright 2003. The American Association of Petroleum Geologists. All rights reserved.

New Mexico, the play is divided into two subplays. The Abo Platform Margin Carbonate subplay consists of reservoirs deposited at the shelf edge, and the Abo Carbonate Shelf subplay consists of reservoirs that are found north of the shelf margin. There are 62 known, discovered 
reservoirs in the New Mexico part of the Abo Platform Carbonate play, 14 of which have produced $>1 \mathrm{MMbbl}\left(1.59 \times 10^{5} \mathrm{~m}^{3}\right)($ fig. 54 ; table 21). Cumulative production from those 14 New Mexico reservoirs was $455 \mathrm{MMbbl}\left(7.23 \times 10^{7} \mathrm{~m}^{3}\right)$ as of 2000 . During the 1970 's, production in the play was dominated by the Empire Abo reservoir and as this important reservoir began to decline in the late 1970's, production from the play in New Mexico went into decline. Abo production in New Mexico increased during the latter half of the 1990's as production in the Monument reservoir increased as a result of additional drilling.

The Abo trend is localized along the preexisting Bone Spring flexure (Snyder, 1962), which apparently formed a hingeline that marked the boundary between the Northwest Shelf and the Delaware Basin during the Early Permian. The Abo trend is delineated in younger, shallower strata by a drape of the overlying sediments, which forms the Artesia-Vacuum Arch (Kelley, 1971).

Reef reservoirs in the Abo Platform Margin Carbonate subplay are white to light-gray, finely to coarsely crystalline dolostones (LeMay, 1960, 1972; Snyder, 1962). Pervasive dolomitization has obliterated depositional sedimentary structures and textures in the New Mexico reservoirs. Pay thickness exceeds $700 \mathrm{ft}(210 \mathrm{~m})$ in parts of the Empire Abo reservoir but is less than $100 \mathrm{ft}(30 \mathrm{~m})$ in most of the other reservoirs. Porosity is vugular, intercrystalline, and fracture. Porosity and permeability are irregularly distributed, and fluid communication within reservoirs is poor (LeMay, 1960, 1972). As a result, small gas pockets are present within structurally low areas of a reservoir.

Traps in the shelf-margin reservoirs are predominantly stratigraphic (LeMay 1960, 1972). The vertical seal is formed by green siliciclastic shales and interbedded finely crystalline dolostones of the shelf facies that has prograded southward over the shelf-margin facies. 
East-west limits of the reservoirs are defined by gentle structural or morphologic plunge of the reservoir facies under the oil-water contact or by occlusion of porosity by anhydrite cement on the shelfward side (LeMay 1960, 1972). Southern limits of the Abo reservoirs are delineated by transition to nonporous, black, argillaceous lime mudstones and fine-grained sandstones of the basinal Bone Spring Formation (fig. 56). Dark-colored rocks of the Bone Spring are organic rich and are the probable source rocks for oil in the shelf-edge carbonate reservoirs.

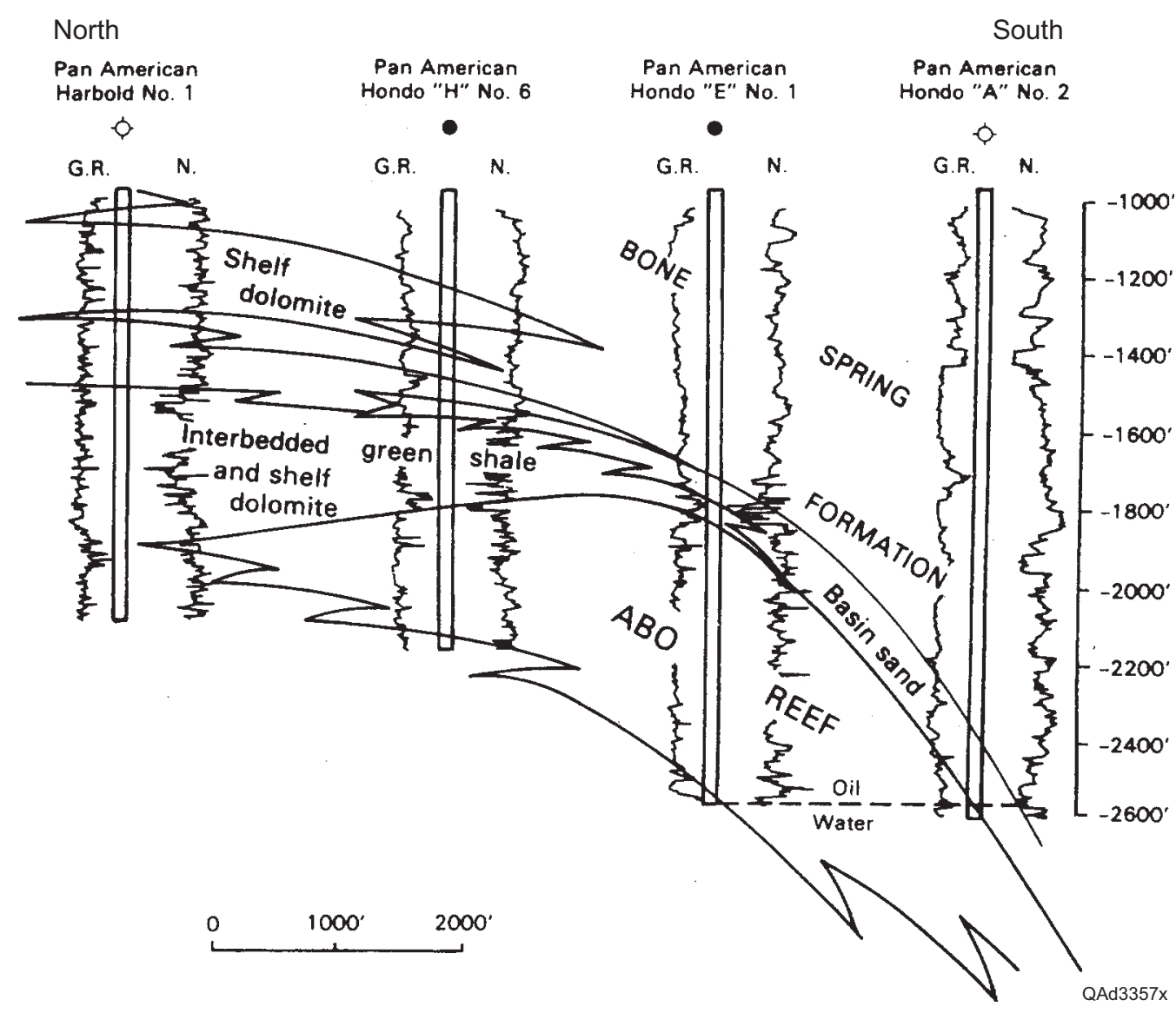

Figure 56. North-south structural cross section of the Empire Abo reservoir showing relationship of porous Abo reef to Abo backreef facies and basinal Bone Spring Formation. Vertical scale is in feet below sea level. From LeMay (1960). See LeMay (1960) for location of cross section. 
Reservoirs in the Abo Carbonate Shelf subplay are dolostones that were deposited on an evaporitic restricted marine shelf. Although poorly documented, traps appear to be formed by broad, low-relief anticlines. Porous zones appear to have relatively good continuity within defined reservoirs. Overall, however, porosity and permeability are unevenly distributed within Abo carbonates on the Northwest Shelf. Reservoirs are generally smaller and have smaller reserves in the Abo Carbonate Shelf subplay than reservoirs in the Abo Platform Margin Carbonate subplay. Only one reservoir in the Abo Carbonate Shelf subplay, Vacuum North, has produced $>1 \mathrm{MMbbl}\left(1.59 \times 10^{5} \mathrm{~m}^{3}\right)$, although there are several other reservoirs that should exceed the $1 \mathrm{MMbbl}\left(1.59 \times 10^{5} \mathrm{~m}^{3}\right)$ level during the next decade.

The primary drive mechanism for Abo carbonate reservoirs is primary gas-cap expansion supplemented by solution-gas drive. Best reservoir practices include perforating the pay well below the gas-oil contact in order to prevent coning of the gas cap into the perforated interval, thereby conserving reservoir energy (Hueni and Schuessler, 1993). Unitization of the field may be implemented in order to initiate gas reinjection so that loss of reservoir energy and, therefore, production rates may be stabilized.

\section{References}

Hueni, G. B., and Schuessler, K. L., 1993, Associated gas reservoirs, in Atlas of major Rocky Mountain gas reservoirs: New Mexico Bureau of Mines and Mineral Resources, p. 190.

Kelley, V. C., 1971, Geology of the Pecos Country, southeastern New Mexico: New Mexico Bureau of Mines and Mineral Resources, Memoir 24, 75 p.

Kerans, C., 2000, Stratigraphic architecture and paleokarst development within the Abo (Leonardian 1) Composite Sequence, Apache Canyon and Kingdom Abo field, Permian Basin, in Reid, S. T., Southwest Section AAPG 2000 Convention Transactions: West Texas Geological Society, Publication SWS 2000-107, p. 250. 
Kerans, C., Kempter, K., and Rush, J., 2000, Facies and stratigraphic controls on a coastal paleokarst, Lower Permian, Apache Canyon, West Texas, in Lindsay, R., Trentham, R., Ward, R. F., and Smith, A. H., eds., Classic Permian geology of West Texas and Southeastern New Mexico, 75 years of Permian Basin oil \& gas exploration \& development: West Texas Geological Society Publication No. 00-108, p. 55-81.

LeMay, W. J., 1960, Abo reefing in southeastern New Mexico, in A symposium of oil and gas fields of southeastern New Mexico, supplement: Roswell Geological Society, p. xvii-xxi.

1972, Empire Abo Field, southeast New Mexico, in Stratigraphic oil and gas fields: American Association of Petroleum Geologists Memoir 16, p. 472-480.

Mazzullo, S. J., 1982, Stratigraphy and depositional mosaics of Lower Clear Fork and Wichita Groups (Permian), Northern Midland Basin, Texas: American Association of Petroleum Geologists Bulletin, v. 66, p. 210-227.

Party, J. M., D’Agostino, A. E., Welch, J. P. F., and Lindsay, R. F., 1998, Geology, facies, and stratigraphy of Kingdom and Kingdom North (Abo) fields, Terry and Hockley Counties, Texas, in DeMis, W. D. and Nelis, M. K., eds., The search continues into the $21 \mathrm{st}$ century: West Texas Geological Society Publication No. 98-105, p. 139-166.

Snyder, D. O., 1962, Geology of the Empire Abo field, Eddy County, New Mexico: University of New Mexico, M.S. thesis, 77 p.

Zeng, H., and Kerans, C., 2003, Seismic frequency control on carbonate seismic stratigraphy: a case study of the Kingdom Abo sequence, west Texas: American Association of Petroleum Geologists Bulletin, v. 87, p. 273-293. 
Leonard Restricted Platform Carbonate (Play 117)

The Leonard Restricted Platform Carbonate play consists of 183 reservoirs that had produced $>1$ MMbbl $\left(1.59 \times 10^{5} \mathrm{~m}^{3}\right)$ of oil through 2000 ; cumulative production from the play was 3,295 MMbbl $\left(5.24 \times 10^{8} \mathrm{~m}^{3}\right)$ (table 22). Reservoirs of Leonardian age on the Central Basin Platform, Northwest Shelf, and Eastern Shelf are included in this play (fig. 57), with the exception of Abo reservoirs on the Northwest Shelf. The Leonard Restricted Platform Carbonate play includes rocks assigned to the Wichita (also known as the Wichita/Albany or Abo), Clear Fork, Tubb, Yeso, Glorieta (also known as the San Angelo), and locally to the Holt (fig. 3). With the exception of the Holt, lower San Andres rocks in the uppermost Leonardian are not included in this play. The Clear Fork Group in Texas is separated into lower and upper Clear Fork units by the Tubb Formation, a zone of silty carbonate. The top of the Clear Fork is separated from the overlying San Andres Formation by the Glorieta silty carbonate. The entire interval is productive, but the lower Clear Fork has had the greatest amount of production (Montgomery, 1998).

Mazzullo (1982) and Mazzullo and Reid (1989) summarized large-scale stratigraphy and depositional systems of the lower Leonard in the Midland Basin. The Leonardian stratigraphic section is $\sim 2,500$ to $3,000 \mathrm{ft}$ ( $\sim 760$ to $915 \mathrm{~m})$ thick, and reservoirs are typically developed at depths between 5,600 and 7,800 ft (1,700 and 2,400 m) (Tyler and others, 1991). Leonardian reservoirs contained an estimated 14.5 $\mathrm{Bbbl}\left(2.31 \times 10^{9} \mathrm{~m}^{3}\right)$ of original oil in place (Holtz and others, 1992), approximately 15 percent of the total resource in the Permian Basin, but recovery efficiencies are the lowest among carbonate reservoirs in the Permian Basin (Ruppel and others, 2000). 
Table 22. Leonard Restricted Platform Carbonate play (play 117). Production shown for fields that have had others combined into them represents the totals; combined fields are highlighted.

\begin{tabular}{|c|c|c|c|c|c|c|c|c|c|}
\hline RRC RESN & RRC & FLDNAME & RESNAME & STATE & COUNTY & DISCYR & DEPTHTOP & 2000 PROD & CUMPROD \\
\hline 292058 & 8 & ABELL & CLEAR FORK & TX & PECOS & 1950 & 3555 & 11,400 & $1,043,523$ \\
\hline 292580 & 8 & ABELL & PERMIAN 3800 & TX & PECOS & 1949 & 3800 & 5,495 & $1,000,919$ \\
\hline 292500 & 8 & ABELL & PERMIAN-GENERAL & $\mathrm{TX}$ & CRANE & 1975 & 4200 & 49,449 & $1,658,580$ \\
\hline 1406001 & $8 \mathrm{~A}$ & ALEX & & $T X$ & TERRY & 1945 & 5150 & 54,445 & $1,623,604$ \\
\hline 3172500 & $8 \mathrm{~A}$ & ANTON & CLEAR FORK, LOWER & TX & HOCKLEY & 1959 & 6502 & 24,778 & $1,045,786$ \\
\hline 3180001 & $8 \mathrm{~A}$ & ANTON, WEST & & $\mathrm{TX}$ & HOCKLEY & 1950 & 6655 & 46,493 & $2,517,174$ \\
\hline 3194001 & $8 \mathrm{~A}$ & ANTON-IRISH & & $T X$ & HALE & 1944 & 5348 & $3,466,252$ & $200,803,233$ \\
\hline 3644568 & 8 & ARMER & TUBB & $\mathrm{TX}$ & CRANE & 1955 & 4865 & 15,168 & $1,441,098$ \\
\hline 4279500 & $7 \mathrm{C}$ & ATKINSON, W. & SAN ANGELO & TX & TOM GREEN & 1965 & 816 & 55,327 & $2,311,838$ \\
\hline 5524830 & 8 & BAR-MAR & TUBB & $\mathrm{TX}$ & CRANE & 1965 & 3962 & 13,153 & $1,022,337$ \\
\hline 6378284 & 8 & BAYVIEW & GLORIETA & TX & CRANE & 1961 & 3008 & 3,671 & $2,595,807$ \\
\hline 6385500 & 8 & BAYVIEW, W. & GLORIETA & $\mathrm{TX}$ & CRANE & 1965 & 3023 & 5,725 & $1,026,923$ \\
\hline 9250001 & 8 & BLOCK 12 & & $\mathrm{TX}$ & ANDREWS & 1946 & 7170 & 24,318 & $3,003,421$ \\
\hline 8944750 & 8 & BLOCK A-28 & WICHITA-ALBANY & $\mathrm{TX}$ & ANDREWS & 1964 & 7463 & 21,924 & $1,690,793$ \\
\hline 8958400 & 8 & BLOCK A-34 & GLORIETA & TX & ANDREWS & 1955 & 5910 & 136,778 & $3,112,350$ \\
\hline 8962500 & 8 & BLOCK A-34, NORTHWEST & GLORIETA & $T X$ & ANDREWS & 1955 & 5914 & 16,864 & $1,402,909$ \\
\hline 11082333 & 8 & BOYDELL, S. & CLEAR FORK, LO. & $\mathrm{TX}$ & ANDREWS & 1967 & 7089 & 132,105 & $2,325,116$ \\
\hline 12118500 & $8 \mathrm{~A}$ & BROADVIEW, WEST & CLEAR FORK & $\mathrm{TX}$ & LUBBOCK & 1960 & 5565 & 155,447 & $3,389,002$ \\
\hline 12230333 & 8 & BROOKLAW & CLEAR FORK, LOWER & TX & PECOS & 1969 & 3460 & 16,172 & $2,195,374$ \\
\hline 12376001 & $8 \mathrm{~A}$ & BROWN & & $\mathrm{TX}$ & GAINES & 1948 & 6030 & 12,203 & $5,380,103$ \\
\hline 12448200 & 8 & BROWN \& THORP & CLEAR FORK & TX & PECOS & 1951 & 3028 & 24,560 & $6,882,219$ \\
\hline 12449800 & 8 & BROWN \& THORP, EAST & TUBB & TX & PECOS & 1965 & 3125 & 84,867 & $2,681,183$ \\
\hline 14200800 & 8 & C-BAR & TUBB & TX & CRANE & 1957 & 5320 & 19,076 & $2,622,880$ \\
\hline 19541001 & 8 & COLEMAN RANCH & & $\mathrm{TX}$ & MITCHELL & 1946 & 2560 & 231,378 & $10,496,867$ \\
\hline 19543500 & 8 & COLEMAN RANCH, N. & CLEAR FORK & $\mathrm{TX}$ & MITCHELL & 1953 & 3050 & 68,512 & $4,051,150$ \\
\hline 20609666 & 8 & CORDONA LAKE, NORTH & TUBB 4500 & $\mathrm{TX}$ & CRANE & 1966 & 4546 & 1,927 & $1,061,583$ \\
\hline 21577450 & 8 & CRAWAR & GLORIETA & $\mathrm{TX}$ & WARD & 1954 & 4040 & 51,440 & $1,285,530$ \\
\hline 21907555 & 8 & CROSSETT & 3000 CLEAR FORK & TX & CRANE & 1952 & 2960 & 38,765 & $3,022,275$ \\
\hline 23907568 & 8 & DEEP ROCK & GLORIETA 5950 & TX & ANDREWS & 1954 & 5700 & 307,694 & $13,186,510$ \\
\hline 24562284 & $8 \mathrm{~A}$ & DIAMOND -M- & CLEAR FORK & TX & SCURRY & 1940 & 3170 & 341,882 & $9,832,055$ \\
\hline 25188200 & 8 & DOLLARHIDE & CLEAR FORK & TX & ANDREWS & 1949 & 6545 & 755,549 & $47,270,501$ \\
\hline 25544001 & $8 \mathrm{~A}$ & DORWARD & & TX & GARZA & 1950 & 2456 & 269,535 & $26,776,688$ \\
\hline 27664500 & $8 \mathrm{~A}$ & EDMISSON & CLEAR FORK & TX & LUBBOCK & 1957 & 5143 & 436,211 & $14,122,508$ \\
\hline 27668500 & $8 \mathrm{~A}$ & EDMISSON, N.W. & CLEAR FORK & TX & LUBBOCK & 1979 & 5446 & 224,312 & $2,958,886$ \\
\hline 28843888 & 8 & EMBAR & 5600 & $\mathrm{TX}$ & ANDREWS & 1955 & 5606 & 23,398 & $6,368,089$ \\
\hline 28843666 & 8 & EMBAR & PERMIAN & TX & ANDREWS & 1942 & 6280 & 30,050 & $6,779,777$ \\
\hline 28961568 & 8 & EMPEROR & HOLT & $\mathrm{TX}$ & WINKLER & 1946 & 4765 & 117,711 & $9,475,152$ \\
\hline 28963500 & 8 & EMPEROR, EAST & CLEAR FORK, LO. & TX & WINKLER & 1962 & 6097 & 11,227 & $1,131,119$ \\
\hline 31222300 & $8 \mathrm{~A}$ & FLANAGAN & CLEARFORK, CONS. & TX & GAINES & 1949 & 7142 & 848,550 & $34,993,943$ \\
\hline 31893333 & $8 \mathrm{~A}$ & FORBES & GLORIETA & TX & CROSBY & 1955 & 3605 & 434,735 & $8,897,397$ \\
\hline 33158250 & 8 & FUHRMAN & GLORIETA & $\mathrm{TX}$ & ANDREWS & 1950 & 5612 & 189,906 & $11,248,689$ \\
\hline 33230001 & 8 & FULLERTON & & TX & ANDREWS & 1941 & 7300 & $3,170,615$ & $309,506,748$ \\
\hline 34113125 & $8 \mathrm{~A}$ & GARZA & GLORIETA & $\mathrm{TX}$ & GARZA & 1956 & 3758 & 3,514 & $1,449,452$ \\
\hline 34113160 & $8 \mathrm{~A}$ & GARZA & GLORIETA, S. DEEP & TX & GARZA & 1985 & 3692 & 33,230 & $4,388,968$ \\
\hline 34742450 & $8 \mathrm{~A}$ & GIEBEL & CFA & TX & GAINES & 1998 & 7670 & 51,489 & $1,507,141$ \\
\hline 35652868 & 8 & GOLDSMITH & 5600 & TX & ECTOR & 1947 & 5600 & $1,147,401$ & $240,096,410$ \\
\hline 35652062 & 8 & GOLDSMITH & CLEAR FORK & TX & ECTOR & 1946 & 6300 & $1,906,142$ & $93,193,807$ \\
\hline 35653333 & 8 & GOLDSMITH, EAST & GLORIETA & $\mathrm{TX}$ & ECTOR & 1955 & 5136 & 6,782 & $1,360,016$ \\
\hline 35659125 & 8 & GOLDSMITH, W. & CLEAR FORK, UP. & TX & ECTOR & 1956 & 5640 & 42,287 & $9,675,776$ \\
\hline 37695500 & $8 \mathrm{~A}$ & $H \& L$ & GLORIETA & TX & GARZA & 1967 & 3397 & 25,087 & $2,838,452$ \\
\hline 38255116 & 8 & HALLEY & CLEAR FORK & TX & WINKLER & 1961 & 5162 & 36,697 & $2,881,280$ \\
\hline 38255406 & 8 & HALLEY & GLORIETA & $\mathrm{TX}$ & WINKLER & 1957 & 5006 & 27,169 & $4,333,697$ \\
\hline 38455500 & $8 \mathrm{~A}$ & HAMILTON & CLEARFORK & TX & HOCKLEY & 1980 & 6459 & 56,904 & $1,207,473$ \\
\hline 39176690 & 8 & HARPER & GLORIETA & $\mathrm{TX}$ & ECTOR & 1988 & 5500 & 52,206 & $1,118,476$ \\
\hline 39242001 & $8 \mathrm{~A}$ & HARRIS & & TX & GAINES & 1949 & 5965 & $1,039,986$ & $77,544,178$ \\
\hline 41769001 & $8 \mathrm{~A}$ & HOBBS, EAST & & TX & GAINES & 1949 & 6390 & 18,953 & $1,623,627$ \\
\hline 42499500 & $8 \mathrm{~A}$ & HOOPLE & CLEAR FORK & TX & LUBBOCK & 1976 & 4432 & 429,394 & $14,531,548$ \\
\hline 42971166 & 8 & HOWARD GLASSCOCK & CLEAR FORK,MI & TX & HOWARD & 1970 & 3705 & 155,631 & $6,808,390$ \\
\hline 42971332 & 8 & HOWARD-GLASSCOCK & GLORIETA & TX & HOWARD & 1925 & 3200 & 603,262 & $39,431,415$ \\
\hline 43731333 & $8 \mathrm{~A}$ & HUNTLEY & GLORIETA & $\mathrm{TX}$ & GARZA & 1954 & 3966 & 31,002 & $7,649,424$ \\
\hline 44148500 & 8 & IATAN, EAST HOWARD & & TX & HOWARD & 1926 & 2700 & $1,837,814$ & $168,656,507$ \\
\hline 44245500 & $8 \mathrm{~A}$ & IDALOU, NORTH & CLEARFORK, LO & TX & LUBBOCK & 1979 & 5650 & 80,698 & $2,252,994$ \\
\hline 45680500 & 8 & JANELLE, SE. & TUBB & TX & WARD & 1962 & 5344 & 74,002 & $4,843,708$ \\
\hline 46134500 & $8 \mathrm{~A}$ & JENKINS, NORTH & CLEAR FORK & TX & GAINES & 1954 & 7148 & 147,180 & $2,690,500$ \\
\hline 47007380 & 8 & JOHNSON & GLORIETA & TX & ECTOR & 1973 & 5452 & 77,950 & $8,122,905$ \\
\hline 47267608 & 8 & JORDAN & TUBB & TX & ECTOR & 1948 & 5250 & 6,226 & $3,416,506$ \\
\hline 48583664 & $8 \mathrm{~A}$ & KELLY SNYDER & CLEAR FORK, LOWER & TX & SCURRY & 1956 & 3320 & 4,561 & $1,227,148$ \\
\hline 49043333 & 8 & KERMIT, SE. & TUBB & $\mathrm{TX}$ & WINKLER & 1965 & 6211 & 12,037 & $1,012,432$ \\
\hline 49099500 & $7 \mathrm{C}$ & KETCHUM MT. & CLEAR FORK & TX & IRION & 1955 & 4548 & 295,594 & $9,226,117$ \\
\hline 49129066 & 8 & KEYSTONE & CLEAR FORK & $T X$ & WINKLER & 1958 & 5739 & 53,239 & $5,291,790$ \\
\hline 49129396 & 8 & KEYSTONE & HOLT & $\mathrm{TX}$ & WINKLER & 1943 & 4800 & 515,675 & $44,955,406$ \\
\hline 49133001 & 8 & KEYSTONE, SOUTH & & TX & WINKLER & 1958 & 6470 & 30,539 & $3,276,871$ \\
\hline 52624900 & 8 & LEA & TUBB & $\mathrm{TX}$ & CRANE & 1955 & 4448 & 19,898 & $1,842,206$ \\
\hline 52872001 & $8 \mathrm{~A}$ & LEE HARRISON & & TX & LUBBOCK & 1941 & 4870 & 268,977 & $15,622,248$ \\
\hline 52916500 & $8 \mathrm{~A}$ & LEEPER & GLORIETA & $T X$ & TERRY & 1958 & 5896 & 447,007 & $14,672,329$ \\
\hline 53759333 & $8 \mathrm{~A}$ & LINKER & CLEAR FORK & TX & HOCKLEY & 1961 & 7162 & 112,546 & $1,953,860$ \\
\hline 55953250 & 8 & LYLES & CLEAR FORK & TX & CRANE & 1970 & 3170 & 18,836 & $2,423,992$ \\
\hline
\end{tabular}


Table 22, continued. Leonard Restricted Platform Carbonate play (play 117).

\begin{tabular}{|c|c|c|c|c|c|c|c|c|c|}
\hline RRC RESN & RRC & FLDNAME & RESNAME & STATE & COUNTY & DISCYR & DEPTHTOP & 2000 PROD & CUMPROD \\
\hline 57774275 & 8 & MARTIN & CONSOLIDATED & $\mathrm{TX}$ & ANDREWS & 2000 & 7490 & 463,407 & $8,977,662$ \\
\hline 57774664 & 8 & MARTIN & TUBB & TX & ANDREWS & 1955 & 6260 & 50,355 & $2,115,646$ \\
\hline 59563333 & 8 & MCKEE & CLEAR FORK, LOWER & $\mathrm{TX}$ & CRANE & 1950 & 4050 & 5,720 & $1,078,221$ \\
\hline 60698664 & $7 \mathrm{C}$ & MERTZON & SAN ANGELO & TX & IRION & 1955 & 1648 & 6,811 & $3,430,892$ \\
\hline 60873426 & 8 & METZ & GLORIETTA & $\mathrm{TX}$ & ECTOR & 1959 & 4426 & 21,951 & $1,802,537$ \\
\hline 62079500 & $8 \mathrm{~A}$ & MIRIAM & GLORIETA 4740 & $\mathrm{TX}$ & LYNN & 1966 & 4867 & 13,720 & $1,145,553$ \\
\hline 62415083 & 8 & MONAHANS & CLEAR FORK & $\mathrm{TX}$ & WARD & 1945 & 4750 & 216,894 & $19,445,953$ \\
\hline 62417110 & 8 & MONAHANS, NORTH & CLEARFORK & $\mathrm{TX}$ & WINKLER & 1987 & 5610 & 80,297 & $1,146,607$ \\
\hline 64890750 & 8 & NELSON & $\begin{array}{l}\text { WICHITA } \\
\text { WIT }\end{array}$ & $\mathrm{TX}$ & ANDREWS & 1948 & 7160 & 3,776 & $2,354,254$ \\
\hline 65567300 & 8 & NIX & CLEARFORK & $\mathrm{TX}$ & ANDREWS & 1989 & 7036 & 64,986 & $2,269,877$ \\
\hline 65572001 & 8 & NIX, SOUTH & & TX & ANDREWS & 1954 & 7386 & 34,829 & $3,279,283$ \\
\hline 67899001 & $8 \mathrm{~A}$ & OWNBY & & $\mathrm{TX}$ & YOAKUM & 1941 & 5350 & 341,910 & $19,365,908$ \\
\hline 67899400 & $8 \mathrm{~A}$ & OWNBY & CLEAR FORK, UPPER & TX & YOAKUM & 1959 & 6592 & 663,398 & $22,886,861$ \\
\hline 69351166 & 8 & PAROCHIAL-BADE & CLEAR FORK & TX & STERLING & 1954 & 2211 & 47,566 & $4,764,467$ \\
\hline 70537924 & 8 & PENWELL & 4500 & $\mathrm{TX}$ & ECTOR & 1948 & 4410 & 0 & $2,805,483$ \\
\hline 70537066 & 8 & PENWELL & CLEAR FORK & TX & ECTOR & 1953 & 4996 & 31,481 & $1,878,499$ \\
\hline 70537462 & 8 & PENWELL & GLORIETA & $\mathrm{TX}$ & ECTOR & 1953 & 4420 & 24,417 & $7,345,775$ \\
\hline 68101500 & $8 \mathrm{~A}$ & P. H. D. & GLORIETA & $\mathrm{TX}$ & GARZA & 1955 & 4296 & 54,844 & $2,535,850$ \\
\hline 72552500 & $8 \mathrm{~A}$ & POST & GLORIETA & TX & GARZA & 1950 & 2700 & 193,539 & $15,161,894$ \\
\hline 72995001 & $8 \mathrm{~A}$ & PRENTICE & & $\mathrm{TX}$ & YOAKUM & 1951 & 5940 & 68,854 & $48,873,597$ \\
\hline 72995498 & $8 \mathrm{~A}$ & PRENTICE & 6700 & TX & YOAKUM & 1950 & 6700 & $2,294,110$ & $150,194,889$ \\
\hline 72995166 & $8 \mathrm{~A}$ & PRENTICE & CLEAR FORK, LOWER & $\mathrm{TX}$ & YOAKUM & 1955 & 8130 & 52,878 & $3,778,472$ \\
\hline 74450300 & $7 \mathrm{C}$ & RAMON & LEONARD & $\mathrm{TX}$ & SCHLEICHER & 1980 & 2617 & 150,855 & $1,177,882$ \\
\hline 76093666 & $8 \mathrm{~A}$ & REVILO & GLORIETA & TX & SCURRY & 1955 & 2624 & 60,635 & $13,908,430$ \\
\hline 76707001 & $8 \mathrm{~A}$ & RILEY, NORTH & & TX & GAINES & 1947 & 6930 & $1,280,855$ & $44,651,363$ \\
\hline 77247600 & 8 & ROBERDEAU & CLEAR FORK, UPPER & $\mathrm{TX}$ & CRANE & 1963 & 3000 & 5,823 & $2,149,749$ \\
\hline 77252111 & 8 & ROBERDEAU, S. & CLEAR FORK LOWER & TX & CRANE & 1965 & 3330 & 10,302 & $1,184,878$ \\
\hline 77252888 & 8 & ROBERDEAU, S. & TUBB & TX & CRANE & 1967 & 3321 & 18,149 & $2,161,929$ \\
\hline 77318666 & $8 \mathrm{~A}$ & ROBERTSON, N. & CLEAR FORK 7100 & TX & GAINES & 1956 & 7114 & $3,949,386$ & $176,656,655$ \\
\hline 77622550 & 7C & ROCK PEN & CLEAR FORK & TX & IRION & 1988 & 3840 & 34,272 & $1,181,195$ \\
\hline 77643333 & $8 \mathrm{~A}$ & ROCKER -A- & CLEAR FORK & TX & GARZA & 1958 & 3236 & 19,900 & $1,269,266$ \\
\hline 77643666 & $8 \mathrm{~A}$ & ROCKER -A- & GLORIETA & TX & GARZA & 1955 & 3082 & 59,510 & $4,308,818$ \\
\hline 78168500 & $8 \mathrm{~A}$ & ROPES, E. & CLEAR FORK & TX & HOCKLEY & 1964 & 6036 & 35,196 & $3,017,622$ \\
\hline 78936600 & 8 & RUNNING W & TUBB & $\mathrm{TX}$ & CRANE & 1962 & 4340 & 3,844 & $1,197,246$ \\
\hline 78938500 & 8 & RUNNING W, N. & HOLT & TX & CRANE & 1964 & 4008 & 12,606 & $1,093,983$ \\
\hline 79002166 & $8 \mathrm{~A}$ & RUSSELL & CLEARFORK 7000 & TX & GAINES & 1943 & 7300 & 389,816 & $63,297,892$ \\
\hline 79002332 & $8 \mathrm{~A}$ & RUSSELL & GLORIETA 6100 & TX & GAINES & 1942 & 6100 & 95,004 & $9,018,065$ \\
\hline 79004750 & $8 \mathrm{~A}$ & RUSSELL, NORTH & 6600 & TX & GAINES & 1957 & 6736 & 89,005 & $2,412,699$ \\
\hline 80473620 & 8 & SAND HILLS & SAN ANGELO, UPPER & $\mathrm{TX}$ & CRANE & 1963 & 3618 & 20,568 & $3,375,873$ \\
\hline 80473682 & 8 & SAND HILLS & TUBB & $\mathrm{TX}$ & CRANE & 1930 & 4500 & 912,916 & $102,067,768$ \\
\hline 82225284 & $8 \mathrm{~A}$ & SEMINOLE & SAN ANGELO & TX & GAINES & 1947 & 6536 & 104,349 & $8,777,639$ \\
\hline 82233600 & $8 \mathrm{~A}$ & SEMINOLE, W. & LEONARD & TX & GAINES & 1956 & 8742 & 0 & $1,473,334$ \\
\hline 82570100 & 8 & SHAFTER LAKE & CLEAR FORK & $\mathrm{TX}$ & ANDREWS & 1948 & 6910 & 438,894 & $10,252,003$ \\
\hline 82710166 & $8 \mathrm{~A}$ & SHARON RIDGE & CLEAR FORK & TX & SCURRY & 1950 & 2994 & 824,804 & $40,352,615$ \\
\hline 83991400 & $8 \mathrm{~A}$ & SLAUGHTER & CLEAR FORK 7190 & $\mathrm{TX}$ & HOCKLEY & 1966 & 7332 & 203,399 & $2,696,681$ \\
\hline 84257333 & 8 & SMITH & CLEAR FORK & TX & ANDREWS & 1950 & 7340 & 48,817 & $1,213,636$ \\
\hline 84345001 & $8 \mathrm{~A}$ & SMYER & & $\mathrm{TX}$ & HOCKLEY & 1944 & 5980 & 562,854 & $48,419,531$ \\
\hline 84469001 & 8 & SNYDER & & TX & HOWARD & 1937 & 2800 & 553,905 & $43,595,719$ \\
\hline 86175500 & $8 \mathrm{~A}$ & STINNETT, SE. & CLEAR FORK & $\mathrm{TX}$ & LUBBOCK & 1963 & 4585 & 100,717 & $2,749,554$ \\
\hline 86252400 & $8 \mathrm{~A}$ & STOCKYARD & CLEARFORK, UPPER & $\mathrm{TX}$ & GAINES & 1991 & 6480 & 226,342 & $1,976,951$ \\
\hline 87143500 & 8 & SUN VALLEY & TUBB, LOWER & $\mathrm{TX}$ & PECOS & 1969 & 3272 & 22,151 & $1,874,552$ \\
\hline 87145500 & 8 & SUN VALLEY, N. & TUBB, LOWER & TX & PECOS & 1969 & 3363 & 13,236 & $1,261,965$ \\
\hline 89010700 & $8 \mathrm{~A}$ & TEX-MEX, SE. & WICHITA ALBANY & $\mathrm{TX}$ & GAINES & 1983 & 7498 & 213,664 & $5,335,900$ \\
\hline 89024333 & $8 \mathrm{~A}$ & TEX-PAC & CLEAR FORK & $\mathrm{TX}$ & GAINES & 1956 & 8290 & 3,113 & $1,886,905$ \\
\hline 90188001 & $7 \mathrm{C}$ & TIPPETT & & TX & CROCKETT & 1947 & 6100 & 1,897 & $3,627,887$ \\
\hline 90188415 & $7 \mathrm{C}$ & TIPPETT & LEONARD, LOWER & TX & CROCKETT & 1962 & 5067 & 49,749 & $4,979,264$ \\
\hline 91903333 & 8 & TURNER-GREGORY & CLEAR FORK & TX & MITCHELL & 1955 & 2668 & 152,698 & $10,555,530$ \\
\hline 88071696 & 8 & TXL & TUBB & $\mathrm{TX}$ & ECTOR & 1950 & 6158 & $1,321,643$ & $56,553,202$ \\
\hline 92450001 & 8 & UNION & & TX & ANDREWS & 1943 & 7459 & 25,373 & $16,655,594$ \\
\hline 93234500 & $8 \mathrm{~A}$ & VAREL & GLORIETA & TX & SCURRY & 1955 & 2680 & 9,478 & $1,559,599$ \\
\hline 93852750 & 8 & VINCENT & CLEAR FORK, LOWER & TX & HOWARD & 1977 & 4410 & 11,131 & $3,111,060$ \\
\hline 95152475 & 8 & WARD-ESTES, N. & WICHITA - ALBANY & TX & WARD & 1995 & 6581 & 207,473 & $1,247,410$ \\
\hline 95245500 & $8 \mathrm{~A}$ & WARHORSE & CLEARFORK, UP. & TX & TERRY & 1975 & 6801 & 31,639 & $3,346,790$ \\
\hline 95431001 & $8 \mathrm{~A}$ & WASSON 72 & & TX & YOAKUM & 1940 & 7200 & $3,095,164$ & $109,696,671$ \\
\hline 95400333 & $8 \mathrm{~A}$ & WASSON, NE. & CLEAR FORK & TX & YOAKUM & 1954 & 7800 & 651,891 & $20,763,808$ \\
\hline 96166333 & 8 & WELLAW & CLEAR FORK, LO. & TX & PECOS & 1967 & 3094 & 0 & $1,181,678$ \\
\hline 96373400 & 8 & WENTZ & CLEAR FORK & TX & PECOS & 1953 & 2415 & 54,010 & $5,045,383$ \\
\hline 96563001 & 8 & WESTBROOK & & $\mathrm{TX}$ & MITCHELL & 1921 & 3100 & $1,086,214$ & $106,699,704$ \\
\hline 96565500 & 8 & WESTBROOK, EAST & CLEAR FORK & TX & MITCHELL & 1975 & 3166 & 48,233 & $2,233,993$ \\
\hline 97057500 & $8 \mathrm{~A}$ & WHITHARRAL & CLEAR FORK, LO. & TX & HOCKLEY & 1971 & 6938 & 90,782 & $3,909,654$ \\
\hline 94432500 & $8 \mathrm{~A}$ & WTG & GLORIETA & TX & GARZA & 1979 & 3232 & 70,399 & $2,712,643$ \\
\hline 99070200 & 8 & WYNNE & CLEAR FORK, UP. & TX & CRANE & 1972 & 3090 & 8,058 & $1,435,782$ \\
\hline
\end{tabular}


Table 22, continued. Leonard Restricted Platform Carbonate play (play 117).

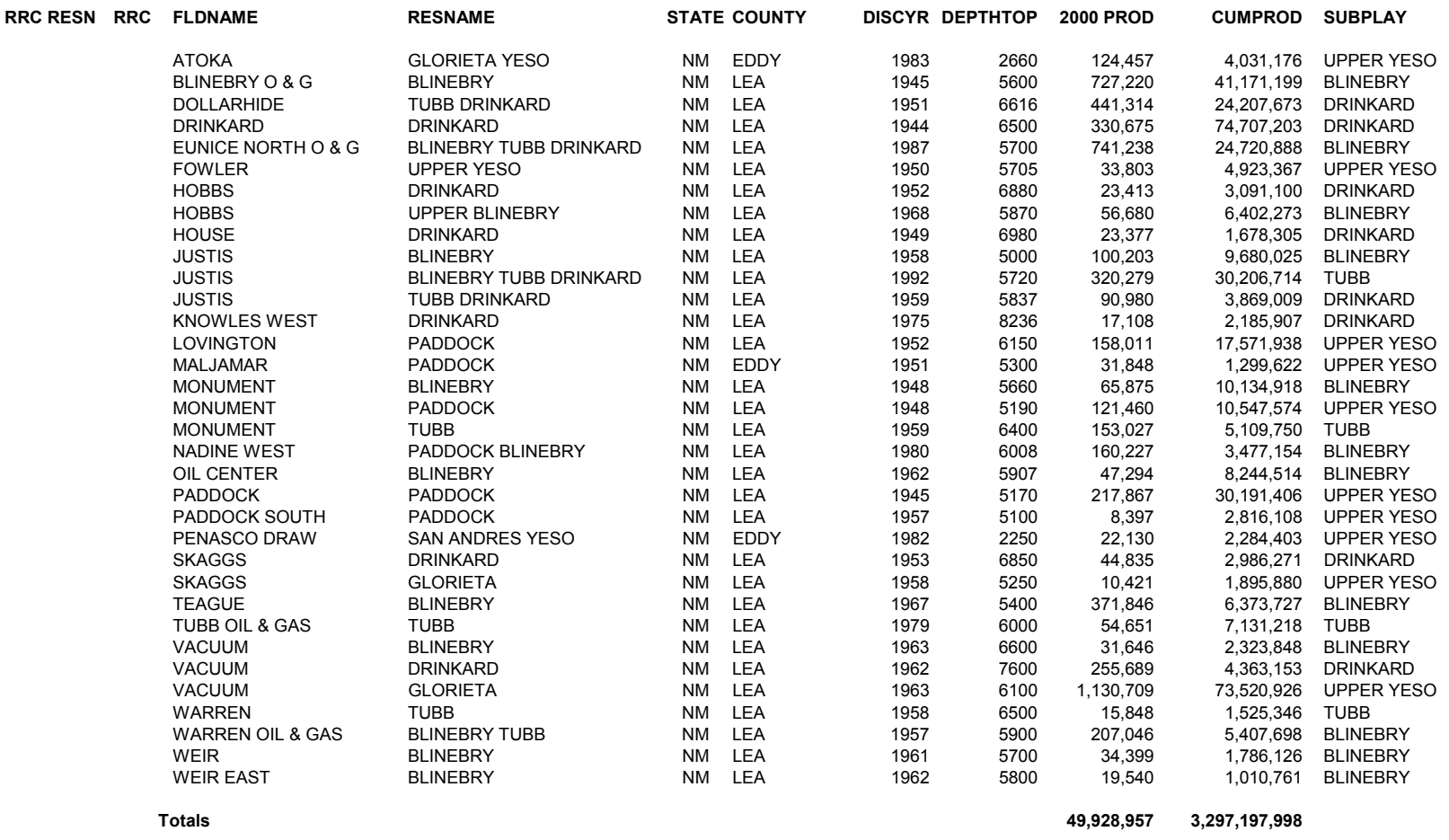

The sequence-scale architecture of Leonardian rocks in the Permian Basin has been documented from integrated outcrop and subsurface studies by Fitchen and others (1995). Ruppel and others (2000) described the high-frequency sequence- and cycle-architecture of the lower Clear Fork, Tubb, and upper Clear Fork in outcrops of the Sierra Diablo Mountains, west Texas.

Leonardian rocks on the Central Basin Platform and Northwest and Eastern Shelves were deposited in restricted, low-energy depositional conditions that occurred on a shallow-water carbonate platform (fig. 58). Leonardian rocks are dominated by cyclic alternations of peritidal, tidal-flat deposits and shallow-water, subtidal rocks (Presley, 1987; Ruppel, 1992; Ruppel and 


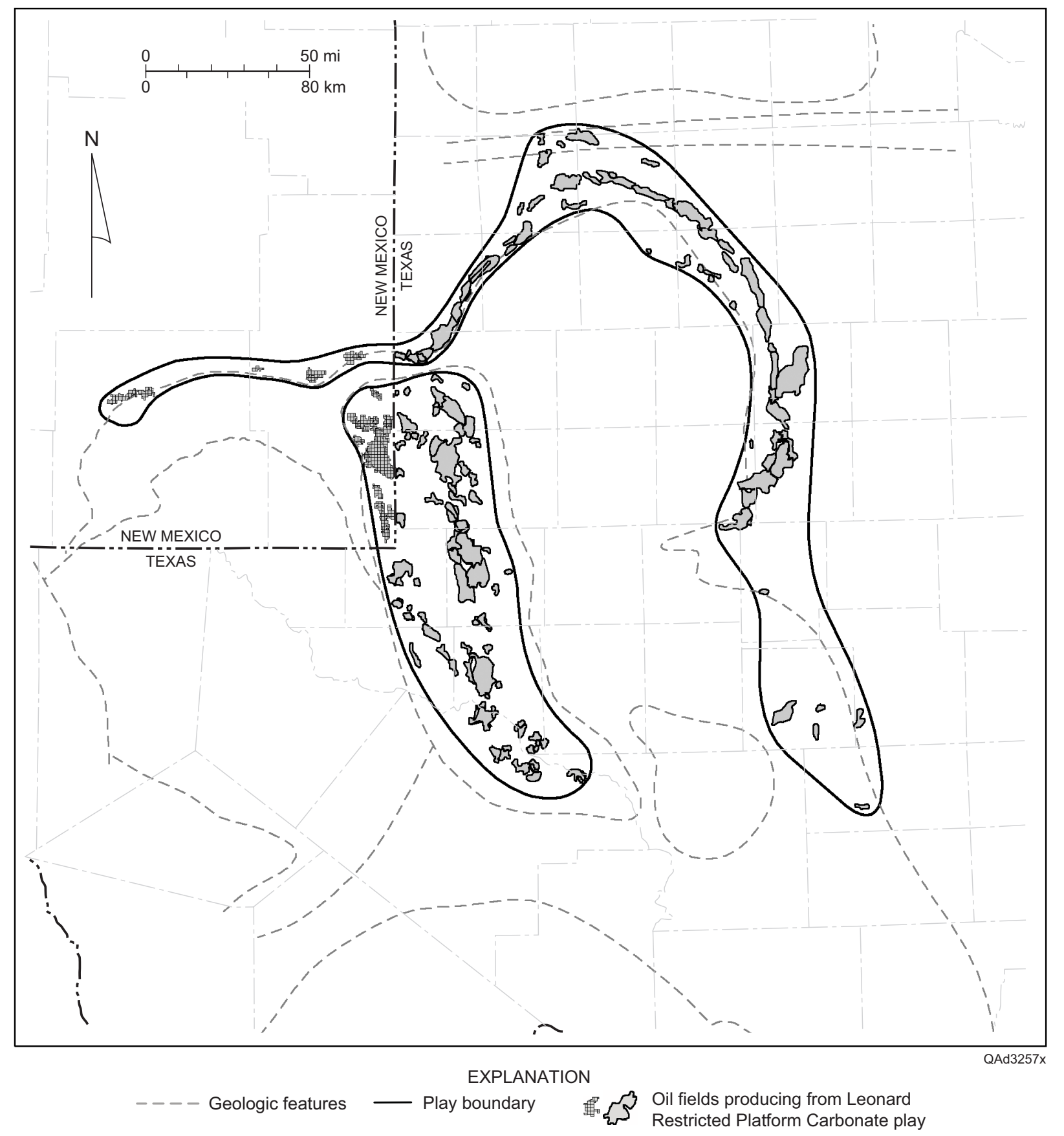

Figure 57. Play map for the Leonard Restricted Platform Carbonate play, showing location of reservoirs having $>1 \mathrm{MMbbl}$ cumulative production, the play boundary, and geologic features. See figure 1 for county names and figure 2 for identification of geologic features. 


\section{DEPOSITIONAL MODEL}

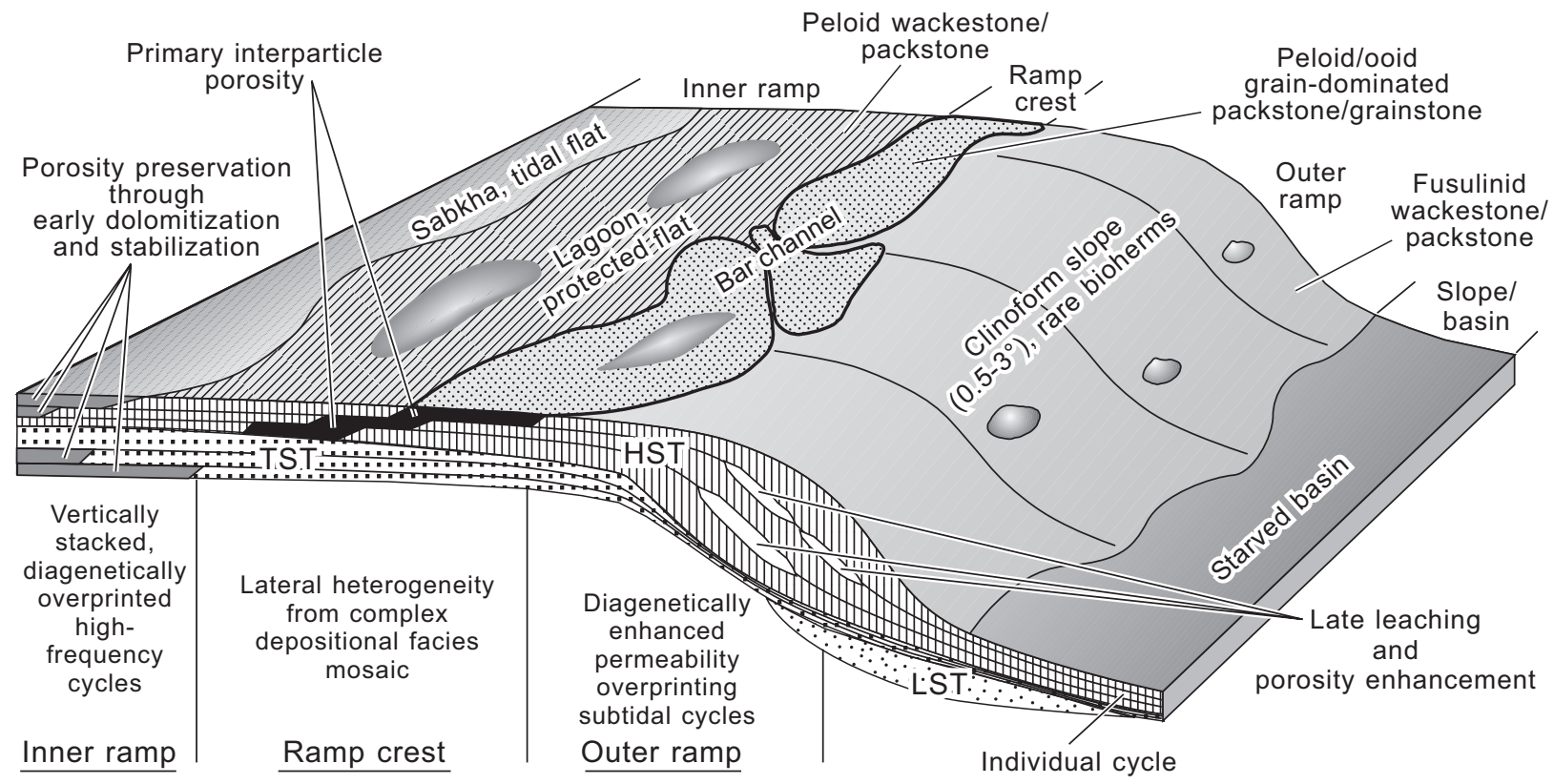

STYLES OF HETEROGENEITY

QAa5300cx

Figure 58. Depositional model for middle Permian carbonate platform deposits in the Permian Basin. From Kerans and Ruppel (1994).

others, 1995; Atchley and others, 1999). The Tubb and Glorieta are composed dominantly of siliciclastic-rich tidal-flat deposits (Ruppel, 2002). High-frequency cycles, averaging $\sim 3$ to $6 \mathrm{ft}$ ( $\sim 1$ to $2 \mathrm{~m}$ ) in thickness, are composed of (1) basal, mud-rich, subtidal rocks; (2) overlying, grain-dominated, subtidal rocks; and (3) cycle-capping, tidal-flat rocks (Ruppel, 1992, 2002; Ruppel and others, 2000). Cycle sets, 20 to $40 \mathrm{ft}$ (6 to $12 \mathrm{~m}$ ) in thickness, are defined by stacking of high-frequency cycles. These cycle sets, plus local variations in paleotopography, controlled the development of depositional and diagenetic fabrics (Atchley and others, 1999; Ruppel, 2002). Although early diagenesis apparently preserved porosity at cycle tops, petrophysical properties are dominantly related to depositional facies (Ruppel, 2002). Tidal-flat deposits have high porosity but low permeability because their pore structure is dominated by fenestral vugs. The best reservoir quality occurs in grain-dominated, dolomitized, subtidal rocks having high 
porosity and relatively high permeability and oil saturation associated with intergranular and intercrystalline pores (Atchley and others, 1999; Ruppel, 2002; Jones and others, 2003).

Stratigraphically controlled petrophysical variability in the South Wasson Clear Fork reservoir (Wasson 72) in Yoakum County produces flow-unit-scale layering that results in highly stratified reservoir behavior (Jennings and others, 2002). South Wasson Clear Fork is undergoing the only $\mathrm{CO}_{2}$ flood currently being conducted in a Clear Fork reservoir in the Permian Basin. The $\mathrm{CO}_{2}$ flood, initiated in 1986 in the early stages of the waterflood, uses a 2:1 WAG injection ratio (Kinder Morgan, 2004).

A reservoir-characterization study of Fullerton Clear Fork field (fig. 59), Andrews County, developed techniques to improve the resolution and predictability of key reservoir properties for construction of more accurate reservoir models. The integration of cyclestratigraphic (Ruppel, 2003), rock-fabric (Jones and others, 2003), and 3-D seismic data (Zeng and others, 2003) provided a robust basis for distributing reservoir rock and fluid properties (Wang and others, 2003). A cycle-stratigraphic framework for the lower Clear Fork, Wichita, and Abo reservoir intervals at Fullerton field was constructed by integrating information from outcrop analogs in the Sierra Diablo Mountains of west Texas (Ruppel and others, 2000) with $>1,500 \mathrm{ft}(>5,000 \mathrm{~m}$ ) of core from the field (figs. 59, 60).

To create a high-resolution permeability model of Fullerton field, core samples were assigned to a petrophysical class on the basis of fabric, pore type, lithology, and crystal size, and then class-specific transforms were used to calculate permeability from wireline-log porosity (Jones and others, 2003). Stratigraphically keyed vertical changes in petrophysical class were mapped throughout a study area within the field, and calculated permeabilities were used to populate a 3-D model that incorporates stratigraphic architecture, rock-fabric data, and 


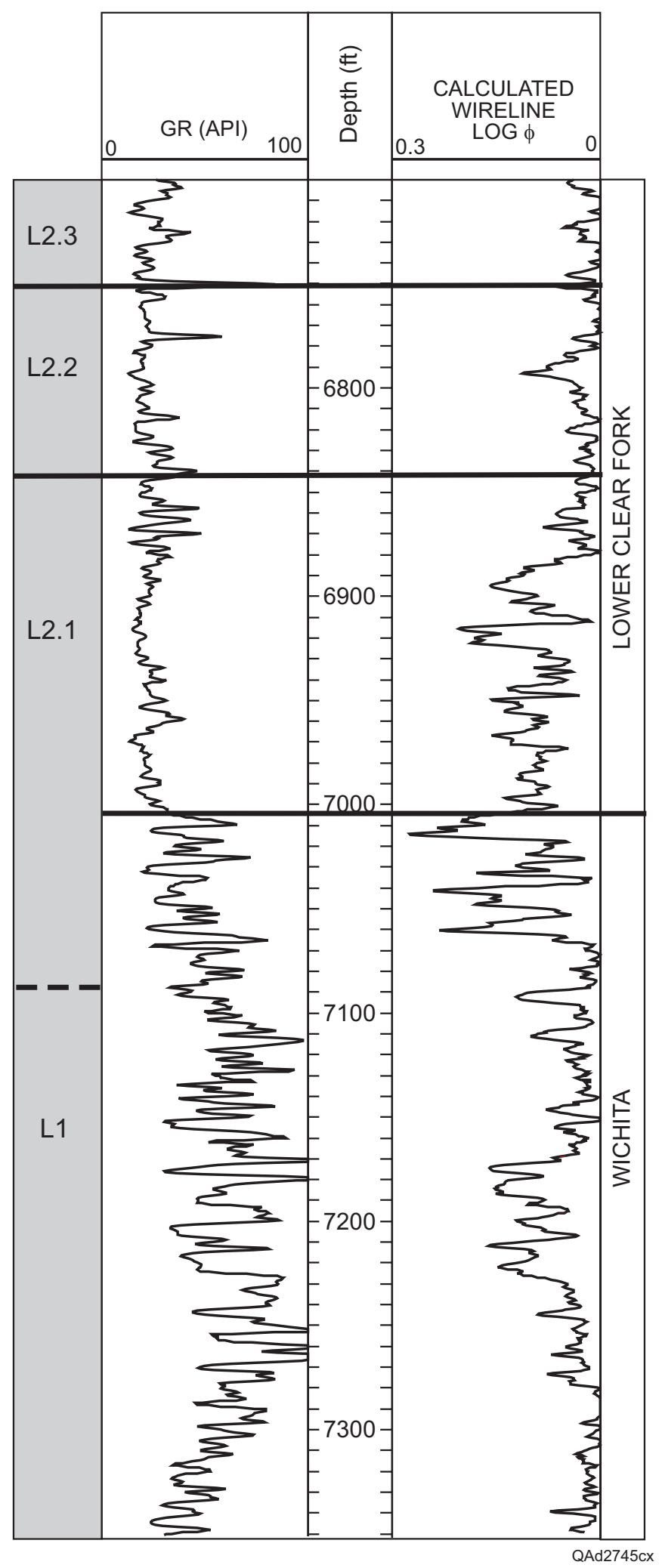

Figure 59. Typical log from Fullerton Clear Fork reservoir, from the Fullerton Clearfork Unit 5927 well. From Jones and others (2003). L1=Leonardian sequence 1; L2.1, L2.2, and L2.3 are Leonardian high-frequency sequences. 


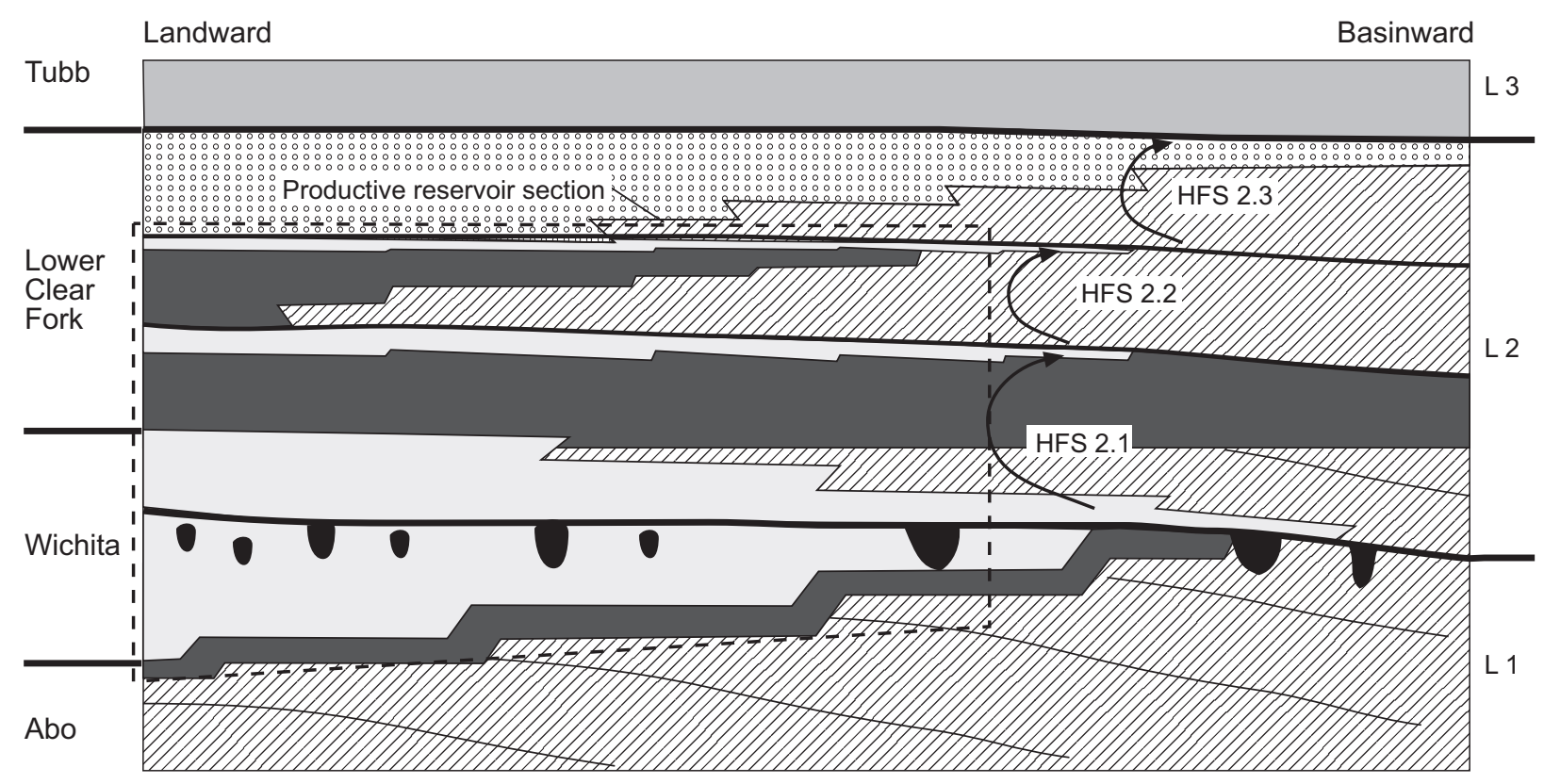

FACIES TRACTS

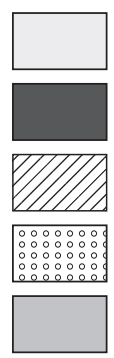

Inner-ramp, amalgamated tidal flat

Ramp-crest, grain-rich packstone

Outer-ramp, fusulinid wackestone-packstone

Inner-ramp, tidal-flat-capped wackestone

TST silty wackestone-siltstone

\section{SEQUENCE STRATIGRAPHY}

HFS High-frequency sequence

L 1 Composite sequence

- Clinoformal bed

Karst breccia and conglomerate

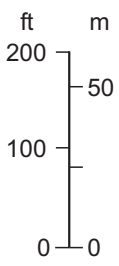

QAd2757cx

Figure 60. Sequence stratigraphic model of the Clear Fork reservoir succession at Fullerton field, Andrews County, Texas. From Ruppel (2003).

petrophysical data. Porosity, permeability, and water saturation were modeled deterministically using a 2,000-ft (610-m) search radius. In general, the lowermost sequence of the lower Clear Fork has the best porosity and permeability. The estimated OOIP for the study area calculated from this model is $185 \mathrm{MMbbl}\left(2.94 \times 10^{7} \mathrm{~m}^{3}\right)$. Because only $40 \mathrm{MMbbl}\left(6.36 \times 10^{6} \mathrm{~m}^{3}\right)$ has been produced to date from this area, $145 \mathrm{MMbbl}\left(2.31 \times 10^{7} \mathrm{~m}^{3}\right)$, or about 80 percent of the OOIP, probably remains. Results of reservoir characterization have been used to target future infill drilling and possible enhanced oil recovery (EOR) by $\mathrm{CO}_{2}$ flood. 
Reservoir characterization and flow modeling of the North Robertson Unit in Gaines County identified infill drilling targets by locating areas having (1) good reservoir quality in porous grainstone facies; (2) better flow capacity, as indicated by permeability-thickness; and (3) substantial remaining mobile oil (Montgomery, 1998; Montgomery and others, 1998; Nevans and others, 1999). New injector and producer wells were drilled using a line-drive pattern to lower costs, optimize injectivity and pressure support, and improve sweep (Nevans and others, 1999). Incremental production was increased by $\sim 900 \mathrm{bbl} / \mathrm{d}\left(\sim 143 \mathrm{~m}^{3} / \mathrm{d}\right)$, and then leveled out at 450 to $500 \mathrm{bbl} / \mathrm{d}$ (32 to $36 \mathrm{bbl} / \mathrm{d} /$ well) $\left[71.5 \mathrm{~m}^{3} / \mathrm{d}\right.$ to $79.5 \mathrm{~m}^{3} / \mathrm{d}(5.1$ to $\left.5.7 \mathrm{~m} / \mathrm{d} / \mathrm{well})\right]$ (Montgomery and others, 1998). The mud log, used with a porosity and resistivity log, was determined to be an effective, low-cost tool for identifying pay zones (Nevans and others, 1999).

Most of the fields in the play produce from large asymmetric anticlines developed over basement structures (Montgomery, 1998). Reservoir net pay in the play ranges widely, from 5 to 360 feet (Holtz and others, 1992; Montgomery, 1998). Porosity ranges from 3 to 23 percent and averages 11.0 percent; permeability ranges from 0.2 to $30 \mathrm{md}\left(0.2\right.$ to $\left.30 \times 10^{-3} \mu \mathrm{m}^{2}\right)$ and averages $5 \mathrm{md}\left(5 \times 10^{-3} \mu \mathrm{m}^{2}\right)($ Holtz and others, 1992).

Reservoirs of the Leonard Restricted Platform Carbonate play in New Mexico lie on the Central Basin Platform and along a curvilinear trend near the south margin of the Northwest Shelf (fig. 57). There are 102 known, discovered Leonard platform reservoirs in New Mexico, and 34 reservoirs have produced $>1 \mathrm{MMbbl}\left(1.59 \times 10^{5} \mathrm{~m}^{3}\right)$ (fig. 57 ; table 22). Most of these reservoirs are productive from platform dolostones and limestones, but some are productive from sandstones.

The Leonard Restricted Platform Carbonate play in New Mexico is productive from reservoirs in the Drinkard, Tubb, Blinebry, and Paddock Members of the Yeso Formation and 
in the Glorieta Formation (fig. 3). In the New Mexico part of the play, four subplays are recognized: (1) Drinkard, (2) Tubb, (3) Blinebry, and (4) upper Yeso (table 23). Maps of the four subplays are included in pdf format on the $\mathrm{CD}$ that accompanies this report, in addition to a pdf map that shows all reservoirs together on one map.

Production from the four subplays is mostly from stacked reservoirs on the Central Basin Platform. On the Northwest Shelf, however, the lower reservoirs (Drinkard, Tubb, Blinebry) are productive from only the east part of the play trend. Production from the upper Yeso reservoirs (Paddock and Glorieta) stretches from the New Mexico-Texas border westward into central Eddy County. The upper Yeso subplay is the most productive of the four Leonard subplays in New Mexico, as well as having the largest geographic extent (table 23). The stratigraphic distinction between the Paddock Member of the Yeso Formation and the Glorieta Formation is imprecise; many reservoirs correlated as Glorieta are actually Paddock (for example, the Vacuum Glorieta reservoir; Martin and Hickey, 2002).

Most reservoirs in the Leonard Restricted Platform Carbonate play in New Mexico are marine limestones and dolostones deposited on a restricted carbonate-dominated platform.

Table 23. The four New Mexico subplays of the Leonard Restricted Platform Carbonate play.

\begin{tabular}{|c|c|c|c|}
\hline Subplay & $\begin{array}{l}\text { Principal productive } \\
\text { stratigraphic units }\end{array}$ & $\begin{array}{c}\text { Number of reservoirs with } \\
\text { cumulative production of } \\
>1 \mathrm{MMbbl} \text { oil }\end{array}$ & $\begin{array}{l}\text { Cumulative oil } \\
\text { production from } \\
\text { reservoirs with } \\
>1 \mathrm{MMbbl} \text { oil } \\
\text { (MMbbl) }\end{array}$ \\
\hline $\begin{array}{l}\text { Upper } \\
\text { Yeso }\end{array}$ & $\begin{array}{l}\text { Glorieta Formation } \\
\text { Paddock Member of Yeso Formation }\end{array}$ & 10 & 149 \\
\hline Blinebry & Blinebry Member of Yeso Formation & 12 & 121 \\
\hline Tubb & Tubb Member of Yeso Formation & 4 & 44 \\
\hline Drinkard & Drinkard Member of Yeso Formation & 8 & 117 \\
\hline
\end{tabular}


Carbonate reservoirs dominate the Drinkard, Blinebry, and Paddock sections. Fine-grained dolomitic sandstone reservoirs are dominant in some areas in the Tubb and Glorieta sections, but dolostone reservoirs are dominant elsewhere in the Tubb and Glorieta. Percentage of sandstone increases westward within the Glorieta, and sandstone reservoirs dominate the Glorieta section in the westernmost part of the play (Broadhead, 1993).

Drinkard reservoirs are productive from carbonates deposited in a variety of shelf and shelf-edge environments. On the Northwest Shelf, reservoir character in the Drinkard Member is related to the location of the underlying Abo reef trend (Martin and others, 1999; see play 116, Abo Platform Carbonate for a description of the Abo reef trend). In reservoirs located shoreward of the underlying Abo platform margin carbonate trend (for example, Vacuum Drinkard), reservoir facies are formed by patch reefs and associated grainstones. Reservoirs located basinward of the Abo trend (for example, Knowles West) are formed by foreslope oolite shoals. In the Justis Tubb Drinkard reservoir on the Central Basin Platform, the best-quality reservoir rocks are grain-dominated limestones; dolomitized grainstones are less porous and permeable (Hoffman, 2002).

Traps are generally formed by low-relief anticlines (fig. 61). A single structure may trap oil and gas in multiple pay zones. Depths to productive reservoirs range from 2,250 to $8,200 \mathrm{ft}$ (690 to 2,500 m). In some reservoirs, facies variations can create porosity pinch-outs on anticlinal noses (fig. 62), as well as unevenness in reservoir quality across a structure, resulting in a stratigraphic component to trapping and production and internal compartmentalization of the reservoirs. Depositional variation within Leonardian stratal units influences the distribution of reservoir facies across an oil accumulation; grainstones, which are the primary productive facies 


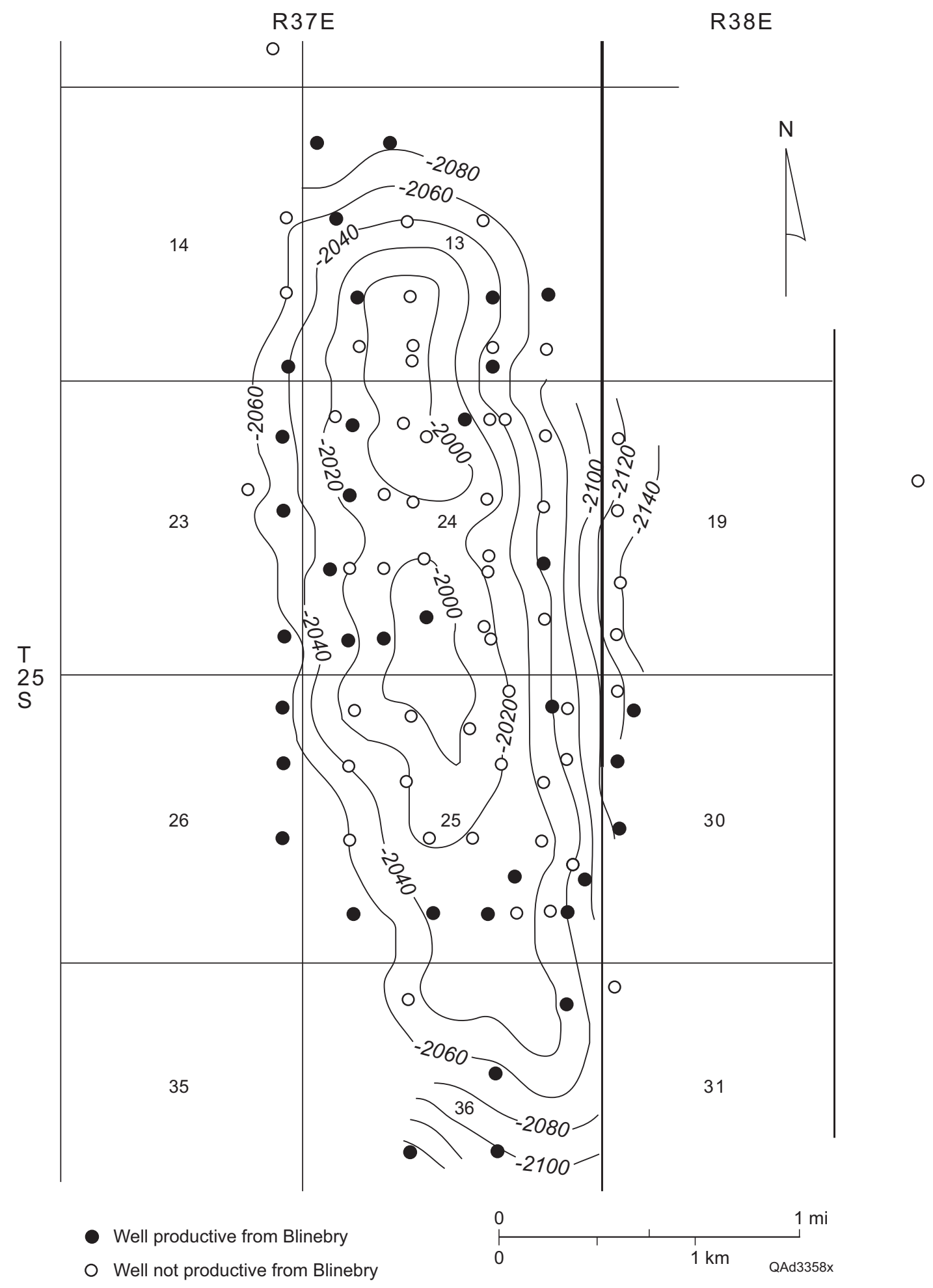

Figure 61. Structure contour map on top of Blinebry Member, Yeso Formation, Justis Blinebry reservoir. Datum is sea level. Contour interval equals $20 \mathrm{ft}$. After Marshall and Foltz (1960). 


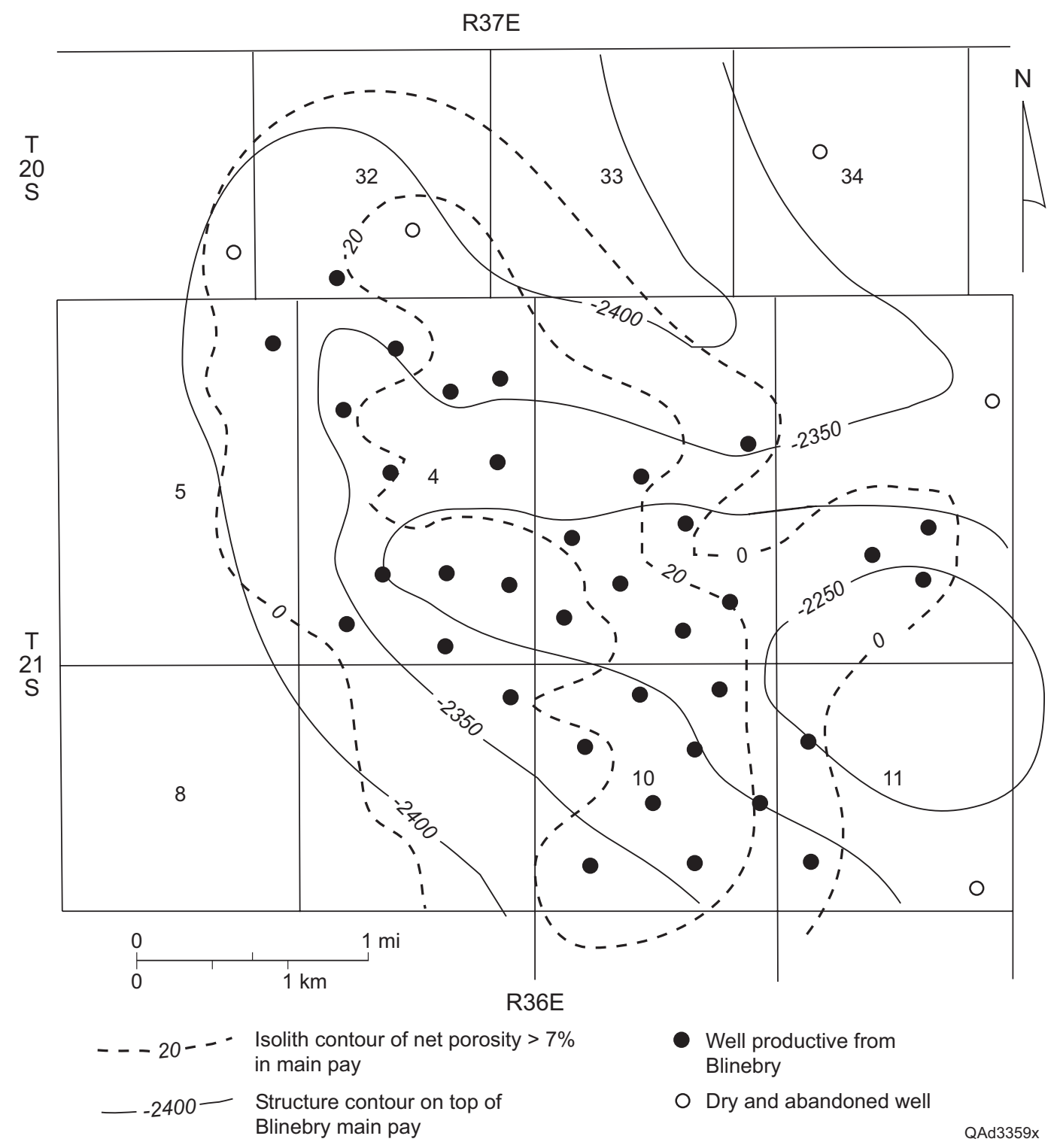

Figure 62. Structure contour map on top of the main Blinebry pay and isolith map of porosity $>7$ percent, Oil Center Blinebry reservoir. Datum is sea level. After Kincheloe and David (1977).

in many reservoirs, are not evenly distributed across an oil field but instead are concentrated in an oolite barrier facies, at least in the Paddock Member (fig. 63).

Many Leonard carbonate reservoirs are densely fractured. Natural fractures do not occur in all strata within a reservoir but may, instead, be confined to only a few stratigraphic intervals 


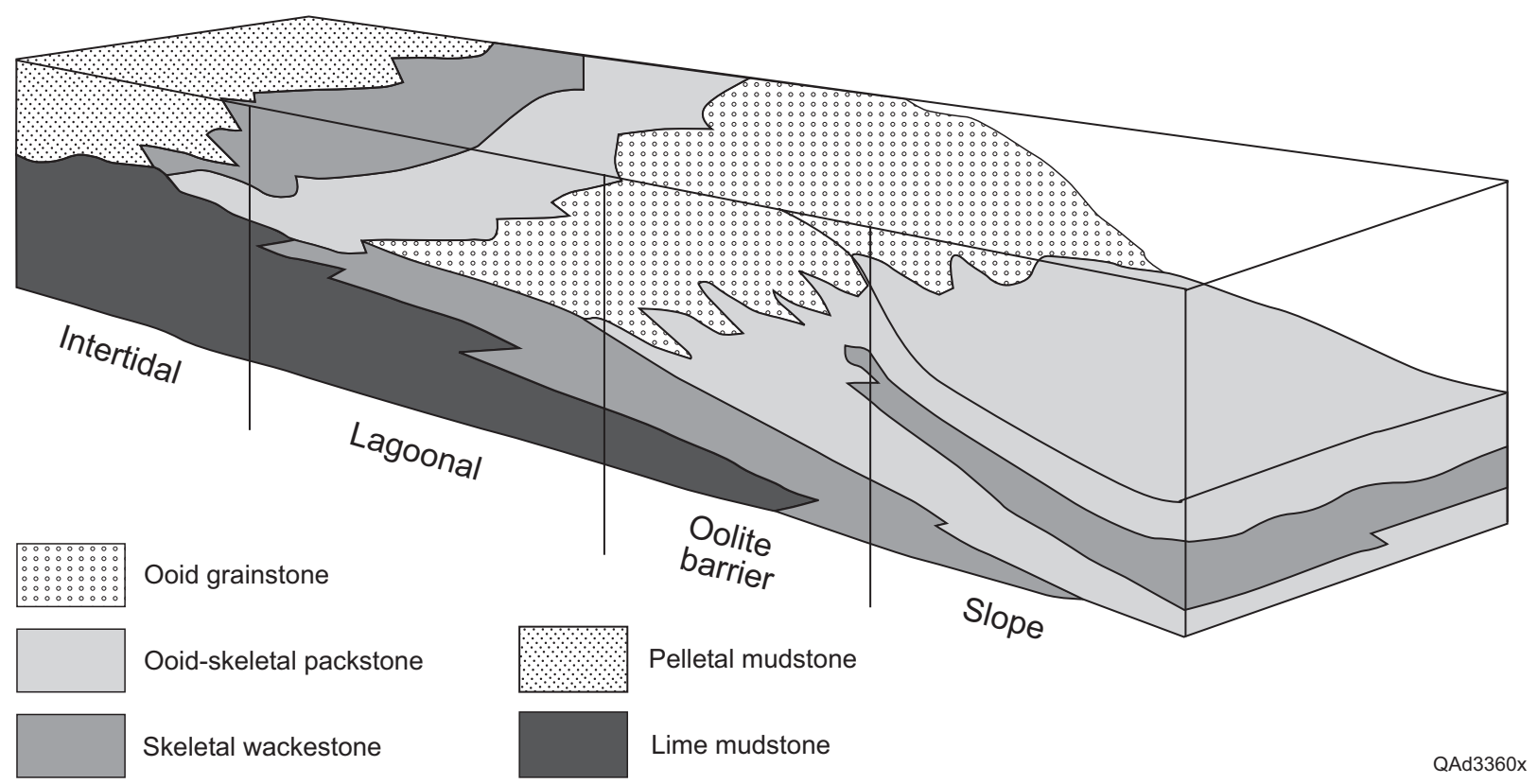

Figure 63. Block diagram of depositional environments in the Paddock Member of the Yeso Formation, Vacuum Glorieta reservoir. After Burnham (1991).

(Martin and Hickey, 2002). Therefore, waterflooding of reservoirs in enhanced recovery operations has often resulted in premature water breakthrough in fractured zones and has left significant volumes of oil unflooded and unrecovered in the nonfractured zones. Methods for optimizing recovery via waterflooding include the drilling of lateral wells in unfractured intervals (Martin and Hickey, 2002). The lateral boreholes are used for both production and water injection. In the Vacuum Glorieta West unit of the Vacuum Glorieta reservoir, horizontal laterals drilled into porous but unfractured reservoir zones are expected to result in increased incremental production of 2.6 MMbbl $\left(4.13 \times 10^{5} \mathrm{~m}^{3}\right)$ (fig. 64; Martin and Hickey, 2002).

Anhydrite-filled fractures are characteristic of some Leonard carbonate reservoirs (Burnham, 1991). When present, they may compartmentalize the reservoir horizontally and, 


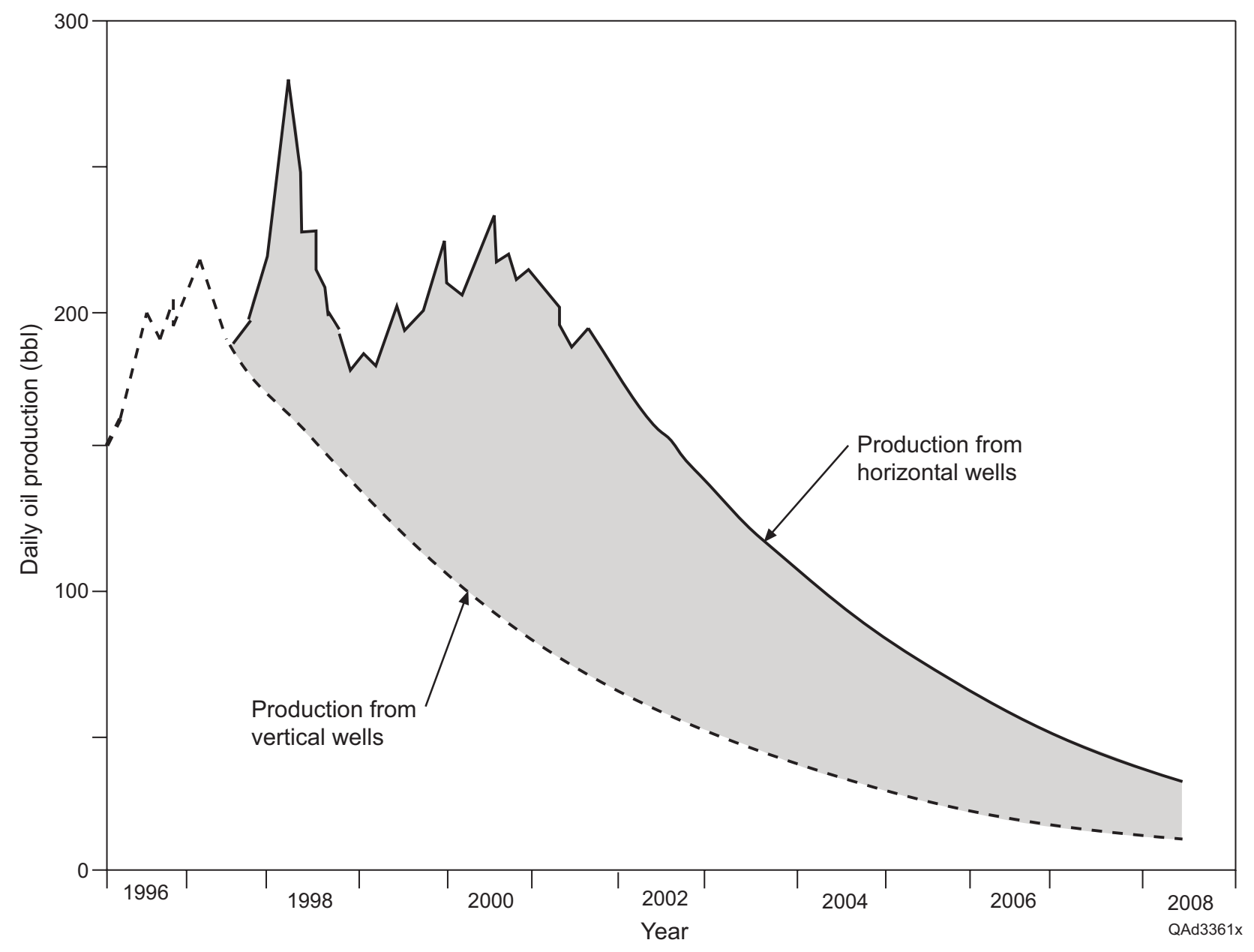

Figure 64. Daily oil production from Vacuum Glorieta West unit showing estimated incremental production that will be derived from the drilling of horizontal wells. From Martin and Hickey (2002).

as a result, be responsible for less than optimal production from standard spacing and patterns of vertical wells.

In the Dollarhide Drinkard reservoir, high-frequency sea-level fluctuations combined with deposition on an uneven paleotopographic surface resulted in a complex reservoir system composed of interbedded, landward- and seaward-stepping cycles; this architecture has given the reservoir a high degree of internal heterogeneity and compartmentalization (Fitchen and others, 
1995; Ruppel and others, 1995; Johnson and others, 1997). Complex patterns of dolomitization controlled by depositional relations to intertidal and subtidal settings have also added heterogeneity to the reservoir. Texaco applied a sinusoidal horizontal drilling technique to optimize production (Johnson and others, 1997). This sinusoidal drilling resulted in a well that has been drilled laterally $2,000 \mathrm{ft}(610 \mathrm{~m})$ and has traversed $150 \mathrm{ft}(46 \mathrm{~m})$ of vertical section in the reservoir. The reservoir was treated with $\mathrm{HCl}$ before completion. The result was substantially increased initial production rates, which increased from $8 \mathrm{bbl} / \mathrm{d}\left(1.3 \mathrm{~m}^{3} / \mathrm{d}\right)$ with original vertical completions to $70 \mathrm{bbl} / \mathrm{d}\left(11.1 \mathrm{~m}^{3} / \mathrm{d}\right)$ from the lateral sinusoidal leg. Presumably the horizontal sinusoidal well either tapped isolated reservoir compartments that were not productive with the vertical wells or penetrated low-permeability portions of the reservoir that were not in adequate communication with the vertical well bore.

\section{References}

Atchley, S. C., Kozar, M. G., and Yose, L. A., 1999, A predictive model for reservoir distribution in the Permian (Leonardian) Clear Fork and Glorieta Formations, Robertson Field, West Texas: American Association of Petroleum Geologists Bulletin, v. 83, p. 1031-1056.

Broadhead, R. F., 1993, Yeso Platform, in Robertson J. M., and Broadhead, R. F., eds., Atlas of major Rocky Mountain gas reservoirs: New Mexico Bureau of Mines \& Mineral Resources, p. 146-148.

Burnham, D. E., 1991, Depositional environments and facies distribution of the Permian Paddock member of the Yeso Formation, Vacuum (Glorieta) field, Lea County, New Mexico: The University of Texas of the Permian Basin, M.S. thesis, 140 p.

Fitchen, W. M., Starcher, M. A., Buffler, R. T., and Wilde, G. L., 1995, Sequence stratigraphic framework and facies models of the early Permian platform margins, Sierra Diablo, West Texas, in Garber, R. A., and Lindsay, R. F., eds., Wolfcampian-Leonardian shelf margin facies of the Sierra Diablo - seismic scale models for subsurface exploration: West Texas Geological Society Publication 95-97, p. 23-66. 
Hoffman, C. L., 2002, Reservoir characterization of the Drinkard Formation of the Justis TubbDrinkard field, Lea County, New Mexico: a valuable tool in optimizing field development, in Hunt, T. J., and Lufholm, P. H., eds., The Permian Basin: preserving our past—securing our future: West Texas Geological Society, Publication 02-111, p. 115116.

Holtz, M. H., Ruppel, S. C., and Hocott, C. R., 1992, Integrated geologic and engineering determination of oil-reserve growth potential in carbonate reservoirs: Journal of Petroleum Technology, v. 44, no. 11, p. 1250-1257.

Jennings, J. W., Jr., Lucia, F. J., and Ruppel, S. C., 2002, 3D modeling of stratigraphically controlled petrophysical variability in the South Wasson Clear Fork Reservoir: Society of Petroleum Engineers Annual Technical Conference and Exhibition Transactions, San Antonio, Texas, 29 September-2 October, SPE 77592, 15 p.

Johnson, I. G., Brown, J. L., and Asquith, G. B., 1997, Using sinusoidal drilling techniques in a diagenetically complex carbonate reservoir: West Dollarhide Drinkard Unit (MidLeonardian), Lea County, southeast New Mexico, in DeMis, W. D., ed., Permian Basin oil and gas fields: turning ideas into production: West Texas Geological Society, Publication 97-102, p. 93-95.

Jones, R. H., Lucia, F. J., Ruppel, S. C., and Kane, J. A., 2003, Better than a porosity cutoff: the rock-fabric approach to understanding porosity and permeability in the Lower Clear Fork and Wichita reservoirs, Fullerton Field, West Texas, in Hunt, T. J., and Lufholm, P. H., eds., The Permian Basin: back to basics: West Texas Geological Society Publication No. 03-112, p. 47-66.

Kerans, C., and Ruppel, S. C., 1994, San Andres sequence framework, Guadalupe Mountains: implications for San Andres type section and subsurface reservoirs, in Garber, R. A., and Keller, D. R., eds., Field guide to the Paleozoic section of the San Andres Mountains: Permian Basin Section SEPM Publication 94-35, p. 105-116.

Kincheloe, D., and David, E. K., 1977, Oil center Blinebry, in A symposium of the oil and gas fields of southeastern New Mexico, supplement: Roswell Geological Society, p. 142143.

Kinder Morgan, 2004, South Wasson Clearfork Unit: http://www.kindermorgan.com/business/co2/success_clearfork.cfm.

Marshall, L. R., and Foltz, G. A., 1960, Justis Blinebry, in A symposium of the oil and gas fields of southeastern New Mexico, supplement: Roswell Geological Society, p. 114-115.

Martin, R. L., and Hickey, K. F., 2002, Horizontal drilling at Vacuum Glorieta West unit, Lea County, New Mexico: a case history, in Hunt, T. J., and Lufholm, P. H., eds., The Permian Basin: preserving our past-securing our future: West Texas Geological Society, Publication 02-111, p. 117-124. 
Martin, R. L., Raines, M. A., and Cole, R. M., 1999, Stratigraphic styles of the Drinkard (Leonardian trend on the Northwest shelf, Lea County, New Mexico): finding oil in a mature area, in Grace, T. D., and Hinterlong, G. D, eds., The Permian Basin: providing energy for America: West Texas Geological Society, Publication 99-106, p. 87.

Mazzullo, S. J., 1982, Stratigraphy and depositional mosaics of Lower Clear Fork and Wichita Groups (Permian), Northern Midland Basin, Texas: American Association of Petroleum Geologists Bulletin, v. 66, p. 210-227.

Mazzullo, S. J., and Reid, A. M., 1989, Lower Permian platform and basin depositional systems, northern Midland Basin, Texas, in Crevello, P. D., Wilson, J. L., Sarg, J. F., and Read, J. F., eds., Controls on carbonate platform and basin development: Society of Economic Paleontologists and Mineralogists Special Publication 44, p. 305-320.

Montgomery, S. L., 1998, Permian Clear Fork Group, North Robertson Unit: integrated reservoir management and characterization for infill drilling, Part I-geological analysis: American Association of Petroleum Geologists Bulletin, v. 82, p. 1797-1814.

Montgomery, S. L., Davies, D. K., Vessell, R. K., Kamis, J. E., and Dixon, W. H., 1998, Permian Clear Fork Group, North Robertson Unit: integrated reservoir management and characterization for infill drilling, Part II-petrophysical and engineering data: American Association of Petroleum Geologists Bulletin, v. 82, p. 1985-2002.

Nevans, J. W., Kamis, J. E., Davies, D. K., Vessell, R. K., Doublet, L. E., and Blasingame, T. A., 1999, An integrated geologic and engineering reservoir characterization of the North Robertson (Clear Fork) Unit, Gaines County, Texas, in Schatzinger, R. A., and Jordan, J. F., eds., Reservoir characterization-recent advances: American Association of Petroleum Geologists Memoir 71, p. 109-124.

Presley, M. W., 1987, Evolution of Permian evaporite basin in Texas Panhandle: American Association of Petroleum Geologists Bulletin, v. 71, p. 167-190.

Ruppel, S. C., 1992, Styles of deposition and diagenesis in Leonardian carbonate reservoirs in West Texas: implications for improved reservoir characterization: Society of Petroleum Engineers Annual Exhibition and Technical Conference, SPE Publication 24691, p. $313-320$.

2002, Geological controls on reservoir development in a Leonardian (Lower Permian) carbonate platform reservoir, Monahans field, west Texas: The University of Texas at Austin, Bureau of Economic Geology Report of Investigations No. 266, 58 p.

2003, Lower Leonardian (Clear Fork-Abo) reservoir architecture: insights from outcrops and Fullerton Field, West Texas, in Hunt, T. J., and Lufholm, P. H., eds., The Permian Basin: back to basics: West Texas Geological Society Publication No. 03-112, p. $45-46$. 
Ruppel, S. C., Kerans, C., Major, R. P., and Holtz, M. H., 1995, Controls on reservoir heterogeneity in Permian shallow water carbonate platform reservoirs, Permian Basin: implications for improved recovery: The University of Texas at Austin, Bureau of Economic Geology Geological Circular 95-2, 30 p.

Ruppel, S. C., Ward, W. B., Ariza, E. E., and Jennings, J. W., Jr., 2000, Cycle and sequence stratigraphy of Clear Fork reservoir-equivalent outcrops: Victorio Peak Formation, Sierra Diablo, Texas, in Lindsay, R., Trentham, R., Ward, R. F., and Smith, A. H., eds., Classic Permian geology of West Texas and Southeastern New Mexico, 75 years of Permian Basin oil \& gas Exploration \& development: West Texas Geological Society Publication 00-108, p. 109-130.

Tyler, N., Bebout, D. G., Garrett, C. M., Jr., Guevara, E. H., Hocott, C. R., Holtz, M. H., Hovorka, S. D., Kerans, C., Lucia, F. J., Major, R. P., Ruppel, S. C., and Vander Stoep, G. W., 1991, Integrated characterization of Permian Basin reservoirs, University Lands, West Texas: targeting the remaining resource for advanced oil recovery: The University of Texas at Austin, Bureau of Economic Geology Report of Investigations No. 203, $136 \mathrm{p}$.

Wang, F. P., Lucia, F. J., and Ruppel, S. C., 2003, 3D reservoir modeling and simulation of the Fullerton Clear Fork Unit, Andrews County, Texas, in Hunt, T. J., and Lufholm, P. H., eds., The Permian Basin: back to basics: West Texas Geological Society Publication No. $03-112$, p. 347.

Zeng, H., Ruppel, S. C., and Jones, R. H., 2003, Reconditioning seismic data for improved reservoir characterization, lower Clear Fork and Wichita, Fullerton Field, West Texas, in Hunt, T. J., and Lufholm, P. H., eds., The Permian Basin: back to basics: West Texas Geological Society Publication No. 03-112, p. 67-78. 
Bone Spring Basinal Sandstone and Carbonate (Play 118)

Reservoirs of the Bone Spring Basinal Sandstone and Carbonate play lie within the north part of the Delaware Basin in New Mexico and stretch southward from the slope at the base of the Abo shelf edge toward the New Mexico-Texas border (fig. 65). There are 132 known, discovered reservoirs in this play, 16 of which have produced $>1 \mathrm{MMbbl}\left(1.59 \times 10^{5} \mathrm{~m}^{3}\right)$ (table 24). Cumulative production from these 16 reservoirs was $71 \mathrm{MMbbl}\left(1.13 \times 10^{7} \mathrm{~m}^{3}\right)$ as of 2000. The Bone Spring Formation is Leonardian in age (fig. 3). Production from this play increased in the 1980's as several new reservoirs were discovered and subsequently declined during the middle and late 1990's as the newer reservoirs started to deplete. During 2000 total production from the play began to increase as a result of additional drilling and increased production in the Shugart North reservoir.

Reservoirs were deposited in a basinal setting seaward of the Abo shelf edge (fig. 66; see play 116). Production has been obtained from carbonate debris flows in the first, second, and third Bone Spring carbonates, as well as fine-grained sandstones in the first, second, and third

Table 24. Bone Spring Basinal Sandstone and Carbonate play (play 118).

$\begin{array}{lll}\text { RRC RESN RRC } & \text { FLDNAME } & \text { RESNAME } \\ & \text { AIRSTRIP } & \\ \text { AIRSTRIP NORTH } & \text { BONE SPRING } \\ \text { EK } & \text { BONE SPRING } \\ \text { LEA } & \text { BONE SPRING } \\ \text { MESCALERO ESCARPE } & \text { BONE SPRING } \\ \text { MIDWAY } & \text { BONE SPRING } \\ \text { OLD MILLMAN RANCH } & \text { ABO } \\ \text { QUAIL RIDGE } & \text { BONE SPRING } \\ \text { QUERECHO PLAINS } & \text { BONE SPRING } \\ \text { RED HILLS } & \text { BONER BONE SPRING } \\ \text { RED TANK } & \text { BONE SPRING } \\ \text { SCHARB } & \text { BONE SPRING } \\ \text { SHUGART NORTH } & \text { BONE SPRING } \\ \text { TAMANO } & \text { BONE SPRING } \\ \text { TEAS } & \text { BONE SPRING } \\ \text { YOUNG NORTH } & \text { BONE SPRING } \\ & \\ \text { Totals } & \\ & \end{array}$

$\begin{array}{ll}\text { STATE COUNTY } \\ \text { NM } & \text { LEA } \\ \text { NM } & \text { LEA } \\ \text { NM } & \text { LEA } \\ \text { NM } & \text { LEA } \\ \text { NM } & \text { LEA } \\ \text { NM } & \text { LEA } \\ \text { NM } & \text { EDDY } \\ \text { NM } & \text { LEA } \\ \text { NM } & \text { LEA } \\ \text { NM } & \text { LEA } \\ \text { NM } & \text { LEA } \\ \text { NM } & \text { LEA } \\ \text { NM } & \text { EDDY } \\ \text { NM } & \text { EDDY } \\ \text { NM } & \text { LEA } \\ \text { NM } & \text { LEA } \\ & \end{array}$

$\begin{array}{rr}\text { DISCYR } & \text { DEPTHTOP } \\ & \\ 1979 & 9329 \\ 1986 & 9600 \\ 1975 & 9450 \\ 1960 & 9480 \\ 1984 & 8660 \\ 1963 & 8850 \\ 1991 & 6140 \\ 1962 & 9315 \\ 1959 & 8538 \\ 1992 & 12200 \\ 1992 & 8820 \\ 1963 & 10152 \\ 1986 & 7680 \\ 1985 & 8100 \\ 1963 & 9300 \\ 1980 & 8416 \\ & \end{array}$




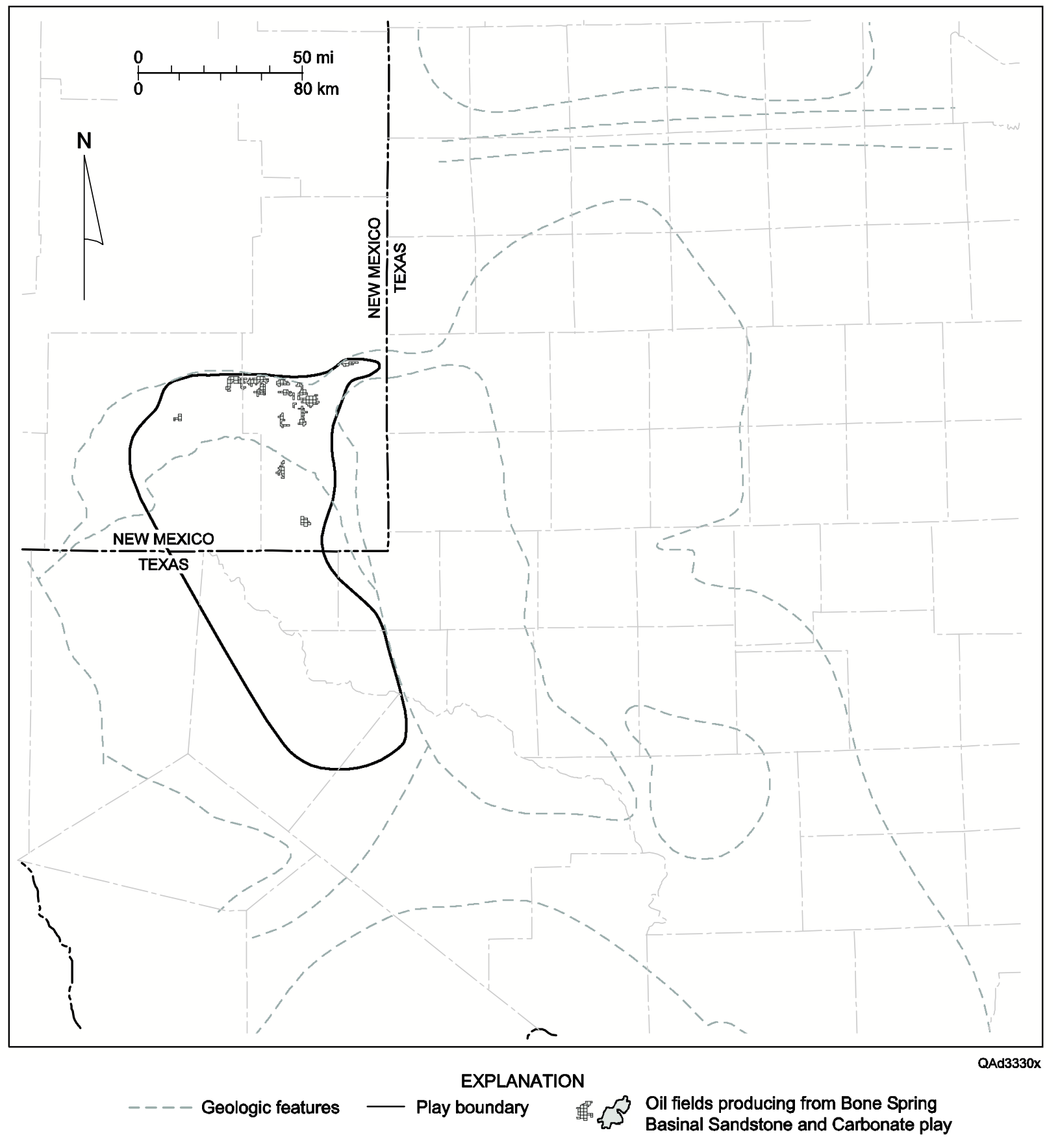

Figure 65. Play map for the Bone Spring Basinal Sandstone and Carbonate play, showing location of reservoirs having $>1 \mathrm{MMbbl}$ cumulative production, the play boundary, and geologic features. See figure 1 for county names and figure 2 for identification of geologic features. 


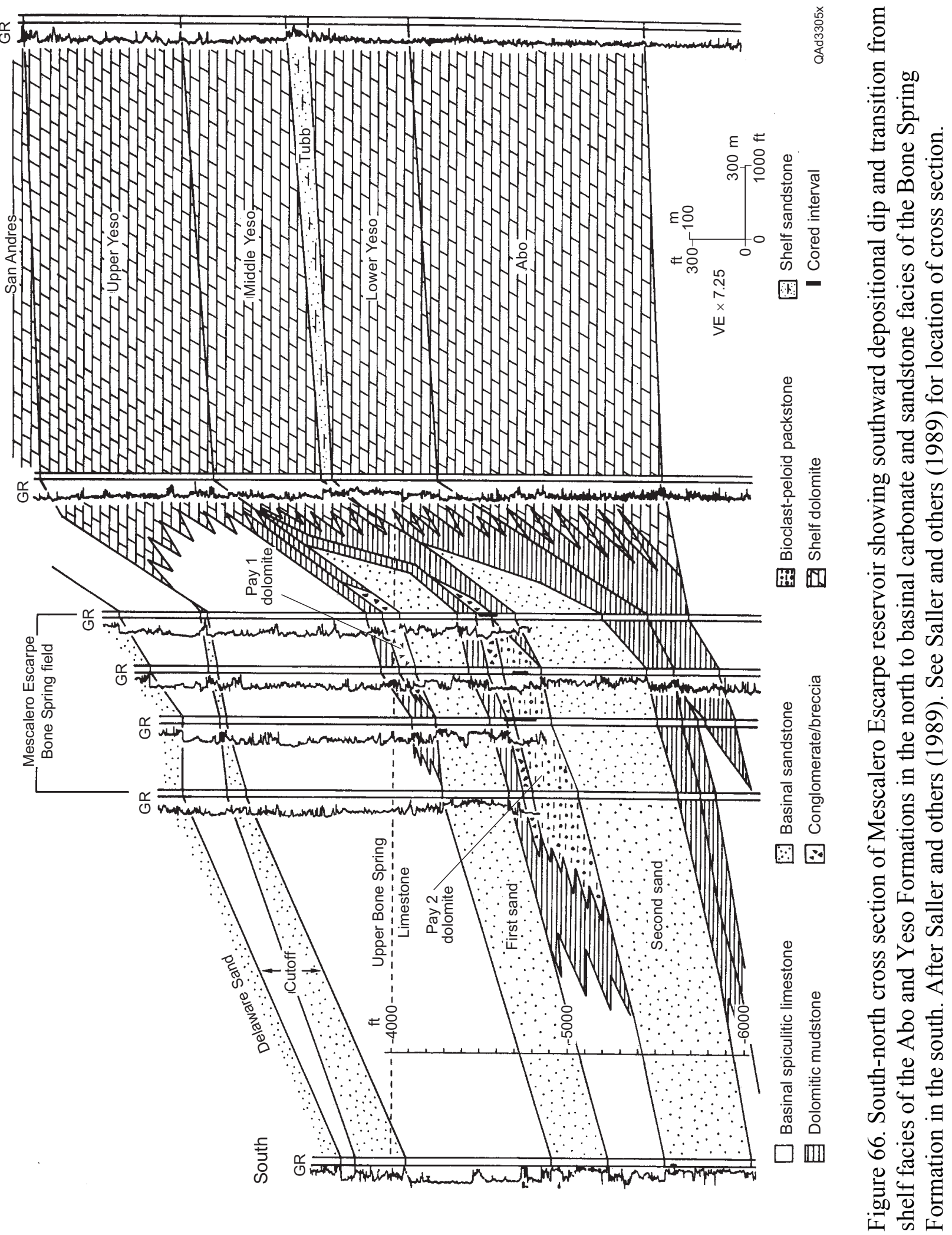


Bone Spring sandstones (fig. 3) (Wiggins and Harris, 1985; Gawloski, 1987; Mazzullo and Reid, 1987; Saller and others, 1989; Montgomery, 1997; Downing and Mazzullo, 2000).

Carbonate debris flows form the primary Bone Spring reservoirs in the northernmost Delaware Basin and constitute the Bone Spring Carbonate subplay. These debris flows are located at the toe of slope of the Abo and Yeso shelf edge and were derived from carbonate detritus at the Abo and Yeso shelf margins. The reservoirs consist of dolomitized conglomerate breccias and dolomitized bioclast-peloid packstones. Porosity is mostly secondary. Vugular, moldic, intergranular, and intercrystalline pores are dominant. In the Mescalero Escarpe reservoir (Saller and others, 1989), open fractures in dolopackstones have enhanced permeability. Traps are stratigraphic or combination structural-stratigraphic, with porous reservoirs contained in channels that pinch out depositionally updip as they rise onto the submarine slope to the north.

Siliciclastic turbidites have widespread distribution in the first, second, and third Bone Spring sandstones. The Bone Spring sandstone reservoirs constitute the Bone Spring Sandstone subplay. These turbidites consist of fine-grained sandstones cemented by dolomite and authigenic clays (Gawloski, 1987; Saller and others, 1989). They appear to have been deposited in a channel and fan system at the base of slope and on the basin plain (Montgomery, 1997; Pearson, 1999). Most reservoirs appear to be present in well-defined channels. Bone Spring sandstones are the primary reservoirs in fields more than 5 miles south of the shelf margin. Traps are stratigraphic or combination structural-stratigraphic, with porous reservoirs confined in channels that pinch out depositionally updip as they rise onto the submarine slope to the north. Recent drilling has extended the Bone Spring Sandstone subplay south into the Texas part of the Delaware Basin. 


\section{References}

Downing, A., and Mazzullo, J., 2000, Slope fan deposits of the $2^{\text {nd }}$ Bone Spring sand, Young North field, Lea County, New Mexico (abs.), in DeMis, W. D., Nelis, M. K., and Trentham, R. C., eds., The Permian Basin: proving ground for tomorrow's technologies: West Texas Geological Society, Publication 00-109, p. 73.

Gawloski, T. F., 1987, Nature, distribution, and petroleum potential of Bone Spring detrital sediments along the Northwest shelf of the Delaware Basin, in Cromwell, D., and Mazzullo, L., eds., The Leonardian facies in W. Texas and S.E. New Mexico and Guidebook to the Glass Mountains, west Texas: Permian Basin Section Society of Economic Paleontologists and Mineralogists, Publication 87-27, p.84-105.

Mazzullo, L. J. , and Reid, A. M., II, 1987, Stratigraphy of the Bone Spring Formation (Leonardian) and depositional setting in the Scharb field, Lea County, New Mexico, in Cromwell, D., and Mazzullo, L., eds., The Leonardian facies in W. Texas and S.E. New Mexico and Guidebook to the Glass Mountains, west Texas: Permian Basin Section Society of Economic Paleontologists and Mineralogists, Publication 87-27, p.107-111.

Montgomery, S. L., 1997, Permian Bone Spring Formation: sandstone play in the Delaware Basin Part I-slope: American Association of Petroleum Geologists Bulletin, v. 81, p. 1239-1258.

Pearson, R. A., 1999, Sequence stratigraphy and seismic-guided estimation of log properties of the second sand member of the Bone Spring Formation, Delaware Basin, New Mexico: New Mexico Institute of Mining and Technology, M.S. thesis, 124 p. plus appendices.

Saller, A. H., Barton, J. W., and Barton, R. E., 1989, Mescalero Escarpe field, oil from carbonate slope detritus, southeastern New Mexico, in Flis, J. E., Price, R. C., and Sarg, J. F., eds., Search for the subtle trap, hydrocarbon exploration in mature basins: West Texas Geological Society, Publication 89-85, p. 59-74.

Wiggins, W. D., and Harris, P. M., 1985, Burial diagenetic sequence in deep-water allochthonous dolomites, Permian Bone Spring Formation, southeast New Mexico, in Crevello, P. D., and Harris, P. M., eds., Deep-water carbonates: buildups, turbidites, debris flows and chalks - a core workshop: Society of Economic Paleontologists and Mineralogists Core Workshop No. 6, p. 140-173. 
Spraberry/Dean Submarine-Fan Sandstone (Play 119)

The Spraberry/Dean Submarine-Fan Sandstone play has produced 1,287 MMbbl $\left(2.05 \times 10^{8} \mathrm{~m}^{3}\right)$ of oil from 40 reservoirs located along a north-south-oriented trend in the center of the Midland Basin (table 25, fig. 67). The play is estimated to have contained more than $10 \operatorname{Bbbl}\left(1.59 \times 10^{9} \mathrm{~m}^{3}\right)$ of original oil in place (Tyler and others, 1984). Recovery efficiency of only 8 to 10 percent in Spraberry fields is typical after nearly 50 years of production, including waterflooding in some areas (Montgomery and others, 2000).

The Leonardian Spraberry and Dean sandstones (fig. 3) are similar in lithology and are made up of (1) very fine grained sandstone and coarse siltstone; (2) carbonate beds, sandy limestone, and minor sandstone; and (3) terrigenous shale (Handford, 1981; Guevara, 1988; Tyler and Gholston, 1988; Tyler and others, 1997). The Spraberry Trend Area Clear Fork reservoir, which produces from deepwater carbonate deposits, is assigned to the Wolfcamp/Leonard Slope and Basinal Carbonate play (115). The Spraberry and Dean were deposited as large basin-floor submarine-fan systems that were fed by turbidity currents and debris flows (Handford, 1981). Most of the production from this fine-grained, mud-rich, submarine-fan complex is from very fine grained sandstone and coarse siltstone units in the Spraberry at depths of 6,800 to $8,000 \mathrm{ft}$ (2,075 to $2,440 \mathrm{~m})$. The Spraberry has been divided into lower, middle, and upper intervals, and most production comes from thick (10 to $50 \mathrm{ft}$ [3 to $15 \mathrm{~m}]$ ), upward-coarsening sandstones in the upper and lower Spraberry (figs. 68, 69) (Guevara, 1988; Tyler and Gholston, 1988; Tyler and others, 1997). Regional updip pinch-out of Spraberry sandstones along the east margin of the Midland Basin (fig. 69) creates stratigraphic traps.

Matrix porosity ranges from 5 to 18 percent and permeability from 0.05 to $3 \mathrm{md}$ ( 0.05 to $3 \times 10^{-3} \mu \mathrm{m}^{2}$ ) (Montgomery and others, 2000). Low permeability results from the fine grain size, 
Play 25. Spraberry/Dean Submarine-Fan Sandstone play (play 119). Production shown for fields that have had others combined into them represents the totals; combined fields are highlighted.

\begin{tabular}{|c|c|c|c|c|c|c|c|c|c|}
\hline RRC RESN & RRC & FLDNAME & RESNAME & STATE & COUNTY & DISCYR & DEPTHTOP & 2000 PROD & CUMPROD \\
\hline 448200 & $8 \mathrm{~A}$ & ACKERLY & DEAN SAND & TX & DAWSON & 1954 & 8172 & 786,965 & $49,582,865$ \\
\hline 450900 & $8 \mathrm{~A}$ & ACKERLY, NORTH & SPRABERRY & TX & DAWSON & 1977 & 7739 & 149,571 & $2,936,419$ \\
\hline 702750 & $8 \mathrm{~A}$ & ADCOCK & SPRABERRY & TX & DAWSON & 1972 & 7556 & 23,587 & $1,268,187$ \\
\hline 7109875 & $7 \mathrm{C}$ & BENEDUM & SPRABERRY & TX & UPTON & 1947 & 7593 & 65,313 & $24,699,962$ \\
\hline 11751200 & 8 & BREEDLOVE & SPRABERRY & $\mathrm{TX}$ & MARTIN & 1962 & 8350 & 50,272 & $2,400,927$ \\
\hline 11752666 & 8 & BREEDLOVE, EAST & SPRABERRY & $\mathrm{TX}$ & MARTIN & 1962 & 8180 & 37,477 & $2,347,842$ \\
\hline 11756500 & 8 & BREEDLOVE, SOUTH & SPRABERRY & TX & MARTIN & 1962 & 8084 & 60,512 & $3,979,507$ \\
\hline 12060500 & $8 \mathrm{~A}$ & BRITT & SPRABERRY & TX & DAWSON & 1957 & 7396 & 10,986 & $1,095,217$ \\
\hline 14627333 & $8 \mathrm{~A}$ & CAIN & SPRABERRY & $\mathrm{TX}$ & GARZA & 1959 & 4916 & 2,511 & $1,370,936$ \\
\hline 18790700 & $8 \mathrm{~A}$ & CLAYTON RANCH, N. & SPRABERRY & TX & BORDEN & 1985 & 5738 & 312,709 & $2,273,366$ \\
\hline 20482001 & $7 \mathrm{C}$ & COPE & & $\mathrm{TX}$ & STERLING & 1951 & 6031 & 51,018 & $12,672,984$ \\
\hline 21090500 & $8 \mathrm{~A}$ & COULTER & SPRABERRY & TX & GARZA & 1979 & 5296 & 50,131 & $1,184,144$ \\
\hline 27451500 & $8 \mathrm{~A}$ & ECHOLS & SPRABERRY & $\mathrm{TX}$ & DAWSON & 1984 & 8277 & 21,438 & $1,375,136$ \\
\hline 30559166 & $8 \mathrm{~A}$ & FELKEN & SPRABERRY & TX & DAWSON & 1955 & 7490 & 143,770 & $5,863,624$ \\
\hline 31236666 & $7 \mathrm{C}$ & FLAT ROCK & SPRABERRY & TX & UPTON & 1951 & 7245 & 1,338 & $1,781,814$ \\
\hline 34961750 & $8 \mathrm{~A}$ & GIN & SPRABERRY & $\mathrm{TX}$ & DAWSON & 1965 & 8068 & 403,213 & $6,412,068$ \\
\hline 34970500 & $8 \mathrm{~A}$ & GIN, NORTH & 8000 & TX & DAWSON & 1975 & 8029 & 106,246 & $3,602,421$ \\
\hline 43878600 & 8 & HUTEX & DEAN & $T X$ & ANDREWS & 1959 & 9595 & 6,935 & $2,273,165$ \\
\hline 46564750 & $8 \mathrm{~A}$ & JO-MILL & SPRABERRY & $\mathrm{TX}$ & BORDEN & 1954 & 7105 & $2,534,834$ & $108,593,322$ \\
\hline 49113750 & $8 \mathrm{~A}$ & KEY & SPRABERRY, UPPER & TX & DAWSON & 1963 & 6978 & 2,474 & $1,040,170$ \\
\hline 49125500 & $8 \mathrm{~A}$ & KEY WEST & SPRABERRY & TX & DAWSON & 1982 & 7680 & 24,178 & $1,404,146$ \\
\hline 51152500 & 8 & LACAFF & DEAN & $\mathrm{TX}$ & MARTIN & 1969 & 9490 & 48,406 & $8,111,254$ \\
\hline 51742666 & $8 \mathrm{~A}$ & LAMESA, WEST & SPRABERRY & TX & DAWSON & 1960 & 7999 & 176,360 & $2,640,850$ \\
\hline 56082500 & 8 & M.A.K. & SPRABERRY & TX & MARTIN & 1963 & 8501 & 29,274 & $1,995,628$ \\
\hline 69233664 & 8 & PARKS & SPRABERRY & TX & MIDLAND & 1957 & 7770 & 249,123 & $7,815,355$ \\
\hline 69570500 & $8 \mathrm{~A}$ & PATRICIA, WEST & SPRABERRY & TX & DAWSON & 1962 & 8370 & 15,017 & $1,228,314$ \\
\hline 70279750 & $7 \mathrm{C}$ & PEGASUS & SPRABERRY & $T X$ & UPTON & 1952 & 8255 & 235,746 & $16,174,394$ \\
\hline 71260500 & $8 \mathrm{~A}$ & PHIL WRIGHT & SPRABERRY & TX & DAWSON & 1982 & 7832 & 127,586 & $3,699,781$ \\
\hline 76043500 & $8 \mathrm{~A}$ & REO & JO MILL, LOWER & TX & BORDEN & 1980 & 7350 & 175,859 & $3,638,537$ \\
\hline 84258500 & $8 \mathrm{~A}$ & SMITH & SPRABERRY & TX & DAWSON & 1950 & 7940 & 15,446 & $1,541,626$ \\
\hline 85279200 & $7 \mathrm{C}$ & SPRABERRY & TREND AREA & TX & GLASSCOCK & 1952 & 6785 & $5,564,574$ & $433,832,105$ \\
\hline 85280300 & 8 & SPRABERRY & TREND AREA & TX & MIDLAND & 1952 & 8000 & $14,978,687$ & $489,365,061$ \\
\hline 85280500 & 8 & SPRABERRY & TREND AREA DEAN-WLFCP & TX & GLASSCOCK & 1966 & 9022 & 0 & $10,704,270$ \\
\hline 85282001 & $8 \mathrm{~A}$ & SPRABERRY, DEEP & & TX & DAWSON & 1949 & 6420 & 82,106 & $11,213,033$ \\
\hline 85282500 & $8 \mathrm{~A}$ & SPRABERRY, DEEP & SPRABERRY, LO. & $\mathrm{TX}$ & DAWSON & 1957 & 7592 & 357,449 & $13,701,528$ \\
\hline 85292450 & $8 \mathrm{~A}$ & SPRABERRY, W. & DEEP, SPRABERRY & TX & DAWSON & 1988 & 7018 & 248,525 & $13,023,206$ \\
\hline 87073333 & 8 & SULPHUR DRAW & DEAN 8790 & TX & MARTIN & 1966 & 9442 & 132,277 & $13,147,477$ \\
\hline 88977284 & $8 \mathrm{~A}$ & TEX-HAMON & DEAN & $\mathrm{TX}$ & DAWSON & 1967 & 9555 & 68,015 & $6,356,866$ \\
\hline 89201500 & $7 \mathrm{C}$ & TEXON, W. & SPRABERRY & TX & REAGAN & 1964 & 6923 & 0 & $2,924,301$ \\
\hline 96068666 & $8 \mathrm{~A}$ & WELCH, SE. & SPRABERRY & $\mathrm{TX}$ & DAWSON & 1952 & 7690 & 226,355 & $7,826,429$ \\
\hline \multicolumn{4}{|c|}{ Totals } & & & & & $27,576,283$ & $1,287,098,237$ \\
\hline
\end{tabular}

quartz and dolomite cement, and authigenic pore-bridging chlorite and illite (Montgomery and others, 2000). The best reservoir zones ( 7 to 18 percent porosity and 0.3 to $3 \mathrm{md}$ [0.3 to $\left.3 \times 10^{-3} \mu^{2}\right]$ permeability) occur in stacked, 1 - to 3 -ft-thick $(0.3$ - to $1-\mathrm{m})$ beds of massive siltstones and very fine grained sandstones (Schechter and McDonald, 1999; Montgomery and others, 2000).

Horizontal cores show that Spraberry sandstones contain two systems of natural fractures, one having vertical fracture sets striking north-northeast and east-northeast and the other having northeast-striking vertical fractures; fracture spacing and orientation are localized areally and 


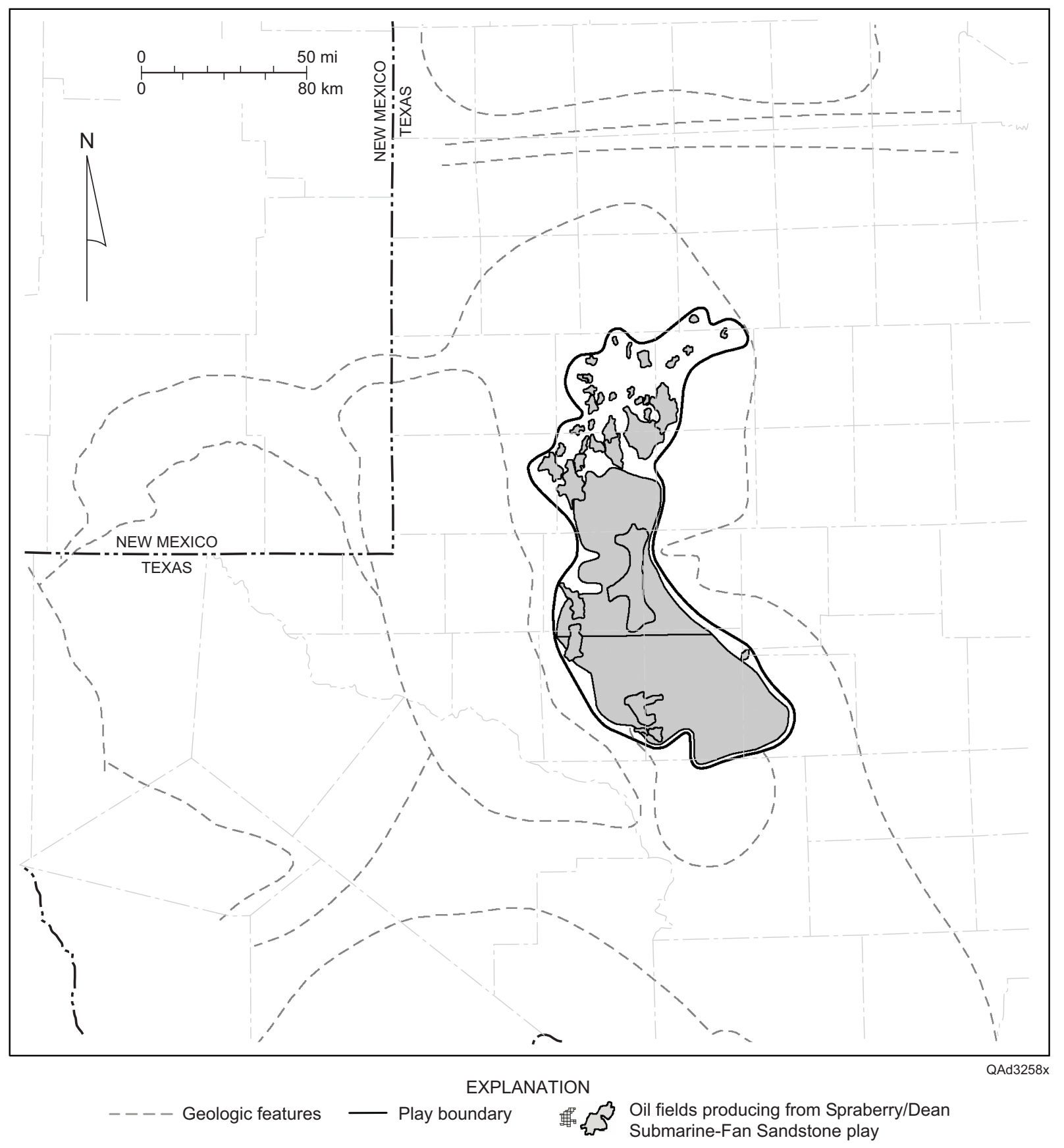

Fig. 67. Play map for the Spraberry/Dean Submarine-Fan Sandstone play, showing location of reservoirs having $>1 \mathrm{MMbbl}$ cumulative production, the play boundary, and geologic features. See figure 1 for county names and figure 2 for identification of geologic features. 


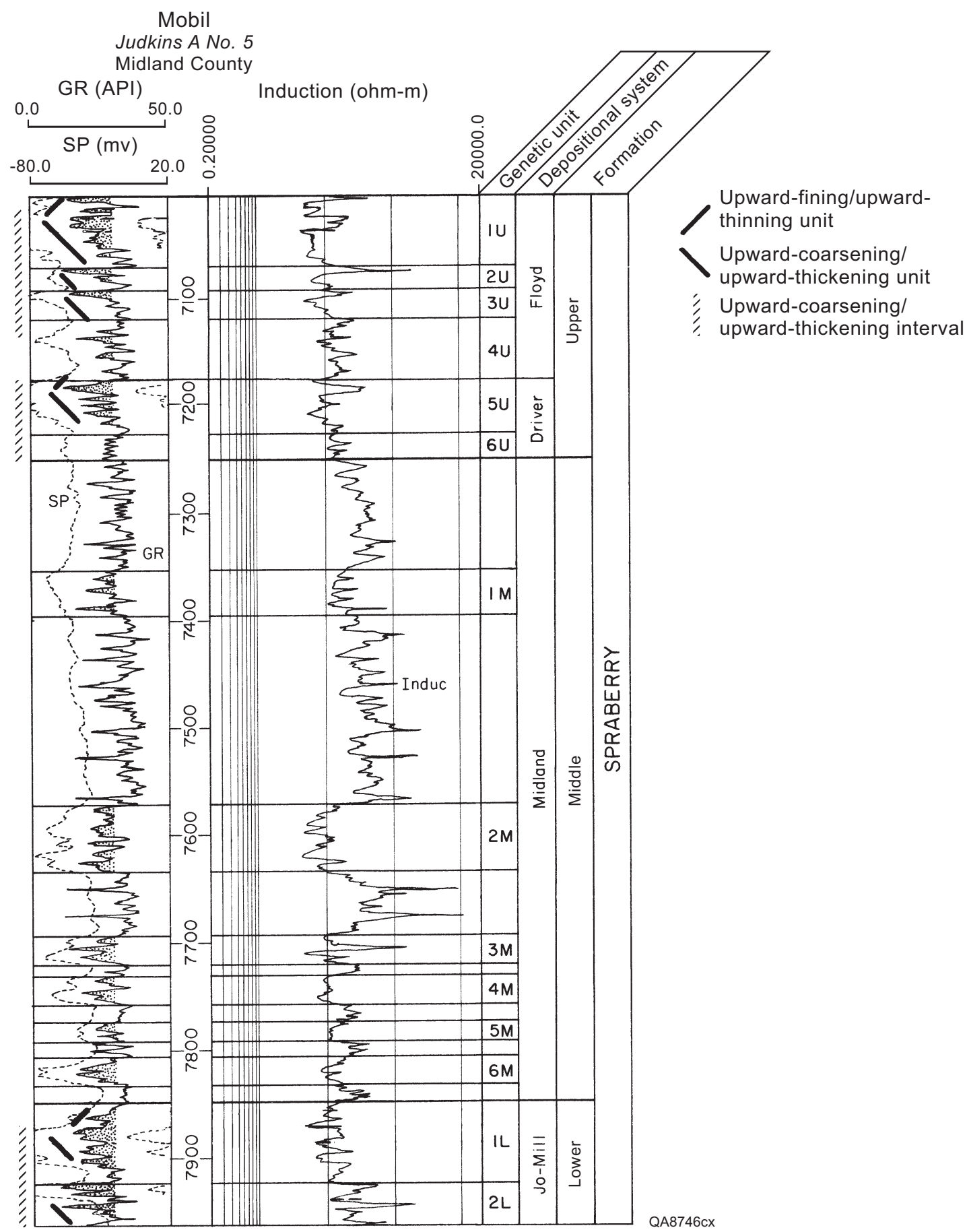

Figure 68. Type log of the Spraberry Formation in the central Spraberry Trend, showing several scales of division of the formation and principal vertical trends. From Tyler and others (1997). 


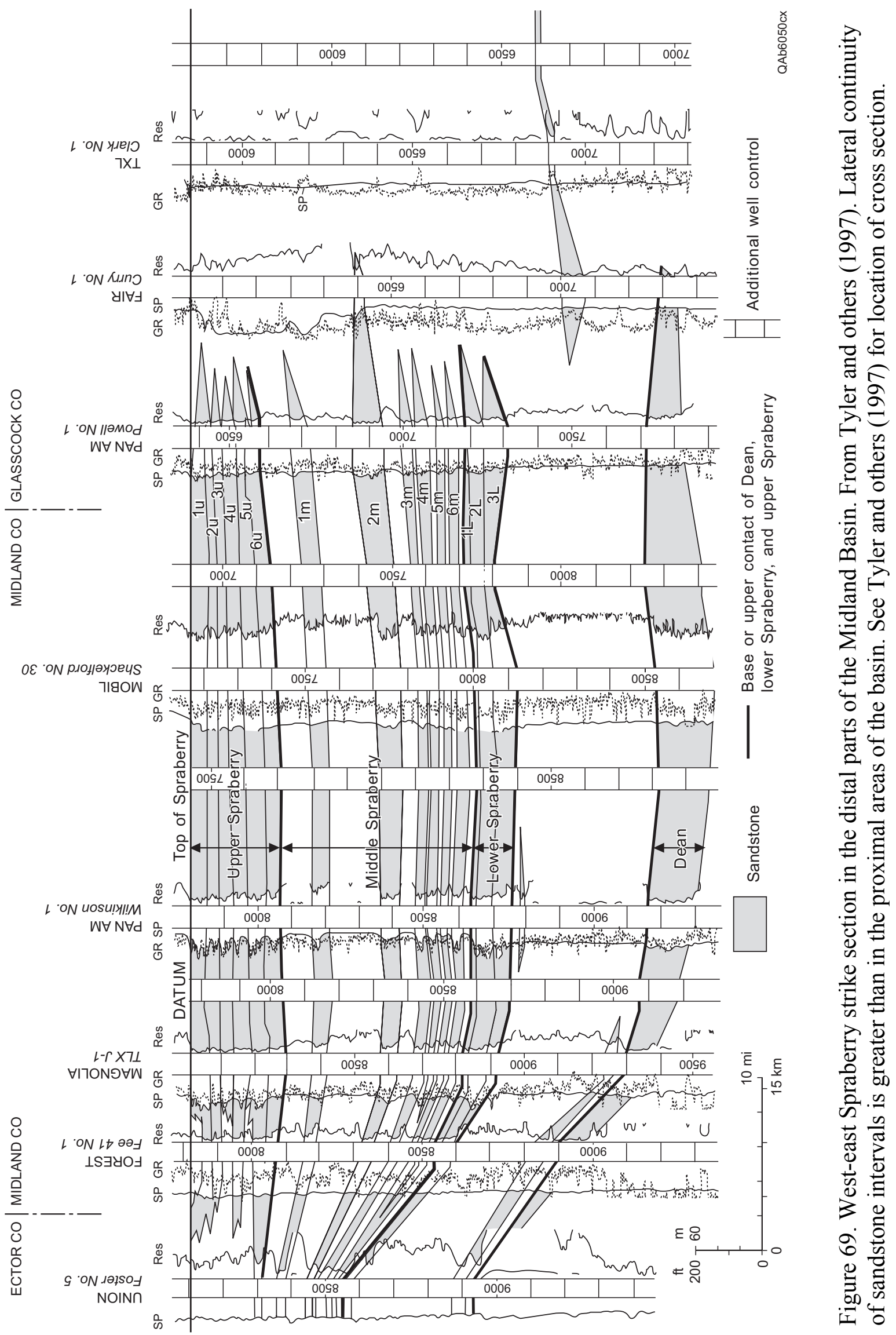


lithologically (Lorenz, 1997; Montgomery and others, 2000; Lorenz and others, 2002). The natural fracture system causes high rates of initial production, but the matrix contains most of the oil (>95 percent) and controls long-term recovery (Montgomery and others, 2000). After early fracture depletion, recovery from Spraberry sandstones is controlled by displacement of matrix oil by water imbibition (Schechter and Guo, 1998; Montgomery and others, 2000).

Pay zones are best identified as having shale volume of $<15$ percent and effective porosity of $>7$ percent (Banik and Schechter, 1996; Schechter and Banik, 1997).

Waterflooding had not been considered an effective recovery technique in the Spraberry, but a recent pilot waterflood in Spraberry Trend Area O'Daniel unit in Midland County indicates that it can be successful (Schechter and others, 2001; Schechter, 2002; Schechter and others, 2002). Low-rate water injection led to a significant increase in oil production in wells located along the primary northeast fracture orientation from the injection wells. Daily oil production increased by 20 to $30 \mathrm{bbl}\left(3.2\right.$ to $\left.4.8 \mathrm{~m}^{3}\right)$ in each of seven on-trend wells. Total oil production in the pilot area increased from $200 \mathrm{bbl} / \mathrm{d}\left(31.8 \mathrm{~m}^{3} / \mathrm{d}\right)$ to $400 \mathrm{bbl} / \mathrm{d}\left(63.6 \mathrm{~m}^{3} / \mathrm{d}\right)$ after 1.5 years of water injection, yielding $>75,000 \mathrm{bbl}\left(>1.19 \times 10^{4} \mathrm{~m}^{3}\right)$ of incremental oil from an area that had previously been waterflooded (Schechter and others, 2002).

\section{References}

Banik, A. K., and Schechter, D. S., 1996, Characterization of the naturally fractured Spraberry trend shaly sands based on core and log data: Society of Petroleum Engineers, SPE Paper $35224,11 \mathrm{p}$.

Guevara, E. H., 1988, Geological characterization of Permian submarine fan reservoirs of the Driver waterflood unit, Spraberry Trend, Midland Basin, Texas: The University of Texas at Austin, Bureau of Economic Geology Report of Investigations No. 172, 44 p. 
Handford, C. R., 1981, Sedimentology and genetic stratigraphy of Dean and Spraberry Formations (Permian), Midland Basin, Texas: American Association of Petroleum Geologists Bulletin, v. 65, p. 1602-1616.

Lorenz, J. C., 1997, Non-congruent natural fracture sets in adjacent beds at depth: data from horizontal cores from the Spraberry Formation, Midland Basin, TX (exp. abs.): American Association of Petroleum Geologists Hedberg Conference on Reservoir Scale Deformation, Characterization, and Prediction, June 22-28, Bryce, Utah, unpaginated.

Lorenz, J. C., Sterling, J. L., Schechter, D. S., Whigham, C. L., and Jensen, J. L., 2002, Natural fractures in the Spraberry Formation, Midland Basin, Texas: the effects of mechanical stratigraphy on fracture variability and reservoir behavior: American Association of Petroleum Geologists Bulletin, v. 86, p. 505-524.

Montgomery, S. L., Schechter, D. S., and Lorenz, J. C., 2000, Advanced reservoir characterization to evaluate carbon dioxide flooding, Spraberry Trend, Midland Basin, Texas: American Association of Petroleum Geologists Bulletin, v. 84, p. 1247-1273.

Schechter, D. S., 2002, Waterflooding and $\mathrm{CO}_{2}$ injection in the naturally fractured Spraberry Trend Area: Journal of Canadian Petroleum Technology, v. 41, no. 10, p. 9-14.

Schechter, D. S., and Banik, A. K., 1997, Integration of petrophysical and geological data with open-hole logs for identification of the naturally fractured Spraberry pay zones: Society of Petroleum Engineers, SPE Paper 38913, 10 p.

Schechter, D. S., and Guo, B., 1998, An integrated investigation for design of a $\mathrm{CO}_{2}$ pilot in the naturally fractured Spraberry Trend area, west Texas: Society of Petroleum Engineers, SPE Paper 39881, 16 p.

Schechter, D. S., and McDonald, P., 1999, Advanced reservoir characterization and evaluation of $\mathrm{CO}_{2}$ gravity drainage in the naturally fractured Spraberry trend area: Annual Report submitted to U.S. Department of Energy (DOE), Report No. DOE/BC/14942-7, 170 p.

Schechter, D. S., Putra, E., Baker, R. O., Knight, W. H., McDonald, W. P., Leonard, P., and Rounding, C., 2001, $\mathrm{CO}_{2}$ pilot design and water injection performance in the naturally fractured Spraberry Trend Area, West Texas: Society of Petroleum Engineers, SPE Paper No. $71605,16 \mathrm{p}$.

2002, Waterflood performance in the naturally fractured Spraberry Trend Area, West Texas: Proceedings, Conference on Naturally Fractured Reservoirs, Oklahoma City, Oklahoma, June 3-4: Mewbourne School of Petroleum and Geological Engineering, University of Oklahoma, Oklahoma Geological Survey, 18 p., CD-ROM. 
Tyler, N., Galloway, W. E., Garrett, C. M., Jr., and Ewing, T. E., 1984, Oil accumulation, production characteristics, and targets for additional recovery in major oil reservoirs of Texas: The University of Texas at Austin, Bureau of Economic Geology Geological Circular 84-2, $31 \mathrm{p}$.

Tyler, N., and Gholston, J. C., 1988, Heterogeneous deep-sea fan reservoirs, Shackelford and Preston waterflood units, Spraberry Trend, West Texas: The University of Texas at Austin, Bureau of Economic Geology Report of Investigations No. 171, 38 p.

Tyler, N., Gholston, J. C., and Guevara, E. H., 1997, Basin morphological controls on submarine-fan depositional trends: Spraberry Sandstone, Permian Basin, Texas: The University of Texas at Austin, Bureau of Economic Geology Geological Circular No. 97-6, 43 p. 
Upper Permian (Guadalupian) Plays

Thirteen oil plays in the Permian Basin are defined in the Upper Permian Guadalupian Series (table 1). San Andres reservoirs are divided into four plays-San Andres Platform Carbonate, Northwest Shelf San Andres Platform Carbonate, Eastern Shelf San Andres Platform Carbonate, and San Andres Karst-Modified Platform Carbonate. The San Andres Platform Carbonate play and the San Andres Karst-Modified Platform Carbonate play were defined by Tyler and others (1991). In the oil atlas, the reservoirs in these two plays made up part of three plays - Yates Area, San Andres/Grayburg (North Central Basin Platform), and San Andres/Grayburg (South Central Basin Platform) (Galloway and others, 1983).

The four Grayburg plays in Texas (Grayburg Platform Carbonate, Grayburg High-Energy Platform Carbonate-Ozona Arch, Grayburg Platform Mixed Clastic/Carbonate, and San Andres/Grayburg Lowstand Carbonate) contain reservoirs that partly composed the San Andres/Grayburg (North Central Basin Platform), and San Andres/Grayburg (South Central Basin Platform) plays of Galloway and others (1983). Two San Andres and Grayburg plays occur in New Mexico: (1) Upper San Andres and Grayburg Platform Mixed—Artesia Vacuum Trend and (2) Upper San Andres and Grayburg Platform Mixed - Central Basin Platform Trend. The three Upper Permian sandstone plays—Queen Tidal-Flat Sandstone, Artesia Platform Sandstone, and Delaware Mountain Group Basinal Sandstone—are similar to the plays in the Atlas of Major Texas Oil Reservoirs, except that the Artesia Platform Sandstone represents only part of the Permian Sandstone and Carbonate play of Galloway and others (1983).

The carbonates and evaporites of the San Andres and Grayburg Platform Carbonate plays were deposited on a shallow-water shelf that surrounded the Midland Basin during the early Guadalupian. Depositional environments varied from open-marine complexes along the shelf 
margin to restricted subtidal complexes and arid tidal flats toward the interior of the platform (Tyler and others, 1991). Through time the entire facies tract prograded basinward, so that the older San Andres shelf edge exists platformward of the younger Grayburg shelf edge. As a result, San Andres reservoirs lie generally platformward of the trend of the younger Grayburg reservoirs. Oil in Upper Permian (Guadalupian) rocks occurs mainly at the boundary between updip evaporites and associated shelf dolomites and clean sandstones and siltstones (Ward and others, 1986).

Significant insight into San Andres reservoirs of the Permian Basin has been developed through studies of the San Andres in outcrop in the Guadalupe Mountains (Lucia and others, 1991, 1992; Kerans and others, 1992, 1994; Hovorka and others, 1993; Grant and others, 1994; Kerans and Fitchen, 1995; Jennings, 2000). Well-exposed outcrops allow the study of lateral relationships in geologic and petrophysical structure in these shallow-water platform carbonates.

\section{References}

Galloway, W. E., Ewing, T. E., Garrett, C. M., Jr., Tyler, N., and Bebout, D. G., 1983, Atlas of major Texas oil reservoirs: The University of Texas at Austin, Bureau of Economic Geology Special Publication, 139 p.

Grant, C. W., Goggin, D. J., and Harris, P. M., 1994, Outcrop analog for cyclic-shelf reservoirs, San Andres Formation of Permian Basin: stratigraphic framework, permeability distribution, geostatistics, and fluid-flow modeling: American Association of Petroleum Geologists Bulletin, v. 78, p. 23-54.

Hovorka, S. C., Nance, H. S., and Kerans, C., 1993, Parasequence geometry as a control on porosity evolution: examples from the San Andres and Grayburg Formations in the Guadalupe Mountains, New Mexico, in Loucks, R. G., and Sarg, J. F. eds., Carbonate sequence stratigraphy: recent developments and applications: American Association of Petroleum Geologists Memoir 57, p. 493-514. 
Jennings, J. W., Jr., 2000, Spatial statistics of permeability data from carbonate outcrops of west Texas and New Mexico: implications for improved reservoir modeling: The University of Texas at Austin, Bureau of Economic Geology Report of Investigations No. 258, 50 p.

Kerans, C., and Fitchen, W. M., 1995, Sequence hierarchy and facies architecture of a carbonateramp system: San Andres Formation of Algerita Escarpment and western Guadalupe Mountains, west Texas and New Mexico: The University of Texas at Austin, Bureau of Economic Geology Report of Investigations No. 235, 86 p.

Kerans, C., Lucia, F. J., and Senger, R. K., 1994, Integrated characterization of carbonate ramp reservoirs using Permian San Andres Formation outcrop analogs: American Association of Petroleum Geologists Bulletin, v. 78, p. 181-216.

Kerans, C., Sonnenfeld, M. D., Fitchen, W. M., Tinker, S. W., Gardner, M. H., and Wardlaw, B. R., 1992, Styles of sequence development within uppermost Leonardian through Guadalupian strata of the Guadalupe Mountains, Texas and New Mexico, in Mruk, D. H., and Curran, C., eds., Permian Basin exploration and production strategies: application of sequence stratigraphic and reservoir characterization concepts: West Texas Geological Society Publication 92-91, p. 1-6.

Lucia, F. J., Kerans, C., and Senger, R. K., 1992a, Defining flow units in dolomitized carbonateramp reservoirs: Society of Petroleum Engineers Paper SPE 24702, p. 399-406.

Lucia, F. J., Senger, R. K., Fogg, G. E., Kerans, C., and Kasap, E., 1991, Scale of heterogeneity and fluid flow response in carbonate ramp reservoirs: San Andres outcrop, Algerita escarpment, New Mexico: Society of Petroleum Engineers Paper SPE 22744, p. 839-840.

Tyler, N., Bebout, D. G., Garrett, C. M., Jr., Guevara, E. H., Hocott, C. R., Holtz, M. H., Hovorka, S. D., Kerans, C., Lucia, F. J., Major, R. P., Ruppel, S. C., and Vander Stoep, G. W., 1991, Integrated characterization of Permian Basin reservoirs, University Lands, West Texas: targeting the remaining resource for advanced oil recovery: The University of Texas at Austin, Bureau of Economic Geology Report of Investigations No. 203, $136 \mathrm{p}$.

Ward, R. F., Kendall, C. G. St. C., and Harris, P. M., 1986, Upper Permian (Guadalupian) facies and their association with hydrocarbons-Permian Basin, west Texas and New Mexico: American Association of Petroleum Geologists Bulletin, v. 70, p. 239-262. 
Northwest Shelf San Andres Platform Carbonate (Play 120)

Reservoirs in San Andres platform carbonates on the Northwest Shelf of the Midland Basin (fig. 70) have a cumulative production of 3,969.3 MMbbl $\left(6.31 \times 10^{8} \mathrm{~m}^{3}\right)$ from 38

reservoirs (table 26), making the Northwest Shelf San Andres Platform Carbonate play the play with the highest oil production in the Permian Basin (table 2). Reservoirs produce from the lower and middle San Andres Formation. Leonard reservoirs were included in this play in the Atlas of Major Texas Oil Reservoirs (Galloway and others, 1983), but those reservoirs have been combined into the Leonard Restricted Platform Carbonate play in this portfolio. Reservoirs in

Table 26. Northwest Shelf San Andres Platform Carbonate play (play 120). Production shown for fields that have had others combined into them represents the totals; combined fields are highlighted.

\begin{tabular}{|c|c|c|c|c|c|c|c|c|c|}
\hline RRC RESN & RRC & FLDNAME & RESNAME & STATE & COUNTY & DISCYR & DEPTHTOP & 2000 PROD & CUMPROD \\
\hline 10406500 & $8 \mathrm{~A}$ & BONANZA & SAN ANDRES & $\mathrm{TX}$ & COCHRAN & 1980 & 4893 & 28,022 & $2,070,837$ \\
\hline 11308001 & $8 \mathrm{~A}$ & BRAHANEY & & $\mathrm{TX}$ & YOAKUM & 1945 & 5301 & $1,018,218$ & $54,223,283$ \\
\hline 12961500 & $8 \mathrm{~A}$ & BUCKSHOT & 4950 & $\mathrm{TX}$ & COCHRAN & 1956 & 5010 & 61,081 & $11,816,602$ \\
\hline 22660500 & $8 \mathrm{~A}$ & D-L-S & SAN ANDRES & $\mathrm{TX}$ & HOCKLEY & 1971 & 5161 & 99,377 & $13,371,869$ \\
\hline 34438500 & $8 \mathrm{~A}$ & GEORGE ALLEN & SAN ANDRES & TX & GAINES & 1956 & 4934 & 12,271 & $1,255,323$ \\
\hline 39717500 & $8 \mathrm{~A}$ & HAVEMEYER & SAN ANDRES & $T X$ & GAINES & 1977 & 5488 & 48,744 & $1,175,130$ \\
\hline 44313666 & $8 \mathrm{~A}$ & ILLUSION LAKE & SAN ANDRES & $\mathrm{TX}$ & LAMB & 1957 & 4116 & 2,023 & $2,274,312$ \\
\hline 51812001 & $8 \mathrm{~A}$ & LANDON & & $\mathrm{TX}$ & YOAKUM & 1945 & 5100 & 46,344 & $7,100,093$ \\
\hline 53411001 & $8 \mathrm{~A}$ & LEVELLAND & & TX & COCHRAN & 1945 & 4927 & $10,354,230$ & $642,609,421$ \\
\hline 54098500 & $8 \mathrm{~A}$ & LITTLEFIELD & SAN ANDRES & $\mathrm{TX}$ & LAMB & 1953 & 4030 & 1,650 & $4,806,609$ \\
\hline 66373750 & $8 \mathrm{~A}$ & ODC & SAN ANDRES & TX & GAINES & 1956 & 5450 & 74,384 & $4,775,959$ \\
\hline 67905500 & $8 \mathrm{~A}$ & OWNBY, WEST & SAN ANDRES & $\mathrm{TX}$ & YOAKUM & 1953 & 5307 & 86,331 & $1,518,031$ \\
\hline 72995470 & $8 \mathrm{~A}$ & PRENTICE & 5100 & TX & YOAKUM & 1974 & 5240 & 23,390 & $1,877,441$ \\
\hline 72999500 & $8 \mathrm{~A}$ & PRENTICE, NW. & SAN ANDRES & $\mathrm{TX}$ & YOAKUM & 1969 & 5164 & 54,585 & $3,740,591$ \\
\hline 75552500 & $8 \mathrm{~A}$ & REEVES & SAN ANDRES & $\mathrm{TX}$ & YOAKUM & 1957 & 5544 & 700,856 & $33,359,158$ \\
\hline 79007500 & $8 \mathrm{~A}$ & RUSSELL, S. & SAN ANDRES & $\mathrm{TX}$ & GAINES & 1964 & 4859 & 51,318 & $2,395,124$ \\
\hline 79393750 & $8 \mathrm{~A}$ & SABLE & SAN ANDRES & $\mathrm{TX}$ & YOAKUM & 1957 & 5258 & 144,755 & $10,835,456$ \\
\hline 83991001 & $8 \mathrm{~A}$ & SLAUGHTER & & TX & COCHRAN & 1937 & 5000 & $13,968,403$ & $1,207,424,888$ \\
\hline 95397001 & $8 \mathrm{~A}$ & WASSON & & TX & YOAKUM & 1937 & 4900 & $22,893,551$ & $1,840,501,580$ \\
\hline 94215500 & $8 \mathrm{~A}$ & WBD & SAN ANDRES & $\mathrm{TX}$ & YOAKUM & 1969 & 5288 & 9,718 & $1,056,403$ \\
\hline 96187333 & $8 \mathrm{~A}$ & WELLMAN, SW. & SAN ANDRES & $\mathrm{TX}$ & TERRY & 1966 & 5509 & 41,568 & $2,982,644$ \\
\hline 96188333 & $8 \mathrm{~A}$ & WELLMAN, W. & SAN ANDRES & $\mathrm{TX}$ & TERRY & 1966 & 5583 & 110,422 & $2,607,101$ \\
\hline 96487001 & $8 \mathrm{~A}$ & WEST & & $\mathrm{TX}$ & YOAKUM & 1938 & 5100 & 22,410 & $2,668,047$ \\
\hline 99343001 & $8 \mathrm{~A}$ & YELLOWHOUSE & & $\mathrm{TX}$ & HOCKLEY & 1944 & 4463 & 199,052 & $15,574,053$ \\
\hline \multirow[t]{15}{*}{99347500} & $8 \mathrm{~A}$ & YELLOWHOUSE, S. & SAN ANDRES & $\mathrm{TX}$ & HOCKLEY & 1957 & 4705 & 95,037 & $2,457,147$ \\
\hline & & BLUITT & SAN ANDRES & NM & ROOSEVELT & 1963 & 4500 & 2,385 & $2,498,864$ \\
\hline & & САТО & SAN ANDRES & NM & CHAVES & 1966 & 3414 & 11,912 & $16,254,326$ \\
\hline & & CHAVEROO & SAN ANDRES & NM & CHAVES \& ROI & 1965 & 4184 & 66,509 & $24,500,761$ \\
\hline & & DIABLO & SAN ANDRES & NM & CHAVES & 1963 & 2000 & 45,487 & $1,332,827$ \\
\hline & & FLYING M & SAN ANDRES & NM & LEA & 1964 & 4400 & 128,934 & $11,164,009$ \\
\hline & & MESCALERO & SAN ANDRES & NM & LEA & 1962 & 4063 & 40,787 & $6,949,075$ \\
\hline & & MILNESAND & SAN ANDRES & NM & ROOSEVELT & 1958 & 4554 & 50,916 & $12,034,011$ \\
\hline & & SAWYER & SAN ANDRES & NM & LEA & 1947 & 5000 & 21,181 & $1,664,257$ \\
\hline & & SAWYER WEST & SAN ANDRES & NM & LEA & 1969 & 4950 & 34,277 & $4,244,060$ \\
\hline & & TODD & LOWER SAN ANDRES & NM & ROOSEVELT & 1965 & 4440 & 7,608 & $2,952,336$ \\
\hline & & ТОМ ТОМ & SAN ANDRES & NM & CHAVES & 1967 & 3914 & 21,292 & $3,539,296$ \\
\hline & & TOMAHAWK & SAN ANDRES & NM & CHAVES \& ROI & 1977 & 4144 & 17,556 & $2,339,193$ \\
\hline & & TWIN LAKES & SAN ANDRES & NM & CHAVES & 1965 & 2600 & 70,286 & $5,306,383$ \\
\hline & & Totals & & & & & & $50,666,870$ & $3,969,256,500$ \\
\hline
\end{tabular}




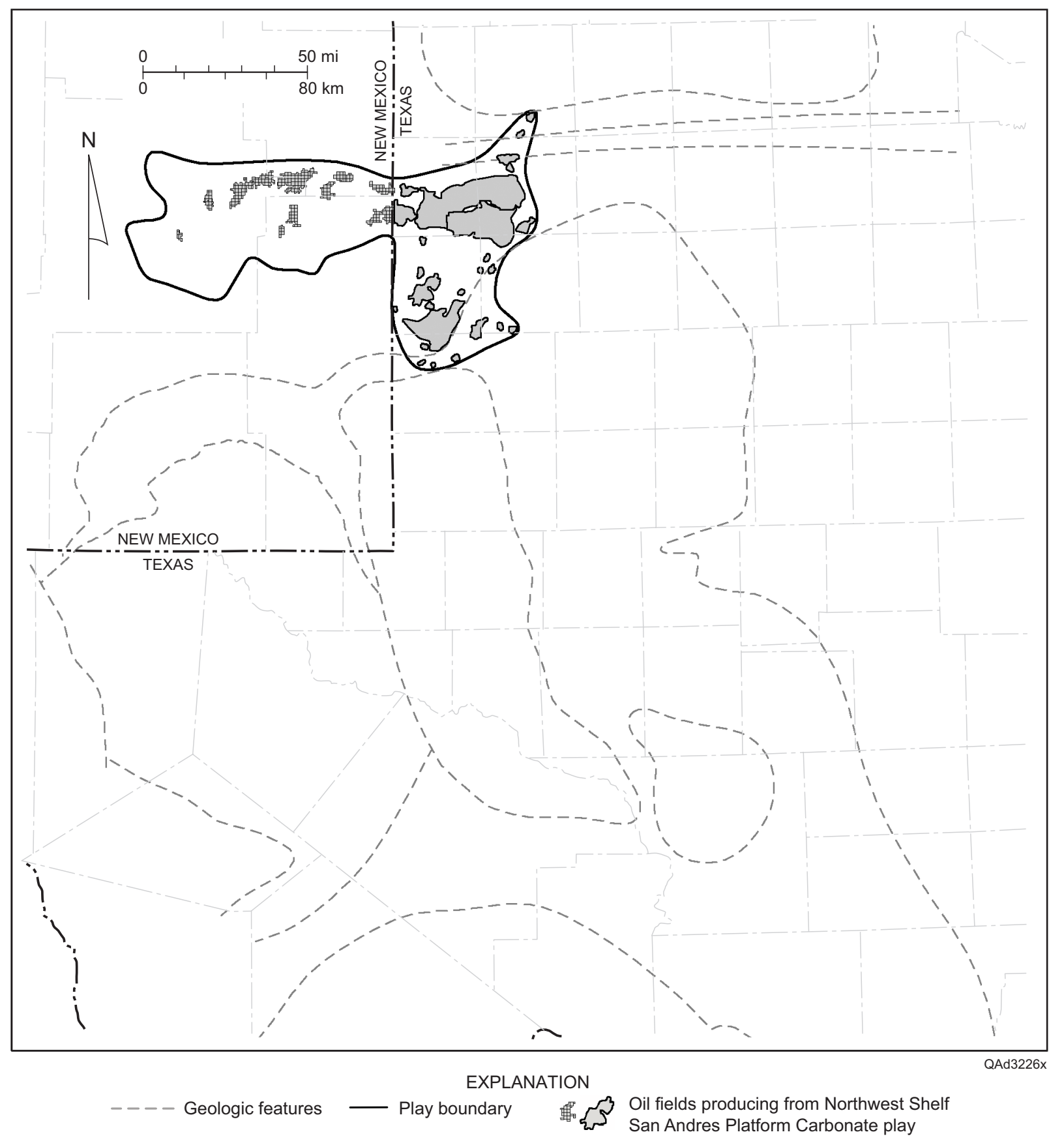

Figure 70. Play map for the Northwest Shelf San Andres Platform Carbonate play, showing location of reservoirs having $>1 \mathrm{MMbbl}$ cumulative production, the play boundary, and geologic features. See figure 1 for county names and figure 2 for identification of geologic features. 
this play are formed by both structural and combined structural/stratigraphic traps (Gratton and LeMay, 1969; Cowan and Harris, 1986; Ward and others, 1986). The largest fields, such as Wasson, Levelland, and Slaughter, apparently result from both structural drape over the buried Abo trend on the southeast and stratigraphic facies changes to the northwest (Galloway and others, 1983). The oil-water contact at Wasson field and at other fields on the Northwest Shelf tilts to the northeast because of hydrodynamic flow in the San Andres (Mathis, 1986; Brown, 2001).

The San Andres on the Northwest Shelf represents a regressive series of cyclic deposits that prograded southward across a broad, low-relief, shallow-water shelf. Porous zones are offset basinward and occur in increasingly younger strata southward (Ramondetta, 1982a, b; Ward and others, 1986). The lower San Andres on the Northwest Shelf is composed, from bottom to top, of (1) open-marine, subtidal limestone; (2) restricted-marine, subtidal dolostones that form the reservoir facies; (3) intertidal and supratidal dolostones, and (4) salina and sabkha anhydrites (Cowan and Harris, 1986). Porosity in the reservoir facies is mostly intercrystalline and moldic. Porosity occurs in multiple zones formed in several upward-shallowing cycles. The base of each succession is formed by porous, subtidal, restricted-shelf carbonates that terminate upward in tight, intertidal and supratidal dolomite and anhydrite (Cowan and Harris, 1986; Mathis, 1986; Ward and others, 1986; Ebanks, 1990; Bent, 1992). Four major cycles, and, therefore, four distinct porosity zones, are found in the lower San Andres (Gratton and LeMay, 1969; Elliot and Warren, 1989), although some workers have identified five cycles (Pitt and Scott, 1981) or even as many as eight cycles (Cowan and Harris, 1986).

Wasson San Andres is the largest reservoir in the Permian Basin, having produced 1,840.5 MMbbl $\left(2.93 \times 10^{8} \mathrm{~m}^{3}\right)$ through 2000; estimated OOIP was 4 Bbbl $\left(6.36 \times 10^{8} \mathrm{~m}^{3}\right)$ 
(Mathis, 1986). Wasson field is located about 40 miles landward of the shelf margin (Ramondetta, 1982a, b; Mathis, 1986). Production from Wasson San Andres occurs from near the middle of the San Andres Formation in two zones, the lower Main Pay zone and the upper First Porosity zone (fig. 71) (Mathis, 1986). The Main Pay produces from dolomitized, openmarine packstones and wackestones; the less-productive First Porosity zone produces from poorer-quality, shallower-water restricted marine and intertidal rocks (fig. 72). Main Pay subtidal pelletal packstones in the Denver unit have porosity of 15 to 20 percent and permeability from

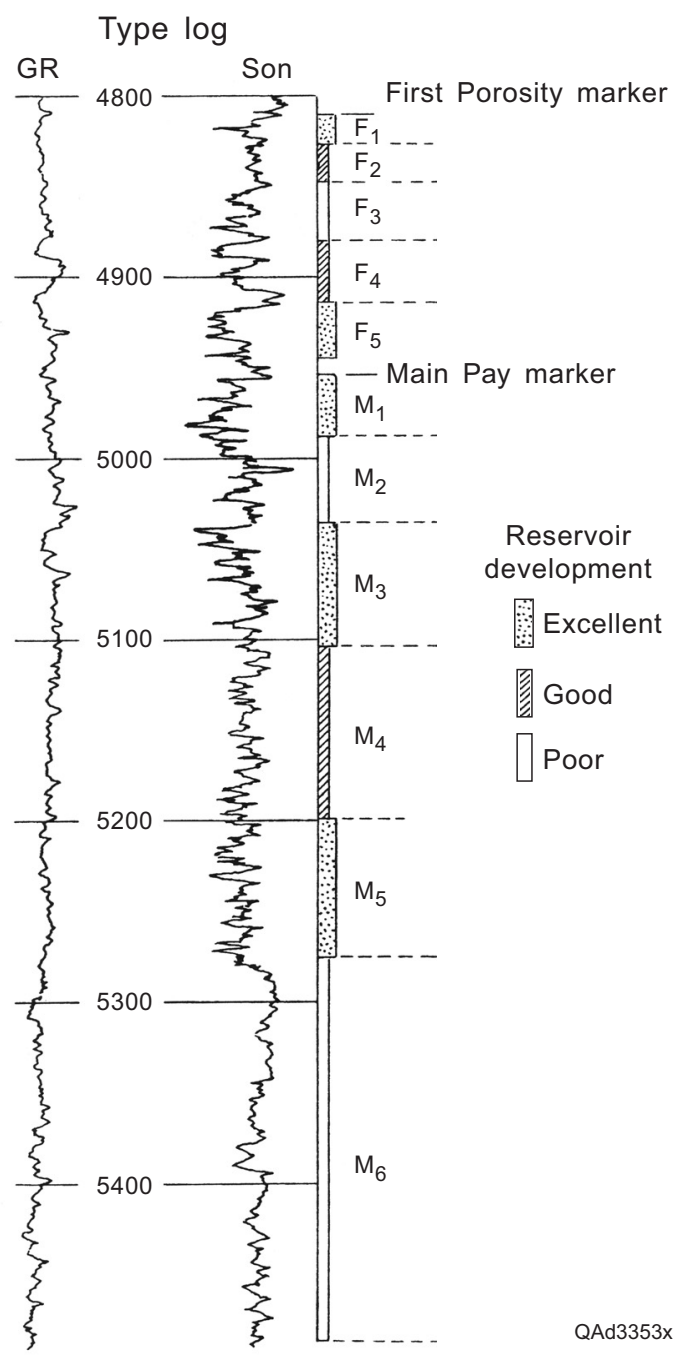

Figure 71. Type log for Denver unit in Wasson San Andres field. From Mathis (1986). 


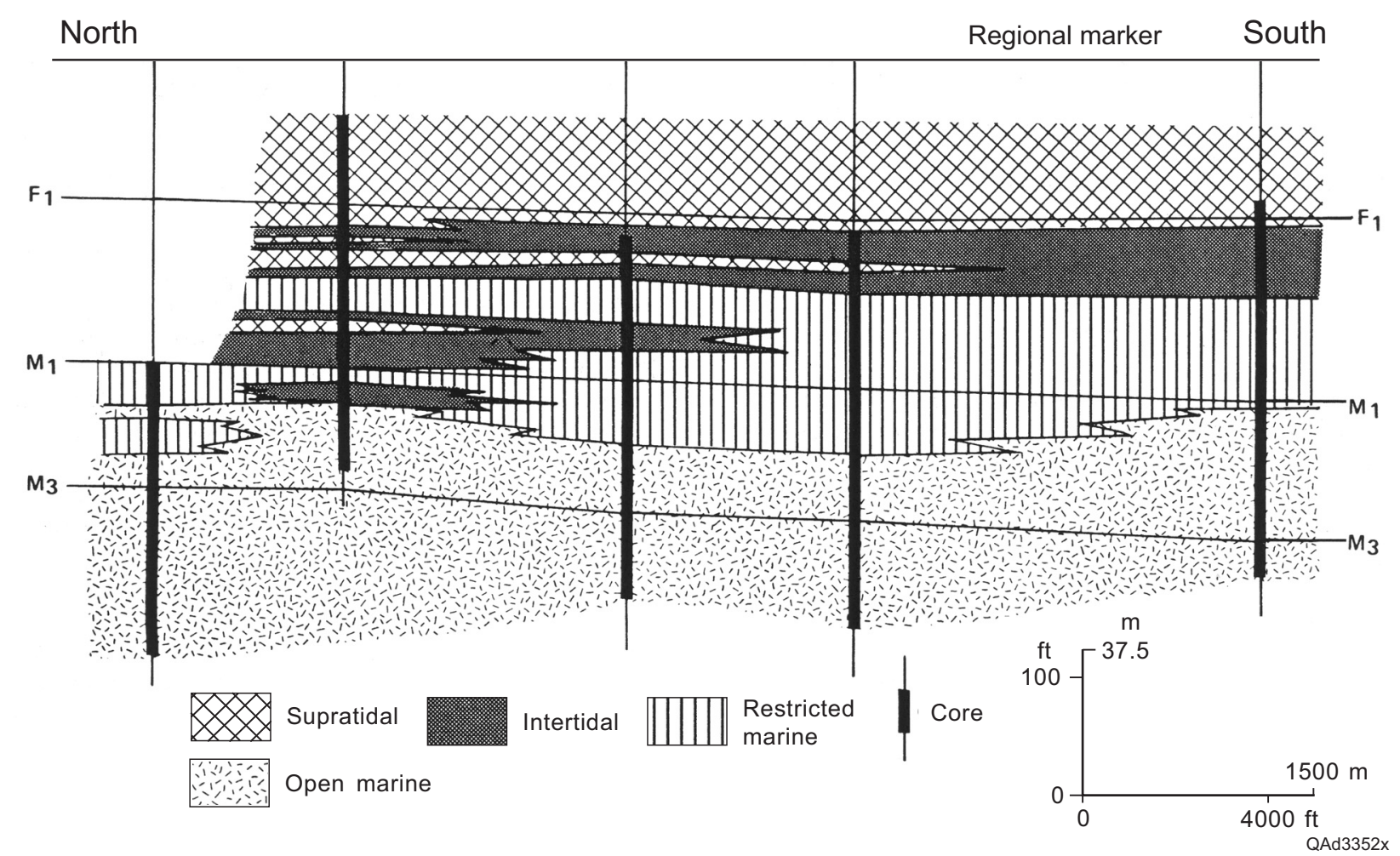

Figure 72. North-south cross section showing the distribution of depositional facies and correlation markers across Denver unit, Wasson San Andres field. From Mathis (1986). See figure 71 for definition of correlation markers.

10 to $50 \mathrm{md}\left(10\right.$ to $50 \times 10^{-3} \mu \mathrm{m}^{2}$ ), whereas Main Pay moldic wackestones have porosity as high as 10 percent but permeability of $<1 \mathrm{md}\left(<1 \times 10^{-3} \mu \mathrm{m}^{2}\right)$ (Mathis, 1986). In the Roberts unit, a permeability cutoff of $\geq 0.3 \mathrm{md}\left(\geq 0.3 \times 10^{-3} \mu \mathrm{m}^{2}\right)$ was used, corresponding to a porosity cutoff of 6 percent (Bent, 1992). Both pay and nonpay zones have good lateral continuity; nonreservoir zones are apparently impermeable barriers to vertical fluid flow. Overlying dense dolomudstone and anhydrite form the seal.

Wasson San Andres field was divided into seven units when waterflooding began in the 1960’s. Primary recovery by solution-gas drive in the Denver unit was about 16 percent of OOIP, and waterflooding recovered an additional 22 percent of OOIP (Mathis, 1986). Several units within Wasson San Andres field are undergoing tertiary $\mathrm{CO}_{2}$ floods (Bent, 1992). 
The Willard unit at Wasson field produces from open-marine, skeletal-peloidal wackestone and packstone (Brown, 2002; Loucks and others, 2002). The highest reservoir quality and most continuous reservoirs are in the dolomitized, inner-ramp restricted lagoon and moderate-energy shoal facies (Loucks and others, 2002). Porosity in these facies is 8.5 percent and geometric mean permeability is 1 to $2 \mathrm{md}\left(1-2 \times 10^{-3} \mu \mathrm{m}^{2}\right)$.

Levelland and Slaughter fields are located $\sim 85 \mathrm{mi}(\sim 135 \mathrm{~km})$ north of the San Andres shelf-margin position (Ramondetta, 1982a, b). Production is from the lower San Andres, below the Pi Marker radioactive siltstone that separates the upper and lower San Andres (Dulaney and Hadik, 1990). The northward pinch-out of porous dolomite into nonporous facies, in combination with subtle structural nosing and hydrodynamics, forms the trap at Levelland and Slaughter fields (Elliot and Walker, 1989). Most production is from subtidal marine facies (Dulaney and Hadik, 1990; Ebanks, 1990). Anhydrite fills the larger vuggy and moldic pores, so fluid flow is controlled by smaller intercrystalline pores in subtidal dolomudstones and dolowackestones (Chuber and Pusey, 1969; Ebanks, 1990). A cutoff of $0.1 \mathrm{md}\left(0.1 \times 10^{-3} \mu \mathrm{m}^{2}\right)$, corresponding to 5 percent porosity, was used to define reservoir rock (Dulaney and Hadik, 1990). In the Mallet Lease of Slaughter field, the subtidal facies has average permeability of $<10 \mathrm{md}$. Some parts of the intertidal facies have permeability of 2 to $3 \mathrm{md}\left(2-3 \times 10^{-3} \mu \mathrm{m}^{2}\right)$, but the rest of the intertidal facies and all of the supratidal facies have permeability $<1 \mathrm{md}$ $\left(<1 \times 10^{-3} \mu \mathrm{m}^{2}\right)($ Ebanks, 1990).

The East Mallet unit in Slaughter field has been under a $\mathrm{CO}_{2}$ miscible flood since 1989, after undergoing primary production from 1941 through 1966 and secondary waterflooding from 1966 until 1989 (Drozd and Gould, 1991). Injection wells are in a northwest-oriented line-drive pattern, with 19-acre well spacing. $\mathrm{CO}_{2}$ injection alternates with water injection in 4-month 
cycles. Porosity in the two productive zones averages 9 to 11 percent, and permeability averages 2 to $4 \mathrm{md}\left(2\right.$ to $4 \times 10^{-3} \mu \mathrm{m}^{2}$ ) (Drozd and Gould, 1991). Other units in Levelland and Slaughter fields are also undergoing $\mathrm{CO}_{2}$ floods (L. S. Melzer, Personal Communication, 2003).

The C. S. Dean "A" unit in Slaughter field underwent secondary recovery by waterflooding developed on 80 -acre, 5-spot patterns. Infill drilling was later done in part of the unit on 20-acre spacing (Watson, 1992).

In New Mexico, the Northwest Shelf San Andres Platform Carbonate play is located in northern Lea, southern Roosevelt, and eastern Chaves Counties (fig. 70). Traps are stratigraphic or combination structural-stratigraphic (Gratton and LeMay, 1969; Yedlosky and McNeal, 1969; Keller, 1992). Porosity zones pinch out updip to the north and northwest where porosity is occluded by anhydrite cement. Combination traps where zero porosity lines are draped across generally south plunging structural noses form the Cato, Chaveroo, and Milnesand reservoirs. The cyclicity of the regressive sequences has led to vertical stacking of porosity zones. In some places, zero-porosity lines in multiple zones are nearly coincident, resulting in production from two or more hydraulically isolated porosity zones within a single reservoir. Evaporite-cemented underseals in some reservoirs prevented oil from secondary migration in structures that were tilted subsequent to entrapment (Keller, 1992), resulting in a tilted base-of-oil.

Some of the San Andres reservoirs are cut by wrench faults of probable Tertiary age (Scott, 1995). At Cato and Tom Tom, faulting is thought to have enhanced low matrix permeability (Scott, 1995). It is therefore likely that permeability varies as a function of proximity to the faults that cut the reservoir. 
Bent, J. V., Jr., 1992, Geologic model of San Andres reservoir, Roberts Unit $\mathrm{CO}_{2}$ Phase III area, Wasson field, Yoakum County, Texas, in Cromwell, D. W., Moussa, M. T., and Mazzullo, L. J., eds., Southwest Section American Association of Petroleum Geologists Transactions, SWS 92-90, p. 113-124.

Brown, A., 2001, Effects of hydrodynamics on Cenozoic oil migration, Wasson field area, Northwest Shelf of the Permian Basin, in Viveiros, J. J., and Ingram, S. M., eds., The Permian Basin: microns to satellites, looking for oil and gas at all scales: West Texas Geological Society Publication No. 01-110, p. 133-142.

2002, Anhydrite diagenesis and reservoir quality, San Andres Formation, Willard Unit of Wasson field, Yoakum County, TX, in Hunt, T. J., and Lufholm, P. H., eds., The Permian Basin: back to basics: West Texas Geological Society Publication No. 03-112, p. $125-141$.

Chuber, S., and Pusey, W. C., 1969, Cyclic San Andres facies and their relationship to diagenesis, porosity, and permeability in the Reeves field, Yoakum County, Texas, in Elam, J. G., and Chuber, S., eds., Cyclic sedimentation in the Permian Basin: West Texas Geological Society Special Publication 69-56, p. 136-151.

Cowan, P. E., and Harris, P. M., 1986, Porosity distribution in San Andres Formation (Permian), Cochran and Hockley Counties, Texas: American Association of Petroleum Geologists Bulletin, v. 70, p. 888-897.

Drozd, J. W., and Gould, J., 1991, East Mallet unit $\mathrm{CO}_{2}$ flood log monitoring program, Slaughter field, Hockley County, Texas, in Candelaria, M., ed., Permian Basin plays, tomorrow's technology today: West Texas Geological Society, Publication No. 91-89, p. 31-33.

Dulaney, J. P. and Hadik, A. L., 1990, Geologic reservoir description of Mobil-operated units in Slaughter (San Andres) field, Cochran and Hockley Counties, Texas, in Bebout, D.G. and Harris, P.M., eds., Geologic and engineering approaches in evaluation of San Andres/Grayburg hydrocarbon reservoirs-Permian Basin: The University of Texas at Austin, Bureau of Economic Geology, p. 53-73.

Ebanks, W. J., Jr., 1990, Geology of the San Andres reservoir, Mallet Lease, Slaughter field, Hockley County, Texas: implications for reservoir engineering projects, in Bebout, D. G., and Harris, P. M., eds., Geologic and engineering approaches in evaluation of San Andres/Grayburg hydrocarbon reservoirs_-Permian Basin: The University of Texas at Austin, Bureau of Economic Geology, p. 75-85. 
Elliott, L. A., and Warren, J. K., 1989, Stratigraphy and depositional environment of lower San Andres Formation in subsurface and equivalent outcrops: Chaves, Lincoln, and Roosevelt Counties, New Mexico: American Association of Petroleum Geologists Bulletin, v. 73, p. 1307-1325.

Galloway, W. E., Ewing, T. E., Garrett, C. M., Jr., Tyler, N., and Bebout, D. G., 1983, Atlas of major Texas oil reservoirs: The University of Texas at Austin, Bureau of Economic Geology Special Publication, 139 p.

Gratton, P. J. F., and LeMay, W. J., 1969, San Andres oil east of the Pecos, in Summers, W. K., and Kottlowski, F. E., The San Andres Limestone, a reservoir for oil and water in New Mexico: New Mexico Geological Society, Special Publication 3, p. 37-43.

Keller, D. R., 1992, Evaporite geometries and diagenetic traps, lower San Andres, Northwest shelf, New Mexico, in Cromwell, D. W., Moussa, M. T., and Mazzullo, L. J., eds., Southwest Section American Association of Petroleum Geologists 1992 Convention Transactions: Southwest Section American Association of Petroleum Geologists, Publication SWS 92-90, p. 183-193.

Loucks, R. G., Mescher, P., Entzminger, D., Braaten, D., 2002, Geologic reservoir characterization of the Willard Unit in the San Andres Wasson field, west Texas: American Association of Petroleum Geologists Annual Convention Official Program, p. 11, p. A107.

Mathis, R. L., 1986, Reservoir geology of the Denver Unit-Wasson San Andres field, Gaines and Yoakum Counties, Texas, in Bebout, D. G., and Harris, P. M., eds., Hydrocarbon reservoir studies, San Andres/Grayburg Formations, Permian Basin: Permian Basin Section Society of Economic Paleontologists and Mineralogists, Publication No. 86-26, 188 p. 43-47.

Pitt, W. D., and Scott, G. L., 1981, Porosity zones of lower part of San Andres Formation, eastcentral New Mexico: New Mexico Bureau of Mines and Mineral Resources, Circular $179,20 \mathrm{p}$.

Ramondetta, P. J., 1982a, Facies and stratigraphy of the San Andres Formation, Northern and Northwestern Shelves of the Midland Basin, Texas and New Mexico: The University of Texas at Austin Bureau of Economic Geology Report of Investigations No. 128, 56 p.

1982b, Genesis and emplacement of oil in the San Andres Formation, Northern Shelf of the Midland Basin, Texas: The University of Texas at Austin Bureau of Economic Geology Report of Investigations No. 116, 39 p.

Scott, G. L., Jr., 1995, Faulting in Cato and Tom-Tom San Andres fields, in A symposium of oil and gas fields of southeastern New Mexico, supplement: Roswell Geological Society, p. $68-73$. 
Ward, R. F., Kendall, C. G. St. C., and Harris, P. M., 1986, Upper Permian (Guadalupian) facies and their association with hydrocarbons-Permian Basin, west Texas and New Mexico: American Association of Petroleum Geologists Bulletin, v. 70, p. 239-262.

Watson, K. A., 1992, In search of the holy grail: predicting producing rates in the C. S. Dean "A" Unit, Slaughter field, Cochran County, Texas, in Mruk, D. H., and Curran, C., eds., Permian Basin exploration and production strategies: application of sequence stratigraphic and reservoir characterization concepts: West Texas Geological Society Publication 92-91, p. 106-115.

Yedlosky, R. J., and McNeal, J. E., 1969, Geological engineering study of Cato field (San Andres), Chaves County, New Mexico, in Summers, W. K., and Kottlowski, F. E., eds., The San Andres Limestone, a reservoir for oil and water in New Mexico: New Mexico Geological Society, Special Publication 3, p. 46-51. 
Eastern Shelf San Andres Platform Carbonate (Play 121)

The 24 reservoirs in the Eastern Shelf San Andres Platform Carbonate play have produced 706.9 MMbbl $\left(1.12 \times 10^{8} \mathrm{~m}^{3}\right)$ of oil (table 27). The play, located on the Eastern Shelf of the Midland Basin (fig. 73), produces from dolomites and sandstones of the Upper Permian Guadalupian (Yates, Seven Rivers, Queen, Grayburg/San Andres) Series (fig. 3). Leonard reservoirs were included in this play in the Atlas of Major Texas Oil Reservoirs (Galloway and others, 1983), but those reservoirs have been combined into the Leonard Restricted Platform Carbonate play (117) in this portfolio. Simple anticlines form the traps within this section of multiple porous dolomite and sandstone reservoirs (Galloway and others, 1983). There is also a stratigraphic component to the trapping caused by the loss of porosity and permeability updip to the east, resulting from porosity occlusion by evaporites (Ward and others, 1986).

Table 27. Eastern Shelf San Andres Platform Carbonate play (play 121). Production shown for fields that have had others combined into them represents the totals; combined fields are highlighted.

\begin{tabular}{|c|c|c|c|c|c|c|c|c|c|}
\hline RRC RESN & RRC & FLDNAME & RESNAME & STATE & COUNTY & DISCYR & DEPTHTOP & 2000 PROD & CUMPROD \\
\hline 13047001 & $8 \mathrm{~A}$ & BUENOS & & $\mathrm{TX}$ & GARZA & 1949 & 3397 & 28,989 & $1,834,059$ \\
\hline 18593666 & 8 & CLARK & SAN ANDRES & $\mathrm{TX}$ & STERLING & 1949 & 890 & 58,468 & $1,568,965$ \\
\hline 19346426 & $8 \mathrm{~A}$ & COGDELL & SAN ANDRES & $\mathrm{TX}$ & KENT & 1951 & 1475 & 13,455 & $1,455,502$ \\
\hline 20553500 & $8 \mathrm{~A}$ & CORAZON & SAN ANDRES & $\mathrm{TX}$ & SCURRY & 1953 & 2139 & 86,512 & $5,457,029$ \\
\hline 34113001 & $8 \mathrm{~A}$ & GARZA & & $\mathrm{TX}$ & GARZA & 1926 & 2900 & $1,365,884$ & $116,170,788$ \\
\hline 34113425 & $8 \mathrm{~A}$ & GARZA & SAN ANDRES, DEEP & $\mathrm{TX}$ & GARZA & 1985 & 3465 & 260,431 & $9,648,491$ \\
\hline 37356666 & $8 \mathrm{~A}$ & GUINN & SAN ANDRES & $\mathrm{TX}$ & LYNN & 1961 & 4031 & 12,836 & $1,875,859$ \\
\hline 40752500 & 8 & HERRELL, EAST & QUEEN SAND & TX & STERLING & 1953 & 1454 & 98,148 & $4,793,966$ \\
\hline 42971001 & 8 & HOWARD GLASSCOCK & & $\mathrm{TX}$ & HOWARD & 1925 & 1500 & $2,741,620$ & $403,182,614$ \\
\hline 43731666 & $8 \mathrm{~A}$ & HUNTLEY & 3400 & TX & GARZA & 1954 & 3387 & 397,269 & $16,691,235$ \\
\hline 43732500 & $8 \mathrm{~A}$ & HUNTLEY, EAST & SAN ANDRES & TX & GARZA & 1956 & 3138 & 145,244 & $8,883,820$ \\
\hline 44147500 & 8 & IATAN & SAN ANDRES & $\mathrm{TX}$ & MITCHELL & 1957 & 2364 & 28,431 & $2,350,479$ \\
\hline 44149001 & 8 & IATAN, NORTH & & $\mathrm{TX}$ & HOWARD & 1943 & 2908 & 31,551 & $3,791,827$ \\
\hline 59304250 & 8 & MCDOWELL & SAN ANDRES & $\mathrm{TX}$ & GLASSCOCK & 1964 & 2341 & 9,867 & $2,526,387$ \\
\hline 62711001 & 8 & MOORE & & TX & HOWARD & 1937 & 3200 & 160,062 & $15,258,997$ \\
\hline 69351498 & 8 & PAROCHIAL-BADE & QUEEN SAND & $\mathrm{TX}$ & STERLING & 1951 & 1103 & 8,791 & $2,031,854$ \\
\hline 68101001 & $8 \mathrm{~A}$ & P. H.D. & & TX & GARZA & 1944 & 3565 & 211,704 & $10,800,728$ \\
\hline 77643001 & $8 \mathrm{~A}$ & ROCKER -A- & & TX & GARZA & 1950 & 2422 & 83,503 & $7,180,789$ \\
\hline 77647333 & $8 \mathrm{~A}$ & ROCKER -A-, NW. & SAN ANDRES & $\mathrm{TX}$ & GARZA & 1959 & 2772 & 97,187 & $2,248,354$ \\
\hline 82710498 & $8 \mathrm{~A}$ & SHARON RIDGE & 1700 & $\mathrm{TX}$ & SCURRY & 1923 & 1759 & 618,179 & $66,480,174$ \\
\hline 87173100 & $8 \mathrm{~A}$ & SUNILAND & & $\mathrm{TX}$ & LYNN & 1978 & 3803 & 76,245 & $9,769,796$ \\
\hline 89732500 & $8 \mathrm{~A}$ & THREE WAY & SAN ANDRES & $\mathrm{TX}$ & GARZA & 1958 & 3493 & 26,924 & $2,192,455$ \\
\hline 93233333 & 8 & VAREL & SAN ANDRES & $\mathrm{TX}$ & HOWARD & 1955 & 3080 & 15,313 & $6,542,943$ \\
\hline 95445666 & $7 \mathrm{C}$ & WATER VALLEY & SAN ANDRES & $\mathrm{TX}$ & TOM GREEN & 1948 & 1035 & 37,224 & $4,159,900$ \\
\hline \multicolumn{4}{|c|}{ Totals } & & & & & $6,613,837$ & $706,897,011$ \\
\hline
\end{tabular}




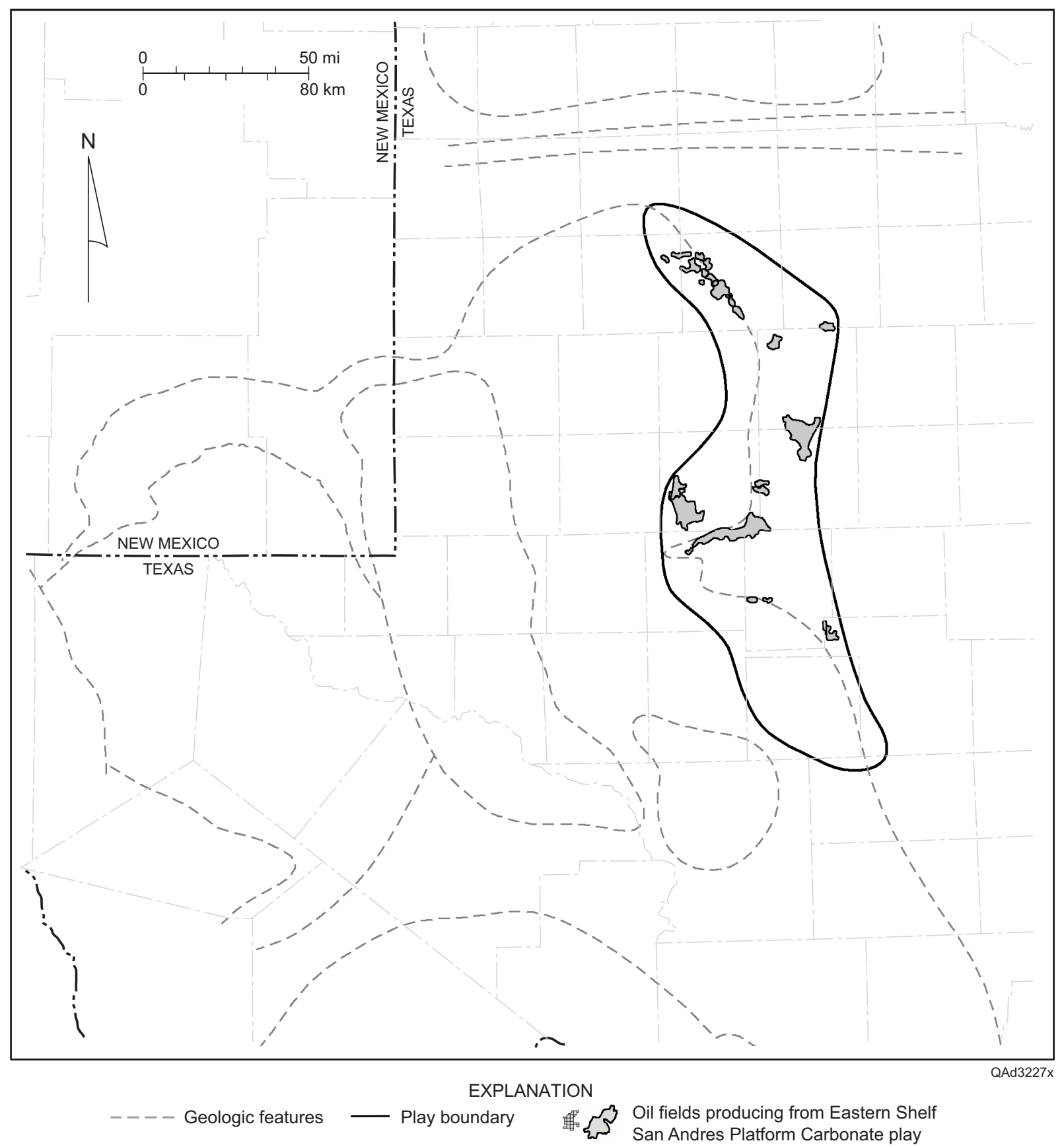

Figure 73. Play map for the Eastern Shelf San Andres Platform Carbonate play, showing location of reservoirs having $>1 \mathrm{MMbbl}$ cumulative production, the play boundary, and geologic features. See figure 1 for county names and figure 2 for identification of geologic features. 
The Permian section on the Eastern Shelf is composed of dolomite, anhydrite, sandstone and siltstone (red beds), and halite (Galloway and others, 1983). The Eastern Shelf prograded westward into the Midland Basin during the Permian (Van Siclen, 1958; Brown and others, 1990), and carbonate deposition ended on the Eastern Shelf during the middle Guadalupian (Ward and others, 1986). Upper Guadalupian rocks are composed of cyclic deposits of sandstone, anhydrite, and halite.

Howard Glasscock, the largest field in the play, produced 403.2 MMbbl $\left(6.41 \times 10^{7} \mathrm{~m}^{3}\right)$ through 2000. Production in Howard Glasscock field comes from the Yates, Seven Rivers, Queen, Grayburg/San Andres, and Glorieta intervals (fig. 74). Until 1969, production from the Leonardian Glorieta interval was reported as part of Howard Glasscock field, but since that date Glorieta production has been reported separately by the Railroad Commission of Texas as Howard-Glasscock Glorieta. The San Andres/Grayburg interval at Howard Glasscock field is a prograding sequence from open marine to supratidal carbonates that are pervasively dolomitized (White, 1984). The dominant reservoir facies is dolomudstone, with scattered areas of oolitic grainstone in the field (Mooney, 1982; White, 1984). Porosity is composed of intercrystalline pores and vugs that are occluded partly by anhydrite (Martin and others, 1997). Average porosity is 10.5 percent and average permeability is $5 \mathrm{md}\left(5 \times 10^{-3} \mu \mathrm{m}^{2}\right)$ (Mooney, 1982).

The Yates, Seven Rivers, and Queen Formations at Howard Glasscock field produce from fine- to coarse-grained quartz sandstones interbedded with red shale and anhydrite (Mooney, 1982) Average porosity in the Yates sandstone is 23 percent and average permeability is $200 \mathrm{md}\left(200 \times 10^{-3} \mathrm{\mu m}^{2}\right)$ (Mooney, 1982). The Seven Rivers and Queen sandstones have average porosity of 19 to 20 percent and average permeability of 11 to $34 \mathrm{md}$ (11 to $34 \times 10^{-3} \mu \mathrm{m}^{2}$ ). The Queen sandstones on the Eastern Shelf were deposited primarily by 


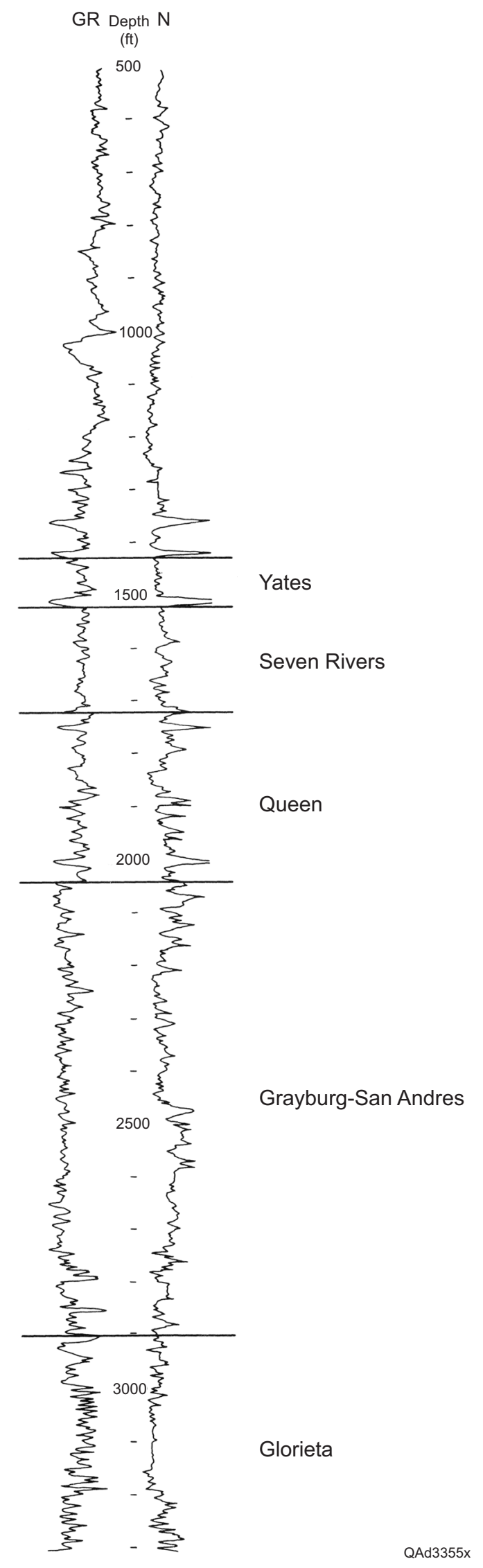

Figure 74. Typical gamma-rayneutron $\log$ through the Permian section in Howard Glasscock field. From Galloway and others (1983). 
fluvial processes in ephemeral stream (wadi) and wadi-fan environments; eolian deposition occurred in isolated areas (Slone and Mazzullo, 2000).

Pilot waterflooding of Howard-Glasscock field began in 1964, and in the 1970's an extensive coring program was conducted to aid in log interpretation, geologic mapping, and injection-well planning (Wilson and Hensel, 1978). The Glorieta, Clear Fork, San Andres, Queen, and Seven Rivers Formations are being waterflooded in Howard Glasscock field on 10-acre patterns with multiple-zone well completions (Miller and others, 1998). Bypassed pay potential in this mature, waterflooded field was identified by characterizing petrophysical flow units (Martin and others, 1997).

Tiltmeter mapping in the Howard Glasscock East unit determined that hydraulic fracturing was occurring under normal waterflood injection conditions in the San Andres carbonates and Seven Rivers and Queen sandstones (Griffin and others, 2000). Average fracture azimuths of the created vertical fractures were approximately east-west. Proper pattern alignment to maximize sweep efficiency on the basis of fracture orientation is to have injectors and producers lined up in an east-west direction (Griffin and others, 2000).

\section{References}

Brown, L. F., Jr., Solís Iriarte, R. F., and Johns, D. A., 1990, Regional depositional systems tracts, paleogeography, and sequence stratigraphy, Upper Pennsylvanian and Lower Permian strata, North- and West-Central Texas: The University of Texas at Austin, Bureau of Economic Geology Report of Investigations No. 197, 116 p.

Galloway, W. E., Ewing, T. E., Garrett, C. M., Jr., Tyler, N., and Bebout, D. G., 1983, Atlas of major Texas oil reservoirs: The University of Texas at Austin, Bureau of Economic Geology Special Publication, 139 p. 
Griffin, L. G., Wright, C. A., Demetrius, S. L., Blackburn, B. D., and Price, D. G., 2000, Identification and implications of induced hydraulic fractures in waterflood: case history HGEU: Society of Petroleum Engineers, Permian Basin Oil and Gas Recovery Conference, Midland, Texas, SPE Publication 59525, 8 p.

Martin, A. J., Soloman, S. T., and Hartmann, D. J., 1997, Characterization of petrophysical flow units in carbonate reservoirs: American Association of Petroleum Geologists Bulletin, v. 81 , p. $734-759$.

Miller, K. K., Prosceno, R. J., Woodroof, R. A., and Haney, R. L., 1998, Permian Basin field tests of propellant-assisted perforating: Society of Petroleum Engineers, Permian Basin Oil and Gas Recovery Conference, Midland, Texas, SPE Publication 39779, 9 p.

Mooney, T. D., 1982, Howard Glasscock, in Selected oil \& gas fields in West Texas: West Texas Geological Society Publication No. 82-75, p. 323-337.

Slone, J. C., and Mazzullo, J., 2000, Lithofacies, stacking patterns, and depositional environments of the Permian Queen Formation, Sterling and Glasscock Counties, Texas, in DeMis, W. D., Nelis, M. K., and Trentham, R. C., eds., The Permian Basin: proving ground for tomorrow's technologies: West Texas Geological Society Publication No. 00-109, p. 63-64.

Van Siclen, D. C., 1958, Depositional topography_examples and theory: American Association of Petroleum Geologists Bulletin, v. 42, p. 1897-1913.

Ward, R. F., Kendall, C. G. St. C., and Harris, R. M., 1986, Upper Permian (Guadalupian) facies and their association with hydrocarbons-Permian Basin, West Texas and New Mexico: American Association of Petroleum Geologists Bulletin, v. 70, p. 239-262.

White, T. C., 1984, Dolomitization, sulfate solution, and porosity development: the San Andres Formation, Howard-Glasscock field, Howard County, Texas, in Moore, G., and Wilde, G., eds., Oil \& gas fields: search for more in '84: Transactions of the Southwest Section American Association of Petroleum Geologists, SWS 84-78, p. 91-102.

Wilson, D. A., and Hensel, W. M., Jr., 1978, Computer log analysis plus core analysis equals improved formation evaluation in West Howard-Glasscock unit: Journal of Petroleum Technology, v. 30, no. 1, p. 43-51. 
San Andres Karst-Modified Platform Carbonate (Play 122)

The six reservoirs in the San Andres Karst-Modified Platform Carbonate play have produced 1,567.1 MMbbl $\left(2.49 \times 10^{8} \mathrm{~m}^{3}\right)$ of oil (table 28$)$ from the structurally high southern end of the Central Basin Platform (fig. 75). Most of the production has come from Yates field $\left(1,381 \mathrm{MMbbl}\left[\left(2.20 \times 10^{8} \mathrm{~m}^{3}\right]\right)\right.$, which occurs on the structural crest and had original oil in place of 4,000 MMbbl $\left(6.36 \times 10^{8} \mathrm{~m}^{3}\right)$ (Galloway and others, 1983; Tyler and others, 1991). The Toborg reservoir produces from shallow Lower Cretaceous Trinity sandstones associated with Yates field.

Post-Guadalupian structural tilting caused northward dip of the Central Basin Platform, but thinning by onlap in the Grayburg and Seven Rivers Formations supports the interpretation that this part of the platform was also a relatively positive feature during the Guadalupian (Tyler and others, 1991). Localized San Andres karst development along the south margin of the Central Basin Platform in Yates (Craig, 1988, 1990), Taylor-Link West (Kerans and Parsley, 1986; Tyler and others, 1991; Lucia and others, 1992), and McCamey (Guiseppe and Trentham, 1999) fields provides further evidence that this area was a positive feature during the Guadalupian (Tyler and others, 1991).

Table 28. San Andres Karst-Modified Platform Carbonate play (play 122).

\begin{tabular}{|c|c|c|c|c|c|c|c|c|c|}
\hline RRC RESN & RRC & FLDNAME & RESNAME & STATE & COUNTY & DISCYR & DEPTHTOP & 2000 PROD & CUMPROD \\
\hline 21766001 & 7C & CROCKETT & & TX & CROCKETT & 1938 & 1571 & 21,883 & $4,762,786$ \\
\hline 58840001 & 7C & MCCAMEY & & TX & UPTON & 1925 & 2100 & 117,862 & $135,137,987$ \\
\hline 77841333 & $7 \mathrm{C}$ & RODMAN-NOEL & GRAYBURG & TX & UPTON & 1953 & 1745 & 1,091 & $1,143,800$ \\
\hline 88567700 & 8 & TAYLOR LINK W. & SAN ANDRES & TX & PECOS & 1984 & 1800 & 75,010 & $1,640,304$ \\
\hline 90286001 & 8 & TOBORG & & TX & PECOS & 1929 & 500 & 126,482 & $43,045,830$ \\
\hline 99295001 & 8 & YATES & & TX & PECOS & 1926 & 1500 & $11,117,801$ & $1,381,373,107$ \\
\hline \multicolumn{4}{|c|}{ Totals } & & & & & $11,460,129$ & $1,567,103,814$ \\
\hline
\end{tabular}




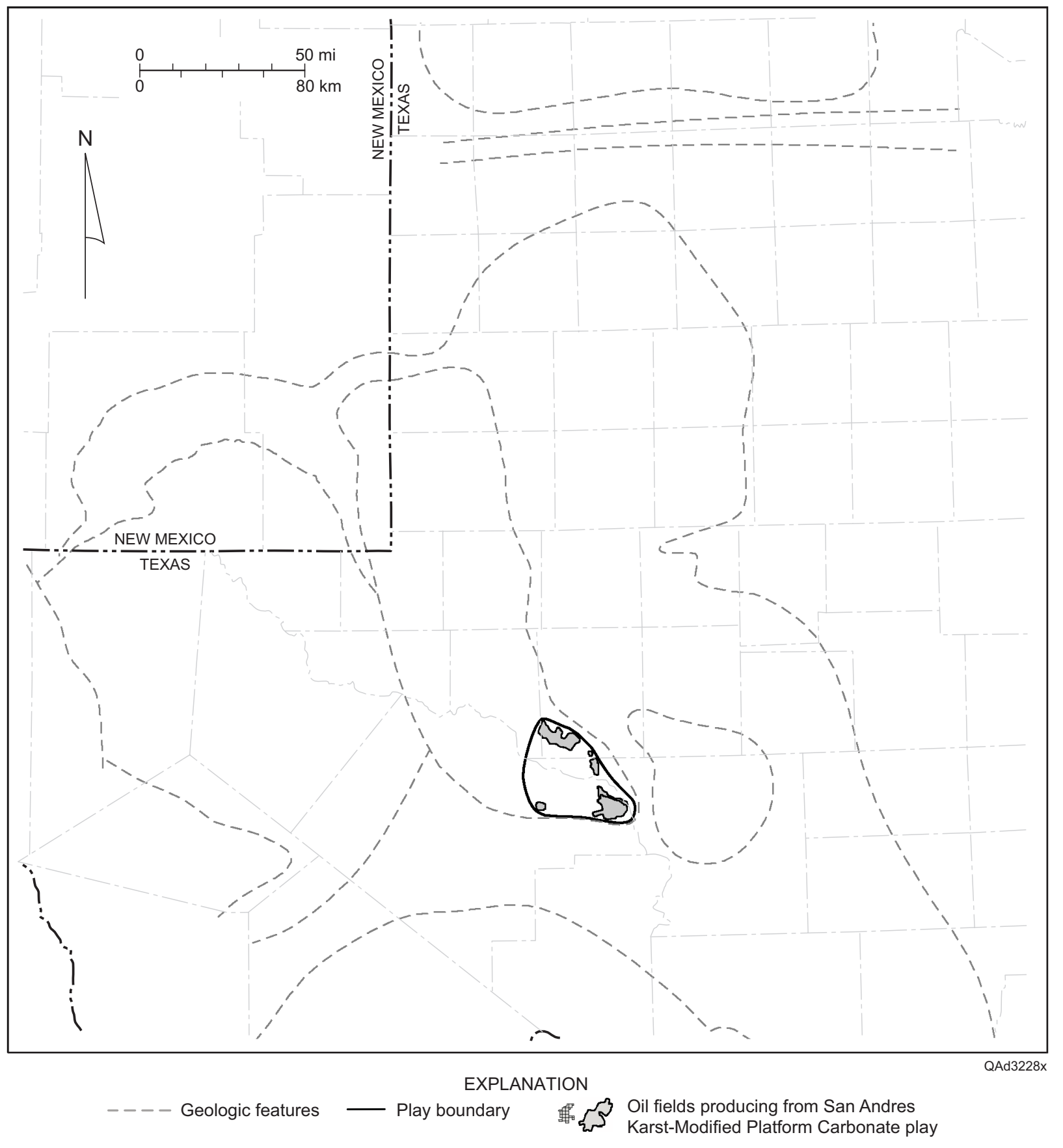

Figure 75. Play map for the San Andres Karst-Modified Platform Carbonate play, showing location of reservoirs having $>1 \mathrm{MMbbl}$ cumulative production, the play boundary, and geologic features. See figure 1 for county names and figure 2 for identification of geologic features. 


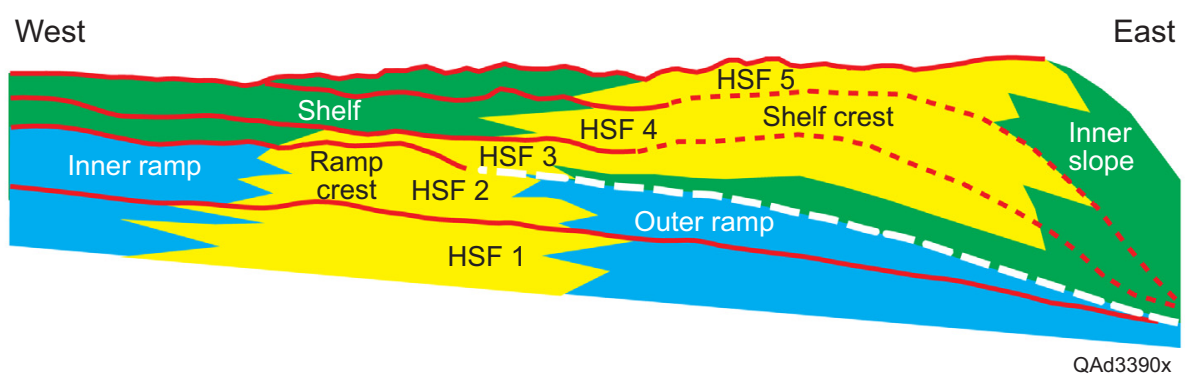

Figure 76. Sequence stratigraphy and facies tracts of Yates field illustrated on a westeast cross section. After Tinker (2000), reprinted by permission of the AAPG, whose permission is required for further use. CCopyright 2000. The American Association of Petroleum Geologists. All rights reserved. The transgressive systems tract is composed of high-frequency sequences (HFS) 1-2, and the highstand systems tract is composed of HFS $3-5$. The shelf-crest facies (yellow) shifted basinward significantly between HFS 2 and HFS 3. See Tinker (2000) for location of seismic section.

The main reservoirs in the play are dolomites of the San Andres Formation, which are characterized by thick accumulations of reservoir-quality grainstones at the top of an upwardshallowing sequence, reflecting the higher-energy depositional setting of the shelf margin facing the Sheffield Channel (Tyler and others, 1991) (fig. 2). The general facies tract is composed of middle-shelf lagoons, shelf-crest (ramp-crest) subtidal shoals/eolian dunes, and slope (outerramp) subtidal environments (Tinker, 1996) (fig. 76). San Andres reservoirs in Yates field are mostly moldic to sucrosic packstones and grainstones deposited in aggrading and prograding shallow subtidal and shoal-island environments (fig. 77) (Tinker and Mruk, 1995). The productive shelf-crest facies are located in the central and east part of the field (fig. 76). Dolomite reservoir zones have average porosity of 15 percent and average matrix permeability of $100 \mathrm{md}\left(100 \times 10^{-3} \mu \mathrm{m}^{2}\right)$ (Snell and Close, 1999). Clastics in the Seven Rivers, Queen, and Grayburg Formations are also productive in Yates field. Clastic reservoir facies include tabular, shallow subtidal siltstones and sandstones in the Grayburg and Queen Formations and sandstones 

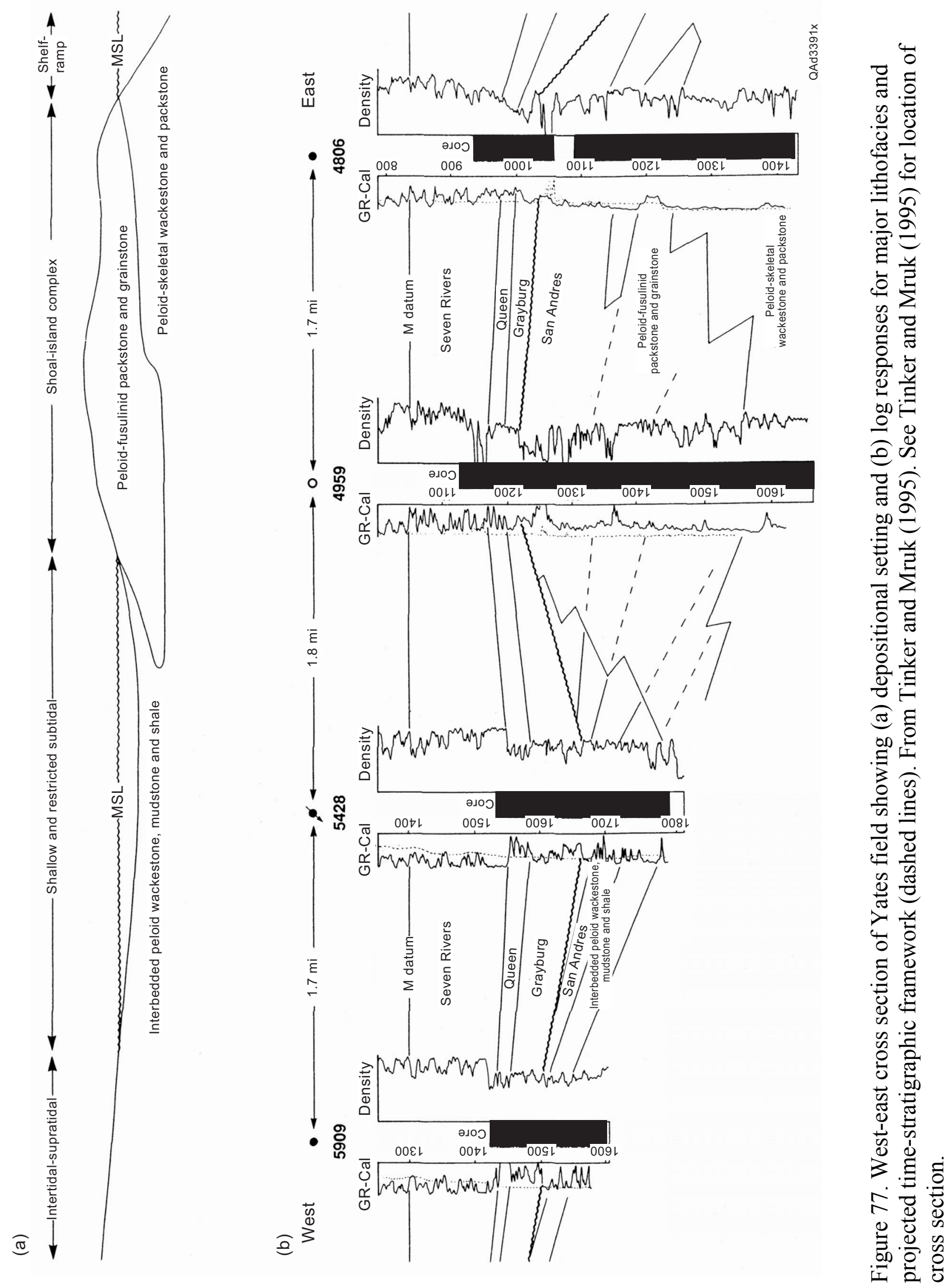
deposited in a beach-dune-bar complex in the lower Seven Rivers Formation (Tinker and Mruk, 1995). The evaporite-dominated Seven Rivers Formation forms the reservoir seal.

Porosity in Yates field occurs as interparticle pores, fractures, and open caves. Permeability was greatly increased by open caves and solution-enlarged joints that developed by karstification during multiple subaerial exposure events in the San Andres (Craig and others, 1986; Craig, 1988, 1990; Tinker and others, 1995). The most significant cave formation occurred during exposure following San Andres deposition. Early development of a regional fracture system provided conduits for solution enlargement during karstification and formation of vuggy and cavernous pores along joints (Tinker and others, 1995). Open caverns in Yates field contributed to bit drops and flow rates in many wells of $>10,000 \mathrm{bbl} / \mathrm{d}\left(>1.59 \times 10^{3} \mathrm{~m}^{3}\right)$ to as high as $200,000 \mathrm{bbl} / \mathrm{d}\left(3.18 \times 10^{4} \mathrm{~m}^{3}\right)$ during early field development (Tinker and others, 1995). Fracture permeability exceeds 1 darcy (Snell and Close, 1999).

Development history of Yates field was summarized by LaPointe and others (1998), Golder Associates (1999), Snell and Close (1999), and Campanella and others (2000). Before 1976, Yates field was operated under primary depletion. The field was unitized in 1976, when a gas-injection pressure-maintenance program was instituted to slow water invasion into the oilproducing part of the reservoir and conserve reservoir energy. The gas-injection program allowed greater use of efficient gas-cap gravity drainage. Waterflooding began on the western flanks of the field in 1979, and a polymer flood of the oil column was initiated in additional areas of the west side from 1983 through 1986. From late 1985 until 1991, $\mathrm{CO}_{2}$ was injected in the north, east, and crestal areas of the field.

A 3-D reservoir model of Yates field was developed to support reservoir management (Tinker and Mruk, 1995; Tinker, 1996). By lowering the gas-oil and water-oil contacts, a 
fieldwide co-production project was initiated in late 1992 to dewater reservoir areas containing oil bypassed by water encroachment. Methods used were (1) high-volume water withdrawals and (2) gas-cap inflation by increasing reservoir pressure using methane and nitrogen injection. Coproduction reversed aquifer encroachment by removing water from the fracture network and allowing the oil to flow from the matrix into the fracture system. Co-production also resulted in gravity drainage within the expanded gas cap.

Fracture models have supported Yates field development since 1992 (LaPointe and others, 1998; Golder Associates, 1999). Wells in the field produce matrix fluids through the extensive natural fracture network. Fracture models were used to identify areas where the fracture network is best developed and thus take advantage of the natural drainage system by maximizing withdrawals from high-rate, high-efficiency wells in these areas. In 1993 and 1994 more than 30 new short-radius horizontal wells were drilled and almost 400 wells were shut in while a stable total daily oil production rate was maintained.

A steam pilot project began in 1998 to improve vertical gravity drainage using a patented process called Thermally Assisted Gravity Segregation (TAGS) (Wadleigh, 1996). Steam was injected into the fractured secondary gas cap to heat oil, reduce viscosity, and improve gravity drainage from dolomite matrix toward conductive fractures (Snell and Close, 1999). Oil mobilized by steam injection drains vertically to the oil column and then laterally via fractures to producing wells.

Taylor Link field is another karst-modified ramp-crest grainstone reservoir (fig. 78) in which karstification influences fluid flow and production. Poor waterflood performance-high produced-water volumes and low oil cut—is probably caused by injected water flowing through a system of karst-related fractures, microbreccias, and large vugs in this dual-porosity system 


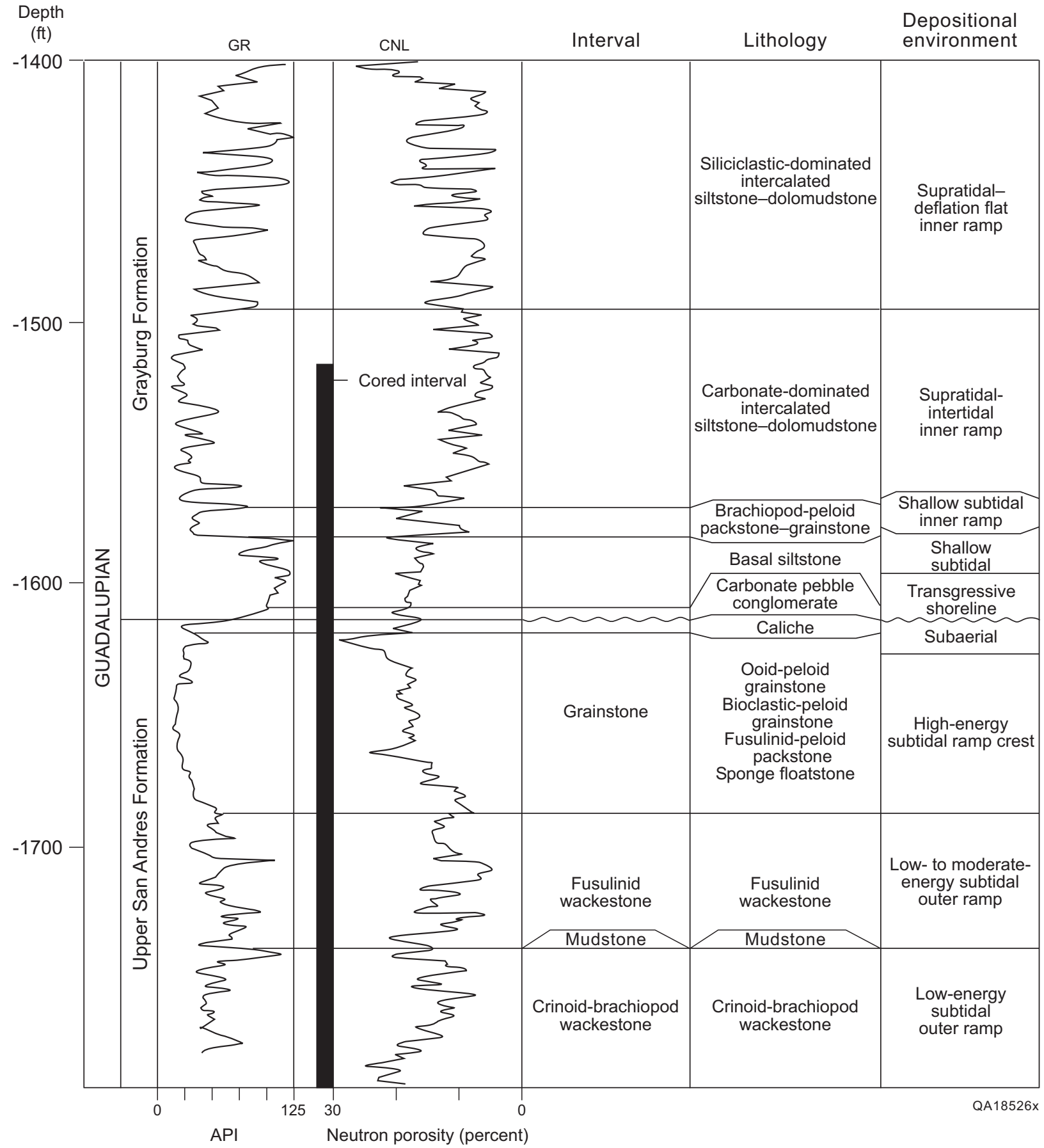

Figure 78. Typical gamma-ray/neutron log and characteristic lithologies and depositional environments for the upper San Andres and Grayburg Formations at Taylor-Link West field. From Lucia and others (1992). 
(Tyler and others, 1991; Lucia and others, 1992). When the water injection rate was increased, oil production decreased because more water flowed through fractured wackestones and less through the oil-saturated ooid-grainstone facies (Tyler and others, 1991). Concentrating the waterflood in the ooid grainstones should increase oil recovery.

\section{References}

Campanella, J. D., Wadleigh, E. E., and Gilman, J. R., 2000, Flow characterization-critical for efficiency of field operations and IOR: Society of Petroleum Engineers International Petroleum Conference, Villahermosa, Mexico, SPE 58996, 14 p.

Craig, D. H., 1988, Caves and other features of Permian karst in San Andres dolomite, Yates field reservoir, West Texas, in James, N. P., and Choquette, P. W., eds., Paleokarst: New York, Springer-Verlag, p. 342-363.

1990, Yates and other Guadalupian (Kazanian) oil fields, U. S. Permian Basin, in Brooks, J., ed., Classic petroleum provinces: Geological Society of London Special Publication No. 50, p. 249-263.

Craig, D. H., Mruk, D. H., Heymans, M. J., Crevello, P. D., and Lanz, R. C., 1986, Stratigraphy and reservoir geology of the San Andres dolomite-Yates field, west Texas, in Bebout, D. G., and Harris, P. M., eds., Hydrocarbon reservoir studies, San Andres/Grayburg Formations, Permian Basin: Permian Basin Section Society of Economic Paleontologists and Mineralogists, Publication No. 86-26, p. 139-143.

Galloway, W. E., Ewing, T. E., Garrett, C. M., Jr., Tyler, N., and Bebout, D. G., 1983, Atlas of major Texas oil reservoirs: The University of Texas at Austin, Bureau of Economic Geology Special Publication, 139 p.

Golder Associates, 1999, Description of Yates field: http://www.fracturedreservoirs.com/niper/FIELDHIS.HTM.

Guiseppe, A. C., and Trentham, R. C., 1999, Stratigraphic framework and reservoir delineation of the McCamey field (Grayburg-San Andres), Upton County, Texas, in Grace, D. T., and Hinterlong, G. D., eds., The Permian Basin: providing energy for America: West Texas Geological Society Publication No. 99-106, p. 43-53.

Kerans, C., and Parsley, M. J., 1986, Depositional facies and porosity evolution in a karstmodified San Andres reservoir-Taylor Link West San Andres, Pecos County, Texas, in Bebout, D. G., and Harris, P. M., eds., Hydrocarbon reservoir studies, San 
Andres/Grayburg Formations, Permian Basin: Permian Basin Section Society of Economic Paleontologists and Mineralogists, Publication No. 86-26, p. 133-134.

LaPointe, P. R., Eiben, T. T., Dershowitz, W., and Wadleigh, E. E., 1998, The application of discrete fracture network models to fractured reservoir engineering: analytical approach, data sets and early results in Yates field, west Texas: Proceedings, RMAG '98 Symposium, Fractured Reservoirs: Practical Exploration and Development Strategies, Denver, January 19-20, 1998; http://www.fracturedreservoirs.com/niper/database/papers/rmag/rmag 60.htm

Lucia, F. J., Kerans, C., and Vander Stoep, G. W., 1992b, Characterization of a karsted, highenergy, ramp-margin carbonate reservoir: Taylor-Link West San Andres Unit, Pecos County, Texas: The University of Texas at Austin, Bureau of Economic Geology Report of Investigations No. 208, 46 p.

Snell, J. S., and Close, A. D., 1999, Yates field steam pilot applies latest seismic and logging monitoring techniques: Society of Petroleum Engineers Annual Technical Conference, Houston, Texas, SPE 56791, $10 \mathrm{p}$.

Tinker, S. W., 1996, Building the 3-D jigsaw puzzle: applications of sequence stratigraphy to 3-D reservoir characterization, Permian Basin: American Association of Petroleum Geologists Bulletin, v. 80, p. 460-485.

Tinker, S. W., Ehrets, J. R., and Brondos, M. D., 1995, Multiple karst events related to stratigraphic cyclicity: San Andres Formation, Yates field, west Texas, in Budd, D. A., Saller, A. H., and Harris, P. M., eds., Unconformities and porosity in carbonate strata: American Association of Petroleum Geologists Memoir 63, p. 213-237.

Tinker, S. W., and Mruk, D. H., 1995, Reservoir characterization of a Permian giant: Yates field, west Texas, in Stoudt, E. L., and Harris, P. M., eds., Hydrocarbon reservoir characterization: geologic framework and flow unit modeling: SEPM (Society for Sedimentary Geology) Short Course No. 34, p. 51-128.

Tyler, N., Bebout, D. G., Garrett, C. M., Jr., Guevara, E. H., Hocott, C. R., Holtz, M. H., Hovorka, S. D., Kerans, C., Lucia, F. J., Major, R. P., Ruppel, S. C., and Vander Stoep, G. W., 1991, Integrated characterization of Permian Basin reservoirs, University Lands, West Texas: targeting the remaining resource for advanced oil recovery: The University of Texas at Austin, Bureau of Economic Geology Report of Investigations No. 203, $136 \mathrm{p}$.

Wadleigh, E. E., 1996, Process for recovering hydrocarbons by thermally assisted gravity segregation, U.S. Patent No. 5503266, April 2, 1996. 
San Andres Platform Carbonate (Play 123)

The San Andres Platform Carbonate play has produced 2,151.3 MMbbl $\left(3.42 \times 10^{8} \mathrm{~m}^{3}\right)$ of oil from 52 reservoirs (table 29), making it the fourth-largest play in the Permian Basin (table 2). The carbonates of the San Andres Platform Carbonate play were deposited on the shallow-water Central Basin Platform (fig. 79) during the early Guadalupian. Depositional environments varied from open-marine complexes along the platform margin to restricted subtidal complexes and arid tidal flats toward the interior of the platform (Tyler and others, 1991). The sequence hierarchy and facies architecture of the San Andres Formation in the Permian Basin have been documented from outcrop studies by Kerans and others (1994) and Kerans and Fitchen (1995). Geologic and engineering characteristics of many of the reservoirs in this play are summarized in two volumes of papers edited by Bebout and Harris $(1986,1990)$.

The upper San Andres reservoirs in this play are developed in thick ( $\sim 300 \mathrm{ft}[\sim 90 \mathrm{~m}])$, dolomitized, subtidal parts of upward-shoaling cycles (Ruppel and Cander, 1988; Garber and Harris, 1990; Major and others, 1990; Tyler and others, 1991) (fig. 80). The lower two-thirds of each cycle is made up of a thick section of subtidal facies composed of dolomitized skeletal wackestone to pellet grainstone; fusulinids and other normal-marine fossils are abundant (figs. 81, 82). The pellet grainstones are poorly sorted and burrowed, indicating relatively lowenergy deposition. Overlying the subtidal section is a thin zone of locally distributed shallowwater subtidal to intertidal pellet, skeletal, and ooid grainstones (fig. 83). These grainstones are well sorted and locally laminated and crossbedded, indicating relative high-energy deposition. Capping the cycle is a supratidal sequence consisting of interbedded mudstone, siliciclastic siltstone, and pisolite facies that form the reservoir seal. 
Table 29. San Andres Platform Carbonate play (play 123). Production shown for fields that have had others combined into them represents the totals; combined fields are highlighted.

\begin{tabular}{|c|c|c|c|c|c|c|c|c|c|}
\hline RRC RESN & RRC & FLDNAME & RESNAME & STATE & COUNTY & DISCYR & DEPTHTOP & 2000 PROD & CUMPROD \\
\hline 8618375 & $8 \mathrm{~A}$ & BLACKWATCH & SAN ANDRES & TX & GAINES & 1995 & 4624 & 289,940 & $1,324,791$ \\
\hline 8958500 & 8 & BLOCK A-34 & SAN ANDRES & TX & ANDREWS & 1979 & 4676 & 16,529 & $1,120,760$ \\
\hline 10821500 & 8 & BOURLAND & SAN ANDRES & TX & ECTOR & 1952 & 4352 & 6,208 & $1,125,033$ \\
\hline 15724500 & $8 \mathrm{~A}$ & CARM-ANN & SAN ANDRES & $\mathrm{TX}$ & GAINES & 1979 & 4779 & 40,031 & $1,307,285$ \\
\hline 14200400 & 8 & C-BAR & SAN ANDRES & TX & CRANE & 1949 & 3520 & 106,116 & $20,386,507$ \\
\hline 21289400 & 8 & COWDEN, NORTH & CLEAR FORK & TX & ECTOR & 1970 & 5239 & 187,810 & $5,850,903$ \\
\hline 21289600 & 8 & COWDEN, NORTH & DEEP & TX & ECTOR & 1939 & 5170 & 890,410 & $69,141,846$ \\
\hline 25347750 & 8 & DONNELLY & HOLT & TX & ECTOR & 1950 & 5275 & 25,315 & $1,710,117$ \\
\hline 25347875 & 8 & DONNELLY & SAN ANDRES & $T X$ & ECTOR & 1950 & 4305 & 16,856 & $8,423,063$ \\
\hline 28899001 & 8 & EMMA & & TX & ANDREWS & 1939 & 4300 & 29,427 & $20,813,110$ \\
\hline 28899415 & 8 & EMMA & GLORIETA & TX & ANDREWS & 1953 & 5405 & 77,925 & $3,630,701$ \\
\hline 33230500 & 8 & FULLERTON & SAN ANDRES & TX & ANDREWS & 1945 & 4785 & $2,263,344$ & $39,796,567$ \\
\hline 33473250 & $8 \mathrm{~A}$ & G-M-K & SAN ANDRES & $T X$ & GAINES & 1957 & 5598 & 348,872 & $15,599,746$ \\
\hline 33477500 & $8 \mathrm{~A}$ & G-M-K, SOUTH & SAN ANDRES & $T X$ & GAINES & 1963 & 5450 & 383,957 & $16,777,664$ \\
\hline 35652001 & 8 & GOLDSMITH & & TX & ECTOR & 1935 & 4300 & 650,195 & $357,953,213$ \\
\hline 35652558 & 8 & GOLDSMITH & HOLT & TX & ECTOR & 1952 & 5106 & 10,859 & $2,298,769$ \\
\hline 35653666 & 8 & GOLDSMITH, EAST & HOLT & $T X$ & ECTOR & 1954 & 4988 & 13,515 & $8,214,446$ \\
\hline 35653888 & 8 & GOLDSMITH, EAST & SAN ANDRES & $T X$ & ECTOR & 1962 & 4224 & 4,172 & $9,088,613$ \\
\hline 35654664 & 8 & GOLDSMITH, N. & SAN ANDRES, CON. & TX & ECTOR & 1964 & 4500 & 242,053 & $22,178,175$ \\
\hline 35659625 & 8 & GOLDSMITH, W. & SAN ANDRES & TX & ECTOR & 1956 & 4280 & 34,462 & $6,843,367$ \\
\hline 38686500 & $8 \mathrm{~A}$ & HANFORD & SAN ANDRES & TX & GAINES & 1977 & 5421 & 199,866 & $11,999,935$ \\
\hline 39176001 & 8 & HARPER & & TX & ECTOR & 1933 & 4300 & 281,997 & $50,261,732$ \\
\hline 42401400 & $8 \mathrm{~A}$ & HOMANN & SAN ANDRES & $\mathrm{TX}$ & GAINES & 1977 & 5328 & 50,334 & $2,058,353$ \\
\hline 37821900 & 8 & H. S. A. & SAN ANDRES & TX & WARD & 1979 & 4485 & 297,120 & $1,491,427$ \\
\hline 46132500 & $8 \mathrm{~A}$ & JENKINS & SAN ANDRES & TX & GAINES & 1950 & 4543 & 149,200 & $3,162,188$ \\
\hline 47007400 & 8 & JOHNSON & HOLT & TX & ECTOR & 1973 & 5303 & 151,214 & $12,446,922$ \\
\hline 47267001 & 8 & JORDAN & & $T X$ & CRANE & 1937 & 3700 & 396,670 & $90,771,561$ \\
\hline 49129594 & 8 & KEYSTONE & SAN ANDRES & TX & WINKLER & 1960 & 4465 & 179,306 & $4,308,999$ \\
\hline 49138100 & 8 & KEYSTONE, SW. & SAN ANDRES & TX & WINKLER & 1981 & 4446 & 32,957 & $1,306,447$ \\
\hline 52497333 & 8 & LAWSON & SAN ANDRES & $T X$ & ECTOR & 1950 & 4320 & 39,262 & $16,068,261$ \\
\hline 52624800 & 8 & LEA & SAN ANDRES & TX & CRANE & 1955 & 3075 & 81,383 & $10,167,344$ \\
\hline 54116500 & 8 & LITTMAN & SAN ANDRES & TX & ANDREWS & 1951 & 4313 & 10,140 & $1,390,768$ \\
\hline 57774581 & 8 & MARTIN & SAN ANDRES & TX & ANDREWS & 1945 & 4300 & 531 & $2,920,470$ \\
\hline 60137001 & 8 & MEANS & & TX & ANDREWS & 1934 & 4400 & $3,879,160$ & $232,243,704$ \\
\hline 69193426 & 8 & PARKER & GRAYBURG, SAN ANDRES & TX & ANDREWS & 1935 & 4800 & 82,719 & $4,322,184$ \\
\hline 70537001 & 8 & PENWELL & & TX & ECTOR & 1926 & 3800 & $1,075,359$ & $100,075,474$ \\
\hline 77316852 & $8 \mathrm{~A}$ & ROBERTSON & SAN ANDRES & TX & GAINES & 1952 & 4700 & 7,244 & $2,221,921$ \\
\hline 77318900 & $8 \mathrm{~A}$ & ROBERTSON, N. & SAN ANDRES & TX & GAINES & 1976 & 4704 & 529,810 & $5,011,781$ \\
\hline 80473248 & 8 & SAND HILLS & JUDKINS & $\mathrm{TX}$ & CRANE & 1960 & 3000 & 149,953 & $12,616,500$ \\
\hline 80473310 & 8 & SAND HILLS & MCKNIGHT & TX & CRANE & 1944 & 3420 & 623,821 & $128,500,389$ \\
\hline 80481001 & 8 & SAND HILLS, WEST & & TX & CRANE & 1943 & 3883 & 34,616 & $2,899,960$ \\
\hline 82225142 & $8 \mathrm{~A}$ & SEMINOLE & SAN ANDRES & TX & GAINES & 1936 & 5032 & $10,074,235$ & $602,619,981$ \\
\hline 82226500 & $8 \mathrm{~A}$ & SEMINOLE, EAST & SAN ANDRES & TX & GAINES & 1959 & 5450 & 225,895 & $10,892,763$ \\
\hline 82228800 & $8 \mathrm{~A}$ & SEMINOLE, NE. & SAN ANDRES & TX & GAINES & 1986 & 5427 & 222,003 & $1,897,871$ \\
\hline 82231500 & $8 \mathrm{~A}$ & SEMINOLE, SE. & SAN ANDRES & TX & GAINES & 1964 & 5310 & 30,980 & $3,007,614$ \\
\hline 82233001 & $8 \mathrm{~A}$ & SEMINOLE, WEST & & TX & GAINES & 1948 & 5042 & 289,706 & $47,466,149$ \\
\hline 82570500 & 8 & SHAFTER LAKE & SAN ANDRES & TX & ANDREWS & 1953 & 4482 & 528,064 & $49,810,814$ \\
\hline 82572666 & 8 & SHAFTER LAKE, N. & SAN ANDRES & $T X$ & ANDREWS & 1952 & 4559 & 2,914 & $1,231,741$ \\
\hline 83977500 & 8 & SLATOR & SAN ANDRES & $\mathrm{TX}$ & ECTOR & 1957 & 4172 & 5,925 & $2,416,337$ \\
\hline 89715400 & $8 \mathrm{~A}$ & THREE-O-THREE & SAN ANDRES & TX & GAINES & 1991 & 5538 & 95,489 & $1,244,903$ \\
\hline 88071580 & 8 & TXL & SAN ANDRES & TX & ECTOR & 1952 & 4380 & 88,578 & $12,508,307$ \\
\hline 94482001 & 8 & WADDELL & & $\mathrm{TX}$ & CRANE & 1927 & 3500 & 966,371 & $108,369,174$ \\
\hline \multicolumn{4}{|c|}{ Totals } & & & & & $26,420,818$ & $2,151,296,650$ \\
\hline
\end{tabular}

Early, pervasive dolomitization preserved much of the primary porosity in these San

Andres reservoirs (Ruppel and Cander, 1988; Leary and Vogt, 1990). As a result, porosity

distribution is controlled mainly by variations in original depositional texture and fabric.

Some porosity was later occluded by anhydrite. Anhydrite forms 20 to 30 percent of the whole

rock in the San Andres Formation at Emma field, where it occurs as nodules, cement, fossil 


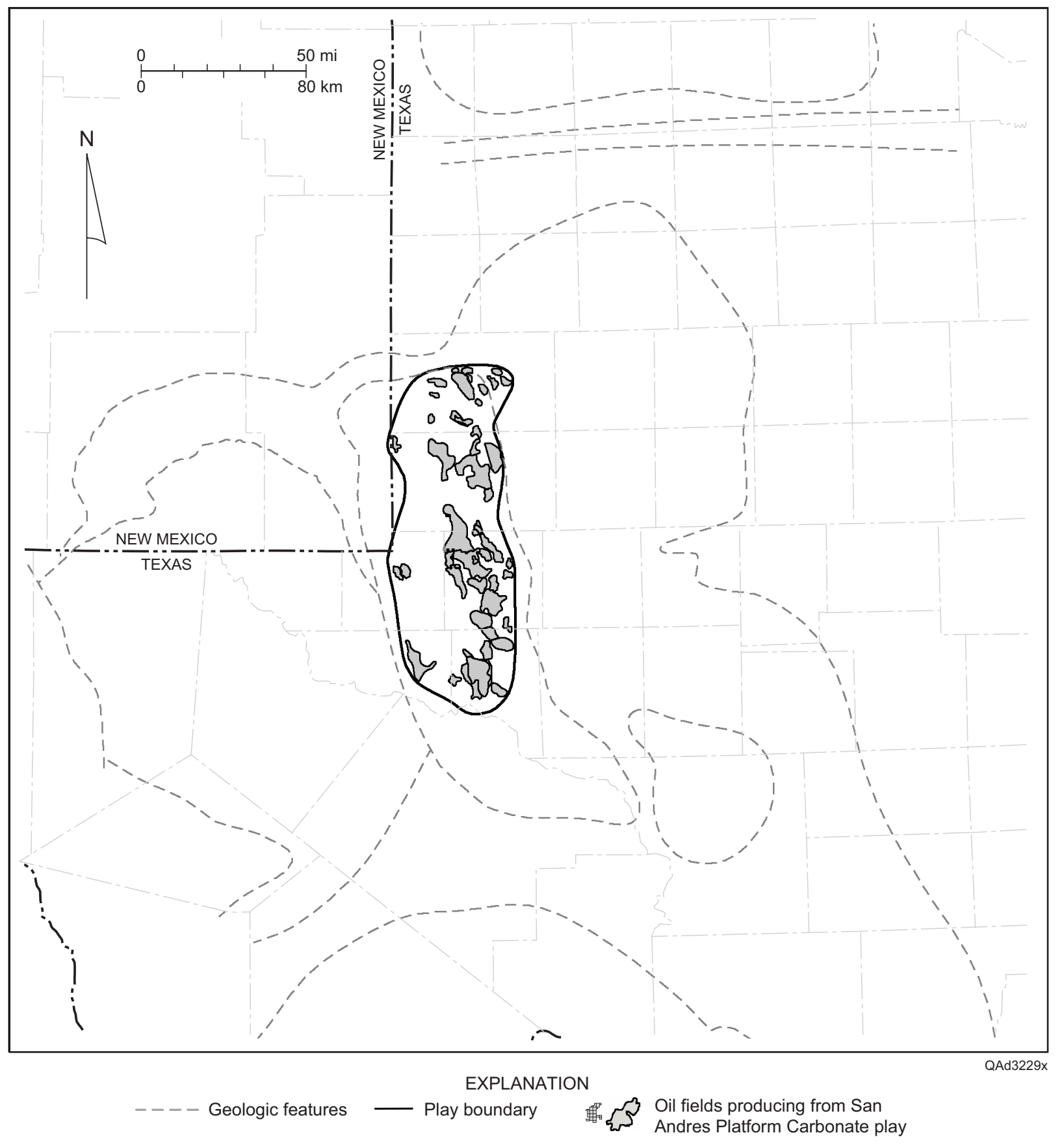

Figure 79. Play map for the San Andres Platform Carbonate play, showing location of reservoirs having $>1 \mathrm{MMbbl}$ cumulative production, the play boundary, and geologic features. See figure 1 for county names and figure 2 for identification of geologic features. 
Emma San Andres reservoir

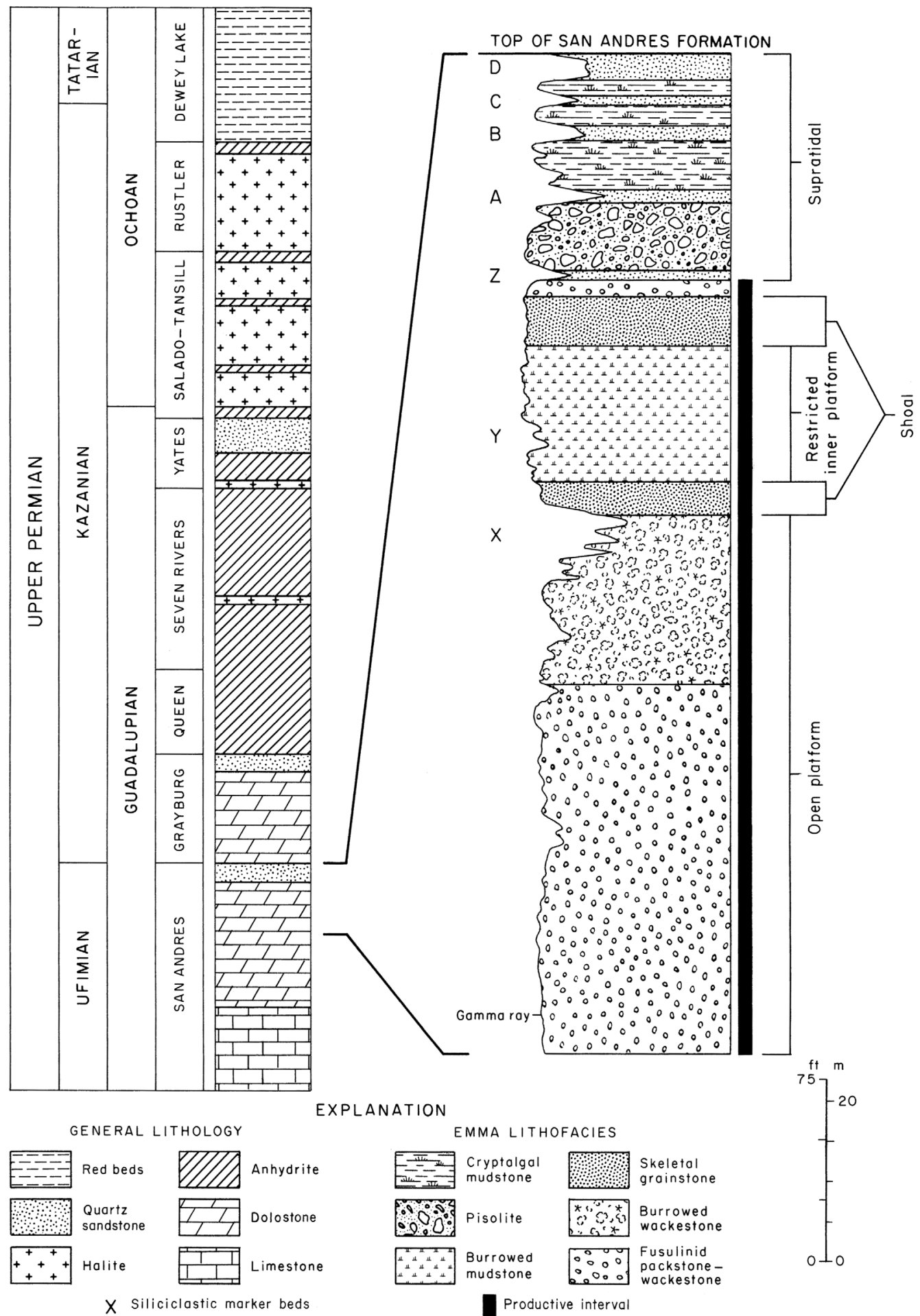

QA7473x

Figure 80. General Upper Permian stratigraphy and upper San Andres facies in the Emma field area, Andrews County. From Ruppel and Cander (1988). 


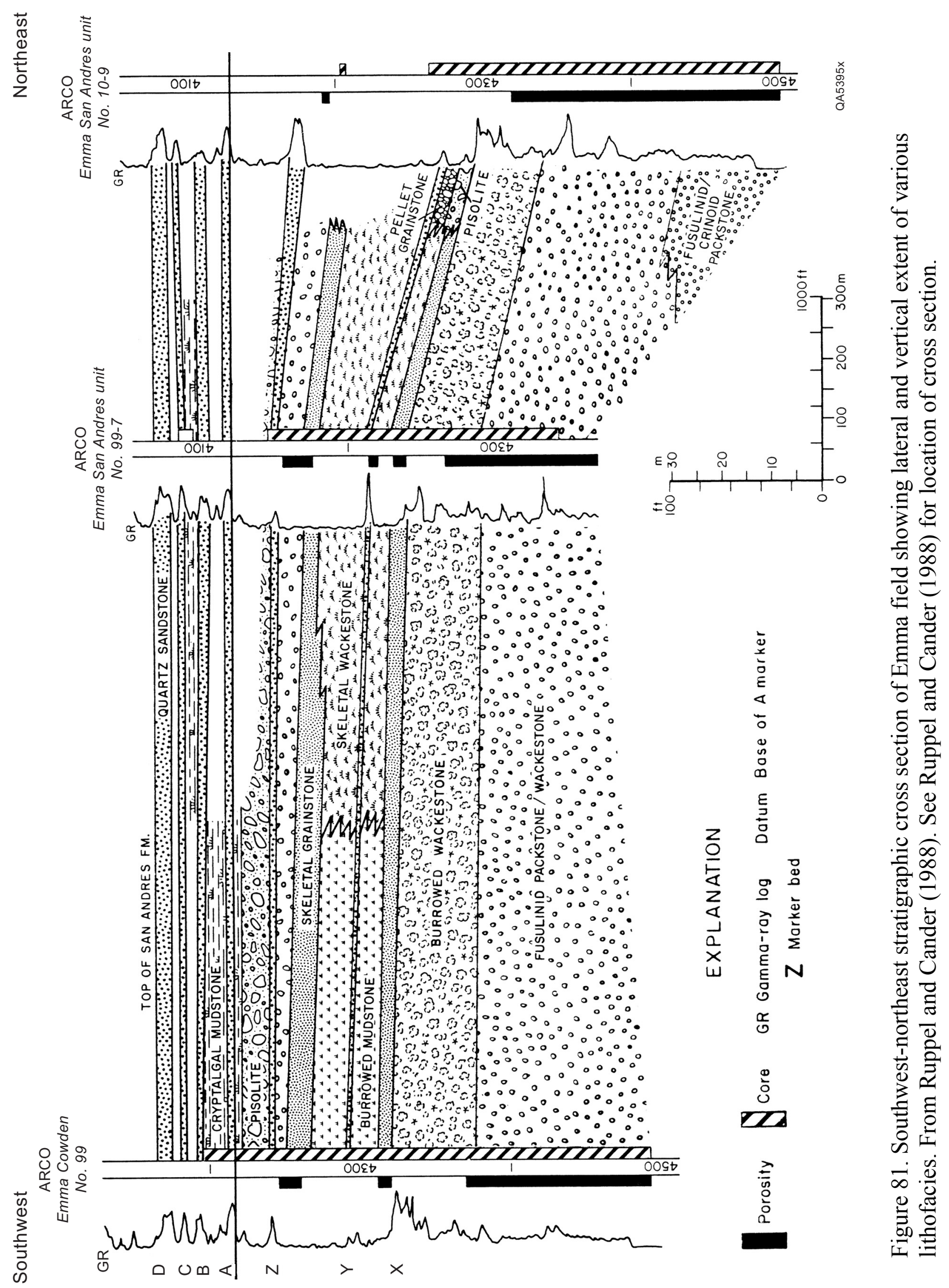




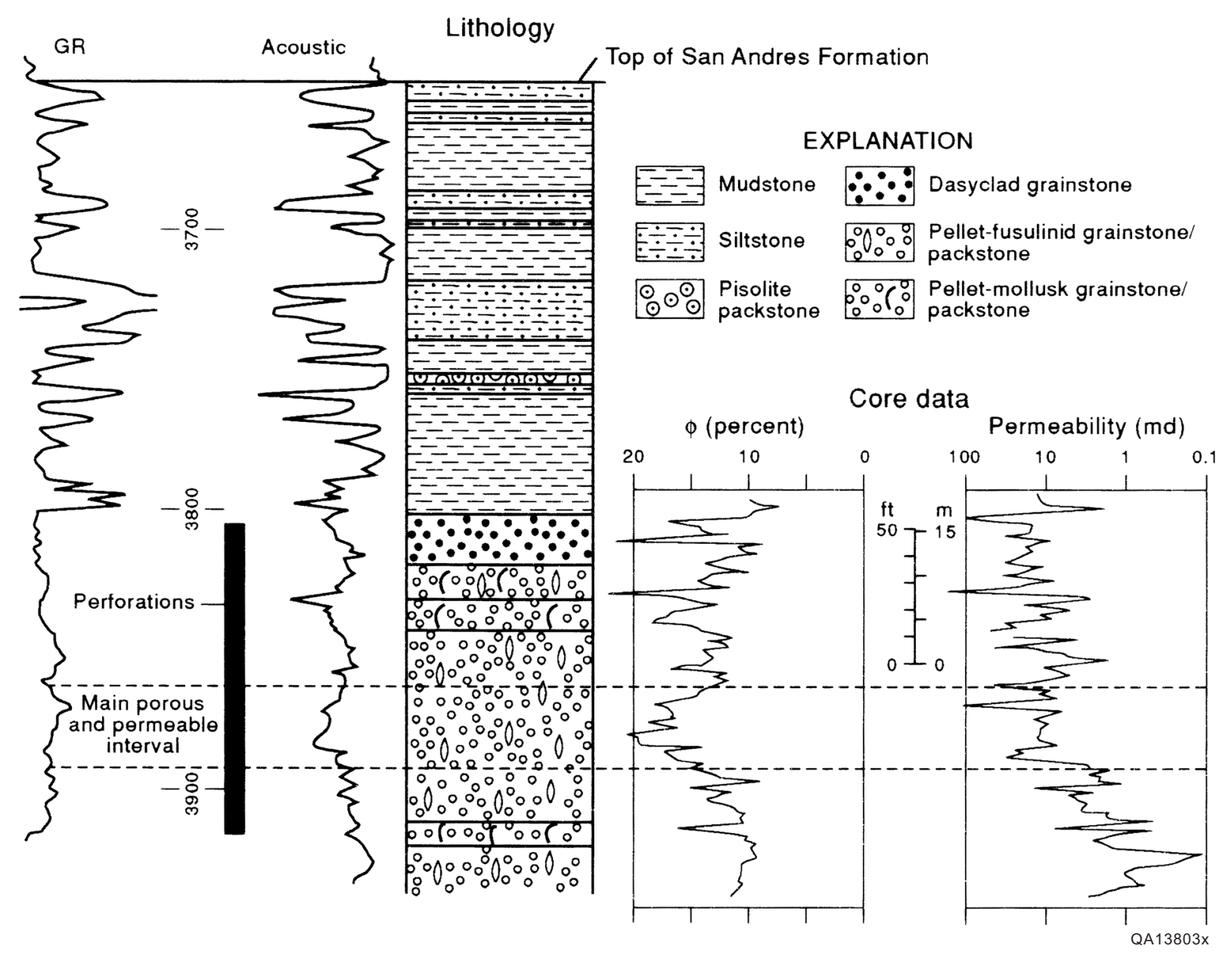

Figure 82. Log/core correlations for the EPSAU No. 207 well in East Penwell San Andres unit (EPSAU), Penwell field, Ector County. From Major and others (1990). Facies are described from core, and porosity and permeability are from whole-core analyses.

mold fillings, and fracture fillings (Ruppel and Cander, 1988). Minor anhydrite leaching locally increased reservoir porosity.

Production from the Emma San Andres reservoir is primarily from open-platform fusulinid packstone/wackestone facies and restricted inner-platform (shoal) skeletal grainstone facies (figs. 81, 84) (Ruppel and Cander, 1988). Porosity in the fusulinid packstone/wackestone facies at Emma field averages 8.7 percent, and permeability averages $1.4 \mathrm{md}\left(1.4 \times 10^{-3} \mu^{2}\right)$. In the skeletal grainstone facies, porosities of 10 to 15 percent and permeabilities of 10 to $100 \mathrm{md}$ 


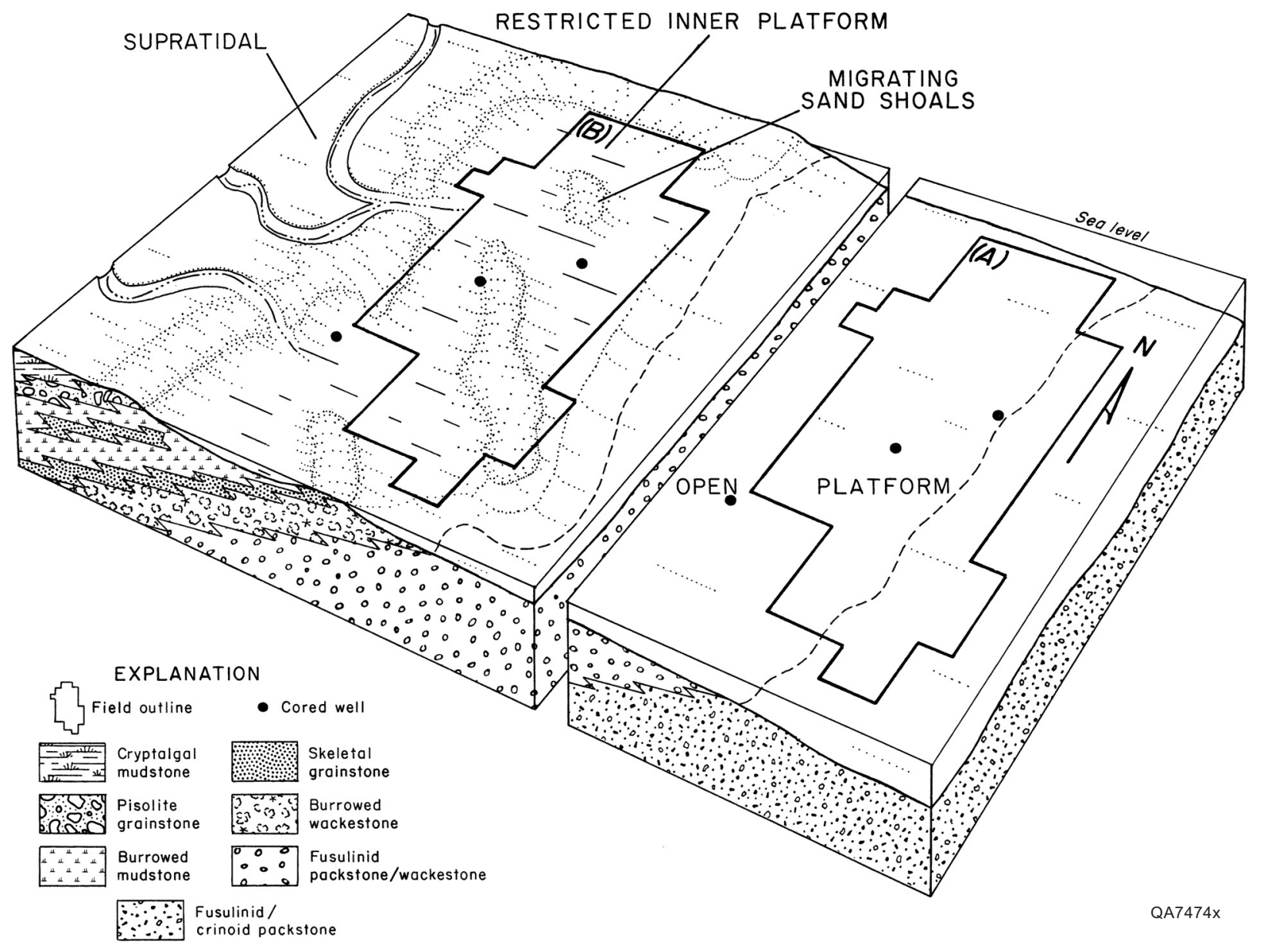

Figure 83. Paleoenvironmental reconstruction of Emma field area during late San Andres time. From Ruppel and Cander (1988). (A) When the lower part of the reservoir sequence was deposited, the area was characterized by deposition of subtidal, open-platform sediments on a gently east sloping carbonate ramp. (B) The upper part of the section was deposited in peritidal to supratidal conditions during a generally upward shallowing trend.

(10 to $100 \times 10^{-3} \mu^{2}$ ) are common (Ruppel and Cander, 1988). At West Seminole field, the San Andres reservoir produces from oolitic and peloidal grainstones and fusulinid packstone/grainstones (Caldwell and Harpole, 1986). The reservoir facies are interbedded with low-permeability fusulinid wackestones in which porosity has been filled by anhydrite.

Reservoirs in this play produce from low-relief anticlines. Trapping results from lateral and vertical facies changes from porous and permeable subtidal dolostones of the reservoir to 


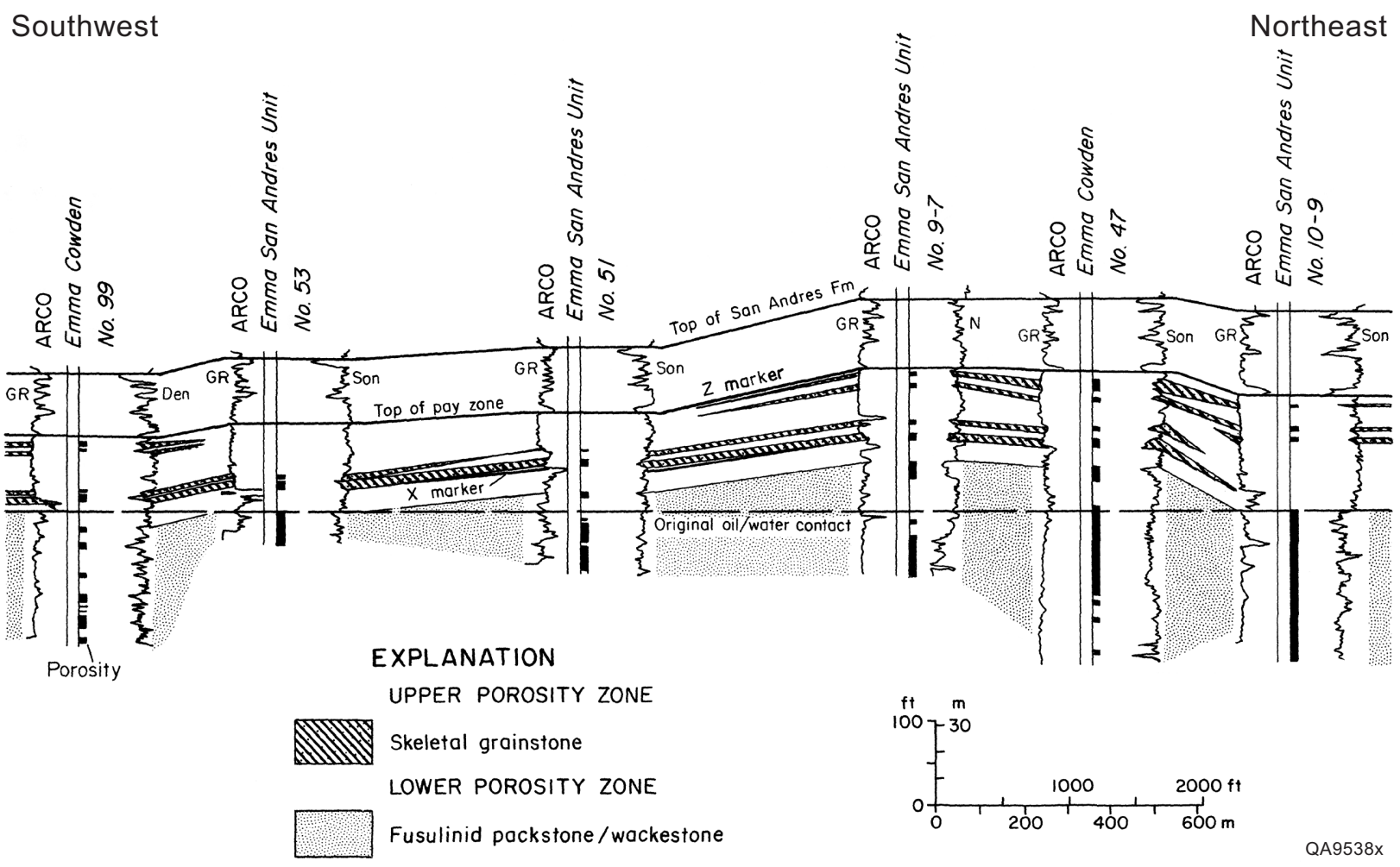

Figure 84. Southwest-northeast cross section showing distribution of skeletal grainstone and fusulinid packstone/wackestone reservoir facies across Emma field. From Ruppel and Cander (1988). Grainstone beds are laterally discontinuous. See Ruppel and Cander (1988) for location of cross section.

low-porosity and low-permeability intertidal and supratidal dolostones and anhydrite (Tyler and others, 1991). Natural fractures may be an important component of heterogeneity in these reservoirs. Productivity at Keystone field is interpreted as being dependent on fracture permeability (Major and Holtz, 1997). Horizontal wells drilled perpendicular to the direction of open natural fractures (northeast-southwest in Keystone field) could maximize primary recovery.

Penwell San Andres reservoir in Ector County (fig. 79) produces mainly from the subtidal pellet grainstone/packstone facies (fig. 82), which has well-preserved interparticle porosity (Major and others, 1990). Late diagenetic dissolution of anhydrite and dolomite in this facies increased porosity and improved reservoir quality (Siemers and others, 1995). The 
presence of gypsum in the San Andres Formation complicates both log interpretation and core analysis in this and other San Andres reservoirs (Bebout and others, 1987; Major and others, 1990). The acoustic log is the most reliable wireline tool for determining porosity (Major and others, 1990; Holtz and Major, 2004). Samples for core analysis should be processed at low temperature to avoid driving off bound water in gypsum during core cleaning (Major and others, 1990).

West Jordan unit of Jordan field, in Crane and Ector Counties (fig. 79), produces from compartmentalized shoal facies that formed on slight paleotopographic highs (French and Hinterlong, 2000). The reservoir produces from an asymmetric anticline formed by drape and compaction of San Andres deposits over Pennsylvanian-age structures. A permeability model of West Jordan unit, constructed using the method of Lucia $(1995,1999)$, incorporates the flow properties characteristic of rock-fabric pore types (French and Hinterlong, 2000). The geometries of the reservoir shoal facies were well defined by net-pay maps computed using a 0.5 -md $\left(0.5 \times 10^{-3} \mu^{2}\right)$ permeability cutoff, and the model closely matches cumulative production.

The Means reservoir in Andrews County (fig. 79) produces from both the San Andres and Grayburg Formations, but the upper $300 \mathrm{ft}$ (90 m) of the San Andres is the most productive interval (Bartel and Broomhall, 1986). Reservoir characterization was conducted prior to initiation of a $\mathrm{CO}_{2}$ flood (George and Stiles, 1986). Core analyses were used to determine a porosity cutoff of 3 percent, equivalent to permeability of $0.1 \mathrm{md}\left(0.1 \times 10^{-3} \mu \mathrm{m}^{2}\right)$ (George and Stiles, 1986). A $\mathrm{CO}_{2}$ flood consisting of 172 inverted 9-spot patterns on 10-acre spacing began at Means San Andres unit (MSAU) of Means field in 1983 (Bartel and Broomhall, 1986; Magruder and others, 1990). Production from the unit was $15,500 \mathrm{bbl} / \mathrm{d}\left(2.46 \times 10^{3} \mathrm{~m}^{3} / \mathrm{d}\right)$ by December 1985, after having dropped below $9,000 \mathrm{bbl} / \mathrm{d}\left(1.43 \times 10^{3} \mathrm{~m}^{3} / \mathrm{d}\right)$ prior to initiation of 
$\mathrm{CO}_{2}$ injection (George and Stiles, 1986). By 1999 MSAU had 476 active wells, and average production from the unit was $10,500 \mathrm{bbl} / \mathrm{d}\left(1.67 \times 10^{3} \mathrm{~m}^{3} / \mathrm{d}\right)$ (Price and others, 2000). An operational challenge at MSAU is the narrow operating-pressure window between minimum miscibility pressure of 1,850 to $2,300 \mathrm{psi}$ (12.8 to $15.9 \mathrm{Mpa}$ ) and formation parting pressure 2,700 to 2,800 psi (18.6 to 19.3 Mpa) (George and Stiles, 1986; Magruder and others, 1990).

Seminole field in Gaines County (fig. 79) produces from an atoll-like mound of aggradationally stacked carbonate developed above a Pennsylvanian-age structure (Lucia and others, 1995; Wang and others, 1996, 1998a, b, c). Seismic data suggest that Seminole is one of several isolated platforms built during the early San Andres that became joined with the rest of the San Andres platform during progradation of the upper San Andres (Lucia and others, 1995). Productive intervals are in the upper San Andres and the upper part of the lower San Andres. Main reservoir facies are fusulinid dolowackestone, fusulinid-peloid grain-dominated dolopackstone, and coated-grain dolograinstone (Sonnenfeld and others, 2001). Reservoir properties are controlled by facies, both through original porosity distribution and later dolomitization. Facies distribution is related to paleohighs trending NNE. Facies maps demonstrate paleostructural control starting with crestal and ending with peripheral concentrations of grain-dominated reservoir facies (Sonnenfeld and others, 2003).

Simulation of Seminole San Andres field indicates that high-frequency cycles and rockfabric units are the two critical scales for modeling these shallow-water carbonate ramp reservoirs (Lucia and others, 1995; Wang and others, 1998a, b, c). Description of rock-fabric facies stacked within high-frequency cycles provided a framework for constructing geologic and reservoir models (fig. 85). Discrete petrophysical functions were fit to rock-fabric units, and fluid flow and recovery efficiency were estimated using petrophysical properties of rock-fabric flow 


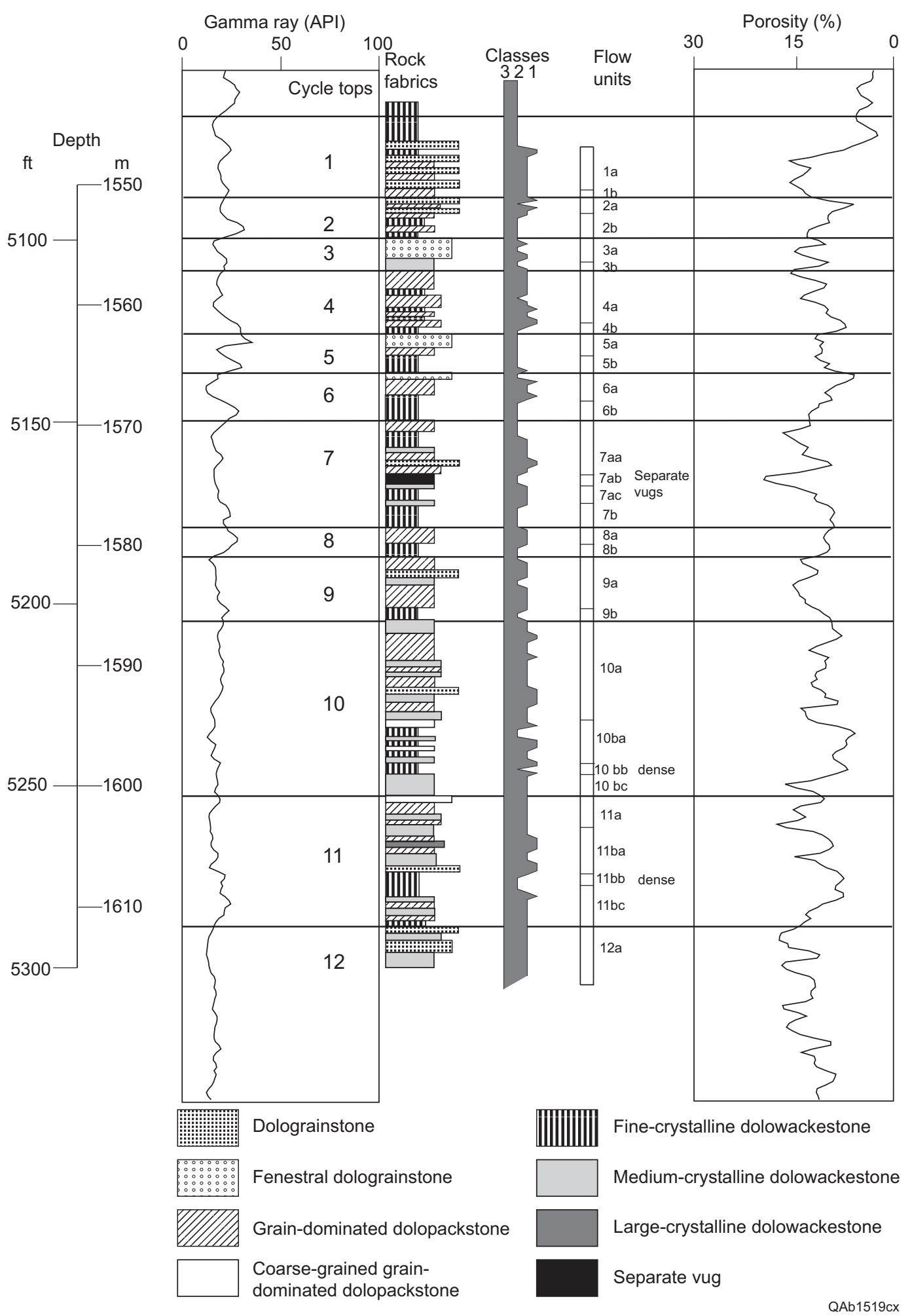

Figure 85. High-frequency cycles and rock-fabric facies in the Amerada Hess SSAU No. 2505 well, Seminole field, Gaines County. From Wang and others (1996). 
units. Simulation results showed that critical factors affecting recovery efficiency are stacking patterns of rock-fabric flow units, the ratio of vertical permeability to horizontal permeability $\left(\mathrm{k}_{\mathrm{vh}}\right.$ ), and dense mudstone distribution (Wang and others, 1998a). $\mathrm{CO}_{2}$ flooding of Seminole

San Andres unit began in 1985. Core, log, seismic, and production data were integrated into an 8-million-cell full-field model of Seminole San Andres unit to enhance reservoir management and estimate remaining reserves (Zahm and others, 2002; Sonnenfeld and others, 2003).

\section{References}

Bartel, J. R., and Broomhall, R. W., 1986, Stratigraphic potential for hydrocarbon entrapment on the east flank of the Means San Andres field, Andrews County, Texas, in Bebout, D. G., and Harris, P. M., eds., Hydrocarbon reservoir studies, San Andres/Grayburg Formations, Permian Basin: Permian Basin Section, Society of Economic Paleontologists and Mineralogists, Publication No. 86-26, p. 83-87.

Bebout, D. G., and Harris, P. M., 1986, Hydrocarbon reservoir studies, San Andres/Grayburg Formations, Permian Basin: Permian Basin Section, Society of Economic Paleontologists and Mineralogists, Publication No. 86-26, 143 p.

1990, Geologic and engineering approaches in evaluation of San Andres/Grayburg hydrocarbon reservoirs-Permian Basin: The University of Texas at Austin, Bureau of Economic Geology Publication, 297 p.

Bebout, D. G., Lucia, F. J., Hocott, C. R., Fogg, G. E., and Vander Stoep, G. W., 1987, Characterization of the Grayburg reservoir, University Lands Dune field, Crane County, Texas: The University of Texas at Austin, Bureau of Economic Geology Report of Investigations No. 168, 98 p.

Caldwell, C. D., and Harpole, K. J., 1986, Influence of reservoir stratigraphy on secondary recovery and gas cap management-West Seminole San Andres Unit, Gaines County, Texas, in Bebout, D. G., and Harris, P. M., eds., Hydrocarbon reservoir studies, San Andres/Grayburg Formations, Permian Basin: Permian Basin Section, Society of Economic Paleontologists and Mineralogists, Publication No. 86-26, p. 69-73.

French, V. L., and Hinterlong, G. D., 2000, Construction of a permeability model applying the Lucia characterization methodology with non-optimal data conditions: West Jordan unit, San Andres Formation, in DeMis, W. D., Nelis, M. K., and Trentham, R. C., eds., The 
Permian Basin: proving ground for tomorrow's technologies: West Texas Geological Society Publication No. 00-109, p. 77-93.

Garber, R. A., and Harris, P. M., 1990, Depositional facies of Grayburg/San Andres dolostone reservoirs, Central Basin Platform, Permian Basin, in Bebout, D. G., and Harris, P. M., eds., Geologic and engineering approaches in evaluation of San Andres/Grayburg hydrocarbon reservoirs-Permian Basin: The University of Texas at Austin, Bureau of Economic Geology Publication, p. 1-19.

George, C. J., and Stiles, L. H., 1986, Planning a $\mathrm{CO}_{2}$ tertiary recovery project, Means San Andres unit, in Bebout, D. G., and Harris, P. M., eds., Hydrocarbon reservoir studies, San Andres/Grayburg Formations, Permian Basin: Permian Basin Section, Society of Economic Paleontologists and Mineralogists, Publication No. 86-26, p. 79-82.

Holtz, M. H., and Major, R. P., 2004, Integrated geological and petrophysical characterization of Permian shallow-water dolostone: Society of Petroleum Engineers Reservoir Evaluation \& Engineering, SPE 87595, v. 7, no. 2, p. 47-58.

Kerans, C., and Fitchen, W. M., 1995, Sequence hierarchy and facies architecture of a carbonateramp system: San Andres Formation of Algerita Escarpment and western Guadalupe Mountains, west Texas and New Mexico: The University of Texas at Austin, Bureau of Economic Geology Report of Investigations No. 235, 86 p.

Kerans, C., Lucia, F. J., and Senger, R. K., 1994, Integrated characterization of carbonate ramp reservoirs using Permian San Andres Formation outcrop analogs: American Association of Petroleum Geologists Bulletin, v. 78, p. 181-216.

Leary, D. A., and Vogt, J. N., 1990, Diagenesis of the San Andres Formation (Guadalupian), Central Basin Platform, Permian Basin, in Bebout, D. G. and Harris, P. M., eds., Geologic and engineering approaches in evaluation of San Andres/Grayburg hydrocarbon reservoirs-Permian Basin: The University of Texas at Austin, Bureau of Economic Geology Publication, p. 21-48.

Lucia, F. J., 1995, Rock-fabric/petrophysical classification of carbonate pore space for reservoir characterization: American Association of Petroleum Geologists Bulletin, v. 79, p. 12751300 .

1999, Carbonate reservoir characterization: New York, Springer-Verlag, 226 p.

Lucia, F. J., Kerans, C., and Wang, F. P., 1995, Fluid-flow characterization of dolomitized carbonate-ramp reservoirs: San Andres Formation (Permian) of Seminole field and Algerita Escarpment, Permian Basin, Texas and New Mexico, in Stoudt, E. L., and Harris, P. M., eds., Hydrocarbon reservoir characterization: geologic framework and flow unit modeling: SEPM (Society for Sedimentary Geology), SEPM Short Course No. 34, p. 129-153. 
Magruder, J. B., Stiles, L. H., and Yelverton, T. D., 1990, Review of the Means San Andres unit full-scale $\mathrm{CO}_{2}$ tertiary project: Journal of Petroleum Technology, SPE 17349, v. 42, no. 5 , p. 638-644.

Major, R. P., and Holtz, M. H., 1997, Identifying fracture orientation in a mature carbonate platform reservoir: American Association of Petroleum Geologists Bulletin, v. 81, p. 1063-1069.

Major, R. P., Vander Stoep, G. W., and Holtz, M. H., 1990, Delineation of unrecovered mobile oil in a mature dolomite reservoir: East Penwell San Andres Unit, University Lands, West Texas: The University of Texas at Austin, Bureau of Economic Geology Report of Investigations No. 194, 52 p.

Price, C., Ryu, C., and Mazzullo, J., 2000, Lithofacies, depositional environments, and reservoir properties of the Permian (Guadalupian) Grayburg and Queen Formations, Means field, Andrews County, Texas, in Reid, S. T., ed., Geo-2000: into the future: Southwest Section, American Association of Petroleum Geologists Transactions, Publication SWS 2000-107, p. 80-97.

Ruppel, S. C., and Cander, H. S., 1988, Effects of facies and diagenesis on reservoir heterogeneity: Emma San Andres field, West Texas: The University of Texas at Austin, Bureau of Economic Geology Report of Investigations No. 178, 67 p.

Siemers, W. W., Prezbindowski, D. R., Skinnider, V. L., Maple, L. C., Gerard, M. G., Nagaty, M. E., and Howard, J. J., 1995, Multidisciplinary study to optimize reservoir management of North Penwell (San Andres) unit, Ector Co., Texas: American Association of Petroleum Geologists Annual Convention Official Program, v. 4, p. A89.

Sonnenfeld, M. D., Wingate, T. P., Canter, K. L., Meng, H. Z., and Zahm, L. C., 2003, Operational sequence stratigraphy for 3-D reservoir modeling of Seminole San Andres Unit (SSAU), Permian Basin, west Texas: American Association of Petroleum Geologists Annual Convention Official Program, v. 12, p. A160-161.

Sonnenfeld, M. D., Zahm, L. C., Ford, G. L., Canter, K. L., Buckner, S. J., Foulk, L. S., Kerans, C., Pluim, S. L., Simon, M., and Tinker, S. W., 2001, Paleostructural control on facies distribution and reservoir quality: Seminole San Andres Unit (Permian, Guadalupian), west Texas: American Association of Petroleum Geologists Annual Convention Official Program, v. 10, p. A189-190.

Tyler, N., Bebout, D. G., Garrett, C. M., Jr., Guevara, E. H., Hocott, C. R., Holtz, M. H., Hovorka, S. D., Kerans, C., Lucia, F. J., Major, R. P., Ruppel, S. C., and Vander Stoep, G. W., 1991, Integrated characterization of Permian Basin reservoirs, University Lands, West Texas: targeting the remaining resource for advanced oil recovery: The University of Texas at Austin, Bureau of Economic Geology Report of Investigations No. 203, $136 \mathrm{p}$. 
Wang, F. P., Lucia, F. J., and Kerans, C., 1996, Integrated reservoir characterization of a carbonate ramp reservoir: Seminole San Andres Unit, Gaines County, Texas, in Proceedings, Formation Evaluation and Reservoir Geology, Society of Petroleum Engineers Annual Technical Conference and Exhibition, October 7-9, Denver, SPE 36515 , p. 237-250.

1998a, Integrated reservoir characterization study of a carbonate ramp reservoir: Seminole San Andres Unit, Gaines County, Texas: Society of Petroleum Engineers Reservoir Evaluation \& Engineering, v. 1, no. 2, p. 105-113.

1998b, Modeling dolomitized carbonate-ramp reservoirs: a case history of the Seminole San Andres unit—Part 1, petrophysical and geologic characterizations: Geophysics, v. 63, no. 6, p. 1866-1875.

Wang, F. P., Dai, J., and Kerans, C., 1998c, Modeling dolomitized carbonate-ramp reservoirs: a case study of the Seminole San Andres unit—Part II, seismic modeling, reservoir geostatistics, and reservoir simulation: Geophysics, v. 63, no. 6, p. 1876-1884.

Zahm, L. C., Sonnenfeld, M. D., Caldwell, D. H., Clawson, S. R., Meng, H. Z., and Wingate, T. P., 2002, Multi-scale data integration for 3-D reservoir modeling of Seminole San Andres Unit: American Association of Petroleum Geologists Annual Convention Official Program, v. 11, p. A197. 
Upper San Andres and Grayburg Platform Mixed—Central Basin Platform Trend (Play 124)

The Upper San Andres and Grayburg Platform Mixed—Central Basin Platform Trend play is located in New Mexico on the northwest part of the Central Basin Platform in Lea County, with some smaller reservoirs $\left(<1 \mathrm{MMbbl}\left[1.59 \times 10^{5} \mathrm{~m}^{3}\right]\right)$ cumulative oil production) located off the northwest flank of the Central Basin Platform within the Delaware Basin (fig. 86). Eight reservoirs have produced $>1 \mathrm{MMbbl}\left(1.59 \times 10^{5} \mathrm{~m}^{3}\right)($ table 30$)$. Cumulative production from these eight reservoirs was $809 \mathrm{MMbbl}$ through 2000. Production is commingled from mixed dolostones and clastics of the upper San Andres Formation and the Grayburg Formation. The play has been in decline over the last 30 years. An upturn in production during the middle to late 1980's was caused by implementation of several large pressure-maintenance projects within the Hobbs Grayburg San Andres reservoir.

Reservoirs of the upper San Andres Formation and Grayburg Formation are high-energy dolograinstones from shoal environments and shallow-marine dolomitic sandstones (Garber and Harris, 1986; Lindsay, 1991). Facies are probably similar to better-studied Texas reservoirs that

Table 30. Upper San Andres and Grayburg Platform Mixed—Central Basin Platform Trend play (play 124).
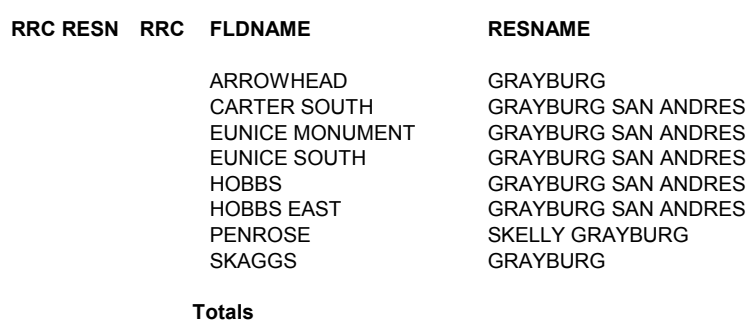

\begin{tabular}{|c|c|}
\hline STATE & COUNTY \\
\hline NM & LEA \\
\hline NM & LEA \\
\hline NM & LEA \\
\hline NM & LEA \\
\hline NM & LEA \\
\hline NM & LEA \\
\hline NM & LEA \\
\hline NM & LEA \\
\hline
\end{tabular}

$\mathbf{5 , 7 9 0 , 3 6 0} \mathbf{8 0 8 , 9 5 7 , 6 9 3}$ 


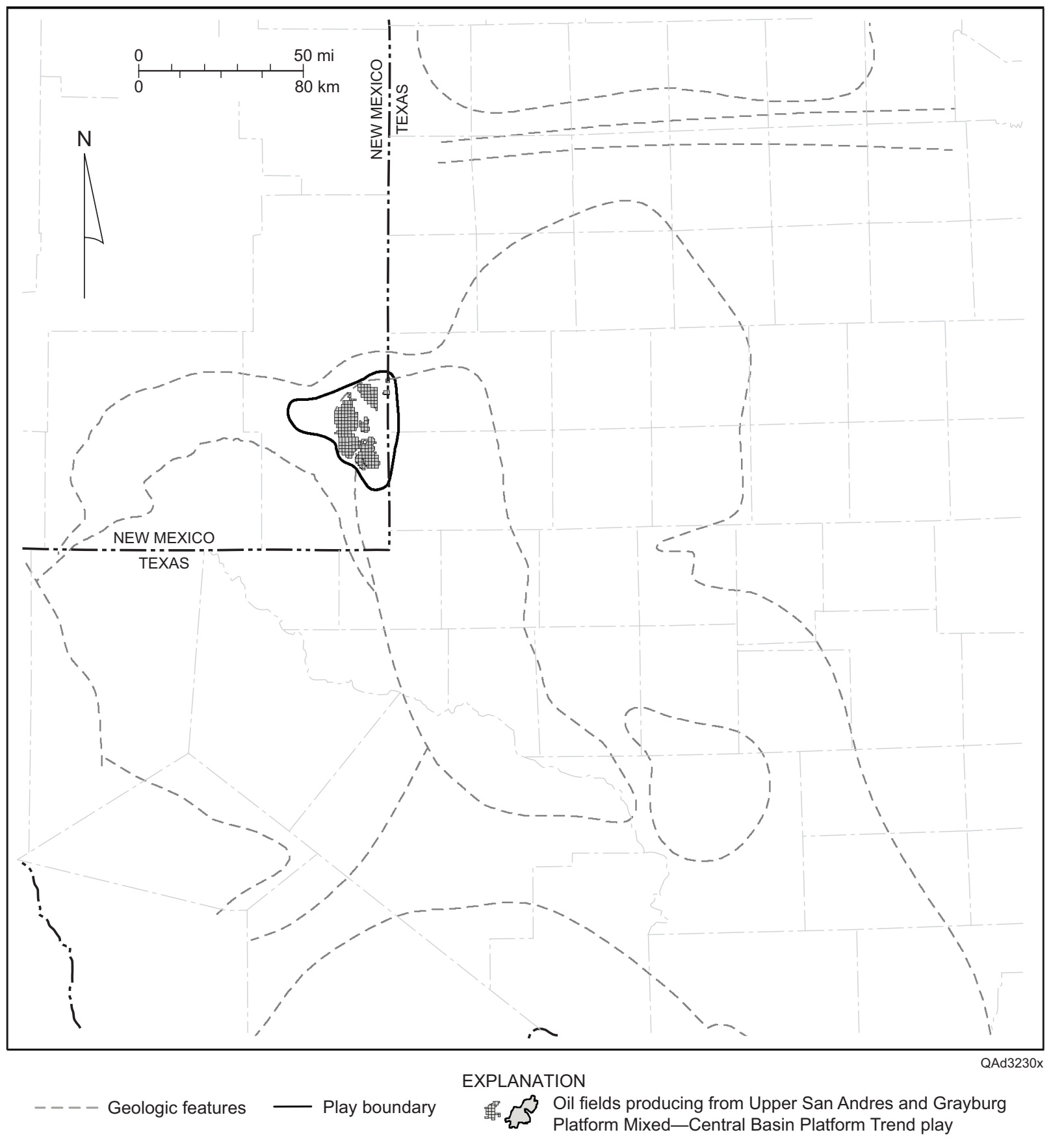

Figure 86. Play map for the Upper San Andres and Grayburg Platform Mixed—Central Basin Platform Trend play, showing location of reservoirs having $>1$ MMbbl cumulative production, the play boundary, and geologic features. See figure 1 for county names and figure 2 for identification of geologic features. 
include environments fluctuating between supratidal through platform margin, with wackestone through boundstone textures (Galloway and others, 1983). Porosity is generally best developed in platform-margin grainstone facies, but lower energy facies have locally developed secondary porosity (Galloway and others, 1983). Traps are formed mainly by gentle, north-south-trending anticlines.

The Eunice Monument reservoir is a combination trap formed by anticlinal closure on the west, north, and south but is stratigraphic to the east where porous dolograinstones of a highenergy shoal complex and subtidal dolomitic sandstones are sealed updip by a back-shoal facies consisting of impermeable dolomitic sandstones, dolostones, and evaporites (Lindsay, 1991). Vertical seals are formed by impermeable evaporitic facies of the upper Grayburg and lower Queen Formations. Reservoirs are typically heterogeneous, and reservoir quality and distribution can vary across a single trap-forming structure (Galloway and others, 1983).

San Andres production from the Hobbs reservoir is from the uppermost part of the San Andres, which shows evidence of karst modification—solution-widened fractures, large vugs, and small pockets of breccia. High well-test permeability suggests that permeability in the field is strongly influenced by a large interconnected pore system. The Hobbs reservoir had a longer primary production history than most San Andres fields.

Dominant production mechanisms in the play are water and solution-gas drive. Waterflooding and pressure maintenance have been successfully implemented in many of the reservoirs in this play and have resulted in substantial increases in recovery. 
Galloway, W. E., Ewing, T. E., Garrett, C. M., Jr., Tyler, N., and Bebout, D. G., 1983, Atlas of major Texas oil reservoirs: The University of Texas at Austin, Bureau of Economic Geology Special Publication, 139 p.

Garber, R. A., and Harris, P. M., 1986, Depositional facies of Grayburg/San Andres dolomite reservoirs - Central Basin Platform, in Bebout, D. G., and Harris, P. M., eds., Hydrocarbon reservoir studies San Andres/Grayburg Formations, Permian Basin: Permian Basin Section Society of Economic Paleontologists and Mineralogists, Publication 86-26, p. 61-66.

Lindsay, R. F., 1991, Grayburg Formation (Permian-Guadalupian): comparison of reservoir characteristics and sequence stratigraphy in the northwest Central Basin Platform with outcrops in the Guadalupe Mountains, New Mexico, in Meader-Roberts, S., Candelaria, M. P., and Moore, G. E., eds., Sequence stratigraphy, facies, and reservoir geometries of the San Andres, Grayburg, and Queen formations, Guadalupe Mountains, New Mexico and Texas: Permian Basin Section, Society of Economic Paleontologists and Mineralogists, Publication 91-32, p. 111-118. 
Upper San Andres and Grayburg Platform Mixed—Artesia Vacuum Trend (Play 125)

Reservoirs of the Upper San Andres and Grayburg Platform Mixed—Artesia Vacuum Trend play extend in an east-west direction from the city of Artesia to Hobbs in Eddy and Lea Counties, New Mexico (fig. 87). The play contains 13 reservoirs with $>1$ MMbbl $\left(1.59 \times 10^{5} \mathrm{~m}^{3}\right)$ cumulative oil production. Cumulative production from these 13 reservoirs was $796 \mathrm{MMbbl}$ $\left(1.27 \times 10^{8} \mathrm{~m}^{3}\right)$ as of 2000 (table 31$)$. Production in most reservoirs is commingled from the San Andres and Grayburg Formations. This is a mature play, especially within the highly productive San Andres carbonates. Production from the play reached a modern peak of $>18 \mathrm{MMbbl} / \mathrm{yr}\left(2.86 \times 10^{6} \mathrm{~m}^{3} / \mathrm{yr}\right)$ in the 1980 's, mostly as a result of waterflooding of the Vacuum reservoir (fig. 88). Recent development of lower permeability Grayburg sandstones in the Grayburg Jackson reservoir during the mid-1990's has been successful to the point of reversing production decline (fig. 89) and is a major focus of current and future development.

The upper San Andres Formation is composed of restricted, backreef dolowackestones, dolopackstones, and dolograinstones (Ward and others, 1986; Purves, 1990). Reservoir facies lie between the Guadalupian (Goat Seep) shelf margin to the south and tight evaporites and dolomites of inner-shelf and lagoonal environments to the north. The overlying

Table 31. Upper San Andres and Grayburg Platform Mixed_Artesia Vacuum Trend play (play 125).

\begin{tabular}{|c|c|c|c|c|c|c|c|c|c|}
\hline \multirow[t]{15}{*}{ RRC RESN } & RRC & FLDNAME & RESNAME & STATE & COUNTY & DISCYR & DEPTHTOP & 2000 PROD & CUMPROD \\
\hline & & ARTESIA & QUEEN GRAYBURG SAN ANDRES & NM & EDDY & 1923 & 2190 & 470,624 & $32,271,228$ \\
\hline & & ATOKA & SAN ANDRES & NM & EDDY & 1950 & 1680 & 108,733 & $6,999,883$ \\
\hline & & EAGLE CREEK & SAN ANDRES & NM & EDDY & 1959 & 1292 & 41,554 & $4,321,284$ \\
\hline & & GRAYBURG JACKSON & SEVEN RIVERS QUEEN GRAYBURG $\subseteq$ & NM & EDDY \& LEA & 1929 & 2700 & $3,432,424$ & $128,043,260$ \\
\hline & & HENSHAW WEST & GRAYBURG & NM & EDDY & 1956 & 2870 & 5,605 & $5,024,733$ \\
\hline & & LOCO HILLS & QUEEN GRAYBURG SAN ANDRES & NM & EDDY & 1949 & 2600 & 103,747 & $48,282,690$ \\
\hline & & LOVINGTON & GRAYBURG SAN ANDRES & NM & LEA & 1986 & 4700 & 66,016 & $14,689,351$ \\
\hline & & LOVINGTON WEST & UPPER SAN ANDRES & NM & LEA & 1990 & 4700 & 72,879 & $13,021,692$ \\
\hline & & MALJAMAR & GRAYBURG SAN ANDRES & NM & EDDY \& LEA & 1939 & 4050 & $1,003,045$ & $158,141,214$ \\
\hline & & RED LAKE & QUEEN GRAYBURG SAN ANDRES & NM & EDDY & 1934 & 1945 & 577,383 & $12,719,172$ \\
\hline & & SQUARE LAKE & GRAYBURG SAN ANDRES & NM & EDDY & 1941 & 3040 & 109,812 & $28,338,035$ \\
\hline & & SQUARE LAKE NORTH & QUEEN GRAYBURG SAN ANDRES & NM & EDDY & 1987 & 3300 & 9,376 & $2,690,235$ \\
\hline & & VACUUM & GRAYBURG SAN ANDRES & NM & LEA & 1929 & 4500 & $5,391,799$ & $341,873,609$ \\
\hline & & tals & & & & & & $11,392,997$ & $796,416,386$ \\
\hline
\end{tabular}




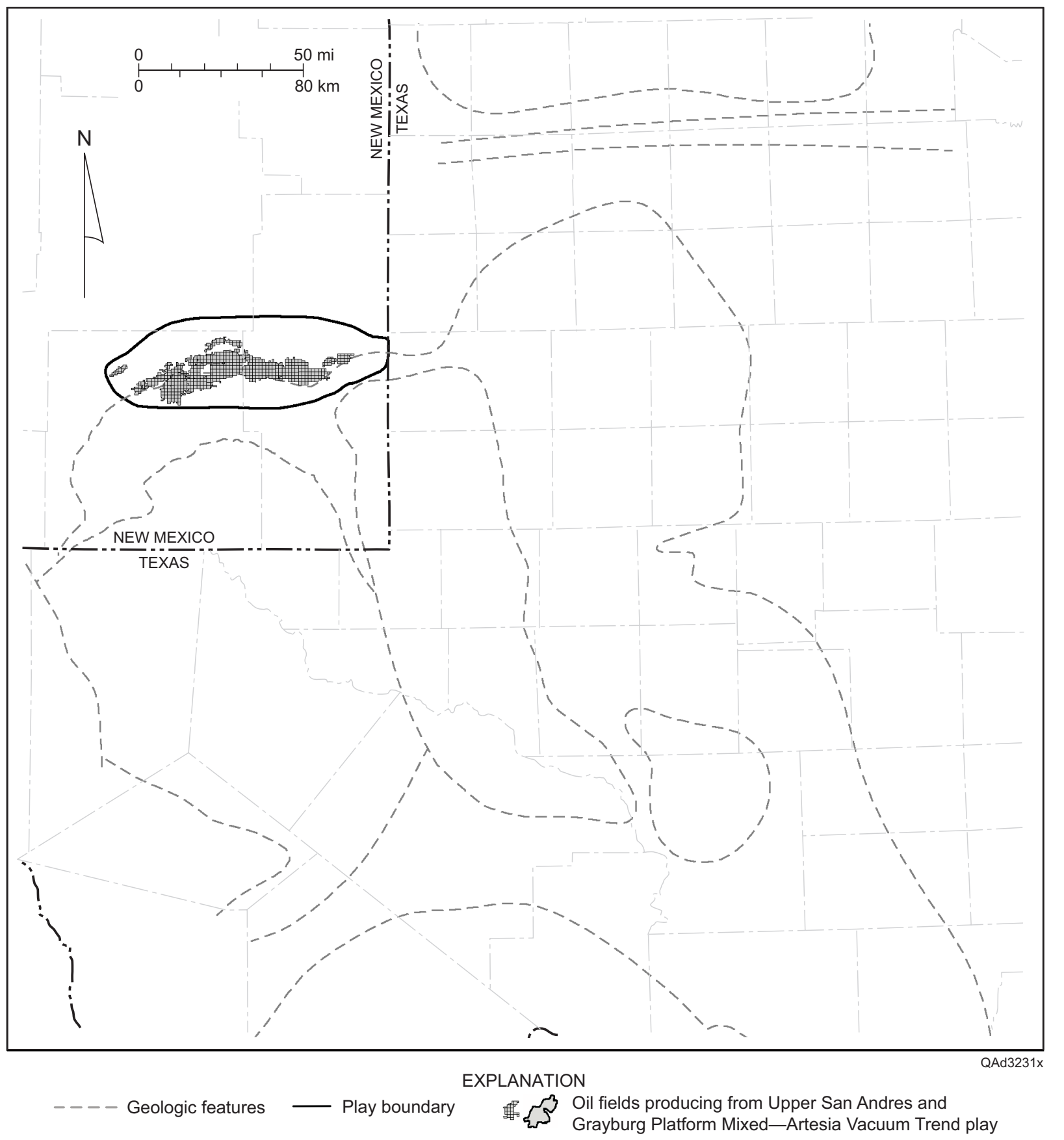

Figure 87. Play map for the Upper San Andres and Grayburg Platform Mixed-Artesia Vacuum Trend play, showing location of reservoirs having $>1 \mathrm{MMbbl}$ cumulative production, the play boundary, and geologic features. See figure 1 for county names and figure 2 for identification of geologic features. 


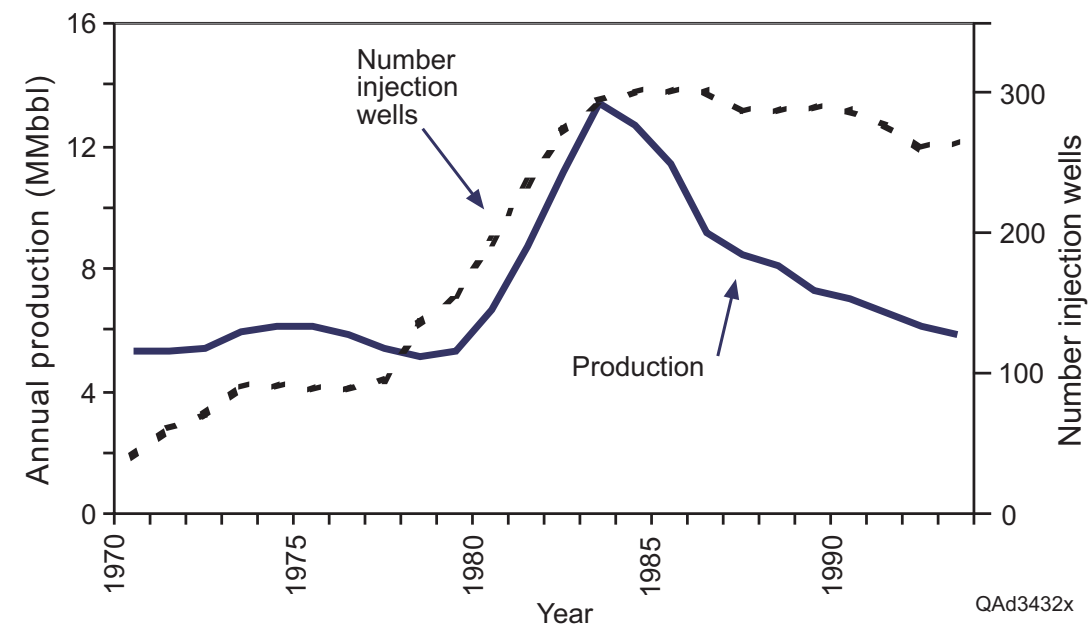

Figure 88. Annual oil production and number of injection wells in the Vacuum Grayburg San Andres reservoir from 1970 through 1993, showing the relationship between injection wells used for enhanced oil recovery and oil production. Most injection wells were used for water injection; after several years, a minor number of water injection wells were converted to polymer injection.

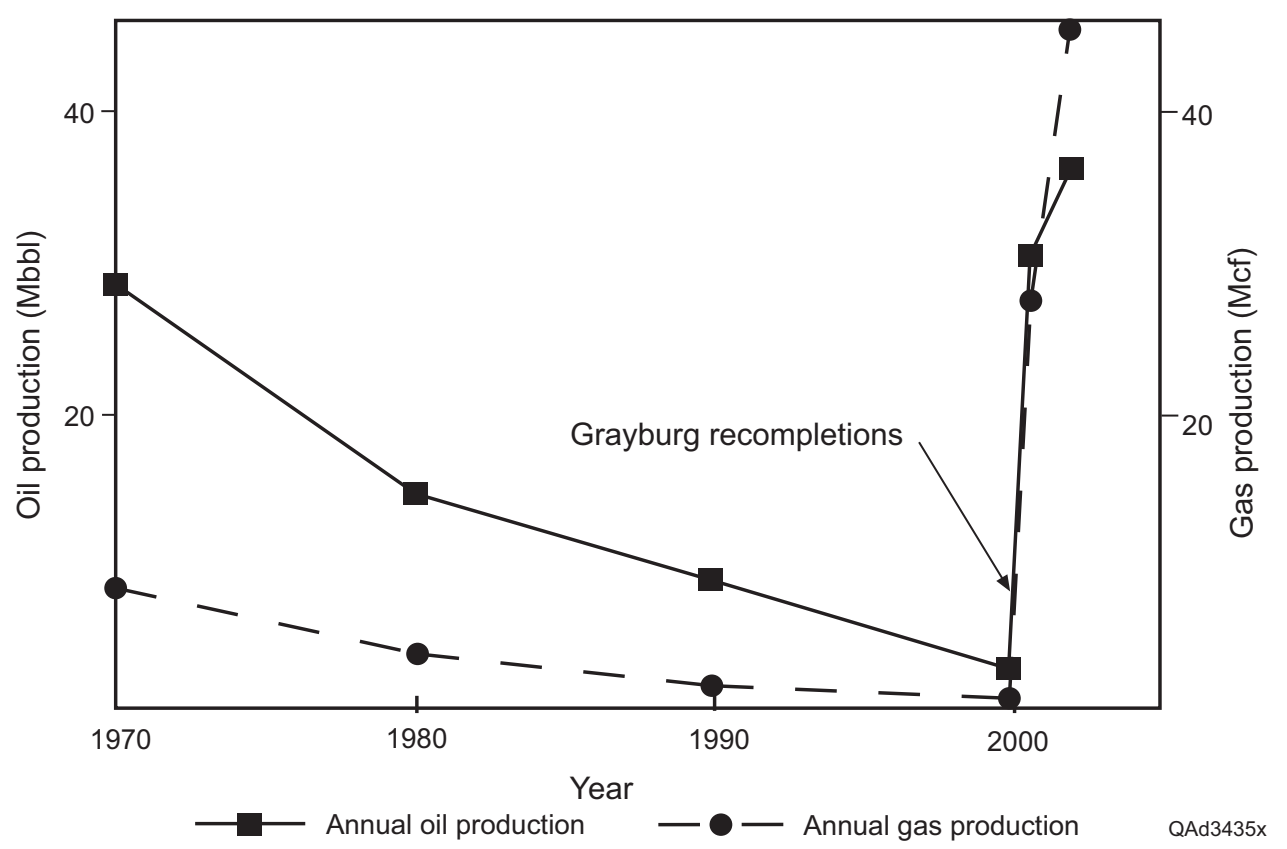

Figure 89. Annual combined oil and gas production for three wells in the Grayburg-Jackson reservoir, Upper San Andres and Grayburg Platform Mixed-Artesia Vacuum Trend play. These wells originally produced from San Andres zones and were in gradual decline, but production was revitalized when they were recompleted in Grayburg pay. 
Grayburg Formation contains interbeds of dolomite, sandstone, and evaporites. Production in the San Andres is obtained principally from dolostones, and production in the Grayburg is obtained largely from sandstones.

Reservoirs in this play lie along the Artesia-Vacuum Arch, a shallow east-west-trending structure that overlies the deeper, older Abo shelf edge reef trend and Bone Spring flexure (Broadhead, 1993). The position of a reservoir with respect to the axis of the Artesia-Vacuum Arch dictates whether the Grayburg Formation or the upper part of the San Andres Formation is more productive. Those reservoirs located along the crest (for example, Maljamar, Vacuum, Grayburg-Jackson) are structurally high enough for the Grayburg and upper San Andres Formations to be in the oil zone, whereas on the flanks of the structure the San Andres is wet, and only the overlying Grayburg is in the regional oil leg. Exact location of some reservoirs is influenced by local structures that may be oriented at an angle to the regional shelf edge (see Purves, 1990). Traps are combination structural and stratigraphic, with the Artesia-Vacuum Arch providing the structural element. Updip (northerly) porosity pinch-outs into tight evaporitic lagoonal facies create the stratigraphic trapping component (Ward and others, 1986). The regional vertical seal is formed by impermeable strata within the overlying upper Grayburg and Queen Formations. Solution-gas drive is the primary production mechanism.

The San Andres Formation of the Northwest Shelf is composed of numerous highfrequency, upward-shoaling, carbonate depositional cycles (Purves, 1986; Handford and others, 1996; Modica and Dorobek, 1996; Stoudt and Raines, 2001; Pranter and others, 2004). Cycles consist of permeable subtidal carbonates that are capped by low-permeability peritidal carbonates that vertically compartmentalize the reservoir. Reservoir zones in the San Andres exhibit lateral as well as vertical variation in permeability (Hinrichs and others, 1986). 
The Grayburg Formation consists of interbedded sandstones, siltstones, and dolomitic carbonates (fig. 90) (Handford and others, 1996; Modica and Dorobek, 1996). The sandstones, deposited in coastal, sabkha, sandflat, and eolian environments (fig. 91), are the principal reservoirs. The carbonates are subtidal deposits that are generally impermeable. Pores are commonly plugged by anhydrite.

The Vacuum reservoir exhibits complex internal vertical and horizontal segmentation of flow units. As described earlier, the reservoir is vertically compartmentalized by upwardshoaling carbonate cycles. It is divided into horizontal compartments by numerous high-angle, low-displacement faults (Pranter and others, 2004). Although vertical throw of the faults is $<25 \mathrm{ft}(<8 \mathrm{~m})$ in most cases, it is sufficient to isolate thin, permeable beds across the faults, which act as horizontal seals. In addition, significant karsting and development of dissolution features, caves, and solution-collapse structures are associated with intraformational sequence boundaries, especially at the prominent sequence boundary that separates the upper part of the San Andres from the lower part of the San Andres (Stoudt and Raines, 2001; Pranter and others, 2004). Although karst development may have enhanced porosity and permeability in some San Andres reservoirs (for example, see Hovorka and others, 1993), karst pore systems at Vacuum are filled with impermeable sandstone, collapsed carbonates, or evaporites and act to further compartmentalize the reservoir both vertically and horizontally (Stoudt and Raines, 2001; Pranter and others, 2004). Similarly, destruction of karst-related porosity by anhydrite cementation has been described in the Maljamar reservoir of this play (Modica and Dorobek, 1996). The complex horizontal and vertical compartmentalization of flow units that formed as a result of cyclic deposition of permeable and impermeable facies, faults, and destruction of karst-derived porosity by sand and evaporite plugging and solution collapse makes 


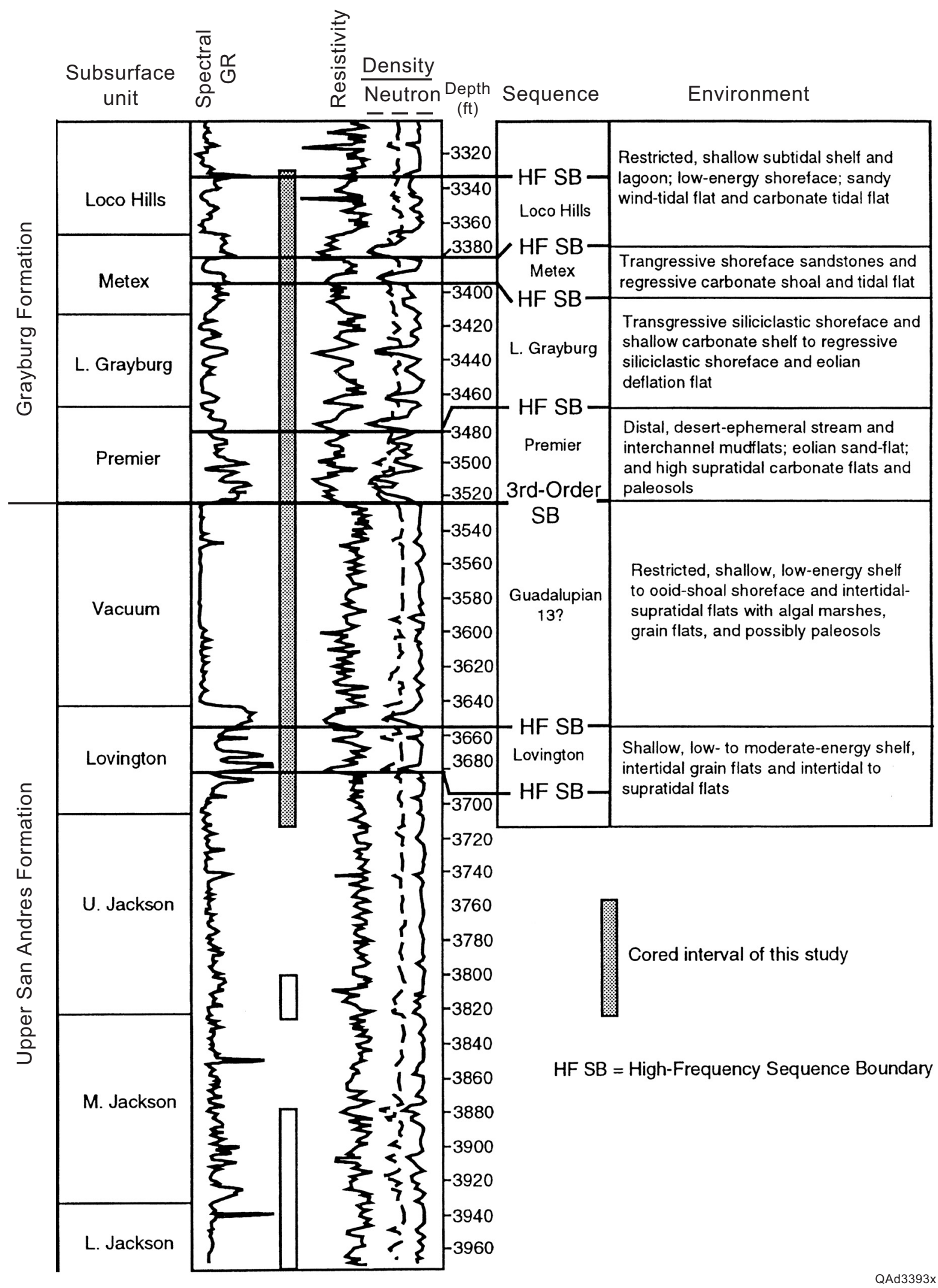

Figure 90. Stratigraphic column for the H. E. West "A" No. 22 well in Jackson-Grayburg field on the Northwest Shelf, Eddy County. From Handford and others (1996). 


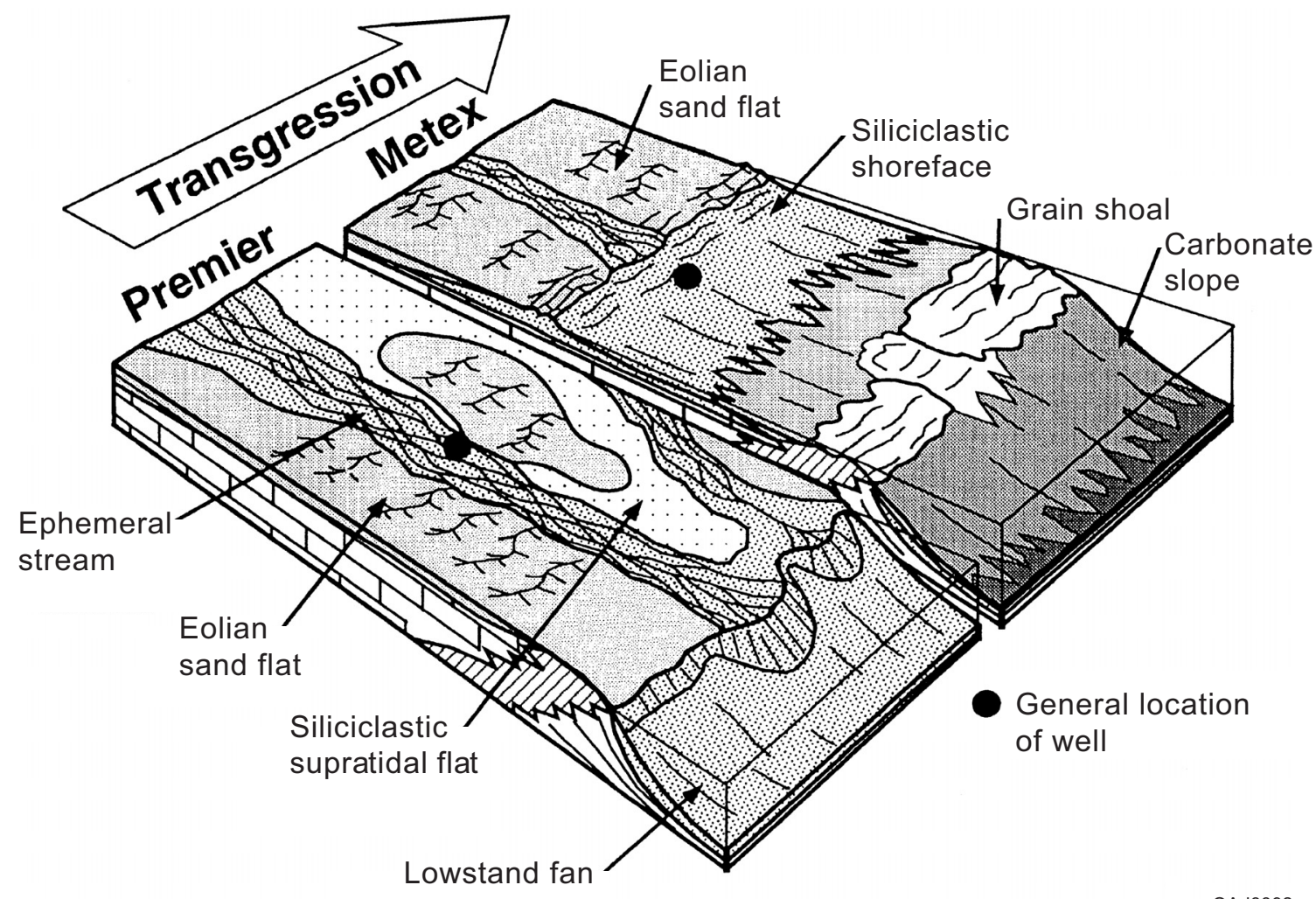

Figure 91. Depositional model of the Grayburg Formation during a base-level rise.

From Handford and others (1996). The general location of the H. E. West "A" No. 22 well shown in figure 90 is indicated.

full development of reservoirs impossible with vertical wells drilled on standard 40-acre spacing.

Enhanced recovery techniques have been successful in reservoirs of the Upper San Andres and Grayburg Platform Mixed-Artesia Vacuum Trend Play. Many of the reservoirs in this play have been successfully waterflooded. $\mathrm{CO}_{2}$ flooding has been employed in portions of the Vacuum reservoir with positive results (Pranter and others, 2004), and the $\mathrm{CO}_{2}$ flood was expanded in the late 1990's. The presence of complex systems of internal reservoir compartments has resulted in parts of the reservoir being unswept by enhanced recovery operations. 
There is significant potential for enhancing production from San Andres carbonates by drilling horizontal laterals from existing vertical well bores, as has been done at the Vacuum reservoir (Pranter and others, 2004). This reservoir, discovered in 1929, is mature. Large parts of it have been waterflooded and, as mentioned earlier, a successful $\mathrm{CO}_{2}$ flood has been employed in part of the reservoir. Although these enhanced-recovery methods have increased production substantially, vertical and horizontal compartmentalization has resulted in significant bypassed pay that has not been drained adequately by vertical wells or completely swept during enhanced recovery. Fault-block boundaries and bypassed-pay zones have been identified by a combination of 3-D seismic surveys and well data (Pranter and others, 2004). Horizontal laterals aimed at intersecting undrained pay were drilled from an existing vertical well and resulted in an increase in production approximately 20 -fold, when compared with what the preexisting vertical well yielded (Pranter and others, 2004). Production from existing vertical-offset wells was not affected by the newer lateral wells, indicating that the lateral wells penetrated untapped reservoir compartments. Rather than the horizontal laterals being drilled as flat segments, they were drilled in a serpentine pattern so that multiple vertical reservoir compartments were penetrated by a single well bore.

Another example of a development practice that significantly enhanced production is derived from a lease in Section 13 T17S R30E in the Grayburg-Jackson reservoir (B. Brister, personal communication, 2003). This area is located along the crest of the Artesia-Vacuum Arch and is sufficiently high structurally that the karsted, highly permeable Jackson zone of the San Andres reservoir is above the oil-water contact. Production in the Grayburg-Jackson reservoir was obtained mostly from dolostones in the San Andres from the 1920's until the mid-1990's, when these wells were recompleted in the Grayburg. Open-hole logs had never been run in the 
older wells, and the Grayburg was located behind casing. Neutron logs failed to show Grayburg

pay zones behind casing because of high gas saturations in reservoir zones. Locations of

Grayburg pay zones were inferred from regional correlations, and Grayburg recompletions

targeted the inferred zones. This methodology resulted in significantly increased levels of both

gas and oil production (fig. 89). Current development practices of completing Grayburg pay

separately from San Andres pay will limit production to a more homogeneous reservoir than

with commingled Grayburg-San Andres completions. One result may be more uniform flooding

and improved recovery if enhanced recovery is employed.

\section{References}

Broadhead, R. F., 1993, San Andres and Grayburg platform, in Atlas of major Rocky Mountain gas reservoirs: New Mexico Bureau of Mines and Mineral Resources, p.142-143.

Handford, C. R., Candelaria, M. P., and Lafollette, S., 1996, Accommodation cycles in peritidal carbonate and continental to shoreface siliciclastic facies, San Andres-Grayburg Formations, Eddy County, New Mexico, in Martin, R. L., ed., Permian Basin oil and gas fields: keys to success that unlock future reserves: West Texas Geological Society, Publication 96-101, p. 65-80.

Hinrichs, P. D., Lucia, F. J., and Mathis, R. L., 1986, Permeability distributions and reservoir continuity in Permian San Andres shelf carbonates, Guadalupe Mountains, New Mexico, in Moore, G. E., and Wilde, G. L., eds., Lower and middle Guadalupian facies, stratigraphy, and reservoir geometries, San Andres/Grayburg Formations, Guadalupe Mountains New Mexico and Texas: Permian Basin Section, Society of Economic Paleontologists and Mineralogists, Publication 86-25, p. 37-47.

Hovorka, S. D., Nance, H. S., and Kerans, C., 1993, Parasequence geometry as a control on permeability evolution: examples from the San Andres and Grayburg Formations in the Guadalupe Mountains, New Mexico, in Loucks, R. G., and Sarg, J. F., Carbonate sequence stratigraphy: American Association of Petroleum Geologists, Memoir 57, p. $493-514$.

Modica, C. J., and Dorobek, S. L., 1996, High frequency sequence framework and effects of exposure events on porosity evolution and reservoir heterogeneity: Maljamar field, Lea County, southeast New Mexico, in Martin, R. L., ed., Permian Basin oil and gas fields: 
keys to success that unlock future reserves: West Texas Geological Society, Publication 96-101, p. 25-30.

Pranter, M. J., Hurley, N. F., Davis, T. L., Raines, M. A., and Wehner, S. C., 2004, Dual-lateral horizontal wells successfully target bypassed pay in the San Andres Formation, Vacuum field, New Mexico: American Association of Petroleum Geologists Bulletin, v. 88, p. $99-113$.

Purves, W. J., 1986, Depositional and diagenetic controls on porosity, upper San Andres Formation-Bridges state leases, Vacuum field, Lea County, New Mexico, in Bebout, D. G., and Harris, P. M., eds., Hydrocarbon reservoir studies, San Andres/Grayburg Formations, Permian Basin: Permian Basin Section Society of Economic Paleontologists and Mineralogists, Publication 86-26, p. 49-53.

1990, Reservoir description of the Mobil Oil Bridges state leases (upper San Andres reservoir), Vacuum field, Lea County, New Mexico, in Bebout, D. G., and Harris, P. M., eds., Geologic and engineering approaches in evaluation of San Andres/Grayburg hydrocarbon reservoirs-Permian Basin: The University of Texas at Austin, Bureau of Economic Geology, p. 87-112.

Stoudt, E. L., and Raines, M. A., 2001, Reservoir compartmentalization in the San Andres Formation of Vacuum field, Lea County, New Mexico - peritidal deposits and karst overprints create vertical and lateral barriers to fluid flow in carbonate platform dolopackstones and dolograinstones (abs.): American Association of Petroleum Geologists Bulletin, v. 85, p. 390.

Ward, R. F., Kendall, C. G. St. C., and Harris, P. M., 1986, Upper Permian (Guadalupian) facies and their association with hydrocarbons-Permian Basin, west Texas and New Mexico: American Association of Petroleum Geologists, Bulletin, v. 70, p. 239-262. 
San Andres/Grayburg Lowstand Carbonate (Play 126)

The 19 reservoirs in the San Andres/Grayburg Lowstand Carbonate play have produced 681.1 MMbbl $\left(1.08 \times 10^{8} \mathrm{~m}^{3}\right)$ of oil from the San Andres and Grayburg Formations in the Midland Basin (table 32, fig. 92). The reservoirs are structurally and topographically well below San Andres and Grayburg shelf-margin production on the Central Basin Platform and Northwest Shelf. The shallow-water facies in these reservoirs are interpreted as having been deposited in the Midland Basin during periods of sea-level lowstand. In contrast to San Andres and Grayburg reservoirs on the Central Basin Platform, oolite grainstones are common reservoir facies in this play. Positions of the isolated reservoirs on the east side of the play-Pegasus, Brazos, Azalea, Germania, and Phoenix — are probably controlled by paleostructures, where shallow-water facies were localized.

Regional subsurface sequence stratigraphic relationships of the San Andres and Grayburg on the Central Basin Platform and in the Midland Basin were established by Dedmon and Dorobek (1993). They concluded that the San Andres platform experienced a prolonged period

Table 32. San Andres/Grayburg Lowstand Carbonate play (play 126). Production shown for fields that have had others combined into them represents the totals; combined fields are highlighted.

\begin{tabular}{|c|c|c|c|c|c|c|c|c|c|}
\hline RRC RESN & RRC & FLDNAME & RESNAME & STATE & COUNTY & DISCYR & DEPTHTOP & 2000 PROD & CUMPROD \\
\hline 570001 & $8 \mathrm{~A}$ & ADAIR & & $\mathrm{TX}$ & GAINES & 1947 & 4874 & 913,427 & $66,079,283$ \\
\hline 4605444 & 8 & AZALEA & GRAYBURG & $\mathrm{TX}$ & MIDLAND & 1967 & 4088 & 34,643 & $2,064,038$ \\
\hline 9116500 & 8 & BLOCK 2 & GRAYBURG & $\mathrm{TX}$ & ANDREWS & 1957 & 4736 & 182,213 & $3,116,332$ \\
\hline 11601500 & 8 & BRAZOS & SAN ANDRES & TX & MIDLAND & 1982 & 4433 & 58,217 & $1,934,677$ \\
\hline 16580001 & $8 \mathrm{~A}$ & CEDAR LAKE & & $\mathrm{TX}$ & GAINES & 1939 & 4800 & $2,369,564$ & $105,374,960$ \\
\hline 16585500 & $8 \mathrm{~A}$ & CEDAR LAKE, SE. & SAN ANDRES & $\mathrm{TX}$ & DAWSON & 1953 & 4940 & 13,074 & $1,649,672$ \\
\hline 34563400 & 8 & GERMANIA & GRAYBURG & TX & MIDLAND & 1952 & 3940 & 68,968 & $5,351,696$ \\
\hline 56378001 & 8 & MABEE & & $\mathrm{TX}$ & ANDREWS & 1943 & 4704 & $1,811,218$ & $115,007,221$ \\
\hline 56159200 & 8 & M.F.E. & GRAYBURG & $\mathrm{TX}$ & ANDREWS & 1991 & 4936 & 174,577 & $3,556,164$ \\
\hline 61118001 & 8 & MIDLAND FARMS & & $\mathrm{TX}$ & ANDREWS & 1945 & 4800 & $1,032,777$ & $161,255,366$ \\
\hline 61119333 & 8 & MIDLAND FARMS, E & GRAYBURG UPPER & $\mathrm{TX}$ & ANDREWS & 1969 & 4780 & 0 & $2,460,219$ \\
\hline 61120500 & 8 & MIDLAND FARMS, NORTH & GRAYBURG & $\mathrm{TX}$ & ANDREWS & 1953 & 4943 & 72,536 & $16,927,251$ \\
\hline 56432700 & $8 \mathrm{~A}$ & MTS & SAN ANDRES & TX & DAWSON & 1984 & 4922 & 70,894 & $3,011,168$ \\
\hline 70279625 & $7 \mathrm{C}$ & PEGASUS & SAN ANDRES & $\mathrm{TX}$ & MIDLAND & 1954 & 5584 & 55,789 & $11,051,115$ \\
\hline 71267500 & 8 & PHOENIX & GRAYBURG & $\mathrm{TX}$ & MARTIN & 1972 & 3930 & 104,273 & $4,620,068$ \\
\hline 82275500 & 8 & SERIO & GRAYBURG & TX & ANDREWS & 1970 & 4806 & 154,358 & $4,834,677$ \\
\hline 85281001 & $8 \mathrm{~A}$ & SPRABERRY & & $\mathrm{TX}$ & DAWSON & 1946 & 3930 & 53,522 & $2,381,850$ \\
\hline 88000500 & $8 \mathrm{~A}$ & TLOC & SAN ANDRES & $\mathrm{TX}$ & TERRY & 1980 & 4904 & 52,796 & $1,457,257$ \\
\hline 96062001 & $8 \mathrm{~A}$ & WELCH & & $\mathrm{TX}$ & DAWSON & 1941 & 5000 & $2,134,395$ & $168,998,863$ \\
\hline
\end{tabular}




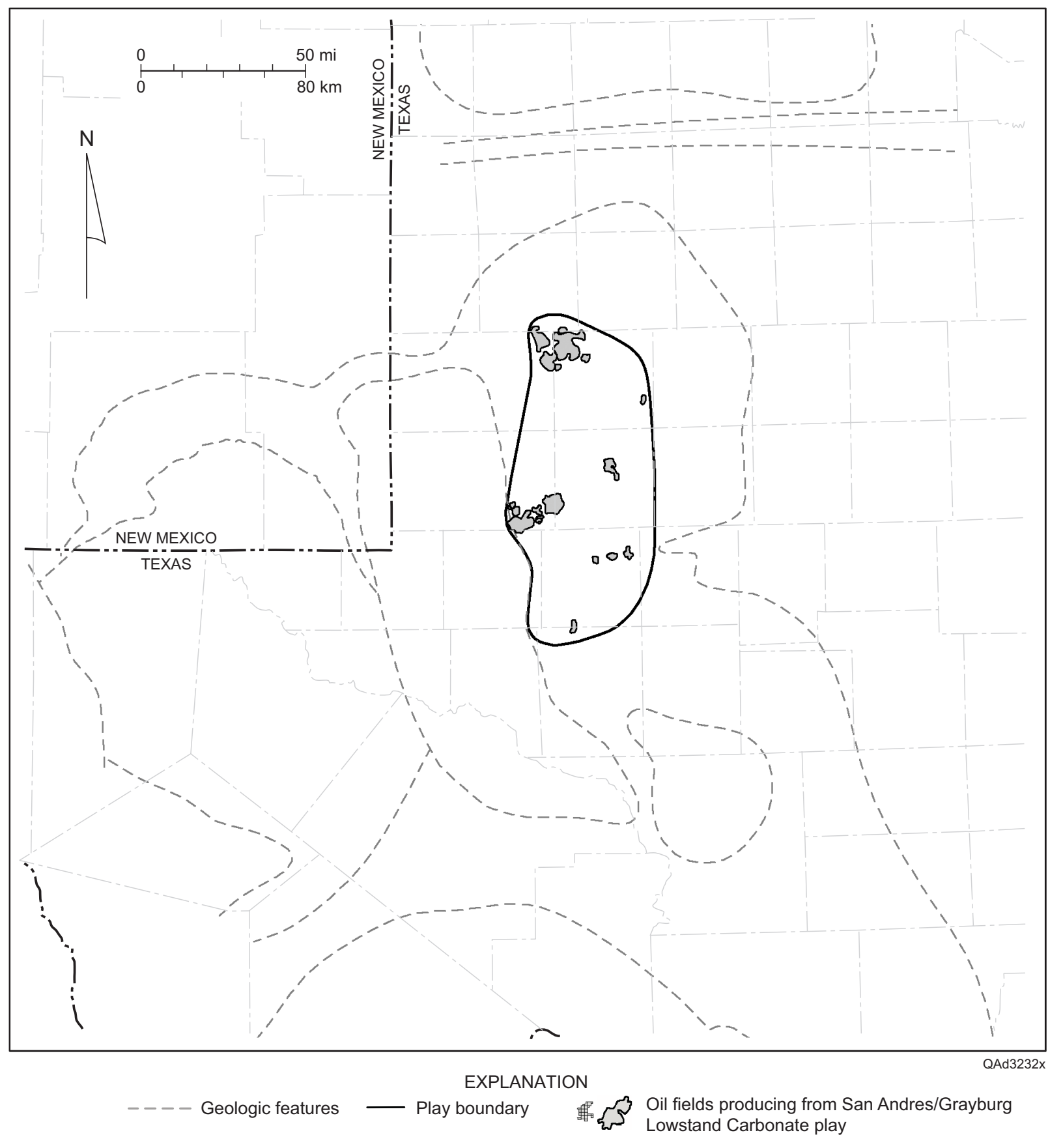

Figure 92. Play map for the San Andres/Grayburg Lowstand Carbonate play, showing location of reservoirs having $>1 \mathrm{MMbbl}$ cumulative production, the play boundary, and geologic features. See figure 1 for county names and figure 2 for identification of geologic features. 
of subaerial exposure before Grayburg deposition. Logs at Midland Farms field show initial Grayburg onlap of the platform downdip of the terminal San Andres margin and indicate that the San Andres-Grayburg contact is a Type 1 sequence boundary.

Mabee field in Andrews County produces from upper San Andres dolomites that are draped over a deep Ordovician structure (Urschel and others, 1986; Friedman and others, 1990; Dull, 1992, 1994; Miller, 1992). The production comes from dolomitized subtidal mudstone/wackestone/peloid packstone and oolite packstone/grainstone facies (fig. 93) (Dull, 1994). Average porosity is 10.5 percent, and geometric mean permeability is $1 \mathrm{md}$ $\left(1 \times 10^{-3} \mu \mathrm{m}^{2}\right)$. Sandstones that interfinger with the ooid facies are tightly cemented and act as barriers within the reservoir (Miller, 1992). The reservoir seal is formed by low-permeability supratidal dolomite containing anhydrite nodules and cement (Urschel and others, 1986; Friedman and others, 1990).

Carbonates in reservoir zones 1 and 2 of Mabee field (fig. 93) are the target of a miscible $\mathrm{CO}_{2}$ flood. Although ooid facies in zone 3 have produced considerable oil, this interval is not being flooded. Zones of high porosity and permeability associated with vuggy porosity and fractures in zone 3 could act as thief zones for injected $\mathrm{CO}_{2}$ (Dull, 1994). Natural fractures appear to be an important component of the heterogeneity in Mabee field. The main direction of natural-fracture orientation in Mabee field is $\mathrm{N} 70 \mathrm{~W}$, and the present maximum horizontal compressive stress direction is N45E (Qui and others, 2001). During primary production, horizontal wells should be placed to intersect the maximum number of open fractures, but Qui and others (2001) recommended that fracture intersection be minimized during secondary and tertiary recovery. During a waterflood or $\mathrm{CO}_{2}$ flood, open fractures located between an injector and producer well will rapidly conduct the injected fluid to the producing well without moving 
Texaco Inc.

J. E. Mabee 'B' NCT-1 No. 26

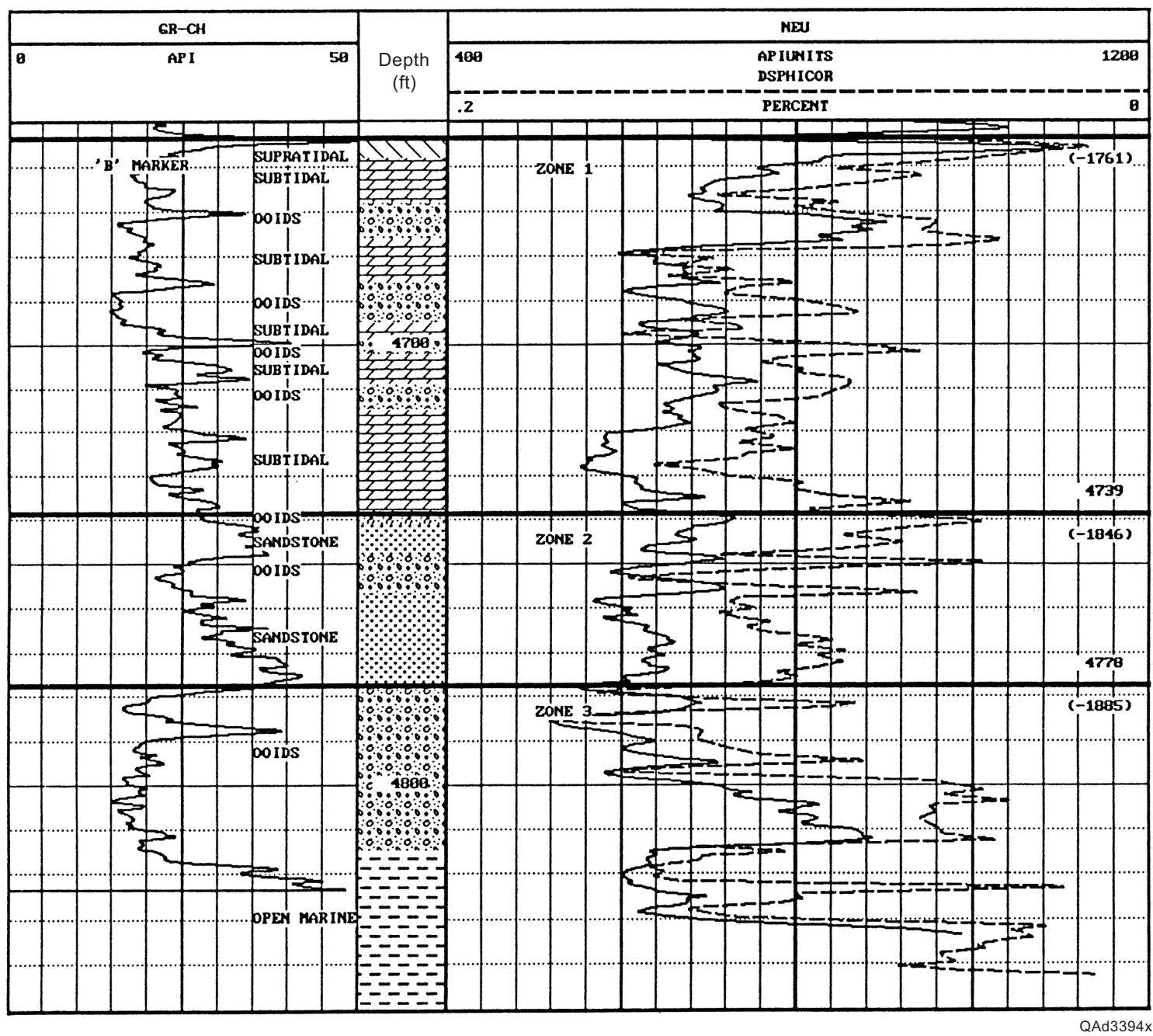

Figure 93. Type log for Mabee field showing vertical facies succession. From Dull (1994).

additional oil. In Mabee field, horizontal wells oriented east-west would minimize the intersection with open fractures (Qui and others, 2001).

Welch field is located northeast of the Central Basin Platform and southeast of the Northwest Shelf (fig. 92). The San Andres rocks in Welch field were deposited in an arid, nearshore, shallow-water sabkha environment (Hinterlong and Taylor, 1996). The reservoir interval is composed of four upward-shallowing carbonate cycles (Watts and others, 1998), in 
which subtidal mudstones and wackestones grade upward into tight packstones and grainstones deposited in a high-energy environment. The subtidal facies thin to the north in the field and are capped by supratidal facies consisting of thick anhydrite and anhydritic dolomite that forms the trap. A 3-D seismic volume and cross-well tomography were used to map the distribution of average porosity in interwell areas and guide the drilling of infill wells. Three seismic attributes — structure, amplitude, and phase — had high correlation with porosity (Watts and others, 1998). Seismic-guided estimates of average porosity were found to be within 1 porosity unit of log-determined porosity in 10 infill wells that were drilled on the basis of the 3-D seismic porosity model. An additional $300,000 \mathrm{bbl}\left(4.77 \times 10^{4} \mathrm{~m}^{3}\right)$ of oil reserves were discovered in West Welch unit using the 3-D seismic interpretation of porosity (Schatzinger, 2003).

\section{References}

Dedmon, R. G., and Dorobek, S. L., 1993, Sequence stratigraphic relationships of the Grayburg Formation, Foster, North Cowden, and Midland Farms fields, Central Basin Platform, west Texas, in Gibbs, J., and Cromwell, D., eds., New dimensions in the Permian Basin: West Texas Geological Society Publication 93-93, p. 19-27.

Dull, D. W., 1992, Porosity calibration of modern porosity logs and old neutron logs, Mabee field, Andrews and Martin Counties, Texas, in Cromwell, D. W., Moussa, M. T., and Mazzullo, L. J., eds., Southwest Section American Association of Petroleum Geologists Transactions, SWS 92-90, p. 137-147.

1994, Geostatistical method to improve permeability estimates - application to the Mabee field, Andrews and Martin Counties, Texas, in Gibbs, J. F., ed., Synergy equals energy - teams, tools, and techniques: West Texas Geological Society Publication 94-94, p. 23-33.

Friedman, G. M., Ghosh, S. K., and Urschel, S., 1990, Petrophysical characteristics related to depositional environments and diagenetic overprint: a case study of the San Andres Formation, Mabee field, west Texas, in Bebout, D. G. and Harris, P. M., eds., Geologic and engineering approaches in evaluation of San Andres/Grayburg hydrocarbon reservoirs - Permian Basin: The University of Texas at Austin, Bureau of Economic Geology Publication, p. 125-144. 
Hinterlong, G. D., and Taylor, A. R., 1996, Characterization of rock types with mixed wettability using log and core data-DOE project Welch field, Dawson County, Texas: Society of Petroleum Engineers, Permian Basin Oil and Gas Recovery Conference, Midland, SPE 35160, p. 139-147.

Miller, K. D., 1992, Geologic description of the San Andres reservoir facies in Mabee field: American Association of Petroleum Geologists Bulletin, v. 76, p. 580.

Qui, Y., Holtz, M. H., and Yang, A., 2001, Applying curvature and fracture analysis to the placement of horizontal wells: example from the Mabee (San Andres) reservoir, Texas: Society of Petroleum Engineers, SPE Permian Basin Oil and Gas Recovery Conference, Midland, SPE 70010, 9 p.

Schatzinger, V. R., 2003, Improved recovery and economics in a lower quality shallow-shelf carbonate reservoir: The Class Act, v. 9, no. 1, p. 9.

Urschel, S. F., Ghosh, S. K., and Friedman, G. M., 1986, Reservoir facies of the Permian San Andres Formation in the Mabee field, Midland Basin, west Texas: characterization for enhanced recovery, in Bebout, D. G., and Harris, P. M., eds., Hydrocarbon reservoir studies, San Andres/Grayburg Formations, Permian Basin: Permian Basin Section, Society of Economic Paleontologists and Mineralogists, Publication No. 86-26, 188 p. 89-95.

Watts, G. P., Hinterlong, G. D., and Taylor, A. R., 1998, Seismic description of a complex carbonate porosity system; Welch field, Permian Basin, Texas, in DeMis, W. D. and Nelis, M. K., eds., The search continues into the 21st century: West Texas Geological Society Publication No. 98-105, p. 223-229. 
Grayburg Platform Mixed Clastic/Carbonate (Play 127)

The Grayburg Platform Mixed Clastic/Carbonate play is composed of three reservoirs on the Central Basin Platform in Texas (fig. 94), located to the northwest of the Grayburg Platform Carbonate play (play 128). The play produced 669.7 MMbbl $\left(1.06 \times 10^{8} \mathrm{~m}^{3}\right)$ through 2000 (table 33). The three reservoirs in this play have been designated as separate from the Grayburg Platform Carbonate play because much of their production is from Grayburg sandstones and siltstones, as well as San Andres and Grayburg carbonates. In that respect the play is similar to the Upper San Andres and Grayburg Platform Mixed — Central Basin Platform Trend play (play 124).

Fuhrman-Mascho field produces from the Grayburg Formation and the upper and lower San Andres Formation in Andrews County (fig. 95). A stratigraphic framework was developed for the University Block 10 area of Fuhrman-Mascho field (Ruppel, 2001). Where core was unavailable, spectral gamma-ray and borehole-imaging logs were used to identify facies and correlate cycles (Ruppel, 2001). Grayburg production in Fuhrman-Mascho field is mainly from porous and permeable fine-grained sandstone and coarse siltstone in the lower Grayburg. Porosity is as high as 25 percent, and permeability can exceed $100 \mathrm{md}\left(100 \times 10^{-3} \mu \mathrm{m}^{2}\right)$. Siliciclastic beds form the base of cycles and are capped by tidal-flat carbonates (fig. 96). The siliciclastics are interpreted to be eolian facies that were deposited during sea-level falls and

Table 33. Grayburg Platform Mixed Clastic/Carbonate play (play 127). Production shown for fields that have had others combined into them represents the totals; combined fields are highlighted.

\begin{tabular}{|c|c|c|c|c|c|c|c|c|c|}
\hline RRC RESN & RRC & FLDNAME & RESNAME & STATE & COUNTY & DISCYR & DEPTHTOP & 2000 PROD & CUMPROD \\
\hline 21289001 & 8 & COWDEN, NORTH & & TX & ECTOR & 1930 & 4400 & $6,827,269$ & $541,669,047$ \\
\hline 33176001 & 8 & FUHRMAN-MASCHO & & TX & ANDREWS & 1930 & 4700 & 918,794 & $119,367,788$ \\
\hline 91350300 & 8 & TRIPLE-N & GRAYBURG & $\begin{array}{l}\text { TX } \\
\text { TX }\end{array}$ & ANDREWS & 1964 & 4338 & 60,777 & $8,690,502$ \\
\hline \multicolumn{4}{|c|}{ Totals } & & & & & $7,806,840$ & $669,727,337$ \\
\hline
\end{tabular}




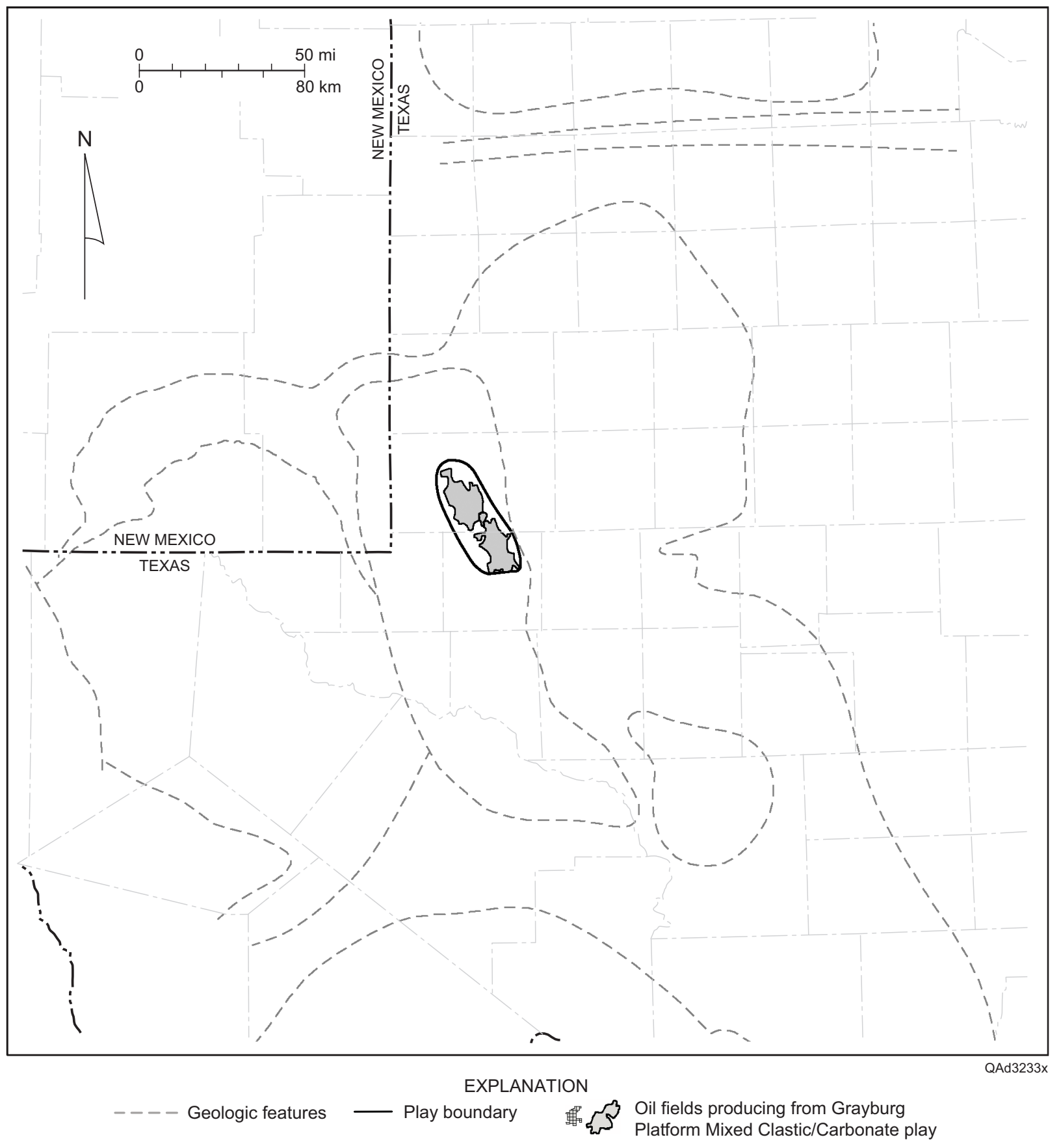

Figure 94. Play map for the Grayburg Platform Mixed Clastic/Carbonate play, showing location of reservoirs having $>1 \mathrm{MMbbl}$ cumulative production, the play boundary, and geologic features. See figure 1 for county names and figure 2 for identification of geologic features. 


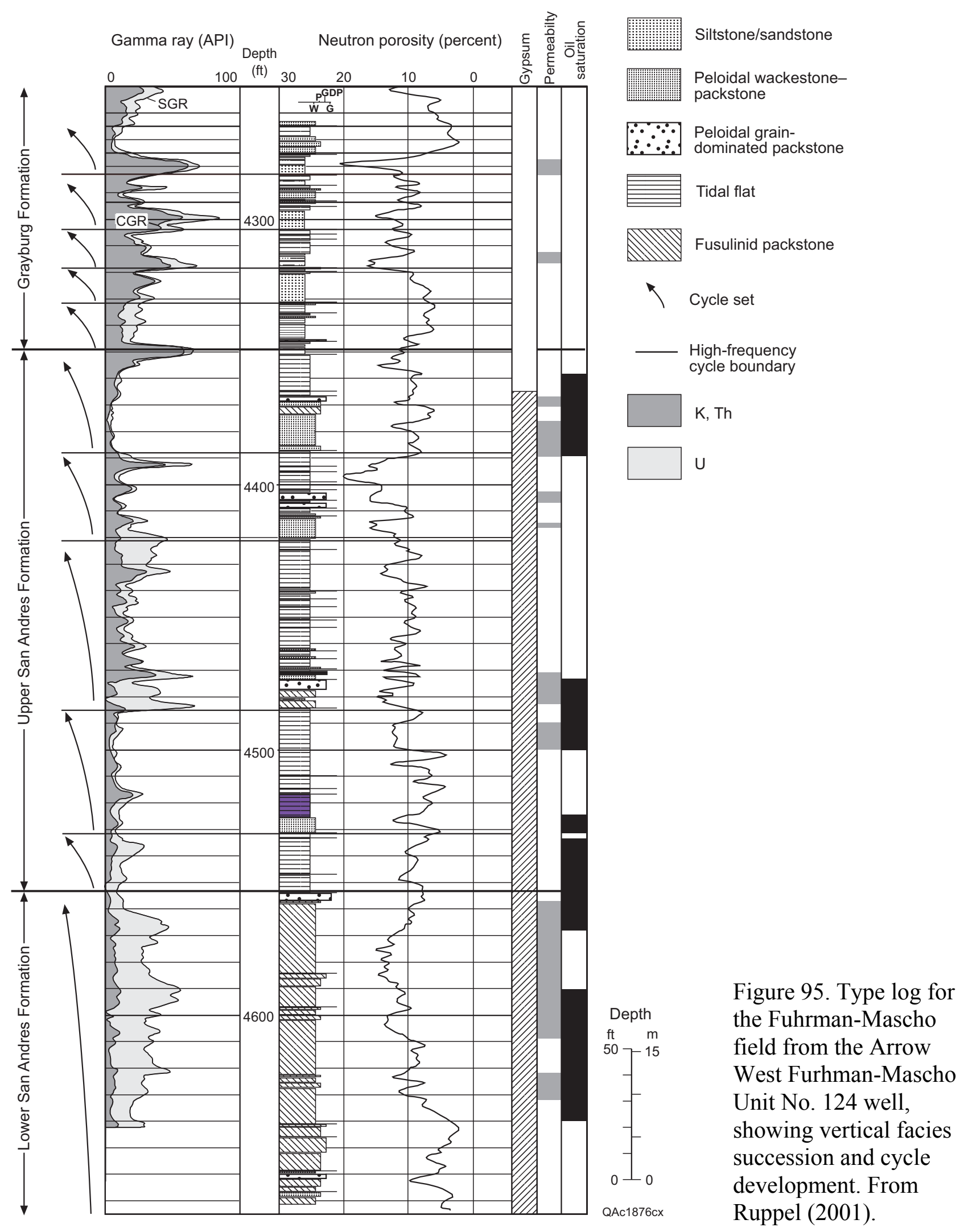




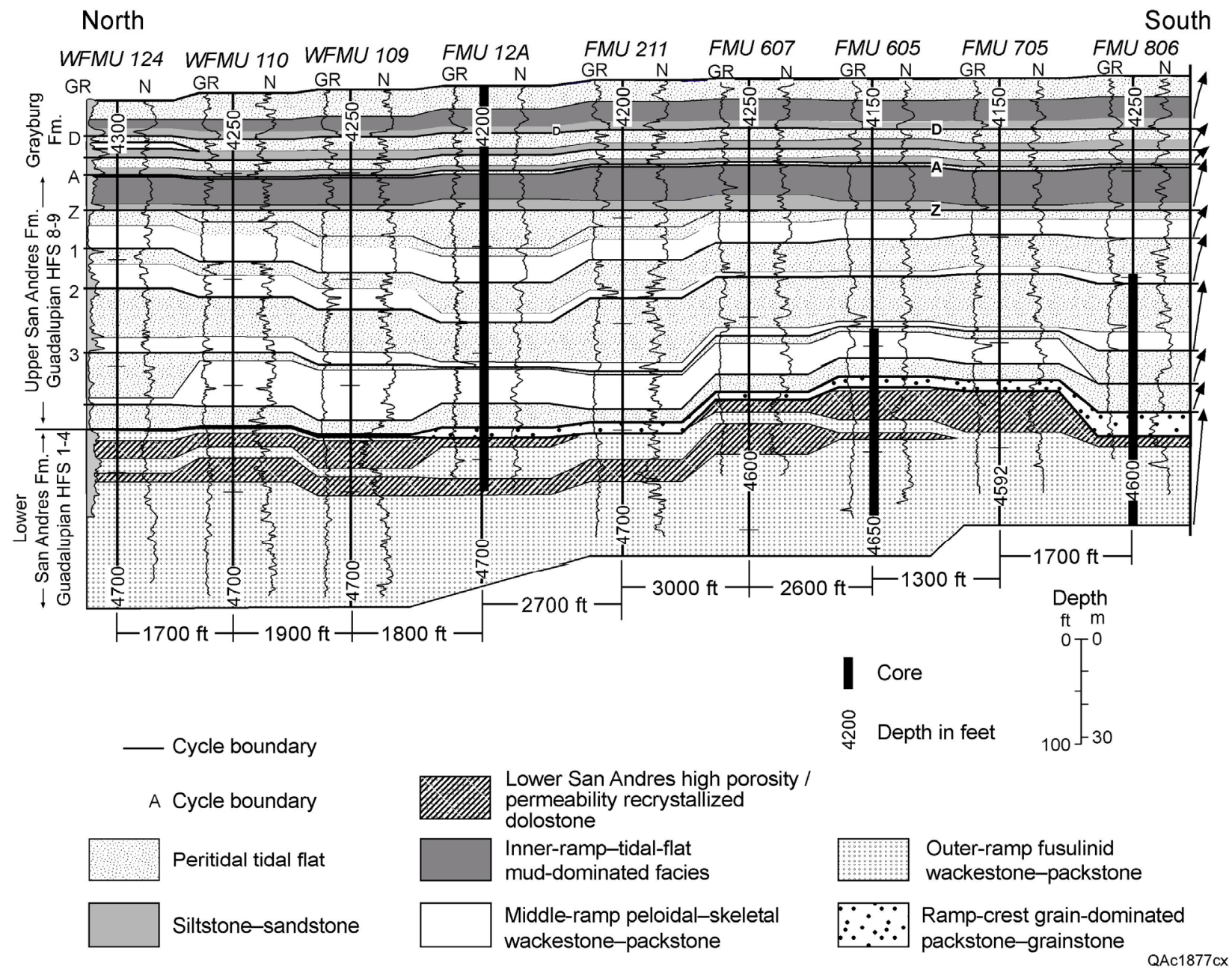

Figure 96. North-south cross section of Fuhrman-Mascho field showing the cycle stratigraphy of the Grayburg and San Andres reservoir section based on cored wells. From Ruppel (2001). See Ruppel (2001) for location of cross section.

reworked during subsequent sea-level rises (Ruppel, 2001). Production from the upper San Andres interval is from permeable subtidal carbonate facies that are most abundant in the south part of the field. Production from the lower San Andres is from the interval immediately underlying the middle San Andres unconformity (fig. 96), where good porosity is developed as a result of diagenesis in a 70 -ft-thick (20-m) zone of burrowed dolomite below the unconformity (Ruppel, 2001). Waterflooding is interpreted to be an efficient recovery method in two laterally 
continuous reservoir intervals - the Grayburg clastics and the unconformity-related porous interval at the top of the lower San Andres (Ruppel, 2001). Because the better reservoir-quality zones in the upper San Andres are more discontinuous, these rocks are probably better candidates for infill drilling.

The largest reservoir in the play is North Cowden, which has produced 541.7 MMbbl $\left(8.61 \times 10^{7} \mathrm{~m}^{3}\right)($ table 33$)$. Two units within North Cowden field, East Cowden Grayburg (Petersen and Jacobs, 2003) and Corrigan Cowden (Entminger and others, 2000), are undergoing modifications to improve waterflood recovery. East Cowden Grayburg unit of North Cowden field produces from both carbonates and clastics (Petersen and Jacobs, 2003). Facies in the San Andres and Grayburg reservoir intervals include subtidal silty-sandy dolomite, shoal crossbedded skeletal grainstone, open-marine-shelf fusulinid wackestone/packstone, intertidal mudstone, supratidal intraclast wackestone/packstone, and intertidal/tidal flat sandstone/siltstone. Porosity in the carbonates is commonly 10 to 15 percent and as high as 21 percent. Permeability in the carbonates ranges from hundredths to hundreds of millidarcys. Porosity in the reservoir sandstones and siltstones is commonly 10 to 16 percent, but permeability is only 1 to $5 \mathrm{md}$ ( 1 to $5 \times 10^{-3} \mu \mathrm{m}^{2}$ ). Reservoir characterization of the unit has established a stratigraphic framework in which 21 zones were identified (Petersen and Jacobs, 2003). Bypassed pay in relatively low permeability siltstones is being targeted by horizontal drilling into those zones from existing vertical well bores.

Corrigan Cowden is located on the east side of North Cowden field. Detailed reservoir characterization was conducted to develop a stratigraphic framework for the reservoir and locate bypassed, swept, and thief (water-cycling) zones (Entminger and others, 2000). Of the four sequences recognized in the Grayburg, zone 4 has received little waterflood support, whereas 
zones 2 and 3 are cycling water. In response, a program of strategic plugbacks, redrilled and infill wells, and horizontal wells have targeted zone 4 , resulting in increased oil production and reduced water cut.

\section{References}

Entzminger, D. J., Ferdinand, K., Lawson, D., Loucks, B., Mescher, P., and Patty, K., 2000, Corrigan-Cowden - breathing new life into an old waterflood, in DeMis, W. D., Nelis, M. K., and Trentham, R. C., eds., The Permian Basin: proving ground for tomorrow's technologies: West Texas Geological Society Publication No. 00-109, p. 75.

Petersen, L. M., and Jacobs, R. S., 2003, Stratigraphic and lithologic zonation in the East Cowden Grayburg unit, Ector County, Texas: potential for horizontal redevelopment of a mature waterflood, in Hunt, T. J., and Lufholm, P. H., eds., The Permian Basin: back to basics: West Texas Geological Society Publication No. 03-112, p. 119-121.

Ruppel, S. C., 2001, Opportunities for recovery of remaining oil in San Andres reservoirs: example from Fuhrman-Mascho field, University Lands Block 10, Andrews County, Texas, in Viveiros, J. J., and Ingram, S. M., eds., The Permian Basin: microns to satellites, looking for oil and gas at all scales: West Texas Geological Society Publication No. 01-110, p. 105-125. 
Grayburg Platform Carbonate (Play 128)

The 11 reservoirs of the Grayburg Platform Carbonate play have produced 1,271.2 MMbbl $\left(2.02 \times 10^{8} \mathrm{~m}^{3}\right)$ of oil (table 34$)$. Reservoirs in this play occur on the east side of the Central Basin Platform in Texas, along the south part of the platform (fig. 97). The more southerly location of Grayburg Platform Carbonate reservoirs compared with that of the San Andres Platform Carbonate reservoirs (fig. 79) is interpreted as resulting from filling of the north half of the Midland Basin during San Andres time, which constricted the basin-rimming Grayburg facies to the remaining south half of the basin (Kosters and others, 1989). The entire facies tract prograded eastward during the early Guadalupian, so the trend of older San Andres reservoirs lies generally platformward (west) of the trend of the younger Grayburg reservoirs (Tyler and others, 1991). This shift is illustrated by Penwell, Jordan, Waddell, Dune, and McElroy fields (fig. 98). The platform interior fields — Penwell, Jordan, Waddell—produce from the San Andres Formation, and Dune and McElroy fields, at the platform structural edge, produce from the Grayburg Formation (Major and others, 1988).

Depositional style and petrophysical properties of Grayburg Platform Carbonate reservoirs are similar to those of the San Andres; both are developed in thick, dolomitized,

Table 34. Grayburg Platform Carbonate play (play 128). Production shown for fields that have had others combined into them represents the totals; combined fields are highlighted.

\begin{tabular}{|c|c|c|c|c|c|c|c|c|c|}
\hline RRC RESN & RRC & FLDNAME & RESNAME & STATE & COUNTY & DISCYR & DEPTHTOP & 2000 PROD & CUMPROD \\
\hline 9358630 & 8 & BLOCK 31 & GRAYBURG & $T X$ & CRANE & 1956 & 3200 & 523 & $4,918,490$ \\
\hline 21292001 & 8 & COWDEN, SOUTH & & TX & ECTOR & 1932 & 5050 & 877,505 & $161,204,532$ \\
\hline 21517001 & 8 & CRANE COWDEN & & TX & CRANE & 1932 & 2550 & 10,966 & $5,824,566$ \\
\hline 25742500 & 8 & DOUBLE -H- & GRAYBURG & TX & ECTOR & 1955 & 4456 & 39,062 & $4,217,866$ \\
\hline 26538001 & 8 & DUNE & & $\mathrm{TX}$ & CRANE & 1938 & 3270 & 849,214 & $192,685,765$ \\
\hline 27739001 & 8 & EDWARDS & & $\mathrm{TX}$ & ECTOR & 1935 & 3400 & 43,924 & $9,431,134$ \\
\hline 32309001 & 8 & FOSTER & & $\mathrm{TX}$ & ECTOR & 1935 & 4300 & $2,033,797$ & $284,565,604$ \\
\hline 47007001 & 8 & JOHNSON & & $\mathrm{TX}$ & ECTOR & 1934 & 4200 & 370,516 & $35,981,707$ \\
\hline 59337001 & 8 & MCELROY & & TX & CRANE & 1926 & 2900 & $5,863,727$ & $569,725,971$ \\
\hline 61269500 & $7 \mathrm{C}$ & MIETHER & GRAYBURG & TX & UPTON & 1956 & 3241 & 4,009 & $1,049,526$ \\
\hline 63143500 & 8 & MOSS & GRAYBURG & $\mathrm{TX}$ & ECTOR & 1955 & 3543 & 10,961 & $1,627,164$ \\
\hline & & Totals & & & & & & $10,104,204$ & $1,271,232,325$ \\
\hline
\end{tabular}




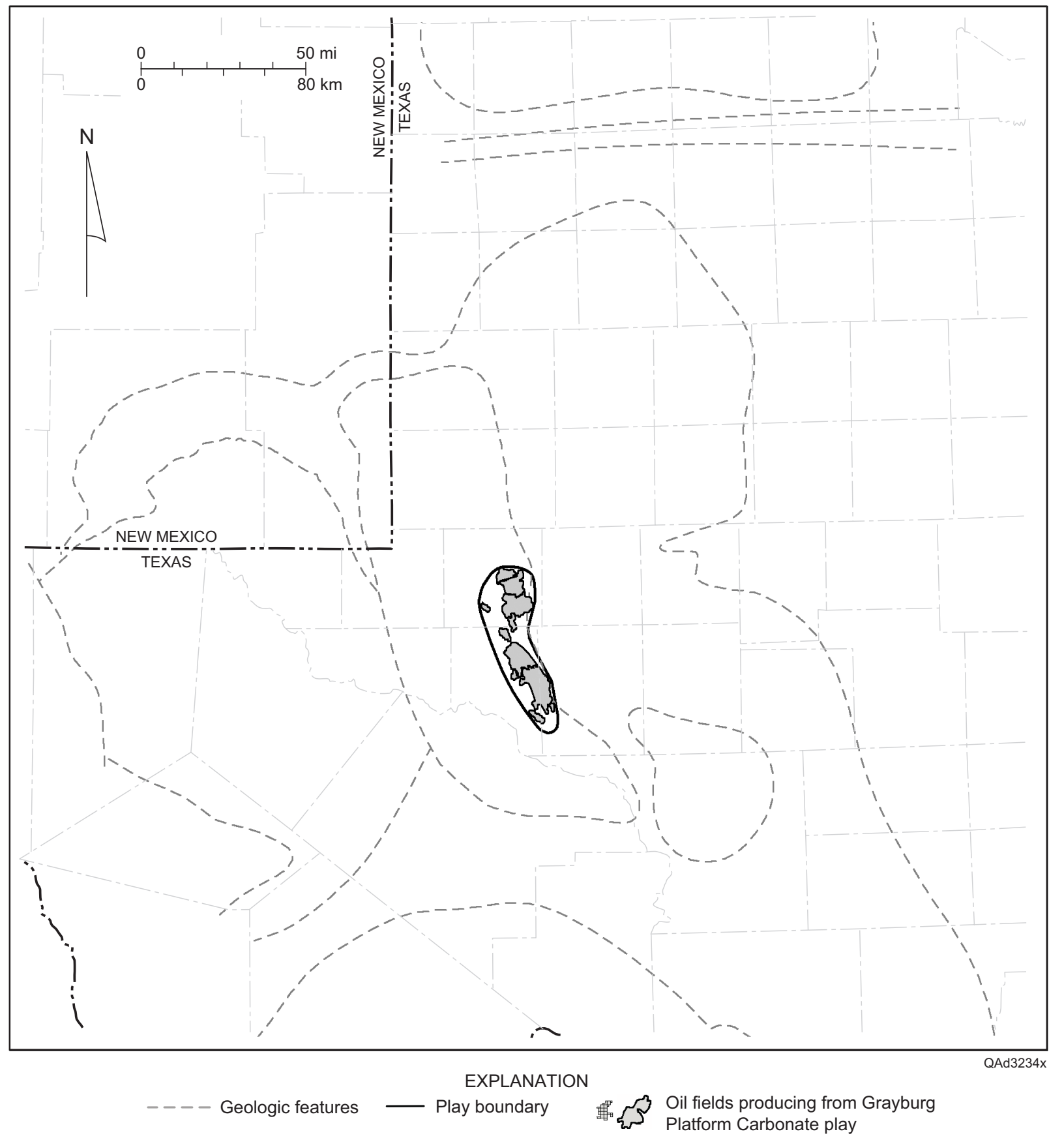

Figure 97. Play map for the Grayburg Platform Carbonate play, showing location of reservoirs having $>1 \mathrm{MMbbl}$ cumulative production, the play boundary, and geologic features. See figure 1 for county names and figure 2 for identification of geologic features. 


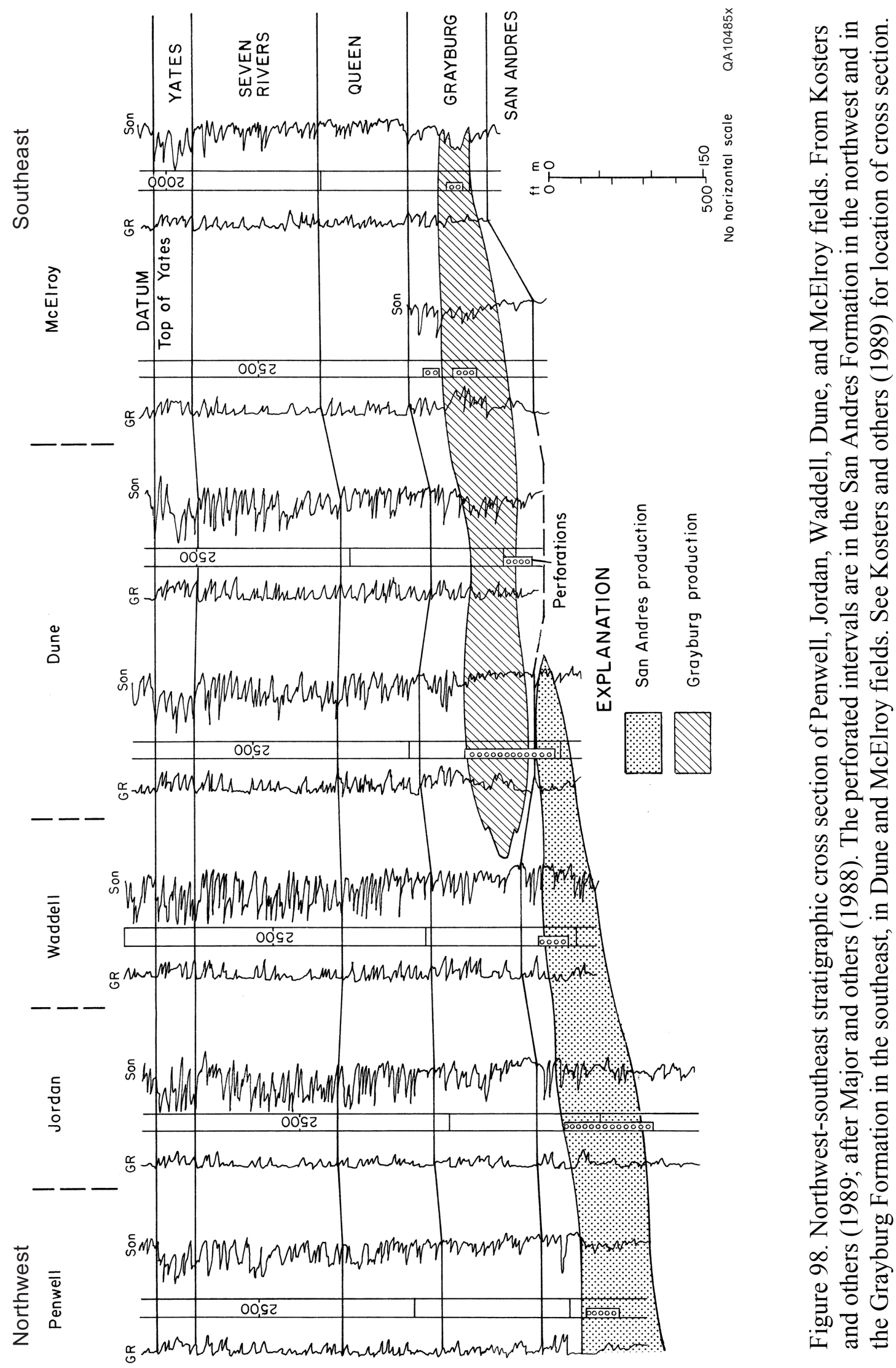


subtidal parts of upward-shoaling cycles (Bebout and others, 1987; Tyler and others, 1991).

Siliciclastic siltstone is abundant in the top part of the Grayburg, where it grades into the overlying interbedded Queen siltstone and anhydrite. Outcrop studies in the Guadalupe Mountains (Kerans and Nance, 1991; Kerans and Fitchen, 1995) and Brokeoff Mountains (Barnaby and Ward, 1995) developed a sequence and cycle stratigraphic framework of the Grayburg Formation that can be used for correlating the Grayburg at regional and reservoir scales.

South Cowden field in Ector County, which had produced 161.2 MMbbl $\left(2.56 \times 10^{7} \mathrm{~m}^{3}\right)$ through 2000 (table 34), has been the subject of several reservoir characterization studies. Investigations of Moss, Emmons, and South Cowden units were published by Lucia and Ruppel (1996), Ruppel and Lucia (1996), Jennings and others (1998), Lucia (2000), Ruppel and Bebout (2001), and Ruppel and others (2002). The Grayburg Formation at South Cowden field was divided into four high-frequency sequences (HFS's) (fig. 99). The lower two HFS's record platform flooding and backstepping, HFS 3 records maximum flooding, and HFS 4 records aggradation and progradation of the platform during sea-level highstand (Ruppel and Lucia, 1996; Jennings and others, 1998). The reservoir is developed mainly in HFS 3 and 4, and these sequences were divided into chronostratigraphic high-frequency cycles to provide a detailed geologic framework (fig. 100). Reservoir quality at South Cowden has been strongly overprinted by diagenesis, particularly dolomite alteration and anhydrite alteration and removal (Ruppel and Lucia, 1996; Jennings and others, 1998). The reservoir interval is composed mainly of grain-dominated dolopackstones, medium crystalline mud-dominated dolostones, and a touching-vug pore system composed of dissolved anhydrite nodules, molds of fusulinids, and microfractures (Lucia, 2000). 


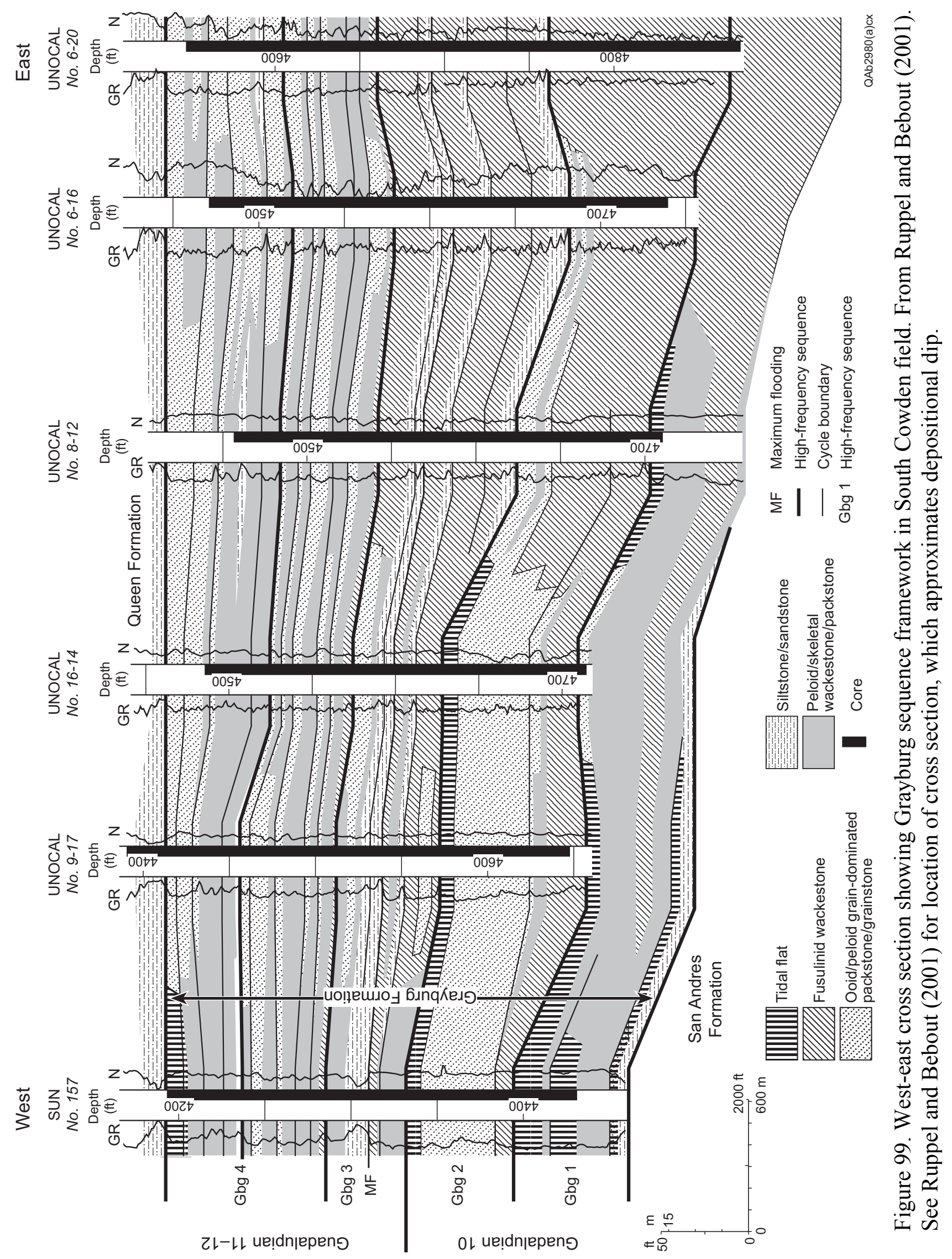




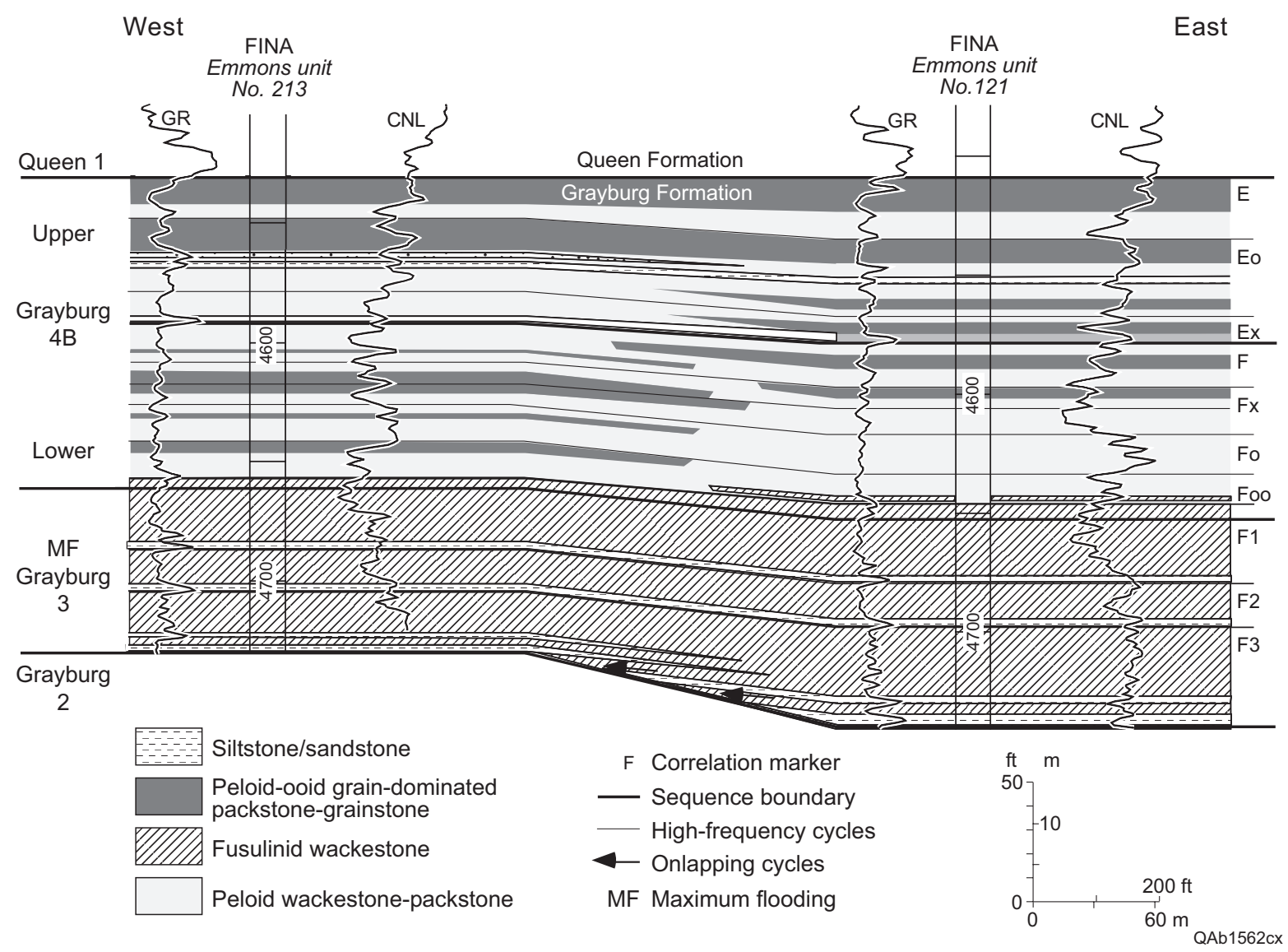

Figure 100. West-east cross section showing high-frequency cycles in Grayburg highstand deposits in South Cowden field. From Ruppel and Lucia (1996). The cycles, averaging 10 to $15 \mathrm{ft}$ in thickness, are correlative throughout the field. See Ruppel and Lucia (1996) for location of cross section.

Highest porosity and permeability in the field are on the east and south margins of the field (Ruppel and Lucia, 1996; Saller and Henderson, 1998), where diagenetic alteration has been most extensive (fig. 101). In this area, permeability distribution generally crosscuts stratigraphy. To the west, where the diagenetic overprint is less severe, porosity and permeability distribution are a function of facies heterogeneity, which is, in turn, controlled by high-frequency cycles (Ruppel and Lucia, 1996). Average porosity in the Grayburg reservoir is 8.8 percent and average permeability is $15 \mathrm{md}\left(15 \times 10^{-3} \mu \mathrm{m}^{2}\right)$. On the east side of the field, in zones of leached anhydrite, porosity is as high as 20 percent, and permeability reaches several hundred millidarcys 


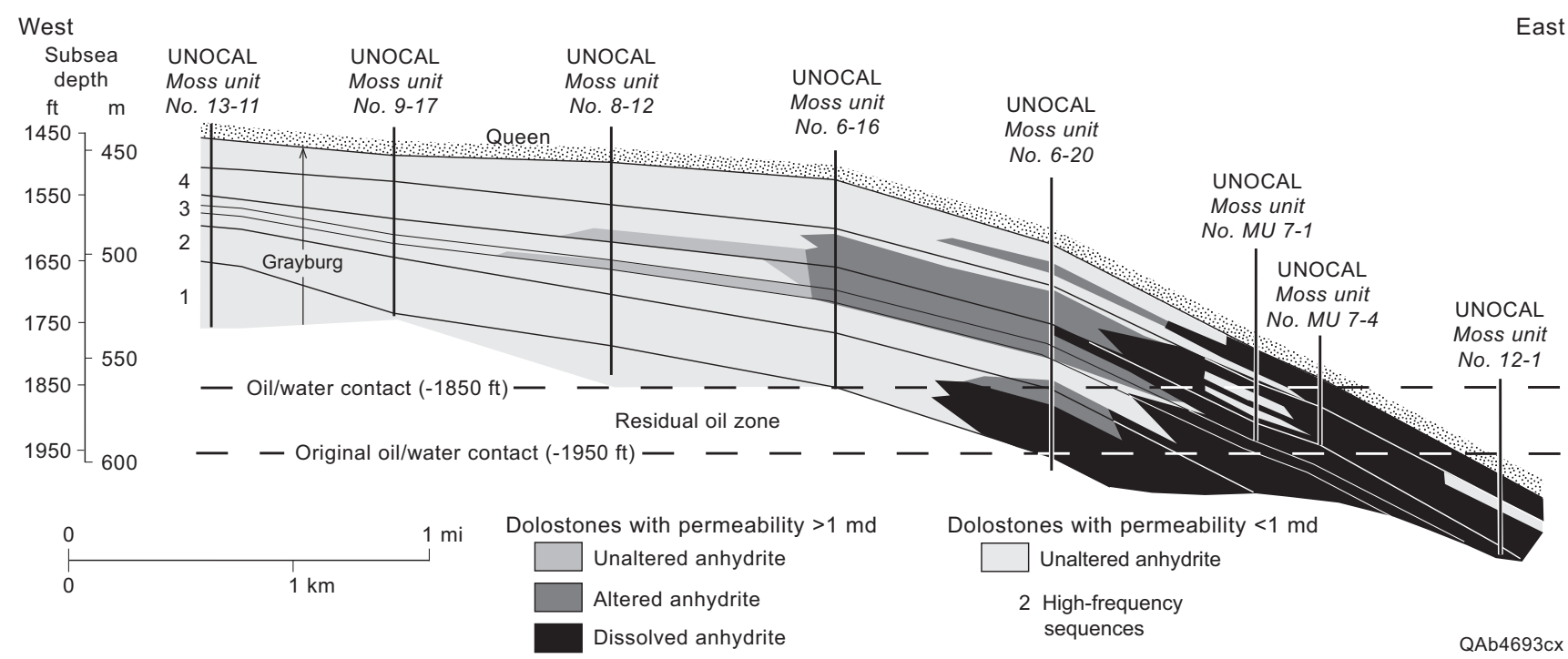

Figure 101. West-east cross section showing that permeability in South Cowden Grayburg is better developed to the east, in the downdip margins of the field where dolomite alteration and anhydrite dissolution have been most extensive. From Ruppel and Lucia (1996). See Ruppel and Lucia (1996) for location of cross section.

(Saller and Henderson, 1998; Lucia, 2000). In the central to west side of the field, porosity averages 4 to 5 percent, and permeability 0.1 to $0.3 \mathrm{md}\left(0.1\right.$ to $\left.0.3 \times 10^{-3} \mu^{2}\right)$ (Saller and Henderson, 1998). Comparison of wireline logs and 3-D seismic amplitude data suggests that amplitude can be used to map horizontal-porosity distribution in the reservoir (Ruppel and others, 2002).

Waterflooding at South Cowden field has been disappointing, having only recovered 21 percent of OOIP, which is 46 percent of the estimated displaceable oil (Jennings and others, 1998; Lucia, 2000). Poor waterflood recovery is due partly to completion of injection and production wells in only the top half of the formation. Bypassed mobile oil remains in zones having permeability of 0.1 to $1.0 \mathrm{md}\left(0.1\right.$ to $\left.1.0 \times 10^{-3} \mu \mathrm{m}^{2}\right)$ because no water is injected into these lower permeability units (Lucia, 2000). Mobile oil also remains in higher permeability 
zones between injection wells in areas of high permeability-thickness (kh) because floodwater streams from the injector to the producer.

Production from South Cowden unit was increased moderately by a $\mathrm{CO}_{2}$ flood using horizontal $\mathrm{CO}_{2}$ injection wells drilled into zones of higher quality reservoir rock (Phillips Petroleum Company, 2002; Schatzinger, 2003). Inability to maintain $\mathrm{CO}_{2}$ injection rate in the targeted zones resulted in poor oil response from many of the wells. However, oil response was good in wells where $\mathrm{CO}_{2}$ injection rates could be maintained in desired injection intervals.

Reservoir characterization and three-dimensional seismic inversion were conducted in Foster and South Cowden fields to identify productive zones in the Grayburg reservoir (Weinbrandt and others, 1998; Trentham and Widner, 1999; Trentham and others, 2000; Schatzinger, 2003). Application of inversion modeling techniques by relating seismic velocity to neutron density enabled detailed porosity mapping to identify bypassed oil zones. The modeling was used to target 3 reentry wells, 4 new wells, and 12 workovers; this work increased production from $37 \mathrm{bbl} / \mathrm{d}\left(5.9 \mathrm{~m}^{3} / \mathrm{d}\right)$ to as much as $467 \mathrm{bbl} / \mathrm{d}\left(74.2 \mathrm{~m}^{3} / \mathrm{d}\right)$. After 2 years, production was maintaining a rate of $280 \mathrm{bbl} / \mathrm{d}\left(44.5 \mathrm{~m}^{3} / \mathrm{d}\right)($ Schatzinger, 2003).

Seismic-attribute analysis of the Grayburg was also used in Corrigan Cowden unit (Ferdinand and others, 2002). A statistically significant relationship between porosity $\times$ thickness (PhiH) and relative amplitude was used to map PhiH across the unit. Areas of high $\mathrm{PhiH}$ that had not previously been penetrated by wells were identified. These areas were targeted by eight lateral wells drilled from existing vertical boreholes, and production was increased by $306 \mathrm{bbl} / \mathrm{d}$ $\left(48.7 \mathrm{~m}^{3} / \mathrm{d}\right)$.

McElroy field, which produced 569.7 MMbbl $\left(9.06 \times 10^{7} \mathrm{~m}^{3}\right)$ of oil through 2000 and is the largest reservoir in the play (table 34), has been the target of numerous reservoir 
characterization studies (Longacre, 1980, 1983, 1990); Harris and others, 1984; Walker and Harris, 1986; Harris and Walker, 1990a, b; Tucker and others, 1998; Dehghani and others, 1999). The reservoir produces from a combined structural-stratigraphic trap (Harris and Walker, 1990a). Prior to deposition of the Grayburg Formation at McElroy field, a regression exposed the underlying San Andres carbonate platform. During subsequent reflooding of the platform, an upward-shoaling sequence of Grayburg carbonate-shelf deposits accumulated (Harris and Walker, 1990a). Open-shelf deposits at the base of the sequence are overlain by shallow-shelf facies and capped by shallow-shelf to intertidal sediments of the upper Grayburg. The Grayburg carbonate deposits at McElroy field are anhydritic dolostones that are more evaporitic and silty toward the top of the formation (Tucker and others, 1998). Terrigenous and evaporite sediments of the Queen Formation, deposited in a supratidal environment, form the reservoir top seal. The main pay interval produces from peloidal dolograinstones and packstones having interparticle and intercrystalline porosity (Tucker and others, 1998). Anhydrite and gypsum reduce interparticle porosity in some areas, and in other areas dissolution of dolomitized grains created vuggy and moldic pores.

McElroy field produces $\sim 17,000 \mathrm{bbl} / \mathrm{d}\left(2.70 \times 10^{3} \mathrm{~m}^{3} / \mathrm{d}\right)$ from a mature waterflood (Dehghani and others, 1999). Thin zones of high vuggy porosity and permeability in the central part of the field decrease waterflood effectiveness and result in bypassed oil being left in the lower permeability matrix. A method was developed to incorporate vuggy zones into reservoir simulation models. History matching of the simulation models indicates that core data underestimate the permeability of vuggy zones (Dehghani and others, 1999).

Part of McElroy field is undergoing a $\mathrm{CO}_{2}$ pilot flood (Bashore and others, 1995; Tucker and others, 1998). Cross-well seismic data were acquired in the area of the pilot flood and 
combined with core and $\log$ data to provide information about interwell-scale heterogeneity.

Velocity and acoustic impedance are controlled mainly by total porosity and changes in mineralogy. Reservoir quality is controlled by a combination of depositional textures and diagenetic overprint. Because both cross-well seismic and log data respond to the diagenetic overprint and petrophysical properties, log facies were used for correlating reservoir flow units and relating them to cross-well images (Tucker and others, 1998).

Dune field lies northwest of McElroy field (fig. 97). The structure on which Dune and McElroy fields are located appears to be controlled by drape over buried Pennsylvanian fault blocks. Dune field produces from multiple cycles of subtidal to tidal-flat sediments (Bebout and others, 1987). OOIP of Dune field was estimated to be $978 \mathrm{MMbbl}\left(1.55 \times 10^{8} \mathrm{~m}^{3}\right)$, and the field had produced 192.7 MMbbl $\left(3.06 \times 10^{7} \mathrm{~m}^{3}\right)$ through 2000. Black-oil simulation experiments indicate that geologically targeted infill wells would improve recovery (Fogg and Lucia, 1990).

Mobile-oil recovery efficiency is 45 to 50 percent at the current well spacing of 10 acres.

Simulations indicate that reducing well spacing to 2.5 acres would increase mobile-oil recovery efficiency by about 30 percentage points (Fogg and Lucia, 1990; Tyler and others, 1991).

\section{References}

Barnaby, R. J., and Ward, W. B., 1995, Sequence stratigraphic framework, high-frequency cyclicity, and three-dimensional heterogeneity: Grayburg Formation, Brokeoff Mountains, New Mexico, in Pause, P. H., and Candelaria, M. P., eds., Carbonate facies and sequence stratigraphy: practical applications of carbonate models: Permian Basin Section SEPM (Society for Sedimentary Geology), Publication No. 95-36, p. 37-49.

Bashore, W. M., Langan, R. T., Tucker, K. E., and Griffith, P. J., 1995, Geostatistical integration of crosswell data for carbonate reservoir modeling, McElroy field, Texas, in Stoudt, E. L., and Harris, P. M., eds., Hydrocarbon reservoir characterization: geologic framework and flow unit modeling: SEPM (Society for Sedimentary Geology), SEPM Short Course No. 34, p. 199-225. 
Bebout, D. G., Lucia, F. J., Hocott, C. R., Fogg, G. E., and Vander Stoep, G. W., 1987, Characterization of the Grayburg reservoir, University Lands Dune field, Crane County, Texas: The University of Texas at Austin, Bureau of Economic Geology Report of Investigations No. 168, 98 p.

Dehghani, K., Harris, P. M., Edwards, K. A., and Dees, W. T., 1999, Modeling a vuggy carbonate reservoir, McElroy field, west Texas: American Association of Petroleum Geologists Bulletin, v. 83, p. 19-42.

Ferdinand, K. J., Entzminger, D. J., and Lawson, D., 2002, The integration of seismic attributes and rock properties for mapping porosity thickness in the heterogeneous Grayburg carbonate reservoir, Corrigan Cowden unit, west Texas, in Hunt, T. J., and Lufholm, P. H., eds., Permian Basin: preserving our past—securing our future: West Texas Geological Society Publication No. 02-111, p. 209-210.

Fogg, G. E., and Lucia, F. J., 1990, Reservoir modeling of restricted platform carbonates: geologic/geostatistical characterization of interwell-scale reservoir heterogeneity, Dune field, Crane County, Texas: The University of Texas at Austin, Bureau of Economic Geology Report of Investigations No. 190, 66 p.

Harris, P. M., Dodman, C. A., and Bliefnick, D. M., 1984, Permian (Guadalupian) reservoir facies, McElroy field, west Texas, in Harris, P. M., ed., Carbonate sands - a core workshop: Society of Economic Paleontologists and Mineralogists Core Workshop No. 5, p. 136-174.

Harris, P. M., and Walker, S. D., 1990a, McElroy field, in Beaumont, E. A., and Foster, N. H., eds., Atlas of oil and gas fields, stratigraphic traps volume I: traps associated with tectonic faulting: American Association of Petroleum Geologists Treatise of Petroleum Geology, p. 195-227.

Harris, P. M., and Walker, S. D., 1990b, McElroy field: development geology of a dolostone reservoir, Permian Basin, west Texas, in Bebout, D. G. and Harris, P. M., eds., Geologic and engineering approaches in evaluation of San Andres/Grayburg hydrocarbon reservoirs - Permian Basin: The University of Texas at Austin, Bureau of Economic Geology Publication, p. 275-296.

Jennings, J. W., Jr., Lucia, F. J., and Ruppel, S. C., 1998, Waterflood performance modeling for the South Cowden Grayburg reservoir, Ector County, Texas: The University of Texas at Austin, Bureau of Economic Geology Report of Investigations No. 247, 46 p.

Kerans, C., and Fitchen, W. M., 1995, Sequence hierarchy and facies architecture of a carbonateramp system: San Andres Formation of Algerita Escarpment and western Guadalupe Mountains, west Texas and New Mexico: The University of Texas at Austin, Bureau of Economic Geology Report of Investigations No. 235, 86 p. 
Kerans, C., and Nance, H. S., 1991, High-frequency cyclicity and regional depositional patterns of the Grayburg Formation, Guadalupe Mountains, New Mexico, in Meader-Roberts, S., Candelaria, M. P., and Moore, G. E., eds., Sequence stratigraphy, facies, and reservoir geometries of the San Andres, Grayburg, and Queen Formations, Guadalupe Mountains, New Mexico and Texas: Permian Basin Section, Society of Economic Paleontologists and Mineralogists, Publication No. 91-32, p. 53-96.

Kosters, E. C., Bebout, D. G., Seni, S. J., Garrett, C. M., Jr., Brown, L. F., Jr., Hamlin, H. S., Dutton, S. P., Ruppel, S. C., Finley, R. J., and Tyler, Noel, 1989, Atlas of major Texas gas reservoirs: The University of Texas at Austin, Bureau of Economic Geology Special Publication, $161 \mathrm{p}$.

Longacre, S. A., 1980, Dolomite reservoirs from Permian biomicrites, in Halley, R. B., and Loucks, R. G., eds., Carbonate reservoir rocks: Society of Economic Paleontologists and Mineralogists Core Workshop No. 1, p. 105-117.

Longacre, S. A., 1983, A subsurface example of a dolomitized Middle Guadalupian (Permian) reef from west Texas, in Harris, P. M., ed., Carbonate buildups - a core workshop: Society of Economic Paleontologists and Mineralogists Core Workshop No. 4, p. 304326.

Longacre, S. A., 1990, The Grayburg reservoir, North McElroy unit, Crane County, Texas, in Bebout, D. G. and Harris, P. M., eds., Geologic and engineering approaches in evaluation of San Andres/Grayburg hydrocarbon reservoirs-Permian Basin: The University of Texas at Austin, Bureau of Economic Geology Publication, p. 239-273.

Lucia, F. J., 2000, Petrophysical characterization and distribution of remaining mobile oil: South Cowden Grayburg reservoir, Ector County, Texas: The University of Texas at Austin, Bureau of Economic Geology Report of Investigations No. 260, 54 p.

Lucia, F. J., and Ruppel, S. C., 1996, Characterization of diagenetically altered carbonate reservoirs, South Cowden Grayburg reservoir, west Texas: Society of Petroleum Engineers Annual Technical Conference and Exhibition, SPE 36650, p. 883-893.

Major, R. P., Bebout, D. G., and Lucia, F. J., 1988, Depositional facies and porosity distribution, Permian (Guadalupian) San Andres and Grayburg Formations, P.J.W.D.M. field complex, Central Basin Platform, west Texas, in Lomando, A. J., and Harris, P. M., eds., Giant oil and gas fields: a core workshop: Society of Economic Paleontologists and Mineralogists, Core Workshop No. 12, p. 615-648.

Phillips Petroleum Company, 2002, Design and implementation of a $\mathrm{CO}_{2}$ flood utilizing advanced reservoir characterization and horizontal injection wells in a shallow shelf carbonate approaching waterflood depletion: Phillips Petroleum Company, final report prepared for U.S. Department of Energy, Assistant Secretary for Fossil Energy, under contract no. DE-FC22-94BC14991, 450 p. 
Ruppel, S. C., and Bebout, D. G., 2001, Competing effects of depositional architecture and diagenesis on carbonate reservoir development: Grayburg Formation, South Cowden field, west Texas: The University of Texas at Austin, Bureau of Economic Geology Report of Investigations No. 263, 62 p.

Ruppel, S. C., and Lucia, F. J., 1996, Diagenetic control of permeability development in a highly cyclic, shallow water carbonate reservoir: South Cowden Grayburg field, Ector County, Texas, in Martin, R. L., ed., Permian Basin oil and gas fields: keys to success that unlock future reserves: West Texas Geological Society Publication 96-101, p. 7-24.

Ruppel, S. C., Park, Y. J., and Lucia, F. J., 2002, Applications of 3-D seismic to exploration and development of carbonate reservoirs: South Cowden Grayburg field, west Texas, in Hunt, T. J., and Lufholm, P. H., eds., Permian Basin: preserving our past-securing our future: West Texas Geological Society Publication No. 02-111, p. 71-87.

Saller, A. H., and Henderson, N., 1998, Distribution of porosity and permeability in platform dolomites: insight from the Permian of west Texas: American Association of Petroleum Geologists Bulletin, v. 82, p. 1528-1550.

Schatzinger, V. R., 2003, Class II shallow-shelf carbonate reservoirs: The Class Act, v. 9, no. 1, p. $1-15$.

Trentham, R. C., Weinbrandt, R., Robinson, W. C., and Widner, K., 2000, An integrated study of the Grayburg/San Andres reservoir, Foster and South Cowden fields, Ector County, Texas: Laguna Petroleum Corporation, final report prepared for U.S. Department of Energy, Assistant Secretary for Fossil Energy, under contract no. DE-FC22-94BC14982, 33 p. plus 37 figures.

Trentham, R. C., and Widner, K. L., 1999, Using produced water analyses to evaluate production problems and recompletions in an "old" waterflood: Foster-South Cowden fields, Ector County, Texas, in Grace, D. T., and Hinterlong, G. D., eds., The Permian Basin: providing energy for America: West Texas Geological Society Publication No. 99-106, p. $9-18$.

Tucker, K. E., Harris, P. M., and Nolen-Hoeksema, R. C., 1998, Geologic investigation of crosswell seismic response in a carbonate reservoir, McElroy field, west Texas: American Association of Petroleum Geologists Bulletin, v. 82, p. 1463-1503.

Tyler, N., Bebout, D. G., Garrett, C. M., Jr., Guevara, E. H., Hocott, C. R., Holtz, M. H., Hovorka, S. D., Kerans, C., Lucia, F. J., Major, R. P., Ruppel, S. C., and Vander Stoep, G. W., 1991, Integrated characterization of Permian Basin reservoirs, University Lands, West Texas: targeting the remaining resource for advanced oil recovery: The University of Texas at Austin, Bureau of Economic Geology Report of Investigations No. 203, $136 \mathrm{p}$. 
Walker, S. D., and Harris, P. M., 1986, McElroy field, development of a dolomite reservoir, Permian Basin of west Texas, in Bebout, D. G., and Harris, P. M., eds., Hydrocarbon reservoir studies, San Andres/Grayburg Formations, Permian Basin: Permian Basin Section, Society of Economic Paleontologists and Mineralogists, Publication No. 86-26, p. $127-132$.

Weinbrandt, R. M., Trentham, R. C., and Robinson, W., 1998, Incorporating seismic attribute porosity into a flow model of the Grayburg reservoir in the Foster-South Cowden field, in DeMis, W. D. and Nelis, M. K., eds., The search continues into the 21 st century: West Texas Geological Society Publication No. 98-105, p. 231-238. 
Grayburg High-Energy Platform Carbonate-Ozona Arch (Play 129)

The Grayburg High-Energy Platform Carbonate-Ozona Arch play consists of 21 reservoirs located on the Ozona Arch in Crockett and Reagan Counties (fig. 102) that had produced $>1$ MMbbl $\left(1.59 \times 10^{5} \mathrm{~m}^{3}\right)$ of oil through 2000; cumulative production from the play is 298.4 MMbbl $\left(4.74 \times 10^{7} \mathrm{~m}^{3}\right)($ table 35$)$. The reservoirs in the play produce from the upper San Andres and Grayburg Formations. By Grayburg time, the Midland Basin was small and shallow, and the Ozona Arch was a shallow-water platform, across which water was exchanged between the open ocean to the south and the restricted basin to the north (Tyler and others, 1991).

The reservoir section in these fields, commonly $>300 \mathrm{ft}(>90 \mathrm{~m})$ thick, is composed of numerous upward-shoaling cycles that are 15 to $40 \mathrm{ft}$ (5 to $12 \mathrm{~m}$ ) thick (Tyler and others, 1991). Siltstone and silty mudstones to wackestones in the lower part of each cycle grade upward into packstone to grainstone in the upper part. Each cycle represents subtidal, low-energy conditions in the lower part and stable-grain-flat to high-energy-bar environments at the top

Table 35. Grayburg High-Energy Platform Carbonate-Ozona Arch play (play 129). Production shown for fields that have had others combined into them represents the totals; combined fields are highlighted.

\begin{tabular}{|c|c|c|c|c|c|c|c|c|c|}
\hline RRC RESN & RRC & FLDNAME & RESNAME & STATE & COUNTY & DISCYR & DEPTHTOP & 2000 PROD & CUMPROD \\
\hline 7919001 & $7 \mathrm{C}$ & BIG LAKE & & $\mathrm{TX}$ & REAGAN & 1923 & 3000 & 304,598 & $133,973,558$ \\
\hline 9521500 & $7 C$ & BLOCK 49 & 2450 & TX & REAGAN & 1955 & 2456 & 47,125 & $2,134,823$ \\
\hline 18500001 & $7 \mathrm{C}$ & CLARA COUCH & & $\mathrm{TX}$ & CROCKETT & 1941 & 2186 & 31,529 & $6,596,133$ \\
\hline 30243500 & $7 \mathrm{C}$ & FARMER & SAN ANDRES & TX & CROCKETT & 1953 & 2240 & 588,661 & $28,675,225$ \\
\hline 36565001 & $7 \mathrm{C}$ & GRAYSON & & TX & REAGAN & 1928 & 3050 & 7,320 & $1,482,688$ \\
\hline 38156001 & $7 \mathrm{C}$ & HALFF & & $\mathrm{TX}$ & CROCKETT & 1951 & 1680 & 12,847 & $3,991,162$ \\
\hline 46935500 & $7 \mathrm{C}$ & JOHN SCOTT & GRAYBURG & $\mathrm{TX}$ & REAGAN & 1953 & 2534 & 71,464 & $5,505,146$ \\
\hline 61204875 & $7 \mathrm{C}$ & MIDWAY LANE & 1300 & $\mathrm{TX}$ & CROCKETT & 1953 & 1300 & 8,181 & $1,712,554$ \\
\hline 61204500 & $7 \mathrm{C}$ & MIDWAY LANE & PERMIAN & $T X$ & CROCKETT & 1956 & 1124 & 99,118 & $7,686,681$ \\
\hline 67284001 & $7 \mathrm{C}$ & OLSON & & $\mathrm{TX}$ & CROCKETT & 1940 & 1828 & 181,097 & $16,082,538$ \\
\hline 73085500 & $7 \mathrm{C}$ & PRICE & GRAYBURG & $\mathrm{TX}$ & REAGAN & 1953 & 2410 & 140,825 & $6,437,211$ \\
\hline 73468001 & $7 \mathrm{C}$ & PURE-BEAN & & TX & CROCKETT & 1952 & 1360 & 8,747 & $1,876,345$ \\
\hline 82663568 & $7 \mathrm{C}$ & SHANNON & SAN ANDRES & TX & CROCKETT & 1943 & 2406 & 43,596 & $12,449,849$ \\
\hline 83703001 & $7 \mathrm{C}$ & SIMPSON & & $\mathrm{TX}$ & CROCKETT & 1938 & 1985 & 23,756 & $1,118,315$ \\
\hline 89198500 & $7 \mathrm{C}$ & TEXON, S & GRAYBURG & $\mathrm{TX}$ & REAGAN & 1968 & 3266 & 16,426 & $1,275,271$ \\
\hline 90314400 & $7 \mathrm{C}$ & TODD & SAN ANDRES & TX & CROCKETT & 1951 & 1440 & 22,675 & $2,183,638$ \\
\hline 93264001 & $7 \mathrm{C}$ & VAUGHN & & $\mathrm{TX}$ & CROCKETT & 1947 & 1445 & 54,241 & $13,265,577$ \\
\hline 95867500 & $7 \mathrm{C}$ & WEGER & SAN ANDRES & TX & CROCKETT & 1955 & 2268 & 27,872 & $2,934,749$ \\
\hline 95869001 & $7 \mathrm{C}$ & WEGER, NORTH & & TX & CROCKETT & 1955 & 2318 & 21,190 & $1,173,145$ \\
\hline 98796001 & $7 \mathrm{C}$ & WORLD & & $\mathrm{TX}$ & CROCKETT & 1925 & 2600 & 166,896 & $45,886,544$ \\
\hline 99023001 & $7 \mathrm{C}$ & WYATT & & $\mathrm{TX}$ & CROCKETT & 1940 & 1224 & 90,521 & $1,937,617$ \\
\hline \multicolumn{4}{|c|}{ Totals } & & & & & $1,968,685$ & $298,378,769$ \\
\hline
\end{tabular}




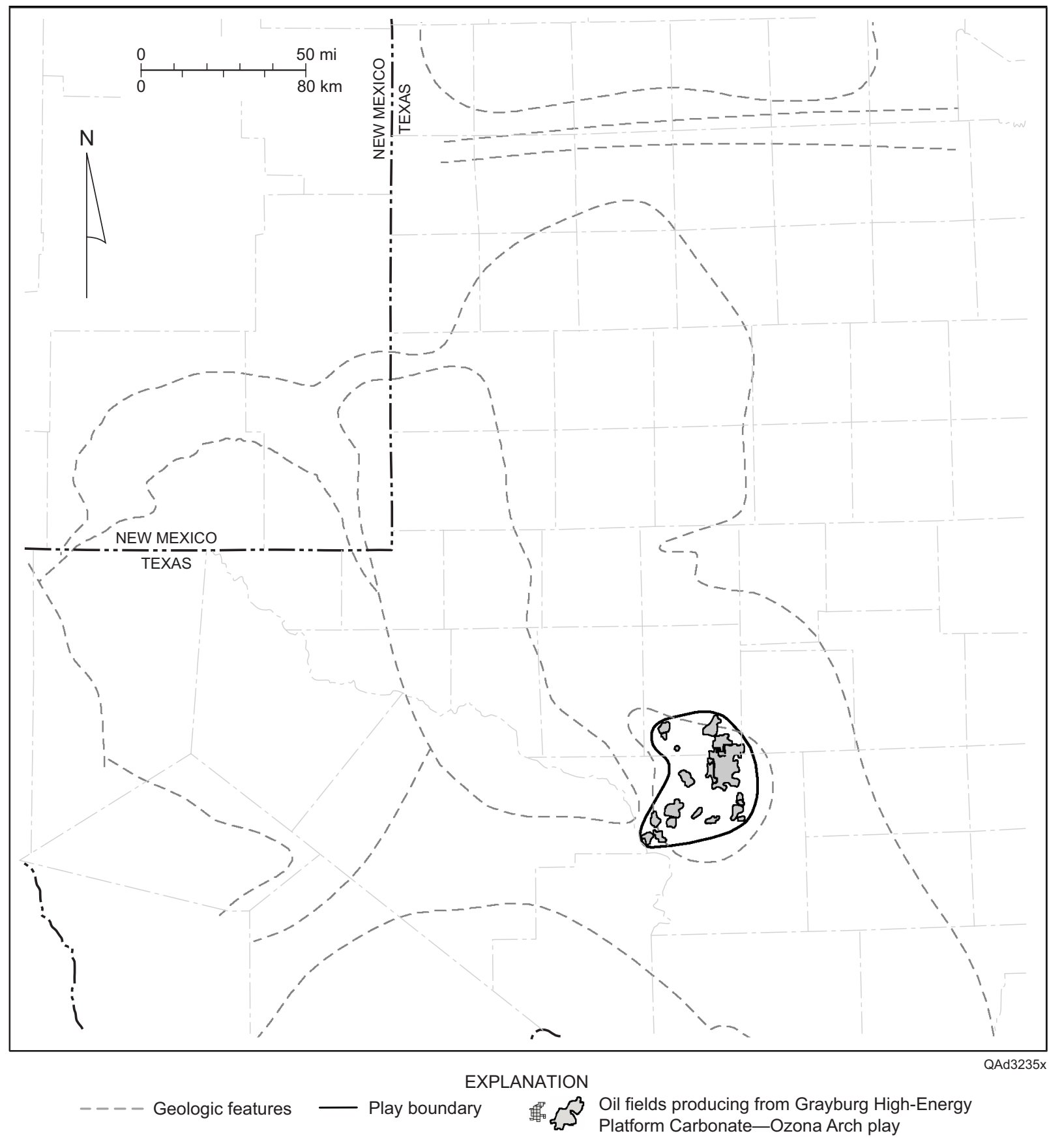

Figure 102. Play map for the Grayburg High-Energy Platform Carbonate-Ozona Arch play, showing location of reservoirs having $>1 \mathrm{MMbbl}$ cumulative production, the play boundary, and geologic features. See figure 1 for county names and figure 2 for identification of geologic features. 
(Tyler and others, 1991). Zones of intergranular porosity occur in the grainstones. Intercrystalline dolomite porosity in the mudstone and wackestone facies of the lower parts of the cycles is correlative from well to well and occurs in thicker sections, but permeability in these facies is low (Tyler and others, 1991). Low-relief structures are present in all reservoirs of this play, but porosity loss because of facies change is a major factor in formation of the trap.

Farmer field has produced 28.7 MMbbl $\left(4.56 \times 10^{6} \mathrm{~m}^{3}\right)($ table 35) from the San Andres, Grayburg, and lower part of the Queen Formation (Bebout, 1994); most production is from the Grayburg Formation (fig. 103). The Grayburg reservoir interval is approximately $350 \mathrm{ft}(107 \mathrm{~m})$ thick and is composed of 14 upward-shoaling cycles (figs. 103, 104) (Tyler and others, 1991). An ideal cycle has siltstone, silty dolomite, and skeletal wackestone at the base, skeletal and pelletal packstone and fine-grained grainstones in the middle, and coarse-grained grainstone at the top (Bebout, 1994). Grayburg cycles can be recognized using a combination of gamma-ray and resistivity logs (Bebout, 1994). The gamma-ray log responds to presence of silt at the base and decrease in silt content upward in each cycle. High resistivity at the top of each cycle reflects the presence of coarse-grained grainstones cemented with gypsum (fig. 104). Thus, the top of each cycle has low gamma-ray values ( $<30$ API units) and high resistivity $(>1,000 \mathrm{ohm}-\mathrm{m})$ (Bebout, 1994). Grainstone units are thicker on the west side of the field, whereas siltstones, wackestones, and packstones are thicker to the east (fig. 104).

Two basic pore types are present in the Farmer Grayburg reservoir: mud-dominated packstones, wackestones, and mudstones with intercrystalline pores between $10-\mu \mathrm{m}$ dolomite crystals and grain-dominated packstones and grainstones with intergranular pores and intragranular microporosity. Porosity ranges from 1 to 21 percent and averages 12 percent. 


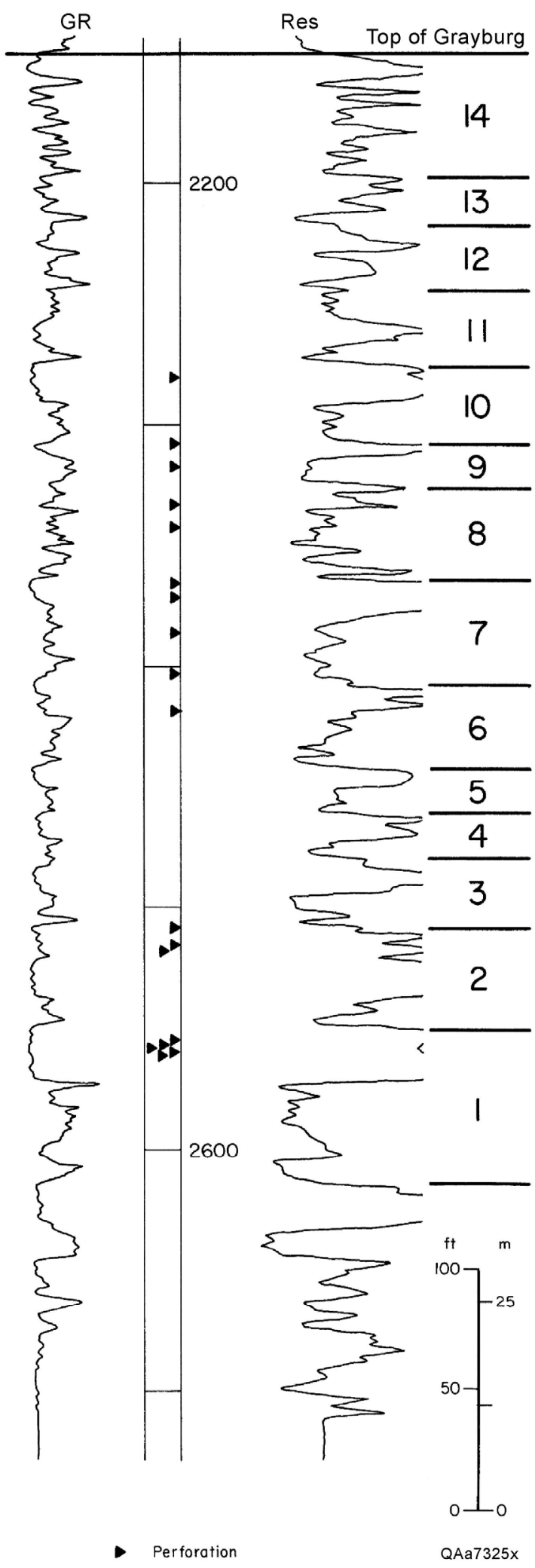

Figure 103. Typical gammaray/resistivity log from Farmer field, Crockett County. From Bebout (1994). The log is from the Marathon University P5 well; see Bebout (1994) for well location. Fourteen upwardshoaling cycles in the reservoir interval have been identified. 


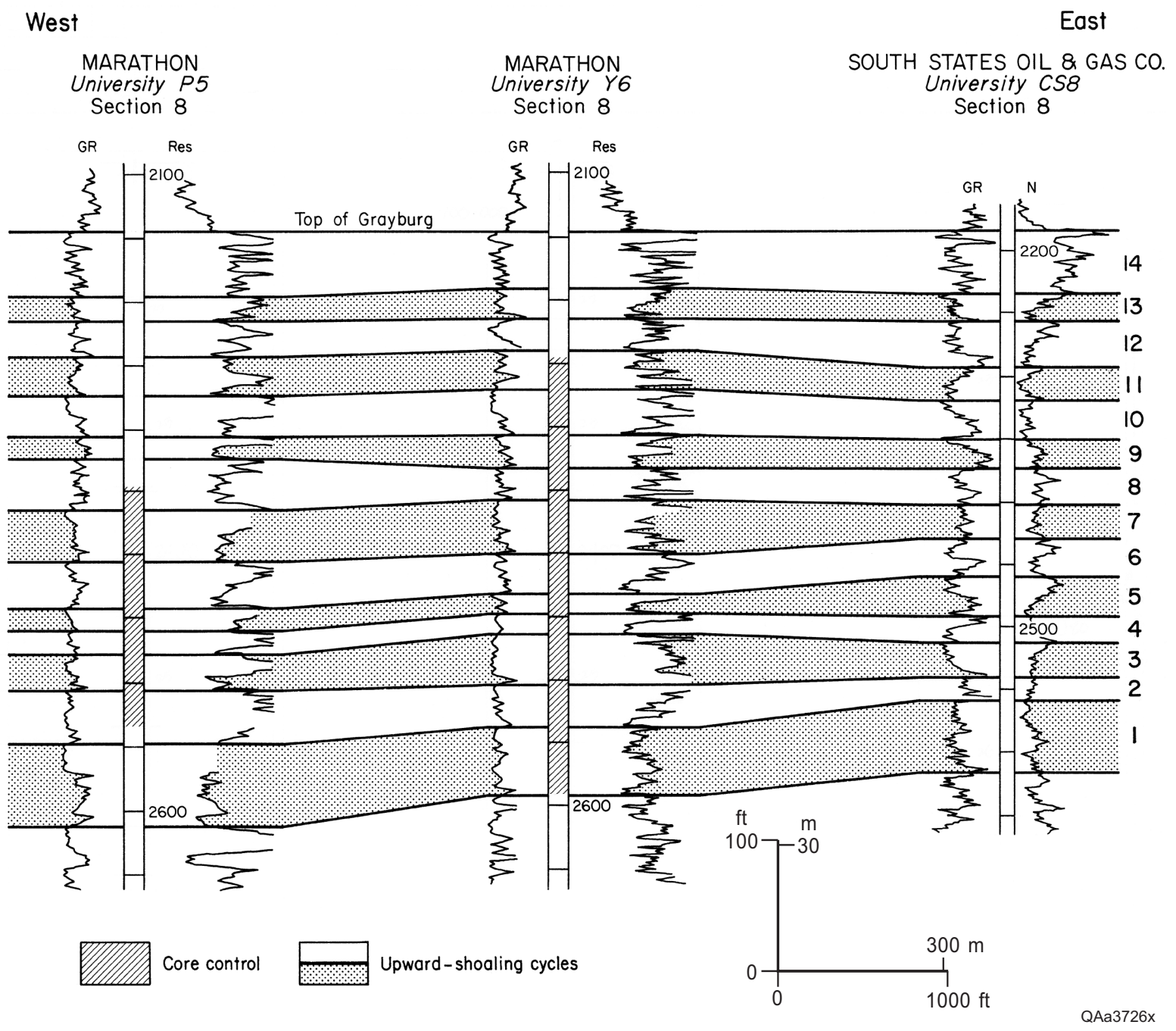

Figure 104. West-east cross section showing upward-shoaling cycles in Farmer field, Crockett County. From Bebout (1994). See Bebout (1994) for location of cross section.

Permeability ranges from $<0.01$ to $19 \mathrm{md}\left(<0.01\right.$ to $\left.19 \times 10^{-3} \mu \mathrm{m}^{2}\right)$ and averages $4 \mathrm{md}$ $\left(4 \times 10^{-3} \mu^{2}\right)$ (Bebout, 1994). Core-analysis porosity was calibrated with acoustic-log porosity because large volumes of gypsum were present.

Olson field in Crockett County (fig. 102) produces from a fractured ooid- grainstone reservoir (Zahm and Tinker, 2000; Hurley and others, 2001). Production is from ooid grainstones and fusulinid grain-dominated packstones that prograded in a basinal direction from the Ozona Arch (Zahm and Tinker, 2000). The tops of the ooid grainstones have low porosity and 
permeability because anhydrite cement fills the intergranular pore space. The best reservoirs are in the toes of the ooid shoals, which were not cemented by anhydrite.

Big Lake, the largest reservoir in this play, produced 134.0 MMbbl $\left(2.13 \times 10^{7} \mathrm{~m}^{3}\right)$ through 2000 (table 35). Big Lake field was the site of the original oil discovery on University of Texas lands by the Texon Oil and Land Company Santa Rita No. 1 well (Galloway and others, 1983). Following the Railroad Commission of Texas, we have assigned all production from Big Lake to the Grayburg reservoir, but $\sim 21 \mathrm{MMbbl}\left(\sim 3.34 \times 10^{6} \mathrm{~m}^{3}\right)$ of that production probably came from the Ellenburger (see play 101, Ellenburger Selectively Dolomitized Ramp Carbonate). Big Lake Grayburg reservoir produces from high-energy, shallow-water carbonate facies that were deposited on a structurally high fault block (Curran, 1996). The gross pay interval in the Grayburg is $170 \mathrm{ft}(52 \mathrm{~m})$, and the net pay thickness is $120 \mathrm{ft}(37 \mathrm{~m})$. Porosity ranges from 6 to 33 percent, and permeability ranges from 0.01 to $90 \mathrm{md}\left(0.01\right.$ to $\left.90 \times 10^{-3} \mu \mathrm{m}^{2}\right)$. Average permeability in dolomite is $20 \mathrm{md}\left(20 \times 10^{-3} \mu \mathrm{m}^{2}\right)$, compared with an average of $2 \mathrm{md}$ $\left(2 \times 10^{-3} \mu \mathrm{m}^{2}\right)$ in limestone facies (Curran, 1996).

\section{References}

Bebout, D. G., 1994, Farmer (Grayburg) field, in Pausé, P., and Entzminger, D., eds., Oil and gas fields in West Texas, symposium volume VI: West Texas Geological Society Publication No. 94-96, p. 61-69.

Curran, B., 1996, Big Lake Field "Grayburg," in Selected oil and gas fields in West Texas volume VII: West Texas Geological Society, Publication No. 96-99, p. 33-36.

Galloway, W. E., Ewing, T. E., Garrett, C. M., Jr., Tyler, N., and Bebout, D. G., 1983, Atlas of major Texas oil reservoirs: The University of Texas at Austin, Bureau of Economic Geology Special Publication, 139 p.

Hurley, N. F., Ustabas, S., and Zahm, L. C., 2001, Incremental oil recovery using horizontal drilling in a compartmentalized oolitic reservoir, San Andres Formation, west Texas: 
American Association of Petroleum Geologists Annual Convention Official Program, v. 10, p. A95.

Tyler, N., Bebout, D. G., Garrett, C. M., Jr., Guevara, E. H., Hocott, C. R., Holtz, M. H., Hovorka, S. D., Kerans, C., Lucia, F. J., Major, R. P., Ruppel, S. C., and Vander Stoep, G. W., 1991, Integrated characterization of Permian Basin reservoirs, University Lands, West Texas: targeting the remaining resource for advanced oil recovery: The University of Texas at Austin, Bureau of Economic Geology Report of Investigations No. 203, $136 \mathrm{p}$.

Zahm, L. C., and Tinker, S. W., 2000, 3-D reservoir characterization in the absence of seismic; Olson field, San Andres/Grayburg, west Texas: American Association of Petroleum Geologists Annual Convention Official Program, v. 9, p. A165. 
Delaware Mountain Group Basinal Sandstone (Play 130)

\section{Introduction}

The reservoirs in the Delaware Mountain Group Basinal Sandstone play produce from deepwater sandstones of the Delaware Mountain Group in the Delaware Basin (fig. 105).

The play consists of 78 reservoirs in Texas and New Mexico that had produced $>1$ MMbbl $\left(1.59 \times 10^{5} \mathrm{~m}^{3}\right)$ of oil through 2000 ; cumulative production from these reservoirs was

351.9 MMbbl $\left(5.59 \times 10^{7} \mathrm{~m}^{3}\right)($ table 36$)$. All three formations in the Delaware Mountain Group

Table 36. Delaware Mountain Group Basinal Sandstone play (play 130). Production shown for fields that have had others combined into them represents the totals; combined fields are highlighted.

\begin{tabular}{|c|c|c|c|c|c|c|c|c|c|c|}
\hline RRC RESN & RRC & FLDNAME & RESNAME & STATE & COUNTY & DISCYR & DEPTHTOP & 2000 PROD & CUMPROD & SUBPLAY \\
\hline 9288500 & 8 & BLOCK 17 , SOUTHEAST & DELAWARE & TX & WARD & 1956 & 5003 & 40,324 & $1,722,191$ & Bell Canyon \\
\hline 15499380 & 8 & CAPRITO & DELAWARE MIDDLE & $\mathrm{TX}$ & WARD & 1974 & 6164 & 193,628 & $5,587,028$ & Cherry Canyon \\
\hline 17029001 & 8 & CHAPMAN & & $T X$ & REEVES & 1948 & 2900 & 10,149 & $1,578,789$ & Bell Canyon \\
\hline 19665200 & 8 & COLLIE & DELAWARE & $\mathrm{TX}$ & WARD & 1981 & 4725 & 115,115 & $3,479,423$ & Bell Canyon \\
\hline 21382250 & 8 & COYANOSA & DELAWARE SD. & $T X$ & PECOS & 1959 & 4793 & 20,112 & $1,327,118$ & Bell Canyon \\
\hline 21384666 & 8 & COYANOSA, N. & DELAWARE & $\mathrm{TX}$ & PECOS & 1966 & 4809 & 18,136 & $3,249,484$ & Bell Canyon \\
\hline 24853400 & 8 & DIMMITT & CHERRY CANYON & $\mathrm{TX}$ & LOVING & 1980 & 6226 & 230,734 & $8,574,522$ & Cherry Canyon \\
\hline 28019500 & 8 & EL MAR & DELAWARE & $\mathrm{TX}$ & LOVING & 1959 & 4532 & 218,771 & $18,927,176$ & Bell Canyon \\
\hline 31908500 & 8 & FORD, EAST & DELAWARE SAND & $\mathrm{TX}$ & REEVES & 1963 & 2730 & 93,295 & $3,401,021$ & Bell Canyon \\
\hline 31913500 & 8 & FORD, WEST & 4100 & $\mathrm{TX}$ & CULBERSON & 1963 & 4143 & 33,736 & $3,010,344$ & Cherry Canyon \\
\hline 34529200 & 8 & GERALDINE & DELAWARE 3400 & TX & CULBERSON & 1982 & 3454 & 7,645 & $1,598,553$ & Bell Canyon \\
\hline 34529666 & 8 & GERALDINE & FORD & TX & REEVES & 1957 & 2557 & 121,301 & $30,222,300$ & Bell Canyon \\
\hline 36924500 & 8 & GRICE & DELAWARE & $\mathrm{TX}$ & LOVING & 1956 & 4510 & 98,088 & $10,207,517$ & Cherry Canyon \\
\hline 43106200 & 8 & HUBBARD & CHERRY CANYON & TX & LOVING & 1982 & 5286 & 39,418 & $1,145,161$ & Cherry Canyon \\
\hline 46296300 & 8 & JESS BURNER & DELAWARE 3800 & $T X$ & REEVES & 1982 & 3802 & 49,375 & $2,828,941$ & Cherry Canyon \\
\hline 48754500 & 8 & KEN REGAN & DELAWARE & $\mathrm{TX}$ & REEVES & 1954 & 3350 & 62,249 & $4,370,922$ & Bell Canyon \\
\hline 53989250 & 8 & LITTLE JOE & DELAWARE & $\mathrm{TX}$ & WINKLER & 1965 & 5034 & 21,409 & $1,728,191$ & Bell Canyon \\
\hline 58099001 & 8 & MASON & & $\mathrm{TX}$ & LOVING & 1937 & 3900 & 3,393 & $3,020,075$ & Bell Canyon \\
\hline 58101500 & 8 & MASON, N. & DELAWARE SAND & $\mathrm{TX}$ & LOVING & 1952 & 4055 & 15,383 & $6,709,456$ & Bell Canyon \\
\hline 62494001 & 8 & MONROE & & $\mathrm{TX}$ & WARD & 1931 & 4600 & 4,664 & $4,146,637$ & Bell Canyon \\
\hline 67074500 & 8 & OLDS & DELAWARE & $\mathrm{TX}$ & REEVES & 1958 & 3029 & 7,490 & $1,340,153$ & Bell Canyon \\
\hline 67604500 & 8 & ORLA, SOUTH & DELAWARE SAND & $T X$ & REEVES & 1953 & 3562 & 0 & $1,044,747$ & Bell Canyon \\
\hline 71542400 & 8 & PINAL DOME & CHERRY CANYON & $\mathrm{TX}$ & LOVING & 1984 & 6485 & 68,790 & $1,432,297$ & Cherry Canyon \\
\hline 73926500 & 8 & QUITO & DELAWARE SAND & $\mathrm{TX}$ & WARD & 1953 & 4934 & 365 & $2,444,299$ & Bell Canyon \\
\hline 73933500 & 8 & QUITO, WEST & DELAWARE & TX & WARD & 1955 & 4732 & 231,531 & $5,329,219$ & Bell Canyon \\
\hline 76184333 & 8 & RHODA WALKER & CANYON 5900 & $T X$ & WARD & 1967 & 6192 & 273,194 & $17,234,663$ & Cherry Canyon \\
\hline 77953250 & 8 & ROJO CABALLOS & DELAWARE & $\mathrm{TX}$ & PECOS & 1962 & 5253 & 13,649 & $1,097,828$ & Bell Canyon \\
\hline 79423500 & 8 & SABRE & DELAWARE & TX & REEVES & 1958 & 2968 & 55,697 & $5,913,660$ & Bell Canyon \\
\hline 81738200 & 8 & SCOTT & CHERRY CANYON & $\mathrm{TX}$ & REEVES & 1978 & 6134 & 41,377 & $1,013,358$ & Cherry Canyon \\
\hline 81738250 & 8 & SCOTT & DELAWARE & $T X$ & WARD & 1946 & 4239 & 186,910 & $5,416,369$ & Bell Canyon \\
\hline 81821333 & 8 & SCREWBEAN, NE. & DELAWARE & TX & REEVES & 1961 & 2519 & 7,244 & $1,224,697$ & Bell Canyon \\
\hline 87025500 & 8 & SULLIVAN & DELAWARE & $\mathrm{TX}$ & REEVES & 1957 & 2665 & 11,204 & $1,861,453$ & Bell Canyon \\
\hline 90781200 & 8 & TORO & DELAWARE & $\mathrm{TX}$ & REEVES & 1961 & 5158 & 8,985 & $1,059,893$ & Bell Canyon \\
\hline 91817001 & 8 & TUNSTILL & & TX & REEVES & 1947 & 3270 & 42,888 & $12,199,635$ & Bell Canyon \\
\hline 91818500 & 8 & TUNSTILL, EAST & DELAWARE & $\mathrm{TX}$ & LOVING & 1959 & 3652 & 25,779 & $2,870,757$ & Bell Canyon \\
\hline 92141333 & 8 & TWOFREDS & DELAWARE & $\mathrm{TX}$ & LOVING & 1957 & 4895 & 102,854 & $14,599,875$ & Bell Canyon \\
\hline 94648166 & 8 & WAHA & DELAWARE & $\mathrm{TX}$ & PECOS & 1960 & 4800 & 36,362 & $1,535,150$ & Bell Canyon \\
\hline 94650333 & 8 & WAHA, NORTH & DELAWARE SAND & TX & REEVES & 1960 & 4917 & 48,487 & $6,771,248$ & Bell Canyon \\
\hline 94656086 & 8 & WAHA, W. & CONSOLIDATED DELAWARE & TX & REEVES & 1974 & 6504 & 41,983 & $2,843,944$ & Cherry Canyon \\
\hline 94656111 & 8 & WAHA, WEST & DELAWARE & $\mathrm{TX}$ & REEVES & 1961 & 5034 & 21,072 & $2,514,728$ & Bell Canyon \\
\hline 95122200 & 8 & WAR-WINK & CHERRY CANYON & TX & WARD & 1965 & 6037 & 511,500 & $3,251,201$ & Cherry Canyon \\
\hline 95123875 & 8 & WAR-WINK, E. & 7000 & TX & WINKLER & 1994 & 7092 & 127,182 & $1,127,453$ & Cherry Canyon \\
\hline 96742001 & 8 & WHEAT & & TX & LOVING & 1925 & 4300 & 51,409 & $22,583,024$ & Bell Canyon \\
\hline 96742300 & 8 & WHEAT & CHERRY CANYON & $\mathrm{TX}$ & LOVING & 1979 & 6610 & 86,088 & $2,118,654$ & Cherry Canyon \\
\hline 98817775 & 8 & WORSHAM & DELAWARE SAND & $\mathrm{TX}$ & REEVES & 1960 & 4932 & 33,238 & $1,691,018$ & Bell Canyon \\
\hline
\end{tabular}


Table 36, continued. Delaware Mountain Group Sandstone Play (Play 130).

\begin{tabular}{|c|c|c|c|c|c|c|c|c|}
\hline FLDNAME & RESNAME & STATE & COUNTY & DISCYR & DEPTHTOP & 2000 PROD & CUMPROD & SUBPLAY \\
\hline AVALON & DELAWARE & NM & EDDY & 1980 & 2550 & 252,989 & $4,952,379$ & Bell Canyon, Cherry Canyon, Brushy Canyon \\
\hline BRUSHY DRAW & DELAWARE & NM & EDDY & 1958 & 3200 & 221,902 & $6,967,405$ & Bell Canyon, Cherry Canyon \\
\hline CABIN LAKE & DELAWARE & NM & EDDY & 1987 & 5625 & 181,767 & $3,798,138$ & Brushy Canyon, Cherry Canyon \\
\hline CATCLAW DRAW EAST & DELAWARE & NM & EDDY & 1990 & 3074 & 75,490 & $1,219,588$ & Brushy Canyon, Bell Canyon, Cherry Canyon \\
\hline CEDAR CANYON & DELAWARE & NM & EDDY & 1976 & 5200 & 184,019 & $1,010,544$ & Cherry Canyon, Brushy Canyon \\
\hline CORBIN WEST & DELAWARE & NM & LEA & 1976 & 5030 & 106,008 & $2,746,804$ & Bell Canyon, Brushy Canyon \\
\hline CRUZ & DELAWARE & NM & LEA & 1961 & 5081 & 781 & $1,034,285$ & Bell Canyon \\
\hline DOUBLE $X$ & DELAWARE & NM & LEA & 1961 & 4914 & 10,270 & $1,400,945$ & Bell Canyon \\
\hline EL MAR & DELAWARE & NM & LEA & 1959 & 4550 & 29,437 & $6,255,832$ & Brushy Canyon \\
\hline ESPERANZA & DELAWARE & NM & EDDY & 1969 & 3400 & 32,732 & $1,272,693$ & Bell Canyon, Cherry Canyon \\
\hline HAT MESA & DELAWARE & NM & LEA & 1989 & 6834 & 264,453 & $1,976,201$ & Brushy Canyon, Cherry Canyon \\
\hline HERRADURA BEND & DELAWARE & NM & EDDY & 1977 & 11086 & 25,209 & $1,012,833$ & Bell Canyon \\
\hline HERRADURA BEND EAST & DELAWARE & NM & EDDY & 1985 & 6062 & 112,309 & $1,555,292$ & Brushy Canyon \\
\hline INDIAN DRAW & DELAWARE & NM & EDDY & 1973 & 3262 & 54,625 & $3,316,622$ & Cherry Canyon \\
\hline INGLE WELLS & DELAWARE & NM & EDDY & 1989 & 8100 & 665,836 & $7,458,269$ & Brushy Canyon \\
\hline LEA NORTHEAST & DELAWARE & NM & LEA & 1988 & 5658 & 436,236 & $4,004,802$ & Cherry Canyon, Brushy Canyon \\
\hline LIVINGSTON RIDGE & DELAWARE & NM & EDDY & 1989 & 7091 & 355,051 & $5,155,100$ & Brushy Canyon, Cherry Canyon \\
\hline LIVINGSTON RIDGE EAST & DELAWARE & NM & LEA & 1992 & 7200 & 100,566 & $1,992,444$ & Brushy Canyon, Cherry Canyon \\
\hline LOS MEDANOS & DELAWARE & NM & EDDY & 1990 & 4218 & 178,629 & $2,894,378$ & Brushy Canyon \\
\hline LOST TANK & DELAWARE & NM & EDDY \& LEA & 1991 & 6783 & 171,309 & $2,688,111$ & Brushy Canyon, Cherry Canyon \\
\hline LOVING & BRUSHY CANYON & NM & EDDY & 1993 & 6050 & 306,580 & $7,074,110$ & Brushy Canyon \\
\hline LUSK WEST & DELAWARE & NM & LEA & 1987 & 6450 & 163,949 & $2,753,235$ & Brushy Canyon, Cherry Canyon \\
\hline MALAGA & DELAWARE & NM & EDDY & 1951 & 2770 & 14,526 & $1,006,678$ & Bell Canyon, Cherry Canyon, Brushy Canyon \\
\hline MASON EAST & DELAWARE & NM & LEA & 1962 & 4370 & 19,378 & $1,427,836$ & Bell Canyon \\
\hline MASON NORTH & DELAWARE & NM & EDDY \& LEA & 1954 & 4115 & 35,016 & $4,737,873$ & Bell Canyon, Cherry Canyon \\
\hline NASH DRAW & BRUSHY CANYON & NM & EDDY & 1992 & 6713 & 282,583 & $1,777,626$ & Brushy Canyon \\
\hline PADUCA & DELAWARE & NM & LEA & 1960 & 4636 & 29,690 & $13,922,378$ & Bell Canyon \\
\hline PARKWAY & DELAWARE & NM & EDDY & 1988 & 4135 & 386,121 & $3,307,433$ & Cherry Canyon, Brushy Canyon \\
\hline RED TANK WEST & DELAWARE & NM & LEA & 1992 & 8330 & 672,646 & $4,873,021$ & Brushy Canyon \\
\hline SAND DUNES & CHERRY CANYON & NM & EDDY & 1970 & 6020 & 10,723 & $1,076,059$ & Cherry Canyon \\
\hline SAND DUNES WEST & DELAWARE & NM & EDDY & 1992 & 7820 & 322,488 & $5,938,672$ & Brushy Canyon \\
\hline SHUGART & DELAWARE & NM & EDDY & 1958 & 4970 & 19,884 & $1,640,470$ & Cherry Canyon \\
\hline SHUGART EAST & DELAWARE & NM & LEA & 1985 & 5012 & 52,842 & $2,310,167$ & Cherry Canyon, Brushy Canyon \\
\hline tals & & & & & & $9,208,247$ & ;1,912,395 & \\
\hline
\end{tabular}

Bold names indicate main productive zone

are productive-Bell Canyon, Cherry Canyon, and Brushy Canyon (fig. 3). The Bell Canyon

has produced the greatest volume of oil $\left(217.5 \mathrm{MMbbl}\left[3.46 \times 10^{7} \mathrm{~m}^{3}\right]\right)$, followed by the Cherry Canyon (77.7 MMbbl $\left.\left[1.24 \times 10^{7} \mathrm{~m}^{3}\right]\right)$ and Brushy Canyon $\left(56.7 \mathrm{MMbbl}\left[9.01 \times 10^{6} \mathrm{~m}^{3}\right]\right)$

(Dutton and others, 2000). The main producing formation in each reservoir is listed in table 36 under the heading Subplay.

\section{Depositional Model}

Upper Permian Delaware Mountain Group strata compose a 4,500-ft-thick (1,375-m)

succession of slope and basin deposits in the Delaware Basin. The Bell Canyon, Cherry Canyon, 


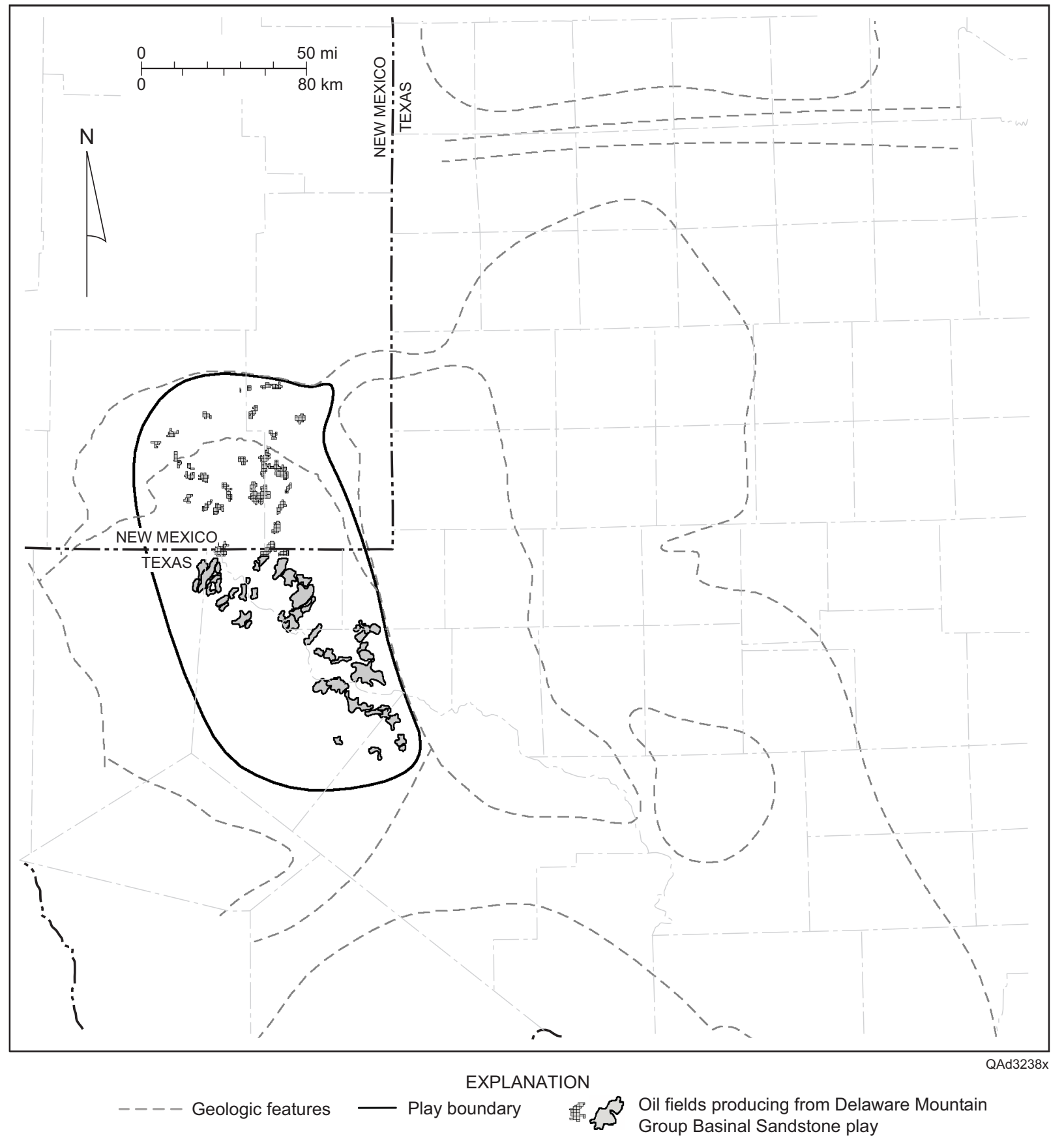

Figure 105. Play map for the Delaware Mountain Group Basinal Sandstone play, showing location of reservoirs having $>1 \mathrm{MMbbl}$ cumulative production, the play boundary, and geologic features. See figure 1 for county names and figure 2 for identification of geologic features. 
and Brushy Canyon Formations are all composed of sandstones, siltstones, and minor amounts of carbonate. The cyclic interbedding of sandstones with organic-rich siltstones and limestones in the Delaware Mountain Group has been interpreted to record frequent changes in relative sea level (Meissner, 1972; Fischer and Sarnthein, 1988; Gardner, 1992, 1997a, b; Gardner and Sonnenfeld, 1996). During highstands in relative sea level, sands were trapped behind a broad, flooded shelf and prevented from entering the basin. Thin, widespread, organic-rich siltstones accumulated on the basin floor by the slow settling of marine algal material and airborne silt. Associated limestones were deposited by sediment gravity flows that originated by the slumping of carbonate debris along the flanks of a rapidly aggrading carbonate platform. During subsequent lowstands in relative sea level, the carbonate shelf was exposed, and sandstones bypassed to the basin floor.

Delaware Mountain Group sandstones have been interpreted by many workers as having been deposited by turbidity currents (Newell and others, 1953; Payne, 1976; Berg, 1979; Jacka, 1979; Gardner, 1992; Zelt and Rossen, 1995; Bouma, 1996; DeMis and Cole, 1996; Gardner and Sonnenfeld, 1996; Barton and Dutton, 1999; Beaubouef and others, 1999; Batzle and Gardner, 2000; Carr and Gardner, 2000; Gardner and Borer, 2000; Dutton and others, 2003). Textural characteristics of the sands, such as the absence of detrital clay-sized material and the lack of channels on the shelf, suggest that wind was an important agent in transporting the sands to the shelf margin (Fischer and Sarnthein, 1988). According to this model, dunes prograded to the shelf break during sea-level lowstands, and eolian sands were then carried into the basin by turbidity currents (Fisher and Sarnthein, 1988; Gardner, 1992). Paleocurrent indicators show that sands entered the basin from the Northwest Shelf and Central Basin Platform (Williamson, 1978, 1979). 
Depositional models of Delaware sandstones have been developed mainly by outcrop studies, including recent studies of the Brushy Canyon (Beaubouef and others, 1999; Carr and Gardner, 2000; Gardner and Borer, 2000) and Bell Canyon (Barton and Dutton, 1999; Dutton and others, 1999; Dutton and others, 2003). Stratigraphic relationships in outcrop indicate that Bell Canyon sandstones were deposited in a basin-floor setting by a system of leveed channels having attached lobes and overbank splays that filled topographically low interchannel areas (fig. 106) (Barton and Dutton, 1999). Lobe sandstones, as much as $25 \mathrm{ft}(8 \mathrm{~m})$ thick and $2 \mathrm{mi}$ $(3.2 \mathrm{~km})$ wide, display a broad tabular geometry. In a prograding system, lobe facies would have

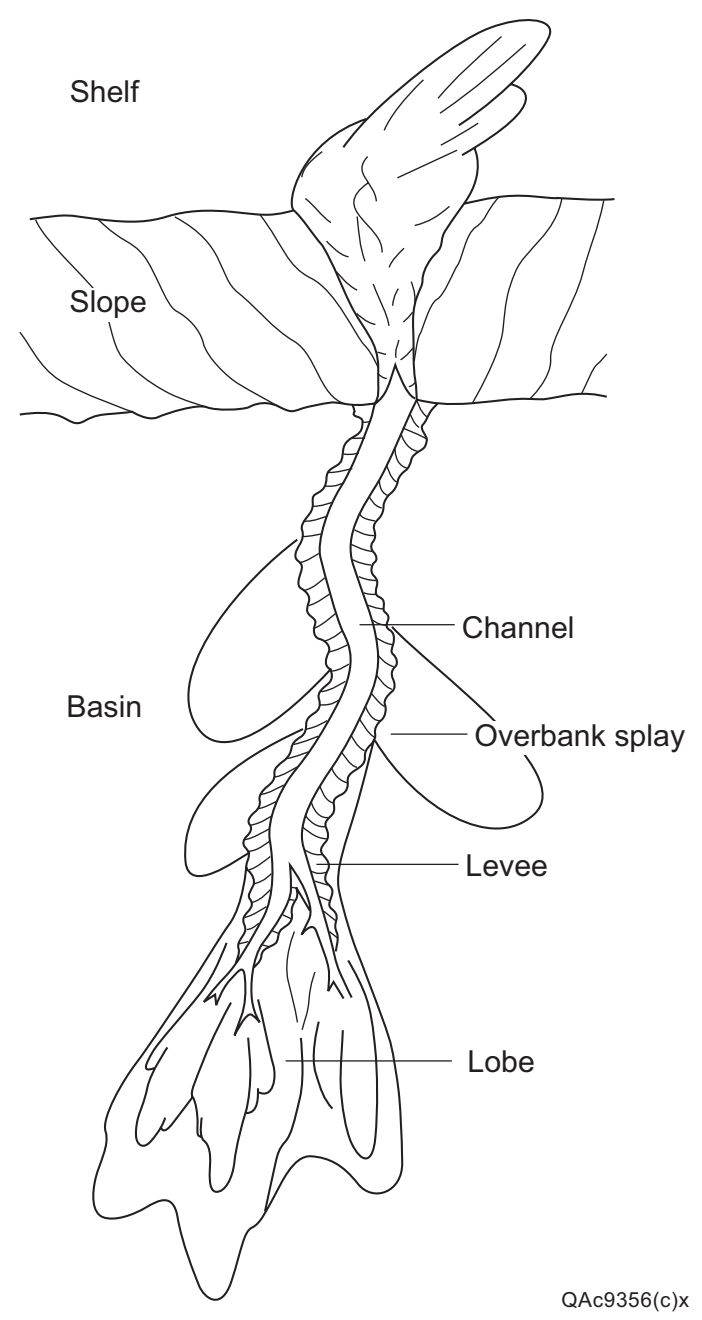

Figure 106. Depositional model proposed for the Bell Canyon sandstone, showing deposition in submarine channels with levees, overbank splays, and attached lobes. From Dutton and others (2003; modified from Galloway and Hobday (1996). From Dutton and others (2003), reprinted by permission of the AAPG, whose permission is required for further use. (C) Copyright 2003. The American Association of Petroleum Geologists. All rights reserved. 
been deposited first and then overlain and partly eroded by the channel-levee-overbank system. Channels are bound at the base by an erosion surface and are largely filled with massive and cross-stratified sandstones. Channels mapped in outcrop range from 10 to $60 \mathrm{ft}$ ( 3 to $18 \mathrm{~m}$ ) in thickness; most are 20 to $40 \mathrm{ft}$ (6 to $12 \mathrm{~m}$ ) thick (Barton and Dutton, 1999). Channel widths are 300 to 3,000 $\mathrm{ft}$ (90 to $900 \mathrm{~m}$ ). Aspect ratios (width:thickness) range from 15 to 40 . The channels bifurcate and widen downdip. Flanking the channels on both sides are wedge-shaped "wings" composed of thinly bedded sandstone and siltstone and interpreted to be levee deposits (Barton and Dutton, 1999). The width of levee deposits mapped in outcrop varies from $\sim 500 \mathrm{ft}(\sim 150 \mathrm{~m})$ to $3,000 \mathrm{ft}(1 \mathrm{~km})$ wide. The levees thin abruptly away from the channel, decreasing in thickness from $20 \mathrm{ft}$ to $1 \mathrm{ft}$ ( 6 to $0.3 \mathrm{~m}$ ). Overbank splays are composed of massive sandstones and display a broad, tabular, to irregular geometry. The splay sandstones are 3 to $25 \mathrm{ft}$ (1 to $8 \mathrm{~m}$ ) thick. Splays on the flanks of the channel system were at least 3,000 ft (900 m) wide and possibly much greater. Volumetrically the splays contain much of the sandstone in the system (Dutton and others, 2003).

A depositional model of the Bell Canyon reservoirs (fig. 107) in East Ford field, Reeves County, was developed using data from Bell Canyon outcrops and subsurface data (Dutton and others, 2000, 2003). The reservoir sandstones are interpreted as having been deposited in a channel-levee system that terminated in broad lobes; overbank splays filled topographically low interchannel areas. Individual channel-levee and lobe complexes stack in a compensatory fashion and are separated by laterally continuous, laminated siltstones (fig. 108). Reservoir sandstones consist of (1) broadly lenticular lobe deposits, (2) elongate channel deposits, and (3) irregular splay deposits. Porosity measured from core plugs ranges from 4.5 to 30.6 percent and averages 22 percent. Permeability ranges from 0.01 to $249 \mathrm{md}\left(0.01\right.$ to $\left.249 \times 10^{-3} \mu \mathrm{m}^{2}\right)$. Average 


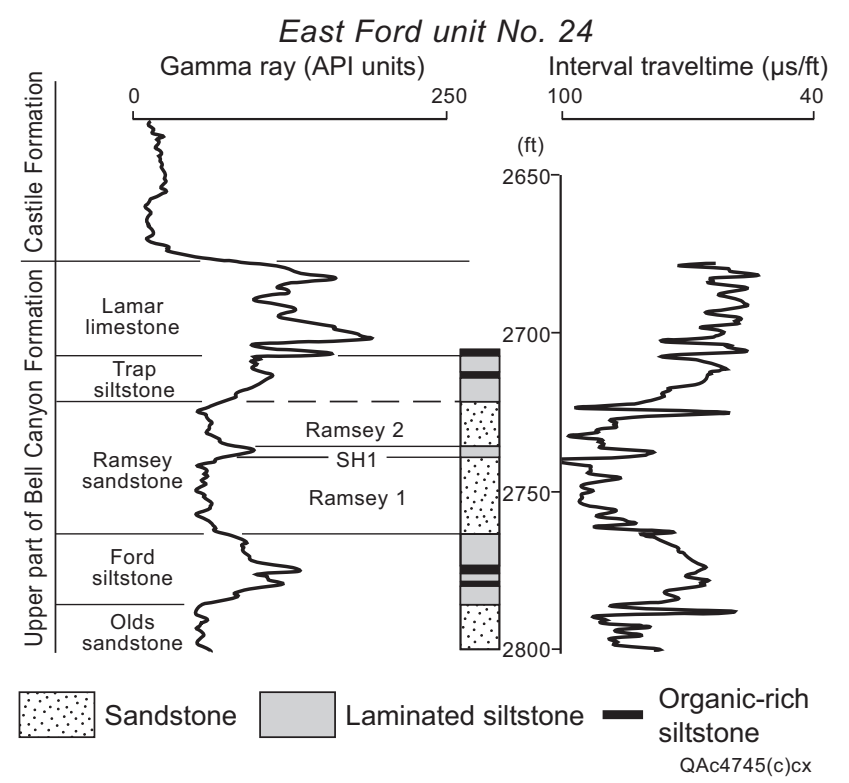

Figure 107. Typical log from East Ford field, which produces from the Ramsey sandstone in the upper Bell Canyon Formation. From Dutton and others (2003), reprinted by permission of the AAPG, whose permission is required for further use. CCopyright 2003. The American Association of Petroleum Geologists. All rights reserved.

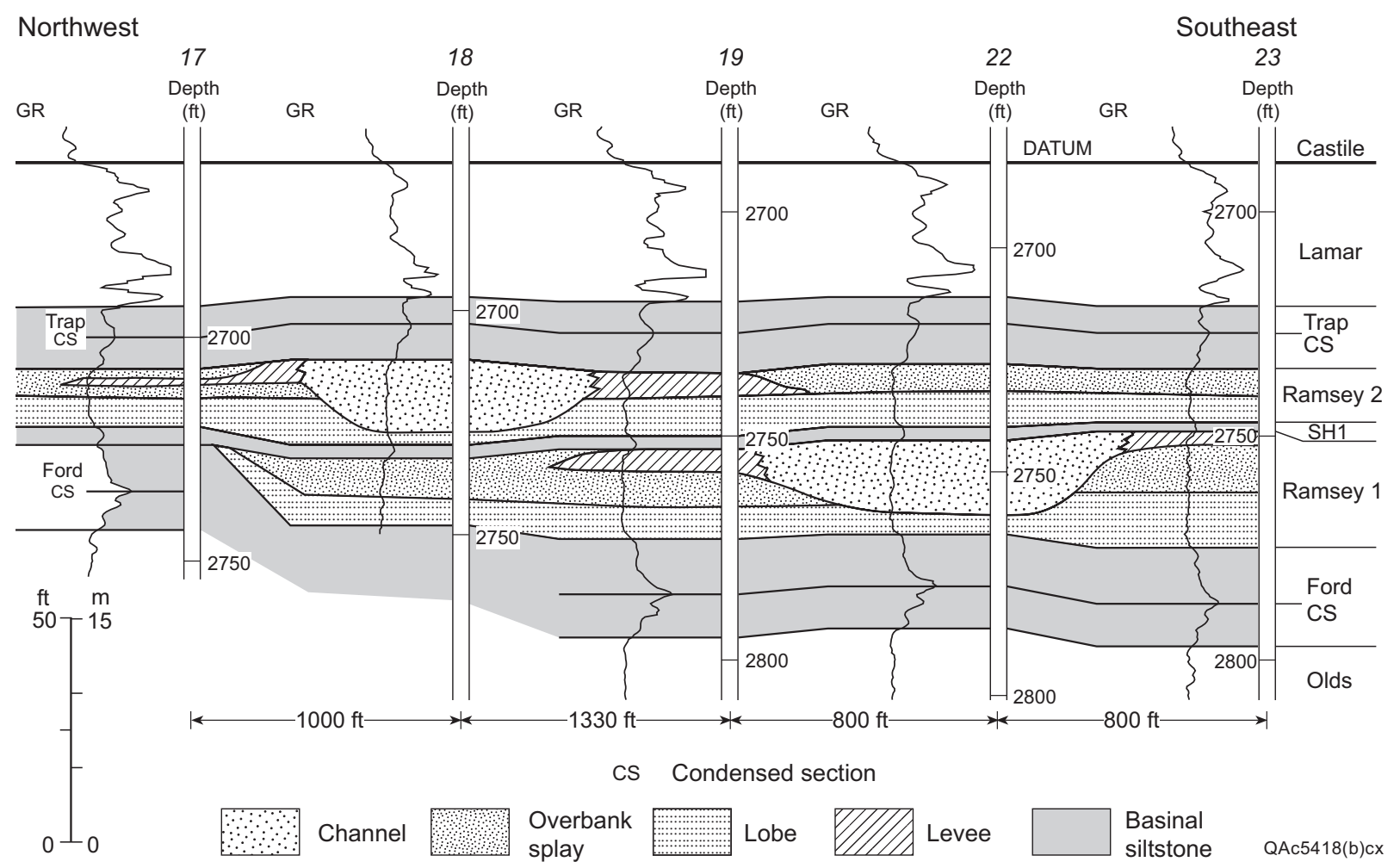

Figure 108. Northwest-southeast strike cross section of the central part of the East Ford unit. See Dutton and others (2003) for location of the cross section. From Dutton and others (2003), reprinted by permission of the AAPG, whose permission is required for further use.

CCopyright 2003. The American Association of Petroleum Geologists. All rights reserved. 
permeability is $40 \mathrm{md}\left(40 \times 10^{-3} \mu \mathrm{m}^{2}\right)$, and geometric mean permeability is $22 \mathrm{md}$ $\left(22 \times 10^{-3} \mu \mathrm{m}^{2}\right)$ (Dutton and others, 2003).

\section{Reservoir Characteristics}

Development of the Delaware Mountain Group Basinal Sandstone play began with the shallowest reservoirs. It is only within the last 15 years that exploration and development have concentrated on the deeper zones. Bell Canyon reservoirs lie at depths of 2,500 to $5,300 \mathrm{ft}$ (750 to $1,600 \mathrm{~m}$ ) (table 36). Cherry Canyon reservoirs lie at depths of 3,000 to 7,000 ft (900 to 2,100 m), and Brushy Canyon reservoirs lie at depths of 6,000 to $8,500 \mathrm{ft}(1,800$ to 2,600 m) (table 36). Most Bell Canyon reservoirs were discovered prior to 1970. Increased production from the play during the early 1990's resulted from the discovery and development of deeper reservoirs, primarily in the Brushy Canyon, but also in the Cherry Canyon.

Traps in the play are predominantly stratigraphic. Reservoir sandstones are complexly interbedded with nonreservoir siltstones and lower-permeability sandstones. Reservoir sandstones may also exhibit complex lateral relationships with nonreservoir facies (fig. 109). As a result, production is typically obtained from multiple separate sandstone layers within a single reservoir. Reservoirs are thought to have no single oil-water contact (Montgomery and others, 1999).

Delaware sandstone reservoirs produce via solution-gas drive. Typical production rates from wells completed in Delaware sandstones are 50 to $400 \mathrm{bbl}\left(8.0\right.$ to $\left.63.6 \mathrm{~m}^{3}\right)$ oil per day and 30 to $350 \mathrm{bbl}\left(4.8\right.$ to $55.6 \mathrm{~m}^{3}$ ) water per day (Montgomery and others, 1999, 2000). Estimated ultimate primary recovery is 50,000 to $100,000 \mathrm{bbl}\left(7.95 \times 10^{3} \mathrm{~m}^{3}\right.$ to $\left.1.59 \times 10^{4} \mathrm{~m}^{3}\right)$ of oil 


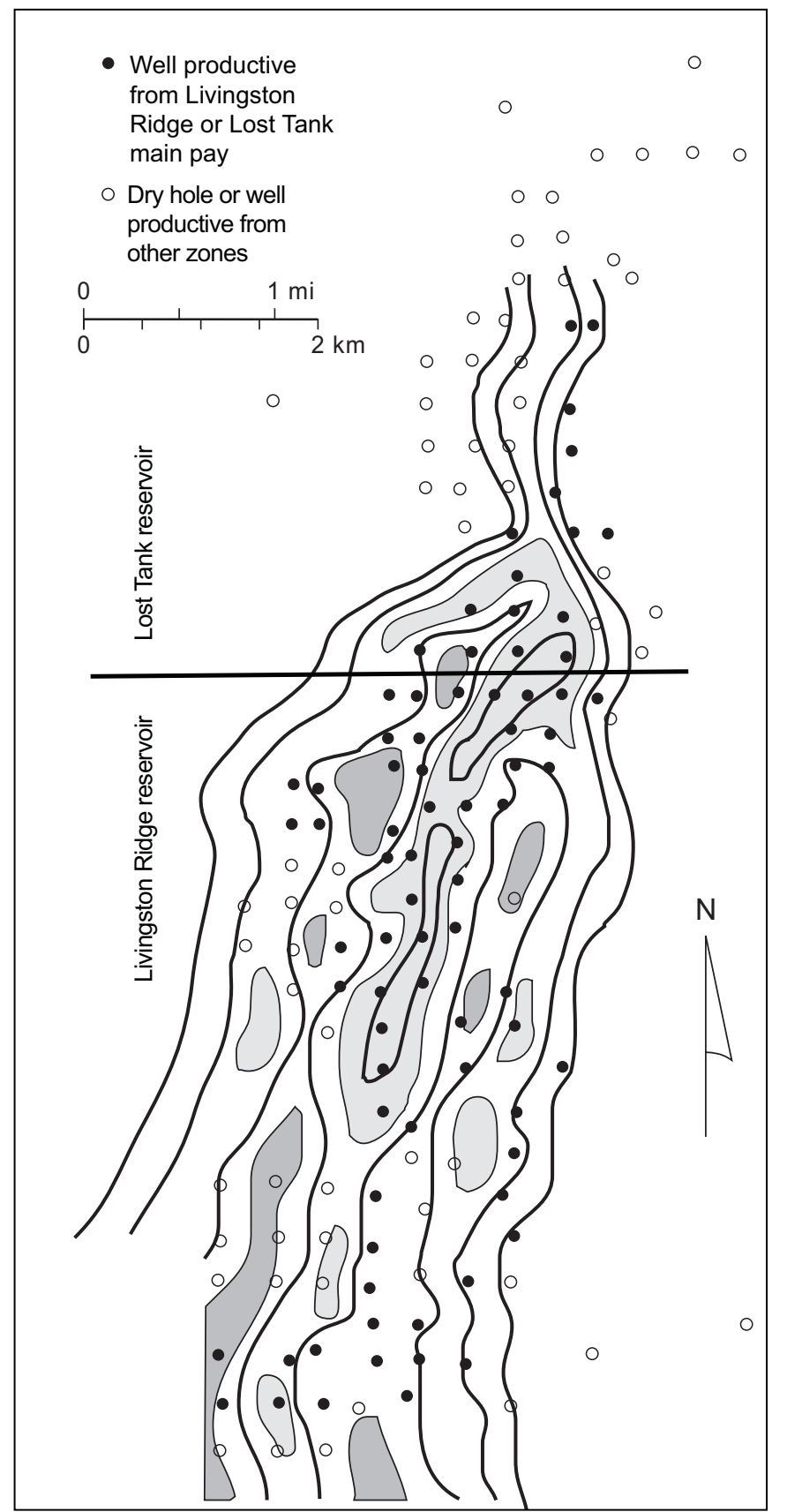

Contour interval $=$ thickness sand with porosity $15 \%$ or more

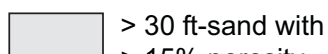

$>15 \%$ porosity
$<10 \mathrm{ft}$-sand with

$>15 \%$ porosity
QAd3436x
Figure 109. Net thickness of sandstone with porosity $\geq 15$ percent in the main pay zone at the Livingston Ridge and Lost Tank reservoirs. After May (1996).

(Montgomery and others, 1999, 2000). Initial production may typically exceed 2,500 bbl/mo $\left(3.97 \times 10^{2} \mathrm{~m}^{3} / \mathrm{mo}\right)$ in a well but will rapidly decline to a few hundred bbl/mo (a few tens of $\mathrm{m}^{3} / \mathrm{mo}$ ) (or less) after 4 years (fig. 110) as solution gas is produced and reservoir pressures 


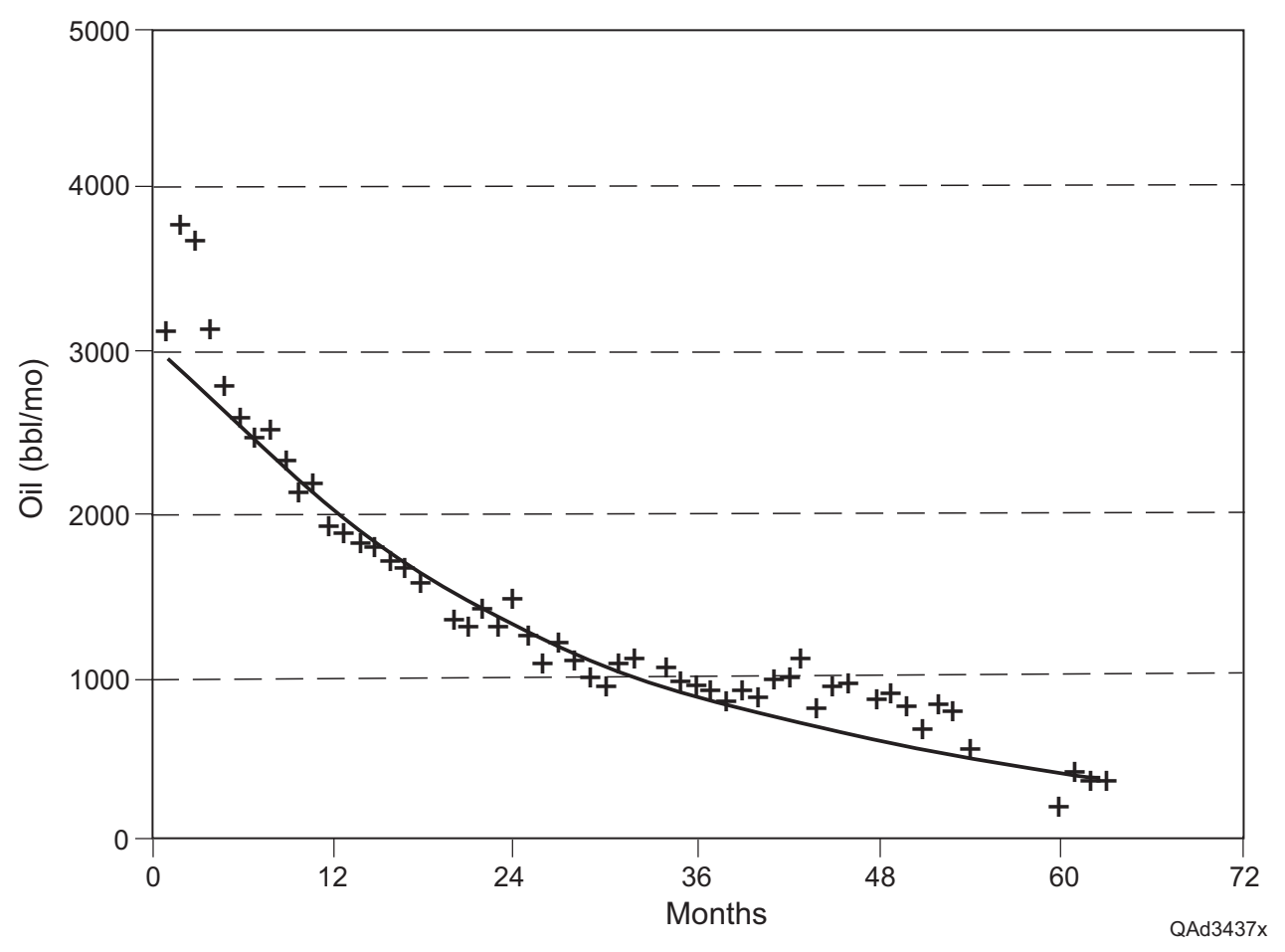

Figure 110. Average-production decline curve for wells productive from Livingston Ridge main pay, Livingston Ridge and Lost Tank reservoirs. From Broadhead and others (1998).

decrease below the bubble point. Injection of water for pressure maintenance can yield a good production response in some reservoirs (fig. 111). Pressure maintenance should be initiated early so that a secondary gas cap is not allowed to form (Mark Murphy, personal communication, 2003).

Primary production from Delaware sandstone fields is commonly $<15$ percent of OOIP (Dutton and others, 1999, 2003; Montgomery and others, 1999). Many Delaware sandstone reservoirs are characterized by relatively high amounts of mobile water at the time of discovery. Among the reasons for low primary production are (1) low solution gas:oil ratio, which results in limited natural drive energy; (2) expenditure of considerable solution-gas drive energy in the 


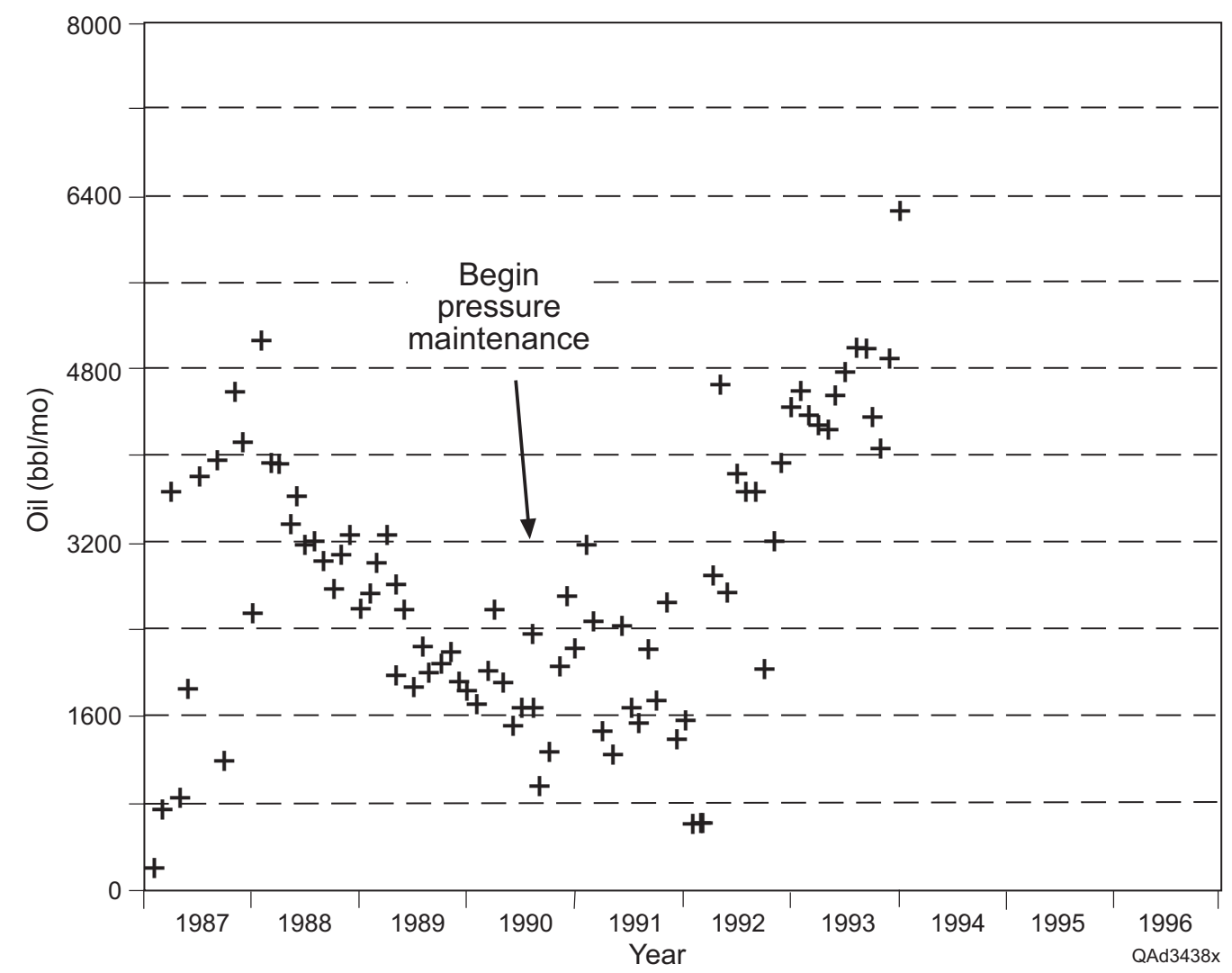

Figure 111. Historical monthly production of oil, Phillips Petroleum Company No. 2 James A well, Cabin Lake reservoir. Note increase in production as a result of water injection for the purpose of pressure maintenance. After Broadhead and others (1998).

recovery of water from the reservoir; and (3) lack of pressure support from an aquifer owing to limited water influx (Dutton and others, 2003).

\section{Reservoir Development Examples}

Secondary waterfloods in two Bell Canyon fields, Geraldine Ford and Twofreds, recovered only an additional 4 to 5 percent OOIP (Pittaway and Rosato, 1991; Flanders and DePauw, 1993). Waterflood recoveries in Bell Canyon sandstones have been low because of 


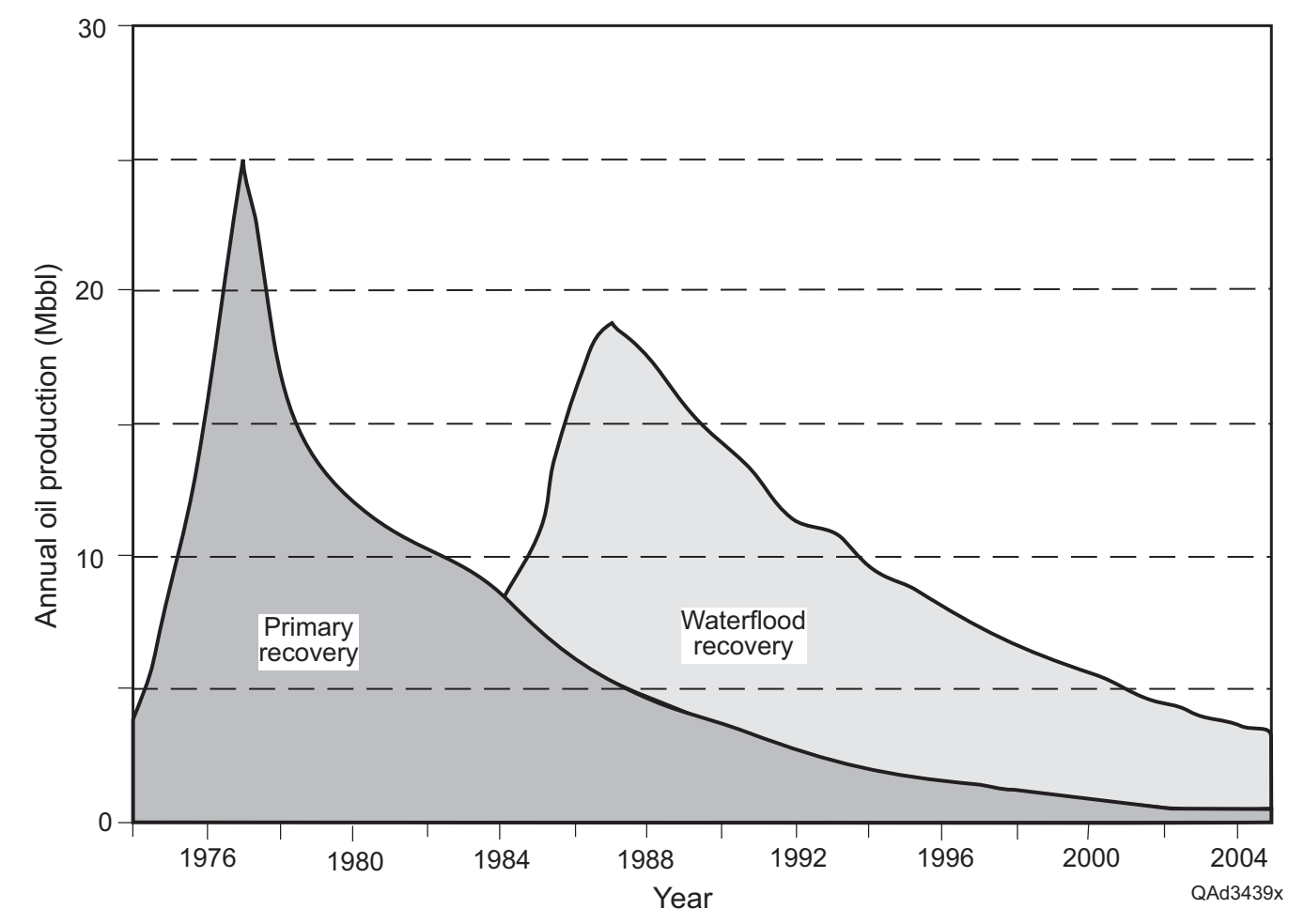

Figure 112. Annual production history of the Indian Draw Delaware reservoir, with production curves for primary and secondary (waterflood) recovery and estimated oil recovery by primary and secondary means. This reservoir is productive from the Cherry Canyon Formation of the Delaware Mountain Group. From Broadhead and others (1998).

poor sweep efficiency caused by (1) abundant mobile water present when the waterflood was started, (2) water injection above formation parting pressure, (3) lack of proper water filtration, and (4) patterns not arranged to exploit depositional characteristics.

Waterflooding of other Delaware sandstone reservoirs, such as Indian Draw, has yielded good results, with secondary recovery reserves equal to as much as 80 percent of primary recovery reserves in some cases (fig. 112). For optimal efficiency, water injection should commence before reservoir pressures decline to the point where a secondary gas cap is formed. The more proximal upper Brushy Canyon and lower Cherry Canyon reservoirs are thought 
to have less lateral sandstone heterogeneity than other reservoirs in the Brushy Canyon and Cherry Canyon and may be more favorable to waterflooding (Montgomery and others, 1999).

In other more heterogeneous Delaware reservoirs with complex internal sandstone distributions and lower permeability, gas injection may be required for optimal pressure maintenance, and carbon dioxide flooding may be needed for enhanced recovery (Montgomery and others, 1999). $\mathrm{CO}_{2}$ floods have been conducted in Twofreds (Kirkpatrick and others, 1985; Flanders and DePauw, 1993), Geraldine Ford (Pittaway and Rosato, 1991), and East Ford fields (Dutton and others, 2003). In Twofreds unit, 12 percent of OOIP was recovered by the $\mathrm{CO}_{2}$ flood; approximately 7 percent of OOIP in the flooded area of Ford Geraldine unit was recovered by the $\mathrm{CO}_{2}$ flood (Dutton and others, 2003). Tertiary recovery from Ford Geraldine unit may be lower because a higher percentage of OOIP (23 percent) was recovered during primary and secondary production than in Twofreds unit (16 percent) owing to a stronger solution-gas drive at Ford Geraldine.

East Ford unit went directly from primary production to tertiary recovery by $\mathrm{CO}_{2}$ flooding in 1995 (Dutton and others, 2003). Prior to initiation of the $\mathrm{CO}_{2}$ flood, production from East Ford unit had declined to $30 \mathrm{bbl} / \mathrm{d}\left(4.8 \mathrm{~m}^{3} / \mathrm{d}\right)$, from a high of $>900 \mathrm{bbl} / \mathrm{d}\left(>143 \mathrm{~m}^{3}\right)$ in 1966 . By 2001, production had increased to $>185 \mathrm{bbl} / \mathrm{d}\left(>29.4 \mathrm{~m}^{3}\right)$ (fig. 113). Oil recovery has been improved substantially by the $\mathrm{CO}_{2}$ flood, but not as much as expected. Geologic heterogeneities, such as interbedded siltstones, are apparently influencing reservoir displacement operations in East Ford unit by limiting cross-flow of fluids between injector and producer wells. Injection wells located in splay sandstones apparently have poor communication with wells in channel sandstones (fig. 108), perhaps because communication is restricted through levee and channelmargin deposits. The south part of the unit is responding well to the flood because injection and 
(a)

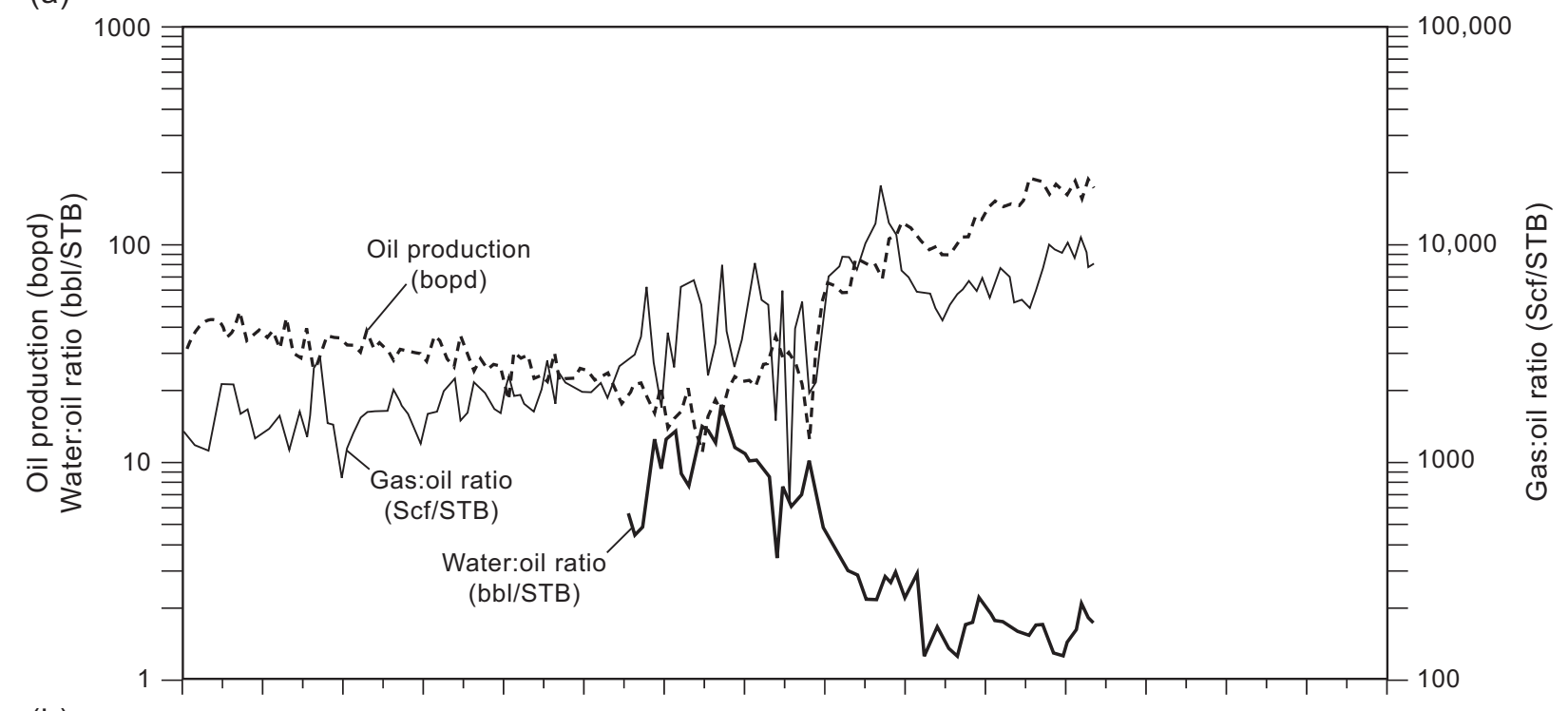

(b)

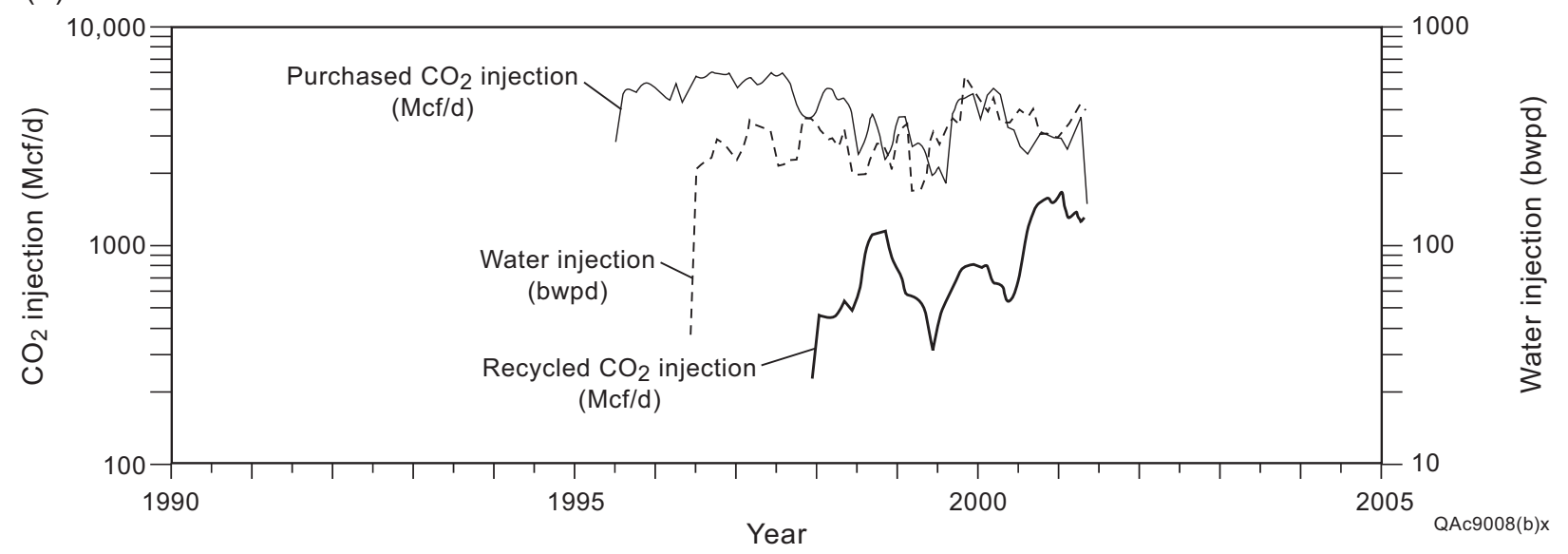

Figure 113. (a) Plot of oil production, water:oil ratio, and gas:oil ratio in East Ford unit since 1990 ; (b) plot of gas and water injection since 1995. From Dutton and others (2003). $\mathrm{CO}_{2}$ flooding began in July 1995. From Dutton and others (2003), reprinted by permission of the AAPG, whose permission is required for further use. CCopyright 2003. The American Association of Petroleum Geologists. All rights reserved.

production wells are in the same interconnected lobe depositional environment. Locating an adequate number of injectors and producers within the same depositional facies - whether channels, splays, or lobes_-will maximize reservoir volume contacted and production rate and minimize displacement across restrictive depositional barriers and time to produce the reservoir. 
Nash Draw field in Eddy County produces from the Brushy Canyon sandstone.

Production at Nash Draw was increased by drilling vertical and horizontal wells that were targeted on the basis of high-quality 3-D seismic data. By using in-field VSP data to calibrate seismic reflection time to depth, turbidite packages $\sim 100 \mathrm{ft}(\sim 30 \mathrm{~m})$ thick at a depth of 7,000 ft $(2,135 \mathrm{~m})$ were detected and interpreted (Hardage and others, 1998a, b). Significant correlations were established between high-amplitude reflection areas and good producing wells (Hardage and others, 1998a, b).

Many additional studies of Delaware Mountain Group reservoirs have been published but are not cited in this summary. The references to those publications are listed separately, under Additional Delaware Mountain Group References. A volume focusing on the Brushy Canyon, published by the Permian Basin Section SEPM, contains many papers about Delaware sandstone fields (DeMis and Cole, 1996).

\section{References}

Barton, M. D., and Dutton, S. P., 1999, Outcrop analysis of a sand-rich, basin-floor turbidite system, Permian Bell Canyon Formation, West Texas, in Transactions, Gulf Coast Section SEPM $19^{\text {th }}$ Annual Bob F. Perkins Research Conference, December 5-8, Houston, p. 53-64.

Batzle, M., and Gardner, M. H., 2000, Lithology and fluids: seismic models of the Brushy Canyon Formation, west Texas, in Bouma, A. H., and Stone, C. G., eds., Fine-grained turbidite systems: American Association of Petroleum Geologists Memoir 72/SEPM Special Publication 68, p. 127-141.

Beaubouef, R. T., Rossen, C., Zelt, F. B., Sullivan, M. D., Mohrig, D. C., and Jennette, D. C., 1999, Deep-water sandstones, Brushy Canyon Formation, West Texas: American Association of Petroleum Geologists Continuing Education Course Note Series No. 40, $48 \mathrm{p}$.

Berg, R. R., 1979, Reservoir sandstones of the Delaware Mountain Group, southeast New Mexico, in Sullivan, N. M., ed., Guadalupian Delaware Mountain Group of West Texas and southeast New Mexico, Symposium and Field Trip Conference Guidebook: Society 
of Economic Paleontologists and Mineralogists (Permian Basin Section) Publication 79-18, p. 75-95.

Bouma, A. H., 1996, Initial comparison between fine- and coarse-grained submarine fans and the Brushy Canyon Formation sandstones, in DeMis, W. D., and Cole, A. G., eds., The Brushy Canyon play in outcrop and subsurface: concepts and examples: guidebook: Permian Basin Section, SEPM, Publication No. 96-38, p. 41-50.

Broadhead, R. F., Luo, F., and Speer, S. W., 1998, Oil and gas resources at the Waste Isolation Pilot Plant (WIPP) site, Eddy County, New Mexico: New Mexico Bureau of Mines and Mineral Resources, Circular 206, p. 3-72.

Carr, M., and Gardner, M. H., 2000, Portrait of a basin-floor fan for sandy deepwater systems, Permian lower Brushy Canyon Formation, west Texas, in Bouma, A. H., and Stone, C. G., eds., Fine-grained turbidite systems: American Association of Petroleum Geologists Memoir 72/SEPM Special Publication 68, p. 215-231.

DeMis, W. D., and Cole, A. G., eds., 1996, The Brushy Canyon play in outcrop and subsurface: concepts and examples: guidebook: Permian Basin Section, SEPM, Publication No. 96$38,188 \mathrm{p}$.

Dutton, S. P., Barton, M. D., Asquith, G. B., Malik, M. A., Cole, A. G., Gogas, J., Guzman, J. I., and Clift, S. J., 1999, Geologic and engineering characterization of turbidite reservoirs, Ford Geraldine Unit, Bell Canyon Formation, West Texas: The University of Texas at Austin, Bureau of Economic Geology Report of Investigations No. 255, 88 p.

Dutton, S. P., Barton, M. D., Zirczy, H. H., and Flanders, W. A., 2000, Characterization of reservoir heterogeneity in slope and basin clastic reservoirs, Bell Canyon Formation, Delaware Basin, Texas, in Reid, S. T., Southwest Section AAPG 2000 Convention transactions: West Texas Geological Society, Publication SWS 2000-107, p. 116-129.

Dutton, S. P., Flanders, W. A., and Barton, M. D., 2003, Reservoir characterization of a Permian deep-water sandstone, East Ford field, Delaware basin, Texas: American Association of Petroleum Geologists Bulletin, v. 87, p. 609-627.

Fischer, A. G., and Sarnthein, M., 1988, Airborne silts and dune-derived sands in the Permian of the Delaware Basin: Journal of Sedimentary Petrology, v. 58, p. 637-643.

Flanders, W. A., and DePauw, R. M., 1993, Update case history: performance of the Twofreds Tertiary $\mathrm{CO}_{2}$ project, in Proceedings, 1993 SPE Annual Technical Conference: Society of Petroleum Engineers, Paper 26614, 10 p.

Galloway, W. E., and Hobday, D. K., 1996, Terrigenous clastic depositional systems: applications to fossil fuel and groundwater resources, $2 \mathrm{~d}$ ed.: New York, SpringerVerlag, $489 \mathrm{p}$. 
Gardner, M. H., 1992, Sequence stratigraphy of eolian-derived turbidites: patterns of deepwater sedimentation along an arid carbonate platform, Permian (Guadalupian) Delaware Mountain Group, West Texas, in Mruk, D. H., and Curran, B. C., eds., Permian Basin exploration and production strategies: applications of sequence stratigraphic and reservoir characterization concepts: West Texas Geological Society Publication 92-91, p. 7-12.

Gardner, M. H., 1997a, Characterization of deep-water siliciclastic reservoirs in the upper Bell Canyon and Cherry Canyon Formations of the northern Delaware Basin, Culberson and Reeves Counties, Texas, in Major, R. P., ed., Oil and gas on Texas State Lands: an assessment of the resource and characterization of type reservoirs: The University of Texas, Bureau of Economic Geology Report of Investigations No. 241, p. 137-146.

1997b, Sequence stratigraphy and hydrocarbon habitat of the Permian (Guadalupian) Delaware Mountain Group, Delaware Basin, West Texas, in Major, R. P., ed., Oil and gas on Texas State Lands: an assessment of the resource and characterization of type reservoirs: The University of Texas, Bureau of Economic Geology Report of Investigations No. 241, p. 147-157.

Gardner, M. H., and Borer, J. M., 2000, Submarine channel architecture along a slope to basin profile, Brushy Canyon Formation, west Texas, in Bouma, A. H., and Stone, C. G., eds., Fine-grained turbidite systems: American Association of Petroleum Geologists Memoir 72/SEPM Special Publication 68, p. 195-214.

Gardner, M. H., and Sonnenfeld, M. D., 1996, Stratigraphic changes in facies architecture of the Permian Brushy Canyon Formation in Guadalupian Mountains National Park, west Texas, in DeMis, W. D., and Cole, A. G., eds., The Brushy Canyon play in outcrop and subsurface: concepts and examples: guidebook: Permian Basin Section, SEPM, Publication No. 96-38, p. 51-59.

Hardage, B. A., Pendleton, V. M., Simmons, J. L., Jr., Stubbs, B. A., and Uszynski, B. J., 1998a, 3-D instantaneous frequency used as a coherency/continuity parameter to interpret reservoir compartment boundaries across an area of complex turbidite deposition: Geophysics, v. 63, p. 1520-1531.

Hardage, B. A., Simmons, J. L., Jr., Pendleton, V. M., Stubbs, B. A., and Uszynski, B. J., 1998b, 3-D seismic imaging and interpretation of Brushy Canyon slope and basin thin-bed reservoirs, northwest Delaware Basin: Geophysics, v. 63, p. 1507-1519.

Jacka, A. D., 1979, Deposition and entrapment of hydrocarbons in Bell Canyon and Cherry Canyon deep-sea fans of the Delaware Basin, in Sullivan, N. M., ed., Guadalupian Delaware Mountain Group of West Texas and Southeast New Mexico: Society of Economic Paleontologists and Mineralogists (Permian Basin Section) Publication 79-18, p. 104-120. 
Kirkpatrick, R. K., Flanders, W. A., and DePauw, R. M., 1985, Performance of the Twofreds $\mathrm{CO}_{2}$ injection project: Society of Petroleum Engineers Annual Technical Conference and Exhibition, SPE Paper 14439, 12 p.

May, B.A., 1996, Geology and development history of the Livingston Ridge and Lost Tank Delaware pools, southeastern New Mexico, in DeMis, W. D., and Cole, A. G., eds., The Brushy Canyon play in outcrop and subsurface: concepts and examples: guidebook: Permian Basin Section SEPM, Publication 96-38, p. 113-118.

Meissner, F. F., 1972, Cyclic sedimentation in Middle Permian strata of the Permian Basin, west Texas and New Mexico, in Cyclic sedimentation in the Permian Basin, 2nd ed.: West Texas Geological Society, p. 203-232.

Montgomery, S. L., Hamilton, D., Hunt, T., and Worrall, J., 2000, Delaware Mountain Group, West Texas, a case of refound opportunity: Part 2-Cherry Canyon Formation: American Association of Petroleum Geologists Bulletin, v. 84, p. 1-11.

Montgomery, S. L., Worrall, J., and Hamilton, D., 1999, Delaware Mountain Group, West Texas, a case of refound opportunity: Part 1-Brushy Canyon: American Association of Petroleum Geologists Bulletin, v. 83, p. 1901-1926.

Newell, N. D., Rigby, J. K., Fischer, A. G., Whiteman, A. J., Hickox, J. E., and Bradley, J. S., 1953, The Permian reef complex of the Guadalupe Mountains region, Texas and New Mexico: San Francisco, Freeman and Co., 236 p.

Payne, M. W., 1976, Basinal sandstone facies, Delaware Basin, West Texas and southeast New Mexico: American Association of Petroleum Geologists Bulletin, v. 60, p. 517-527.

Pittaway, K. R., and Rosato, R. J., 1991, The Ford Geraldine unit $\mathrm{CO}_{2}$ flood-update 1990: Society of Petroleum Engineers Reservoir Engineering, v. 6, no. 4, p. 410-414.

Williamson, C. R., 1978, Depositional processes, diagenesis and reservoir properties of Permian deep-sea sandstones, Bell Canyon Formation, Texas-New Mexico: The University of Texas at Austin, Austin, Texas, Ph.D. dissertation, 262 p.

1979, Deep sea sedimentation and stratigraphic traps, Bell Canyon Formation (Permian), Delaware basin, in Sullivan, N. M., ed., Guadalupian Delaware Mountain Group of West Texas and southeast New Mexico, Symposium and Field Trip Conference Guidebook: Society of Economic Paleontologists and Mineralogists (Permian Basin Section) Publication 79-18, p. 39-74.

Zelt, F. B., and Rossen, C., 1995, Geometry and continuity of deep-water sandstones and siltstones, Brushy Canyon Formation (Permian) Delaware Mountains, Texas, in Pickering, K. T., Hiscott, R. N., Kenyon, N. H., Ricci Lucchi, F., and Smith, R. D. A., eds., Atlas of deep water environments, architectural style in turbidite systems: London, Chapman \& Hall, p. 167-183. 
Asquith, G. B., Dutton, S. P., and Cole, A. G., 1997, "Delaware effect" and the Ramsey Sandstone, Ford Geraldine Unit, Reeves and Culberson Counties, Texas, in DeMis, W. D., ed., Permian Basin oil and gas fields: turning ideas into production: West Texas Geological Society Publication No. 97-102, p. 71-74.

Asquith, G. B., Dutton, S. P., Cole, A. G., Razi, M., and Guzman, J. I., 1997, Petrophysics of the Ramsey Sandstone, Ford Geraldine Unit, Reeves and Culberson Counties, Texas, in DeMis, W. D., ed., Permian Basin oil and gas fields: turning ideas into production: West Texas Geological Society Publication No. 97-102, p. 61-69.

Basham, W. L., 1996, Delaware Mountain Group sandstone channel orientations: implications for sediment source and deposition, in DeMis, W. D., and Cole, A. G., eds., The Brushy Canyon play in outcrop and subsurface: concepts and examples: guidebook: Permian Basin Section SEPM, Publication No. 96-38, p. 91-102.

Behnken, F. H., and Troschinetz, J., 1994, Impact of reservoir characterization on well completion and production economics, Permian Cherry Canyon sandstones, Loving County, Texas, in Gibbs, J. F., ed., Synergy equals energy - teams, tools, and techniques: West Texas Geological Society Publication 94-94, p. 3-13.

Broadhead, R. F., and Justman, H. A., 2000, Regional controls on oil accumulations, lower Brushy Canyon Formation, southeast New Mexico, in DeMis, W. D., Nelis, M. K., and Trentham, R. C., eds., The Permian Basin: proving ground for tomorrow's technologies: West Texas Geological Society, Publication No. 00-109, p. 9-18.

Dutton, S. P., and Barton, M. D., 1999, Application of outcrop analogs to reservoir characterization of Permian deep-water sandstones, Bell Canyon Formation, Ford Geraldine Unit, West Texas (Delaware Basin), in Transactions, Gulf Coast Section SEPM 19th Annual Bob F. Perkins Research Conference, December 5-8, Houston, p. $65-76$.

Dutton, S. P., Barton, M. D., Clift, S. J., Guzman, J. I., and Cole, A. G., 1997, Depositional history of Ramsey Sandstone channel-levee and lobe deposits, Bell Canyon Formation, Ford Geraldine Unit, West Texas (Delaware Basin), in DeMis, W. D., ed., Permian Basin oil and gas fields: turning ideas into production: West Texas Geological Society Publication No. 97-102, p. 53-60.

Dutton, S. P., and Flanders, W. A., 2001a, Application of advanced reservoir characterization, simulation, and production optimization strategies to maximize recovery in slope and basin clastic reservoirs, West Texas (Delaware Basin): The University of Texas at Austin, Bureau of Economic Geology, final report prepared for U.S. Department of Energy, $\mathrm{DOE} / \mathrm{BC} / 14936-18,170 \mathrm{p}$. 
Dutton, S. P., and Flanders, W. A., 2001b, Deposition and diagenesis of turbidite sandstones in East Ford Field, Bell Canyon Formation, Delaware Basin, Texas: American Association of Petroleum Geologists Southwest Section, 2001 Annual Meeting Papers and Abstracts, Dallas, Texas, March 10-13, 12 p.

Hamilton, D., and Hunt, T., 1996, War-Wink Cherry Canyon trend, "serendipity in spades," in Martin, R. L., ed., Permian Basin oil and gas fields: keys to success that unlock future reserves: West Texas Geological Society Publication 96-101, p. 107-115.

Harms, J. C., and Brady, M. J., 1996, Deposition of the Brushy Canyon Formation: 30 years of conflicting hypotheses, in DeMis, W. D., and Cole, A. G., eds., The Brushy Canyon play in outcrop and subsurface: concepts and examples: guidebook: Permian Basin Section, SEPM, Publication No. 96-38, p. 51-59.

Hayes, P. D., and Tieh, T. T., 1992, Organic geochemistry and diagenesis of the Delaware Mountain Group, west Texas and southeast New Mexico, in Cromwell, D. W., Moussa, M. T., and Mazzullo, L. J., eds., Southwest Section American Association of Petroleum Geologists Transactions, SWS 92-90, p. 155-175.

Justman, H. A., and Broadhead, R. F., 2000, Source rock analysis for the Brushy Canyon Formation, Delaware Basin, southeastern New Mexico, in DeMis, W. D., Nelis, M. K., and Trentham, R. C., eds., The Permian Basin: proving ground for tomorrow's technologies: West Texas Geological Society, Publication No. 00-109, p. 211-220.

Kane, T. V., 1992, Sequence stratigraphy improves definition of reservoir architecture at Avalon (Delaware) field, Eddy County, New Mexico, in Mruk, D. H., and Curran, B. C., eds., Permian Basin exploration and production strategies: applications of sequence stratigraphic and reservoir characterization concepts: West Texas Geological Society Publication 92-91, p. 12-18.

Leiphart, D. J., and Hart, B. S., 2000, Probabilistic neural network used to predict porosity from 3-D seismic attributes in lower Brushy Canyon Formation, southeast New Mexico, in DeMis, W. D., Nelis, M. K., and Trentham, R. C., eds., The Permian Basin: proving ground for tomorrow's technologies: West Texas Geological Society, Publication No. 00-109, p. 187-191.

Lewis, P., Cross, S., and Hoose, G., 1996, Delaware Mountain Group production map, in DeMis, W. D., and Cole, A. G., eds., The Brushy Canyon play in outcrop and subsurface: concepts and examples: guidebook: Permian Basin Section SEPM, Publication No. 96-38, separate map in back pocket.

Ruggiero, R. W., 1993, Depositional history and performance of a Permian Bell Canyon sandstone reservoir, Ford-Geraldine field, West Texas, in Rhodes, E. G., and Moslow, T. F., eds., Marine clastic reservoirs: New York, Springer-Verlag, p. 201-229. 
Segrest, C. C., 1993, Identification of productive intervals and definition of original oil in place, Brushy Canyon Delaware Formation, Delaware Basin, in Gibbs, J., and Cromwell, D., eds., New dimensions in the Permian Basin: West Texas Geological Society Publication 93-93, p. 47-54.

Spain, D. R., 1992, Petrophysical evaluation of a slope fan/basin-floor fan complex: Cherry Canyon Formation, Ward County, Texas: American Association of Petroleum Geologists Bulletin, v. 76, p. 805-827.

Thomerson, M. D., and Asquith, G. B., 1992, Petrophysical analysis of the Brushy Canyon Formation, Hat Mesa field, Lea County, New Mexico, in Mruk, D. H., and Curran, C., eds., Permian Basin Exploration and production strategies: application of sequence stratigraphic and reservoir characterization concepts: West Texas Geological Society Publication 92-91, p. 80-90.

Walling, S. D., Hays, P. D., and Tieh, T. T., 1992, Chlorites in reservoir sandstones of the Guadalupian Delaware Mountain Group, in Cromwell, D. W., Moussa, M. T., and Mazzullo, L. J., eds., Southwest Section, American Association of Petroleum Geologists, Transactions, SWS 92-90, p. 149-154.

Weiss, W. W., Stubbs, B. A., and Balch, R. S., 2001, A new tool for lower Brushy Canyon completion decisions, in Viveiros, J. J., and Ingram, S. M., eds., The Permian Basin: microns to satellites, looking for oil and gas at all scales: West Texas Geological Society Publication No. 01-110, p. 99-104. 
Queen Tidal-Flat Sandstone (Play 131)

The 17 reservoirs in the Queen Tidal-Flat Sandstone play, which produce from the middle Guadalupian Queen Formation (fig. 3), had produced 179.6 MMbbl $\left(2.86 \times 10^{7} \mathrm{~m}^{3}\right)$ of oil through 2000 (table 37). In the Atlas of Major Texas Oil Reservoirs, this play was called the Queen Platform/Strandplain Sandstone (Galloway and others, 1983). Queen Formation reservoirs in this play occur within eolian-sand-sheet, tidal-flat, tidal-channel, and shoreface deposits located on the east and south margins of the Central Basin Platform (fig. 114) (Tyler and others, 1991).

The vertical sequence of siliciclastic and evaporite sediments is the product of upwardshoaling environments. Sandstone facies are overlain by sabkha dolomudstones and massive anhydrite, and the massive anhydrite is commonly overlain by eolian sheet sands (Tyler and others, 1991). Queen sandstones at Yates field on the south part of the Central Basin Platform are interpreted as having been deposited on a coastal mud flat fed by eolian sands (Spencer and Warren, 1986). Some of the sands were probably reworked in tidal channels and ponds.

Table 37. Queen Tidal-Flat Sandstone play (play 131). Production shown for fields that have had others combined into them represents the totals; combined fields are highlighted.

\begin{tabular}{|c|c|c|c|c|c|c|c|c|c|}
\hline RRC RESN & RRC & FLDNAME & RESNAME & STATE & COUNTY & DISCYR & DEPTHTOP & 2000 PROD & CUMPROD \\
\hline 20004666 & 8 & CONCHO BLUFF & QUEEN & $T X$ & CRANE & 1956 & 4131 & 47,654 & $8,689,957$ \\
\hline 20006500 & 8 & CONCHO BLUFF, NORTH & QUEEN & $\mathrm{TX}$ & ECTOR & 1956 & 4490 & 547,809 & $15,394,816$ \\
\hline 39242333 & $8 \mathrm{~A}$ & HARRIS & QUEEN & $T X$ & GAINES & 1957 & 4148 & 16,438 & $1,672,816$ \\
\hline 56822625 & 8 & MAGUTEX & QUEEN & $\mathrm{TX}$ & ANDREWS & 1958 & 4862 & 87,928 & $4,868,087$ \\
\hline 59419664 & 8 & MCFARLAND & QUEEN & $\mathrm{TX}$ & ANDREWS & 1955 & 4790 & 201,349 & $42,782,895$ \\
\hline 59420500 & 8 & MCFARLAND, EAST & QUEEN & $T X$ & ANDREWS & 1955 & 4789 & 26,551 & $2,560,021$ \\
\hline 60137500 & 8 & MEANS & QUEEN SAND & $\mathrm{TX}$ & ANDREWS & 1954 & 4024 & 77,759 & $39,045,231$ \\
\hline 60139500 & 8 & MEANS, N. & QUEEN SAND & TX & GAINES & 1955 & 4341 & 40,834 & $8,270,696$ \\
\hline 62781500 & 8 & MOOSE & QUEEN & $T X$ & ECTOR & 1958 & 4512 & 255,601 & $9,078,764$ \\
\hline 65674001 & $7 \mathrm{C}$ & NOELKE & & TX & CROCKETT & 1940 & 1133 & 779 & $5,595,084$ \\
\hline 73167500 & 8 & PRIEST \& BEAVERS & QUEEN & $\mathrm{TX}$ & PECOS & 1957 & 2180 & 7,958 & $2,387,501$ \\
\hline 82570700 & 8 & SHAFTER LAKE & YATES & $\mathrm{TX}$ & ANDREWS & 1952 & 3054 & 7,293 & $1,951,628$ \\
\hline 88562001 & 8 & TAYLOR LINK & & TX & PECOS & 1929 & 1800 & 14,399 & $15,896,612$ \\
\hline 93958525 & 8 & VIREY & QUEEN & $T X$ & MIDLAND & 1988 & 4299 & 151,810 & $1,991,053$ \\
\hline 94747001 & 8 & WALKER & & $T X$ & PECOS & 1940 & 2016 & 10,627 & $9,482,673$ \\
\hline 96875001 & 8 & WHITE \& BAKER & & $T X$ & PECOS & 1934 & 1100 & 9,742 & $5,575,897$ \\
\hline 99295333 & 8 & YATES & SMITH SAND & $T X$ & PECOS & 1944 & 1100 & 12,970 & $4,356,435$ \\
\hline \multicolumn{4}{|c|}{ Totals } & & & & & $1,517,501$ & $179,600,166$ \\
\hline
\end{tabular}




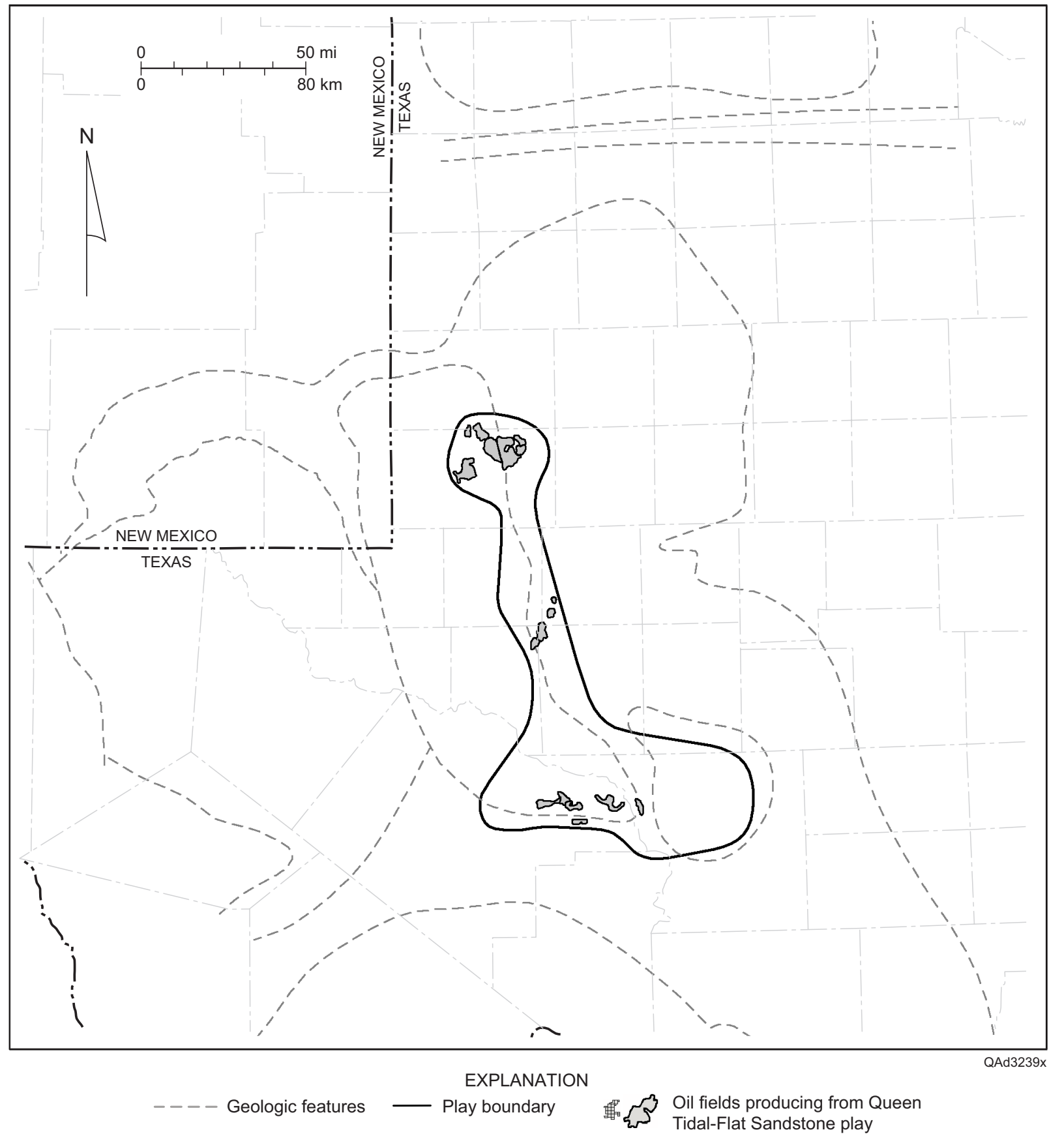

Figure 114. Play map for the Queen Tidal-Flat Sandstone play, showing location of reservoirs having $>1 \mathrm{MMbbl}$ cumulative production, the play boundary, and geologic features. See figure 1 for county names and figure 2 for identification of geologic features. 
Production comes from multiple siltstone and very fine grained sandstone beds within the reservoirs (Price and others, 2000). Each sandstone is sealed by massive impermeable anhydrite on both the top and bottom, resulting in barriers to vertical fluid flow (Tyler and others, 1991). Thus, the sandstones act as separate reservoir units. Within the reservoir sandstones, flow continuity is further complicated by juxtaposition of tidal-channel, tidal-flat, shoreface, and eolian facies. Sandstone productivity is controlled both by depositional heterogeneities and postdepositional diagenesis. Porosity development is controlled mainly by the amount of dolomite and anhydrite cement filling intergranular pores. Porosity in productive sandstones ranges from 11 to 27 percent and averages 17 percent (Tyler and others, 1991).

Small anticlines, anticlinal noses, and irregularly shaped domes, combined with an overlapping seal of massive anhydrite, form the traps in these reservoirs (Tyler and others, 1991). The structures resulted from draping of the Queen Formation over preexisting paleotopography. Queen sandstone distribution was influenced by paleotopography associated with deep-seated structures (Trentham, 2003).

The McFarland Queen reservoir in Andrews County produces from two sandstones in the lower Queen Formation (fig. 115) (Tyler and others, 1991; Holtz, 1994). The sandstones, which form the bases of progradational, upward-shoaling cycles, were deposited in intertidal-flat, tidal-channel, and shoreface environments. They are overlain by supratidal dolomudstones and massive anhydrite at the top (Holtz, 1994). Production is highest where the sandstones are thickest, in areas interpreted to be tidal-channel deposits. Porosity ranges from 11 to 24 percent and averages 12 percent; permeability ranges from 3 to $24 \mathrm{md}\left(3\right.$ to $\left.24 \times 10^{-3} \mu \mathrm{m}^{2}\right)$ and averages $12 \mathrm{md}\left(12 \times 10^{-3} \mu \mathrm{m}^{2}\right)($ Holtz, 1994). 


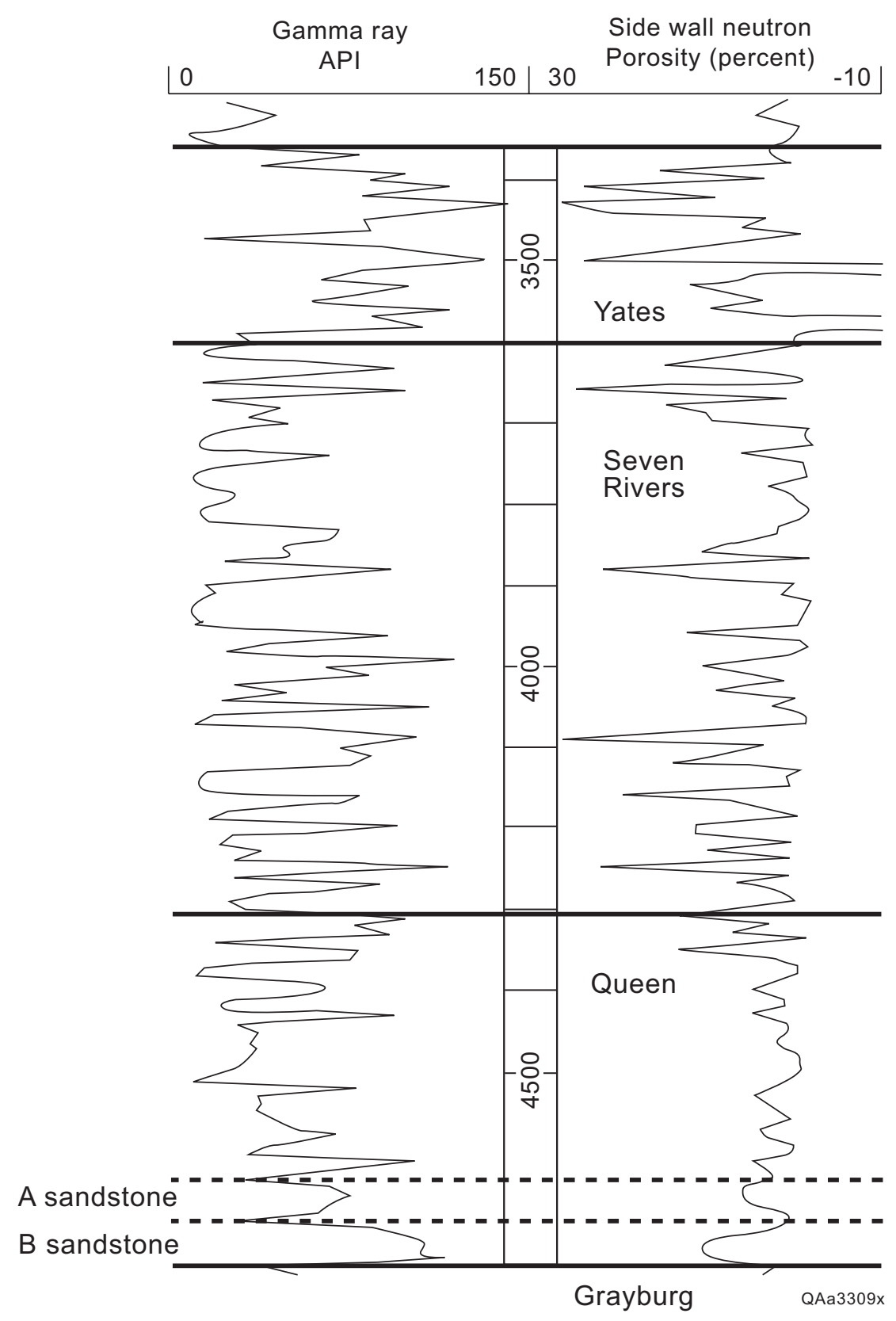

Figure 115. Typical log of upper Permian Queen, Seven Rivers, and Yates Formations in the McFarland Queen reservoir, Andrews County, showing producing Queen sandstones A and B. From Holtz (1994). 


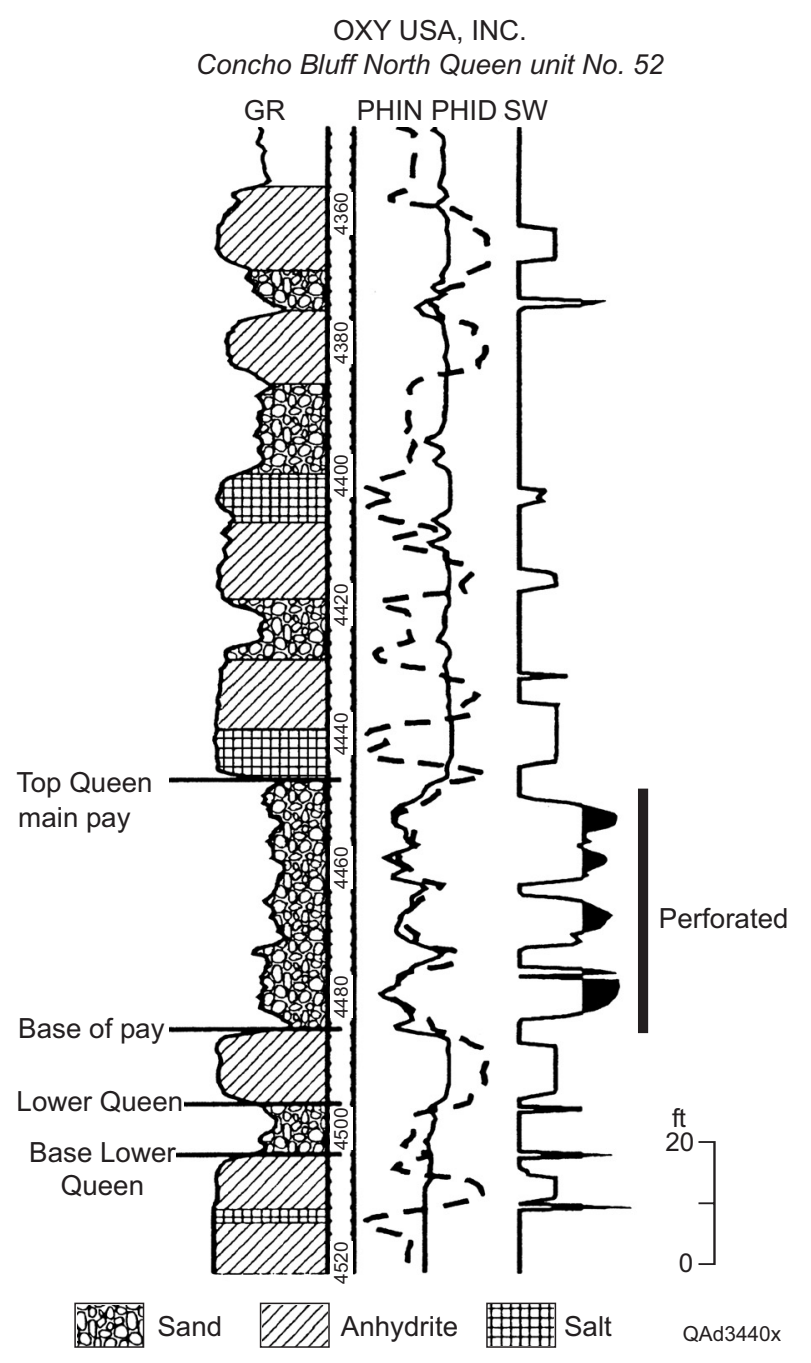

Figure 116. Typical log from Concho Bluff North Queen unit, Ector County, showing reservoir sandstones interbedded with halite and anhydrite. From Lufholm and others (1996).

The reservoir interval at North Concho Bluff field consists of several sandstones interbedded with anhydrite and salt in the upper Queen Formation (fig. 116) (Mazzullo and others, 1992; Lufholm and others, 1996). The depositional setting was a broad, low-relief shelf where clastics interfingered with evaporite deposits during lowstands of sea level. Permeability in the reservoir sandstones ranges from 1 to $1200 \mathrm{md}\left(1\right.$ to $\left.1200 \times 10^{-3} \mu^{2}\right)$ and averages $70 \mathrm{md}$ $\left(70 \times 10^{-3} \mu \mathrm{m}^{2}\right)$; porosity ranges from 9 to 26 percent and averages 16 percent (Mazzullo and others, 1992). 
Production from the North Concho Bluff Queen reservoir had declined to $35 \mathrm{bbl} / \mathrm{d}$ $\left(5.6 \mathrm{~m}^{3} / \mathrm{d}\right)$ by $1994.3-\mathrm{D}$ seismic data were acquired over the field, and a seismic-guided method to estimate reservoir properties was used to populate a reservoir model with average porosity and permeability values (Lufholm and others, 1996). Reservoir simulation identified areas of "banked oil" that were poorly swept by waterflooding. After two infill wells were drilled and two existing wells were converted to injectors, production increased to $200 \mathrm{bbl} / \mathrm{d}\left(31.8 \mathrm{~m}^{3} / \mathrm{d}\right)$. The reservoir model identified additional potential recoverable reservoirs of $>2 \mathrm{MMbbl}$ $\left(>3.18 \times 10^{5} \mathrm{~m}^{3}\right)$ (Lufholm and others, 1994).

\section{References}

Galloway, W. E., Ewing, T. E., Garrett, C. M., Jr., Tyler, N., and Bebout, D. G., 1983, Atlas of major Texas oil reservoirs: The University of Texas at Austin, Bureau of Economic Geology Special Publication, 139 p.

Holtz, M. H., 1994, McFarland (Queen) reservoir, in Selected oil and gas fields in West Texas v. VI: West Texas Geological Society, Publication No. 94-96, p. 169-177.

Lufholm, P., Watts, G., and Lofton, L., 1996, Improved reservoir modeling using gridded seismic attributes: North Concho Bluff field, west Texas, in Martin, R. L., ed., Permian Basin oil and gas fields: keys to success that unlock future reserves: West Texas Geological Society Publication 96-101, p. 145-159.

Mazzullo, J., Malicse, A., Newsom, D., Harper, J., McKone, C. and Price, B., 1992, Facies, depositional environments, and reservoir properties of the upper Queen Formation, Concho Bluff and Concho Bluff North fields, Texas, in Mruk, D. H., and Curran, B. C., eds., Permian Basin exploration and production strategies: applications of sequence stratigraphic and reservoir characterization concepts: West Texas Geological Society, Publication 92-91, p. 67-78.

Price, C., Ryu, C., and Mazzullo, J., 2000, Lithofacies, depositional environments and reservoir properties of the Permian (Guadalupian) Grayburg and Queen Formations, Means field, Andrews County, Texas, in Reid, S. T., ed., Geo-2000: into the future: Southwest Section American Association of Petroleum Geologists Transactions, Publication SWS 2000-107, p. $80-97$. 
Slone, J. C., and Mazzullo, J., 2000, Lithofacies, stacking patterns, and depositional environments of the Permian Queen Formation, Sterling and Glasscock Counties, Texas, in DeMis, W. D., Nelis, M. K., and Trentham, R. C., eds., The Permian Basin: proving ground for tomorrow's technologies: West Texas Geological Society Publication No. 00-109, p. 63-64.

Spencer, A. W., and Warren, J. K., 1986, Depositional styles in the Queen and Seven Rivers Formations-Yates field, Pecos Co., Texas, in Bebout, D. G., and Harris, P. M., eds., Hydrocarbon reservoir studies, San Andres/Grayburg Formations, Permian Basin: Permian Basin Section, Society of Economic Paleontologists and Mineralogists, Publication No. 86-26, 135-137.

Trentham, R. C., 2003, Impact of paleostructure on Guadalupian age clastic sediment distribution in the Midland Basin, Central Basin Platform, and eastern Delaware Basin, in Hunt, T. J., and Lufholm, P. H., eds., The Permian Basin: back to basics: West Texas Geological Society Publication No. 03-112, p. 79-95.

Tyler, N., Bebout, D. G., Garrett, C. M., Jr., Guevara, E. H., Hocott, C. R., Holtz, M. H., Hovorka, S. D., Kerans, C., Lucia, F. J., Major, R. P., Ruppel, S. C., and Vander Stoep, G. W., 1991, Integrated characterization of Permian Basin reservoirs, University Lands, West Texas: targeting the remaining resource for advanced oil recovery: The University of Texas at Austin, Bureau of Economic Geology Report of Investigations No. 203, $136 \mathrm{p}$. 
Artesia Platform Sandstone (Play 132)

The Artesia Platform Sandstone play, which was called the Permian Sandstone and Carbonate Play in the Atlas of Major Texas Oil Reservoirs (Galloway and others, 1983), has produced 1,855.4 MMbbl $\left(2.95 \times 10^{8} \mathrm{~m}^{3}\right)$ of oil from 77 reservoirs (table 38 , fig. 117).

Reservoirs that make up the play are in the Queen, Seven Rivers, and Yates Formations of the Artesia Group (figs. 3, 118) and are located along the west edge of the Central Basin Platform and on the Northwest Shelf (fig. 117). Queen reservoirs on the east side of the Central Basin Platform are in the Queen Tidal-Flat Sandstone play (play 131). Principal productive sandstones

Table 38. Artesia Platform Sandstone play (play 132). Production shown for fields that have had others combined into them represents the totals; combined fields are highlighted.

\begin{tabular}{|c|c|c|c|c|c|c|c|c|c|}
\hline RRC RESN & RRC & FLDNAME & RESNAME & STATE & COUNTY & DISCYR & DEPTHTOP & 2000 PROD & CUMPROD \\
\hline 292551 & 8 & ABELL & PERMIAN 2200 & TX & PECOS & 1949 & 2200 & 22,870 & $1,074,575$ \\
\hline 4184666 & 8 & ATAPCO & QUEEN & $\mathrm{TX}$ & CRANE & 1959 & 2140 & 26,481 & $1,351,920$ \\
\hline 6853333 & 8 & BELDING & YATES & $\mathrm{TX}$ & PECOS & 1964 & 2672 & 100,936 & $1,138,199$ \\
\hline 14155001 & 8 & BYRD & & $T X$ & WARD & 1942 & 2700 & 5,047 & $1,148,651$ \\
\hline 25501500 & 8 & DORR & QUEEN SAND & $T X$ & WARD & 1955 & 2291 & 21,036 & $1,045,088$ \\
\hline 28962001 & 8 & EMPEROR, DEEP & & $\mathrm{TX}$ & WINKLER & 1935 & 3000 & 39,499 & $11,773,170$ \\
\hline 32124001 & 8 & FORT STOCKTON & & $T X$ & PECOS & 1944 & 2892 & 259,922 & $34,386,845$ \\
\hline 32124625 & 8 & FORT STOCKTON & YATES LOWER & TX & PECOS & 1943 & 3072 & 0 & $1,770,005$ \\
\hline 32344800 & 8 & FOUR C & SAN ANDRES & TX & PECOS & 1975 & 2302 & 51,217 & $1,110,536$ \\
\hline 38255001 & 8 & HALLEY & & $\mathrm{TX}$ & WINKLER & 1939 & 3150 & 129,142 & $44,608,756$ \\
\hline 38260664 & 8 & HALLEY, SOUTH & QUEEN SAND & $\mathrm{TX}$ & WINKLER & 1960 & 3113 & 57,841 & $4,788,167$ \\
\hline 40354001 & 8 & HENDERSON & & TX & WINKLER & 1936 & 3030 & 33,553 & $16,617,751$ \\
\hline 40406001 & 8 & HENDRICK & & $T X$ & WINKLER & 1926 & 3100 & 315,251 & $265,038,391$ \\
\hline 49038001 & 8 & KERMIT & & TX & WINKLER & 1928 & 2800 & 215,702 & $111,012,043$ \\
\hline 49129132 & 8 & KEYSTONE & COLBY & TX & WINKLER & 1939 & 3300 & 219,044 & $75,325,366$ \\
\hline 53000830 & 8 & LEHN-APCO & 1600 & $\mathrm{TX}$ & PECOS & 1939 & 1700 & 6,812 & $3,296,731$ \\
\hline 53002666 & 8 & LEHN-APCO, NORTH & 1600 & $\mathrm{TX}$ & PECOS & 1946 & 1945 & 3,515 & $3,200,802$ \\
\hline 56761001 & 8 & MAGNOLIA SEALY & & $\mathrm{TX}$ & WARD & 1939 & 3000 & 63,721 & $5,774,660$ \\
\hline 56766001 & 8 & MAGNOLIA SEALY, SOUTH & & TX & WARD & 1940 & 2847 & 11,688 & $3,580,223$ \\
\hline 56949500 & 8 & MALICKY & QUEEN SAND & $T X$ & PECOS & 1949 & 1964 & 7,577 & $3,604,412$ \\
\hline 58164001 & 8 & MASTERSON & & $\mathrm{TX}$ & PECOS & 1929 & 1500 & 2 & $2,723,125$ \\
\hline 62415747 & 8 & MONAHANS & QUEEN SAND & $\mathrm{TX}$ & WARD & 1960 & 3269 & 29,452 & $6,505,467$ \\
\hline 62420666 & 8 & MONAHANS, SOUTH & QUEEN & $\mathrm{TX}$ & WARD & 1961 & 3108 & 25,049 & $8,027,310$ \\
\hline 64995001 & 8 & NETTERVILLE & & $T X$ & PECOS & 1934 & 2400 & 4,223 & $3,325,351$ \\
\hline 66588001 & 8 & OATES & & TX & PECOS & 1947 & 790 & 47,335 & $1,595,709$ \\
\hline 69873001 & 8 & PAYTON & & $\mathrm{TX}$ & PECOS & 1938 & 2000 & 46,004 & $14,835,765$ \\
\hline 70129580 & 8 & PECOS VALLEY & HIGH GRAVITY & $\mathrm{TX}$ & PECOS & 1928 & 1800 & 55,939 & $20,014,222$ \\
\hline 70129638 & 8 & PECOS VALLEY & LOW GRAVITY & TX & PECOS & 1928 & 1600 & 14,576 & $6,747,210$ \\
\hline 81392001 & 8 & SCARBOROUGH & & TX & WINKLER & 1927 & 3200 & 23,055 & $37,034,546$ \\
\hline 81394001 & 8 & SCARBOROUGH, NORTH & & TX & WINKLER & 1947 & 3286 & 3,290 & $3,443,096$ \\
\hline 81952500 & 8 & SEALY, SOUTH & YATES & TX & WARD & 1946 & 2700 & 4,676 & $1,229,767$ \\
\hline 82822001 & 8 & SHEARER & & $\mathrm{TX}$ & PECOS & 1938 & 1400 & 0 & $4,684,529$ \\
\hline 83292500 & 8 & SHIPLEY & QUEEN SAND & $\mathrm{TX}$ & WARD & 1928 & 3075 & 34,250 & $29,037,233$ \\
\hline 85104001 & 8 & SPENCER & & $\mathrm{TX}$ & WARD & 1941 & 2900 & 9,365 & $3,071,702$ \\
\hline 92304500 & 8 & USM & QUEEN & $T X$ & PECOS & 1964 & 3368 & 24,088 & $2,219,718$ \\
\hline 95138001 & 8 & WARD, SOUTH & & TX & WARD & 1938 & 2700 & 280,237 & $108,366,864$ \\
\hline 95152001 & 8 & WARD-ESTES, NORTH & & $\mathrm{TX}$ & WARD & 1929 & 3000 & $1,320,287$ & $412,799,795$ \\
\hline 95970200 & 8 & WEINER & COLBY SAND & $\mathrm{TX}$ & WINKLER & 1941 & 3200 & 25,399 & $9,239,506$ \\
\hline 97201500 & 8 & WICKETT, SOUTH & YATES & $T X$ & WARD & 1952 & 2640 & 7,080 & $1,894,254$ \\
\hline
\end{tabular}


are in the Yates and Queen Formations, although sandstones of the Seven Rivers Formation

provide significant production in some reservoirs. Dolostones of the Queen, Seven Rivers, Yates, and Tansill Formations form secondary reservoirs. Production from the dolostones is generally commingled with production from the more prolific sandstone reservoirs.

Siliciclastic, carbonate, and evaporite rocks of the Artesia Group were deposited on a broad, shallow shelf in a back-reef lagoonal setting located updip of the shelf-margin reef carbonates that rimmed the Delaware Basin (Silver and Todd, 1969; Ward and others, 1986). The Yates and Seven Rivers Formations are the restricted-platform equivalents of the middle and lower Capitan Reef platform-margin carbonates, and the Queen Formation is the

Table 38, continued. Artesia Platform Sandstone Play (Play 132).

\begin{tabular}{|c|c|}
\hline FLDNAME & RESNAME \\
\hline BARBER & YATES \\
\hline BENSON NORTH & QUEEN GRAYBURG \\
\hline BOWERS & SEVEN RIVERS \\
\hline CAPROCK & QUEEN \\
\hline CORBIN & QUEEN \\
\hline CORBIN CENTRAL & QUEEN \\
\hline DOLLARHIDE & QUEEN \\
\hline DOS HERMANOS & YATES SEVEN RIVERS \\
\hline DOUBLE L & QUEEN \\
\hline $\mathrm{E}-\mathrm{K}$ & YATES SEVEN RIVERS QUEEN \\
\hline E-K EAST & QUEEN \\
\hline EMPIRE & YATES SEVEN RIVERS \\
\hline EUMONT & YATES SEVEN RIVERS QUEEN \\
\hline EUNICE SOUTH & SEVEN RIVERS QUEEN \\
\hline FREN & SEVEN RIVERS \\
\hline GETTY & YATES \\
\hline HACKBERRY NORTH & YATES SEVEN RIVERS \\
\hline HIGH LONESOME & QUEEN \\
\hline HUME & QUEEN \\
\hline JALMAT & TANSILL YATES SEVEN RIVERS \\
\hline LANGLIE MATTIX & SEVEN RIVERS QUEEN GRAYBURG \\
\hline LEONARD SOUTH & QUEEN \\
\hline LYNCH & YATES SEVEN RIVERS \\
\hline MESA & QUEEN \\
\hline MILLMAN EAST & QUEEN GRAYBURG SAN ANDRES \\
\hline PEARL & QUEEN \\
\hline PEARSALL & QUEEN \\
\hline QUERECHO PLAINS & QUEEN \\
\hline RED LAKE EAST & QUEEN GRAYBURG \\
\hline RHODES & YATES SEVEN RIVERS \\
\hline SCARBOROUGH & YATES SEVEN RIVERS \\
\hline SHUGART & YATES SEVEN RIVERS QUEEN GRAYBURG \\
\hline SULIMAR & QUEEN \\
\hline TEAS & YATES SEVEN RIVERS \\
\hline TEAS WEST & YATES SEVEN RIVERS \\
\hline TURKEY TRACK & SEVEN RIVERS QUEEN GRAYBURG SAN ANDRES \\
\hline WILSON & YATES SEVEN RIVERS \\
\hline YOUNG & QUEEN \\
\hline
\end{tabular}

$\begin{array}{llrrrr}\text { STATE } & \text { COUNTY } & \text { DISCYR } & \text { DEPTHTOP } & \mathbf{2 0 0 0} \text { PROD } & \text { CUMPROD } \\ \text { NM } & \text { EDDY } & 1937 & 1442 & 4,831 & \\ \text { NM } & \text { EDDY } & 1954 & 2844 & 19,518 & 3,973,771 \\ \text { NM } & \text { LEA } & 1935 & 3553 & 11,527 & 4,234,936 \\ \text { NM } & \text { CHAVES \& LEA } & 1950 & 3030 & 24,082 & 74,210,930 \\ \text { NM } & \text { LEA } & 1938 & 4258 & 4,074 & 1,550,004 \\ \text { NM } & \text { LEA } & 1985 & 4228 & 26,201 & 1,091,714 \\ \text { NM } & \text { LEA } & 1952 & 3670 & 40,334 & 6,743,430 \\ \text { NM } & \text { EDDY } & 1955 & 1631 & 4,339 & 1,605,623 \\ \text { NM } & \text { CHAVES } & 1971 & 1980 & 11,290 & 3,511,218 \\ \text { NM } & \text { LEA } & 1954 & 4387 & 166,428 & 6,559,436 \\ \text { NM } & \text { LEA } & 1957 & 4387 & 6,233 & 1,315,635 \\ \text { NM } & \text { EDDY } & 1926 & 1600 & 5,383 & 1,291,409 \\ \text { NM } & \text { LEA } & 1953 & 2950 & 337,929 & 75,072,680 \\ \text { NM } & \text { LEA } & 1930 & 3610 & 14,112 & 32,423,951 \\ \text { NM } & \text { EDDY } & 1943 & 1940 & 0 & 6,680,361 \\ \text { NM } & \text { EDDY } & 1954 & 1343 & 0 & 1,822,000 \\ \text { NM } & \text { EDDY } & 1953 & 2047 & 18,529 & 3,468,223 \\ \text { NM } & \text { EDDY } & 1939 & 1800 & 9,535 & 4,609,851 \\ \text { NM } & \text { LEA } & 1956 & 3950 & 0 & 1,389,000 \\ \text { NM } & \text { LEA } & 1953 & 2800 & 397,842 & 77,336,091 \\ \text { NM } & \text { LEA } & 1935 & 2852 & 726,379 & 136,874,684 \\ \text { NM } & \text { LEA } & 1948 & 3400 & 4,419 & 2,098,167 \\ \text { NM } & \text { LEA } & 1929 & 3730 & 83,297 & 15,935,153 \\ \text { NM } & \text { LEA } & 1962 & 3350 & 2,225 & 1,701,072 \\ \text { NM } & \text { EDDY } & 1959 & 2413 & 210,946 & 8,307,502 \\ \text { NM } & \text { LEA } & 1955 & 4830 & 114,440 & 22,411,023 \\ \text { NM } & \text { LEA } & 1940 & 3685 & 18,436 & 2,968,614 \\ \text { NM } & \text { LEA } & 1972 & 3910 & 38,554 & 1,289,650 \\ \text { NM } & \text { EDDY } & 1960 & 1560 & 14,937 & 1,439,093 \\ \text { NM } & \text { LEA } & 1927 & 3040 & 30,337 & 14,226,051 \\ \text { NM } & \text { LEA } & 1965 & 3050 & 12,160 & 17,437,636 \\ \text { NM } & \text { EDDY } & 1937 & 3440 & 390,172 & 28,507,187 \\ \text { NM } & \text { CHAVES } & 1968 & 1960 & 8,489 & 2,334,105 \\ \text { NM } & \text { LEA } & 1929 & 3343 & 51,371 & 3,555,628 \\ \text { NM } & \text { LEA } & 1959 & 3225 & 65,726 & 1,966,523 \\ \text { NM } & \text { EDDY } & 1950 & 1655 & 50,856 & 3,885,863 \\ \text { NM } & \text { LEA } & 1928 & 3815 & 62 & 9,303,607 \\ \text { NM } & \text { LEA } & 1945 & 3765 & 56,522 & 2,367,621 \\ & & & & & \\ & & & & 6,526,676 & 1,855,409,025 \\ \end{array}$




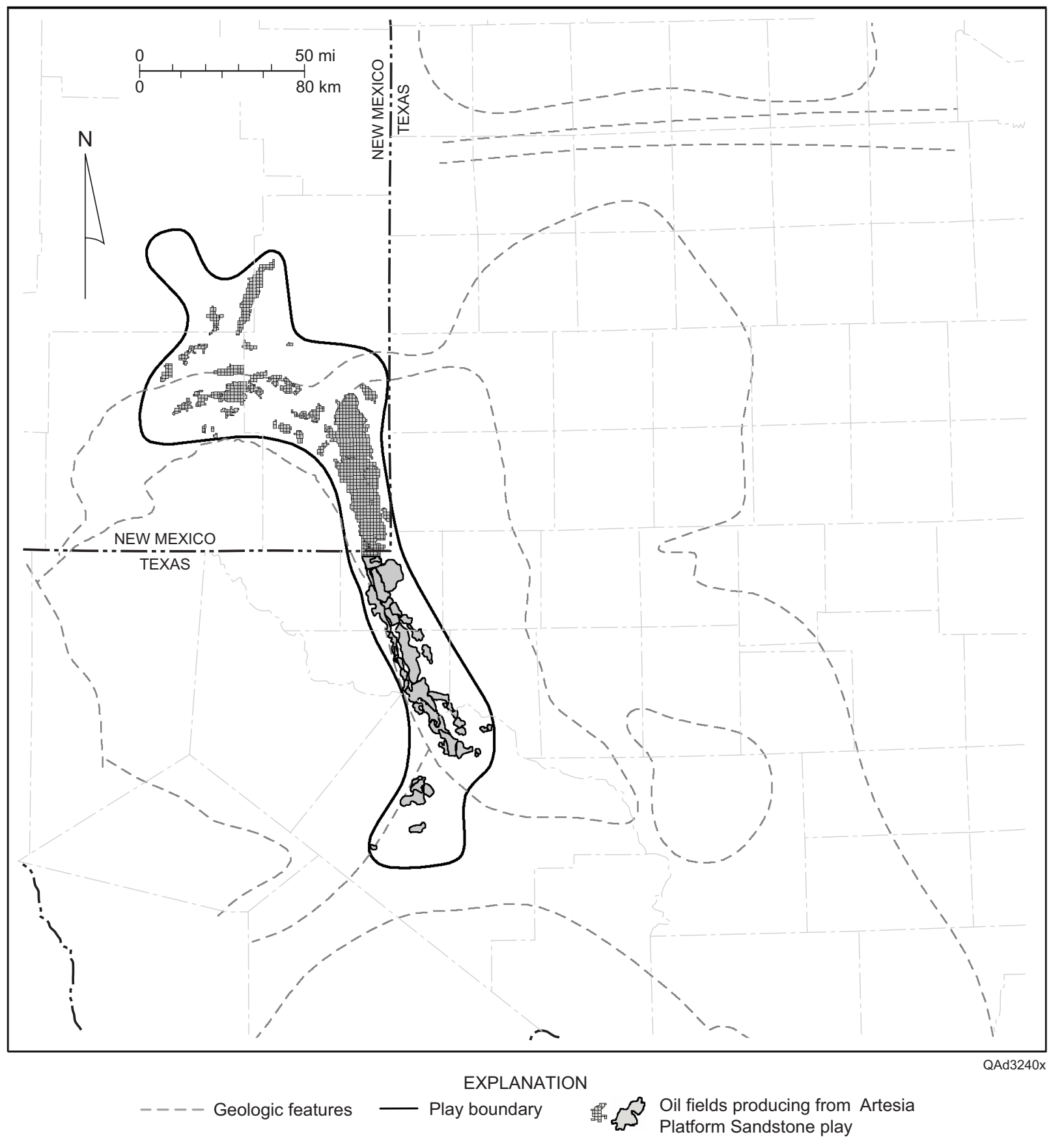

Figure 117. Play map for the Artesia Platform Sandstone play, showing location of reservoirs having $>1 \mathrm{MMbbl}$ cumulative production, the play boundary, and geologic features. See figure 1 for county names and figure 2 for identification of geologic features. 


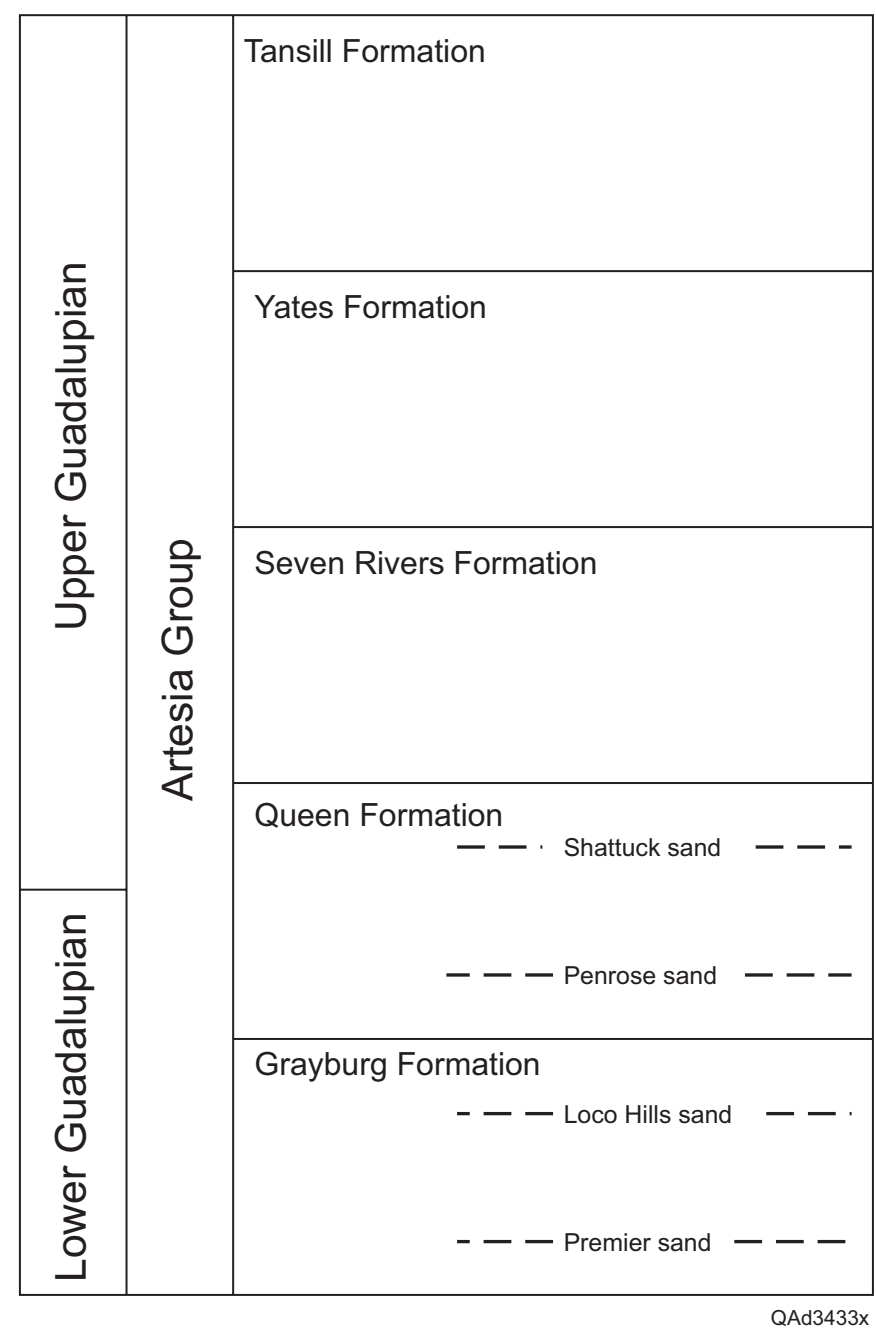

Figure 118. Stratigraphic column of Guadalupian Artesia Group, Central Basin Platform and Northwest Shelf.

restricted-platform equivalent of the older Goat Seep Reef (Silver and Todd, 1969; Ward and others, 1986). The Queen Formation on the west side of the Central Basin Platform is composed of interbedded clastics and carbonates, with minor amounts of evaporites (Eide and Mazzullo, 1993). The Seven Rivers Formation is composed mainly of evaporites and dolomites, with only minor siliciclastics (Sarg, 1981; Borer and Harris, 1991a; Andreason, 1992).

The Yates Formation marks a period of major siliciclastic shelf deposition (Andreason, 1992). The Yates Formation is an overall upward-shallowing sequence of cyclically interbedded 
siliciclastics associated with sabkha carbonates and evaporites (Ward and others, 1986;

Casavant, 1988; Borer and Harris, 1991a; Andreason, 1992). The Yates is interpreted as having been deposited in a complex of coastal and lagoonal environments upslope of the shelf-margin reef (Andreason, 1992). Yates reservoirs produce mainly from fine-grained sandstone and siltstone; cement and clay matrix content vary greatly within reservoirs, contributing to heterogeneity. Siliciclastic sources of the Yates are from the Northwest and Eastern Shelves (Mear and Yarbrough, 1961; Ward and others, 1986; Trentham, 2003).

Traps in the play are largely stratigraphic, with an updip seal formed by evaporitic facies of the inner shelf. Many fields on the Central Basin Platform are trapped by a combination of facies change and northwest- southeast-trending, elongate anticlinal structures formed by compaction draping over buried structures (Tyler and others, 1991).

The Keystone Colby reservoir, Winkler County (fig. 117), produces from sandstone units of the Queen Formation that are interbedded with nonproductive dolomite and anhydrite (figs. 119, 120) (Major and Ye, 1992, 1997). Colby reservoir rocks are interpreted as having been deposited in a lagoonal setting behind a carbonate rimmed-bank margin, in a series of upward-shoaling cycles composed of sandstone and dolomite. During sea-level highstands the lagoon was flooded, and carbonate sediments were deposited. During sea-level lowstands the lagoonal carbonate sediments probably were exposed and subjected to erosion and dissolution (Major and Ye, 1992, 1997). As sea level rose again, windblown sand was deposited in marine and peritidal environments in the lagoon. The most porous sandstones are interpreted as having been deposited in a relatively shallow water marine setting (Major and Ye, 1992, 1997). Porosity in the sandstones ranges from 6 to 19 percent. 


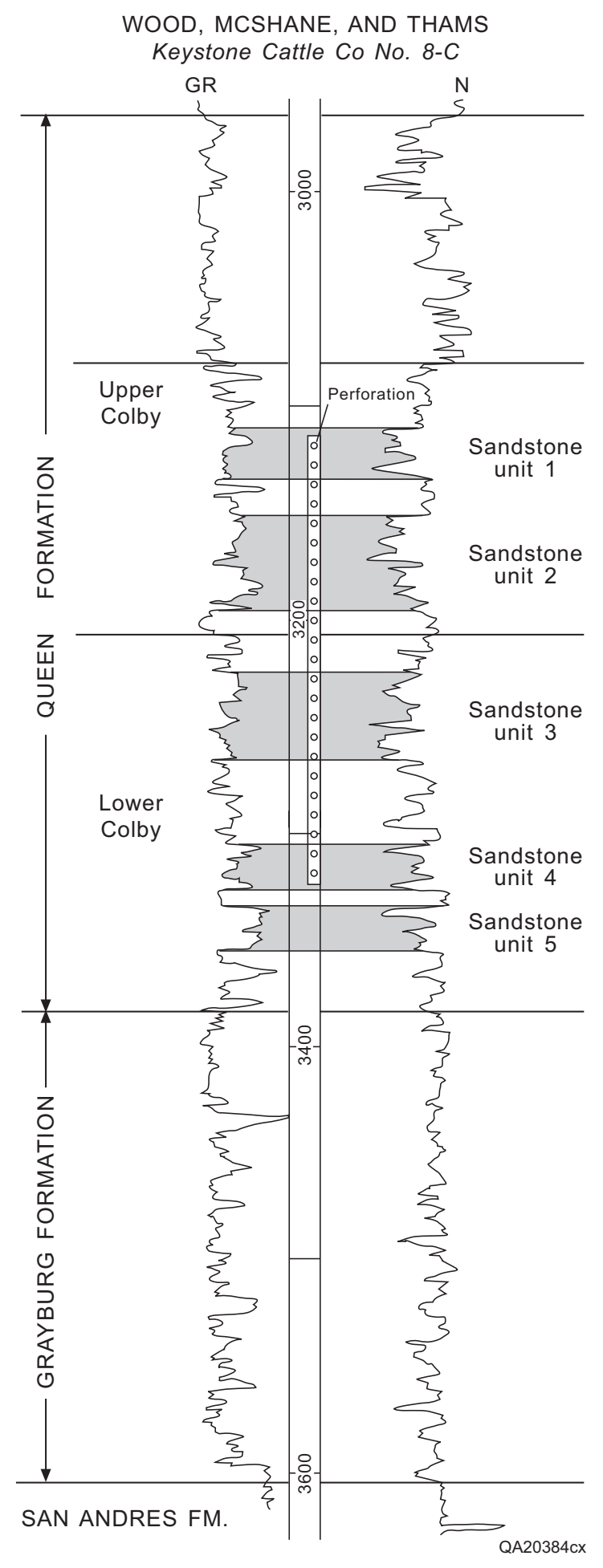

Figure 119. Representative log of the Keystone Colby reservoir illustrating the five major Queen sandstone packages. From Major and Ye (1992, 1997). 


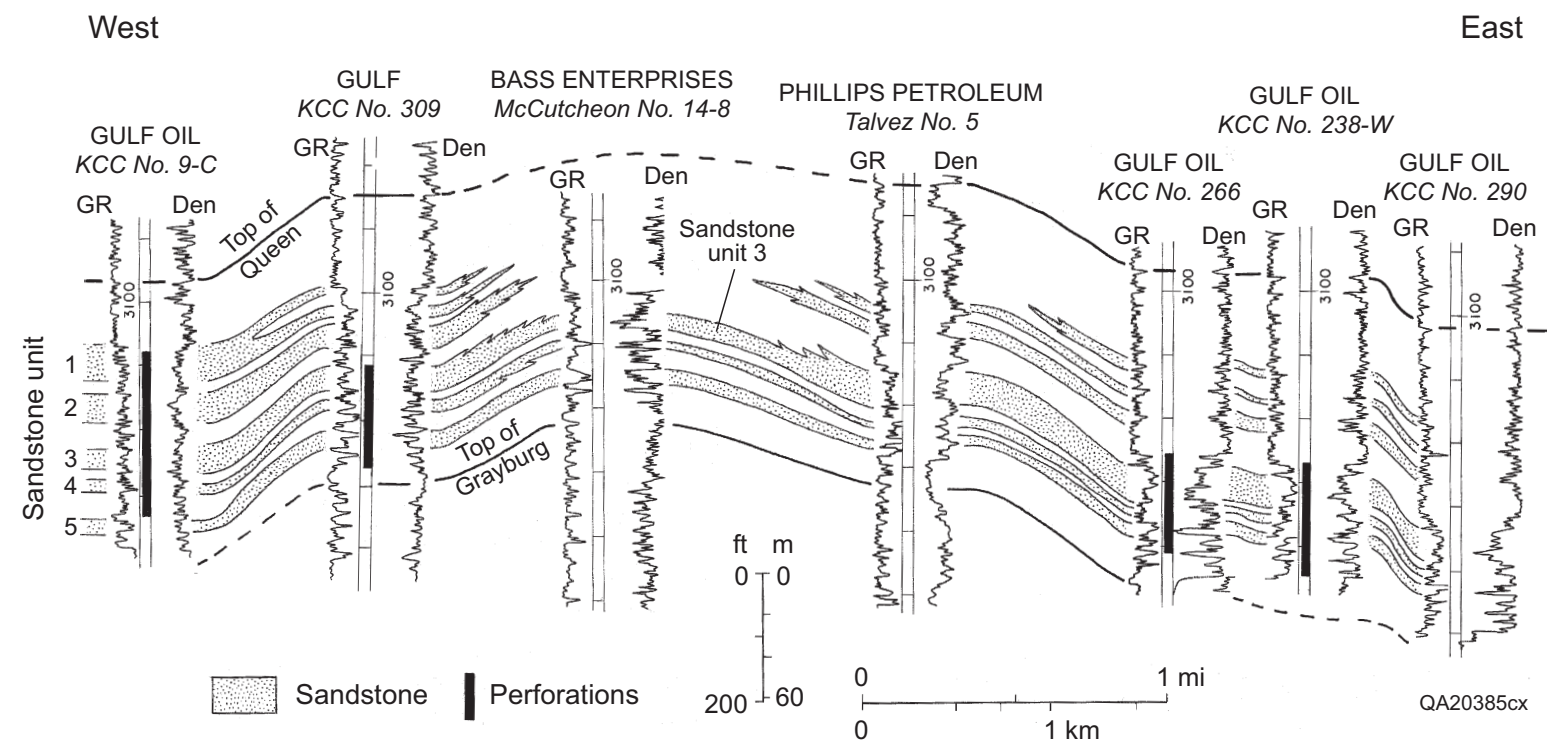

Figure 120. West-east cross section of Keystone Colby reservoir. From Major and Ye (1997). Pinch-out of sandstone units 1 and 2 toward the crest of the structure may indicate that the structure was syndepositional (Major and Ye, 1992, 1997).

Reservoirs in New Mexico that are productive solely from Queen sandstones occur along and north of a trend that extends from Hobbs to Artesia (fig. 117). The Queen sandstones in this area were deposited in coastal, sandy braided streams; fluvial sandflats and fluvial-dominated coastal sabkhas; and poorly channelized sheet deltas that filled in lagoonal areas (Mazzullo, 1992). Traps are largely stratigraphic, with porosity plugged updip by evaporites (Ward and others, 1986; Malisce and Mazzullo, 1990). Productive Queen sandstones are fine to medium grained; average reservoir porosities range from 17 to 22 percent.

The largest reservoir in the play is North Ward-Estes in Ward County (table 38), which produces from sandstones in the Yates, Seven Rivers, and Queen Formations (Andreason, 1992; Eide and Mazzullo, 1993; Bain, 1994; Mazzullo and others, 1996). Most of the production is from the Yates Formation, from very fine grained sandstones and siltstones interbedded with low-permeability dolomites (fig. 121) (Ring and Smith, 1995). North Ward-Estes is part of a 


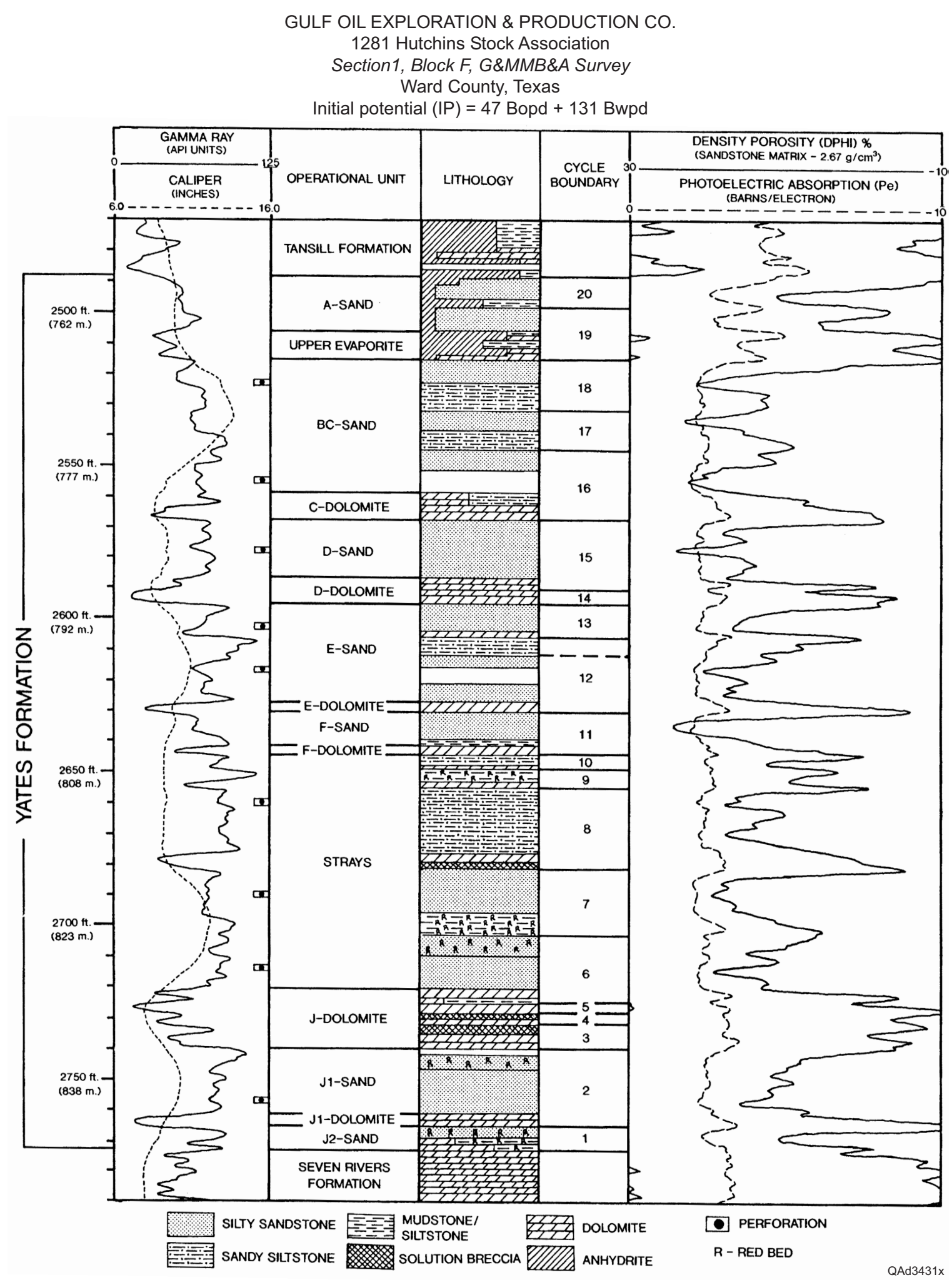

Figure 121. Typical log of Yates reservoir section in North Ward Estes field. From Andreason (1992). From Andreason (1992), reprinted by permission of the AAPG, whose permission is required for further use. (C) Copyright 1992. The American Association of Petroleum Geologists. All rights reserved. 
series of fields that produce from the Yates Formation on the west side of the Central Basin Platform (Ward and others, 1986). The Yates shelf was subdivided into three parts: (1) an outer carbonate shelf that included the Capitan reef, backreef flats, and pisolitic shelf crest; (2) a middle, siliciclastic-dominated shelf composed of stacked beach ridges and siliciclastic sabkhas; and (3) an evaporative inner shelf composed of playa mud flats, salinas, and stabilized sand sheets (Andreason, 1992). The siliciclastics were deposited during periods of shelf emergence during lowstand and transgressive periods, whereas carbonates were deposited mainly during highstand periods, when the shelf was submerged. Most hydrocarbon production comes from strike-oriented beach-ridge sandstones (Andreason, 1992).

Recovery in North Ward-Estes field during secondary waterflooding was improved by drilling infill wells, realigning patterns, and increasing water injection (Ring and Smith, 1995). $\mathrm{A} \mathrm{CO}_{2}$ flood was initiated in the Yates Formation in 1989 (Bain, 1994; Ring and Smith, 1995). Oil recovery during the $\mathrm{CO}_{2}$ flood has been maximized by maintaining a consistent wateralternating-gas (WAG) process, optimizing use of $\mathrm{CO}_{2}$, and maintaining a balance between patterns (Ring and Smith, 1995).

Productive Yates sandstones in New Mexico are poorly consolidated, silty, and fine grained with porosities of 15 to 28 percent (Borer and Harris, 1991a, b). Clean, productive sandstones are interbedded with argillaceous sandstones that form poor reservoirs. The sandstones occur in a clastic-rich belt on the middle shelf that separates the evaporitic inner shelf to the north from the carbonate-rich outer shelf to the south. Depositional processes that formed the reservoir sandstones are poorly understood (Borer and Harris, 1991a). Traps are largely stratigraphic, with an updip seal formed by evaporitic facies of the inner shelf. 


\section{References}

Andreason, M. W., 1992; Coastal siliciclastic sabkhas and related evaporative environments of the Permian Yates Formation, North Ward-Estes field, Ward County, Texas: American Association of Petroleum Geologists Bulletin, v. 76, p. 1735-1759.

Bain, R. C., 1994, North Ward-Estes, in Selected oil and gas fields in West Texas, v. VI: West Texas Geological Society, Publication No. 94-96, p. 275-279.

Borer, J. M., and Harris, P. M., 1991a, Lithofacies and cyclicity of the Yates Formation, Permian Basin: implications for reservoir heterogeneity: American Association of Petroleum Geologists Bulletin, v. 75, p. 726-779.

1991b, Depositional facies and model for mixed siliciclastics and carbonates of the Yates Formation, Permian Basin, in Lomando, A. J., and Harris, P. M., eds., Mixed carbonate-siliciclastic sequences, in Society of Economic Paleontologists and Mineralogists, Core Workshop 15, p. 1-133.

Casavant, R. R., 1988, Reservoir geology and paleo-environmental reconstruction of Yates Formation, Central Basin Platform, West Texas (abs.): American Association of Petroleum Geologists Bulletin, v. 72, p. 169.

Eide, M., and Mazzullo, J., 1993, Facies, depositional environments and stratigraphy of the Queen Formation in North Ward-Estes field, Ward County, Texas, in Gibbs, J., and Cromwell, D., eds., New dimensions in the Permian Basin: West Texas Geological Society Publication 93-93, p. 28-42.

Galloway, W. E., Ewing, T. E., Garrett, C. M., Jr., Tyler, N., and Bebout, D. G., 1983, Atlas of major Texas oil reservoirs: The University of Texas at Austin, Bureau of Economic Geology Special Publication, 139 p.

Major, R. P., and Ye, Q., 1992, Lateral and vertical reservoir heterogeneity in siliciclastic peritidal facies, Keystone (Colby) reservoir, west Texas, in Mruk, D. H., and Curran, C., eds., Permian Basin Exploration and production strategies: application of sequence stratigraphic and reservoir characterization concepts: West Texas Geological Society Publication 92-91, p. 91-99.

1997, Characterization of siliciclastic tidal-flat reservoir: Keystone (Colby) field, Winkler County, Texas, in Major, R. P., ed., Oil and gas on Texas State Lands: an assessment of the resource and characterization of type reservoirs: The University of Texas at Austin, Bureau of Economic Geology Report of Investigations No. 241, p. $127-135$.

Malicse, A., and Mazzullo, J., 1990, Reservoir properties of the desert Shattuck Member, Caprock field, New Mexico, in Barwis, J. H., McPherson, J. G., and Studlick, J. R. J., eds., Sandstone petroleum reservoirs: New York, Springer Verlag, p. 133-152. 
Mazzullo, J., 1992, Fluvial and deltaic facies in the Queen Formation, Permian Basin of Texas and New Mexico: an overview, in Mruk, D. H., and Curran, B. C., eds., Permian Basin exploration and production strategies: applications of sequence stratigraphic and reservoir characterization concepts: West Texas Geological Society, Publication 92-91, p. 79.

Mazzullo, J., Dronamraju, S., Johnson, R., and Ahr, W., 1996, Facies and sequence stratigraphy of the late Permian Yates Formation on the western margin of the Central Basin Platform of the Permian Basin, North Ward-Estes and South Ward fields, Ward County, Texas, in Martin, R. L., ed., Permian Basin oil and gas fields: keys to success that unlock future reserves: West Texas Geological Society Publication 96-101, p. 117-120.

Mear, C. E., and Yarbrough, D. V., 1961, Yates Formation in southern Permian Basin of West Texas: American Association of Petroleum Geologists Bulletin, v. 45, p. 1545-1556.

Ring, J. N., and Smith, D. J., 1995, An overview of the North Ward-Estes $\mathrm{CO}_{2}$ flood, in SPE Annual Technical Conference: Society of Petroleum Engineers, Paper 30729, p. 293-300.

Sarg, J. F., 1981, Petrology of the carbonate-evaporite facies transition of the Seven Rivers Formation (Guadalupian, Permian), southeast New Mexico: Journal of Sedimentary Petrology, v. 51, p. 73-96.

Silver, B. A., and Todd, R. G., 1969, Permian cyclic strata, northern Midland and Delaware Basins, west Texas and southeastern New Mexico: American Association of Petroleum Geologists Bulletin, v. 53, p. 2223-2251.

Trentham, R. C., 2003, Impact of paleostructure on Guadalupian age clastic sediment distribution in the Midland Basin, Central Basin Platform, and eastern Delaware Basin, in Hunt, T. J., and Lufholm, P. H., eds., The Permian Basin: back to basics: West Texas Geological Society Publication No. 03-112, p. 79-95.

Tyler, N., Bebout, D. G., Garrett, C. M., Jr., Guevara, E. H., Hocott, C. R., Holtz, M. H., Hovorka, S. D., Kerans, C., Lucia, F. J., Major, R. P., Ruppel, S. C., and Vander Stoep, G. W., 1991, Integrated characterization of Permian Basin reservoirs, University Lands, West Texas: targeting the remaining resource for advanced oil recovery: The University of Texas at Austin, Bureau of Economic Geology Report of Investigations No. 203, $136 \mathrm{p}$.

Ward, R. F., Kendall, C. G. St. C., and Harris, R. M., 1986, Upper Permian (Guadalupian) facies and their association with hydrocarbons-Permian Basin, West Texas and New Mexico: American Association of Petroleum Geologists Bulletin, v. 70, p. 239-262. 


\section{PRODUCTION ANALYSIS}

The Permian Basin is a major oil-producing region in the United States. It produced 17 percent of total U.S. oil production in 2002 (fig. 122a), and it contains an estimated 22 percent of the proved oil reserves in the United States (fig. 122b) (Energy Information Administration, 2003). The Permian Basin produced only slightly less than the Offshore Gulf of Mexico and Alaska in 2002. In proved reserves, it ranked ahead of all oil-producing areas in 2002. Geographically, most of the production and proved reserves in the Permian Basin are in Texas (fig. 123).

The Permian Basin has the biggest potential for additional oil production in the country, containing 29 percent $\left(17.6 \mathrm{Bbbl}\left[2.80 \times 10^{9} \mathrm{~m}^{3}\right]\right)$ of estimated future oil reserve growth (Root and others, 1995). Original oil in place (OOIP) in the Permian Basin was about $106 \mathrm{Bbbl}$ $\left(1.69 \times 10^{10} \mathrm{~m}^{3}\right)$ of oil (Tyler and Banta, 1989). After reaching a peak production of more than

(a)

2002 U.S. Oil Production

$(1,875 \mathrm{MMbbl})$

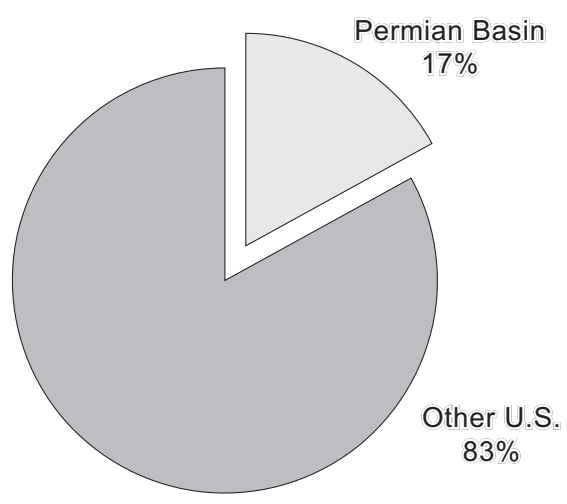

(b)

2002 U.S. Proved Oil Reservoirs $(22,677 \mathrm{MMbbl})$

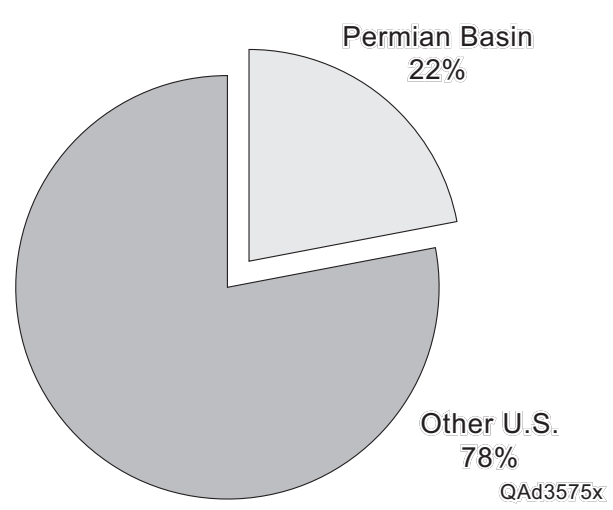

Figure 122. (a) Composition of 2002 U.S. oil production. (b) Composition of 2002 U.S. proved oil reserves. From Energy Information Administration (2003). Permian Basin numbers include production from reservoirs of all sizes, in Railroad Commission of Texas Districts 7C, 8, and 8A in Texas and the New Mexico East region. This area is somewhat larger than that in the definition of the Permian Basin used in this portfolio. 
(a)

\section{Permian Basin Oil Production} (327 MMbbl)

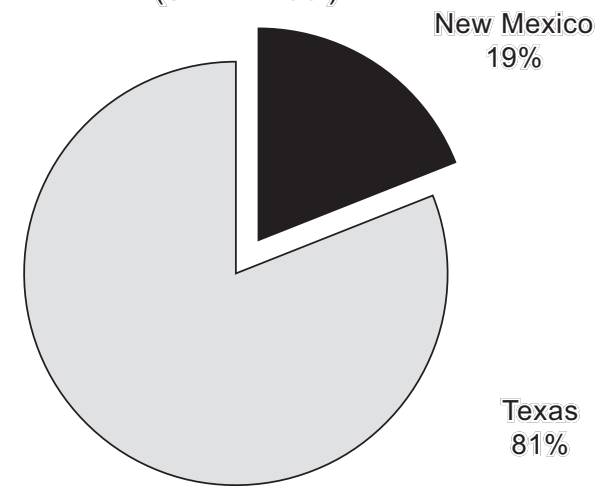

(b)

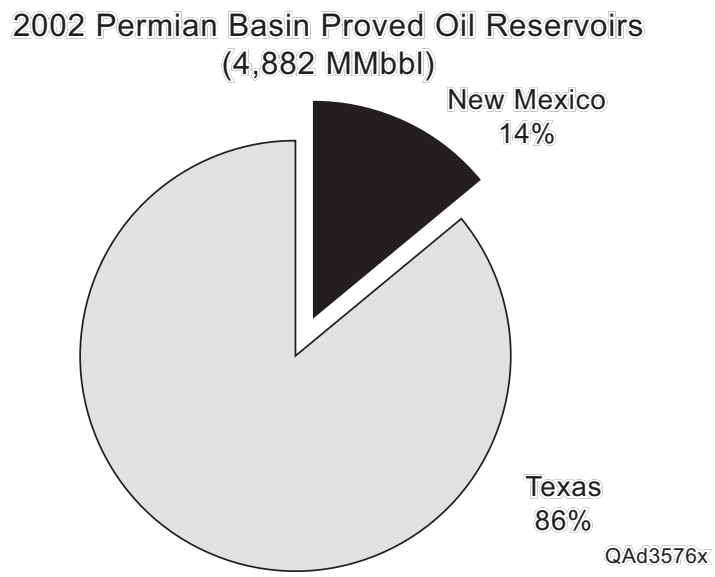

Figure 123. (a) Geographic distribution of 2002 Permian Basin oil production. (b) Geographic distribution of 2002 Permian Basin proved oil reserves. From Energy Information Administration (2003).

$665 \mathrm{MMbbl}\left(1.06 \times 10^{8} \mathrm{~m}^{3}\right)$ per year in the early 1970 's, Permian Basin oil production has continuously fallen. By 2002 , production had fallen to $327 \mathrm{MMbbl}\left(5.20 \times 10^{7} \mathrm{~m}^{3}\right)$, or less than half its peak production (Energy Information Administration, 2003). Despite the continuing fall in production, the Permian Basin still holds a significant volume of oil. Although $\sim 29$ Bbbl $\left(\sim 4.61 \times 10^{9} \mathrm{~m}^{3}\right)$ of oil has been produced to date, this production represents only $\sim 27$ percent of the OOIP. Of the huge remaining resource in the basin, as much as $30 \mathrm{Bbbl}\left(4.77 \times 10^{9} \mathrm{~m}^{3}\right)$ of mobile oil and $45 \mathrm{Bbbl}\left(7.15 \times 10^{9} \mathrm{~m}^{3}\right)$ of residual oil remains as a target for improved technology and recovery strategies (Tyler and Banta, 1989). More than in any other region, increased use of preferred management practices in Permian Basin oil fields will have a substantial impact on domestic production.

Production analysis of this major oil-producing region was conducted to better understand production trends. Production data compiled for the 32 oil plays in the Permian Basin were utilized as the main data source (table 1). These oil plays included all significant-sized oil 
reservoirs in the Permian Basin having a cumulative production of $>1 \mathrm{MMbbl}\left(1.59 \times 10^{5} \mathrm{~m}^{3}\right)$ through December 31, 2000.

\section{Discovery History}

The Westbrook reservoir in the Leonard Restricted Carbonate Platform play, discovered in 1921 (fig. 124), was the first major oil reservoir in the Permian Basin. Since discovery, it has produced $>107 \mathrm{MMbbl}\left(>1.70 \times 10^{7} \mathrm{~m}^{3}\right)$. Shortly after that discovery, several major oil reservoirs were discovered in 1926 (fig. 124), including the Yates reservoir in the San Andres Karst-Modified Platform Carbonate play. Two of the largest oil reservoirs in the Permian Basin, the Wasson and Slaughter reservoirs in the Northwest Shelf San Andres Platform Carbonate

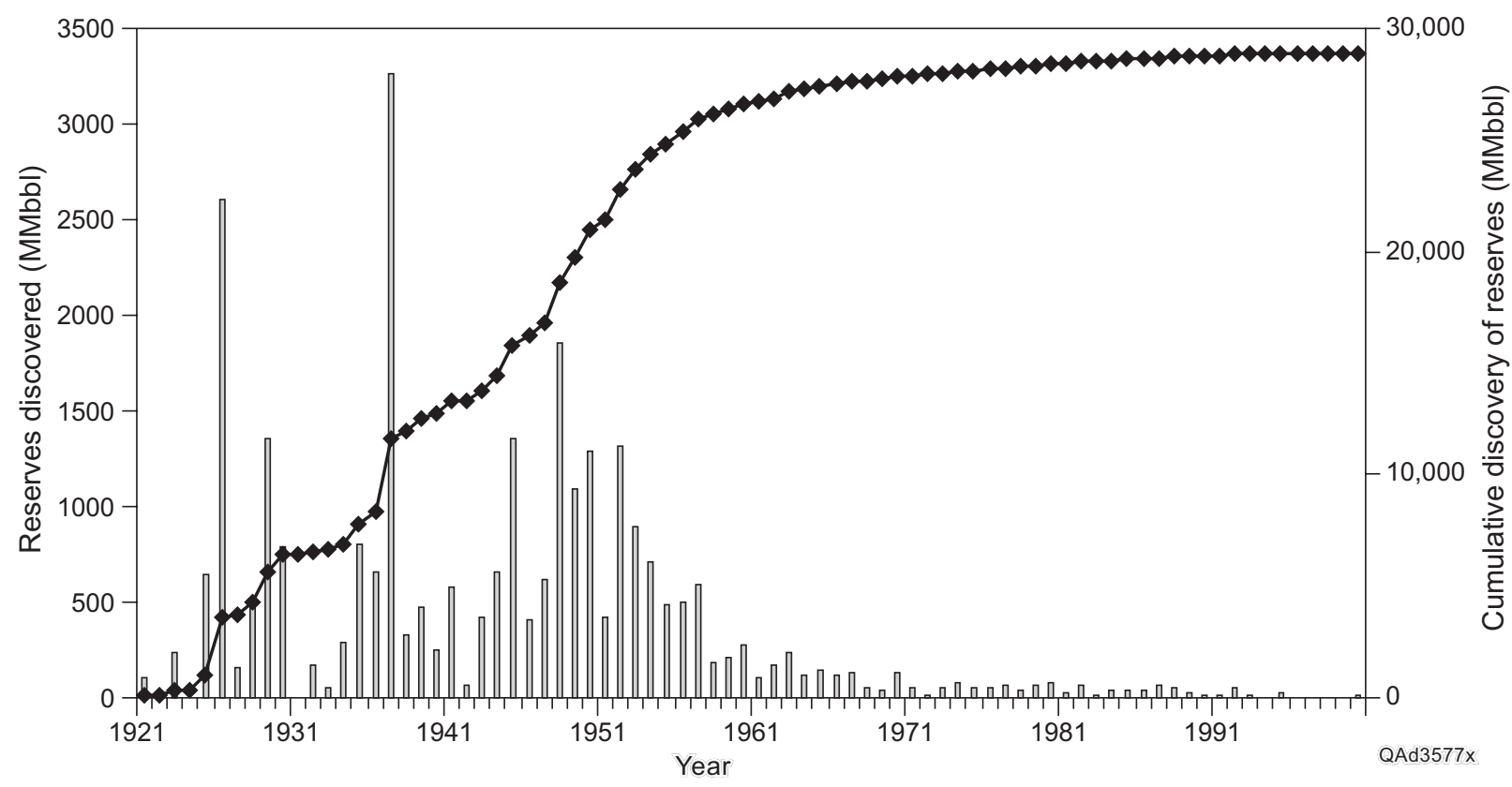

Figure 124. Permian Basin cumulative oil production discovered by year. Bars show years in which reservoirs were discovered, with height of bar indicating volume of oil produced by those reservoirs through 2000 . 
play, were discovered in 1937 (fig. 124). Another major oil reservoir in the Permian Basin, the Kelly-Snyder reservoir in the Pennsylvanian and Lower Permian Horseshoe Atoll Carbonate play, was discovered in 1948 (fig. 124). Although the Martin (Consolidated) reservoir, reported with a discovery year as 2000 , is the last significant-sized oil reservoir discovered in the Permian Basin, this reservoir has been consolidated from various reservoirs that had been discovered prior to 2000. Therefore, the Geibel (CFA) reservoir, discovered in 1998, should be considered the last significant-sized oil reservoir discovered in the Permian Basin that had produced $>1 \mathrm{MMbbl}$ $\left(1.59 \times 10^{5} \mathrm{~m}^{3}\right)$ through 2000 .

Numerous large oil reservoirs have been discovered in the Permian Basin throughout its history, as seen in figure 124. However, the region is now mature, with fewer significant-sized oil reservoirs discovered after the late 1950's. An asymptote starts to form in the late 1950's as the cumulative reserves discovered in the Permian Basin levels off (fig. 124). When the significant-sized oil reservoirs of the Permian Basin are plotted in terms of a discovery-year histogram (fig. 125), it can be seen that more than 80 percent of the significant-sized oil reservoirs were discovered prior to the 1970's. The period between 1951 and 1960 represents the greatest number of significant-sized oil reservoirs discovered in the Permian Basin. The average discovery year of significant-sized oil reservoirs in the Permian Basin is 1959.

\section{Production History and Attributes}

Production data for significant-sized oil reservoirs in the Permian Basin was compiled from 1970 through 2000. When aggregated as a whole, Permian Basin oil production has steadily decreased through time (fig. 126). A noticeable increase in annual production can be seen in 1973, where the largest oil reservoirs in the Permian Basin reported significantly higher annual 


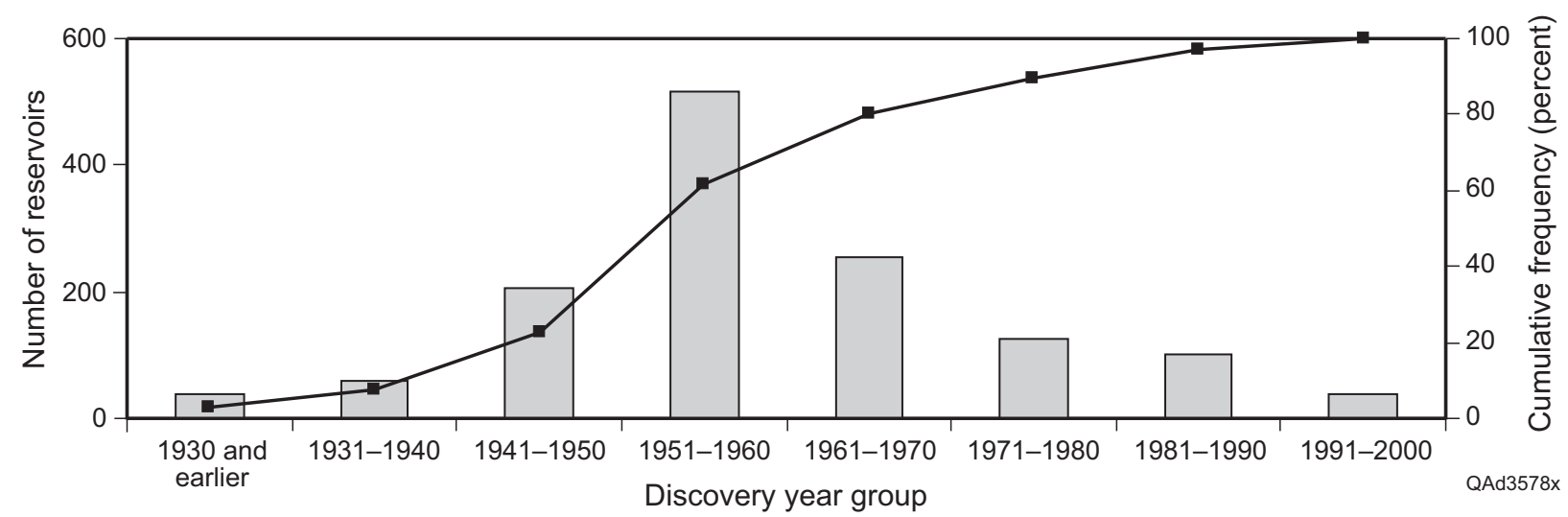

Figure 125. Reservoir discovery-year histogram of the 1,339 major oil reservoirs in the Permian Basin that produced $>1$ MMbbl through 2000.

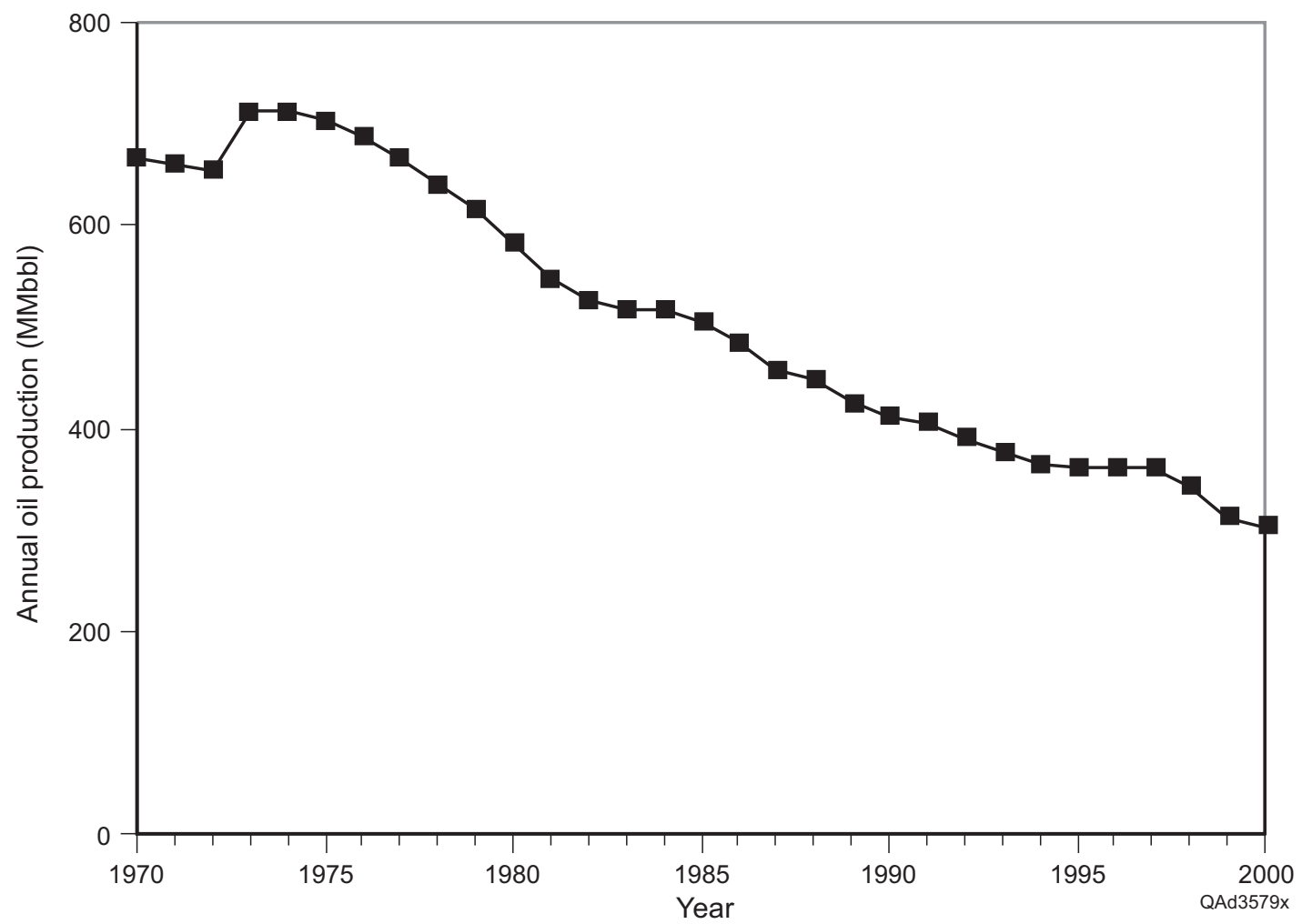

Figure 126. Permian Basin oil production history from 1970 through 2000 for the 1,339 significant-sized oil reservoirs in the Permian Basin. 
production. The two largest oil plays in the Permian Basin, the Northwest Shelf San Andres Platform Carbonate and the Pennsylvanian and Lower Permian Horseshoe Atoll Carbonate plays, displayed significant incremental production. This incremental production can be attributed to the peak of U.S. oil production and that of Texas occurring around this time period and thereafter declining.

Historical production data of the significant-sized oil reservoirs composing each of the 32 oil plays in the Permian Basin were aggregated. Play-level data are provided in the GIS database and can be accessed by opening up the attribute file linked with the play boundaries. (Each of the 32 play-boundary shapefiles, contained in the play_bnd folder, appears as a separate layer within the $\mathrm{ArcView}{ }^{\mathrm{TM}}$ project, and each of these layers is linked to a play-production data table.) In cases where the play boundary is separated into two parts, each part shows total play production, as well as other attribute data, for the play. Play-level production history revealed that the largest plays in the Permian Basin, such as the Northwest Shelf San Andres Platform Carbonate and the Pennsylvanian and Lower Permian Horseshoe Atoll Carbonate plays, have experienced significant decline. However, another large play, the Leonard Restricted Platform Carbonate play, revealed a relatively stable to slightly declining production history. Moreover, the Spraberry/Dean Submarine-Fan Sandstone play revealed a stable to slightly increasing production history.

Analysis of production data indicates that the Permian Basin remains a major oilproducing region. Oil production from significant-sized reservoirs in the Permian Basin having cumulative production $>1 \mathrm{MMbbl}\left(1.59 \times 10^{5} \mathrm{~m}^{3}\right)$ was $301.4 \mathrm{MMbbl}\left(4.79 \times 10^{7} \mathrm{~m}^{3}\right)$ in 2000 (table 1). The largest production in 2000 was from the Wasson $\left(22.9 \mathrm{MMbbl}\left[3.64 \times 10^{6} \mathrm{~m}^{3}\right]\right)$ in Yoakum County in the Northwest Shelf San Andres Platform Carbonate play. Six major oil 
reservoirs - Wasson, Spraberry (Trend Area), Slaughter, Yates, Levelland, and Seminole (San Andres) produced $>10 \mathrm{MMbbl}\left(>1.59 \times 10^{6} \mathrm{~m}^{3}\right)$ in 2000. All of these major oil reservoirs are in Texas and are very mature, discovered prior to 1952.

The 2000 production data make it easy to see which reservoirs are still producing significant volumes of oil, versus those that are no longer producing. A histogram based on annual production in 2000 from the 1,339 significant-sized oil reservoirs of the Permian Basin revealed a lognormal distribution, with the majority of reservoirs producing $\leq 50,000 \mathrm{bbl}$ $\left(7.95 \times 10^{3} \mathrm{~m}^{3}\right)$. However, the few outlier, larger-sized reservoirs (those producing $>500,000 \mathrm{bbl}$ $\left.\left[7.95 \times 10^{4} \mathrm{~m}^{3}\right]\right)$ in 2000 ) accounted for 75 percent of the production in 2000. The top-four oil-producing plays in terms of 2000 annual production were the Northwest Shelf San Andres Platform Carbonate play (50.7 MMbbl $\left.\left[8.06 \times 10^{6} \mathrm{~m}^{3}\right]\right)$, the Leonard Restricted Platform Carbonate play (49.9 MMbbl $\left.\left[7.93 \times 10^{6} \mathrm{~m}^{3}\right]\right)$, the Spraberry/Dean Submarine-Fan Sandstone play (27.6 MMbbl $\left.\left[4.39 \times 10^{6} \mathrm{~m}^{3}\right]\right)$, and the San Andres Platform Carbonate play (26.4 MMbbl $\left.\left[4.20 \times 10^{6} \mathrm{~m}^{3}\right]\right)$.

Cumulative Permian Basin production through 2000 was $28.9 \mathrm{Bbbl}\left(4.59 \times 10^{9} \mathrm{~m}^{3}\right)$ (table 1). The largest reservoir was Wasson $\left(1.84 \mathrm{Bbbl}\left[\left(2.93 \times 10^{8} \mathrm{~m}^{3}\right)\right]\right)$; three other major reservoirs had cumulative production $>1$ Bbbl $\left(1.59 \times 10^{8} \mathrm{~m}^{3}\right)$ through 2000 (Yates, KellySnyder, and Slaughter). A histogram based on cumulative production through 2000 from the significant-sized oil reservoirs of the Permian Basin also revealed a lognormal distribution, with 60 percent of the reservoirs having cumulative production $\leq 5 \mathrm{MMbbl}\left(7.95 \times 10^{5} \mathrm{~m}^{3}\right)$. The few outlier, major reservoirs (>45 MMbbl $\left[\left(7.15 \times 10^{6} \mathrm{~m}^{3}\right)\right]$ cumulative production), however, accounted for 69 percent of the cumulative production in the Permian Basin. The top four plays in terms of cumulative production are the Northwest Shelf San Andres Platform Carbonate 
play (3.97 Bbbl $\left.\left[6.31 \times 10^{8} \mathrm{~m}^{3}\right]\right)$, the Leonard Restricted Platform Carbonate play $(3.30 \mathrm{Bbbl}$ $\left.\left[5.25 \times 10^{8} \mathrm{~m}^{3}\right]\right)$, the Pennsylvanian and Lower Permian Horseshoe Atoll Carbonate play (2.70 Bbbl $\left.\left[4.29 \times 10^{8} \mathrm{~m}^{3}\right]\right)$, and the San Andres Platform Carbonate play (2.15 Bbbl $\left.\left[3.42 \times 10^{8} \mathrm{~m}^{3}\right]\right)$. The largest reservoir in each play is listed in table 39 . The large variation in size of the largest reservoir in the different plays reflects the large differences in cumulative production from the plays.

Guadalupian-age reservoirs dominate both cumulative production and production in 2000, with 54 and 53 percent of the total, respectively (fig. 127). Leonardian- and Pennsylvanian-age reservoirs make up 18 and 13 percent, respectively, of cumulative Permian Basin oil production (fig. 127a). Leonardian- and Pennsylvanian-age reservoirs each make up 29 and 8 percent, respectively, of Permian Basin production in 2000 (fig. 127b). Production histories of significant-sized oil reservoirs in the Permian Basin by geologic age are shown in figure 128. Whereas Guadalupian- and Pennsylvanian-age reservoirs show a rapid decline in production, Leonardian-age reservoirs reveal a stable production trend.

Carbonate reservoirs dominate both cumulative production and production in 2000 , with 75 and 74 percent of the total, respectively (fig. 129). Sandstone reservoirs contributed 14 percent of cumulative production and 16 percent of production in 2000. Oil reservoirs with mixed sandstone and carbonate lithology produced 8 percent of both cumulative production and production in 2000. Chert reservoirs produced 3 percent of cumulative production and 2 percent of production in 2000. Production histories of significant-sized oil reservoirs in the Permian Basin by lithology are shown in figure 130. Carbonate reservoirs reveal a rapidly decreasing production trend, whereas sandstone, mixed sandstone/carbonate, and chert reservoirs show a relatively stable production trend. 

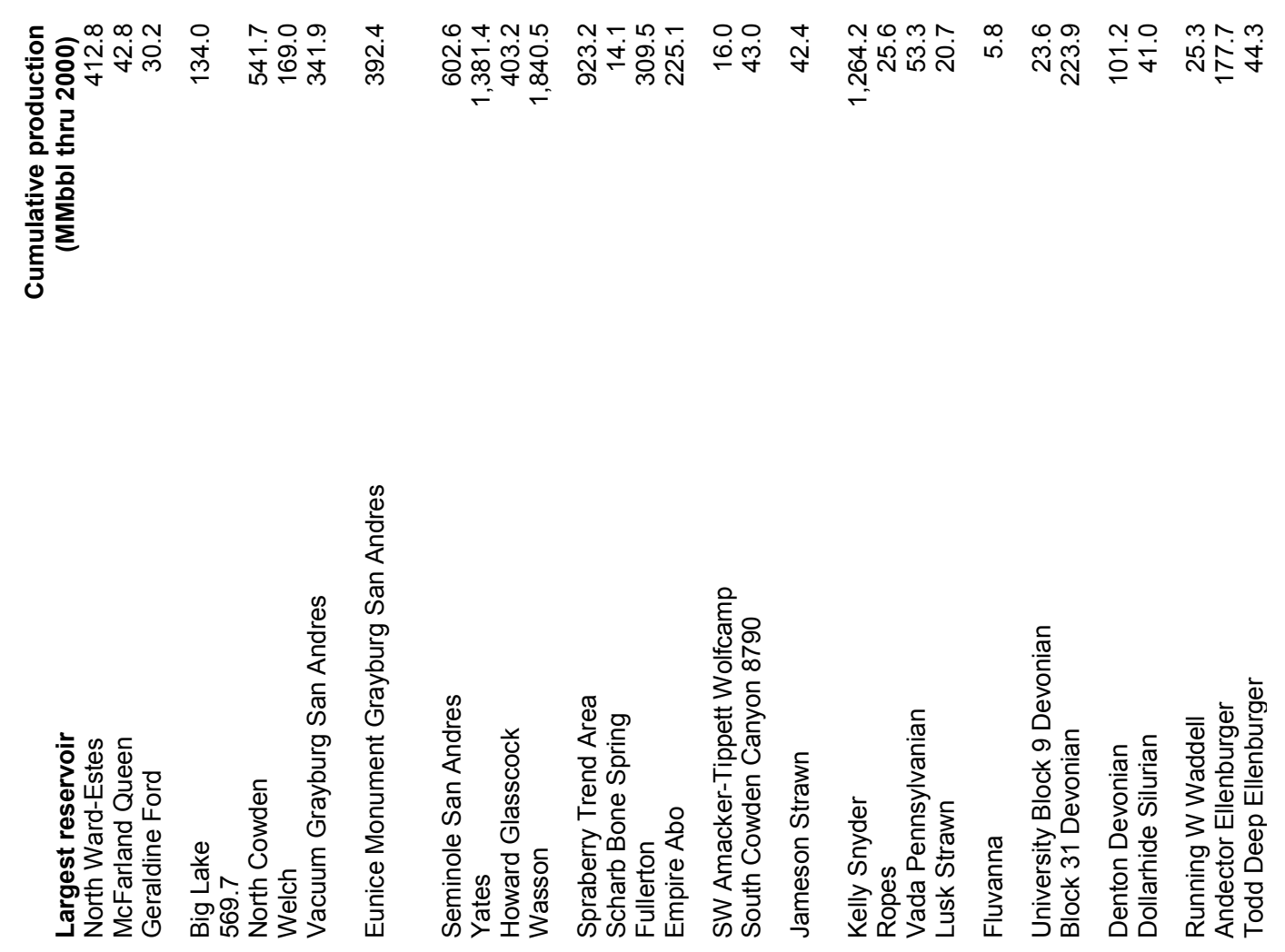

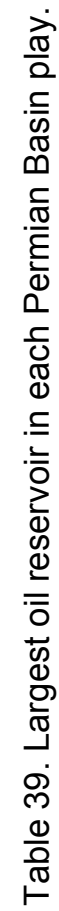

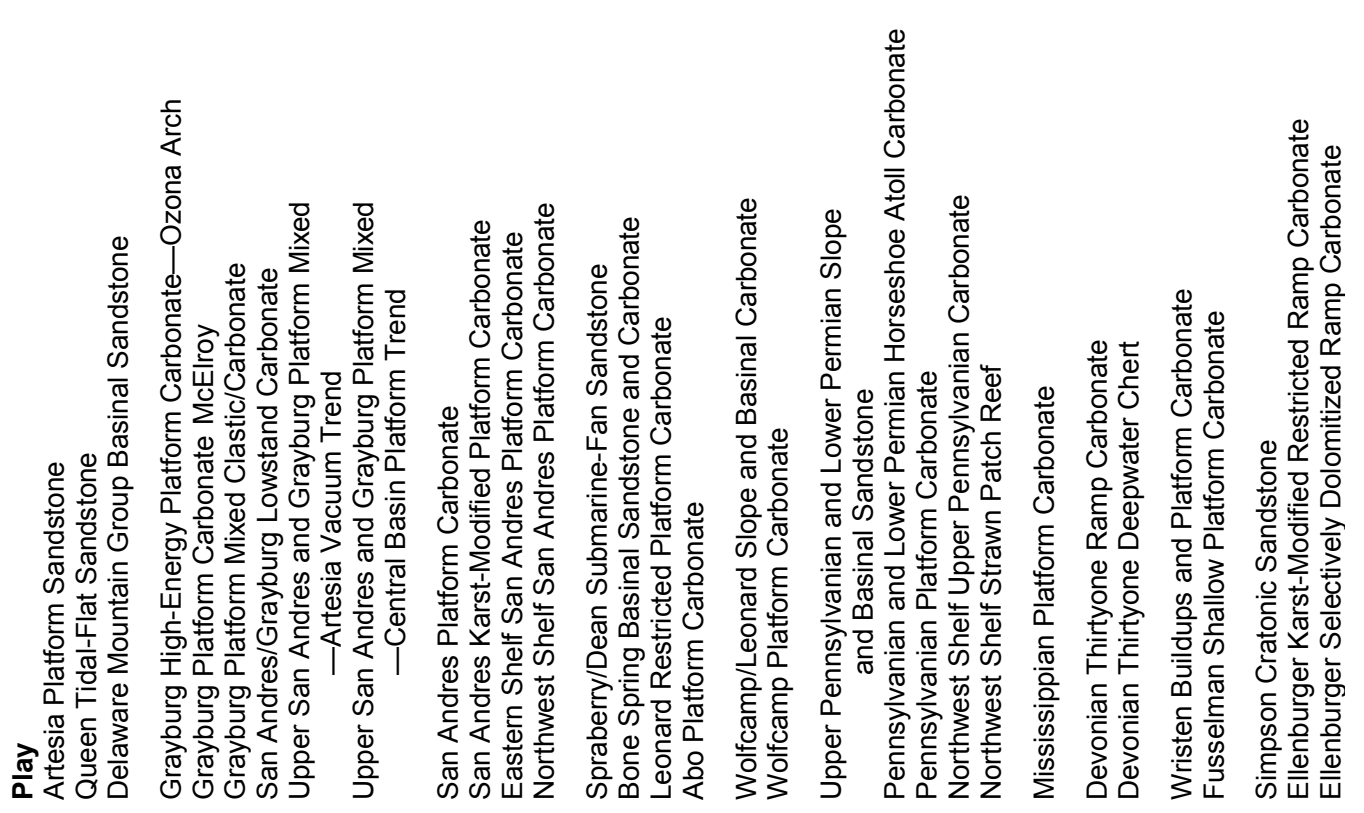


(a)

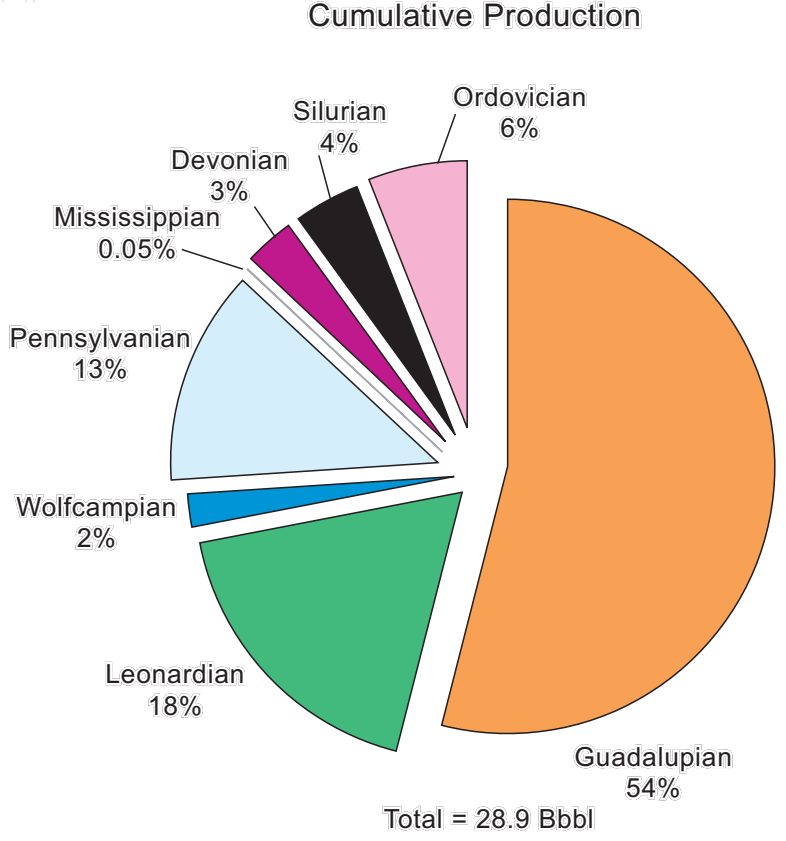

(b)

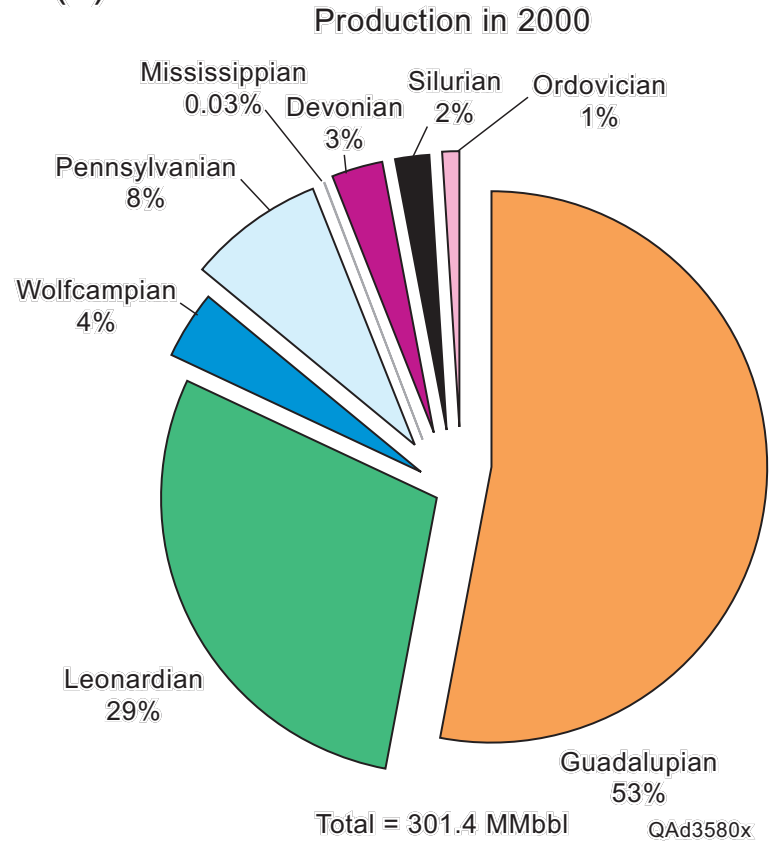

Figure 127. (a) Permian Basin cumulative production through 2000, by geologic age. (b) Permian Basin production in 2000, by geologic age.

The 1,040 significant-sized reservoirs in the Texas part of the Permian Basin had cumulative production of $24.4 \mathrm{Bbbl}\left(3.88 \times 10^{9} \mathrm{~m}^{3}\right)$ through 2000 , and the 299 significant-sized reservoirs in New Mexico had cumulative production of $4.5 \mathrm{Bbbl}\left(7.15 \times 10^{8} \mathrm{~m}^{3}\right)$. In 2000, the Texas reservoirs produced 253.7 MMbbl $\left(4.03 \times 10^{7} \mathrm{~m}^{3}\right)$, and the New Mexico reservoirs produced 47.7 MMbbl $\left(7.58 \times 10^{6} \mathrm{~m}^{3}\right)$. Thus, Texas has produced 84 percent of the cumulative production from the Permian Basin, and it also produced 84 percent of the 2000 production.

The 1,339 significant-sized reservoirs that had produced $>1 \mathrm{MMbbl}\left(1.59 \times 10^{5} \mathrm{~m}^{3}\right)$ through 2000 account for most of the production from the Permian Basin. Cumulative production through 2000 from reservoirs of all sizes is estimated at $30.4 \mathrm{Bbbl}\left(4.83 \times 10^{9} \mathrm{~m}^{3}\right)-25.6 \mathrm{Bbbl}$ $\left(4.07 \times 10^{9} \mathrm{~m}^{3}\right)$ from Texas and $4.8 \mathrm{Bbbl}\left(7.63 \times 10^{8} \mathrm{~m}^{3}\right)$ from New Mexico. Thus, the 1,339 reservoirs included in this report have accounted for 95 percent of Permian Basin production. 


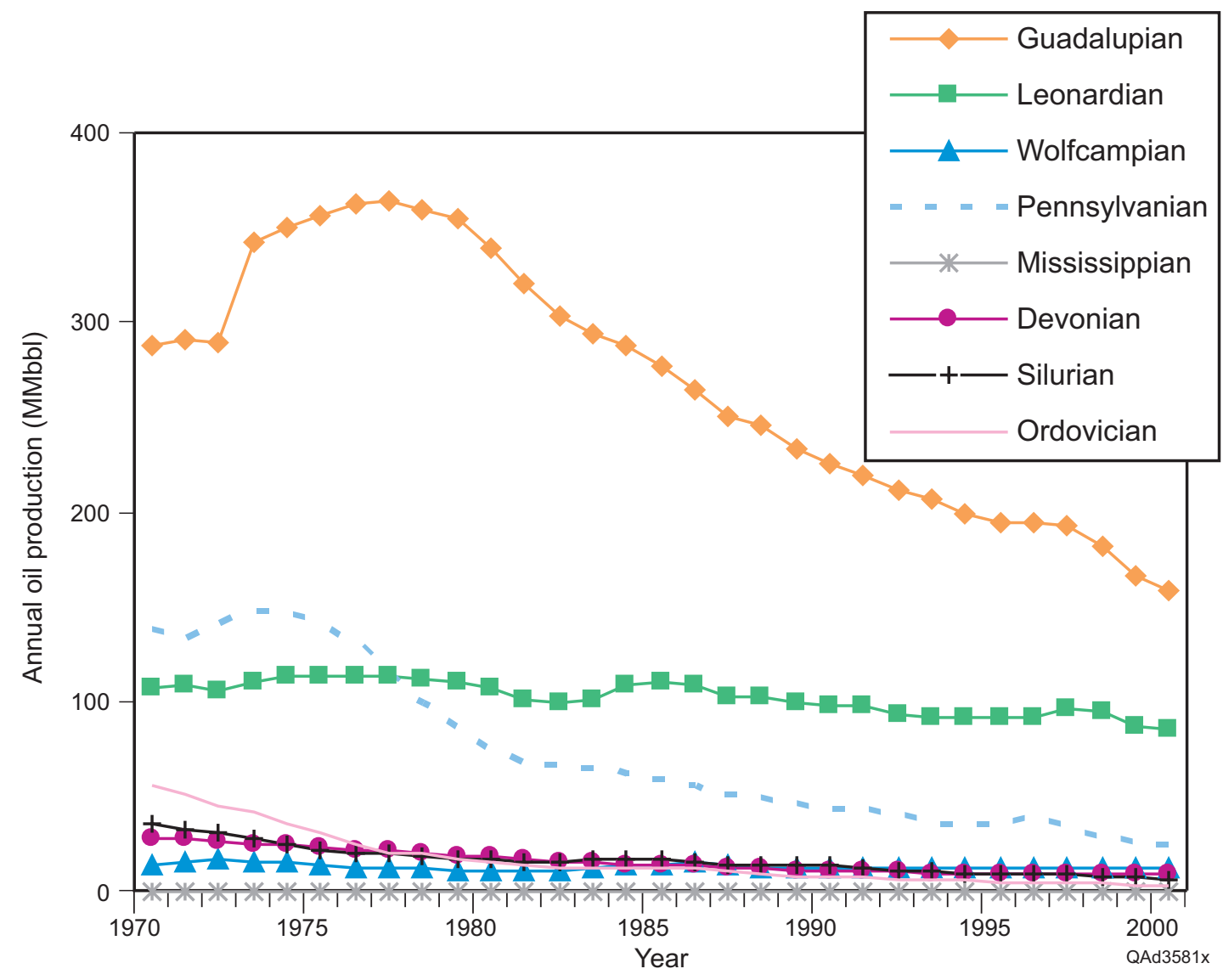

Figure 128. Production histories of significant-sized oil reservoirs in the Permian Basin by geologic age.

(a)

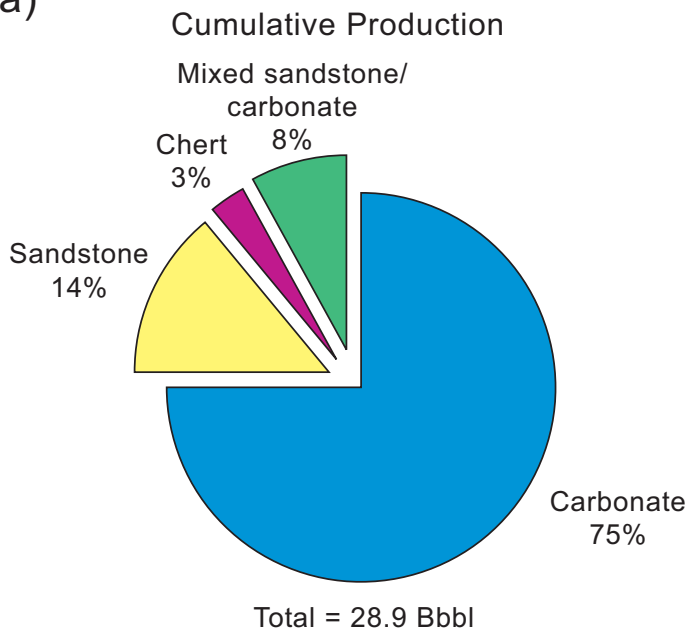

(b)

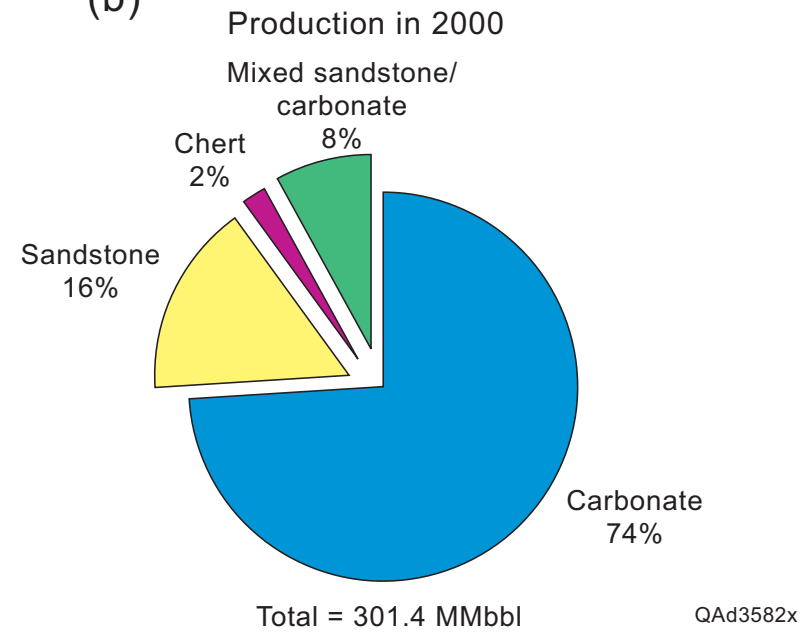

Figure 129. (a) Permian Basin cumulative production through 2000, by lithology. (b) Permian Basin production in 2000, by lithology. 


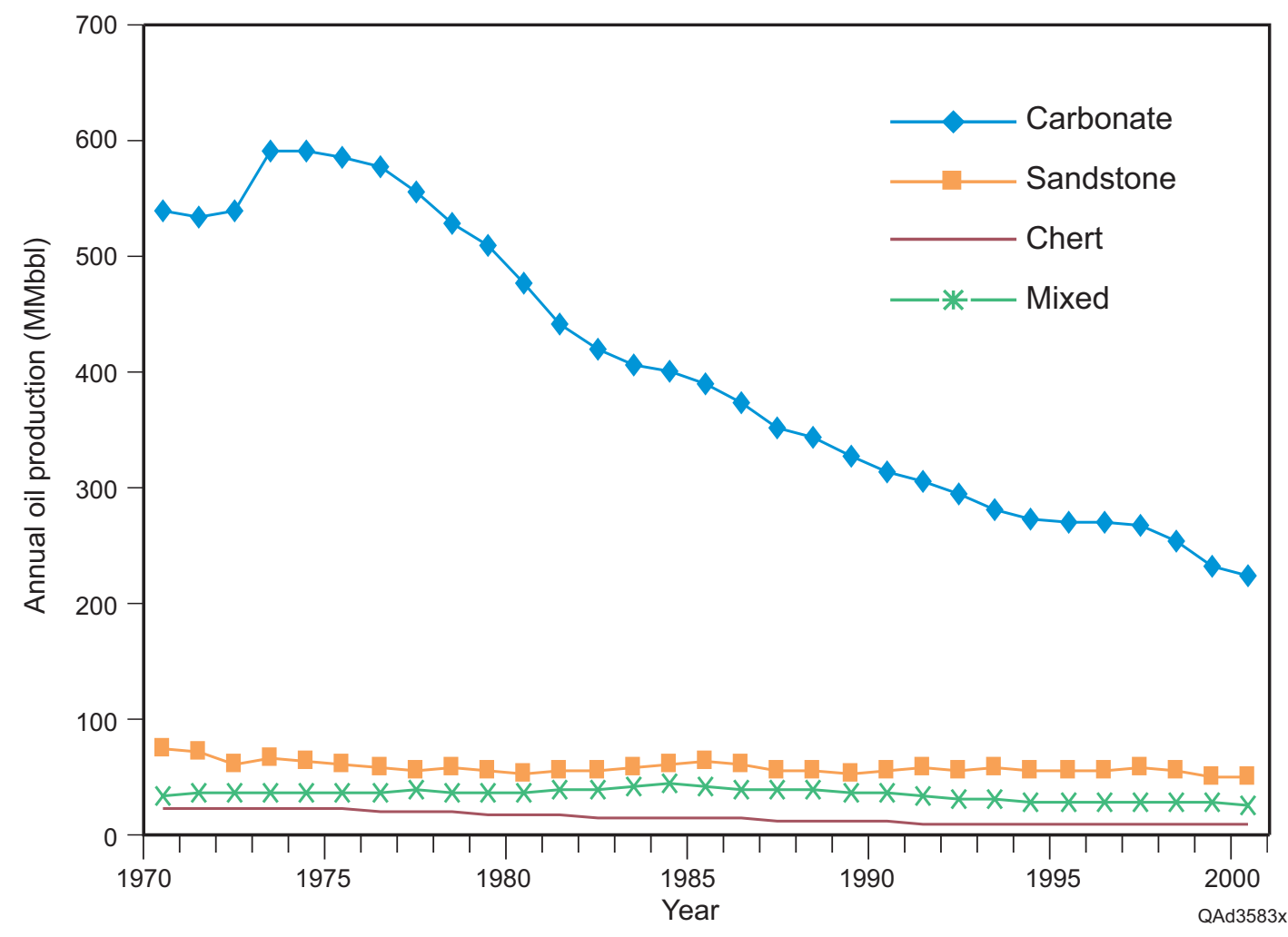

Figure 130. Production histories of significant-sized oil reservoirs in the Permian Basin by lithology.

\section{Reservoir Depths}

Approximately 80 percent of the significant-sized oil reservoirs in the Permian Basin produce from depths of $<10,000 \mathrm{ft}(<3,050 \mathrm{~m})$ (fig. 131). Significant-sized oil reservoirs in the Permian Basin produce across a broad spectrum of reservoir depths, with the average depth being 7,069 $\mathrm{ft}(2,155 \mathrm{~m})$. The shallowest production occurred at $500 \mathrm{ft}(152 \mathrm{~m})$ in the Toborg reservoir of the San Andres Karst-Modified Platform Carbonate play. The deepest production occurred at 13,939 $\mathrm{ft}(4,249 \mathrm{~m})$ in the Nolley (Ellenburger) reservoir of the Ellenburger KarstModified Restricted Ramp Carbonate play. All of the deepest significant-sized oil reservoirs $(>13,800 \mathrm{ft}[4,206 \mathrm{~m}])$ were in the Ellenburger Karst-Modified Restricted Ramp Carbonate play. 


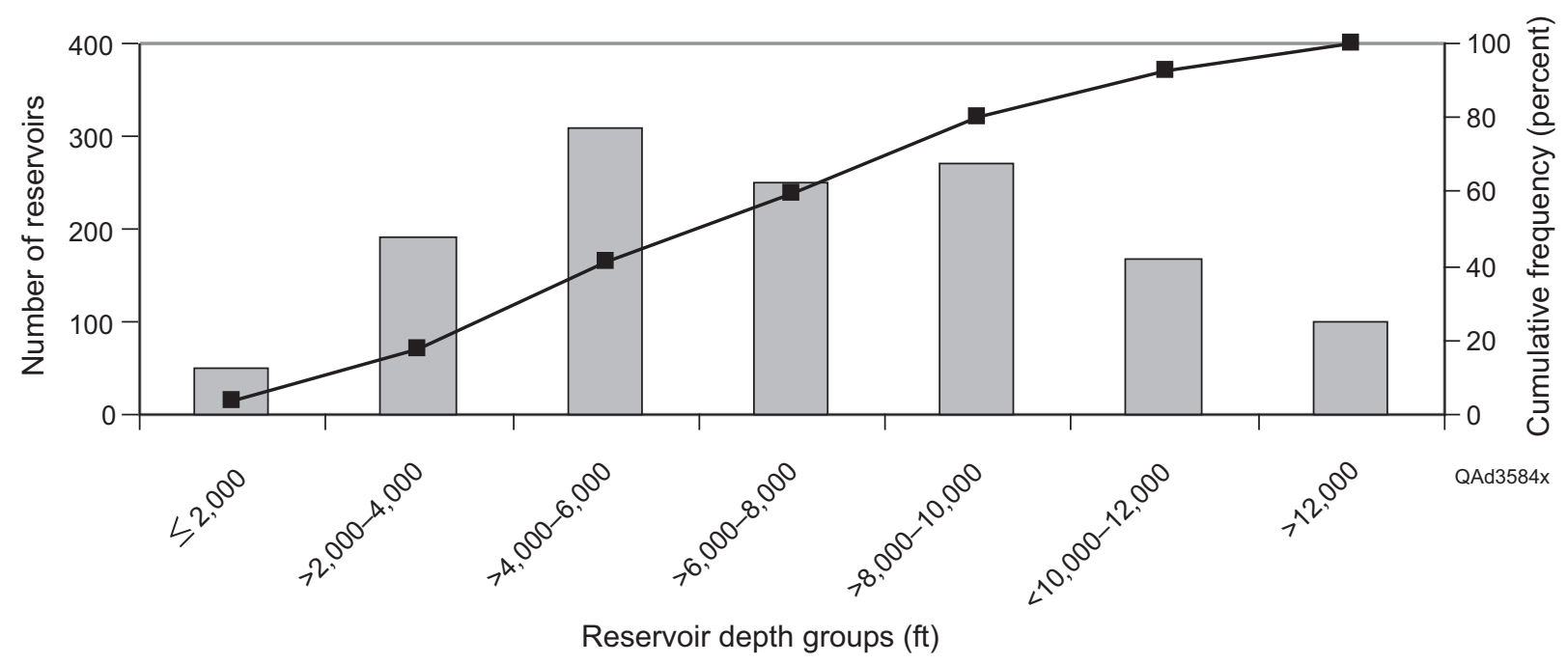

Figure 131. Reservoir-depth histogram of significant-sized oil reservoirs in the Permian Basin.

\section{Remaining Reserves}

Remaining reserves of the significant-sized oil reservoirs in the Permian Basin were estimated by using decline-curve analysis. This analysis is a widely accepted and utilized production-performance tool used in estimating remaining reserves to be recovered, future expected production rate, and remaining productive life. Decline-curve analysis is applicable once history is sufficient to show a trend in a performance variable that is a continuous function of either time or cumulative production. Common types of decline curves include linear, exponential, hyperbolic, and harmonic (Amyx and others, 1960). In general, most reservoirs exhibit a hyperbolic decline during early life and degenerate to exponential decline with progressive reservoir depletion. Because most significant-sized oil reservoirs in the Permian Basin are in mature stages of production and reaching depletion, exponential decline curves were utilized. Historical production profiles of the 32 oil plays in the Permian Basin were plotted using production data from 1970 through 2000. Production-decline curves were established for 
complete production histories since 1990, if a general decline trend was clearly established in its most recent history. When irregular production trends existed, decline-curve analysis was applied only for time periods where a steady decline trend could be established.

Remaining reserves to be produced from the 32 oil plays in the Permian Basin were calculated to year-end 2015. Total remaining oil reserves from the 32 oil plays of the Permian Basin and its significant-sized oil reservoirs are calculated as $3.25 \mathrm{Bbbl}\left(5.17 \times 10^{8} \mathrm{~m}^{3}\right)$ (fig. 132, table 40). The Northwest Shelf San Andres Platform Carbonate and Leonard Restricted Platform Carbonate plays make up over 41 percent $\left.\left(1.34 \mathrm{Bbbl}\left[2.13 \times 10^{8} \mathrm{~m}^{3}\right)\right]\right)$ of this total.

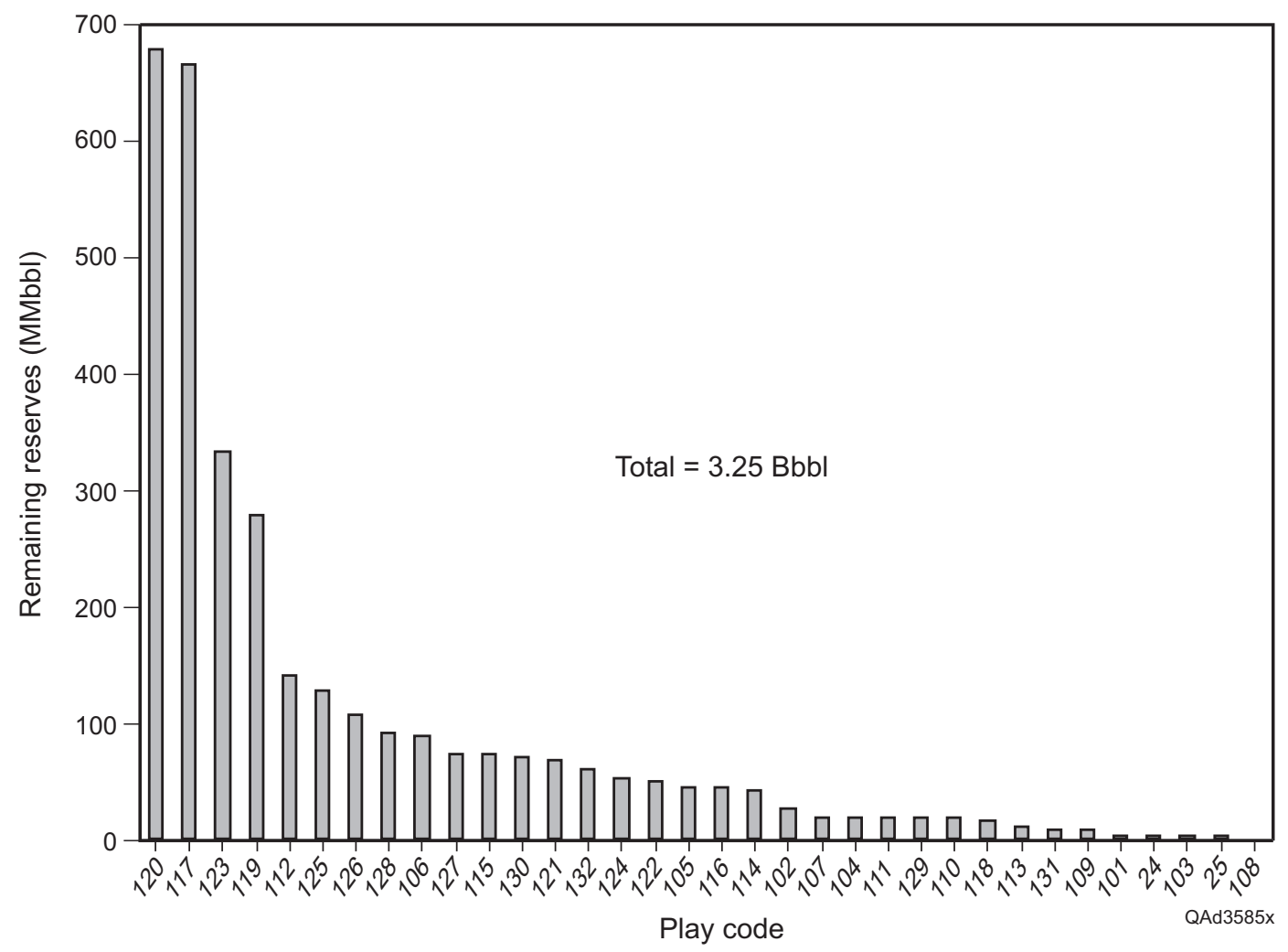

Figure 132. Permian Basin remaining reserves to 2015 by plays. Play codes listed in table 40 . 
Table 40. Permian Basin remaining reserves to 2015 , by play.

Play code Play name

Remaining

reserves

(MMbbl)

$120 \quad$ Northwest Shelf San Andres Platform Carbonate $\quad 679.8$

117 Leonard Restricted Platform Carbonate $\quad 665.7$

123 San Andres Platform Carbonate 331.9

119 Spraberry/Dean Submarine-Fan Sandstone 277.3

112 Pennsylvanian and Lower Permian Horseshoe Atoll Carbonate 139.5

125 Upper San Andres and Grayburg Platform Mixed-Artesia Vacuum Trend 128

126 San Andres/Grayburg Lowstand Carbonate 106.9

128 Grayburg Platform Carbonate $\quad 89.8$

106 Devonian Thirtyone Deepwater Chert $\quad 89.2$

127 Grayburg Platform Mixed Clastic/Carbonate $\quad 72.7$

115 Wolfcamp/Leonard Slope and Basinal Carbonate $\quad 72.4$

130 Delaware Mountain Group Basinal Sandstone $\quad 69$

$121 \quad$ Eastern Shelf San Andres Platform Carbonate $\quad 66.9$

132 Artesia Platform Sandstone 61

$124 \quad$ Upper San Andres and Grayburg Platform Mixed-Central Basin Platform Trend 52.8

122 San Andres Karst-Modified Platform Carbonate 48.3

105 Wristen Buildups and Platform Carbonate 44.7

116 Abo Platform Carbonate 43.4

$114 \quad$ Wolfcamp Platform Carbonate $\quad 41.3$

102 Ellenburger Karst-Modified Restricted Ramp Carbonate 25.2

107 Devonian Thirtyone Ramp Carbonate 19

104 Fusselman Shallow Platform Carbonate $\quad 17.5$

111 Pennsylvanian Platform Carbonate 17.3

129 Grayburg High-Energy Platform Carbonate-Ozona Arch 17.2

110 Northwest Shelf Upper Pennsylvanian Carbonate 17.2

118 Bone Spring Basinal Sandstone and Carbonate 16.9

113 Upper Pennsylvanian and Lower Permian Slope and Basinal Sandstone 11

131 Queen Tidal-Flat Sandstone $\quad 8$

109 Northwest Shelf Strawn Patch Reef $\quad 7.9$

101 Ellenburger Selectively Dolomitized Ramp Carbonate 3.8

$24 \quad$ Upper Pennsylvanian Shelf Sandstone (Permian Basin part only) 3.4

103 Simpson Cratonic Sandstone $\quad 3.2$

25 Pennsylvanian and Lower Permian Reef/Bank (Permian Basin part only) 1.8

108 Mississippian Platform Carbonate $\quad 0.8$

Total

It should be noted that the remaining reserves to be produced to year-end 2015 are that

component of the resource base that has already discovered been discovered and is producing.

Additional future production from the Permian Basin will be attributable to reserve growth

and undiscovered resources. 


\section{References}

Amyx, J. W., Bass, D. M., Jr., and Whiting, R. L., 1960, Petroleum reservoir engineering: New York, McGraw-Hill, 610 p.

Energy Information Administration, 2003, U.S. crude oil, natural gas, and natural gas liquids reserves: 2002 annual report, DOE/EIA-0216 (2002), 48 p.

Root, D. H., Attanasi, E. D., Mast, R. F., and Gautier, D. L., 1995, Estimates of inferred reserves for the 1995 USGS national oil and gas resource assessment: U.S. Geological Survey Open-File Report 95-75L, 29 p.

Tyler, N., and Banta, N. J., 1989, Oil and gas resources remaining in the Permian Basin: targets for additional hydrocarbon recovery: The University of Texas at Austin, Bureau of Economic Geology Geological Circular 89-4, 20 p.

\section{TECHNOLOGY TRANSFER}

Technology transfer of project results has taken place in several ways during the project.

Posters were displayed at the 2003 and 2004 annual meetings of the American Association of Petroleum Geologists (AAPG), the 2003 West Texas Geological Society (WTGS) Fall Symposium, and the 2004 annual meeting of the Southwest Section AAPG. A poster was also presented at the 2003 workshop New Methods for Locating and Recovering Remaining Hydrocarbons in the Permian Basin, sponsored by the Bureau of Economic Geology, PTTC Texas Region, and University Lands West Texas Operations in Midland, Texas. Papers about the project were published in the Class Act Newsletter, 2003 WTGS Fall Symposium volume, and Transactions of the Southwest Section AAPG. A project Web site is maintained at http://www.beg.utexas.edu/resprog/permianbasin/playanalysis.htm. 
The following publications have resulted from the project.

Broadhead, R. F., and Raatz, W. D., 2003, Play analysis of major oil reservoirs in the New Mexico part of the Permian Basin: a tool for highgrading future exploration and development opportunities, in Hunt, T. J., and Lufholm, P. H., eds., The Permian Basin: back to basics: West Texas Geological Society, Publication 03-112, p. 363-378.

2004, Play analysis of major oil reservoirs in the New Mexico part of the Permian Basin: a tool for highgrading future exploration and development opportunities, in Southwest Section AAPG: Reservoirs in the sky: the lower Paleozoic of the Southwest, Abstracts CD volume, $1 \mathrm{p}$.

Broadhead, R. F., Raatz, W. D., Dutton, S. P., and Kim, E. M., 2004, Play analysis and digital portfolio of major oil reservoirs in the Permian Basin: New Mexico: American Association of Petroleum Geologists Annual Convention Official Program, v. 13, Dallas, Texas, p. A17.

Dutton, S. P., Kim, E. M., Breton, C. L., Broadhead, R. F., and Raatz, W. D., 2004, Digital play portfolio of a major U.S. oil province: the Permian Basin: American Association of Petroleum Geologists Annual Convention Official Program, v. 13, Dallas, Texas, p. A38A39.

2003, Permian Basin play analysis: The Class Act, newsletter of the U.S. Department of Energy, National Petroleum Technology Office, v. 9, no. 2, p. 4-6. http://www.npto.doe.gov/CA/CASum2003.pft

Dutton, S. P., Kim, E. M., Broadhead, R. F., Breton, C. L., Raatz, W. D., Ruppel, S. C., and Kerans, C., 2004, Play analysis and digital portfolio of major oil reservoirs in the Permian Basin: application and transfer of advanced geological and engineering technologies for incremental production opportunities: The University of Texas at Austin, Bureau of Economic Geology, annual report prepared for U.S. Department of Energy, Assistant Secretary for Fossil Energy, under contract no. DE-FC26-02NT15131, 104 p.

Dutton, S. P., Kim, E. M., Broadhead, R. F., Raatz, W., Breton, C., Ruppel, S. C., Kerans, C., and Holtz, M. H., 2003, Play analysis and digital portfolio of major oil reservoirs in the Permian Basin: application and transfer of advanced geological and engineering technologies for incremental production opportunities: The University of Texas at Austin, Bureau of Economic Geology, annual report prepared for U.S. Department of Energy, Assistant Secretary for Fossil Energy, under contract no. DE-FC26-02NT15131, 67 p.

Dutton, S. P., Kim, E. M., and Holtz, M. H., 2003, Play analysis of major oil reservoirs in the Permian Basin, West Texas: American Association of Petroleum Geologists Annual Convention Official Program, v. 12, Salt Lake City, Utah, p. A46. 
2003, Play analysis of major oil reservoirs in the Permian Basin, West Texas, in Hunt, T. J., and Lufholm, P. H., eds., The Permian Basin: back to basics: West Texas Geological Society, Publication 03-112, p. 379.

2003, Play analysis of major oil reservoirs in the Permian Basin, West Texas, in New methods for locating and recovering remaining hydrocarbons in the Permian Basin: The University of Texas at Austin, Bureau of Economic Geology; Petroleum Technology Transfer Council; and University Lands West Texas Operations, p. 7.

\section{CONCLUSIONS}

The target of this PUMP project was the Permian Basin of west Texas and southeast New Mexico, which is still one of the largest petroleum-producing basins in the United States. More than in any other region, increased use of preferred management practices in Permian Basin oil fields will have a substantial impact on domestic production because of the large remaining oil resource. Thirty-two oil plays covering both the Texas and New Mexico parts of the Permian Basin were defined. All 1,339 significant-sized reservoirs in the Permian Basin having cumulative production of $>1 \mathrm{MMbbl}\left(1.59 \times 10^{5} \mathrm{~m}^{3}\right)$ of oil were assigned to a play. A reservoir database was established that lists the RRC reservoir number and district (Texas only), official field and reservoir name, year reservoir was discovered, depth to top of the reservoir, production in 2000, and cumulative production through 2000. Some tables also list subplays.

The 1,339 significant-sized oil reservoirs were mapped by play in $\operatorname{ArcView}^{\mathrm{TM}}$ GIS. The GIS play maps from Texas and New Mexico were merged to form digital data files, or shapefiles, of each play in the Permian Basin. The final reservoir shapefile for each play contains the geographic location of each reservoir and all associated reservoir information within the linked dBASE data table. Play boundaries were drawn for each play. The final GIS product of this process is an ArcView project file containing the base map, the series of play-specific reservoir shapefiles, and play-boundary shapefiles. 
Each oil play is described using information from published literature and illustrated by selected appropriate diagrams. Preferred upstream management practices that have been used in Permian Basin reservoirs are described so that successful recovery techniques can be applied to other, similar reservoirs in the play.

\section{ACKNOWLEDGMENTS}

This research was funded by the U.S. Department of Energy under contract number DE-FC26-02NT15131, Daniel F. Ferguson, project manager. Support was also provided by the Bureau of Economic Geology's University Lands project and the Characterization of San Andres and Grayburg Reservoirs project, as well as the New Mexico Bureau of Geology and Mineral Resources.

Mark H. Holtz, F. Jerry Lucia, and Robert G. Loucks generously provided their expertise on Permian Basin geology and hydrocarbon production to the project. Jianhua Zhou performed the GIS mapping of New Mexico oil fields. Drafting was by John T. Ames, a member of the Graphics staff of the Bureau of Economic Geology under the direction of Joel L. Lardon, Media and Information Technology Manager. Scott D. Rodgers produced the CD. Others contributing to the publication of this report were Lana Dieterich, word processing and editing, and Jamie H. Coggin, layout.

\section{ALL REFERENCES CITED}

Amthor, J. E., and Friedman, G. M., 1989, Petrophysical character of Ellenburger karst facies: Stateline (Ellenburger) field, Lea County, southeastern New Mexico, in Cunningham, B. K., and Cromwell, D. W., eds., The lower Paleozoic of West Texas and southern New Mexico-modern exploration concepts: Permian Basin Section Society of Economic Paleontologists and Mineralogists, PBS-SEPM Publication No. 89-31, p. $133-144$. 
Amyx, J. W., Bass, D. M., Jr., and Whiting, R. L., 1960, Petroleum reservoir engineering: New York, McGraw-Hill, 610 p.

Andreason, M. W., 1992; Coastal siliciclastic sabkhas and related evaporative environments of the Permian Yates Formation, North Ward-Estes field, Ward County, Texas: American Association of Petroleum Geologists Bulletin, v. 76, p. 1735-1759.

Anderson, K. F., Elliott, W. C., Jr., and Moore, J. L., 1954, Petroleum-engineering study of the Ellenburger reservoir, Big Lake field, Reagan County, Tex.: U.S. Bureau of Mines Report of Investigations No. 5048, 28 p.

Asquith, G. B., Dutton, S. P., and Cole, A. G., 1997, "Delaware effect" and the Ramsey Sandstone, Ford Geraldine Unit, Reeves and Culberson Counties, Texas, in DeMis, W. D., ed., Permian Basin oil and gas fields: turning ideas into production: West Texas Geological Society Publication No. 97-102, p. 71-74.

Asquith, G. B., Dutton, S. P., Cole, A. G., Razi, M., and Guzman, J. I., 1997, Petrophysics of the Ramsey Sandstone, Ford Geraldine Unit, Reeves and Culberson Counties, Texas, in DeMis, W. D., ed., Permian Basin oil and gas fields: turning ideas into production: West Texas Geological Society Publication No. 97-102, p. 61-69.

Asquith, G. B., Hardage, B. A., Lancaster, D. E., and Pendleton, V. M., 1998, Petrophysics of the Mississippian limestones in the Waha/West Waha area Reeves and Pecos counties, Texas, in DeMis, W. D. and Nelis, M. K., eds., The search continues into the 21st century: West Texas Geological Society Publication No. 98-105, p. 173-180.

Atchley, S. C. Kozar, M. G., and Yose, L. A., 1999, A predictive model for reservoir distribution in the Permian (Leonardian) Clear Fork and Glorieta Formations, Robertson Field, West Texas: American Association of Petroleum Geologists Bulletin, v. 83, no. 7, p. 1031-1056.

Bain, R. C., 1994, North Ward-Estes, in Selected oil and gas fields in West Texas, v. VI: West Texas Geological Society, Publication No. 94-96, p. 275-279.

Baldonado, D., and Broadhead, R., 2002, Preliminary investigation of the regional stratigraphy of Siluro-Devonian carbonates, Tobosa Basin, New Mexico, in Hunt, T. J., and Lufholm, P. H., eds., The Permian Basin: preserving our past—securing our future: West Texas Geological Society, Publication 02-111, p. 55-69.

Ball, B. C., 2002, A Fusselman and Montoya core from the Dollarhide field, Andrews County, Texas, in Hunt, T. J., and Lufholm, P. H., eds., Permian Basin: preserving our pastsecuring our future: West Texas Geological Society Publication No. 02-111, p. 207-208.

2003, Identifying bypassed pay in the Fusselman and Montoya reservoirs of the Dollarhide field, Andrews County, Texas, in Hunt, T. J., and Lufholm, P. H., eds., 
The Permian Basin: back to basics: West Texas Geological Society Publication No. 03-112, p. 1-12.

Banik, A. K., and Schechter, D. S., 1996, Characterization of the naturally fractured Spraberry trend shaly sands based on core and log data: Society of Petroleum Engineers, SPE Paper $35224,11 \mathrm{p}$.

Barnaby, R. J., Grubb, J. G., Barros-Griffiths, I., and Lake, L. W., 1998, Reservoir heterogeneity of turbidite channel/levee and submarine fan facies in a Lower Devonian chert and siliceous carbonate reservoir: University Waddell field, west Texas, in DeMis, W. D., and Nelis, M. K., eds., The search continues into the 21st century: West Texas Geological Society Publication No. 98-105, p. 93.

Barnaby, R. J., and Ward, W. B., 1995, Sequence stratigraphic framework, high-frequency cyclicity, and three-dimensional heterogeneity: Grayburg Formation, Brokeoff Mountains, New Mexico, in Pause, P. H., and Candelaria, M. P., eds., Carbonate facies and sequence stratigraphy: practical applications of carbonate models: Permian Basin Section SEPM, Publication No. 95-36, p. 37-49.

Barrick, J. E., 1995, Biostratigraphy of uppermost Ordovician through Devonian depositional sequences in the Permian basin, west Texas and Southeastern New Mexico, in Pausé, P. H., and Candelaria, M. P., eds., Carbonate facies and sequence stratigraphy: practical applications of carbonate models: Permian Basin Section, Society of Economic Paleontologists and Mineralogists, Publication 95-36, p. 207-216.

Barrick, J. E., Finney, S. C., and Haywa-Branch, J. N., 1993, Revision of ages of the Fusselman, Wristen, and Thirtyone formations (Late Ordovician-Early Devonian) in the subsurface of West Texas based on conodonts and graptolites: Texas Journal of Science, v. 45, p. 231-247.

Bartel, J. R., and Broomhall, R. W., 1986, Stratigraphic potential for hydrocarbon entrapment on the east flank of the Means San Andres field, Andrews County, Texas, in Bebout, D. G., and Harris, P. M., eds., Hydrocarbon reservoir studies, San Andres/Grayburg Formations, Permian Basin: Permian Basin Section, Society of Economic Paleontologists and Mineralogists, Publication No. 86-26, p. 83-87.

Barton, M. D., and Dutton, S. P., 1999, Outcrop analysis of a sand-rich, basin-floor turbidite system, Permian Bell Canyon Formation, West Texas, in Transactions, Gulf Coast Section SEPM 19th Annual Bob F. Perkins Research Conference, December 5-8, Houston, p. 53-64.

Basham, W. L., 1996, Delaware Mountain Group sandstone channel orientations: implications for sediment source and deposition, in DeMis, W. D., and Cole, A. G., eds., The Brushy Canyon play in outcrop and subsurface: concepts and examples: Permian Basin Section SEPM, Publication No. 96-38, p. 91-102. 
Bashore, W. M., Langan, R. T., Tucker, K. E., and Griffith, P. J., 1995, Geostatistical integration of crosswell data for carbonate reservoir modeling, McElroy field, Texas, in Stoudt, E. L., and Harris, P. M., eds., Hydrocarbon reservoir characterization: geologic framework and flow unit modeling: SEPM (Society for Sedimentary Geology), SEPM Short Course No. 34, p. 199-225.

Batzle, M., and Gardner, M. H., 2000, Lithology and fluids: seismic models of the Brushy Canyon Formation, west Texas, in Bouma A. H., and Stone, C. G., eds., Fine-grained turbidite systems, American Association of Petroleum Geologists Memoir 72/SEPM Special Publication 68, p. 127-141.

Beaubouef, R. T., Rossen, C., Zelt, F. B., Sullivan, M. D., Mohrig, D. C., and Jennette, D. C., 1999, Deep-water sandstones, Brushy Canyon Formation, West Texas: American Association of Petroleum Geologists Continuing Education Course Note Series No. 40, $48 \mathrm{p}$.

Bebout, D. G., 1994, Farmer (Grayburg) field, in Pausé, P., and Entzminger, D., eds., Oil and gas fields in West Texas, symposium volume VI: West Texas Geological Society Publication No. 94-96, p. 61-69.

Bebout, D. G., and Harris, P. M., 1986, Hydrocarbon reservoir studies, San Andres/Grayburg Formations, Permian Basin: Permian Basin Section, Society of Economic Paleontologists and Mineralogists, Publication No. 86-26, 143 p.

1990, Geologic and engineering approaches in evaluation of San Andres/Grayburg hydrocarbon reservoirs - Permian Basin: The University of Texas at Austin, Bureau of Economic Geology Publication, 297 p.

Bebout, D. G., Lucia, F. J., Hocott, C. R., Fogg, G. E., and Vander Stoep, G. W., 1987, Characterization of the Grayburg reservoir, University Lands Dune field, Crane County, Texas: The University of Texas at Austin, Bureau of Economic Geology Report of Investigations No. 168, 98 p.

Becher, J. W., and von der Hoya, H. A., 1990, Wolfcampian and Early Leonardian fore-reef debris fans: Midland Basin, west Texas, in Flis, J. E., and Price, R. C., eds., Permian Basin oil and gas fields: innovative ideas in exploration and development: West Texas Geological Society, Publication No. 90-87, p. 153-155.

Behnken, F. H., 2003, Montoya conventional core description, depositional lithofacies, diagenesis and thin section petrography from the Pure Resources, Inc., Dollarhide Unit 25-2-S, Andrews County, Texas, in Hunt, T. J., and Lufholm, P. H., eds., The Permian Basin: back to basics: West Texas Geological Society Publication No. 03-112, p. 13-35.

Behnken, F. H., and Troschinetz, J., 1994, Impact of reservoir characterization on well completion and production economics, Permian Cherry Canyon sandstones, Loving County, Texas, in Gibbs, J. F., ed., Synergy equals energy - teams, tools, and techniques: West Texas Geological Society Publication 94-94, p. 3-13. 
Bent, J. V., Jr., 1992, Geologic model of San Andres reservoir, Roberts Unit CO2 Phase III area, Wasson field, Yoakum County, Texas, in Cromwell, D. W., Moussa, M. T., and Mazzullo, L. J., eds., Southwest Section American Association of Petroleum Geologists Transactions, SWS 92-90, p. 113-124.

Berg, R. R., 1979, Reservoir sandstones of the Delaware Mountain Group, southeast New Mexico, in Sullivan, N. M., ed., Guadalupian Delaware Mountain Group of West Texas and southeast New Mexico, Symposium and Field Trip Conference Guidebook: Society of Economic Paleontologists and Mineralogists (Permian Basin Section) Publication 79-18, p. 75-95.

Borer, J. M., and Harris, P. M., 1991, Lithofacies and cyclicity of the Yates Formation, Permian Basin: implications for reservoir heterogeneity: American Association of Petroleum Geologists Bulletin, v. 75, p. 726-779.

1991b, Depositional facies and model for mixed siliciclastics and carbonates of the Yates Formation, Permian Basin, in Lomando, A. J., and Harris, P. M., eds., Mixed carbonate-siliciclastic sequences: Society of Economic Paleontologists and Mineralogists, Core Workshop 15, p. 1-133.

Bouma, A. H., 1996, Initial comparison between fine- and coarse-grained submarine fans and the Brushy Canyon Formation sandstones, in DeMis, W. D., and Cole, A. G., eds., The Brushy Canyon play in outcrop and subsurface: concepts and examples: guidebook: Permian Basin Section, SEPM, Publication No. 96-38, p. 41-50.

Bowsher, A. L., and Abendshein, M., 1988, Wantz Granite Wash (oil), in A symposium of oil and gas fields of southeastern New Mexico, supplement: Roswell Geological Society, p. 328-329.

Britt, T. L., 1988, Joy of searching for eroded Ellenburger traps (abs.): American Association of Petroleum Geologists Bulletin, v. 72, p. 99.

Broadhead, R. F., 1993, San Andres and Grayburg platform, in Atlas of major Rocky Mountain gas reservoirs: New Mexico Bureau of Mines and Mineral Resources, p.142-143.

1993, Yeso Platform, in J. M. Robertson and R. F. Broadhead, eds., Atlas of Major Rocky Mountain Gas Reservoirs, New Mexico Bureau of Mines \& Mineral Resources, p. 146-148.

Broadhead, R. F., 1999, Underdeveloped oil fields-Upper Pennsylvanian and lower Wolfcampian carbonate reservoirs of southeast New Mexico: Carbonates and Evaporites, v. 14 , no. 1 , p. $84-105$.

Broadhead, R. F., and Justman, H. A., 2000, Regional controls on oil accumulations, lower Brushy Canyon Formation, southeast New Mexico, in DeMis, W. D., Nelis, M. K., and 
Trentham, R. C., eds., The Permian Basin: proving ground for tomorrow's technologies: West Texas Geological Society, Publication No. 00-109, p. 9-18.

Broadhead, R. F., Luo, F., and Speer, S. W., 1998, Oil and gas resources at the Waste Isolation Pilot Plant (WIPP) site, Eddy County, New Mexico: New Mexico Bureau of Mines and Mineral Resources, Circular 206, p. 3-72.

Brown, A., 2001, Effects of hydrodynamics on Cenozoic oil migration, Wasson field area, Northwest Shelf of the Permian Basin, in Viveiros, J. J., and Ingram, S. M., eds., The Permian Basin: microns to satellites, looking for oil and gas at all scales: West Texas Geological Society Publication No. 01-110, p. 133-142.

2002, Anhydrite diagenesis and reservoir quality, San Andres Formation, Willard Unit of Wasson field, Yoakum County, TX, in Hunt, T. J., and Lufholm, P. H., eds., The Permian Basin: back to basics: West Texas Geological Society Publication No. 03-112, p. $125-141$.

Brown, L. F., Jr., 1969, North Texas (Eastern Shelf) Pennsylvanian delta systems, in Fisher, W. L., Brown, L. F., Jr., Scott, A. J., and McGowen, J. H., Delta systems in the exploration for oil and gas: The University of Texas at Austin, Bureau of Economic Geology Special Publication, p. 40-53.

Brown, L. F., Jr., Solís Iriarte, R. F., and Johns, D. A., 1987, Regional stratigraphic cross sections, Upper Pennsylvanian and Lower Permian strata (Virgilian and Wolfcampian Series), North-Central Texas: The University of Texas at Austin, Bureau of Economic Geology cross sections, 27 p. and 27 plates.

1990, Regional depositional systems tracts, paleogeography, and sequence stratigraphy, Upper Pennsylvanian and Lower Permian strata, North- and West-Central Texas: The University of Texas at Austin, Bureau of Economic Geology Report of Investigations No. 197, 116 p.

Bureau of Economic Geology, 1957, Occurrence of oil and gas in West Texas, in Herald, F. A., ed., University of Texas, Austin, Bureau of Economic Geology, Publication No. 5716, $442 \mathrm{p}$.

Burkett, M. A., 2002, Application of horizontal drilling in low-permeability reservoirs, in Transactions, Southwest Section, American Association of Petroleum Geologists, Ruidoso, New Mexico, p. 139-146.

Burnham, D. E., 1991, Depositional environments and facies distribution of the Permian Paddock member of the Yeso Formation, Vacuum (Glorieta) field, Lea County, New Mexico: The University of Texas of the Permian Basin, M.S. thesis, 140 p.

Caldwell, C. D., and Harpole, K. J., 1986, Influence of reservoir stratigraphy on secondary recovery and gas cap management_-West Seminole San Andres Unit, Gaines County, 
Texas, in Bebout, D. G., and Harris, P. M., eds., Hydrocarbon reservoir studies, San Andres/Grayburg Formations, Permian Basin: Permian Basin Section, Society of Economic Paleontologists and Mineralogists, Publication No. 86-26, p. 69-73.

Campanella, J. D., Wadleigh, E. E., and Gilman, J. R., 2000, Flow characterization-critical for efficiency of field operations and IOR: Society of Petroleum Engineers International Petroleum Conference, Villahermosa, Mexico, SPE 58996, 14 p.

Candelaria, M. P., 1990, Atoka detrital a subtle stratigraphic trap in the Midland Basin, in Flis, J. E., and Price, R. C., eds., Permian Basin oil and gas fields: innovative ideas in exploration and development: West Texas Geological Society, Publication No. 90-87, p. $104-106$.

Candelaria, M. P., Handford, C. R., and Reed, C. L., 1994, Sequence model for the Simpson Group of the southern mid-continent: a tool for stratigraphic trap prediction, in Gibbs, J. F., ed., Synergy equals energy - teams, tools, and techniques: West Texas Geological Society Publication 94-94, p. 177.

Candelaria, M. P. Sarg, J. F., and Wilde, G. L., 1992, Wolfcamp sequence stratigraphy of the eastern Central Basin Platform, in Mruk, D. H., and Curran, C., eds., Permian Basin Exploration and production strategies: Application of sequence stratigraphic and reservoir characterization concepts: West Texas Geological Society Publication 92-91, p. $27-44$.

Canter, K. L., Wheeler, D. M., and Geesaman, R. C., 1992, Sequence stratigraphy and depositional facies of the Siluro-Devonian interval of the northern Permian Basin, in Candelaria, M. P., and Reed, C. L., eds., Paleokarst, karst-related diagenesis, and reservoir development: examples from Ordovician-Devonian age strata of West Texas and the Mid-Continent: Permian Basin Section, Society of Economic Paleontologists and Mineralogists, Field Trip Guidebook, Publication No. 92-33, p. 93-109.

Carr, M., and Gardner, M. H., 2000, Portrait of a basin-floor fan for sandy deepwater systems, Permian lower Brushy Canyon Formation, west Texas, in Bouma, A. H., and Stone, C. G., eds., Fine-grained turbidite systems: American Association of Petroleum Geologists Memoir 72/SEPM Special Publication 68, p. 215-231.

Casavant, R. R., 1988, Reservoir geology and paleo-environmental reconstruction of Yates Formation, Central Basin Platform, West Texas (abs.): American Association of Petroleum Geologists Bulletin, v. 72, p. 169.

Caughey, C. A., 1988, Lovington Penn. Northeast (oil), in A symposium of oil and gas fields of southeastern New Mexico, supplement: Roswell Geological Society, p. 231-232.

Chuber, S., and Pusey, W. C., 1969, Cyclic San Andres facies and their relationship to diagenesis, porosity, and permeability in the Reeves field, Yoakum County, Texas, in 
Elam, J. G., and Chuber, S., eds., Cyclic sedimentation in the Permian Basin: West Texas Geological Society Special Publication 69-56, p. 136-151.

Clemons, R. E., 1989, The Ellenburger-El Paso connection: Lower Ordovician shelf carbonates, in Cunningham, B. K., and Cromwell, D. W., eds., The lower Paleozoic of West Texas and southern New Mexico-modern exploration concepts: Permian Basin Section Society of Economic Paleontologists and Mineralogists, Publication No. 89-31, p. $85-104$.

Collier, H., Shaw, R., and McCracken, M., 1998, Integrating sample, seismic, petrophysical, and engineering data to revitalize an old field; Ropes Canyon Reef Unit, Hockley County, Texas, in DeMis, W. D. and Nelis, M. K., eds., The search continues into the $21 \mathrm{st}$ century: West Texas Geological Society Publication No. 98-105, p. 105-106.

Combs, D. M., Loucks, R. G., and Ruppel, S. C., 2003, Lower Ordovician Ellenburger Group collapsed Paleocave facies and associated pore network in the Barnhart field, Texas, in Hunt, T. J., and Lufholm, P. H., eds., The Permian Basin: back to basics: West Texas Geological Society Publication No. 03-112, p. 397-418.

Comer, J. B., 1991, Stratigraphic analysis of the Upper Devonian Woodford Formation, Permian Basin, West Texas and southeastern New Mexico: The University of Texas at Austin, Bureau of Economic Geology Report of Investigations No. 201, 63 p.

Cotton, C. B., 1966, Barnhart, in Oil and gas fields in west Texas symposium: West Texas Geological Society, Publication No. 66-52, p. 38-41.

Cowan, P. E., and Harris, P. M., 1986, Porosity distribution in San Andres Formation (Permian), Cochran and Hockley Counties, Texas: American Association of Petroleum Geologists Bulletin, v. 70, p. 888-897.

Cox, D. M., Brinton, L., and Tinker, S. W., 1998, Depositional facies and porosity development of an Upper Pennsylvanian algal mound reservoir, South Dagger Draw, Eddy County, New Mexico, in Winfree, K., ed., Cored reservoir examples from Upper Pennsylvanian and Lower Permian carbonate margins, slopes and basinal sandstones: West Texas Geological Society, Publication 98-103, variously paginated.

Craig, D. H., 1988, Caves and other features of Permian karst in San Andres dolomite, Yates field reservoir, West Texas, in James, N. P., and Choquette, P. W., eds., Paleokarst: New York, Springer-Verlag, p. 342-363.

1990, Yates and other Guadalupian (Kazanian) oil fields, U.S. Permian Basin, in Brooks, J., ed., Classic petroleum provinces: Geological Society of London Special Publication No. 50, p. 249-263.

Craig, D. H., Mruk, D. H., Heymans, M. J., Crevello, P. D., and Lanz, R. C., 1986, Stratigraphy and reservoir geology of the San Andres dolomite-Yates field, west Texas, in Bebout, 
D. G., and Harris, P. M., eds., Hydrocarbon reservoir studies, San Andres/Grayburg Formations, Permian Basin: Permian Basin Section Society of Economic Paleontologists and Mineralogists, Publication No. 86-26, p. 139-143.

Curran, B., 1996, Big Lake Field "Grayburg," in Selected oil and gas fields in West Texas volume VII: West Texas Geological Society, Publication No. 96-99, p. 33-36.

Cys, J. M., 1986, Lower Permian grainstone reservoirs, southern Tatum Basin, southeastern New Mexico, in Ahlen, J. L., and Hanson, M. E., eds., Southwest Section of American Association of Petroleum Geologists Transactions and guidebook of 1986 convention, Ruidoso, New Mexico: New Mexico Bureau of Mines and Mineral Resources, p. 115120.

Cys, J. M., and Mazzullo, S. J., 1985, Depositional and diagenetic history of a Lower Permian (Wolfcamp) phylloid-algal reservoir, Hueco Formation, Morton field, southeastern New Mexico, in Roehl, P. O., and Choquette, P. W., eds., Carbonate petroleum reservoirs: New York, Springer-Verlag, p. 277-288.

Dedmon, R. G., and Dorobek, S. L., 1993, Sequence stratigraphic relationships of the Grayburg Formation, Foster, North Cowden, and Midland Farms fields, Central Basin Platform, west Texas, in Gibbs, J., and Cromwell, D., eds., New dimensions in the Permian Basin: West Texas Geological Society Publication 93-93, p. 19-27.

Dehghani, K., Harris, P. M., Edwards, K. A., and Dees, W. T., 1999, Modeling a vuggy carbonate reservoir, McElroy field, west Texas: American Association of Petroleum Geologists Bulletin, v. 83, p. 19-42.

DeMis, W. D., and Cole, A. G., 1996, The Brushy Canyon play in outcrop and subsurface: concepts and examples: Guidebook, Permian Basin Section, SEPM, Publication No. 96-38, 188 p.

Dickson, J. A. D., and Saller, A. H., 1995, Identification of subaerial exposure surfaces am porosity preservation in Pennsylvanian and lower Permian shelf limestones, eastern Central Basin Platform Texas, in Budd, D. A., Saller, A. H., and Harris, P. M., eds., Unconformities in carbonate shelf strata - their recognition and the significance of associated porosity: American Association of Petroleum Geologists Memoir 57, p. 239-257.

Downing, A., and Mazzullo, J., 2000, Slope fan deposits of the 2nd Bone Spring sand, Young North field, Lea County, New Mexico (abstract), in DeMis, W. D., Nelis, M. K., and Trentham, R. C., eds., The Permian Basin: proving ground for tomorrow's technologies: West Texas Geological Society, Publication 00-109, p. 73.

Drozd, J. W., and Gould, J., 1991, East Mallet unit $\mathrm{CO}_{2}$ flood log monitoring program, Slaughter field, Hockley County, Texas, in Candelaria, M., ed., Permian Basin plays, tomorrow's technology today: West Texas Geological Society, Publication No. 91-89, p. 31-33. 
Dufford, S., and Holland, T., 1993, Wolfcamp detrital: a 3D case history Glasscock County, Texas, in Gibbs, J., and Cromwell, D., eds., New dimensions in the Permian Basin: West Texas Geological Society Publication 93-93, p. 75.

Dulaney, J. P. and Hadik, A. L., 1990, Geologic reservoir description of Mobil-operated units in Slaughter (San Andres) field, Cochran and Hockley Counties, Texas, in Bebout, D.G. and Harris, P.M., eds., Geologic and engineering approaches in evaluation of San Andres/Grayburg hydrocarbon reservoirs-Permian Basin: The University of Texas at Austin, Bureau of Economic Geology, p. 53-73.

Dull, D. W., 1992, Porosity calibration of modern porosity logs and old neutron logs, Mabee field, Andrews and Martin Counties, Texas, in Cromwell, D. W., Moussa, M. T., and Mazzullo, L. J., eds., Southwest Section American Association of Petroleum Geologists Transactions, SWS 92-90, p. 137-147.

1994, Geostatistical method to improve permeability estimates - application to the Mabee field, Andrews and Martin Counties, Texas, in Gibbs, J. F., ed., Synergy equals energy - teams, tools, and techniques: West Texas Geological Society Publication 94-94, p. 23-33.

Dutton, S. P., and M. D. Barton, 1999, Application of outcrop analogs to reservoir characterization of Permian deep-water sandstones, Bell Canyon Formation, Ford Geraldine Unit, West Texas (Delaware Basin), in Transactions, Gulf Coast Section SEPM 19th Annual Bob F. Perkins Research Conference, December 5-8, Houston, p. 65-76.

Dutton, S. P., Barton, M. D., Asquith, G. B., Malik, M. A., Cole, A. G., Gogas, J., Guzman, J. I., and Clift, S. J., 1999, Geologic and engineering characterization of turbidite reservoirs, Ford Geraldine Unit, Bell Canyon Formation, West Texas: The University of Texas at Austin, Bureau of Economic Geology Report of Investigations No. 255, 88 p.

Dutton, S. P., Barton, M. D., Clift, S. J., Guzman, J. I., and Cole, A. G., 1997, Depositional history of Ramsey Sandstone channel-levee and lobe deposits, Bell Canyon Formation, Ford Geraldine Unit, West Texas (Delaware Basin) in DeMis, W. D., ed., Permian Basin oil and gas fields: turning ideas into production: West Texas Geological Society Publication No. 97-102, p. 53-60.

Dutton, S. P., Barton, M. D., Zirczy, H. H., and Flanders, W. A., 2000, Characterization of reservoir heterogeneity in slope and basin clastic reservoirs, Bell Canyon Formation, Delaware Basin, Texas, in Reid, S. T., Southwest Section AAPG 2000 Convention transactions: West Texas Geological Society, Publication SWS 2000-107, p. 116-129.

Dutton, S. P., and W. A. Flanders, 2001, Application of advanced reservoir characterization, simulation, and production optimization strategies to maximize recovery in slope and basin clastic reservoirs, West Texas (Delaware Basin): The University of Texas at Austin, 
Bureau of Economic Geology, final report prepared for U.S. Department of Energy, $\mathrm{DOE} / \mathrm{BC} / 14936-18,170 \mathrm{p}$.

2001, Deposition and diagenesis of turbidite sandstones in East Ford Field, Bell Canyon Formation, Delaware Basin, Texas: American Association of Petroleum Geologists Southwest Section, 2001 Annual Meeting Papers and Abstracts, Dallas, Texas, March 10-13, 12 p.

Dutton, S. P., Flanders, W. A., and Barton, M. D., 2003, Reservoir characterization of a Permian deep-water sandstone, East Ford field, Delaware basin, Texas: American Association of Petroleum Geologists Bulletin, v. 87, p. 609-627.

Dutton, S. P., Kim, E. M., Broadhead, R. F., Raatz, W., Breton, C., Ruppel, S. C., Kerans, C., and Holtz, M. H., 2003, Play analysis and digital portfolio of major oil reservoirs in the Permian Basin: application and transfer of advanced geological and engineering technologies for incremental production opportunities: The University of Texas at Austin, Bureau of Economic Geology, annual report prepared for U.S. Department of Energy, Assistant Secretary for Fossil Energy, under contract no. DE-FC26-02NT15131, 67 p.

Dutton, S. P., Kim, E. M., Broadhead, R. F., Breton, C. L., Raatz, W. D., Ruppel, S. C., and Kerans, C., 2004, Play analysis and digital portfolio of major oil reservoirs in the Permian Basin: application and transfer of advanced geological and engineering technologies for incremental production opportunities: The University of Texas at Austin, Bureau of Economic Geology, annual report prepared for U.S. Department of Energy, Assistant Secretary for Fossil Energy, under contract no. DE-FC26-02NT15131, 104 p.

Dutton, S. P., Zirczy, H. H., Tremblay, T. A., and Scott, A. R., 2000b, Update of oil and gas reservoir data base, Permian and Fort Worth Basins, Texas: The University of Texas at Austin, Bureau of Economic Geology, final report prepared for the U.S. Geological Survey under order no. 99CRSA1102, $31 \mathrm{p}$.

Ebanks, W. J., Jr., 1988, Geologic description of Middle Devonian chert reservoir, Block 31 Field, Crane County, Texas (abs.): American Association of Petroleum Geologists Bulletin, v. 72, p. 181.

1990, Geology of the San Andres reservoir, Mallet Lease, Slaughter field, Hockley County, Texas: implications for reservoir engineering projects, in Bebout, D. G., and Harris, P. M., eds., Geologic and engineering approaches in evaluation of San Andres/Grayburg hydrocarbon reservoirs-Permian Basin: The University of Texas at Austin, Bureau of Economic Geology, p. 75-85.

Eide, M., and Mazzullo, J., 1993, Facies, depositional environments and stratigraphy of the Queen Formation in North Ward-Estes field, Ward County, Texas, in Gibbs, J., and Cromwell, D., eds., New dimensions in the Permian Basin: West Texas Geological Society Publication 93-93, p. 28-42. 
Elliott, L. A., and Warren, J. K., 1989, Stratigraphy and depositional environment of lower San Andres Formation in subsurface and equivalent outcrops: Chaves, Lincoln, and Roosevelt Counties, New Mexico: American Association of Petroleum Geologists Bulletin, v. 73, p. 1307-1325.

Energy Information Administration, 2003, U.S. crude oil, natural gas, and natural gas liquids reserves: 2002 annual report, DOE/EIA-0216 (2002), 48 p.

Entzminger, D. J., Ferdinand, K., Lawson, D., Loucks, B., Mescher, P., and Patty, K., 2000, Corrigan-Cowden-breathing new life into an old waterflood, in DeMis, W. D., Nelis, M. K., and Trentham, R. C., eds., The Permian Basin: proving ground for tomorrow's technologies: West Texas Geological Society pub. No. 00-109, p. 75.

Entzminger, D. J., and Loucks, R. G., 1992, Paleocave reservoirs in the Wristen Formation at Emerald Field, Gaines and Yoakum Counties, Texas, in Candelaria, M. P., and Reed, C. L., eds., Paleokarst, karst-related diagenesis, and reservoir development: examples from Ordovician-Devonian age strata of West Texas and the Mid-Continent: Permian Basin Section- Society of Economic Paleontologists and Mineralogists, Field Trip Guidebook, Publication No. 92-33, p. 126-130.

Ewing, T. E., 1990, Tectonic map of Texas: The University of Texas at Austin, Bureau of Economic Geology, scale 1:750,000, 4 sheets.

Fassihi, M. R., Yannimaras, D. V., Westfall, E. E., and Gilham, T. H., 1996, Economics of light oil injection projects, in SPE/DOE 35393, Tenth Symposium on Improved Oil Recovery, Tulsa, Oklahoma: Society of Petroleum Engineers, SPE/DOE 35393, p. 501-509.

Ferdinand, K. J., Entzminger, D. J., and Lawson, D., 2002, The integration of seismic attributes and rock properties for mapping porosity thickness in the heterogeneous Grayburg carbonate reservoir, Corrigan Cowden unit, west Texas, in Hunt, T. J., and Lufholm, P. H., eds., Permian Basin: preserving our past—securing our future: West Texas Geological Society Publication No. 02-111, p. 209-210.

Fischer, A. G., and Sarnthein, M., 1988, Airborne silts and dune-derived sands in the Permian of the Delaware Basin: Journal of Sedimentary Petrology, v. 58, p. 637-643.

Fitchen, W. M., Starcher, M. A., Buffler, R. T., and Wilde, G. L., 1995, Sequence stratigraphic framework and facies models of the early Permian platform margins, Sierra Diablo, West Texas, in Garber, R. A., and Lindsay, R. F., eds., Wolfcampian-Leonardian shelf margin facies of the Sierra Diablo - seismic scale models for subsurface exploration: West Texas Geological Society Publication 95-97, p. 23-66.

Flanders, W. A., and DePauw, R. M., 1993, Update case history: performance of the Twofreds Tertiary CO2 project, in Proceedings, 1993 SPE Annual Technical Conference: Society of Petroleum Engineers, Paper 26614, 10 p. 
Fogg, G. E., and Lucia, F. J., 1990, Reservoir modeling of restricted platform carbonates: geologic/geostatistical characterization of interwell-scale reservoir heterogeneity, Dune field, Crane County, Texas: The University of Texas at Austin, Bureau of Economic Geology Report of Investigations No. 190, 66 p.

French, V. L., and Hinterlong, G. D., 2000, Construction of a permeability model applying the Lucia characterization methodology with non-optimal data conditions: West Jordan unit, San Andres Formation, in DeMis, W. D., Nelis, M. K., and Trentham, R. C., eds., The Permian Basin: proving ground for tomorrow's technologies: West Texas Geological Society Publication No. 00-109, p. 77-93.

Frenzel, H. N., Bloomer, R. R., Cline, R. B., Cys, J. M., Galley, J. E., Gibson, W. R., Hills, J. M., King, W. E., Seager, W. R., Kottlowski, F. E., Thompson, S., III, Luff, G. C., Pearson, B. T., and Van Siclen, D. C., 1988, The Permian Basin region, in Sloss, L. L., ed., Sedimentary cover-North American Craton; U.S.: Boulder, Colorado, Geological Society of America, The Geology of North America, v. D-2, p. 261-306.

Friedman, G. M., Ghosh, S. K., and Urschel, S., 1990, Petrophysical characteristics related to depositional environments and diagenetic overprint: a case study of the San Andres Formation, Mabee field, west Texas, in Bebout, D. G. and Harris, P. M., eds., Geologic and engineering approaches in evaluation of San Andres/Grayburg hydrocarbon reservoirs-Permian Basin: The University of Texas at Austin, Bureau of Economic Geology Publication, p. 125-144.

Galley, J. D., 1958, Oil and gas geology in the Permian Basin in Texas and New Mexico, in Weeks, L. G., ed., Habitat of oil — a symposium: Tulsa, Oklahoma, American Association of Petroleum Geologists, p. 395-446.

Galloway, W. E., and Brown, L. F., Jr., 1972, Depositional systems and shelf-slope relationships in Upper Pennsylvanian rocks, North-Central Texas: The University of Texas at Austin, Bureau of Economic Geology Report of Investigations No. 75, 62 p.

Galloway, W. E., Ewing, T. E., Garrett, C. M., Jr., Tyler, N., and Bebout, D. G., 1983, Atlas of major Texas oil reservoirs: The University of Texas at Austin, Bureau of Economic Geology Special Publication, 139 p.

Galloway, W. E., and D. K. Hobday, 1996, Terrigenous clastic depositional systems: applications to fossil fuel and groundwater resources, $2 \mathrm{~d}$ ed.: New York, SpringerVerlag, $489 \mathrm{p}$.

Garber, R. A., and Harris, P. M., 1986, Depositional facies of Grayburg/San Andres dolomite reservoirs - Central Basin Platform, in Bebout, D. G., and Harris, P. M., eds., Hydrocarbon reservoir studies San Andres/Grayburg Formations, Permian Basin: Permian Basin Section Society of Economic Paleontologists and Mineralogists, Publication 86-26, p. 61-66. 
1990, Depositional facies of Grayburg/San Andres dolostone reservoirs, Central Basin Platform, Permian Basin, in Bebout, D. G., and Harris, P. M., eds., Geologic and engineering approaches in evaluation of San Andres/Grayburg hydrocarbon reservoirsPermian Basin: The University of Texas at Austin, Bureau of Economic Geology Publication, p. 1-19.

Gardner, M. H., 1992, Sequence stratigraphy of eolian-derived turbidites: patterns of deep water sedimentation along an arid carbonate platform, Permian (Guadalupian) Delaware Mountain Group, West Texas, in Mruk, D. H., and Curran, B. C., eds., Permian Basin exploration and production strategies: applications of sequence stratigraphic and reservoir characterization concepts: West Texas Geological Society Publication 92-91, p. 7-12.

Gardner, M. H., 1997, Characterization of deep-water siliciclastic reservoirs in the upper Bell Canyon and Cherry Canyon Formations of the northern Delaware Basin, Culberson and Reeves Counties, Texas, in Major, R. P., ed., Oil and gas on Texas State Lands: an assessment of the resource and characterization of type reservoirs: The University of Texas, Bureau of Economic Geology Report of Investigations No. 241, p. 137-146.

1997, Sequence stratigraphy and hydrocarbon habitat of the Permian (Guadalupian) Delaware Mountain Group, Delaware Basin, West Texas, in Major, R. P., ed., Oil and gas on Texas State Lands: an assessment of the resource and characterization of type reservoirs: The University of Texas, Bureau of Economic Geology Report of Investigations No. 241, p. 147-157.

Gardner, M. H., and J. M. Borer, 2000, Submarine channel architecture along a slope to basin profile, Brushy Canyon Formation, west Texas, in Bouma, A. H., and Stone, C. G., eds., Fine-grained turbidite systems: American Association of Petroleum Geologists Memoir 72/SEPM Special Publication 68, p. 195-214.

Gardner, M. H., and Sonnenfeld, M. D., 1996, Stratigraphic changes in facies architecture of the Permian Brushy Canyon Formation in Guadalupian Mountains National Park, west Texas, in DeMis, W. D., and Cole, A. G., eds., The Brushy Canyon play in outcrop and subsurface: concepts and examples: guidebook: Permian Basin Section, SEPM, Publication No. 96-38, p. 51-59.

Garfield, T. R., and Longman, 1989, Depositional variations on the Fusselman formation, Central Midland Basin, West Texas, in Cunningham, B. K. and Cromwell, D. W., eds., The lower Paleozoic of West Texas and southern New Mexico-modern exploration concepts: Permian Basin Section, Society of Economic Paleontologists and Mineralogists, Publication No. 89-31, p. 187-202.

Gawloski, T. F., 1987, Nature, distribution, and petroleum potential of Bone Spring detrital sediments along the Northwest shelf of the Delaware Basin, in Cromwell, D., and Mazzullo, L., eds., The Leonardian facies in W. Texas and S.E. New Mexico and Guidebook to the Glass Mountains, West Texas: Permian Basin Section Society of Economic Paleontologists and Mineralogists, Publication 87-27, p. 84-105. 
Geesaman, R. C., and Scott, A. J., 1989, Stratigraphy, lithofacies and depositional models of the Fusselman /Formation, Central Midland Basin, in Cunningham, B. K., and Cromwell, D. W., eds., The lower Paleozoic of West Texas and southern New Mexicomodern exploration concepts: Permian Basin Section, Society of Economic Paleontologists and Mineralogists, Publication No. 89-31, p. 175-186.

Genetti, D. B., Whitaker, C. A., Smith, D. P., and Price, L. M., 2003, Applying improved recovery processes and effective reservoir management to maximize oil recovery at Salt Creek: Society of Petroleum Engineers, SPE $13^{\text {th }}$ Middle East Oil Show \& Conference, Bahrain, April, 2003, SPE 81458, 11 p.

Geomap Company, 1998, Executive reference map, Permian Basin, Dallas, Texas, scale 1 inch = $32,000 \mathrm{ft}$.

George, C. J., and Stiles, L. H., 1986, Planning a $\mathrm{CO}_{2}$ tertiary recovery project, Means San Andres unit, in Bebout, D. G., and Harris, P. M., eds., Hydrocarbon reservoir studies, San Andres/Grayburg Formations, Permian Basin: Permian Basin Section, Society of Economic Paleontologists and Mineralogists, Publication No. 86-26, p. 79-82.

Gibson, G. R., 1965, Oil and gas in southwestern region—geologic framework, in Young, A., and Galley, J. E., eds., Fluids in the subsurface environment, American Association of Petroleum Geologists Memoir 4, p. 66-100.

Glandt, C. A., Pieterson, R., Dombrowski, A., and Balzarini, M. A., 1998, Coral Creek field study: a comprehensive assessment of the potential of high-pressure air injection in a mature waterflood project, in SPE Midcontinent Operations Symposium, Oklahoma City, Oklahoma: Society of Petroleum Engineers, SPE 52198, 11 p.

Godfrey, C. B., 1982, Ropes \& South Ropes Penn.: selected oil \& gas fields in West Texas: West Texas Geological Society Publication No. 82-75, p. 565-567.

Golder Associates, 1999, Description of Yates field: http://www.fracturedreservoirs.com/niper/FIELDHIS.HTM.

Goldhammer, R. K., Lehmann, P. J., and Dunn, P. A., 1993, The origin of high-frequency platform carbonate cycles and third-order sequences (Lower Ordovician El Paso Group, west Texas): constraints from outcrop data and stratigraphic modeling: Journal of Sedimentary Petrology, v. 63, p. 318-359.

Gomez, L. A., Gale, J. F. W., Ruppel, S. C., and Laubach, S. E., 2001, Fracture characterization using rotary-drilled sidewall cores: an example from the Ellenburger Formation, West Texas, in Viveiros, J. J., and Ingram, S. M., eds., The Permian Basin: microns to satellites, looking for oil and gas at all scales: West Texas Geological Society Publication No. $01-110$, p. $81-89$. 
Grant, P. R., Jr., and Foster, R. W., 1989, Future petroleum provinces in New Mexicodiscovering new reserves: New Mexico Bureau of Mines and Mineral Resources, $94 \mathrm{p}$.

Grant, C. W., Goggin, D. J., and Harris, P. M., 1994, Outcrop analog for cyclic-shelf reservoirs, San Andres Formation of Permian Basin: stratigraphic framework, permeability distribution, geostatistics, and fluid-flow modeling: American Association of Petroleum Geologists Bulletin, v. 78, p. 23-54.

Gratton, P. J. F., and LeMay, W. J., 1969, San Andres oil east of the Pecos, in Summers, W. K., and Kottlowski, F. E., The San Andres Limestone, a reservoir for oil and water in New Mexico: New Mexico Geological Society, Special Publication 3, p. 37-43.

Griffin, L. G., Wright, C. A., Demetrius, S. L., Blackburn, B. D., and Price, D. G., 2000, Identification and implications of induced hydraulic fractures in waterflood: case history HGEU: Society of Petroleum Engineers, Permian Basin Oil and Gas Recovery Conference, Midland, Texas, SPE Publication 59525, 8 p.

Grimes, D. N., 1982, Fluvanna field: selected oil \& gas fields in West Texas: West Texas Geological Society Publication No. 82-75, p. 232-236.

Guevara, E. H., 1988, Geological characterization of Permian submarine fan reservoirs of the Driver waterflood unit, Spraberry Trend, Midland Basin, Texas: The University of Texas at Austin, Bureau of Economic Geology Report of Investigations No. 172, 44 p.

Guiseppe, A. C., and Trentham, R. C., 1999, Stratigraphic framework and reservoir delineation of the McCamey field (Grayburg-San Andres), Upton County, Texas, in Grace, D. T., and Hinterlong, G. D., eds., The Permian Basin: providing energy for America: West Texas Geological Society Publication No. 99-106, p. 43-53.

Hamilton, D. C., and Asquith, G. B., 2000, Depositional, diagenetic, and production histories of Chester ooid grainstones in the Austin (Upper Mississippian) field: Lea County, New Mexico, in DeMis, W. D., Nelis, M. K., and Trentham, R. C., eds., The Permian Basin: proving ground for tomorrow's technologies: West Texas Geological Society Publication No. 00-109, p. 95-106.

Hamilton, D., and Hunt, T., 1996, War-Wink Cherry Canyon trend, "serendipity in spades," in Martin, R. L., ed., Permian Basin oil and gas fields: keys to success that unlock future reserves: West Texas Geological Society Publication 96-101, p. 107-115.

Hammes, U., Lucia, F. J., and Kerans, C., 1996, Reservoir heterogeneity in karst-related reservoirs: Lower Ordovician Ellenburger Group, west Texas, in Stoudt, E. L., ed., Precambrian-Devonian geology of the Franklin Mountains, west Texas-analogs for exploration and production in Ordovician and Silurian karsted reservoirs in the Permian Basin: West Texas Geological Society Publication 96-100, p. 99-115. 
Handford, C. R., 1981, Sedimentology and genetic stratigraphy of Dean and Spraberry Formations (Permian), Midland Basin, Texas: American Association of Petroleum Geologists Bulletin, v. 65, p. 1602-1616.

Handford, C. R., Candelaria, M. P., and Lafollette, S., 1996, Accommodation cycles in peritidal carbonate and continental to shoreface siliciclastic facies, San Andres-Grayburg Formations, Eddy County, New Mexico, in Martin, R. L., ed., Permian Basin oil and gas fields: keys to success that unlock future reserves: West Texas Geological Society, Publication 96-101, p. 65-80.

Hanson, B. M., Powers, B. K., Garrett, C. M., Jr., McGookey, D. E., McGlasson, E. H., Horak, R. L., Mazzullo, S. J., Reid, A. M., Calhoun, G. G., Clendening, J., and Claxton, B., 1991, The Permian Basin, in Gluskoter, H. J., Rice, D. D., and Taylor, R. B., eds., The Geology of North America, v. P-2, Economic Geology, U.S.: Geological Society of America, p. 339-356.

Hardage, B. A., Pendleton, V. M., Simmons, J. L., Jr., Stubbs, B. A., and Uszynski, B. J., 1998, 3-D instantaneous frequency used as a coherency/continuity parameter to interpret reservoir compartment boundaries across an area of complex turbidite deposition: Geophysics, v. 63, p. 1520-1531.

Hardage, B. A., Simmons, J. L., Jr., Pendleton, V. M., Stubbs, B. A., and Uszynski, B. J., 1998, 3-D seismic imaging and interpretation of Brushy Canyon slope and basin thin-bed reservoirs, northwest Delaware Basin: Geophysics, v. 63, p. 1507-1519.

Harms, J. C., and Brady, M. J., 1996, Deposition of the Brushy Canyon Formation: 30 years of conflicting hypotheses, in DeMis, W. D., and Cole, A. G., eds., The Brushy Canyon play in outcrop and subsurface: concepts and examples: Guidebook, Permian Basin Section, SEPM, Publication No. 96-38, p. 51-59.

Harris, D. C., 1990, Ramp buildups in the lower Strawn limestone (Penn.): controls on stratigraphic reservoir variability, in Flis, J. E., and Price, R. C., eds., Permian Basin oil and gas fields: innovative ideas in exploration and development: West Texas Geological Society, Publication 90-87, p. 91-101.

Harris, P. M., Dodman, C. A., and Bliefnick, D. M., 1984, Permian (Guadalupian) reservoir facies, McElroy field, west Texas, in Harris, P. M., ed., Carbonate sands-a core workshop: Society of Economic Paleontologists and Mineralogists Core Workshop No. 5, p. 136-174.

Harris, P. M., and Walker, S. D., 1990, McElroy field, in Beaumont, E. A., and Foster, N. H., eds., Atlas of oil and gas fields, stratigraphic traps volume I: traps associated with tectonic faulting: American Association of Petroleum Geologists Treatise of Petroleum Geology, p. 195-227. 
1990, McElroy field: development geology of a dolostone reservoir, Permian Basin, west Texas, in Bebout, D. G. and Harris, P. M., eds., Geologic and engineering approaches in evaluation of San Andres/Grayburg hydrocarbon reservoirs-Permian Basin: The University of Texas at Austin, Bureau of Economic Geology Publication, p. 275-296.

Hayes, P. D., and Tieh, T. T., 1992, Organic geochemistry and diagenesis of the Delaware Mountain Group, west Texas and southeast New Mexico, in Cromwell, D. W., Moussa, M. T., and Mazzullo, L. J., eds., Southwest Section American Association of Petroleum Geologists Transactions, SWS 92-90, p. 155-175.

Heckel, P. H., 1986, Sea-level curve for Pennsylvanian eustatic marine transgressive-regressive depositional cycles along the Midcontinent outcrop belt, North America: Geology, v. 14, p. 330-334.

Herald, F. A., ed., 1957, Occurrence of oil and gas in west Texas: University of Texas, Austin, Bureau of Economic Geology Publication No. 5716, 442 p.

Hills, J. M., 1984, Sedimentation, tectonism, and hydrocarbon generation in Delaware Basin, West Texas and southeastern New Mexico: American Association of Petroleum Geologists Bulletin, v. 68, p. 250-267.

Hinrichs, P. D., Lucia, F. J., and Mathis, R. L., 1986, Permeability distributions and reservoir continuity in Permian San Andres shelf carbonates, Guadalupe Mountains, New Mexico, in Moore, G. E., and Wilde, G. L., eds., Lower and middle Guadalupian facies, stratigraphy, and reservoir geometries, San Andres/Grayburg Formations, Guadalupe Mountains New Mexico and Texas: Permian Basin Section, Society of Economic Paleontologists and Mineralogists, Publication 86-25, p. 37-47.

Hinterlong, G. D., and Taylor, A. R., 1996, Characterization of rock types with mixed wettability using log and core data-DOE project Welch field, Dawson County, Texas: Society of Petroleum Engineers, Permian Basin Oil and Gas Recovery Conference, Midland, SPE 35160, p. 139-147.

Hobson, J. P., Caldwell, C. D., and Toomey, D. F., 1985, Early Permian deep-water allochthonous limestone facies and reservoir, west Texas: American Association of Petroleum Geologists Bulletin, v. 69, p. 2130-2147.

1985, Sedimentary facies and biota of early Permian deep-water allochthonous limestone, southwest Reagan County, Texas, in Crevello, P. D., and Harris, P. M., eds., Deep-water carbonates - a core workshop: Society of Economic Paleontologists and Mineralogists Core Workshop No. 6, p. 93-139.

Hoffman, C. L., 2002, Reservoir characterization of the Drinkard Formation of the Justis Tubb-Drinkard field, Lea County, New Mexico: a valuable tool in optimizing field development, in Hunt, T. J., and Lufholm, P. H., eds., The Permian Basin: preserving 
our past-securing our future: West Texas Geological Society, Publication 02-111, p. $115-116$.

Holtz, M. H., 1993, Estimating oil reserve variability by combining geologic and engineering parameters: Society of Petroleum Engineers Hydrocarbon Economics and Evaluation Symposium, Dallas, Texas, Paper No. 25827, p. 85-95.

Holtz, M. H., 1994, McFarland (Queen) reservoir, in West Texas Geological Society, Selected oil \& gas fields in West Texas vol. VI: Midland, Texas, Publication No. 94-96, p. 169177.

Holtz, M. H., Garrett, C. M., Jr., and Tremblay, T. A., 1993, Update of Atlas of Major Texas Oil Reservoirs Data Base and Atlas of Major Texas Gas Reservoirs Data Base: The University of Texas at Austin, Bureau of Economic Geology contract report prepared for the U.S. Geological Survey under Contract No. 1434-93-C-40079, 14 p. plus data tape.

Holtz, M. H., and Kerans, C., 1992, Characterization and categorization of West Texas Ellenburger reservoirs, in Candelaria, M. P., and Reed, C. L., eds., Paleokarst, karstrelated diagenesis, and reservoir development: examples from Ordovician-Devonian age strata of West Texas and the Mid-Continent: Permian Basin Section, Society of Economic Paleontologists and Mineralogists, Field Trip Guidebook, Publication No. $92-33$, p. $45-54$.

Holtz, M. H., and Major, R. P., 2004, Integrated geological and petrophysical characterization of Permian shallow-water dolostone: Society of Petroleum Engineers Reservoir Evaluation \& Engineering, SPE 87595, v. 7, no. 2, p. 47-58.

Holtz, M. H., Ruppel, S. C., and Hocott, C. R., 1992, Integrated geologic and engineering determination of oil-reserve growth potential in carbonate reservoirs: Journal of Petroleum Technology, v. 44, no. 11, p. 1250-1257.

Holtz, M. H., Tyler, N., Garrett, C. M., Jr., White, W. G., and Banta, N. J., 1991, Atlas of major Texas oil reservoirs: data base: The University of Texas at Austin, Bureau of Economic Geology Special Publication, data disk.

Hovorka, S. C., Nance, H. S., and Kerans, C., 1993, Parasequence geometry as a control on porosity evolution: examples from the San Andres and Grayburg Formations in the Guadalupe Mountains, New Mexico, in Loucks, R. G., and Sarg, J. F. eds., Carbonate sequence stratigraphy: recent developments and applications: American Association of Petroleum Geologists Memoir 57, p. 493-514.

Hueni, G. B. and Schuessler, K. L., 1993, Associated gas reservoirs, in Atlas of major Rocky Mountain gas reservoirs: New Mexico Bureau of Mines and Mineral Resources, p. 190.

Hunt, T., 2000, Review of Barnhart field: Ellenburger Group, Ozona Uplift, Reagan County, Texas, in DeMis, W. D., Nelis, M. K., and Trentham, R. C., eds., The Permian Basin: 
proving ground for tomorrow's technologies: West Texas Geological Society Publication No. 00-109, p. 107-111.

Hurley, N. F., Ustabas, S., and Zahm, L. C., 2001, Incremental oil recovery using horizontal drilling in a compartmentalized oolitic reservoir, San Andres Formation, west Texas: American Association of Petroleum Geologists Annual Convention Official Program, v. 10, p. A95.

Jacka, A. D., 1979, Deposition and entrapment of hydrocarbons in Bell Canyon and Cherry Canyon deep-sea fans of the Delaware Basin, in Sullivan, N. M., ed., Guadalupian Delaware Mountain Group of West Texas and Southeast New Mexico: Society of Economic Paleontologists and Mineralogists (Permian Basin Section) Publication 79-18, p. $104-120$.

Jennings, J. W., Jr., 2000, Spatial statistics of permeability data from carbonate outcrops of west Texas and New Mexico: implications for improved reservoir modeling: The University of Texas at Austin, Bureau of Economic Geology Report of Investigations No. 258, 50 p.

Jennings, J. W., Jr., Lucia, F. J., and Ruppel, S. C., 1998, Waterflood performance modeling for the South Cowden Grayburg reservoir, Ector County, Texas: The University of Texas at Austin, Bureau of Economic Geology Report of Investigations No. 247, 46 p.

2002, 3D modeling of stratigraphically controlled petrophysical variability in the South Wasson Clear Fork Reservoir: Society of Petroleum Engineers Annual Technical Conference and Exhibition Transactions, San Antonio, Texas, 29 September-2 October, SPE 77592, 15 p.

Johnson, I. G., Brown, J. L., and Asquith, G. B., 1997, Using sinusoidal drilling techniques in a diagenetically complex carbonate reservoir: West Dollarhide Drinkard Unit (MidLeonardian), Lea County, southeast New Mexico, in DeMis, W. D., ed., Permian Basin oil and gas fields: turning ideas into production: West Texas Geological Society, Publication 97-102, p. 93-95.

Johnson, M. E., 1987, Extent and bathymetry of North American platform seas in the Early Silurian: Paleoceanography, v. 2, no. 2, p. 185-211.

Jones, R. H., Lucia, F. J., Ruppel, S. C., and Kane, J. A., 2003, Better than a porosity cutoff: the rock-fabric approach to understanding porosity and permeability in the Lower Clear Fork and Wichita reservoirs, Fullerton Field, West Texas, in Hunt, T. J., and Lufholm, P. H., eds., The Permian Basin: back to basics: West Texas Geological Society Publication No. 03-112, p. 47-66.

Justman, H. A., and Broadhead, R. F., 2000, Source rock analysis for the Brushy Canyon Formation, Delaware Basin, southeastern New Mexico, in DeMis, W. D., Nelis, M. K., and Trentham, R. C., eds., The Permian Basin: proving ground for tomorrow's technologies: West Texas Geological Society, Publication No. 00-109, p. 211-220. 
Kane, T. V., 1992, Sequence stratigraphy improves definition of reservoir architecture at Avalon (Delaware) field, Eddy County, New Mexico, in Mruk, D. H., and Curran, B. C., eds., Permian Basin exploration and production strategies: applications of sequence stratigraphic and reservoir characterization concepts: West Texas Geological Society Publication 92-91, p. 12-18.

Kaufman, J., Fiske, D., and Caputo, J., 2001, Contrasting depositional models for Wolfcamp periplatform carbonate reservoirs, Reagan and Upton Counties, Midland Basin, Texas, in Stoudt, E. L., and Sivils, D. J., eds., Wolfcampian of West Texas (Permian Basin, Sierra Diablo and Hueco Mountains) — shelfal and periplatform carbonate reservoirs and outcrop analogs: Permian Basin Section SEPM Core Workshop and Field Trip Guidebook, Publication No. 2001-41, p. 1-1-1-2.

Keller, D. R., 1992, Evaporite geometries and diagenetic traps, lower San Andres, Northwest shelf, New Mexico, in Cromwell, D. W., Moussa, M. T., and Mazzullo, L. J., eds., Southwest Section American Association of Petroleum Geologists 1992 Convention Transactions: Southwest Section American Association of Petroleum Geologists, Publication SWS 92-90, p. 183-193.

Kelley, V. C., 1971, Geology of the Pecos Country, southeastern New Mexico: New Mexico Bureau of Mines and Mineral Resources, Memoir 24, 75 p.

Kerans, C., 1988, Karst-controlled reservoir heterogeneity in Ellenburger Group carbonates of West Texas: American Association of Petroleum Geologists Bulletin, v. 72, p. 11601183.

1989, Karst-controlled reservoir heterogeneity and an example from the Ellenburger (Lower Ordovician) of West Texas: The University of Texas at Austin, Bureau of Economic Geology Report of Investigations No. 186, 40 p.

1990, Depositional systems and karst geology of the Ellenburger Group (Lower Ordovician), subsurface West Texas: The University of Texas at Austin, Bureau of Economic Geology Report of Investigations No. 193, 37 p.

2000, Stratigraphic architecture and paleokarst development within the Abo (Leonardian 1) Composite Sequence, Apache Canyon and Kingdom Abo field, Permian Basin, in Reid, S. T., Southwest Section AAPG 2000 Convention transactions: West Texas Geological Society, Publication SWS 2000-107, p. 250.

2001, Reservoir architecture at SACROC and the Canyon-Cisco transition, in Viveiros, J. J., and Ingram, S. M., eds., The Permian Basin: Microns to Satellites, Looking for Oil and Gas at all Scales: West Texas Geological Society Publication No. 01-110, p. 49. 
2001, Stratigraphic and diagenetic controls on reservoir architecture of a non-reefal icehouse isolated platform-Sacroc Unit, Horseshoe Atoll, Texas (abs.): American Association of Petroleum Geologists Bulletin, v. 85, p. 386-387.

Kerans, C., and Fitchen, W. M., 1995, Sequence hierarchy and facies architecture of a carbonateramp system: San Andres Formation of Algerita Escarpment and western Guadalupe Mountains, west Texas and New Mexico: The University of Texas at Austin, Bureau of Economic Geology Report of Investigations No. 235, 86 p.

Kerans, C., Holtz, M. H., and Tyler, N., 1989, Controlling styles of reservoir heterogeneity in Ellenburger Group carbonates, West Texas, in Cunningham, B. K., and Cromwell, D. W., eds., The lower Paleozoic of west Texas and southern New Mexico-modern exploration concepts: Permian Basin Section, Society of Economic Paleontologists and Mineralogists, Publication No. 89-31, p. 131-144.

Kerans, C., Kempter, K., and Rush, J., 2000, Facies and stratigraphic controls on a coastal paleokarst, Lower Permian, Apache Canyon, West Texas, in Lindsay, R., Trentham, R., Ward, R. F., and Smith, A. H., eds., Classic Permian geology of West Texas and Southeastern New Mexico, 75 years of Permian Basin oil \& gas exploration \& development: West Texas Geological Society Publication No. 00-108, p. 55-81.

Kerans, C., and Lucia, F. J., 1989, Recognition of second, third, and fourth/fifth order scales of cyclicity in the El Paso Group and their relation to genesis and architecture of Ellenburger reservoirs, in Cunningham, B. K., and Cromwell, D. W., eds., The lower Paleozoic of West Texas and southern New Mexico-modern exploration concepts: Permian Basin Section, Society of Economic Paleontologists and Mineralogists, Publication No. 89-31, p. 105-110.

Kerans, C., Lucia, F. J., and Senger, R. K., 1994, Integrated characterization of carbonate ramp reservoirs using Permian San Andres Formation outcrop analogs: American Association of Petroleum Geologists Bulletin, v. 78, p. 181-216.

Kerans, C., and Nance, H. S., 1991, High-frequency cyclicity and regional depositional patterns of the Grayburg Formation, Guadalupe Mountains, New Mexico, in Meader-Roberts, S., Candelaria, M. P., and Moore, G. E., eds., Sequence stratigraphy, facies, and reservoir geometries of the San Andres, Grayburg, and Queen Formations, Guadalupe Mountains, New Mexico and Texas: Permian Basin Section SEPM, Publication No. 91-32, p. 53-96.

Kerans, C., and Parsley, M. J., 1986, Depositional facies and porosity evolution in a karstmodified San Andres reservoir-Taylor Link West San Andres, Pecos County, Texas, in Bebout, D. G., and Harris, P. M., eds., Hydrocarbon reservoir studies, San Andres/Grayburg Formations, Permian Basin: Permian Basin Section Society of Economic Paleontologists and Mineralogists, Publication No. 86-26, p. 133-134.

Kerans, C., and Ruppel, S. C., 1994, San Andres sequence framework, Guadalupe Mountains: implications for San Andres type section and subsurface reservoirs, in Garber, R. A., and 
Keller, D. R., eds., Field guide to the Paleozoic section of the San Andres Mountains: Permian Basin Section SEPM Publication 94-35, p. 105-116.

Kerans, C., Sonnenfeld, M. D., Fitchen, W. M., Tinker, S. W., Gardner, M. H., and Wardlaw, B. R., 1992, Styles of sequence development within uppermost Leonardian through Guadalupian strata of the Guadalupe Mountains, Texas and New Mexico, in Mruk, D. H., and Curran, C., eds., Permian Basin Exploration and production strategies: application of sequence stratigraphic and reservoir characterization concepts: West Texas Geological Society Publication 92-91, p. 1-6.

Kincheloe, D., and David, E. K., 1977, Oil Center Blinebry, in A symposium of the oil and gas fields of southeastern New Mexico, supplement: Roswell Geological Society, p. $142-143$.

Kinder Morgan, 2004, North Cross Devonian unit: http://www.kindermorgan.com/business/co2/success_north_cross.cfm.

2004, South Wasson Clearfork Unit: http://www.kindermorgan.com/business/co2/success clearfork.cfm.

Kirkpatrick, R. K., Flanders, W. A., and DePauw, R. M., 1985, Performance of the Twofreds $\mathrm{CO}_{2}$ injection project: Society of Petroleum Engineers Annual Technical Conference and Exhibition, SPE Paper 14439, 12 p.

Kosters, E. C., Bebout, D. G., Seni, S. J., Garrett, C. M., Jr., Brown, L. F., Jr., Hamlin, H. S., Dutton, S. P., Ruppel, S. C., Finley, R. J., and Tyler, Noel, 1989, Atlas of major Texas gas reservoirs: The University of Texas at Austin, Bureau of Economic Geology Special Publication, $161 \mathrm{p}$.

Kumar, V. K., Fassihi, M. R., and Yannimaras, D. V., 1995, Case history and appraisal of the Medicine Pole Hills Unit air-injection project, in SPE Reservoir Engineering, August 1995: Society of Petroleum Engineers, p. 198-202.

Kupecz, J. A., and Land, L. S., 1991, Late-stage dolomitization of the Lower Ordovician Ellenburger Group, West Texas: Journal of Sedimentary Petrology, v. 61, p. 551-574.

LaPointe, P. R., Eiben, T. T., Dershowitz, W., and Wadleigh, E. E., 1998, The application of discrete fracture network models to fractured reservoir engineering: analytical approach, data sets and early results in Yates field, west Texas: Proceedings, RMAG '98 Symposium, Fractured Reservoirs: Practical Exploration and Development Strategies, Denver, January 19-20, 1998; http://www.fracturedreservoirs.com/niper/database/papers/rmag/rmag_60.htm.

Lasser Texas Production CD, 2003, Texas production database, Fort Worth, Texas, http://www.lasser.com/data/data.html. 
Leary, D. A., and Vogt, J. N., 1990, Diagenesis of the San Andres Formation (Guadalupian), Central Basin Platform, Permian Basin, in Bebout, D. G. and Harris, P. M., eds., Geologic and engineering approaches in evaluation of San Andres/Grayburg hydrocarbon reservoirs-Permian Basin: The University of Texas at Austin, Bureau of Economic Geology Publication, p. 21-48.

Leiphart, D. J., and Hart, B. S., 2000, Probabilistic neural network used to predict porosity from 3-D seismic attributes in lower Brushy Canyon Formation, southeast New Mexico, in DeMis, W. D., Nelis, M. K., and Trentham, R. C., eds., The Permian Basin: proving ground for tomorrow's technologies: West Texas Geological Society, Publication No. 00-109, p. 187-191.

LeMay, W. J., 1960, Abo reefing in southeastern New Mexico, in A symposium of oil and gas fields of southeastern New Mexico, supplement: Roswell Geological Society, p. xvii-xxi.

1972, Empire Abo Field, southeast New Mexico, in Stratigraphic oil and gas fields: American Association of Petroleum Geologists Memoir 16, p. 472-480.

LeMone, D. V., 1996, The Tobosa basin-related stratigraphy of the Franklin Mountains, Texas and New Mexico, in Stoudt, E. L., ed., Precambrian-Devonian geology of the Franklin Mountains, West Texas - analogs for exploration and production in Ordovician and Silurian karsted reservoirs in the Permian Basin: West Texas Geological Society, Guidebook No. 96-100, p. 47-70.

Lewis, P., Cross, S., and Hoose, G., 1996, Delaware Mountain Group production map, in DeMis, W. D., and Cole, A. G., eds., The Brushy Canyon play in outcrop and subsurface: concepts and examples: Permian Basin Section SEPM, Publication No. 96-38, separate map in back pocket.

Lindsay, R. F., 1991, Grayburg Formation (Permian-Guadalupian): comparison of reservoir characteristics and sequence stratigraphy in the northwest Central Basin Platform with outcrops in the Guadalupe Mountains, New Mexico, in Meader-Roberts, S., Candelaria, M. P., and Moore, G. E., eds., Sequence stratigraphy, facies, and reservoir geometries of the San Andres, Grayburg, and Queen formations, Guadalupe Mountains, New Mexico and Texas: Permian Basin Section, Society of Economic Paleontologists and Mineralogists, Publication 91-32, p. 111-118.

Longacre, S. A., 1980, Dolomite reservoirs from Permian biomicrites, in Halley, R. B., and Loucks, R. G., eds., Carbonate reservoir rocks: Society of Economic Paleontologists and Mineralogists Core Workshop No. 1, p. 105-117.

1983, A subsurface example of a dolomitized Middle Guadalupian (Permian) reef from west Texas, in Harris, P. M., ed., Carbonate buildups - a core workshop: Society of Economic Paleontologists and Mineralogists Core Workshop No. 4, p. 304-326. 
1990, The Grayburg reservoir, North McElroy unit, Crane County, Texas, in Bebout, D. G. and Harris, P. M., eds., Geologic and engineering approaches in evaluation of San Andres/Grayburg hydrocarbon reservoirs-Permian Basin: The University of Texas at Austin, Bureau of Economic Geology Publication, p. 239-273.

Lorenz, J. C., 1997, Non-congruent natural fracture sets in adjacent beds at depth: data from horizontal cores from the Spraberry Formation, Midland Basin, TX (exp. abs.): American Association of Petroleum Geologists Hedberg Conference on Reservoir Scale Deformation, Characterization, and Prediction, June 22-28, Bryce, Utah, unpaginated.

Lorenz, J. C., Sterling, J. L., Schechter, D. S., Whigham, C. L., and Jensen, J. L., 2002, Natural fractures in the Spraberry Formation, Midland Basin, Texas: the effects of mechanical stratigraphy on fracture variability and reservoir behavior: American Association of Petroleum Geologists Bulletin, v. 86, p. 505-524.

Loucks, R. G., 1999, Paleocave carbonate reservoirs: origins, burial-depth modifications, spatial complexity, and reservoir implications: American Association of Petroleum Geologists Bulletin, v. 83, p. 1795-1834.

2003, Understanding the development of breccias and fractures in Ordovician carbonate reservoirs, in Hunt, T. J., and Lufholm, P. H., eds., The Permian Basin: back to basics: West Texas Geological Society Publication No. 03-112, p. 231-252.

Loucks, R. G., Brown, A. A., Achauer, C. W., and Budd, D. A., 1985, Carbonate gravity flow sedimentation on low angle slopes off the Wolfcampian northwest shelf of the Delaware Basin, in Crevello, P. D., and Harris, P. M., eds., Deep-water carbonates - a core workshop: Society of Economic Paleontologists and Mineralogists Core Workshop No. 6, p. 56-92.

Loucks, R. G., and Handford, C. R., 1992, Origin and recognition of fractures, breccias, and sediment fills in paleocave-reservoir networks, in Candelaria, M. P., and Reed, C. L., eds., Paleokarst, karst related diagenesis and reservoir development: examples from Ordovician-Devonian age strata of west Texas and the mid-continent: Permian Basin Section, Society of Economic Paleontologists and Mineralogists, Publication 92-33, p. 31-44.

Loucks, R. G., Mescher, P., Entzminger, D., Braaten, D., 2002, Geologic reservoir characterization of the Willard Unit in the San Andres Wasson field, west Texas: American Association of Petroleum Geologists Annual Convention Official Program, v. 11, p. A107.

Lucia, F. J., 1995, Lower Paleozoic cavern development, collapse, and dolomitization, Franklin Mountains, El Paso, Texas, in Budd, D. A., Saller, A. H., and Harris, P. M., eds., Unconformities and porosity in carbonate strata: American Association of Petroleum Geologists, American Association of Petroleum Geologists Memoir 63, p. 279-300. 
1995, Rock-fabric/petrophysical classification of carbonate pore space for reservoir characterization: American Association of Petroleum Geologists Bulletin, v. 79, p. 12751300 .

1999, Carbonate reservoir characterization: New York, Springer-Verlag, 226 p.

Lucia, F. J., 2000, Petrophysical characterization and distribution of remaining mobile oil: South Cowden Grayburg reservoir, Ector County, Texas: The University of Texas at Austin, Bureau of Economic Geology Report of Investigations No. 260, 54 p.

Lucia, F. J., Kerans, C., and Senger, R. K., 1992, Defining flow units in dolomitized carbonateramp reservoirs: Society of Petroleum Engineers Paper SPE 24702, p. 399-406.

Lucia, F. J., Kerans, C., and Vander Stoep, G. W., 1992, Characterization of a karsted, highenergy, ramp-margin carbonate reservoir: Taylor-Link West San Andres Unit, Pecos County, Texas: The University of Texas at Austin, Bureau of Economic Geology Report of Investigations No. 208, 46 p.

Lucia, F. J., Kerans, C., and Wang, F. P., 1995, Fluid-flow characterization of dolomitized carbonate-ramp reservoirs: San Andres Formation (Permian) of Seminole field and Algerita Escarpment, Permian Basin, Texas and New Mexico, in Stoudt, E. L., and Harris, P. M., eds., Hydrocarbon reservoir characterization: geologic framework and flow unit modeling: SEPM (Society for Sedimentary Geology), SEPM Short Course No. 34, p. 129-153.

Lucia, F. J., and Ruppel, S. C., 1996, Characterization of diagenetically altered carbonate reservoirs, South Cowden Grayburg reservoir, west Texas: Society of Petroleum Engineers Annual Technical Conference and Exhibition, SPE 36650, p. 883-893.

Lucia, F. J., Senger, R. K., Fogg, G. E., Kerans, C., and Kasap, E., 1991, Scale of heterogeneity and fluid flow response in carbonate ramp reservoirs: San Andres outcrop, Algerita escarpment, New Mexico: Society of Petroleum Engineers Paper SPE 22744, p. 839-840.

Lufholm, P., Watts, G., and Lofton, L., 1996, Improved reservoir modeling using gridded seismic attributes: North Concho Bluff field, west Texas, in Martin, R. L., ed., Permian Basin oil and gas fields: keys to success that unlock future reserves: West Texas Geological Society Publication 96-101, p. 145-159.

Magruder, J. B., Stiles, L. H., and Yelverton, T. D., 1990, Review of the Means San Andres unit full-scale $\mathrm{CO}_{2}$ tertiary project: Journal of Petroleum Technology, SPE 17349, v. 42, no. 5, p. 638-644.

Major, R. P., Bebout, D. G., and Lucia, F. J., 1988, Depositional facies and porosity distribution, Permian (Guadalupian) San Andres and Grayburg Formations, P.J.W.D.M. field complex, Central Basin Platform, west Texas, in Lomando, A. J., and Harris, P. M., eds., 
Giant oil and gas fields: a core workshop: Society of Economic Paleontologists and Mineralogists, Core Workshop No. 12, p. 615-648.

Major, R. P., and Holtz, M. H., 1997, Identifying fracture orientation in a mature carbonate platform reservoir: American Association of Petroleum Geologists Bulletin, v. 81, p. 1063-1069.

Major, R. P., Vander Stoep, G. W., and Holtz, M. H., 1990, Delineation of unrecovered mobile oil in a mature dolomite reservoir: East Penwell San Andres Unit, University Lands, West Texas: The University of Texas at Austin, Bureau of Economic Geology Report of Investigations No. 194, 52 p.

Major, R. P., and Ye, Q., 1992, Lateral and vertical reservoir heterogeneity in siliciclastic peritidal facies, Keystone (Colby) reservoir, west Texas, in Mruk, D. H., and Curran, C., eds., Permian Basin exploration and production strategies: application of sequence stratigraphic and reservoir characterization concepts: West Texas Geological Society Publication 92-91, p. 91-99.

1997, Characterization of siliciclastic tidal-flat reservoir: Keystone (Colby) field, Winkler County, Texas, in Major, R. P., ed., Oil and gas on Texas State Lands: an assessment of the resource and characterization of type reservoirs: The University of Texas at Austin, Bureau of Economic Geology Report of Investigations No. 241, p. $127-135$.

Malek-Aslani, M., 1970, Lower Wolfcampian reef in Kemnitz field, Lea County, New Mexico: American Association of Petroleum Geologists Bulletin, v. 54, p. 2317-2335.

1985, Permian patch-reef reservoir, North Anderson Ranch field, southeastern New Mexico, in Roehl, P. O., and Choquette, P. W., eds., Carbonate petroleum reservoirs: New York, Springer-Verlag, p. 265-276.

Malicse, A., and Mazzullo, J., 1990, Reservoir properties of the desert Shattuck Member, Caprock field, New Mexico, in Barwis, J. H., McPherson, J. G., and Studlick, J.R . J., eds., Sandstone petroleum reservoirs: New York, Springer Verlag, p. 133-152.

Marshall, L. R., and Foltz, G. A., 1960, Justis Blinebry, in A symposium of the oil and gas fields of southeastern New Mexico, supplement: Roswell Geological Society, p. 114-115.

Martin, A. J., Soloman, S. T., and Hartmann, D. J., 1997, Characterization of petrophysical flow units in carbonate reservoirs: American Association of Petroleum Geologists Bulletin, v. 81, p. 734-759.

Martin, R. L., and Hickey, K. F., 2002, Horizontal drilling at Vacuum Glorieta West unit, Lea County, New Mexico: a case history, in Hunt, T. J., and Lufholm, P. H., eds., The Permian Basin: preserving our past-securing our future: West Texas Geological Society, Publication 02-111, p. 117-124. 
Martin, R. L., Raines, M. A., and Cole, R. M., 1999, Stratigraphic styles of the Drinkard (Leonardian trend on the Northwest shelf, Lea County, New Mexico): finding oil in a mature area, in Grace, T. D., and Hinterlong, G. D, eds., The Permian Basin: providing energy for America: West Texas Geological Society, Publication 99-106, p. 87.

Martin, A. J., Soloman, S. T., and Hartmann, D. J., 1997, Characterization of petrophysical flow units in carbonate reservoirs: American Association of Petroleum Geologists Bulletin, v. 81, p. 734-759.

Martin, R. L., Welch, C. L., Hinterlong, G. D., Meyer, J., and Evans, R., 2002, Using crosswell seismic tomography to provide better resolution in the Wolfcamp Formation in Lea County, New Mexico, in Hunt, T. J., and Lufholm, P. H., eds., The Permian Basin: preserving our past—-securing our future: West Texas Geological Society, Publication 02-111, p. 25-34.

Mathis, R. L., 1986, Reservoir geology of the Denver Unit-Wasson San Andres field, Gaines and Yoakum Counties, Texas, in Bebout, D. G., and Harris, P. M., eds., Hydrocarbon reservoir studies, San Andres/Grayburg Formations, Permian Basin: Permian Basin Section Society of Economic Paleontologists and Mineralogists, Publication No. 86-26, p. $43-47$.

May, B.A., 1996, Geology and development history of the Livingston Ridge and Lost Tank Delaware pools, southeastern New Mexico, in DeMis, W.D., and Cole, A.G., eds., The Brushy Canyon play in outcrop and subsurface: concepts and examples: Permian Basin Section SEPM, Publication 96-38, p. 113-118.

Mazzullo, J., 1992, Fluvial and deltaic facies in the Queen Formation, Permian Basin of Texas and New Mexico: an overview, in Mruk, D. H., and Curran, B. C., eds., Permian Basin exploration and production strategies: applications of sequence stratigraphic and reservoir characterization concepts: West Texas Geological Society, Publication 92-91, p. 79.

Mazzullo, L. J., and Arrant, B.G., 1988, Scharb Wolfcamp (oil), in A symposium of oil and gas fields of southeastern New Mexico, supplement: Roswell Geological Society, p. 289290.

Mazzullo, J., Dronamraju, S., Johnson, R., and Ahr, W., 1996, Facies and sequence stratigraphy of the late Permian Yates Formation on the western margin of the Central Basin Platform of the Permian Basin, North Ward-Estes and South Ward fields, Ward County, Texas, in Martin, R. L., ed., Permian Basin oil and gas fields: keys to success that unlock future reserves: West Texas Geological Society Publication 96-101, p. 117-120.

Mazzullo, J., Malicse, A., Newsom, D., Harper, J., McKone, C. and Price, B., 1992, Facies, depositional environments, and reservoir properties of the upper Queen Formation, Concho Bluff and Concho Bluff North fields, Texas, in Mruk, D. H., and Curran, B. C., eds., Permian Basin exploration and production strategies: applications of sequence 
stratigraphic and reservoir characterization concepts: West Texas Geological Society, Publication 92-91, p. 67-78.

Mazzullo, L. J., Mazzullo, S. J., and Durham, T. E., 1989, Geologic controls on reservoir development in Silurian and Devonian carbonates northern Midland Basin, Texas, in Cunningham, B. K., and Cromwell, D. W., eds., The lower Paleozoic of West Texas and southern New Mexico - modern exploration concepts: Permian Basin Section, Society of Economic Paleontologists and Mineralogists, Publication No. 89-31, p. 209-218.

Mazzullo, L.J., and Reid, A.M., II, 1987, Stratigraphy of the Bone Spring Formation (Leonardian) and depositional setting in the Scharb field, Lea County, New Mexico, in Cromwell, D., and Mazzullo, L., eds., The Leonardian facies in w. Texas and S.E. New Mexico and Guidebook to the Glass Mountains, west Texas: Permian Basin Section Society of Economic Paleontologists and Mineralogists, Publication 87-27, p.107-111.

Mazzullo, S. J., 1982, Stratigraphy and depositional mosaics of Lower Clear Fork and Wichita Groups (Permian), Northern Midland Basin, Texas: American Association of Petroleum Geologists Bulletin, v. 66, p. 210-227.

1982, Types and controls on Permo-Pennsylvanian carbonate stratigraphic traps of shallow-marine origin in Permian Basin: exploration models: Oil and Gas Journal, v. 80, p. $127-141$.

1989, Formational and zonal subdivisions of the Ellenburger Group (Lower Ordovician), southern Midland Basin, Texas, in Cunningham, B. K. and Cromwell, D. W., eds., The lower Paleozoic of West Texas and southern New Mexico-modern exploration concepts: Permian Basin Section, Society of Economic Paleontologists and Mineralogists Publication No. 89-31, p. 113-121.

1997, Stratigraphic exploration plays in Ordovician to Lower Permian strata in the Midland Basin and on the Eastern Shelf, in DeMis, W. D., ed., Permian Basin oil and gas fields: turning ideas into production: West Texas Geological Society Publication No. 97102 , p. $1-37$.

1998, Depositional model and exploration strategies for the Cisco-Canyon (Upper Pennsylvanian) on the Northwest shelf, southeastern New Mexico, in DeMis, W. D., and Nelis, M. K., eds., The search continues into the 21 st century: West Texas Geological Society, Publication 98-105, p. 31-40.

2000, Models of porosity evolution in Pennsylvanian lowstand carbonates (now in slope-to-basinal settings) and in Lower Permian, highstand-resedimented basinal carbonates, in Reid, S. T., ed., Geo-2000: into the future: Transactions, Southwest Section American Association of Petroleum Geologists, Publication SWS 2000-107, p. $130-138$. 
Mazzullo, S. J., and Mazzullo, L. J., 1992, Paleokarst and karst-associated hydrocarbon reservoirs in the Fusselman Formation, West Texas, Permian Basin, in Candelaria, M. P., and Reed, C. L., eds., Paleokarst, karst related diagenesis and reservoir development: examples from Ordovician-Devonian age strata of west Texas and the mid-continent: Permian Basin Section, Society of Economic Paleontologists and Mineralogists, Publication 92-33, p. 110-120.

Mazzullo, S. J., and Reid, A. M., 1987, Basinal Lower Permian facies, Permian Basin: part IIdepositional setting and reservoir facies of Wolfcampian-lower Leonardian basinal carbonates: West Texas Geological Society Bulletin, v. 26, no. 8, p. 5-10.

1989, Lower Permian platform and basin depositional systems, northern Midland Basin, Texas, in Crevello, P. D., Wilson, J. L., Sarg, J. F., and Read, J. F., eds., Controls on carbonate platform and basin development: Society of Economic Paleontologists and Mineralogists Special Publication 44, p. 305-320.

Mazzullo, S. J., Reid, A. M., and Mazzullo, L. J., 1987, Basinal Lower Permian facies, Permian Basin: part 1-stratigraphy of the Wolfcampian-Leonardian boundary: West Texas Geological Society Bulletin, v. 26, no. 7, p. 5-9.

McGlasson, E. H., 1967, The Siluro-Devonian of West Texas and southeast New Mexico, in Oswald, D. H., ed., International Symposium on the Devonian System, v. II: Calgary, Alberta, Alberta Society of Petroleum Geologists, p. 937-948.

Mear, C. E., and Yarbrough, D. V., 1961, Yates Formation in southern Permian Basin of West Texas: American Association of Petroleum Geologists Bulletin, v. 45, p. 1545-1556.

Meissner, F. F., 1972, Cyclic sedimentation in Middle Permian strata of the Permian Basin, west Texas and New Mexico, in Cyclic sedimentation in the Permian Basin, 2nd ed.: West Texas Geological Society, p. 203-232.

Merriam, C. H., 2001, Depositional history of Lower Permian (Wolfcampian-Leonardian) carbonate buildups, Midland Basin, Upton County, Texas, Texas, in Stoudt, E. L., and Sivils, D. J., eds., Wolfcampian of West Texas (Permian Basin, Sierra Diablo and Hueco Mountains) - shelfal and periplatform carbonate reservoirs and outcrop analogs: Permian Basin Section SEPM Core Workshop and Field Trip Guidebook, Publication No. 200141, p. 2-1-2-22.

Midland Map Company, 1997, Producing zone map, the Permian Basin, West Texas and Southeast New Mexico: Midland, Texas, 1 inch $=32,000 \mathrm{ft}$.

Miller, K. D., 1992, Geologic description of the San Andres reservoir facies in Mabee field: American Association of Petroleum Geologists Bulletin, v. 76, p. 580. 
Miller, K. K., Prosceno, R. J., Woodroof, R. A., and Haney, R. L., 1998, Permian Basin field tests of propellant-assisted perforating: Society of Petroleum Engineers, Permian Basin Oil and Gas Recovery Conference, Midland, Texas, SPE Publication 39779, 9 p.

Modica, C. J., and Dorobek, S. L., 1996, High frequency sequence framework and effects of exposure events on porosity evolution and reservoir heterogeneity: Maljamar field, Lea County, southeast New Mexico, in Martin, R. L., ed., Permian Basin oil and gas fields: keys to success that unlock future reserves: West Texas Geological Society, Publication 96-101, p. 25-30.

Montgomery, S. L., 1996, Permian "Wolfcamp" limestone reservoirs: Powell Ranch field, eastern Midland Basin: American Association of Petroleum Geologists Bulletin, v. 80, p. 1349-1365.

1997, Permian Bone Spring Formation: sandstone play in the Delaware Basin Part I-slope: American Association of Petroleum Geologists, Bulletin, v. 81, p. 1239-1258.

1998, Permian Clear Fork Group, North Robertson Unit: integrated reservoir management and characterization for infill drilling, Part I-geological analysis: American Association of Petroleum Geologists Bulletin, v. 82, p. 1797-1814.

1998, Thirtyone Formation, Permian Basin, Texas: structural and lithologic heterogeneity in a Lower Devonian chert reservoir: American Association of Petroleum Geologists Bulletin, v. 82, p. 1-24.

Montgomery, S. L., Davies, D. K., Vessell, R. K., Kamis, J. E., and Dixon, W. H., 1998, Permian Clear Fork Group, North Robertson Unit: integrated reservoir management and characterization for infill drilling, Part II-petrophysical and engineering data: American Association of Petroleum Geologists Bulletin, v. 82, p. 1985-2002.

Montgomery, S. L., Hamilton, D., Hunt, T., and Worrall, J., 2000, Delaware Mountain Group, West Texas, a case of refound opportunity: Part 2-Cherry Canyon Formation: American Association of Petroleum Geologists Bulletin, v. 84, p. 1-11.

Montgomery, S. L., Schechter, D. S., and Lorenz, J. C., 2000, Advanced reservoir characterization to evaluate carbon dioxide flooding, Spraberry Trend, Midland Basin, Texas: American Association of Petroleum Geologists Bulletin, v. 84, p. 1247-1273.

Montgomery, S. L., Worrall, J., and Hamilton, D., 1999, Delaware Mountain Group, West Texas, a case of refound opportunity: Part 1-Brushy Canyon: American Association of Petroleum Geologists Bulletin, v. 83, p. 1901-1926.

Mooney, T. D., 1982, Howard Glasscock, in Selected oil \& gas fields in West Texas: West Texas Geological Society Publication No. 82-75, p. 323-337. 
Mozynski, D. C., and Reid, A. M., 1992, Perriwinkle-Perriwinkle North fields, Martin County, Texas: a Cisco-Canyon lowstand reef complex, in Cromwell, D. W., Moussa, M. T., and Mazzullo, L. J., eds., Transactions, Southwest Section American Association of Petroleum Geologists, SWS 92-90, p. 61-78.

Neuberger, D. J., 1987, Swastika (Upper Pennsylvanian) shelf-margin deltas and delta-fed turbidites, Flowers "Canyon Sand Field" area, Stonewall County, Texas: The University of Texas at Austin, Master's Thesis, 171 p.

Nevans, J. W., Kamis, J. E., Davies, D. K., Vessell, R. K., Doublet, L. E., and Blasingame, T. A., 1999, An integrated geologic and engineering reservoir characterization of the North Robertson (Clear Fork) Unit, Gaines County, Texas, in Schatzinger, R. A., and Jordan, J. F., eds., Reservoir characterization-recent advances: American Association of Petroleum Geologists Memoir 71, p. 109-124.

New Mexico Bureau of Mines and Mineral Resources, 1993, Atlas of major Rocky Mountain gas reservoirs: New Mexico Bureau of Mines and Mineral Resources, 206 p.

New Mexico Oil and Gas Engineering Committee, 1993, Annual report of the New Mexico Oil \& Gas Engineering Committee, v. 1A, southeast New Mexico: New Mexico Oil \& Gas Engineering Committee, Inc., Hobbs, New Mexico, 703 p.

Newell, N. D., Rigby, J. K., Fischer, A. G., Whiteman, A. J., Hickox, J. E., and Bradley, J. S., 1953, The Permian reef complex of the Guadalupe Mountains region, Texas and New Mexico: San Francisco, Freeman and Co., 236 p.

Pacht, J. A., Brooks, L., Messa, F., 1995, Stratigraphic analysis of 3D and 2D seismic data to delineate porous carbonate debris flows in Permian strata along the northwestern and eastern margins of the Midland Basin, in Martin, R. L., ed., In search of new Permian Basin oil and gas fields: using today's technologies and tomorrow's ideas for exploration, development, and 3D seismic in a mature basin: West Texas Geological Society Publication No. 95-98, p. 83-86.

Party, J. M., D’Agostino, A. E., Welch, J. P. F., and Lindsay, R. F., 1998, Geology, facies, and stratigraphy of Kingdom and Kingdom North (Abo) fields, Terry and Hockley Counties, Texas, in DeMis, W. D. and Nelis, M. K., eds., The search continues into the $21 \mathrm{st}$ century: West Texas Geological Society Publication No. 98-105, p. 139-166.

Payne, M. W., 1976, Basinal sandstone facies, Delaware Basin, West Texas and southeast New Mexico: American Association of Petroleum Geologists Bulletin, v. 60, p. 517-527.

Pearson, R.A., 1999, Sequence stratigraphy and seismic-guided estimation of log properties of the Second sand member of the Bone Spring Formation, Delaware Basin, New Mexico: New Mexico Institute of Mining and Technology, M.S. thesis, 124 p. plus appendices. 
Petersen, L. M., and Jacobs, R. S., 2003, Stratigraphic and lithologic zonation in the East Cowden Grayburg unit, Ector County, Texas: potential for horizontal redevelopment of a mature waterflood, in Hunt, T. J., and Lufholm, P. H., eds., The Permian Basin: back to basics: West Texas Geological Society Publication No. 03-112, p. 119-121.

Phillips Petroleum Company, 2002, Design and implementation of a $\mathrm{CO}_{2}$ flood utilizing advanced reservoir characterization and horizontal injection wells in a shallow shelf carbonate approaching waterflood depletion: Phillips Petroleum Company, final report prepared for U.S. Department of Energy, Assistant Secretary for Fossil Energy, under contract no. DE-FC22-94BC14991, 450 p.

Pitt, W. D., and Scott, G. L., 1981, Porosity zones of lower part of San Andres Formation, eastcentral New Mexico: New Mexico Bureau of Mines and Mineral Resources, Circular $179,20 \mathrm{p}$.

Pittaway, K. R., and Rosato, R. J., 1991, The Ford Geraldine unit $\mathrm{CO}_{2}$ flood - update 1990: Society of Petroleum Engineers Reservoir Engineering, v. 6, no. 4, p. 410-414.

Pranter, M. J., Hurley, N. F., Davis, T. L., Raines, M. A., and Wehner, S. C., 2004, Dual-lateral horizontal wells successfully target bypassed pay in the San Andres Formation, Vacuum field, New Mexico: American Association of Petroleum Geologists Bulletin, v. 88, p. 99-113.

Presley, M. W., 1987, Evolution of Permian evaporite basin in Texas Panhandle: American Association of Petroleum Geologists Bulletin, volume 71, p. 167-190.

Price, C., Ryu, C., and Mazzullo, J., 2000, Lithofacies, depositional environments, and reservoir properties of the Permian (Guadalupian) Grayburg and Queen Formations, Means field, Andrews County, Texas, in Reid, S. T., ed., Geo-2000: into the future: Southwest Section, American Association of Petroleum Geologists Transactions, Publication SWS 2000-107, p. 80-97.

Purves, W. J., 1986, Depositional and diagenetic controls on porosity, upper San Andres Formation-Bridges state leases, Vacuum field, Lea County, New Mexico, in Bebout, D. G., and Harris, P. M., eds., Hydrocarbon reservoir studies, San Andres/Grayburg Formations, Permian Basin: Permian Basin Section, Society of Economic Paleontologists and Mineralogists, Publication 86-26, p. 49-53.

1990, Reservoir description of the Mobil Oil Bridges state leases (upper San Andres reservoir), Vacuum field, Lea County, New Mexico, in Bebout, D. G., and Harris, P. M., eds., Geologic and engineering approaches in evaluation of San Andres/Grayburg hydrocarbon reservoirs-Permian Basin: The University of Texas at Austin, Bureau of Economic Geology, p. 87-112.

Qui, Y., Holtz, M. H., and Yang, A., 2001, Applying curvature and fracture analysis to the placement of horizontal wells: example from the Mabee (San Andres) reservoir, Texas: 
Society of Petroleum Engineers, SPE Permian Basin Oil and Gas Recovery Conference, Midland, Texas, SPE 70010, 9 p.

Railroad Commission of Texas, 2001, 2000 Oil \& gas annual report, volume I: Austin, Texas, Railroad Commission of Texas Oil and Gas Division, 454 p.

Raines, M. A., 2002, Interpretations on a Pennsylvanian reef, in Transactions, American Association of Petroleum Geologists Southwest Section Convention: Roswell Geological Society, p. 210.

2003, Reef heterogeneity as seen by wireline and cross-well seismic in the Pennsylvanian SACROC Unit, Scurry County, Texas, in Hunt, T. J., and Lufholm, P. H., eds., The Permian Basin: back to basics: West Texas Geological Society Publication No. 03-112, p. 325.

Raines, M. A., Dobitz, J. K., and Wehner, S. C., 2001, A review of the Pennsylvanian SACROC unit, in Viveiros, J. J., and Ingram, S. M., eds., The Permian Basin: microns to satellites, looking for oil and gas at all scales: West Texas Geological Society Publication No. 01110 , p. 67-74.

Ramondetta, P. J., 1982, Facies and stratigraphy of the San Andres Formation, Northern and Northwestern Shelves of the Midland Basin, Texas and New Mexico: The University of Texas at Austin Bureau of Economic Geology Report of Investigations No. 128, 56 p.

1982, Genesis and emplacement of oil in the San Andres Formation, Northern Shelf of the Midland Basin, Texas: The University of Texas at Austin Bureau of Economic Geology Report of Investigations No. 116, 39 p.

Read, A., Broadhead, R., Lopez, A., Fleming, E., and Watrous, J., 2000, New Mexico oil and gas pool maps: New Mexico Bureau of Mines and Mineral Resources, NMBMMR Circular 209, version 1.0, $1 \mathrm{CD}$.

Reddy, G., 1995, Dagger Draw South, in A symposium of oil and gas fields of southeastern New Mexico, supplement: Roswell Geological Society, p. 76-77.

Reid, A. M., Mozynski, D. C., and Robinson, W. C., 1990, B.C. Canyon field: a low sea level stand, early Canyon carbonate buildup, in Flis, J. E., and Price, R. C., eds., Permian Basin oil and gas fields: innovative ideas in exploration and development: West Texas Geological Society, Publication No. 90-87, p. 119-129.

Reid, A. M., and Reid, S. A. T., 1991, The Cogdell Field study, Kent and Scurry Counties, Texas: a post-mortem, in Candelaria, M., ed., Permian Basin plays, tomorrow's technology today: West Texas Geological Society, Publication No. 91-89, p. 39-66.

1999, Glacio-eustatic sea level fluctuations and the formation of Pennsylvanian age carbonate reservoirs in the Permian Basin of West Texas, in Grace, D. T., and 
Hinterlong, G. D., eds., The Permian Basin: providing energy for America: West Texas Geological Society Publication No. 99-106, p. 71-79.

Richards, J. W., 1982, Crossett, South-El Cinco: selected oil \& gas fields in West Texas: West Texas Geological Society Publication No. 82-75, p. 205-211.

Ring, J. N., and Smith, D. J., 1995, An overview of the North Ward-Estes CO2 flood, in SPE Annual Technical Conference: Society of Petroleum Engineers, Paper 30729, p. 293-300.

Root, D. H., Attanasi, E. D., Mast, R. F., and Gautier, D. L., 1995, Estimates of inferred reserves for the 1995 USGS national oil and gas resource assessment: U.S. Geological Survey Open-File Report 95-75L, 29 p.

Roswell Geological Society, 1956, A symposium of oil and gas fields of southeastern New Mexico: 376 p.

1960, A symposium of oil and gas fields of southeastern New Mexico, 1960 supplement: $129 \mathrm{p}$. $185 \mathrm{p}$.

1967, A symposium of oil and gas fields of southeastern New Mexico, supplement:

1977, A symposium of oil and gas fields of southeastern New Mexico, supplement: $220 \mathrm{p}$. $336 \mathrm{p}$.

1988, A symposium of oil and gas fields of southeastern New Mexico, supplement:

1995, A symposium of oil and gas fields of southeastern New Mexico, supplement: $360 \mathrm{p}$.

Rowan, D. E., Miller, K., and Cowley, E., 2002, Horizontal lateral revitalization of a low permeable carbonate reservoir at the Bryant -G- Field, Midland County, Texas: Transactions, Southwest Section, American Association of Petroleum Geologists, Ruidoso, New Mexico, p. 96.

Ruggiero, R. W., 1993, Depositional history and performance of a Permian Bell Canyon sandstone reservoir, Ford-Geraldine field, West Texas, in Rhodes, E. G., and Moslow, T. F., eds., Marine clastic reservoirs: New York, Springer-Verlag, p. 201-229.

Ruppel, S. C., 1983, Facies and depositional setting of Mississippian rocks in the Palo DuroHardeman Basin area, in Shaw, R. L., and Pollan, B. J., Permian Basin cores-a workshop: Permian Basin Section, Society of Economic Paleontologists and Mineralogists Core Workshop No. 2, Midland, Texas, May 17-18, p. 47-67.

1989, Summary of Mississippian stratigraphy in north and north-central Texas, in Mear, C. E., McNulty, C. L., and McNulty, M. E., eds., A symposium on the petroleum 
geology of Mississippian carbonates in north-central Texas: Fort Worth Geological Society and Texas Christian University, p. 49-55.

1992, Styles of deposition and diagenesis in Leonardian carbonate reservoirs in West Texas: implications for improved reservoir characterization: Society of Petroleum Engineers Annual Exhibition and Technical Conference, SPE Publication 24691, p. 313320.

2001, Opportunities for recovery of remaining oil in San Andres reservoirs: example from Fuhrman-Mascho field, University Lands Block 10, Andrews County, Texas, in Viveiros, J. J., and Ingram, S. M., eds., The Permian Basin: microns to satellites, Looking for oil and gas at all scales: West Texas Geological Society Publication No. 01-110, p. $105-125$.

2001, Stratal architecture and facies development in a middle Wolfcampian platform carbonate reservoir: University Block 9 Field Andrews County, Texas, in Stoudt, E. L., and Sivils, D. J., eds., Wolfcampian of West Texas (Permian Basin, Sierra Diablo and Hueco Mountains) - shelfal and periplatform carbonate reservoirs and outcrop analogs: Permian Basin Section SEPM Core Workshop and Field Trip Guidebook, Publication No. 2001-41, p. 3-1-3-18.

2002, Geological controls on reservoir development in a Leonardian (Lower Permian) carbonate platform reservoir, Monahans field, west Texas: The University of Texas at Austin, Bureau of Economic Geology Report of Investigations No. 266, 58 p.

2003, Lower Leonardian (Clear Fork-Abo) reservoir architecture: insights from outcrops and Fullerton Field, West Texas, in Hunt, T. J., and Lufholm, P. H., eds., The Permian Basin: Back to Basics: West Texas Geological Society Publication No. 03-112, p. $45-46$.

Ruppel, S. C., and Barnaby, R. J., 2001, Contrasting styles of reservoir development in proximal and distal chert facies: Devonian Thirtyone Formation, Texas: American Association of Petroleum Geologists Bulletin, v. 84, p. 7-34.

Ruppel, S. C., and Bebout, D. G., 2001, Competing effects of depositional architecture and diagenesis on carbonate reservoir development: Grayburg Formation, South Cowden field, west Texas: The University of Texas at Austin, Bureau of Economic Geology Report of Investigations No. 263, 62 p.

Ruppel, S. C., and Cander, H. S., 1988, Effects of facies and diagenesis on reservoir heterogeneity: Emma San Andres field, West Texas: The University of Texas at Austin, Bureau of Economic Geology Report of Investigations No. 178, 67 p.

Ruppel, S. C., and Holtz, M. H., 1994, Depositional and diagenetic facies patterns and reservoir development in Silurian and Devonian rocks of the Permian Basin: The University of Texas at Austin, Bureau of Economic Geology Report of Investigations No. 216, 89 p. 
Ruppel, S. C., and Hovorka, S. D., 1995, Chert reservoir development in the Devonian Thirtyone Formation: Three Bar Field, west Texas: The University of Texas at Austin, Bureau of Economic Geology Report of Investigations No. 230, 50 p.

1995, Controls on reservoir development in Devonian chert: Permian Basin, Texas: American Association of Petroleum Geologists Bulletin, v. 79, p. 1757-1785.

Ruppel, S. C., Kerans, C., Major, R. P., and Holtz, M. H., 1995, Controls on reservoir heterogeneity in Permian shallow water carbonate platform reservoirs, Permian Basin: implications for improved recovery: The University of Texas at Austin, Bureau of Economic Geology Geological Circular 95-2, 30 p.

Ruppel, S. C., and Lucia, F. J., 1996, Diagenetic control of permeability development in a highly cyclic, shallow water carbonate reservoir: South Cowden Grayburg field, Ector County, Texas, in Martin, R. L., ed., Permian Basin oil and gas fields: keys to success that unlock future reserves: West Texas Geological Society Publication 96-101, p. 7-24.

Ruppel, S. C., Park, Y. J., and Lucia, F. J., 2002, Applications of 3-D seismic to exploration and development of carbonate reservoirs: South Cowden Grayburg field, west Texas, in Hunt, T. J., and Lufholm, P. H., eds., Permian Basin: preserving our past-securing our future: West Texas Geological Society Publication No. 02-111, p. 71-87.

Ruppel, S. C., Ward, W. B., Ariza, E. E., and Jennings, J. W., Jr., 2000, Cycle and sequence stratigraphy of Clear Fork reservoir-equivalent outcrops: Victorio Peak Formation, Sierra Diablo, Texas, in Lindsay, R., Trentham, R., Ward, R. F., and Smith, A. H., eds., Classic Permian Geology of West Texas and Southeastern New Mexico, 75 Years of Permian Basin Oil \& Gas Exploration \& Development: West Texas Geological Society Pub. 00108, p. 109-130.

Saller, A. H., Ball, B., Robertson, S., McPherson, B., Wene, C., Nims, R. and Gogas, J., 2001, Reservoir characteristics of Devonian cherts and their control on oil recovery: Dollarhide Field, west Texas: American Association of Petroleum Geologists Bulletin, v. 85, p. 3550 .

Saller, A. H., Barton, J. W., and Barton, R. E., 1989, Mescalero Escarpe field, oil from carbonate slope detritus, southeastern New Mexico, in Flis, J. E., Price, R. C., and Sarg, J. F., eds., Search for the subtle trap, hydrocarbon exploration in mature basins: West Texas Geological Society, Publication 89-85, p. 59-74.

Saller, A. H., Dickson, J. A. D., and Boyd, S. A., 1994, Cycle stratigraphy and porosity in Pennsylvanian and lower Permian shelf limestones, eastern Central Basin Platform, Texas: American Association of Petroleum Geologists Bulletin, v. 78, p. 1820-1842.

Saller, A. H., Dickson, J. A. D., and Matsuda, F., 1999, Evolution and distribution of porosity associated with subaerial exposure in upper Paleozoic platform limestones, West Texas: American Association of Petroleum Geologists Bulletin, v. 83, p. 1835-1854. 
Saller, A. H., Dickson, J. A. D., Rasbury, E. T., and Ebato, T., 1999b, Effects of long-term accommodation changes on short term cycles: Upper Paleozoic platform limestones, West Texas, in Advances in carbonate sequence stratigraphy: application to reservoirs, outcrops, and models: Society of Economic Paleontologists and Mineralogists Special Publication No. 63, p. 227-246.

Saller, A. H., and Henderson, N., 1998, Distribution of porosity and permeability in platform dolomites: insight from the Permian of west Texas: American Association of Petroleum Geologists Bulletin, v. 82, p. 1528-1550.

Saller, A. H., Van Horn, D., Miller, J. A., and Guy, B. T., 1991, Reservoir geology of Devonian carbonates and chert-implications for tertiary recovery, Dollarhide Field, Andrews County, Texas: American Association of Petroleum Geologists Bulletin, v. 75, p. 86-107.

Sarg, J. F., 1981, Petrology of the carbonate-evaporite facies transition of the Seven Rivers Formation (Guadalupian, Permian), southeast New Mexico: Journal of Sedimentary Petrology, v. 51, p. 73-96.

Schatzinger, R. A., 1988, Changes in facies and depositional environments along and across the trend of the Horseshoe Atoll, Scurry and Kent Counties, Texas, in Cunningham, B. K., ed., Permian and Pennsylvanian stratigraphy, Midland Basin, West Texas: studies to aid in hydrocarbon exploration: Permian Basin Section, Society of Economic Paleontologists and Mineralogists, Publication No. 88-28, p. 79-107.

Schatzinger, V. R., 2003, Class II shallow-shelf carbonate reservoirs: The Class Act, v. 9, no. 1, p. $1-15$.

Schechter, D. S., 2002, Waterflooding and $\mathrm{CO}_{2}$ injection in the naturally fractured Spraberry Trend Area: Journal of Canadian Petroleum Technology, v. 41, no. 10, p. 9-14.

Schechter, D. S., and Banik, A. K., 1997, Integration of petrophysical and geological data with open-hole logs for identification of the naturally fractured Spraberry pay zones: Society of Petroleum Engineers, SPE Paper 38913, 10 p.

Schechter, D. S., and Guo, B., 1998, An integrated investigation for design of a $\mathrm{CO}_{2}$ pilot in the naturally fractured Spraberry Trend area, west Texas: Society of Petroleum Engineers, SPE Paper 39881, $16 \mathrm{p}$.

Schechter, D. S., and McDonald, P., 1999, Advanced reservoir characterization and evaluation of $\mathrm{CO}_{2}$ gravity drainage in the naturally fractured Spraberry trend area: Annual Report submitted to U.S. Department of Energy (DOE), Report No. DOE/BC/14942-7, 170 p.

Schechter, D. S., Putra, E., Baker, R. O., Knight, W. H., McDonald, W. P., Leonard, P., and Rounding, C., 2001, $\mathrm{CO}_{2}$ pilot design and water injection performance in the naturally fractured Spraberry Trend Area, West Texas: Society of Petroleum Engineers, SPE Paper No. 71605,16 p. 
2002, Waterflood performance in the naturally fractured Spraberry Trend area, West Texas: Proceedings, Conference on Naturally Fractured Reservoirs, Oklahoma City, Oklahoma, June 3-4: Mewbourne School of Petroleum and Geological Engineering, University of Oklahoma, Oklahoma Geological Survey, 18 p., CD-ROM.

Scott, G. L., Jr., 1995, Faulting in Cato and Tom-Tom San Andres fields, in A symposium of oil and gas fields of southeastern New Mexico, supplement: Roswell Geological Society, p. $68-73$.

Segrest, C. C., 1993, Identification of productive intervals and definition of original oil in place, Brushy Canyon Delaware Formation, Delaware Basin, in Gibbs, J., and Cromwell, D., eds., New dimensions in the Permian Basin: West Texas Geological Society Publication 93-93, p. 47-54.

Sharp, J. L., 1956, Teague (McKee), in Oil and gas fields of southeastern New Mexico: Roswell Geological Society, p. 334-335.

Siemers, W. W., Prezbindowski, D. R., Skinnider, V. L., Maple, L. C., Gerard, M. G., Nagaty, M. E., and Howard, J. J., 1995, Multidisciplinary study to optimize reservoir management of North Penwell (San Andres) unit, Ector Co., Texas: American Association of Petroleum Geologists Annual Convention Official Program, v. 4, p. A89.

Silver, B. A., and Todd, R. G., 1969, Permian cyclic strata, northern Midland and Delaware Basins, west Texas and southeastern New Mexico: American Association of Petroleum Geologists Bulletin, v. 53, p. 2223-2251.

Simo, J. A., Wahlman, G. P., Beall, J. L., and Stoklosa, M. L., 2000, Lower Permian (Wolfcampian) in the Hueco Mountains; stratigraphic and age relations, in DeMis, W. D., Nelis, M. K., and Trentham, R. C., eds., The Permian Basin: proving ground for tomorrow's technologies: West Texas Geological Society, Publication No. 00-109, p. 41-50. [P. 63-64 ON P. 117]

Sivils, D. J., 2001, Examples of Wolfcampian debris flow deposits from the Eastern Shelf of the Midland Basin, Glasscock County, Texas, in Stoudt, E. L., and Sivils, D. J., eds., Wolfcampian of West Texas (Permian Basin, Sierra Diablo and Hueco Mountains) shelfal and periplatform carbonate reservoirs and outcrop analogs: Permian Basin Section SEPM Core Workshop and Field Trip Guidebook, Publication No. 2001-41, p. 4-1-4-9.

2002, Reservoir characterization of the Strawn (Desmoinesian) from St. Lawrence Field, Glasscock County, Texas, in Transactions, Southwest Section, American Association of Petroleum Geologists, Ruidoso, New Mexico, p. 193-197.

Sivils, D. J., and Stoudt, E. L., 2001, Basinal Wolfcampian carbonate debris flow, Midland Basin, Texas, in Stoudt, E. L., and Sivils, D. J., eds., Wolfcampian of West Texas (Permian Basin, Sierra Diablo and Hueco Mountains) - shelfal and periplatform 
carbonate reservoirs and outcrop analogs: Permian Basin Section SEPM Core Workshop and Field Trip Guidebook, Publication No. 2001-41, p. 5-1-5-3.

2001, Reservoir characterization of the Strawn (Desmoinesian) from St. Lawrence field, Glasscock County, Texas, in Viveiros, J. J., and Ingram, S. M., eds., The Permian Basin: microns to satellites, looking for oil and gas at all scales: West Texas Geological Society Publication No. 01-110, p. 53.

Slone, J. C., and Mazzullo, J., 2000, Lithofacies, stacking patterns, and depositional environments of the Permian Queen Formation, Sterling and Glasscock Counties, Texas, in DeMis, W. D., Nelis, M. K., and Trentham, R. C., eds., The Permian Basin: proving ground for tomorrow's technologies: West Texas Geological Society Publication No. 00109 , p. 63-64.

Snell, J. S., and Close, A. D., 1999, Yates field steam pilot applies latest seismic and logging monitoring techniques: Society of Petroleum Engineers Annual Technical Conference, Houston, Texas, SPE 56791, 10 p.

Snyder, D. O., 1962, Geology of the Empire Abo field, Eddy County, New Mexico: University of New Mexico, M.S. thesis, 77 p.

Sonnenfeld, M. D., Wingate, T. P., Canter, K. L., Meng, H. Z., and Zahm, L. C., 2003, Operational sequence stratigraphy for 3-D reservoir modeling of Seminole San Andres Unit (SSAU), Permian Basin, west Texas: American Association of Petroleum Geologists Annual Convention Official Program, v. 12, p. A160-161.

Sonnenfeld, M. D., Zahm, L. C., Ford, G. L., Canter, K. L., Buckner, S. J., Foulk, L. S., Kerans, C., Pluim, S. L., Simon, M., and Tinker, S. W., 2001, Paleostructural control on facies distribution and reservoir quality: Seminole San Andres Unit (Permian, Guadalupian), west Texas: American Association of Petroleum Geologists Annual Convention Official Program, v. 10, p. A189-190.

Spain, D. R., 1992, Petrophysical evaluation of a slope fan/basin-floor fan complex: Cherry Canyon Formation, Ward County, Texas: American Association of Petroleum Geologists Bulletin, v. 76, p. 805-827.

Speer, S. W., 1993, Granite Wash (Permian), in Atlas of major Rocky Mountain gas reservoirs: New Mexico Bureau of Mines and Mineral Resources, p. 162.

1993, Strawn, in Atlas of major Rocky Mountain gas reservoirs: New Mexico Bureau of Mines and Mineral Resources, p. 157.

1993, Upper Pennsylvanian, in Atlas of major Rocky Mountain gas reservoirs: New Mexico Bureau of Mines and Mineral Resources, p. 154-156. 
Spencer, A. W., and Warren, J. K., 1986, Depositional styles in the Queen and Seven Rivers Formations-Yates field, Pecos Co., Texas, in Bebout, D. G., and Harris, P. M., eds., Hydrocarbon reservoir studies, San Andres/Grayburg Formations, Permian Basin: Permian Basin Section, Society of Economic Paleontologists and Mineralogists, Publication No. 86-26, 135-137.

Stoudt, E. L., Prezbindowski, D. R., and Sivils, D. J., 2001, Phillips Edwards West field, Ector County, Texas - controls on reservoir distribution in Wolfcamp shelfal carbonates, in Viveiros, J. J., and Ingram, S. M., eds., The Permian Basin: microns to satellites, looking for oil and gas at all scales: West Texas Geological Society Publication No. 01-110, p. 55.

Stoudt, E. L., and Raines, M. A., 2001, Reservoir compartmentalization in the San Andres Formation of Vacuum field, Lea County, New Mexico - peritidal deposits and karst overprints create vertical and lateral barriers to fluid flow in carbonate platform dolopackstones and dolograinstones (abs.): American Association of Petroleum Geologists, Bulletin, v. 85, p. 390.

Structurmaps, Ltd., 1970, The Permian Basin of west Texas and southeast New Mexico, Permian structure map showing oil \& gas production: Midland, Texas, 1 inch $=29,333 \mathrm{ft}$.

Suhm, R. W., and Ethington, R. L., 1975, Stratigraphy and Conodonts of Simpson Group (Middle Ordovician), Beach and Baylor Mountains, West Texas: American Association of Petroleum Geologists Bulletin, v. 59, p. 1126-1135.

Symposium Committee, 1956, Hare (Simpson), in Oil and gas fields of southeastern New Mexico: Roswell Geological Society, p. 197.

Tai, P., and Dorobek, S. L., 1999, Preliminary study on the Late Paleozoic tectonic and stratigraphic history at Wilshire field, central Upton County, southwestern Midland Basin, west Texas, in Grace, D. T., and Hinterlong, G. D., eds., The Permian Basin: Providing Energy for America, West Texas Geological Society Publication No. 99-106, p. 19-29.

Thomerson, M. D., and Asquith, G. B., 1992, Petrophysical analysis of the Brushy Canyon Formation, Hat Mesa field, Lea County, New Mexico, in Mruk, D. H., and Curran, C., eds., Permian Basin Exploration and production strategies: application of sequence stratigraphic and reservoir characterization concepts: West Texas Geological Society Publication 92-91, p. 80-90.

Thornton, D. E., and Gaston, H. H., Jr., 1967, Lusk Strawn field, in A symposium of oil and gas fields of southeastern New Mexico, supplement: Roswell Geological Society, p. 15-20. 
Tinker, S. W., 1996, Building the 3-D jigsaw puzzle: applications of sequence stratigraphy to 3-D reservoir characterization, Permian Basin: American Association of Petroleum Geologists Bulletin, v. 80, p. 460-485.

Tinker, S. W., Ehrets, J. R., and Brondos, M. D., 1995, Multiple karst events related to stratigraphic cyclicity: San Andres Formation, Yates field, west Texas, in Budd, D. A., Saller, A. H., and Harris, P. M., eds., Unconformities and porosity in carbonate strata: American Association of Petroleum Geologists Memoir 63, p. 213-237.

Tinker, S. W., and Mruk, D. H., 1995, Reservoir characterization of a Permian giant: Yates field, west Texas, in Stoudt, E. L., and Harris, P. M., eds., Hydrocarbon reservoir characterization: geologic framework and flow unit modeling: SEPM (Society for Sedimentary Geology) Short Course No. 34, p. 51-128.

Trentham, R. C., 2003, Impact of paleostructure on Guadalupian age clastic sediment distribution in the Midland Basin, Central Basin Platform, and eastern Delaware Basin, in Hunt, T. J., and Lufholm, P. H., eds., The Permian Basin: Back to Basics: West Texas Geological Society Publication No. 03-112, p. 79-95.

Trentham, R. C., Weinbrandt, R., Robinson, W. C., and Widner, K., 2000, An integrated study of the Grayburg/San Andres reservoir, Foster and South Cowden fields, Ector County, Texas: Laguna Petroleum Corporation, final report prepared for U.S. Department of Energy, Assistant Secretary for Fossil Energy, under contract no. DE-FC22-94BC14982, 33 p. plus 37 figures.

Trentham, R. C., and Widner, K. L., 1999, Using produced water analyses to evaluate production problems and recompletions in an "old" waterflood: Foster-South Cowden fields, Ector County, Texas, in Grace, D. T., and Hinterlong, G. D., eds., The Permian Basin: providing energy for America: West Texas Geological Society Publication No. 99-106, p. $9-18$.

Troschinetz, J., 1989, An example of karsted Silurian reservoir: Buckwheat field, Howard County, Texas, in Candelaria, M. P., and Reed, C. L., eds., Paleokarst, karst-related diagenesis, and reservoir development: examples from Ordovician-Devonian age strata of West Texas and the Mid-Continent: Permian Basin Section, Society of Economic Paleontologists and Mineralogists, Field Trip Guidebook, Publication No. 92-33, p. 131-133.

Tucker, K. E., Harris, P. M., and Nolen-Hoeksema, R. C., 1998, Geologic investigation of crosswell seismic response in a carbonate reservoir, McElroy field, west Texas: American Association of Petroleum Geologists Bulletin, v. 82, p. 1463-1503.

Tyler, N., and Banta, N. J., 1989, Oil and gas resources remaining in the Permian Basin: targets for additional hydrocarbon recovery: The University of Texas at Austin, Bureau of Economic Geology Geological Circular 89-4, 20 p. 
Tyler, N., Bebout, D. G., Garrett, C. M., Jr., Guevara, E. H., Hocott, C. R., Holtz, M. H., Hovorka, S. D., Kerans, C., Lucia, F. J., Major, R. P., Ruppel, S. C., and Vander Stoep, G. W., 1991, Integrated characterization of Permian Basin reservoirs, University Lands, West Texas: targeting the remaining resource for advanced oil recovery: The University of Texas at Austin, Bureau of Economic Geology Report of Investigations No. 203, $136 \mathrm{p}$.

Tyler, N., Galloway, W. E., Garrett, C. M., Jr., and Ewing, T. E., 1984, Oil accumulation, production characteristics, and targets for additional recovery in major oil reservoirs of Texas: The University of Texas at Austin, Bureau of Economic Geology Geological Circular 84-2, $31 \mathrm{p}$.

Tyler, N., and Gholston, J. C., 1988, Heterogeneous deep-sea fan reservoirs, Shackelford and Preston waterflood units, Spraberry Trend, West Texas: The University of Texas at Austin, Bureau of Economic Geology Report of Investigations No. 171, 38 p.

Tyler, N., Gholston, J. C., and Guevara, E. H., 1997, Basin morphological controls on submarine-fan depositional trends: Spraberry Sandstone, Permian Basin, Texas: The University of Texas at Austin, Bureau of Economic Geology Geological Circular No. 97-6, 43 p.

Urschel, S. F., Ghosh, S. K., and Friedman, G. M., 1986, Reservoir facies of the Permian San Andres Formation in the Mabee field, Midland Basin, west Texas: characterization for enhanced recovery, in Bebout, D. G., and Harris, P. M., eds., Hydrocarbon reservoir studies, San Andres/Grayburg Formations, Permian Basin: Permian Basin Section, Society of Economic Paleontologists and Mineralogists, Publication No. 86-26, 188 p. 89-95.

U.S. Geological Survey, 1995, National assessment of United States oil and gas resources: U.S. Geological Survey Circular 1118, 20 p.

1996, 1995 National assessment of United States oil and gas resources - results, methodology, and supporting data: U.S. Geological Survey Digital Data Series DDS-30, release 2, 1 CD-ROM.

Van Der Loop, M., 1990, Amacker Tippett Wolfcamp field, Upton County, Texas, in Flis, J. E., and Price, R. C., eds., Permian Basin oil and gas fields: innovative ideas in exploration and development: West Texas Geological Society, Publication No. 90-87, p. 133-151.

1991, Depositional environments in the Arenoso field, Winkler County, Texas, in Candelaria, M., ed., Permian Basin plays-tomorrow's technology today: West Texas Geological Society Publication No. 91-89, p. 73-91.

Van Siclen, D. C., 1958, Depositional topography—examples and theory: American Association of Petroleum Geologists Bulletin, v. 42, p. 1897-1913. 
Verseput, T. D., 1989, Depositional setting of the Ellenburger-Langley field, Lea County, New Mexico, in Cunningham, B. K., and Cromwell, D. W., eds., The lower Paleozoic of West Texas and southern New Mexico-modern exploration concepts: Permian Basin Section, Society of Economic Paleontologists and Mineralogists, Publication No. 89-31, p. $145-158$.

Vest, E. L., 1970, Oil fields of Pennsylvanian-Permian Horseshoe Atoll, West Texas, in Halbouty, M. T., ed., Geology of giant petroleum fields: American Association of Petroleum Geologists Memoir 14, p. 185-203.

Wadleigh, E. E., 1996, Process for recovering hydrocarbons by thermally assisted gravity segregation, U.S. Patent No. 5503266, April 2, 1996.

Wahlman, G. P., 2001, Pennsylvanian-Lower Permian mounds and reefs in the Permian Basin (west Texas-New Mexico): composition, evolution, distribution, and reservoir characteristics, in Viveiros, J. J., and Ingram, S. M., eds., The Permian Basin: microns to satellites, looking for oil and gas at all scales: West Texas Geological Society Publication No. 01-110, p. 57-64.

2002, Pennsylvanian and Lower Permian shelf-margin mounds and reefs in the Permian Basin region (West Texas-New Mexico): composition, evolution, distribution, and reservoir characteristics, in Transactions, Southwest Section, American Association of Petroleum Geologists, Ruidoso, New Mexico, p. 169.

Walker, D. A., Golonka, J., Reid, A., and Reid, S., 1995, The effects of paleolatitude and paleogeography on carbonate sedimentation in the Late Paleozoic, in Huc, A.-Y., ed., Paleogeography, paleoclimate, and source rocks: American Association of Petroleum Geologists Studies in Geology No. 40, p. 133-155.

Walker, D. A., Golonka, J., Reid, A., and Tomlinson-Reid, S., 1991, The effects of late Paleozoic paleolatitude and paleogeography on carbonate sedimentation in the Midland basin, Texas, in Candelaria, M., ed., Permian Basin plays - tomorrow's technology today: West Texas Geological Society Publication No. 91-89, p. 141-162.

Walker, S. D., and Harris, P. M., 1986, McElroy field, development of a dolomite reservoir, Permian Basin of west Texas, in Bebout, D. G., and Harris, P. M., eds., Hydrocarbon reservoir studies, San Andres/Grayburg Formations, Permian Basin: Permian Basin Section, Society of Economic Paleontologists and Mineralogists, Publication No. 86-26, p 127-132.

Walling, S. D., Hays, P. D., and Tieh, T. T., 1992, Chlorites in reservoir sandstones of the Guadalupian Delaware Mountain Group, in Cromwell, D. W., Moussa, M. T., and Mazzullo, L. J., eds., Southwest Section American Association of Petroleum Geologists Transactions, SWS 92-90, p. 149-154. 
Wang, F. P., Lucia, F. J., and Kerans, C., 1996, Integrated reservoir characterization of a carbonate ramp reservoir: Seminole San Andres Unit, Gaines County, Texas, in Proceedings, Formation Evaluation and Reservoir Geology, Society of Petroleum Engineers Annual Technical Conference and Exhibition, October 7-9, Denver, SPE 36515 , p. 237-250.

1998, Integrated reservoir characterization study of a carbonate ramp reservoir: Seminole San Andres Unit, Gaines County, Texas: Society of Petroleum Engineers Reservoir Evaluation \& Engineering, v. 1, no. 2, p. 105-113.

1998, Modeling dolomitized carbonate-ramp reservoirs: a case history of the Seminole San Andres unit-Part 1, petrophysical and geologic characterizations: Geophysics, v. 63, no. 6, p. 1866-1875.

Wang, F. P., Dai, J., and Kerans, C., 1998, Modeling dolomitized carbonate-ramp reservoirs: a case study of the Seminole San Andres unit-Part II, seismic modeling, reservoir geostatistics, and reservoir simulation: Geophysics, v. 63, no. 6, p. 1876-1884.

Wang, F. P., Lucia, F. J., and Ruppel, S. C., 2003, 3D reservoir modeling and simulation of the Fullerton Clear Fork Unit, Andrews County, Texas, in Hunt, T. J., and Lufholm, P. H., eds., The Permian Basin: back to basics: West Texas Geological Society Publication No. 03-112, p. 347.

Ward, R. F., Kendall, C. G. St. C., and Harris, R. M., 1986, Upper Permian (Guadalupian) facies and their association with hydrocarbons-Permian Basin, West Texas and New Mexico: American Association of Petroleum Geologists Bulletin, v. 70, p. 239-262.

Watson, K. A., 1992, In search of the holy grail: predicting producing rates in the C. S. Dean "A" Unit, Slaughter field, Cochran County, Texas, in Mruk, D. H., and Curran, C., eds., Permian Basin exploration and production strategies: application of sequence stratigraphic and reservoir characterization concepts: West Texas Geological Society Publication 92-91, p. 106-115.

Watts, B. C., Hall, T. F., and Petri, D. J., 1997, The Horse Creek air injection project: an overview, in SPE Rocky Mountain Regional Meeting, Casper, Wyoming: Society of Petroleum Engineers, SPE 38359, p. 143-154.

Watts, G. P., Hinterlong, G. D., and Taylor, A. R., 1998, Seismic description of a complex carbonate porosity system; Welch field, Permian Basin, Texas, in DeMis, W. D. and Nelis, M. K., eds., The search continues into the 21 st century: West Texas Geological Society Publication No. 98-105, p. 223-229.

Weinbrandt, R. M., Trentham, R. C., and Robinson, W., 1998, Incorporating seismic attribute porosity into a flow model of the Grayburg reservoir in the Foster-South Cowden field, in DeMis, W. D. and Nelis, M. K., eds., The search continues into the 21 st century: West Texas Geological Society Publication No. 98-105, p. 231-238. 
Weiner, S., and Heyer, J., 1999, Geological model of a highly compartmentalized reservoir: the Devonian Thirtyone Formation, University Block 9 Field, in Grace, D. T., and Hinterlong, G. D., eds., The Permian Basin: Providing Energy for America, West Texas Geological Society Publication No. 99-106, p. 1-8.

2000, Horizontal well applications in a highly compartmentalized reservoir: the Devonian Thirtyone Formation, University Block 9 Field, Andrews County, Texas, in Reid, S. T., ed., Geo-2000: into the future: Transactions, Southwest Section, American Association of Petroleum Geologists, Publication SWS 2000-107, p. 255.

Weiss, W. W., Stubbs, B. A., and Balch, R. S., 2001, A new tool for lower Brushy Canyon completion decisions, in Viveiros, J. J., and Ingram, S. M., eds., The Permian Basin: microns to satellites, looking for oil and gas at all scales: West Texas Geological Society Publication No. 01-110, p. 99-104.

West Texas Geological Society, 1982, Selected oil \& gas fields in West Texas, a reprint of symposium vol. I, II, and III: Midland, Texas, Publication No. 82-75, 691 p.

1987, Selected oil \& gas fields in West Texas vol. IV: Midland, Texas, Publication No. 87-83, 130 p.

1990, Selected oil \& gas fields in West Texas vol. V: Midland, Texas, Publication No. 90-86, 208 p.

1994, Selected oil \& gas fields in West Texas vol. VI: Midland, Texas, Publication No. 94-96, 325 p.

1996, Selected oil \& gas fields in West Texas vol. VII: Midland, Texas, Publication No. 96-99, 284 p.

White, D. A., 1980, Assessing oil and gas plays in facies-cycle wedges: American Association of Petroleum Geologists Bulletin, v. 64, p. 1158-1178.

White, T. C., 1984, Dolomitization, sulfate solution, and porosity development: the San Andres Formation, Howard-Glasscock field, Howard County, Texas, in Moore, G., and Wilde, G., eds., Oil \& gas fields: search for more in '84: Transactions of the Southwest Section American Association of Petroleum Geologists, SWS 84-78, p. 91-102.

Whitsitt, P., 1992, Petrography and log analysis of the Zan Zan middle "Canyon" sandstone, eastern Irion County, Texas, in Cromwell, D. W., Moussa, M. T., and Mazzullo, L. J., eds., Transactions, Southwest Section American Association of Petroleum Geologists, SWS 92-90, p. 101-106.

1992, Sequence stratigraphy of the upper and middle "Canyon" oil and gas fields in eastern Irion County, Texas and the potential for future exploration, in Cromwell, D. W., 
Moussa, M. T., and Mazzullo, L. J., eds., Transactions, Southwest Section American Association of Petroleum Geologists, SWS 92-90, p. 107-111.

Wiggins, W. D., and Harris, P. M., 1985, Burial diagenetic sequence in deep-water allochthonous dolomites, Permian Bone Spring Formation, southeast New Mexico, in Crevello, P. D., and Harris, P. M., eds., Deep-water carbonates: buildups, turbidites, debris flows and chalks - a core workshop: Society of Economic Paleontologists and Mineralogists Core Workshop No. 6, p. 140-173.

Williamson, C. R., 1978, Depositional processes, diagenesis and reservoir properties of Permian deep-sea sandstones, Bell Canyon Formation, Texas-New Mexico: The University of Texas at Austin, Austin, Texas, Ph.D. dissertation, 262 p.

1979, Deep sea sedimentation and stratigraphic traps, Bell Canyon Formation (Permian), Delaware basin, in Sullivan, N. M., ed., Guadalupian Delaware Mountain Group of West Texas and southeast New Mexico, Symposium and Field Trip Conference Guidebook: Society of Economic Paleontologists and Mineralogists (Permian Basin Section) Publication 79-18, p. 39-74.

Wilson, D. A., and Hensel, W. M., Jr., 1978, Computer log analysis plus core analysis equals improved formation evaluation in West Howard-Glasscock unit: Journal of Petroleum Technology, v. 30, no. 1, p. 43-51.

Wilson, J. L., 1975, Carbonate facies in geologic history: New York, Springer-Verlag, 471 p.

Wind, F. H., 1998, Early silica mobilization and certification in the Thirtyone Formation, Bryant G Devonian Unit, Midland Co., TX, in DeMis, W. D. and Nelis, M. K., eds., The search continues into the 21st century: West Texas Geological Society Publication No. 98-105, p. $67-72$.

Wingate, T. P., 1996, Kelly-Snyder Field (SACROC unit): Oil \& gas fields in West Texas, v. VII, West Texas Geological Society Publication Number 96-99, p.71-76.

Wojcik, R., 1990, Crawar (Waddell), in Grace, R. M., ed., Oil \& Gas Fields in West Texas Symposium, v. 5: West Texas Geological Society, Publication No. 90-86, p. 71-72.

Wright, W. F., 1979, Petroleum geology of the Permian Basin: West Texas Geological Society Publication No. 79-71, 98 p.

Yedlosky, R. J., and McNeal, J. E., 1969, Geological engineering study of Cato field (San Andres), Chaves County, New Mexico, in Summers, W. K., and Kottlowski, F. E., eds., The San Andres Limestone, a reservoir for oil and water in New Mexico: New Mexico Geological Society, Special Publication 3, p. 46-51.

Zahm, L. C., Sonnenfeld, M. D., Caldwell, D. H., Clawson, S. R., Meng, H. Z., and Wingate, T. P., 2002, Multi-scale data integration for 3-D reservoir modeling of Seminole San Andres 
Unit: American Association of Petroleum Geologists Annual Convention Official Program, v. 11, p. A197.

Zahm, L. C., and Tinker, S. W., 2000, 3-D reservoir characterization in the absence of seismic; Olson field, San Andres/Grayburg, west Texas: American Association of Petroleum Geologists Annual Convention Official Program, v. 9, p. A165.

Zelt, F. B., and Rossen, C., 1995, Geometry and continuity of deep-water sandstones and siltstones, Brushy Canyon Formation (Permian) Delaware Mountains, Texas, in Pickering, K. T., Hiscott, R. N., Kenyon, N. H., Ricci Lucchi, F., and Smith, R. D. A., eds., Atlas of deep water environments, architectural style in turbidite systems: London, Chapman \& Hall, p. 167-183.

Zeng, H., and Kerans, C., 2003, Seismic frequency control on carbonate seismic stratigraphy: a case study of the Kingdom Abo sequence, west Texas: American Association of Petroleum Geologists Bulletin, v. 87, p. 273-293.

Zeng, H., Ruppel, S. C., and Jones, R. H., 2003, Reconditioning seismic data for improved reservoir characterization, lower Clear Fork and Wichita, Fullerton Field, West Texas, in Hunt, T. J., and Lufholm, P. H., eds., The Permian Basin: back to basics: West Texas Geological Society Publication No. 03-112, p. 67-78. 


\section{LIST OF ACRONYMS AND ABBREVIATIONS}

$\begin{array}{ll}\text { AAPG } & \text { American Association of Petroleum Geologists } \\ \text { Bbbl } & \text { Billion barrels } \\ \text { bbl/d } & \text { Barrels per day } \\ \text { BEG } & \text { Bureau of Economic Geology } \\ \mathrm{CO}_{2} & \text { Carbon dioxide } \\ \text { GIS } & \text { Geographic Information System } \\ \text { HPAI } & \text { High-pressure air injection } \\ \text { MMbbl } & \text { Million barrels } \\ \text { NMBGMR } & \text { New Mexico Bureau of Geology and Mineral Resources } \\ \text { OCD } & \text { Oil Conservation Division of the New Mexico Energy, } \\ \text { OOIP } & \text { Minerals and Natural Resources Department } \\ \text { PUMP } & \text { Original oil in place } \\ \text { RRC } & \text { Preferred upstream management practices } \\ \text { SACROC } & \text { Railroad Commission of Texas } \\ \text { WAG } & \text { Scurry Area Canyon Reef Operators Committee } \\ \text { WTGS } & \text { West Texas alternating gas }\end{array}$

